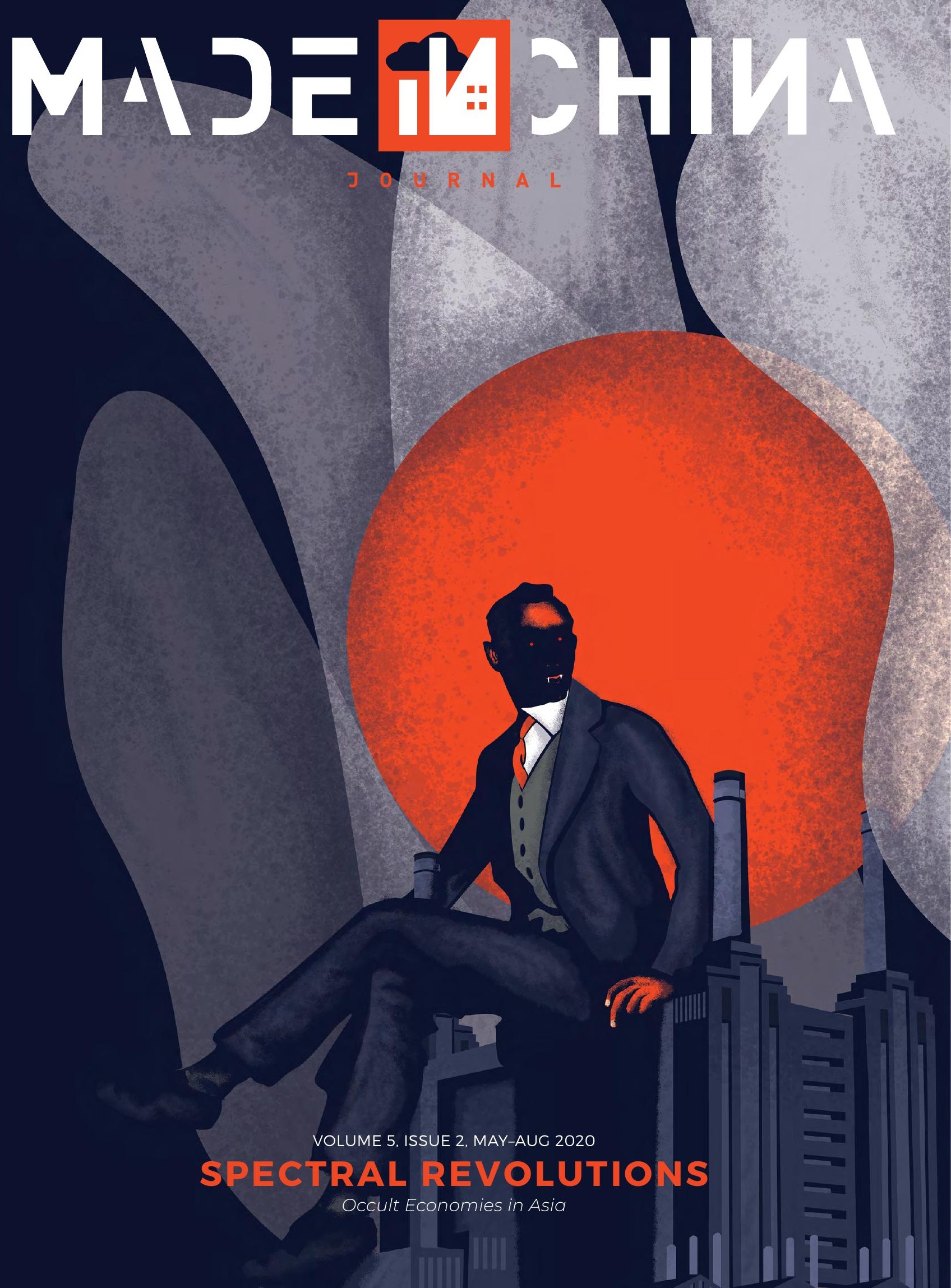





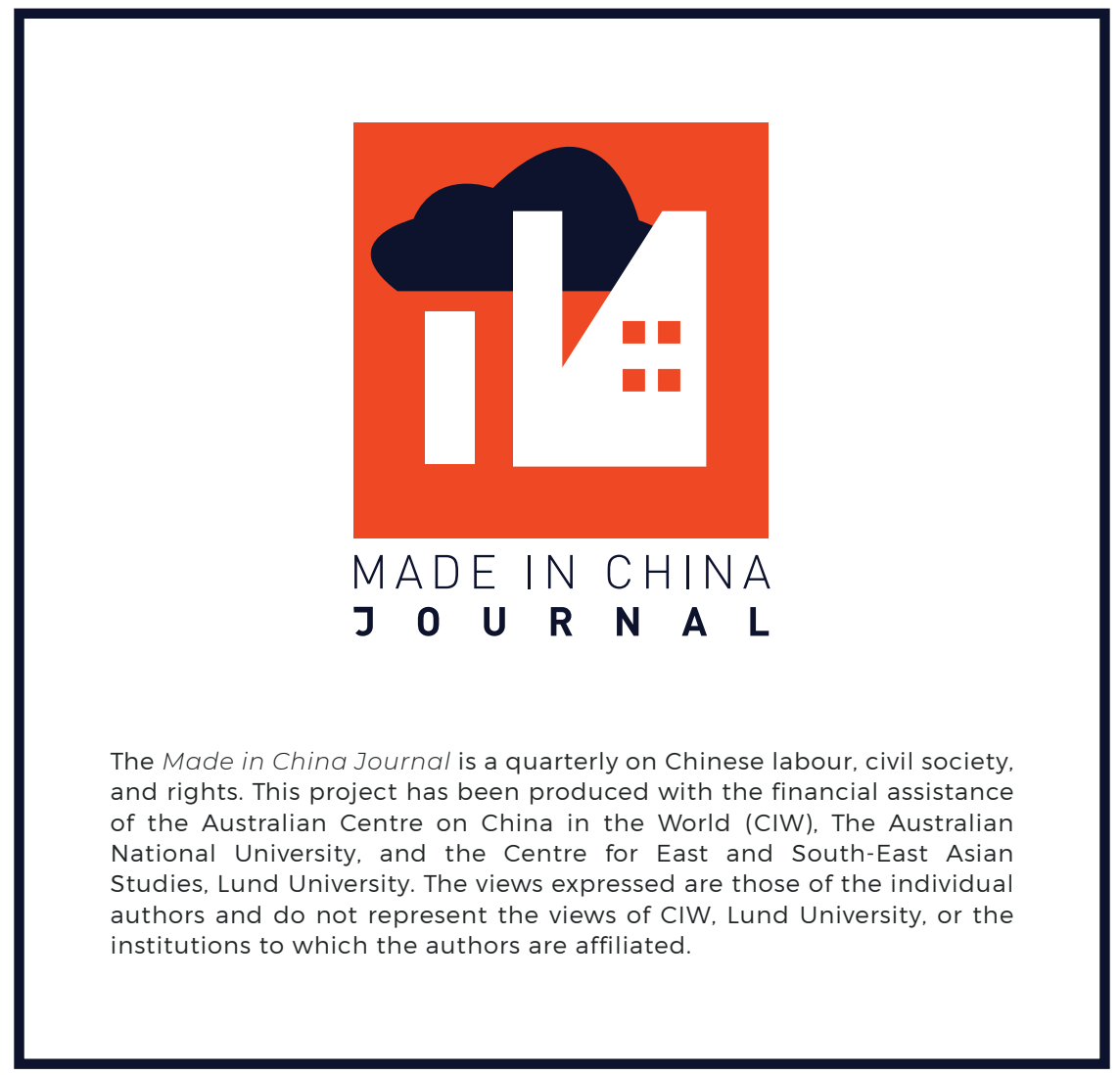

中全球研究中心

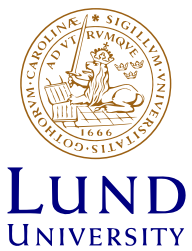




\section{ANU \\ PRESS}

Made in China Journal is published by ANU Press

The Australian National University

Acton ACT 2601, Australia

Email: anupress@anu.edu.au

This title is available online at press.anu.edu.au

ISSN 2652-6352 (print)

ISSN 2206-9119 (online)

All issues are published under Creative Commons Attribution-NonCommercialNoDerivatives 4.0 International (CC BY-NC-ND 4.0).

\section{cc) (i) $\Theta$}

The full licence terms are available at

creativecommons.org/licenses/by-nc-nd/4.0/legalcode

This edition $\odot 2020$ ANU Press

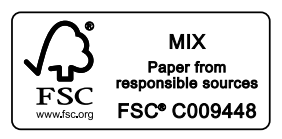

\section{EDITORS IN CHIEF}

Ivan Franceschini and Nicholas Loubere

\section{AIMS AND SCOPE:}

The Made in China Journal (MIC) is a publication focussing on labour, civil society, and human rights in China. It is founded on the belief that spreading awareness of the complexities and nuances underpinning socioeconomic change in contemporary Chinese society is important, especially considering how in today's globalised world Chinese labour issues have reverberations that go well beyond national borders. MIC rests on two pillars: the conviction that today, more than ever, it is necessary to bridge the gap between the scholarly community and the general public, and the related belief that open access publishing is necessary to ethically reappropriate academic research from commercial publishers who restrict the free circulation of ideas.

INFORMATION FOR CONTRIBUTORS:

Authors are invited to submit articles, notes, or book reviews, but are encouraged to discuss their ideas with the editors beforehand. All manuscripts are subject to a refereeing process. Manuscripts and editorial correspondence should be emailed to: editors@madeinchinajournal.com.

INFORMATION FOR READERS:

The Made in China Journal is published by ANU Press three times a year. It is freely available online with ANU Press (press.anu.edu.au) or at madeinchinajournal.com.

NOTE ON VISUAL MATERIAL

All images in this publication have been fully accredited. As this is a non-commercial publication, certain images have been used under a Creative Commons licence. These images have been sourced from Flickr. Wikipedia Commons, and the copyright owner of each original picture is acknowledged and indicated in the source information.

The Australian Centre on China in the World is an initiative of the Commonwealth Government of Australia and The Australian National University. 
The most Gothic description of Capital is also the most accurate. Capital is an abstract parasite, an insatiable vampire and zombiemaker; but the living flesh it converts into dead labor is ours, and the zombies it makes are us. There is a sense in which it simply is the case that the political elite are our servants; the miserable service they provide from us is to launder our libidos, to obligingly re-present for us our disavowed desires as if they had nothing to do with us. 


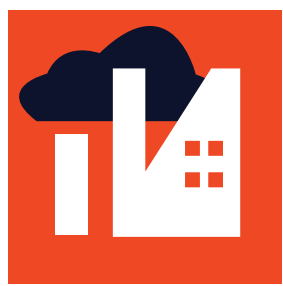

MADE IN CHINA

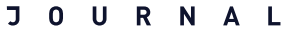

VOLUME 5, ISSUE \#2

MAY-AUG 2020

ISSN 2652-6352 (print)

ISSN 2206-9119 (online)

CHIEF EDITORS

Ivan Franceschini, Nicholas Loubere

EDITORIAL BOARD

Yige Dong, Kevin Lin, Andrea Enrico Pia,

Holly Snape, Christian Sorace, Hong Zhang

ISSUE CONTRIBUTORS

Au Loong-Yu, Mara Benadusi, Alvin Camba,

Anita Chan, Robert Cliver, Ivan Franceschini, Erin Y. Huang, Andrew Alan Johnson,

Nitasha Kaul, Frédéric Keck, James Leibold, Nicholas Loubere, Sylvia J. Martin, William Matthews, Carwyn Morris, Emily Ng, Andrea E. Pia, Rebekah Plueckhahn, Matthew P. Robertson, Gerald Roche, Flair Donglai Shi, Edoardo Siani, Christian Sorace, Chris K. K. Tan, Malcolm Thompson, Rian Thum, Michael G. Vann, Chenchen Zhang, Zhang Yueran, Mengyang Zhao, Konstantinos Zorbas

COPY-EDITING

Jan Borrie

EDITORIAL ASSISTANTS

Angelina Chen, Nan Liu

ART DIRECTION

Tommaso Facchin

COVER ARTWORK

Marc Verdugo Lopez
TABLE OF CONTENTS

EDITORIAL P.9

BRIEFS P.12

OP-EDS P.17

WHAT ABOUT WHATABOUTISM?

VIRAL LOADS AND HYPERACTIVE IMMUNE RESPONSES IN THE CHINA DEBATE P.18 IVan FRANCESCHINI

Nicholas LOUBERE

CHINA'S SECOND-GENERATION ETHNIC POLICIES ARE ALREADY HERE: WHAT CHINA'S HISTORY OF PAPER GENOCIDE CAN TELL US ABOUT THE FUTURE OF ITS 'MINORITY NATIONALITIES' P.31

Gerald ROCHE

James LEIBOLD

UNDOING LENIN: ON THE RECENT

CHANGES TO CHINA'S ETHNIC POLICY P.36

Christian SORACE

\section{CHINA COLUMNS P.46}

THE SPATIAL CLEANSING OF XINJIANG: MAZAR DESECRATION IN CONTEXT P. 48 Rian THUM

CHINA : XINJIANG :: INDIA : KASHMIR P. 62 Nitasha KAUL

COUNTERTERRORISM OR CULTURAL GENOCIDE? THEORY AND NORMATIVITY IN KNOWLEDGE PRODUCTION ABOUT CHINA'S 'XINJIANG STRATEGY' P.72 Matthew P. ROBERTSON

LENINISTS IN A CHINESE FACTORY: REFLECTIONS ON THE JASIC LABOUR ORGANISING STRATEGY P. 82 ZHANG Yueran 
FROM UNORGANISED STREET PROTESTS TO ORGANISING UNIONS: THE BIRTH OF A NEW TRADE UNION MOVEMENT IN HONG KONG P. 89

Anita CHAN

CHINESE DIASPORA ACTIVISM AND THE FUTURE OF INTERNATIONAL SOLIDARITY P.97

Mengyang ZHAO

\section{FOCUS P.102}

SPECTRAL REVOLUTION: NOTES ON A MAOIST COSMOLOGY P.104

Emily NG

THE YIJING ETHIC AND THE SPIRIT OF CAPITALISM WITH CHINESE CHARACTERISTICS P.112

William MATTHEWS

THE MACABRE AFFECTIVE LABOUR OF CADAVERS IN CHINESE GHOST MARRIAGES P.118

Chris K. K. TAN

ON UFOLOGY WITH CHINESE

CHARACTERISTICS AND THE FATE OF

CHINESE SOCIALISM P.125

Malcolm THOMPSON

SHARED VISIONS:

THE GIFT OF THE EYE P.131

Sylvia J. MARTIN

ACCIDENTS AND AGENCY: DEATH AND OCCULT ECONOMIES IN THAILAND P.138 Andrew Alan JOHNSON

THE DIVINER AND THE BILLIONAIRE: WEALTH AS MYSTERY IN BUDDHIST THAILAND P.144 Edoardo SIANI HUNTING SORCERERS IN CAMBODIA P.148 Ivan FRANCESCHINI
SHAMANISM, OCCULT MURDER, AND POLITICAL ASSASSINATION IN SIBERIA AND BEYOND P.154

Konstantinos ZORBAS

FORUM P.160

COVID-19 IN CHINA: FROM 'CHERNOBYL MOMENT' TO IMPETUS FOR NATIONALISM P.162

Chenchen ZHANG

GRATITUDE: THE IDEOLOGY OF SOVEREIGNTY IN CRISIS P.166

Christian SORACE

THE SURVEILLANCE VACCINE:

SURVEILLANCE, CENSORSHIP, AND THE BODY UNDER COVID-19 P.170

Carwyn MORRIS

SINOPHOBIA WILL NEVER BE THE SAME AFTER COVID-19 P.176

Flair Donglai SHI

BREATHING WHAT AIR? REFLECTIONS

ON MONGOLIA BEFORE AND AFTER

COVID-19 P.184

Rebekah PLUECKHAHN

THE GREAT HANOI RAT HUNT: A CONVERSATION WITH MICHAEL G.

VANN P.190

Ivan FRANCESCHINI

ASIAN RESERVOIRS: A CONVERSATION

WITH FRÉDÉRIC KECK P.202

Mara BENADUSI

Andrea Enrico PIA

WINDOW ON ASIA P. 208

BETWEEN ECONOMIC AND SOCIAL EXCLUSIONS: CHINESE ONLINE GAMBLING CAPITAL IN THE PHILIPPINES P.209 Alvin CAMBA 
WORK OF ARTS P. 218

SCHOLARS AND SPIES: EXPERIENCES

FROM THE SOVIET UNION, COMMUNIST

ROMANIA, AND CHINA P.219

Ivan FRANCESCHINI

EXPERIENCES OF THE SOUL: ON WILLIAM

SOMERSET MAUGHAM'S FAR EASTERN

WRITINGS P. 230

Ivan FRANCESCHINI

ZOMBIES OF CAPITAL: ON READING LING

MA'S SEVERANCE P.243

Ivan FRANCESCHINI

\section{CONVERSATIONS P. 248}

HONG KONG IN REVOLT: A CONVERSATION WITH AU LOONG-YU P.248

Ivan FRANCESCHINI

URBAN HORROR: A CONVERSATION WITH ERIN Y. HUANG P.261

Christian SORACE

RED SILK: A CONVERSATION WITH ROBERT

CLIVER P.266

Ivan FRANCESCHINI

CONTRIBUTORS P. 272

BIBLIOGRAPHY P. 276 


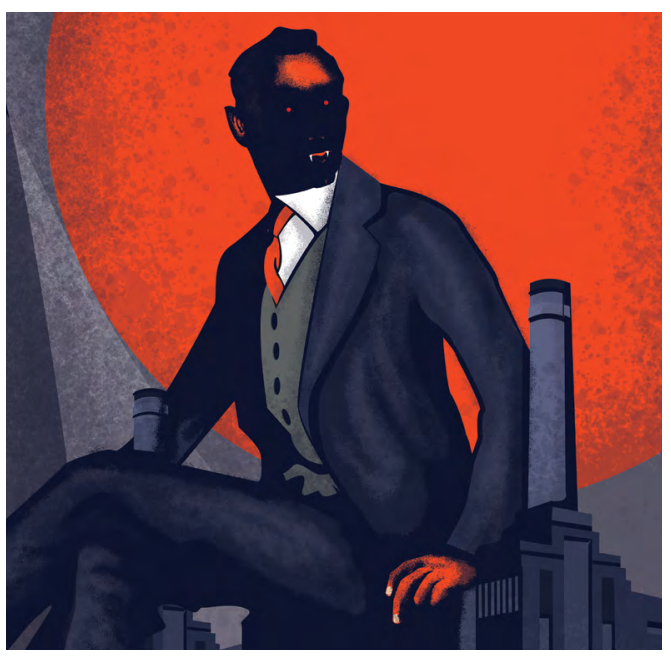

The most Gothic description of Capital is also the most accurate. Capital is an abstract parasite, an insatiable vampire and zombiemaker; but the living flesh it converts into dead labor is ours, and the zombies it makes are us. There is a sense in which it simply is the case that the political elite are our servants; the miserable service they provide from us is to launder our libidos, to obligingly re-present for us our disavowed desires as if they had nothing to do with us.

Mark Fisher, Capitalist Realism (2009)

\section{Spectral Revolutions Occult Economies in Asia}

G hostly analogies drawn from the gothic imaginary are common in the Marxist canon, with the most famous case in point being the incipit of Marx and Engels's Manifesto of the Communist Party, where readers are told that 'the spectre of communism' is haunting Europe. Far from being considered curious aberrations, these preternatural metaphors have given rise to a whole literature on spectral capitalism that spans to our present stage of late capitalism. In the 1980s, Aihwa Ong made waves with her study of spirit possessions on the shopfloors of modern factories in Malaysia, in which she argued that these spectres represented a form of resistance by workers otherwise powerless in the face of capital. In another instance from the 1990s, Jean and John Comaroff introduced the idea of 'occult economies' to make sense of the wave of episodes in which real or imagined magical means were deployed in pursuit of material gains that occurred in South Africa after the end of apartheid. While both conceptualisations received a fair share of criticism-not least for presenting the ghosts of capitalism as dreams and the anthropologist as the psychoanalyst instead of dealing with the proper social and historical context of these phenomena-this issue of the Made in China Journal cuts the Gordian knot by focussing on how individuals in China and other contexts in Asia live and interact with the supernatural. In some cases, ghosts, fortunetellers, shamans, sorcerers, zombies, corpse brides, and aliens merely assist people to get by and cope with the difficulties they face in their daily lives; in others, these beings play subversive roles, undermining the rules that underpin contemporary society. In both cases, they challenge the status quo, hence the title 'spectral revolutions'. 
The special section opens with five essays in Chinese settings. Emily Ng draws from her fieldwork in Henan to explain the cosmological role of Mao in ritual and spirit mediumship in rural China, highlighting the cosmic reverberations of Mao's earthly rule. William Matthews describes how Chinese fortunetellers use the classical text of the Yijing, contending that their naturalistic worldview provides an excellent method for people to navigate day-to-day economic decisions by forecasting fortune in a way that is trustworthy and morally blameless. Chris K. K. Tan retells some stories reported by Chinese media about criminal grave robbing and murder for the purpose of selling the corpses for use in 'ghost marriages', arguing that the cadavers perform a sort of macabre affective labour. Malcolm Thompson excavates the strange history of UFOlogy in post reform China, asking if there is, or ever was, revolutionary potential in the movement. Sylvia J. Martin analyses the 2002 Hong Kong-Thai movie The Eye within the context of the occult economies of organ transplantation, contending that through the genre of a horror film cultural meanings of vision are highlighted and heightened that go beyond the political economic analysis of extraction and exchange.

The remaining four essays are set in different contexts in Asia. Drawing from his fieldwork in Bangkok, Andrew Alan Johnson reflects on the relationship between economic 'development' and new religious movements, refusing the popular explanation that attributes this increasingly de-centred religiosity to the vicissitudes of new economic regimes, and positing it instead as an acknowledgement of a shared world in flux, with humans and nonhumans alike struggling to come to terms with what existing in a changed present might mean. Against the backdrop of Bangkok's skyscrapers, Edoardo Siani delves into the role of fortune-telling in contemporary Thai society and how the practice relates to Buddhism and the widespread desire to accumulate wealth. Moving to Cambodia, Ivan Franceschini looks back to several episodes of people in Cambodian being murdered or evicted from their villages over suspicions of sorcery, arguing that these events hark back to a primordial conflict between fields and forests that has been exacerbated by the country's development in recent years. Finally, Konstantinos Zorbas probes the revival of shamanism in a Siberian city, identifying a new type of shamanic detective and entrepreneur, whose techniques of counter-cursing cut across the state's operations of security and justice.

This issue also includes a forum titled 'Viral Loads: China and the World after Covid-19' in which we offer a few reflections on the pandemic. Chenchen Zhang describes how the Chinese Communist Party managed to get over a potential 'Chernobyl moment' in the early stages of the pandemic, after the death of Doctor Li Wenliang had caused widespread outrage, by employing a set of 'hard' and 'soft' tools to suppress dissent and overcome the trust crisis. In a similar vein, Christian Sorace notes how in the midst of the pandemic, both in China and abroad, expressions of gratitude were everywhere, and argues that the politics of gratitude ensnares us in a complicated logic of sovereignty, indebtedness, and depoliticisation that ultimately benefits the ruling authorities while also exposing their vulnerability. Carwyn Morris discusses surveillance, biopolitics, and social imaginaries related to governmental responses to Covid-19, considering why, in a period where virus and censorship converged to create a legitimacy crisis for the Chinese government, technologies that may otherwise be considered repressive came to be desired as 'technologies of vaccination'. Flair Donglai Shi considers the surge in anti-Asian racist incidents in the wake of the pandemic, arguing that Covid-19 has brought about substantive changes in Western Sinophobia and proposing a possible way out for diasporic communities. Ivan Franceschini interviews historian Michael G. Vann about his recent book The Great Hanoi Rat Hunt, which details how the French authorities (mis-) managed a plague outbreak in Hanoi in 1903, 
highlighting uncanny parallelisms and possible lessons that can be drawn from that experience. Finally, Mara Benadusi and Andrea E. Pia interview anthropologist Frédérick Keck about his recent monograph Avian Reservoirs, in which he challenges the idea of zoonosis as an Asian problem, and shows how attending to the wild and domesticated behaviours and physiology of birds reveals the multiple and often contradictory ways in which virologists and citizen scientists make sense of epidemics.

The issue includes two op-eds, the first by Ivan Franceschini and Nicholas Loubere about the whataboutism and essentialism that have become so widespread in current discussions of China, the second by Gerald Roche and James Leibold on the threat that 'second-generation ethnic policies' pose for socalled Chinese 'minority nationalities'. In the China Columns section, Rian Thum documents the Chinese state's programme of religious and historical destruction in Xinjiang, outlining its significance for affected Uyghurs, and placing it in the wider context of government efforts to transform the Uyghur built environment, both historically and in contemporary times. Nitasha Kaul examines the cases of Kashmir and Xinjiang, showing how both regions have witnessed political power as exercised by India and China, including systematic human rights violations in the name of curbing separatism and terrorism. Matthew Robertson engages with a recent high-profile paper classifying the Chinese state's coercive actions against Uyghurs as 'preventive repression', using it as a window into fundamental questions in the social scientific project. Zhang Yueran examines the decade-long labour organising strategy implemented by the Maoist activists behind the Jasic struggle of 2018. Anita Chan describes how, although Hong Kong historically has a weak trade union culture, in early 2020 activists in the protest movement turned to demanding union representation and began forming dozens of small unions from the ground up. Finally, Mengyang Zhao challenges the common misperception of diaspora activism as limited to activists' involvement in topics directly related to their homelands, often non-democracies with repressive systems, arguing that this perception trivialises the potential interaction and mutual learning between Chinese activists abroad and their local peers.

The cultural section features three review essays by Ivan Franceschini, respectively about the uneasy relationship between academia and espionage, William Somerset Maugham's writings about the Far East, and Ling Ma's prescient zombie novel Severance. In the Window on Asia section, Alvin Camba looks into the impact of Chinese online gambling capital on Philippine society. Finally, we wrap up the issue with conversations with Au Loong-Yu, Erin Y. Huang, and Robert Cliver about their recently published books.

The Editors 


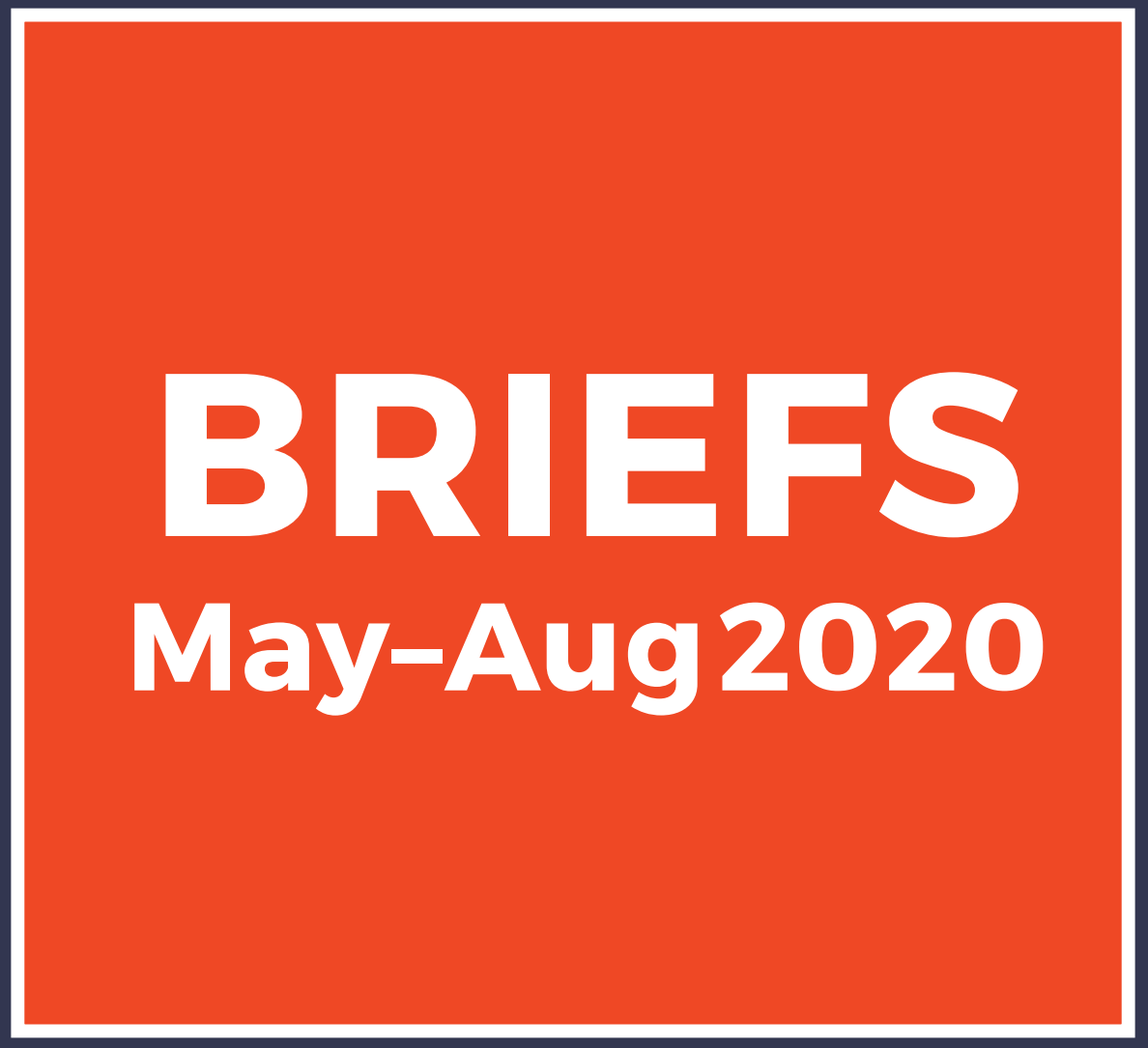




\section{MAY-AUG 2020}

\section{The National Security Law Chills Hong Kong}

The middle of the year saw the Hong Kong and mainland governments intervening with a heavy hand to rein in unrest in the former British colony. On 15 May, a 21-year-old became the first protester to plead guilty to rioting during the 2019 protests and was sentenced to four years in jail. Meanwhile, the Independent Police Complaints Council released its report on how the Hong Kong police force had handled the protests. The report concluded that the police had generally acted within guidelines and was largely dismissed as a whitewash by the city's activists. On 4 June, the National Anthem Law, which criminalises any disrespect of China's national anthem, was passed in the Legislative Council. The date was not coincidental: on the same day, thousands in the city attended the annual vigil marking the anniversary of the Tiananmen Square crackdown of 1989, defying the police ban, which had been issued for the first time in over three decades. Twenty-five activists were later charged for attending the event. Disquiet in Hong Kong peaked on 30 June, when mainland lawmakers passed a new National Security Law, which had been announced barely a month earlier. The enactment of the Law-which allowed mainland state security to establish a formal presence in the special administrative region, granted the Hong Kong police new sweeping powers, and due to its vagueness effectively acted as a sword of Damocles hanging over any dissenting voice-provoked an international backlash. In July, Canada, Australia, the United Kingdom, and New Zealand announced the suspension of their extradition treaties with Hong Kong; China retaliated by suspending extradition and judiciary assistance agreements between the first three countries and Hong Kong. The United Kingdom and Australia also extended residency rights for eligible Hongkongers, the former offering up to three million Hongkongers a pathway to British citizenship and the latter providing a five-year visa extension to Hongkongers currently in Australia. Meanwhile, on 14 July the United States revoked the special status of Hong Kong, halting defence exports and restricting the territory's access to high technology products, and on 7 August imposed sanctions on 11 former and current senior officials in Hong Kong, including Chief Executive Carrie Lam. In retaliation, China sanctioned 11 American citizens, including lawmakers. Amid such global backlash, suppression in Hong Kong continued unabated. In mid-July, Hong Kong authorities rejected a work visa application from Chris Buckley, a veteran Australian Journalist for The New York Times. On 27 July, Shiu Ka-chun, a pro-democracy lawmaker, was told his lecturing contract with Hong Kong Baptist University would not be renewed, and on 28 July, Benny Tai, a leader of the 2014 Umbrella Movement, was sacked from his tenured position as associate professor of law at the University of Hong Kong. Meanwhile, four students were detained under the National Security Law for alleged secessionist activities on social media, and the order was issued to arrest six pro-democracy activists living in exile, including US citizen Samuel Chu. Having disqualified 12 pro-democracy candidates from running in the legislative elections, on 31 July the Hong Kong government announced that the elections would be delayed by one year, citing the recent Covid-19 outbreak. On 10 August, the foreign ministries of the Five Eyes issued a joint letter expressing concerns over the disqualification of the candidates and postponement of the elections. On the same day, Jimmy Lai, a newspaper mogul, and Agnes Chow, a prominent pro-democracy activist, were arrested under the National Security Law on a charge of 'collusion with foreign powers'. Both were later released on bail. NLiu

(Sources: ABC 1; ABC 2; BBC; Hong Kong Free Press 1; Hong Kong Free Press 2; Reuters 1; Reuters 2; Reuters 3; SBS News; South China Morning Post 1; South China Morning Post 2; The Guardian 1; The Guardian 2; The New York Times; Wall Street Journal) 


\section{International Spotlight on Xinjiang}

In the middle of the year Xinjiang has remained in the international spotlight. In May, the US Congress overwhelmingly passed a bill calling for sanctions on Chinese officials implicated in the oppression of Uyghurs in Xinjiang. The Uyghur Human Rights Policy Act was signed into law by President Trump on 17 June. Roughly at the same time, the US Commerce Department also imposed new restrictions and export controls on 33 Chinese companies that were accused of helping Chinese authorities to enforce surveillance on Uyghurs in the region. Meanwhile, the Chinese government was reported to have resumed its job placement scheme for Uyghurs who had completed compulsory programmes at reeducation camps in Xinjiang after a hiatus due to the pandemic. In late June, investigations by the AP revealed that forced birth control in Xinjiang was far more widespread and systematic than previously known. On 9 July, the US Treasury Department imposed sanctions under the Global Magnitsky Human Rights Accountability Act on four Chinese officials, including Chen Quanguo, a member of China's Politburo and Party Secretary of Xinjiang. On 20 July, the US Commerce Department blacklisted another 11 Chinese companies that it said were implicated in using forced labour and conducting DNA collection and analysis on Uyghurs in Xinjiang. On 31 July, the US Treasury Department blacklisted the Xinjiang Production and Construction Corps, freezing its US assets and prohibiting Americans from dealing with it. Apart from US sanctions, more than 190 organisations from 36 countries called for formal commitments from clothing brands to sever ties with suppliers implicated in using forced labour in Xinjiang. In early August, Merdan Ghappar, a detained Uyghur fashion model, sent a video and multiple text messages that provided rare first-hand insights into the dramatic conditions inside the camps. NLiu

(Sources: BBC; Reuters 1; Reuters 2; The Associated Press; The Guardian; The New York Times 1; The New York Times 2;)

\section{Worrying News on the Human Rights Front}

Citizen-reporters and activists involved in documenting the situation in Wuhan right after the outbreak faced increased repression over the past months. Citizen journalist Chen Qiushi went missing in February and in early September 2020 there was still no news about him. Citizen journalist Zhang Zhan and activists Chen Mei and Cai Wei were detained between April and May, and only in mid-June it was announced they were to stand trial for 'picking quarrels and provoking trouble'. Repression has targeted people from all walks of life. Anti-corruption blogger Chen Jieren was sentenced to 15 years in prison on 30 April. In late June, human rights lawyer Yu Wensheng was secretly sentenced to four years in prison for 'inciting subversion of state power', while human rights lawyers $\mathrm{Xu}$ Zhiyong and Ding Jiaxi were charged with the same crime. Three Canadians were also indicted-Michael Kovrig and Michael Spavor were accused of stealing state secrets, and Sun Qian, a Falun Gong practitioner, was sentenced to eight years in prison for 'organising/ using a cult to undermine implementation of the law' after 'voluntarily' renouncing her Canadian citizenship. On 12 July, after one week in custody on allegations of soliciting prostitution, Professor $\mathrm{Xu}$ Zhangrun, the author of several essays highly critical of Xi Jinping's leadership, returned home but was later fired by Tsinghua University. In early August, rights activist Yu Xinyong, who assisted vulnerable citizens with their petitions, was sentenced to four and a half years in prison for 'picking quarrels and provoking trouble'. On the positive side, in early May five labour activists were released more than 15 months after their arrest. In late June, Lu Yuyu, who collected information about mass protests in China, and Liu Xianbin, who wrote articles critical of the Chinese government, were both released from jail. NLiu

(Sources: Caixin; CNN; Hong Kong Free Press 1; Hong Kong Free Press 2; National Post; Radio Free Asia 1; Radio Free Asia 2; Reuters; South China Morning Post 1; South China Morning Post 2; South China Morning Post 3; SupChina; The Guardian; The New York Times;) 


\section{Academia in Turmoil}

The second quarter of 2020 has seen institutions, researchers, and students with ties to China coming under growing scrutiny in the West. In February, the European Commission sent a 'concept note' to national authorities and universities suggesting that academic institutions appoint civilian spy-catchers to stop China and others from stealing secrets. In May, Sweden closed down all Confucius Institutes and Classrooms in the country, while in mid-August the US government designated them as 'foreign missions', thus requiring that they register and adhere to restrictions similar to those placed on diplomatic embassies.

The US government has been cracking down particularly hard on scientists with ties to China. In early June it was announced that 54 scientists had resigned or had been fired as a result of an ongoing investigation by the National Institute of Health (NIH) into failure of its grantees to disclose financial ties to foreign governments $-93 \%$ of the 189 scientists under scrutiny were related to China. Some of these scientists were formally charged. For instance, Harvard University's Charles Lieber, a chemist and pioneer in nanoscience and nanotechnology, was charged with tax offences; Ohio State University's Song Guo Zheng, an immunologist, faced a charge of grant fraud; Emory University's Xiao-Jiang Li, a neuroscientist, pleaded guilty to filing a false tax return.

In other cases, University of Arkansas' Simon Saw-Teong Ang, an electrical engineer, was indicted on 44 counts of fraud for failing to disclose close ties to the Chinese government and Chinese companies when he obtained federal grants. Qing Wang, a former Cleveland Clinic Foundation doctor, was arrested on charges of wire fraud and making false claims to obtain millions in federal grant funding; Stanford's Song Chen, a neurologist, was charged with visa fraud for lying about her status as an active member of China's People's Liberation Army (PLA). Juan Tang, a researcher in the Department of Radiation Oncology at UC Irvine was arrested on the same charges after leaving the Chinese consulate in San Francisco.
University administrations struggled to keep up with the developments. An incident where a Chinese student was arrested and pleaded guilty to taking photos of a US Navy base in February fuelled allegations of Chinese students as spying threats. In May, officials confirmed that the Trump administration planned to expel Chinese graduate students with ties to the PLA, a move that became effective only in early September, when the US government revoked the visas of more than 1,000 Chinese students deemed a security risk. Following the abrupt order to close Houston's Chinese Consulate in late July, researchers at the University of Texas were notified about an FBI probe over claims that the Chinese government tried to illegally obtain coronavirus research. In late August, the University of North Texas cut ties with the China Scholarship Council, the Chinese Ministry of Education's non-profit organisation that provides support for international academic exchange, effectively leading to the expulsion of 15 Chinese visiting scholars.

This wave of repression notwithstanding, several incidents led to renewed worries about China's influence on academic freedom across the globe. For instance, in Australia an article critical of the Chinese government's actions in Hong Kong by the Australia Director of Human Rights Watch Elaine Pearson was removed by the University of New South Wales after complaints from nationalist Chinese students. On a more structural level, the National Security Law in Hong Kong raised concerns about Chinese students' safety in foreign classrooms, hampering discussions of issues sensitive to the Chinese authorities. Ostensibly in response to the passage of the law, on 14 July the US government suspended the Fulbright programme for China and Hong Kong. $A C$

(Sources: Bloomberg; EU Observer; Denton RecordChronicle; Military.com; National Public Radio 1; National Public Radio 2; ScandAsia; Science; South China Morning Post 1; South China Morning Post 2; South China Morning Post 3; South China Morning Post 4; SupChina; The Crimson; The Guardian; The New York Times; Sydney Morning Herald; Wall Street Journal; US Department of Justice 1; US Department of Justice 2; US Department of Justice 3) 


\section{Resistance against New Bilingual Education Policy in Inner Mongolia}

A new bilingual education policy announced in China's Inner Mongolia Autonomous Region (IMAR) in July 2020 has sparked one of the largest protests by ethnic Mongolians in the region in recent decades. Under the new policy, Mongolian will be gradually replaced with Chinese as the medium of instruction for the classes in 'language and literature', 'morality and law (politics)', and 'history' throughout the nine years of compulsory schooling in the IMAR. Additionally, Chinese statecompiled textbooks will be used for these subjects as part of the unified national curriculum, which was previously rolled out in Xinjiang in 2017 and Tibet in 2018. While the official rationale for the imposition of the new bilingual education policy is that the new national textbooks and curriculum standards are of the highest quality, it is believed that the implementation of this policy is closely linked to the Second Generation Ethnic Policy promoted by scholar-officials in Beijing as well as to the increasing ideological control pursued by the central government. Some ethnic Mongolians have welcomed the proposed Chinese language instruction at school, believing it will help better prepare their children for top Chinese universities and coveted jobs in the Chinese economy. However, most disapprove, worrying that the prioritisation of Chinese over Mongolian will not only undermine the use of the latter as the language of instruction at school, but also erode their children's Mongolian language abilities and even their cultural identities. Amid widespread concerns and fears about the new policy, thousands of ethnic Mongolians, including parents, students, teachers, and activists, signed petitions to the education bureau of the IMAR government within days of the official announcement of the new policy on 6 July. The widely circulated petitions called for the repeal of the new policy, arguing that it violated both the Constitution and the Autonomy Law of China. As the new school semester-when the first phase of the new policy was to be implementeddrew closer, many ethnic Mongolians took to the streets to protest against the new policy, with parents vowing not to send their children to school this upcoming semester and teachers planning to go on strike. Some ethnic Mongolians also posted videos on social media, proudly declaring their Mongolian identity and singing in Mongolian. In response to the growing public anger, authorities took a series of actions. On 23 August, the only Mongolian social media application 'Beinu' was shut down, and discussions of 'Bilingual Education' were removed from various other social media platforms. Police started to break up public gatherings and protests while warning ethnic Mongolians not to attend any demonstrations and threatening to fire any teachers or other staff members participating in strikes. On 2 September, police in Tongliao city published photos of 90 people suspected of 'picking quarrels and stirring up trouble' on social media, and police in the broader Horqin district issued separate notices calling for information on over 100 people for the same accusation, with promises of 1,000-yuan cash rewards for anyone who supplied reliable information. Meanwhile, the Global Times spoke of the undue attention of anti-China forces, overseas separatists, and Western media on the situation in the IMAR, and Chinese Foreign Ministry spokesperson Hua Chunying dismissed recent reports on the IMAR as political hype. Outside China, former president of Mongolia Tsakhiagiin Elbegdorj voiced his support on Twitter for protestors in the IMAR, stressing the inalienable right for ethnic Mongolians to learn Mongolian. The Southern Mongolian Human Rights Information Centre, an exile group based in New York, also condemned the new policy. NLiu

(Sources: Bloomberg; Global Times; Made in China Journal; Radio Free Asia 1; Radio Free Asia 2; The New York Times; Wall Street Journal) 


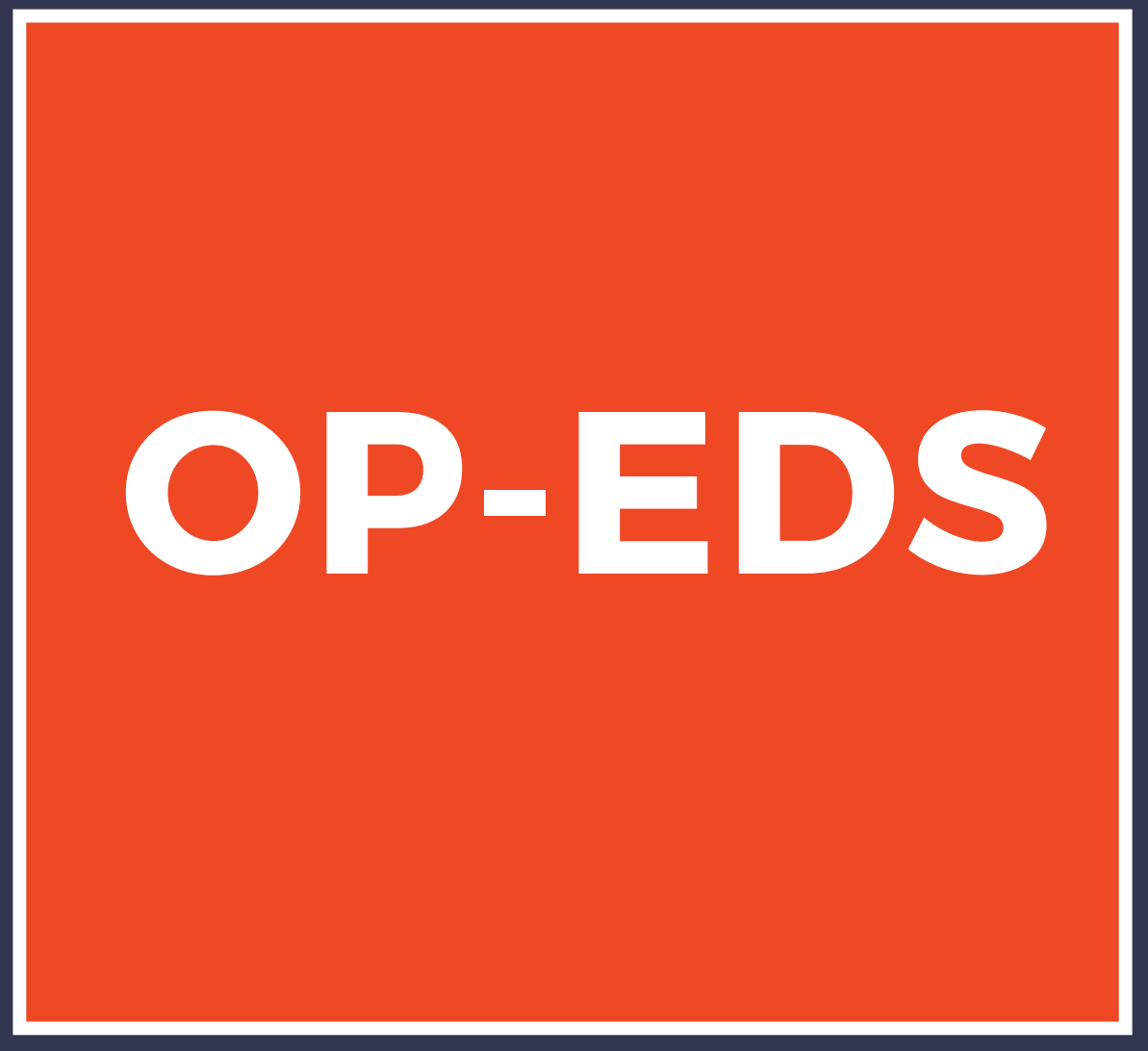



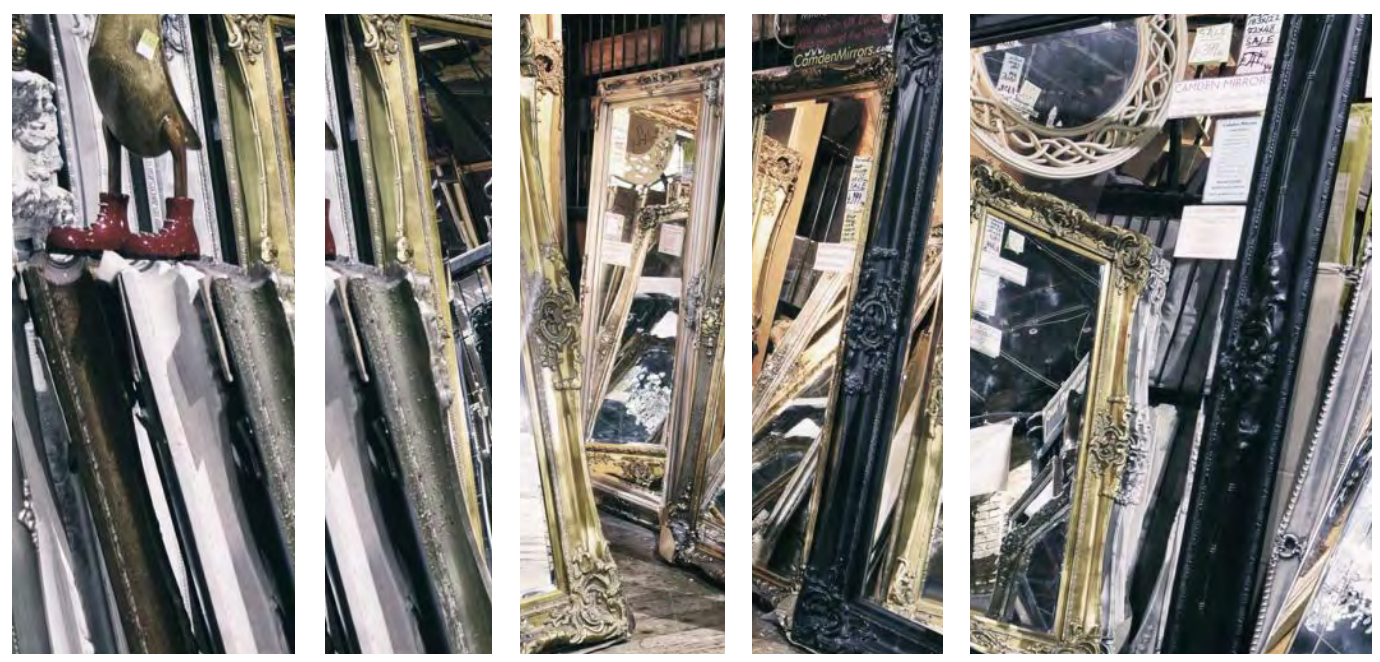

PC: Vlad B., flickr.com.

What about

Whataboutism?

Viral Loads and Hyperactive

Immune Responses in the China Debate

Ivan FRANCESCHINI

Nicholas LOUBERE

'If people actually cared about slavery they would be

holding demonstrations out the front of their local

Chinese Embassy demanding that the Falun Gong and

Uyghurs be set free.'

Tweet by an Australian journalist, 15 June 2020

'Forget about \#StandWithHK. It's time to stand with

\#Minneapolis.

Tweet by a Chinese journalist, 29 May 2020

T

weets like these are symptoms of a severe disease that has infected the public discourse surrounding Chinese and US politics: whataboutism. In recent weeks, as protests against police brutality and racism erupted in American cities, social media platforms have been awash with voices pointing out the hypocrisy of the US government in condemning the actions of the Chinese authorities in Hong Kong-unable to 
As Teng puts it, 'you say that corruption in China is serious, they say that the United States is the same; you say that China is culturally annihilating Uyghurs and Tibetans, they say that the United States also massacred the Indians and enslaved black people; you say China carries out extraterritorial kidnappings, they say that the United States attacked Iraq.' control social unrest at home, what right do US politicians have to comment on what is going on in the former British colony? Similarly, in stigmatising the mass incarcerations of Uyghurs in Xinjiang, how could they ignore their own moral bankruptcy, made evident by the grim situation of their prison system, the mass detention on the American border, and the disasters unleashed by the US-led War on Terror? Conversely, how can anyone connected to the Chinese state (even loosely) dare to comment on the protests in the United States or the plight of immigrants in detention centres on the US border, considering the situations in Hong Kong and Xinjiang?

Certainly, whataboutism is not limited to discussion of China and the United States-it can be applied to almost everything these days. Also, we are not the first to highlight its viral load. In a recent op-ed, US-based Chinese human rights lawyer Teng Biao (2020) has argued that constant comparisons between China and the United States have become a 'virus' (病毒). Taking as an example the exchanges of blows between the US and Chinese governments regarding the activities of each other's media in early 2020, Teng makes a compelling argument for how meaningless comparisons have contributed to poisoning the debate. In particular, he highlights two types of questionable comparison: the first one is shallow congruencies that do not extend beyond the surface level; the second is 'whataboutism' (比烂主义) proper. As Teng puts it, 'you say that corruption in China is serious, they say that the United States is the same; you say that China is culturally annihilating Uyghurs and Tibetans, they say that the United States also massacred the Indians and enslaved black people; you say China carries out extraterritorial kidnappings, they say that the United States attacked Iraq.'

While nothing prevents these criticisms levelled at China and the United States from being concurrently accurateindeed, both are true but one does not excuse the other-Teng is correct in his grim assessment that the current China debate is mired in superficial comparisons, false equivalencies, and whataboutist argumentation. The virus of whataboutism produces at least two symptoms. On the one hand, it fosters apathy: if any form of criticism is just seen as hypocrisy, then what is the point of having endless discussions? When does one become qualified to criticise? On the other hand, it blinds by obscuring basic similarities, muddying the water and making it difficult to identify actual commonalities that extend beyond national borders and are inherent to the organisation of the global economy in our current stage of late capitalism. Whether whataboutism finds fertile ground simply due to 
Essentialism also produces a myopic outlook, and often manifests as selfrighteous outrage at any suggestion that there might be more to the picture than what immediately meets the eye. From this perspective, there can be no linkages, seepages, or parallels between liberal democracies and authoritarian regimes. the helpless narrow-mindedness of the infected subject or is an act of purposeful contagion by voices that have a stake in misrepresenting certain truths, the result is the same: the victim becomes passive and myopic, focussing on the detail and losing sight of the broader picture, making meaningful discussion difficult.

However, this is not the end of the story. The pervasiveness of the whataboutist virus also produces a powerful hyperactive immune response in the China debate that manifests itself as the very opposite of whataboutism-i.e. a complete dismissal of any attempt to find similarities between dynamics in China and elsewhere. This is a form of argumentation that can be defined as 'essentialism', in that it tends to emphasise the set of attributes specific to a certain context as its defining elements, a line of reasoning eerily reminiscent of the debates over China's 'national character' (国民性) that raged in China and the West a century ago. While in the past similar discussions revolved around issues of race, today's essentialist arguments mostly centre around the idea that authoritarian China cannot be compared with liberal democratic countries because they represent fundamentally different political systems-and any suggestion that there may be commonalities is immediately and vociferously denounced as whataboutism and moral relativism.

Essentialism also produces a myopic outlook, and often manifests as self-righteous outrage at any suggestion that there might be more to the picture than what immediately meets the eye. From this perspective, there can be no linkages, seepages, or parallels between liberal democracies and authoritarian regimes. China must be analysed in isolation, and any analysis must identify the authoritarianism of the Chinese Communist Party (CCP) as the only constant underpinning all problems. If outside actors are involved, such as foreign governments, multinational companies, universities, etc., their participation is perceived as the result of their corruption at the hands of the CCP rather than a reflection of wider systemic issues-hence, for instance, the widespread surprise when it was revealed that the sitting president of the United States expressed support for reeducation camps in Xinjiang. At their most extreme, these essentialising responses to whataboutism insinuate that those seeking to identify convergences between China and elsewhere are apologists, useful idiots who unwittingly reproduce authoritarian talking points, or active agents strengthening authoritarianism and undermining democracy. It goes without saying that this also has the effect of shutting down debate. 


\section{Finding Parallels in Social Credit}

An illustrative example of how these two faces of the whataboutist discourse obscure and confuse our understanding of contemporary China is the discussion around 'social credit'. China's emerging social credit system-which is currently fragmented and made up of diverse models being trialled by different actors-is frequently depicted monolithically in the media as an all-encompassing, technologically sophisticated, big data-driven rating apparatus where people receive scores based on their social and economic activities (Carney 2018). When comparisons are made, it is often likened to an episode of the dystopian sci-fi show Black Mirror and/or is depicted as an extension of some traditional Chineseness-either a new manifestation of Confucian ethics or the realisation of the goals of Mao-era surveillance (Clover 2016; Palin 2018; Zeng 2018). This has resulted in widespread confusion about what social credit actually is, focussing attention on imagined fears and making it difficult to perceive its true repressive potentialities.

A number of researchers and journalists have expended considerable energy attempting to contextualise and nuance the public discussions surrounding social credit, and also illuminate the parallels and linkages with big data surveillance regimes emerging globally. However, their interventions are frequently subjected to accusations of whataboutism, with the result being that the essentialised depictions mentioned above have come to dominate. In these discourses, social credit is often constructed as a dark perversion of the supposed liberation technologies of our digital age, one that could only emerge from an authoritarian context like China. In the words of The Economist (2016a): 'In the West, too, the puffs of data that people leave behind them as they go about their lives are being vacuumed up by companies such as Google and Facebook. Those with access to these data will know more about people than people know about themselves. But you can be fairly sure that the West will have rules-especially where the state is involved. In China, by contrast, the monitoring could result in a digital dystopia.' This form of essentialist argumentation has the potential to be convincing because it contains a kernel of truth-i.e. that there are fewer impediments to the creation of a big data-driven mass surveillance regime in China than in the West. However, it also sets up a false binary between the West and China that can cause us to miss the crucial ways in which particular practices in China are shaped by, and contribute to shaping, global processes and tendencies that transcend states or political systems. In other words, it obscures the parallels 
and linkages that are crucial for understanding the dynamics of Chinese social credit and its implications for people both inside and outside of China.

In order for us to gain this broader, more holistic perspective, it is necessary to examine the goals underpinning the development of social credit in China, and consider how they link to, or resonate with, wider global trends and discourses. So, what is Chinese social credit trying to achieve? For one, it aims to create a credit evaluation and rating system to facilitate risk assessment for financial institutions and increase inclusion in the formal economy (Daum 2017). In this sense, our starting point for understanding social credit should not be as an exoticised, novel, dystopian practice, but rather as a credit rating/scoring system. China lacks a widespread infrastructure for evaluating economic risk for organisations and individuals, which has proved difficult for financial institutions, and has resulted in high transaction costs and lending bottlenecks. The social credit system seeks to fix this problem by helping financial institutions assess risk, essentially greasing the wheels of Chinese capitalism. The difference between social credit and credit scoring systems elsewhere is that the Chinese version proposes to draw on a much larger amount of data from both the social and the economic spheres (although it is unclear exactly to what extent). However, this is a difference in degree, rather than of a fundamental nature. As such, we can gain important insights into the potential functioning of social credit in China by looking at the practices and outcomes of credit scoring in other contexts, and by examining Chinese social credit we can anticipate the ways in which Western credit scoring systems might expand their risk assessment criteria in the age of big data. Indeed, one does not need to look hard to find instances of lenders leveraging information from social media in the United States and elsewhere. For example, the San Francisco-based company Affirm, which was founded by PayPal's Max Levchin, scrutinises the digital footprints of potential customers to make lending decisions (Reisinger 2015). And more cases can be found among an emerging class of digital lenders across the Global South that are 'innovating' new methods for assessing risk, often using intrusive methods (Loubere and Brehm 2018; The Economist 2016c).

Secondly, social credit is envisioned as an administrative enforcement mechanism, which will utilise data analytics to ensure regulatory compliance. This is accomplished through rewards for companies that consistently comply with regulations, and various blacklists and other forms of punishment for violators (Daum 2019; Zhang 2020). As such, this component of social credit reflects the wider global expansion of data-driven algorithmic governance techniques, 
and to fully understand the dynamics at play it is necessary to make comparisons between China's social credit system and emerging regulatory regimes around the world (Backer 2019).

Finally, the Chinese social credit system seeks to increase 'trustworthiness' (守信) and 'integrity' (诚信) through moral education as part of a wider civilisational imperative (Daum 2019). While this civilising component of social credit is rooted in longstanding state goals of creating a 'modern', 'rational' citizenry, it also draws on global discourses associated with good governance and socioeconomic development. In particular, the moral language of social credit parallels much of the discourse utilised by microcredit and financial inclusion programmes, which aim to transform 'underdeveloped' places and people into developed subjects through integration into the market. Chinese government microcredit programmes-drawing on the theories and practices of the global financial inclusion movement-seek to instil a modern credit consciousness in marginalised populations, which is explicitly linked to the concepts of honesty and trustworthiness (诚实守信) (Loubere 2018). For both microcredit and social credit, trustworthiness becomes conflated with creditworthiness. Social credit's civilising mission also resonates with the idea pushed by behavioural economists-and promoted by the World Bank (2015)-that good decision making and behaviour can be socially engineered through 'tweaks' and 'nudges' targeting individuals, ultimately resulting in broad social benefits. These ideas have been popularised in recent decades, culminating in the 2017 Nobel Prize in Economics being awarded to Richard Thaler for his work on 'nudge theory' and the 2019 Nobel Prize in Economics being awarded to three development economists who pioneered the randomised control trial (RCT) for socioeconomic development. Both of these approaches have been key to the expansion of social experiments on populations (mainly in the Global South) in an attempt to socially engineer different types of behaviour (Chelwa and Muller 2019). The comparisons with the goals of social credit are obvious and necessary.

Ultimately, as legal scholar Jeremy Daum (2019) points out: 'There can be great comparative value for democracies in watching China's integration of technology, governance, and society, but meaningful comparison requires accurate understanding.' In order to acquire this more accurate understanding, it is necessary to be able to identify crucial commonalities with what is happening in China and elsewhere, and how these things are connected. If we fail to do this, then we either ignore one of the most important developments in digital social control because we relativise through whataboutist arguments; or adopt an essentialist stance and 
The Xinjiang camps can also be considered an extension of settler colonial logics and practices dating back to European colonialism, where native populations were brutally suppressed and concentrated on reservations (Nemser 2017). assume that social credit is something unique to China's brand of authoritarianism, thus failing to see how it is actually rooted in, and contributing to, a global trajectory of rapidly expanding algorithmic governance and surveillance. At the extreme end, this inability to identify parallels and linkages results in absurdities, such as The Economist running an article titled 'Test of Character' praising the use of 'psychometrics with social media and mobile-phone records' to assess financial risk in the Global South-allowing financial institutions to 'peer into their customers' souls'-while just two months later publishing another article on China's social credit system titled 'China Invents the Digital Totalitarian State' (The Economist 2016b and 2016c). Needless to say, the failure to perceive the shared rationalities, practices, and potential outcomes of intrusive private psychometric surveillance and China's social credit system impairs our ability to collectively militate against the rapid emergence of oppressive technologies around the world.

\section{Carceral Capitalism in Xinjiang and Beyond}

A second example of dynamics in China that require us to identify global linkages can be found in the horrific 'reeducation' camps of Xinjiang. These camps-where an estimated one and a half million Uyghurs have been locked up since 2017-also do not exist in a void. While the current situation in Xinjiang has deep roots in longstanding Han suppression of Ugyhur identity, as well as in discourses of 'blood lineage' emerging in the Maoist era, this is not the whole story (Cliff 2016; Yi 2019). The Xinjiang camps can also be considered an extension of settler colonial logics and practices dating back to European colonialism, where native populations were brutally suppressed and concentrated on reservations (Nemser 2017). Indeed, the recent revelations that the Chinese government is engaging in the forced sterilisation of Uyghurs echo the eugenics campaigns targeting native populations in the United States and elsewhere in the twentieth century (Amy and Rowlands 2018; BBC 2020). The Xinjiang camps can also be seen as the culmination of a century-long global process in which concentration camps were first conceived by the Spanish in Cuba in the late 1890s, expanded by the British in South Africa during the Boer War, normalised by all warring factions during the First World War, and finally manifesting in the extreme variants of the Soviet Gulags and the Nazi lagers, before lapsing into the more familiar forms of 'black' detention sites that became common in Latin America in the 1970s.

Western liberal democracies have also repeatedly established concentration camps in recent history, from the British experience in Malaysia and Kenya in the 1950s-stories that 
the British government has consistently attempted to hide and manipulate (Monbiot 2020)-to the latest experiments of the US government with extrajudicial detentions in Guantanamo Bay and mass internment of undocumented immigrants. As journalist Andrea Pitzer (2018, 13) has argued, concentration camps are deeply rooted in modernity, particularly in advances in public health, census taking, and bureaucratic efficiency that took place in the late nineteenth century. They are also inextricably linked to inventions like barbed wire and automatic weapons. At the same time, 'only rarely have governments publicly acknowledged the use of camps as deliberate punishment, more often promoting them as part of a civilizing mission to uplift supposedly inferior cultures and races' (Pitzer 2018, 6). In this sense, the Chinese authorities are not only trailing this tradition by maximising the 'benefits' of the latest progress in surveillance technology to establish its twenty-first century version of concentration camps in Xinjiang, but they are also lifting heavily from established discourses to justify such an endeavour.

Concentration camps in Xinjiang are not monads even in the context of today's world. It is possible to identify both discursive and material linkages between the events unfolding in northwest China and global trends. On the discursive side, the Chinese authorities have widely appropriated international discourses of anti-terrorism related to the US-led War on Terror to justify their securitisation of Xinjiang. David Brophy (2019) has written about the 'war of words' over the Xinjiang question between Chinese authorities and foreign critics, pointing out how Chinese officials justify the camps by citing what they see as a worldwide consensus-which emerged in the wake of the global War on Terror-on the need to combat radicalisation through preemptive measures that identify, isolate, and rehabilitate potential extremists. According to the logic of the Chinese authorities, if the camps in Xinjiang go beyond any Western attempt at countering extremism, it is simply because counterextremism policing in the West, focussing only on select individuals, has not done enough to prevent acts of terrorism.

In the same vein, Darren Byler (2019b) has put on display the poignant similarities between the attempts to construct a 'human terrain system' through weaponised ethnography by the US forces in Iraq and Afghanistan, and the way in which the Chinese authorities are acting in Xinjiang, while also unearthing how shifts in US military doctrine in the field of counterinsurgency since the late 2000s were first received and adapted in China, before being put into practice in Xinjiang. This link is also made in an influential recent paper by Sheena Greitens, Myunghee Lee, and Emir Yazici (2020), in which the authors argue that China's rhetoric about Central Asia's Uyghur 
diaspora began to shift following the attacks of 11 September 2001, with the Party-state drawing connections between Uyghur organisations and jihadist groups, especially those in Afghanistan and Pakistan, instead of emphasising pan-Turkic separatism.

While the implications of this cooptation by the Chinese authorities of counterinsurgency discourses emanating from the War on Terror remain highly controversial (Robertson 2020), the material side of the global dimension of the camps is a more straightforward example of the 'complicities' existing between Western capitalism and the People's Republic of China (Dirlik 2017). There is no denying that Chinese and multinational corporations are deeply involved in the development of surveillance technologies that are used in Xinjiang. As Darren Byler (2020) has highlighted, local authorities in Xinjiang have recently started outsourcing their policing responsibilities to private and state-owned technology companies in order to enhance their surveillance capacities through private-public partnerships. These companies, especially those that are leading the way in the field of artificial intelligence, operate well beyond Chinese borders. In an uncanny instance that he cites, in April 2020 Amazon received a shipment of 1,500 heat-sensing camera systems to take the temperatures of its workers during the coronavirus pandemic. These units came from Dahua, a Chinese company that in 2017 received over 900 million USD to build comprehensive surveillance systems to support the expansion of extra-legal internment, checkpoints, and ideological training in Xinjiang ( $\mathrm{Hu}$ and Dastin 2020).

The global mercenary business is also involved. For instance, in early 2019 the Frontier Services Group, a private security firm run by Blackwater founder Erik Prince, announced plans to open a 'training centre' in Xinjiang (Roche 2019). Although all the information about the company's involvement in the region was subsequently taken offline (Ordonez 2019), the announcement highlighted another problematic set of complicities between global capitalism and repressive practices of cultural suppression in China and beyond.

At the same time, foreign universities are actively taking part in developing the technology and techniques that the Chinese authorities are using to ramp up surveillance in Xinjiang. Leading international academic institutions, including the Massachusetts Institute of Technology, have come under scrutiny for having research partnerships with artificial intelligence companies that have business ties with state security organs in the region (Harney 2019). To cite just a few specific examples, in August 2018 Anil K. Jain, head of Michigan State University's Biometrics Research Group, travelled to Xinjiang's capital, Ürümqi, and gave a speech about facial recognition at 
the Chinese Conference on Biometrics Recognition, for which he also sat on the advisory board (Rollet 2019). In 2019, the University of Technology Sydney (UTS) and Curtin University in Perth both had to review their links to Chinese companies and researchers over concerns that the partnerships could be helping China persecute Uyghurs (McNeill et al. 2019). UTS, in particular, was revealed to have a ten-million-AUD partnership with CETC, a Chinese state-owned military tech company that developed an app used by Chinese security forces to track and detain Uyghurs. Finally, also in 2019, it emerged that to bolster their DNA tracking capabilities, scientists affiliated with China's police force drew on material and expertise provided by Kenneth Kidd, a prominent Yale University geneticist, while using equipment made by Thermo Fisher, a Massachusetts company (Wee 2019).

In fact, there are many instances of Chinese companies approaching foreign universities either directly or through their shadow subsidiaries, and offering funds under the generic banner of 'supporting collaboration between academia and industry'. While fostering international partnerships and collaboration is undoubtedly part of the core mission of universities, as James Darrowby (2019) has pointed out, the key areas for proposed collaboration in the case of Chinese companies often focus on the development of the next generation of audiovisual tracking tools, which represent significant potential for military and domestic surveillance applications. With neoliberal universities often forced to seek and accept funds from any available source to justify their very existence in the eyes of the government, they frequently sidestep due-diligence procedures and end up abetting projects that contribute to ramped-up surveillance and repression in China and elsewhere. And this kind of complicity does not even touch upon matters such as the nature of research affiliations with foreign institutions, conflicts of interest, undisclosed double appointments, and the dissemination and application of sensitive project outputs. Essentialist depictions of this situation are widespread but again only provide us with a partial picture. While emphasis is frequently placed on the nefarious activities undertaken by Chinese state actors aimed at corrupting Western higher education institutions, there is much less attention paid to the ways in which the marketised and managerialised university has become eminently pliable to outside interests through funding and research partnerships.

It would be a mistake, however, to reduce corporate involvement in Xinjiang to high-tech actors involved in surveillance and carceral capitalism, as the camps also represent an opportunity for more 'traditional' business. As Darren Byler (2019a) has shown, since 2017 Chinese factories 
have been flocking to Xinjiang to take advantage of the cheap labour and subsidies offered by the reeducation camp system, a move that can partly be explained by the rising labour costs in more developed parts of the country. Significantly, even before the beginning of the camps, the Chinese Party-state was already planning to move more than one million textile and garment industry jobs to the region (Patton 2016). While many of these companies are obviously linked to global supply chains, they are not the only ones benefiting from the rampedup securitisation of the area. A recent report by the Australian Strategic Policy Institute (Xu et al. 2020) has shown that more than 80,000 Uyghurs were transferred out of Xinjiang to work in factories across China between 2017 and 2019, with some of them sent directly from detention camps. Far from producing exclusively for domestic consumption, these Uyghurs are working in factories that are in the supply chains of at least 83 well-known global brands in the technology, clothing, and automotive sectors, including Apple, BMW, Gap, Huawei, Nike, Samsung, Sony, and Volkswagen.

In that the goal of the internment factories is to turn Kazakhs and Uyghurs into a docile yet productive lumpen class-one without the social welfare afforded the rightsbearing working class' (Byler 2019a), the camps in Xinjiang appear to be a manifestation of a capitalist system always hunting for new workers and markets to exploit in order to sustain itself. In other words, it could be argued that the camps are not really an anomaly or a sign of the capitalist system being corrupted by China, but simply a feature of the system itself. These systemic features can also be seen, for instance, in the policing and incarceration systems of the United States, where widespread racial profiling leads to the detention of a hugely disproportionate number of young black men-a demographic that is systematically maintained and reproduced as a lowwage labour supply (Benns 2015). In fact, if we consider the discursive and material linkages and parallels outlined above as a whole, the recent Uyghur Human Rights Policy Act as recently passed by the US government and the blacklisting of a few Chinese companies working on artificial intelligence and facial recognition, while highly symbolic and undoubtedly important, play little more than a cosmetic role rather than addressing the root causes of the abuses.

In such a context, both whataboutist and essentialist arguments, while constructed in opposition to each other, serve to obscure the situation in Xinjiang in similar ways-by fragmenting and atomising our analysis, and thus causing us to miss crucial parallels, linkages, and complicities. Whataboutism does this dismissively, resorting to moral relativism and claims of hypocrisy to rationalise away wrongdoing, while failing to 
recognise that global practices are connected. Essentialism does it by attributing the horrifying situation in Xinjiang solely to the CCP, thus failing to identify the linkages emerging from a global system. As such, both whataboutism and essentialism serve as blinders, forcing us to focus on a single part of the picture-e.g. the fact that the United States is involved in abuses too or that the CCP has a long history of repression in Xinjiang-while ignoring the bigger story. These atomised and myopic perspectives fail to provide us with the analytical tools necessary to diagnose and organise against the horrors unfolding in Xinjiang and elsewhere.

\section{Casting Out the Beam}

So, how should we deal with the virus of whataboutism and its essentialist hyperactive immune reaction? We definitely cannot succumb to the feelings of apathy and the blindingly myopic outlook that they produce. With regard to the accusations of hypocrisy so common in whataboutist arguments, it would be nice if we all heeded Jesus's injunction to 'first cast out the beam out of thine own eye; and then shalt thou see clearly to cast out the mote out of thy brother's eye'-leaving aside the issue of who has a beam and who a mote in their eye-but if we were to wait for that to happen before we speak up, most likely there would not be much debate going around. On the other side, if we fall into essentialist reasoning, the only solution to any problem appears to be complete regime change in China. From this perspective the fall of the CCP serves as a deus ex machina for the world's problems, which paradoxically can produce both euphoric (but misguided) optimism for the future based on imagined signals that the regime is on the brink of collapse or, alternatively, a sense of dejected apathy at the hopelessness of the situation.

To inoculate ourselves against whataboutism while also preventing the pendulum swing into essentialism, we should strive to identify meaningful commonalities and underlying dynamics at both discursive and material levels. If nothing else, that is where we can still hope to find some power to act. While China's social credit system and mass incarceration in Xinjiang present us with two instances of global connections that are frequently obscured in current debates on Chinese politics, these examples are also part of an extremely grim broader picture. Around the world we are seeing some very disturbing trends-a general authoritarian shift, the development of repressive technologies, and the further normalisation of mass detention regimes. As easy as it is to lay the blame for all this on China-and undeniable as it is that the Chinese government 
It is our belief that it is not whataboutism to condemn tyranny in different places and that authoritarianism in all its variations must be opposed everywhere. Indeed, finding parallels and linkages between the Islamophobic policies of the Trump administration, the anti-Muslim populism currently ravaging India, and the brutal situation in Xinjiang need not be an act of whataboutism, but rather a statement that these practices are unacceptable everywhere, and must be contested as a whole. is playing an important role in all this-these trends are not emanating solely from one country. Rather, what is happening in China is just one dramatic manifestation of global phenomenaphenomena that are, in turn, shaped by broader forces. For this reason, we need to go beyond essentialist and whataboutist approaches and carefully document (and denounce) what is happening in China, while also highlighting the ways in which Chinese developments link up with events elsewhere.

It is our belief that it is not whataboutism to condemn tyranny in different places and that authoritarianism in all its variations must be opposed everywhere. Indeed, finding parallels and linkages between the Islamophobic policies of the Trump administration, the anti-Muslim populism currently ravaging India, and the brutal situation in Xinjiang need not be an act of whataboutism, but rather a statement that these practices are unacceptable everywhere, and must be contested as a whole. Similarly, we cannot overlook the role of international actors, including multinational corporations and universities, in fostering the worst abuses we are witnessing all over the world today. Only by finding the critical parallels, linkages, and complicities can we develop immunity to the virus of whataboutism and avoid its essentialist hyperactive immune response, achieving the moral consistency and holistic perspective that we need in order to build up international solidarity and stop sleepwalking towards the abyss. 


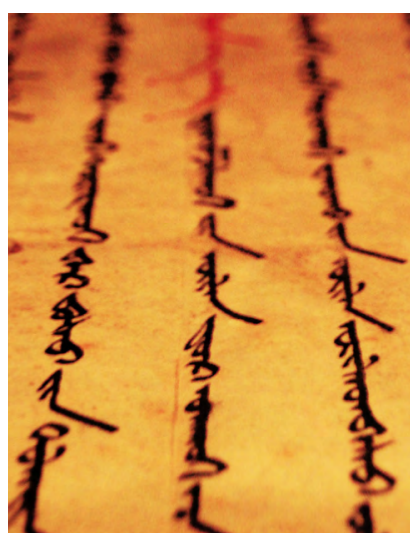

Old Mongolian Script, PC: Svenni Zimsen.

\section{China's Second- generation Ethnic Policies Are Already Here \\ What China's History of Paper Genocide Can Tell Us about the Future of Its 'Minority Nationalities'}

\section{Gerald ROCHE}

James LEIBOLD

$\mathrm{n}$ early June this year, officials in the Inner Mongolia Autonomous Region (IMAR) released a new policy that would drastically undermine the use of the Mongolian language in schools, effectively replacing it as a language of instruction with Chinese (Baioud 2020). In response to this unwelcome imposition, petitions began circulating, calling for the repeal of the policy and eventually leading to street demonstrations, school boycotts, and other protests (Qiao 2020; Zhou 2020). The situation remains tense.

The policy that has been announced in Inner Mongolia, and the protests it prompted, bears many similarities to the situation in Qinghai province a decade ago. There, local government officials announced similar changes to the Tibetan-medium education system, effectively relegating Tibetan language to the status of a subject, and implementing a Chinese-medium system. These announcements were followed by street and campus protests throughout Qinghai and beyond (Wong 2010).

Meanwhile, in the Xinjiang Uyghur Autonomous Region (XUAR) and the Tibetan Autonomous Region (TAR), mother tongue education for Uyghurs and Tibetans has also come under fire. In Xinjiang, this culminated in an official pronouncement that, like in Qinghai and now Inner Mongolia, Chinese would become the new medium of instruction (Byler 2019). Meanwhile, in the TAR, a recent Human Rights Watch report (2020) has described how schools are under increasing pressure to 'reduce the availability of mother tongue education' and 'shift to Chinese-medium teaching'. Party officials claim the universalisation of the 'national language' (普通话, putonghua) is necessary to promote poverty alleviation, interethnic mingling, and social stability, despite the right for ethnic 
Ethnic minorities like the Mongols, Tibetans, and Uyghurs no longer have special exceptions to family planning laws. The extra points they once received on the national university entrance exam (高考) are being reduced and will soon be eliminated entirely. minorities to 'use and develop' their languages being enshrined in the Chinese Constitution, and mother tongue education being encouraged in law (Roche 2020).

In his recent analysis of the situation in Inner Mongolia, Chrisopher Atwood (2020) ties the government's response there to the 'second-generation ethnic policies' (第二代民族 政策). Earlier events in Qinghai, Xinjiang, and the TAR also seem to emerge from this new approach, thus prompting the question: what are these second-generation ethnic policies?

\section{Second-generation Ethnic Policies}

First proposed in late 2011 by two scholar-officials, Hu Angang and $\mathrm{Hu}$ Lianhe, the policies call on China to abandon its failed 'hors d'oeuvres'-style ethnic policies, which they contend the Chinese Communist Party copied indiscriminately from the Soviet Union, and instead adopt a 'melting pot' formula more in line with Chinese tradition and international norms (Leibold 2013). This requires the abandonment of ethnic privilege and distinction, and the proactive forging of a common culture, consciousness, and identity. If such measures are not adopted, these ethnic policy reformers argue, China would share the fate of the USSR and come apart along its ethnic seams.

This reform agenda found a sympathetic ear with the appointment of Xi Jinping as Party Secretary General in 2013, and over subsequent years key parts of the policy have been gradually yet steadily implemented across China (Leibold 2015 and 2019). This involves not only the universalisation of putonghua-medium education, but also the scaling back and eventual elimination of a range of preferential policies (优惠政 策) protected under the Chinese Constitution and the 1984 Law of Regional Ethnic Autonomy.

Ethnic minorities like the Mongols, Tibetans, and Uyghurs no longer have special exceptions to family planning laws. The extra points they once received on the national university entrance exam (高考) are being reduced and will soon be eliminated entirely. Judicial leniency has now been replaced with heavyhanded incarceration and reeducation in the name of stability maintenance. And any cultural or religious rights-beyond the tokenistic and voyeuristic-are being slowly hollowed out and replaced with a heavy dose of 'patriotic education', 'interethnic mingling', and lessons in 'becoming Chinese' (Leibold 2016 and 2019).

What unites these policies is their focus on removing 'minority privileges' as a way to ensure integration, promote nationalism, and create a more homogeneous society. In this sense, they share much in common with colonial practices that have been tried and tested elsewhere. 


\section{The Recognised and the Unrecognised}

We can identify two related colonial techniques. One is to deny the existence of subaltern groups. Another is to recognise the existence of these groups, but to bar membership to them. Both techniques create a division between the recognised and unrecognised-between those with and without collective rights.

In Sweden, the 'reindeer laws' based Sami identity on participation in reindeer herding, and so Sami who practised agriculture or lived in towns were denied recognition (Axelsson 2010). In the United States, the system of federally recognised tribes denies the existence of certain groups (Ramirez 2007). In Australia, Indigenous groups must be able to show an ongoing connection to their traditional territory to gain access to native title, and in cases where they cannot, their claims are denied (Vincent 2017). In India, the state reduces the over 10,000 languages named by its citizens in the census to just over 100, by imposing arbitrary standards such as a population threshold of 10,000 (Kidwai 2019).

In all these cases, the state aims to avoid meeting its obligations to Indigenous and minority peoples by declaring them nonexistent. In short, they engage in what has been called 'paper genocide'-the destruction of a people by their exclusion from formal recognition by the state (Deerinwater 2019).

The second-generation ethnic policies, however, do not propose to undertake paper genocide by denying the existence of the 55 formally recognised minority nationalities (少数民族) in the People's Republic of China (PRC). Rather they achieve similar effects by making the distinctiveness of minority nationalities meaningless, by removing the legal significance of this recognised distinction while slowly integrating them into mainstream society and its norms. Therefore, in order to understand the impacts this is likely to have, we can look at the historical experience of groups in China that have undergone paper genocide: those that were refused recognition in the ethnic classification process. These groups, denied recognition by the state, offer a window onto the future of recognised nationalities (民族, minzu) under the second-generation policies.

\section{Victims of Paper Genocide}

Non-recognised peoples emerged in the PRC as a result of the ethnic classification process (民族识别) during the 1950s. Rather than a way to negotiate rights and privileges for preexisting groups, this process aimed to establish what the 
categories of recognition were to be, and then decided what rights, such as regional autonomy, would be delegated to them (Bulag 2019).

Thomas Mullaney (2011) has described how this process involved both expert testimony and the consent of the classified. In Yunnan, linguists classified the population on the basis of linguistic similarity. Local cadres then worked with representatives of those populations to convince them that they 'actually' spoke those languages, highlighting points of similarity across barriers of mutual unintelligibility. Through similar processes of amalgamation, the original $400+$ groups initially recognised in the PRC were reduced to the 56 nationalities recognised in China today.

This process involved vast and violent processes of merging and melding, lumping together disparate groups on the basis of their 'ethnic potential'. Cherished identities were rendered nonexistent. Groups that were caretakers of centuries of collective memory were suddenly obliterated in the eyes of the state and, in order to make their claims legible, were required to represent themselves in the state's terms-regardless of the language they spoke, identity they professed, customs they practised, and affinities they felt.

Occasionally, the groups that were obliterated in this process resurface to remind the state of their existence. For example, in Sichuan, the Baima people, who are classified as Tibetans, have petitioned to be recognised as a separate nationality (Upton 2000). The authorities refused, and the Baima are now compelled by the state to be Tibetan, and hence must choose between 'mother tongue education' in Tibetan, or education in Chinese-neither of which is their own language. Similarly, the Ersu people have petitioned to have their distinct identity recognised and to refuse their classification as Tibetans, and the state refused ( $\mathrm{Wu} 2015$ ). Guizhou is home to some 21 distinct groups who are 'unclassified'. Yet in 2014, Xi called an end to this game-declaring China would not only have no new minzu groups but that it also needed to actively fuse the existing ones together (Leibold 2014).

Non-recognition and the removal of 'minority privileges' have the same effects: they both deny groups their rights to their own cultures, languages, and identities. Non-recognition silences by denying the existence of the group while secondgeneration ethnic policies recognise the existence of the group, but deny that they should have any specific rights. Both end in the same place: with the denial of collective rights.

What has happened to the unrecognised groups of the PRC since they were stripped of their rights? Although their identities sometimes remain, they have been subordinated to official categories, giving rise to new hybrid terms such as 
Baima-Tibetans, or semi-official, sub-minzu categories like Mosuo or Chuanqing people (人 ren, rather than minzu) that have no standing in the law. Denied the right to exist, these groups have largely succumbed to the state's assimilatory pressures.

Among Tibetans, for example, the languages associated with unrecognised groups are all in the process of being eliminated, with most groups shifting towards Chinese, and a few to Tibetan (Roche 2019). More broadly, the refusal to recognise these groups is driving the widespread elimination of languages across the PRC: linguists in China estimate that half the country's languages are being replaced with either putonghua or languages of recognised minzu (Xu 2013).

\section{On Having Something to Lose}

Unrecognised groups in China have never protested the removal of their languages from schools, because their languages have never been used in schools. As the state and its institutions were built around them, these groups and their languages were excluded every step of the way.

Mongols are protesting because they have something to lose. They have an education system and other institutions that recognise and reproduce their language. And they can look to Xinjiang and Tibet to see what happens when these institutions are taken away.

But we should also look to the unrecognised groups of China, and see how paper genocide has led to cultural genocide. What Mongols fear to lose, most languages in China have never been granted. The situation in Inner Mongolia rightly raises concerns about the assimilatory intent of second-generation ethnic policies. The PRC's unrecognised peoples show us how warranted these fears are, because they have been living with these policies since 1949 . 


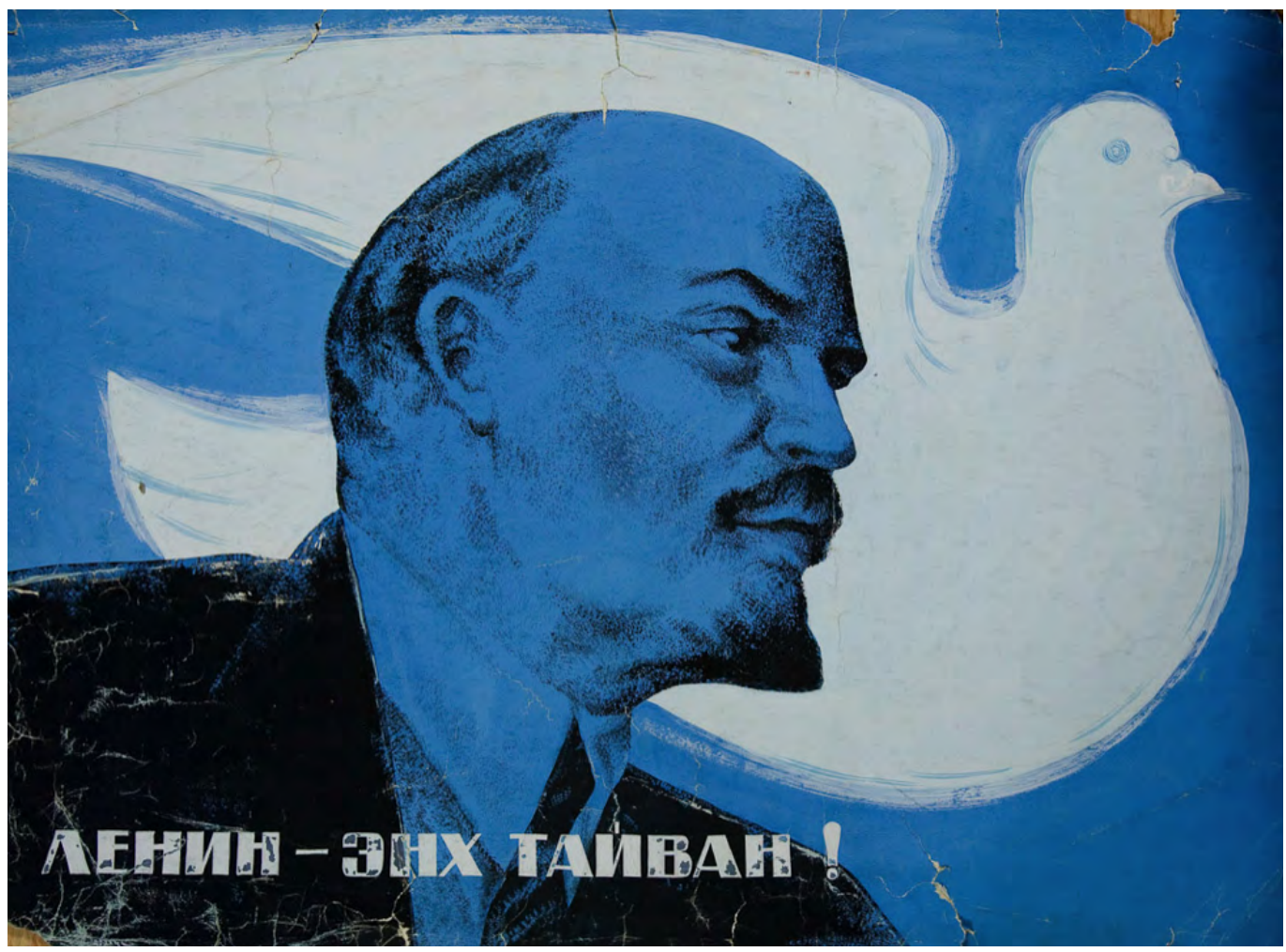

Ts. Davaahuu 'Lenin-Peace!' PC: Courtesy of Mongolian National Modern Art Gallery.

\section{Undoing Lenin \\ On the Recent Changes to China's Ethnic Policy}

Christian SORACE

Were has been a lot of ink spilled over recent weeks on the changes to 'bilingual education' policy in the Inner Mongolia Autonomous Region (IMAR) of China, and protests among ethnic Mongolians in response to what is feared might become the first step in the eventual erasure of the Mongolian language and identity. For this reason, I will not delve into the specifics of the immediate matter, which has been covered comprehensively in Christopher Atwood's 'Primer' in the Made in China Journal, a joint letter from anthropologists Caroline Humphrey and Uradyn Bulag, an essay from the Red Horse Reading Club (红马读书会) that has been translated from Chinese into English, and op-eds by Gegentuul Baioud and Li Narangoa. Instead, I want to elaborate one point that 
bears repeating and that is missing from most of the coverage of what is happening: the current language policy is in direct contradiction to the views Lenin held in the last years of his life on national autonomy and a departure from the political vision of the early Mao years that is still enshrined in the Constitution of the People's Republic of China (PRC). Instead it is a turn toward a Chinese national 'multiculturalism' inspired by the United States. This is not a good thing.

This intervention is a response to three untenable positions: 1) Empty talking heads who repeat the catechism that $\mathrm{Xi}$ is enacting a return to Mao, because they reduce all politics to the question of power and therefore understand neither; 2) All of the red-baiters in the United States who emphasise the 'Communist' in the Chinese Communist Party (CCP) and are attempting to reheat the stale leftovers of the Cold War (afraid of the rising socialist and communist consciousness among millennials domestically); and 3) those on the left whose logic inverts that of the second group, believing that China is indeed 'Communist', which absolves it of the sins of settler colonialism, capitalism, and environmental destruction.

\section{Down with Great Power Chauvinism!}

In the final years of his life, Lenin declared 'war to the death on dominant-nation chauvinism' (Lenin 2017, 111). Presciently terrified that the Bolsheviks would continue the Tsarist mentality and imperialist tendencies of Great Russian Chauvinism, Lenin mused whether the Soviet state apparatus remained the one 'we took over from Tsarism and slightly anointed with Soviet

'At the Commissariat of Education, or connected with it, there are communists who dare say that our schools are uniform schools, and therefore don't dare teach in any language but Russian! In my opinion, such a Communist is a Great Russian chauvinist. Many of us harbour such sentiments and they must be combated.' oil' $(1975,720)$ or whether it could be destroyed and remade along communist principles. These principles would require a definitive rupture with chauvinist tendencies that Lenin saw all around him. To provide one example pertinent to the issue of language education, Lenin $(1975,660)$ unequivocally rejected the idea of Russian linguistic dominance at the expense of national languages: 'At the Commissariat of Education, or connected with it, there are communists who dare say that our schools are uniform schools, and therefore don't dare teach in any language but Russian! In my opinion, such a Communist is a Great Russian chauvinist. Many of us harbour such sentiments and they must be combated.'

From the above passages, two important points emerge. First, communist revolution is not simply a change of who is in power but must be a transformation of the relations of power-in 1945, Mao's answer to the question of how to break free from the cyclical history of dynastic rise and collapse (周期轮) was 
'democracy' (Barmé 2011). Second, for Lenin, communism must be international, and therefore multilingual, or it would be nothing at all.

Lenin's rejection of great power chauvinism needs to be understood alongside his defence of the independence of smaller nations. Historian Moshe Lewin (2005, 87; also see Lenin 1975, 722) describes Lenin's view of the different forms of nationalism: 'In order to make amends for the wrongs committed against the small nations, the big nation must accept an inequality unfavourable to itself.' Following these principles, the Central Committee in Moscow would have to win the goodwill and trust of its neighbours who historically suffered under Tsarism; internationalism could not be strong-armed into being. Late in 1922, Lenin grew increasingly alarmed by reports that Stalin, then Commissar for the Nationalities, and Ordzhonikidze, then head of the Party's Caucasian bureau, were doing precisely what he feared-using brutish methods to bring the Georgian Central Committee in line with Moscow's plans for economic and political integration. Against Stalin's plan to include the independent Republics in the Russian Federation as 'autonomous Republics', Lenin insisted that national independence must be preserved. We know from history that although Lenin's proposal was adopted, it was in name only.

Lenin's concept of 'Great Russian Chauvinism' was translated into the Chinese context as the tendency of 'Great Han Chauvinism' (大汉族主义). Following Leninist principles, the CCP also realised that it needed to win the trust of minzu (民 族) in the borderlands as a matter of survival; I will leave minzu in the Chinese because it encompasses a range of contested meanings and approximate translations ranging from nation/ nationality to ethnicity (as it is currently officially translated), and its reformulation into shaoshu minzu 少数民族, which connotes both national minorities and minority nationalities (Bulag 2019, 147). During the Long March (1934-35), Red Army forces traversed Miao, Yi, and Tibetan territories and needed to differentiate themselves from the Nationalists (Bulag 2012, 100). To accomplish this goal, the Communists-not without controversy and debate-formulated the distinction between 'good Han' (好汉人) and 'bad Han' (坏汉人) to form alliances and friendship with non-Han peoples (Bulag 2012, 95). The 'good Han' were those who fought 'against imperialist tendencies within one's nation' (Bulag 2012, 97), rejected all violent manifestations of Han chauvinism, and supported the self-determination of non-Han minzu, in direct contrast with the Nationalists' assimilationist vision of the zhonghua minzu (中华民族) or Chinese nation as a large family. Although the 
Communists also debated the idea of a zhonghua minzu, it did not become a political concept until its recent appearance as the dominant vision of the nation under Xi (Bulag 2019). Despite its Nationalist pedigree, to underscore its newness, the term zhonghua minzu was only first mentioned in the PRC Constitution in 2018 (Ma 2019).

Although it is too complex to go into the historical details of the period, the main point I want to distil is that the related struggles against Han chauvinism on behalf of minzu autonomy are built into the foundation of the People's Republic. Although the historical record did not live up to its ideal, as it was an unstable balance of power subject to fluctuating discursive environments and political pressures, the institutionalisation of minzu autonomy was still a relatively bright spot of the early Mao period-especially when compared with the abhorrent treatment of indigenous peoples in North America and other settler colonial contexts (Estes 2019; Dunbar-Ortiz 2015). This also means that minzu autonomy is entirely a product and category of the modern Chinese state.

\section{The Case of Inner Mongolia}

In 1947, the 'Inner Mongolian Autonomous Government' was established as an autonomous representative of the Inner Mongolian people within an (implicitly) federal Republic of China. It contained recognisable hallmarks of sovereignty-its own flag, basic law, 'Prime Minister', 'army ministry', and so on. It was not until December 1949 that all of these attributes of locally derived sovereignty were dismantled and recomposed as the IMAR, explicitly integrated as a local government in a unitary People's Republic of China (see Atwood 2002, 2004; Bulag 2012; Liu 2006).

Japanese occupation of Inner Mongolia from 1931 to 1945 permanently heightened Mongol expectations. The Japanese militarists created autonomous provinces and states in what is now Inner Mongolia; after 1945, the Chinese nationalists aimed to eliminate them and go back to the pre-war policy of settler colonialism and assimilation of the Mongols. Meanwhile the Communists won crucial support from Mongol nationalists by being willing to accept these Japanese-era Mongol autonomous institutions as the nucleus of a new Communiststyle autonomous government. Here, too, the parallels with Lenin's time are worth noting: against the majority Bolshevik opinion that local governments set up under German (Ukraine), Turkish (Transcaucasia), and Japanese (Buryatia) auspices were reactionary enclaves of local nationalism that should be eliminated, Lenin was a very powerful voice in the wilderness arguing that the Bolsheviks needed to respect and 
In the history of the People's Republic, it was only during the Cultural Revolution, when ethnic Mongolians were persecuted and over 16,000 murdered on the basis of the paranoid suspicion, which conjured the unexorcised ghosts of revolutionary history, that Mongolians belonged to a separatist, underground Party-the so-called 'neiren dang' (内人 党)-that Mongolian language education was terminated (Yang 2014). work with autonomous local institutions, to avoid the project of internationalism becoming a Soviet version of imperialist chauvinism.

In this historical context, Mongolian language education was indispensable to autonomy. Even though he personally did not speak Mongolian, Mongolian language education was of paramount importance to Ulaanhuu (乌兰夫, whose name means 'red son' in Mongolian), Inner Mongolia's most influential political figure, who served as the Communist Party Secretary of the IMAR from 1947 to 1966, was promoted to Vice-Premier in 1954, and later became Vice-President of the People's Republic from 1983 to 1988. For Ulaanhuu and his Mongolian comrades, it was necessary to continue the legacy of the previous regime and allow for primary and middle schools to teach in Mongolian language (without being detrimental to Mandarin fluency) and for Mongolian cadres to learn and conduct administrative work in Mongolian. During the Socialist Education Campaign (1963-65), Ulaanhuu boldly suggested that all cadres, regardless of ethnicity, working in predominantly Mongolian areas should learn how to speak Mongolian in order to connect with and serve the masses. In a clever application of Maoist logic, Ulaanhuu argued that if the masses speak Mongolian, then so should the cadres. Otherwise, there would be a risk of alienation that would 'severely impact the relationship between the Party and the people' (Heqiyeletu 2020).

The commitment to linguistic diversity in the IMAR was also conducted on the cultural front. In 1957, the cultural troupe Ulaan möchir 'Red Twig' (乌兰牧骑) was formed with the purpose of travelling to IMAR's far-flung localities in order entertain, educate, and disseminate propaganda (I am not using this in a pejorative sense) to Mongolian herders. In the 1960s, teams of travelling film projectionists were encouraged to study the local dialect so that they could provide 'oral translations' (口头翻译) for local audiences (Lam 2019). In the early Mao years, multilingual acts of nation-building and socialist political education belonged to the same 'imagined community' of the People's Republic and were not viewed as mutually exclusive (Anderson 2016).

In the history of the People's Republic, it was only during the Cultural Revolution, when ethnic Mongolians were persecuted and over 16,000 murdered on the basis of the paranoid suspicion, which conjured the unexorcised ghosts of revolutionary history, that Mongolians belonged to a separatist, underground Party-the so-called neiren dang (内人党)-that Mongolian language education was terminated (Yang 2014). It 
goes without saying that Ulaanhuu became a target of struggle in the early years of the Cultural Revolution, although he was politically rehabilitated as early as 1973 .

In the late 1970s and early 1980s, the Communist Party sought to 'restore order' and 'rectify the left tendency (左 倾) of Great Han Chauvinism' that left behind tremendous turmoil and trauma in the borderlands. One way of doing that was the promise of increased autonomy and opportunities for language education. For example, Clause 36 of the Regional Autonomy Law promulgated in 1984 grants the right of regional autonomous governments to determine educational policies, including 'the language of the school', which should 'to the extent possible, use textbooks written in the minority language, and the classroom language should also be that of the minority'. Other clauses deal with the distribution of power between the regional autonomous governments and the central government, including autonomy over economic construction and national resource development. Massive student-led protests broke out across the IMAR in 1981 when it seemed that the local officials were reneging on the Party's commitment to territorial, linguistic, cultural, and economic autonomy (Jankowiak 1988). The shadow of the Cultural Revolution, under which these children grew up, gave them good reason to be anxious over the future.

\section{From Lenin to the 'Multicultural' United States?}

It may seem puzzling to the outside observer why Inner Mongolians have been protesting-and why there have even been reported suicides-over seemingly minor changes to the model of language education and slight modifications of textbooks. The Chinese state has not banned the use of the Mongolian language, as some have exaggerated.

One way to explain the reaction is that small adjustments can be the harbinger of larger, more seismic changes under way. Are these changes to language education policy 'surreptitiously implementing'-as Atwood (2020) has suggested-a version of the 'Second Generation Ethnic Policy' (第二代民族政策) that has been proposed by $\mathrm{Hu}$ Angang (Centre for China Studies, Tsinghua University), $\mathrm{Hu}$ Lianhe (an official with the United Front Department, also affiliated with Tsinghua University), and Ma Rong (Peking University), which would indicate a shift from ethnic autonomy to multiculturalism ( $\mathrm{Hu}$ and $\mathrm{Hu}$ 2011; Ma 2019)? As Christopher Atwood (2020) explains, for these thinkers, 'the Soviet-based ethnic autonomy built into China's constitutional structure was a mistake and should be replaced by a "depoliticised" ethnic policy modelled on that of the United States, where ethnic groups have individual rights 
to equality but no rights to territorial autonomy and no statesupported education or cultural maintenance.' Although it is highly improbable that the Chinese government will abolish autonomous regions, Beijing seems to have embraced the spirit behind their proposals that territorially grounded ethnic autonomy and consciousness stand in the way of the broader vision of the 'Chinese dream' (中国梦) and the renewal and 'great rejuvenation of the Chinese nation' (中华民族伟大复 兴), as it oscillates between multiculturalism and assimilation. The right to 'develop one's own language' guaranteed by the Constitution and Regional Autonomy Law that was a key plank of ethnic relations in the Mao and reform eras is being directly challenged by the new bilingual education policy. The changing reality will most likely leave in place the institutional structure and name of the Autonomous Region, while further emptying its content and any remaining meaningful sense of 'autonomy'.

The potential reason for these transformations can be gleaned from Xi Jinping's description of the relationship between Chinese ethnic groups as 'closely united like the seeds of a pomegranate that stick together’ (像石榴籽一样紧紧 抱在一起) (Xi 2017)-the American melting pot with Chinese characteristics. The irony here is that China is aspiring to be more like the United States while Trump is taking a page from the CCP playbook and calling for 'patriotic education' to douse the flames ignited by the combustible history of the United States' foundations in slavery and settler colonialism.

What is it about the US multicultural model that these thinkers are drawn to? From their perspective, the problem with China's system of minzu autonomous regions is that it promotes 'territorial consciousness' (领土意识), which is believed to sow the seed of 'separatism' (分裂主义). Instead, Ma Rong calls for a dual process of 'culturalisation' (文化化) and 'de-politicisation' (去政治化) that would reduce minzu autonomy to a deracinated form of 'culture'-in other words, while cultural difference is to be celebrated, political autonomy is to be eradicated (Sinica 2019). As the anthropologist Bulag $(2003,762)$ put it over a decade ago, 'domesticated Mongols can now choose to sing and dance as they please, even speak their language if they care. But they have lost the economic, social, and cultural preconditions, as well as the political powers that can meaningfully define the purpose and quality of their native speech.' To me, this sounds uncannily similar to Audra Simpson's (2014) criticism that in North America, the political existence of sovereign indigenous nations is reduced to questions of race (in the United States) and culture (in Canada), erasing the ongoing disputes over territory and political sovereignty. Indigenous protests and uprisings are reminders that indigenous people are 'not settled, they are not done, they are not gone' (Simpson 2014, 33). 


\section{Blinded by the Light}

When it comes to understanding these ongoing indigenous struggles against the infrastructural expansion and carceral policies of North American settler colonial empires, I reach for the work of indigenous thinkers like Audra Simpson, Glen Coulthard, and Nick Estes. So, it has been puzzling to me why Estes-whose work I admire greatly-has recently dismissed criticism of China coming from the left as Orientalist. On 8 August, responding to a Tweet in which the Indigenous Anarchist Federation accused China of settler colonialism, Estes responded: 'Orientalism is a helluva drug. Just say no.'

Tweets like this are part of a growing tendency on the left to downplay criticism of China based on the fear that it will play into the hands of United States imperialism-or less charitably, because of a faith-like need to believe that China still upholds socialist values. The latter position is epitomised by Vijay Prashad (2020), who at a recent forum of the Progressive International dismissed concerns raised by other leftists over the Chinese Communist Party's abysmal record of labour repression (in the reform era) as mere contradiction or confabulation (as if with a wave of the hand the discriminatory household registration system, dormitory regime, managerial despotism, and state repression of workers and Maoist student reading groups could just magically vanish into thin air). I, too, value international solidarity and am thoroughly exhausted by how the left cannibalises its own, but as labour sociologist Eli Friedman pointed out on Twitter, this still begs the question: solidarity with whom?

These more difficult discussions, however, are almost immediately drowned out on social media by the endless accusations that criticism of China means support for the United States-and here the stakes of leftist solidarity have deteriorated into a game of identity politics and standpoint epistemology. It does not matter what you say, only where you say it from. Take, for example, the Qiao Collective-whose proChina positions have been dissected by Brian Hioe (2020)-and their recently published defence of the Chinese state's bilingual language policy in Inner Mongolia, which takes official claims at face value, while ignoring Mongolian voices, and blames Western media for over-sensationalising the issue. To make their case, Qiao (2020) relies entirely on 'clarifications offered by local officials as well as a debunking by the Global Times'. I am not saying that official statements and discourse should be ignored; I have always argued the opposite point that they need to be critically examined and contextualised (Sorace 2017). Qiao, however, simply accepts the official line that changes are minimal and a 'far cry from what Western media 
has claimed is a "push to wipe out Mongolian culture". By blaming Western media, Qiao entirely ignores the collective petitions and voices of Mongolians both within IMAR and the Mongolian diasporic community, who, it is important to note, do not speak in a homogeneous voice despite shared opposition to the policy; Inner Mongolians have carefully petitioned on the basis of law, while many Mongolians in Ulaanbaatar and abroad have tended to engage in more inflammatory rhetoric. Again, this is a textbook example of ignoring the viewpoints of non-Han, marginalised groups by reframing the problem as one of Western imperial arrogance toward China. Almost on cue, Qiao (2020) argues that 'assuming that the Chinese people are not extensively dialoguing over a longstanding and deeply felt policy such as bilingual education is the height of chauvinism', without one mention of the importance of indigenous language instruction in combating Great Han chauvinism, and why the changes to it might undermine those very principles. Qiao seems incapable of asking: are Mongolians part of this conversation about the future of their own language?

It is beyond disheartening that the language of antiimperialism is being deployed in defence of chauvinist attitudes, which, following Lenin, should be fought wherever they appear. In one video on WeChat, a Chinese man justifying the proposed changes shouts into the camera: 'You are Chinese, why don't you speak the language of China?' (你是中国人, 为 什么你不会说中国话?). Can Qiao or Prashad enlighten me as to what distinguishes this attitude from the American who barks: 'This is America, speak English'?

\section{And Back to Lenin's Anti-imperialism}

I wholeheartedly agree that we need to oppose the antiChina consensus, narrative, and war machine in the United States. For these reasons, I am against petitions to the United States government-especially those addressed to the current President-to act on behalf of people oppressed by the Chinese state. Anyone who turns to Donald Trump as a 'saviour', even symbolically or in desperation, is undermining the struggles against ascendant fascism and white supremacy in the United States. It allows US political elites-many of whom were responsible for the war crimes of invading Afghanistan and Iraq-to maintain the delusion that the United States is a beacon of freedom and democracy. Furthermore, as comrades in the Lausan Collective (2019; also see Chan 2020) have demonstrated, US grandstanding against China's actions in Hong Kong not only has been ineffective, but worse, has entirely backfired. To anyone naïve enough to still believe that 
US politicians care about them beyond their instrumental value to stick China in the eye, I recite the Chinese saying: 'When the hare is dead, cook the hunting dog' (兔死狗烹).

Perhaps I am being overly cynical, but I would venture that neither the vocal pro-China left nor anti-China hawks actually give a damn about what is happening in Inner Mongolia, Xinjiang, Hong Kong, or elsewhere. The latter look for any ammunition they can find and fire indiscriminately, while the former grasp for anything that they can use as a shield to deflect criticism. Most 'discourse' that falls into the binary of being either for or against China is nothing more than the enjoyment of short-lived attention and moral outrage. In the end, we are all stupider.

In opposing the rhetoric of Sinophobia in the United States and any corresponding military action, we must not forgo shared leftist commitments to end the oppression of indigenous peoples, the exploitation of the working class, and destruction of the environment that take place in China. The choice we are facing is not China versus the United States, but international proletarian solidarity or ethno-nationalist capitalism.

That is why it is important to remember, and salvage, the Leninist opposition to great power chauvinism at the forgotten origins of the language policy. To my knowledge, this point has only been articulated by the 'Cherry Society' (樱桃社) - a Marxist-Leninist reading group formed during the pandemicwho argues that the new language education policy sacrifices Marxist-Leninist principles to a 'Han imperialist dream' (大汉 帝国梦). Their proposed slogan 'long live class solidarity of the working people of all ethnicities' (各民族劳动人民的阶级团结 万岁) should resonate beyond the Chinese context.

As China deracinates its remaining Leninist roots, it is only 'communist' in the imaginations of people who need it to be so for their own political ends. This not only blunts any analytic capacity to understand what is happening in China, but it also enervates our collective imagination of what a communist future might look like.

The author would like to thank Christopher Atwood for commenting on earlier drafts of this essay. 


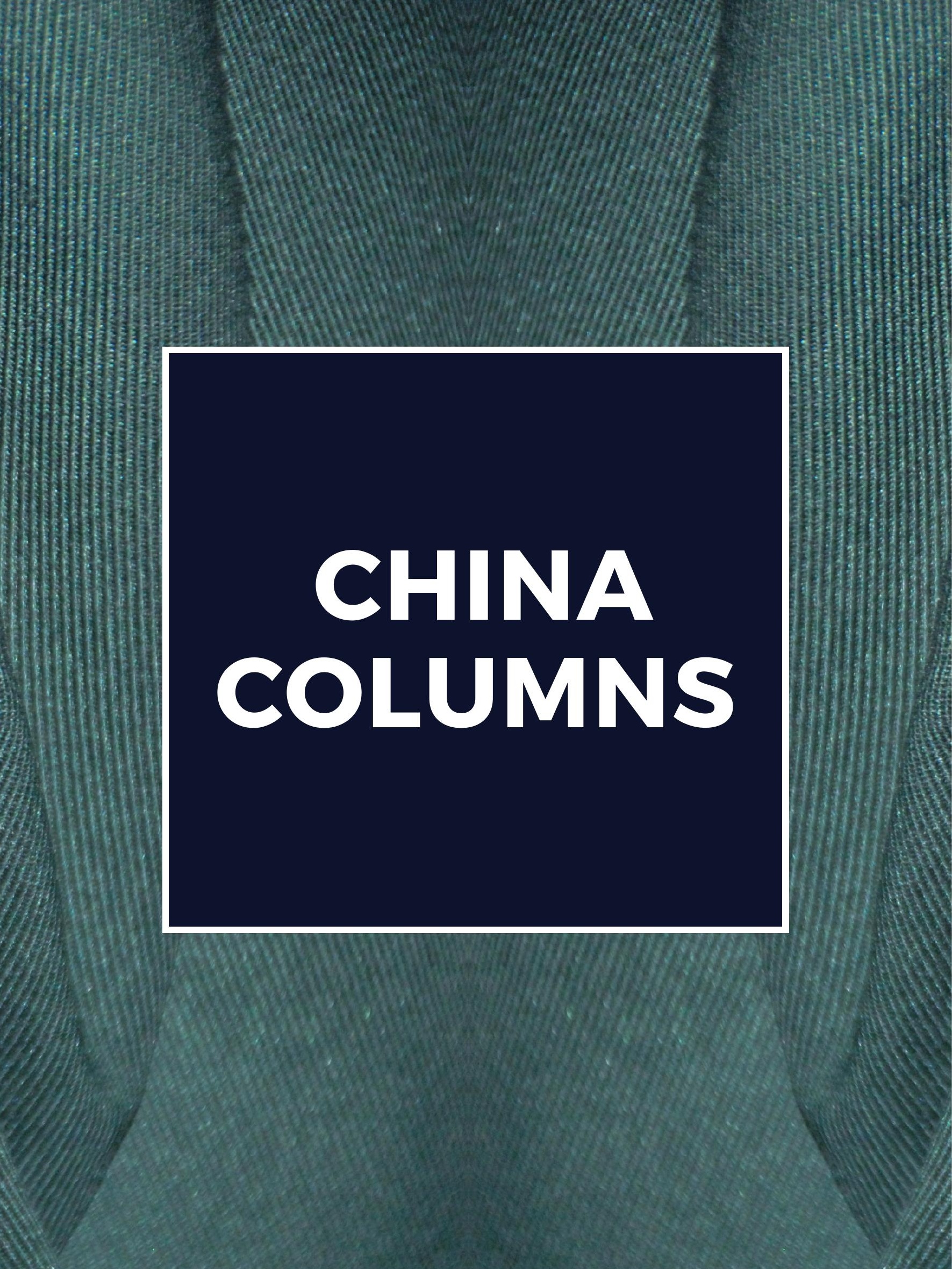




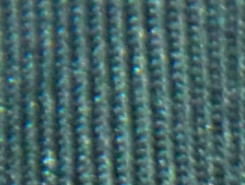

(1)

I

就
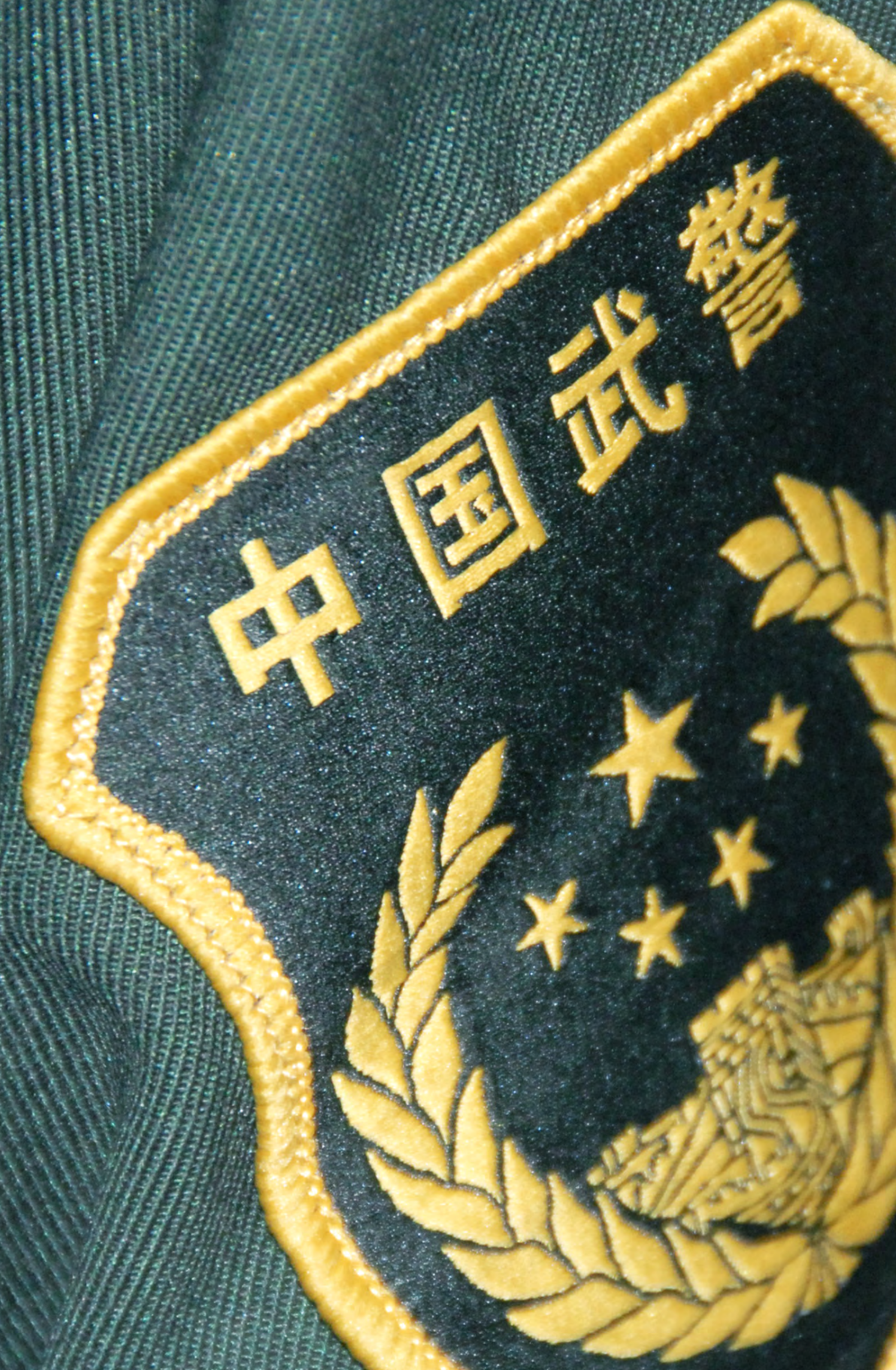


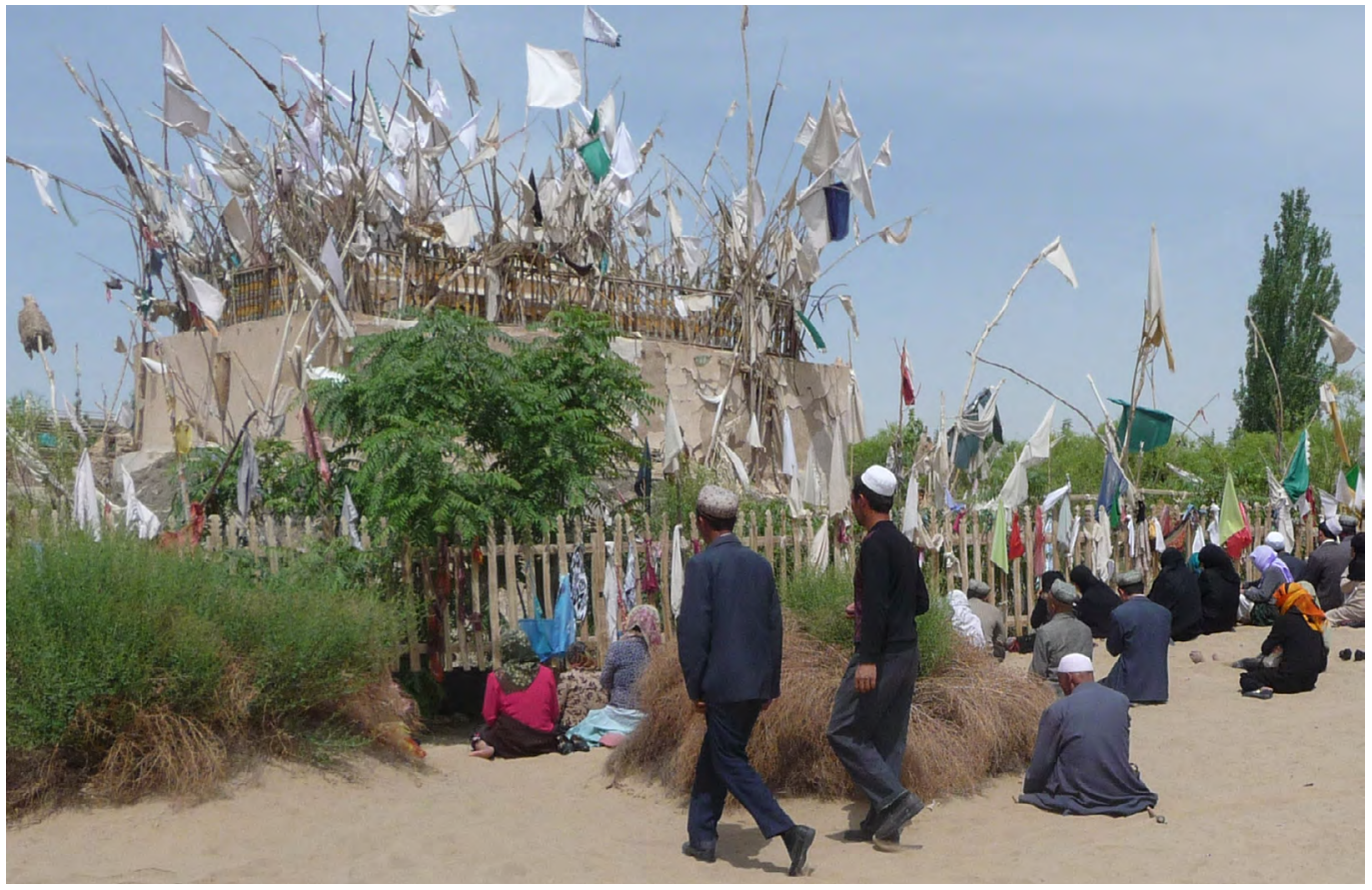

\section{The Spatial Cleansing of Xinjiang:}

\section{Mazar Desecration in Context}

Pilgrims praying at Imam Asim mazar, 2010.PC: Rian Thum.

Rian THUM

In 2017 and 2018, Chinese authorities destroyed or desecrated three of the most revered sacred and historical sites of the Uyghurs. Based on ethnographic fieldwork conducted across multiple visits from 2003 to 2017, along with satellite imagery, this essay documents the state's programme of religious and historical destruction, outlines its significance for affected Uyghurs, and places it in the wider context of government efforts to transform the Uyghur built environment, both historical and contemporary.

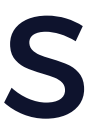
ometime between 10 and 17 March 2018, on a high sand dune 75 kilometres from the town of Niya, a beloved historical monument disappeared (Kuo 2019). For at least 450 years the site had drawn pilgrims from across the expanse of Altishahr, the southern half of what is now known variously as Eastern Turkistan or Xinjiang (Dūghlāt 1996 [1543], 190). Pilgrims came to be in the presence of Imam Je'firi Sadiq-a founding father and hero who had died there a thousand years earlier, while 
bringing Islam to their homeland . At his tomb they wept, prayed, and gained blessings from contact with the physical structure.

The white-painted tomb had the shape of an ordinary grave marker, but on the scale of a giant, like a grave for someone six metres tall, resting on a platform fifteen metres square. Some pilgrims wrote graffiti in a wooden, boxlike prayer house erected in the sand nearby, recording their shared presence with the saint in the very location where their society and their history were born. All around, flags and strips of cloth whipped loudly in the wind, thousands of offerings tied to various sacred structures, testifying to the crowds of fellow Uyghurs who had come over the years to venerate this point of historical origin and connection to the divine. In the early autumn, pilgrims came in especially large numbers, cooking communal meals in a gigantic pot and sleeping near the site. All of this disappeared in the middle of March 2018, leaving an empty dune. ${ }^{1}$

In the ensuing two years, the Chinese state has destroyed and desecrated Uyghur historical and holy places at a scale unprecedented in the history of Eastern Turkistan (Altishahr, Xinjiang) as a Chinese-dominated region. Among the demolished places were mosques, and these have received the bulk of international media attention. But another kind of sacred site, less legible to outsiders, has arguably been a more significant crux of desecration. This is the mazar, a point on the landscape that holds particular numinous authenticity, a connection to and presence of the divine that surpasses the sacredness even of the mosque as a physical structure.

For many Uyghurs in urban contexts, mazars have become peripheral, irrelevant, or entirely forgotten. But the majority of Uyghurs live in rural environments, where mazars have commonly functioned as community resources, historical archives, arenas of dispute, and independent social actors. At a mazar one can seek fertility or healing. The pilgrim can learn about the history of the shrine's buried saints, and thus of her own land. Local religious leaders can promote their understandings of right behaviour against the claims of others. And the shrine itself can intervene in the everyday lives of its constituencies by entering their dreams or bringing rain.

Mazars are nearly always marked by some physical construction, ranging from high domes with green, glazed tiles to nothing more than a few flags on crooked twig poles (Dawut 2001). Most are graves, purported to hold the physical remains of an individual whose accomplishments in life-whether scholarly, heroic, or miraculous-are thought to grant his or her immortal personage a closeness to God that can be shared with the living. Mazars can also be other points of transcendent contact: sacred trees or springs, footprints or stopping places of holy people, or the locations where sacred personages disappeared. Such nonburial sites represent a tiny minority of mazars, but they demonstrate the capaciousness of the term and the potential for points on the landscape to become sacred by multiple means. Whatever the physical and narrative form of a particular mazar, in practice, 'mazar' denotes the most immediate, tangible manifestation of the sacred in physical and geographical form.

The miraculous power of a mazar's substance is visible in the habits of pilgrims. Women who seek to get pregnant will sometimes reach into a crack in a mazar's walls or a hole in the earth on which the mazar sits, grasp the first thing they touch, such as a small clod of dirt or mortar, and swallow it. Such faith in the power of the mazar's physical material has been prominent enough to earn the condemnation of reform-minded Muslims in the region, as in the case of the early-twentieth-century critic Abdu Vali Akhon, who complained about 'common' pilgrims 'rubbing their face and eyes on shrine's walls' (Abdu Vali Akhon 1905, 162). Another reformist of that era, visiting Kashgar from Ottoman lands, similarly complained about people 'rubbing their faces on sheep horns ... and on cow tails' kept at the shrines (Kemal 1925 , 94). Especially devoted pilgrims, such as 


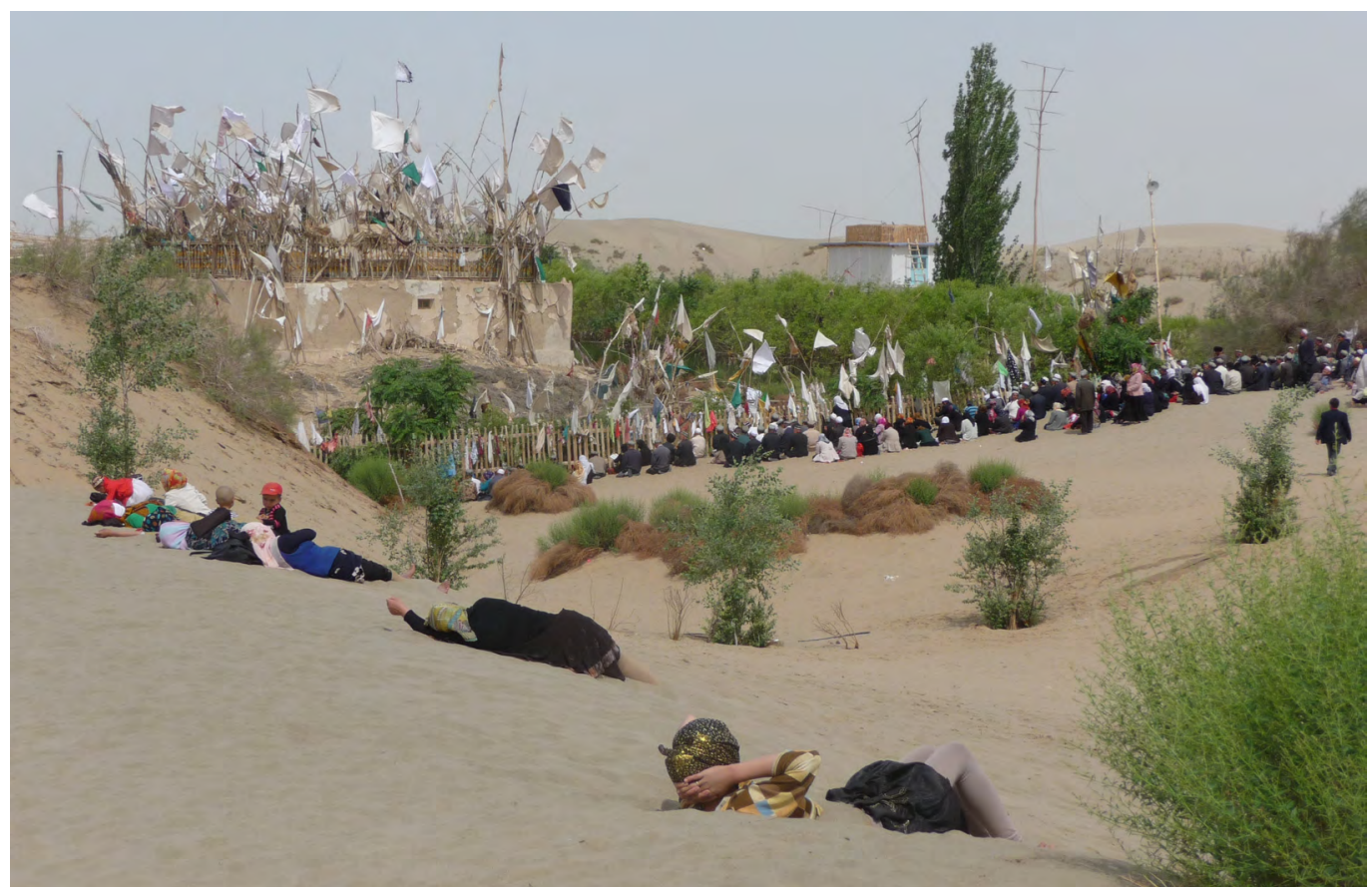

Pilgrims bathing in the sand at Imam Asim mazar for its healing properties, 2010. PC: Rian Thum.

a man I met at a tomb in Yarkand in 2007, will sometimes sleep inside a mazar structure itself, in the hope of receiving miraculous inspiration in their dreams.

These properties of the mazar stand in some contrast to attitudes toward mosques. I have not been able to document any similar interactions with the physical structure of a mosque, even where a mosque is attached to a mazar. This is not to say that mosques are not sacred. They provide a space of purity where worshippers can engage in devotions toward God, and the collective acts of devotional prayer can generate miraculous effects. In Kashgar in the 2010s, women would line up at the exits of the Id Kah mosque and hold out food for departing worshippers to blow a puff of air upon, lending the food curative properties. But here the curative power was generated by the activities and personal traits of other worshippers, not the physical substance of the mosque.

\section{The Nature and Goals of Desecration}

Authorities in Xinjiang clearly share some awareness of the power of mazars. The circumstances of Imam Je'firi Sadiq's destruction show that it was the mazar itself that attracted the authorities' attention, not the economic value of the land. The remote and barren dunes on which the mazar stood have no other use. Elsewhere, some aspects of China's assault on sacred spaces have involved economic incentives. Over one hundred graveyards have been destroyed across Xinjiang in the last three years, in some cases making valuable urban land available to developers or the state (Xiao and Yiu 2019; Rivers 2020). But Je'firi Sadiq's destruction paved the way for 
precisely nothing. Destruction seems to have been the point in and of itself, not a sacrifice to some economically valuable end.

For decades authorities have been nervous about the large festivals (seyla) that some mazars inspire. Officials across China tend to be wary of potential for independent gatherings to create alternative sources of political power or develop into protests. Across those decades, however, the state demonstrated that complete destruction of a mazar is not necessary to prevent gatherings. For over twenty years authorities have prevented mass pilgrimage to the only site more revered than even Je'firi Sadiq's mazar: the Ordam Padishah mazar, located in the desert outside of Yengisar. The occasional lucky or connected party slipped through the police net from time to time (I was arrested when I tried), but the famous festivals of Ordam Padishah, with their tens of thousands of attendees, were successfully killed off (Harris and Dawut 2002). Based on my own visits, I can confirm the same for Chüje Padishahim mazar (near Yengisar), Ujme mazar (near Khotan), and, more recently, Imam Asim mazar (also near Khotan). Even Je'firi Sadiq itself had already been closed to all pilgrimage sometime after my successful 2007 visit, and I was turned away when I returned in 2015. The destruction was not needed to prevent pilgrimage; destruction appears to have been an end in and of itself.

Even when locked behind a wall of police roadblocks and roadside informants, mazars wield power. They enter people's dreams and give them guidance. One can petition them from a distance or send personal prayers ( $\left.d u^{\prime} a\right)$ in their direction, as I witnessed a man do after being turned away from Imam Je'firi Sadiq mazar in 2015. Simply knowing that the mazar is standing out there between the Uyghurinhabited oases maintains a community tie to history and the land. I met one of the handful of lucky Uyghurs who managed to reach Ordam Padishah long after it had been closed, and she told me what happened when she mentioned her good fortune, standing outside a village mosque, weeks later. The men she was talking to began weeping and begged to collect some of the dust of the mazar from her jacket. To judge from publicly available satellite imagery, Ordam Padishah is now gone, too (Google Earth 2020, 38.9144 ${ }^{\circ}, 76.6567^{\circ}$ ).

After the Notre Dame cathedral in Paris was partly destroyed by fire in April 2019, the French government began a billion-dollar response that continues today. Fallen stones are cleaned with lasers. Previously inaccessible materials are examined for clues that can shed new light upon the monument's history. Scientists analyse lead from the fallen spire and trace its environmental impact on the Seine River and beyond. And a team of anthropologists studies the emotional trauma that the monument's damage has inflicted on Parisians and visitors from around the world (Lesté-Lasserre 2020).

The many Uyghurs whose relationship to Ordam Padishah parallels the Parisian and global attachments to Notre Dame would surely welcome a similar effort. The rubble of Ordam's destruction holds abundant clues to its history. Archaeologists could undertake tree-ring dating of the sort that scientists have planned for Notre Dame's fallen timbers. Ancient refuse and offerings left by pilgrims could reveal changes in patterns of worship over the centuries. Because many of Xinjiang's desert shrines sit on or near older Buddhist sites, Ordam's destruction may have revealed traces of even earlier sacred monuments. It is unlikely that many Uyghurs inside Xinjiang have learned yet about the destruction of Ordam Padishah, but when they do, emotional trauma will be no less acute than in Paris after the cathedral fire.

Of course in the case of Ordam Padishah, the cultural destruction is not accidental. The shortest distance from Ordam Padishah to cultivated land is 14 kilometres, over soft sand and high dunes. The expense and effort required to bring equipment capable of obliterating Ordam's network of monuments, mosques, rest houses, and mounds in the open desert must have been substantial. The recent pattern of government activity thus suggests that further destruction and desecration in 
Xinjiang are far more likely than the kind of state-led effort at recovery, remediation, and reparations one might expect in a context like Paris. As at Je'firi Sadiq, the land around Ordam Padishah is remote and barren, and the shrine has been replaced with nothing; destruction of the Uyghurs' most sacred site seems to have been the goal, part of the government's broader efforts to define and control Uyghur material culture and history

Full obliteration of the sort that Je'firi Sadiq and Ordam Padishah suffered is not the only attack that Uyghur holy places have suffered. The wave of mazar closures of the last three decades was already a form of destruction. Mazars are continually created and recreated through pilgrimage. Their structures accumulate mass as pilgrims bring flag poles, cloth lengths, sheep horns, oil lamps, animal skins, and other ephemeral offerings. The offerings pile up and the accumulated flag poles sometimes reach ten metres into the sky. The slow deterioration of wood, cloth, and skin testifies to the age and continuity of pilgrimage. The constant replenishing of the flags and skins manifests the continued power of the mazar over its constituencies, and reminds the pilgrim that his devotion embeds him in a community larger and less knowable than the circles of his home village. Shrine closure interrupts this continuous production of the sacred site.

At the mazar of Imam Asim, near Khotan, it almost looks like local authorities share this understanding of continual incarnation through pilgrimage. Recent photos show that the mudbrick structure of the tomb itself was unharmed as of 2018 (MarcelTraveller 2018). But the site is unrecognisable. The associated mosque has been demolished. The mazar proper has been denuded of its flags, offerings, and wooden railings. The grave marker, which sits atop a low mudbrick building, was previously invisible behind a forest of pilgrims' flags, their poles affixed to the wood fence on the building's roof. It now stands naked, motionless, and monochrome, shorn of the colourful, flapping attire of sacred offerings.
Authorities have stopped one step short of total obliteration. But they have crossed the wooden fence into a zone that is forbidden even for most believing pilgrims, and desecrated the mazar by denuding it of its external display of community veneration.

For officials who came into close contact with them before the closures, mazar activities and pilgrimage festivals made otherwise hidden troubles visible. Particularly at times of mass pilgrimage, shrines revealed themselves as alternative sources of legitimacy and authenticity outside the control of the state. The crowds of pilgrims in group prayer demonstrated-not just to observers, but also to pilgrims themselves-the emotional power of collective action. The mixing of devotees from far-flung regions circumvented the ubiquitous state control of long-distance communication. Even outside of the large pilgrimage festivals, daily, small-scale devotions revealed the state's tenuous hold on life-cycle rituals, knowledge production, and medical care. In a more general way, the architectural, sonic, and overall aesthetic qualities of the shrine made it immediately clear that it was a world entirely alien to the self-consciously modernist, 'harmonious', and totalitarian society pursued by the Chinese state.

\section{The History and Scope of Desecration}

Although the extreme acts of desecration and demolition described above seem to have begun in 2018, states have always been interested in Uyghur mazars as centres of economic and political power. When the Qing dynasty's Qianlong emperor (1711-99) conquered Eastern Turkistan in 1759 and incorporated it into the new administrative entity of 'Xinjiang', he issued an order to protect and even repair the region's mazars. However, in the succeeding 150 years, the Qing state would frequently confiscate mazar landholdings in the wake of rebellions, targeting particular mazars that 


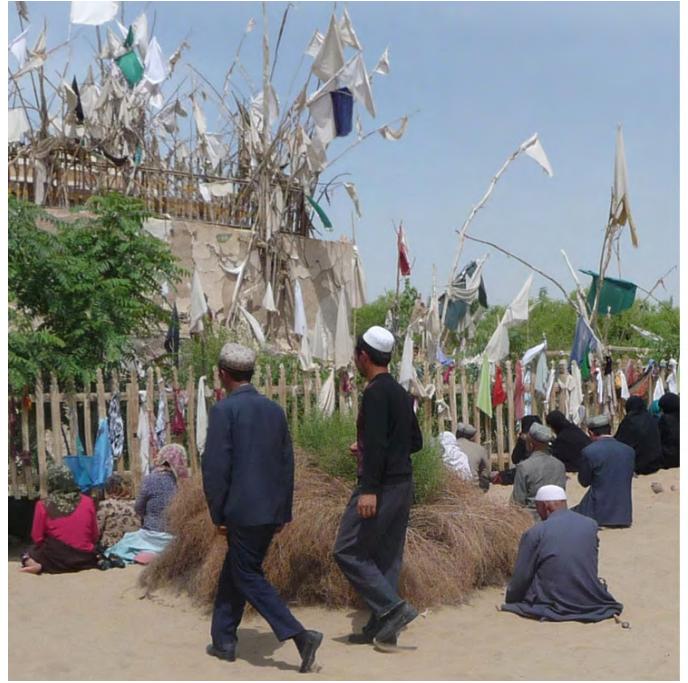

were associated with rebel factions (Zhang 2016, 130-31). Nonetheless, beyond the occasional economic dispossession of mazars, the Qing did little to disrupt pilgrimage or physical structures. On the contrary, their system of indirect rule gave local elites latitude to perpetuate and, in some cases, even promote mazars (Brophy and Thum 2015). The tombs of some Qing client-administrators themselves became mazars.

Chinese officials ended the system of indirect rule in the late nineteenth century and began to introduce assimilationist policies, but even then mazars seem to have largely escaped notice. The earliest attempt to control sacred sites on a systematic scale may be the efforts of warlord governor Sheng Shicai (who ruled from 1933 to 1944) to bureaucratise the landholdings of mazars, all of which he confiscated in the mid-1930s (Sugawara 2016, 155; Zhang 2016, 132). Landholding again brought mazars under state scrutiny in the 1950 s, as the newly arrived Chinese Communist Party confiscated their land and turned their religious personnel into

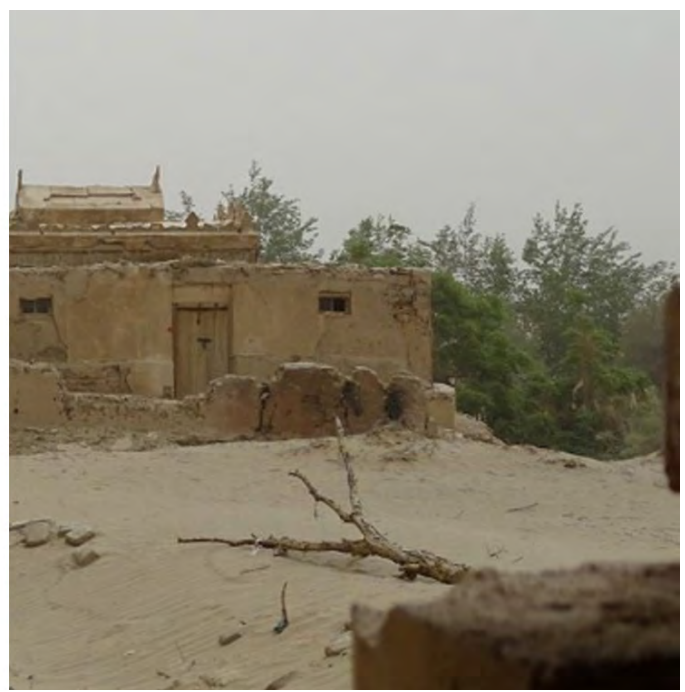

[Left] Pilgrims praying at the Imam Asim mazar, near Khotan. May 2010. Photo by the author. [Right] Imam Asim mazar after desecration. Posted to Tripadvisor in 2018 by user MarcelTraveller.

state employees (Wang n.d.). Personnel were gradually reduced until, during the Cultural Revolution, mazars throughout Xinjiang were closed completely.

With the loosening of restrictions on cultural and religious practices in the 1980s, mazars sprang back to life in two different ways. Some, like Ordam Padishah, enjoyed a grassroots revival of festivals and ordinary pilgrimage. Others, most notably Afaq Khoja in Kashgar, were transformed by the state into museumlike tourist attractions. This museumification was the earliest wave of mazar disruption in reform-era China.

The museumification of Afaq Khoja, once a site of large gatherings, kept pilgrimage to a trickle. The few members of the mazar's rural constituency who could afford a highpriced entry ticket discovered a sacred site with no religious authorities, a secularised environment denuded of visible offerings, and sanctuaries full of Han Chinese tourists, souvenir sellers, and guides. Pilgrimage festivals and overnight activities were 
prevented entirely. Similar efforts at the Altunluq ('golden') cemetery in Yarkand, the Sultan Sutuq Bughrakhan mazar in Artush, and the Yusup Khas Hajip mazar in Kashgar lacked the resounding tourist success of Afaq Khoja, but similarly curtailed pilgrimage. The important mazar of Eshabulkehf, near Turpan, continued to receive somewhat more pilgrims (though no large gatherings), perhaps due to looser and more affordable ticketing policies that exempted some locals.

In the late 1990 s and early 2000 s, as pilgrimage festivals expanded at mazars that had escaped museumification, authorities began imposing restrictions. They levied entry fees at Imam Asim (2 yuan) and Imam Je'firi Sadiq (50 yuan), adding strict identity registration procedures at the latter. Ordam Padishah's 1997 closure is the earliest documented for the post-reform period, but others followed. By 2008 authorities closed the shrines of Ujme (Khotan) and Chūjie Padishahim (Yengisar), both of which had hosted large festivals. By 2015 there were no shrine festivals taking place anywhere in Xinjiang.

The demolitions and desecrations that began in 2018 have so far left most minor mazars unscathed. Hundreds or perhaps thousands of small mazars punctuate the sacred geography of Xinjiang. These provide some of the same devotional and miraculous functions of the famous mazars, without the large gatherings or regional community-building effects. Satellite photos suggest that a handful of more historically significant mazars with impressive domed structures have also been spared, notably Yarkand's two most famous holy sites, Chilten and Muhemmed Sherip. In the early 2000s, Chilten drew a steady flow of pilgrims on market days and holidays, but did not host large gatherings of the type that led to the closures of other mazars. However, given the criminalisation of most religious activities, all mazars are likely under some level of restriction or de facto closure.
Full demolition and desecration have so far been aimed at mazars that have drawn large crowds, have region-wide reputations, and have not been museumified. My fieldwork among pilgrims conducted between 2003 and 2017, combined with historical documentation, suggests that among the hundreds or thousands of Uyghur mazars, five have exceptionally strong and historically deep regional reputations for holiness (Table 1). The destruction of Imam Jafiri Sadiq and Ordam Padishah has now taken two of those most widely revered mazars off the map. The remaining three have physically survived as museumified destinations for Han Chinese and foreign tourists. Among these five sites, the newly demolished Ordam Padishah is often described, both by living pilgrims and historical sources, as the holiest site in Eastern Turkistan (Jarring 1935).

At the same time that authorities have destroyed Uyghur historical monuments, they have promoted their own shrine-like structures, built from the 1980s onward but often claiming antiquity. For example, in 1994 they built Kashgar's Ban Chao Memorial Park (班超纪念公园), which was expanded in the 2010s into the Pantu City Scenic Area ([RT1] 盘囊城景区), a park with statues, reliefs, and architectural imitations of ancient Chinese fortifications. It commemorates the period between 73 and $102 \mathrm{CE}$ when the Eastern Han dynasty conquered and briefly controlled the region under the Chinese general Ban Chao (Millward 2009, 24). The memorial and park are claimed to occupy the site of Ban Chao's original fortifications. Chinese tourists from throughout the country are encouraged to visit this 'patriotic education base' (爱国主义教育基 地), where they learn about the state's vision of a Han-dominated national community, in much the same way that Uyghur pilgrims once learned about their community history at Ordam Padishah mazar. Recognising that entry fees can disrupt the functions of a pilgrimage site, authorities recently made entry to the park free of charge (Xu 2018). 


\begin{tabular}{|l|l|l|}
\hline Shrine Name & Nearest Town & Status as of 2020 \\
\hline *Imam Je'firi Sadiq & Niya & Demolished \\
\hline Turt Imam & Khotan & Intact, status otherwise unknown \\
\hline Imam Asim & Khotan & Closed and desecrated \\
\hline Ujme & Khotan & Closed, physical status unknown \\
\hline *Ordam Padishah & Yengisar & Demolished \\
\hline Chūje Padishah & Yengisar & Closed, standing \\
\hline *Afaq Khoja & Kashgar & Museumified \\
\hline *Eshebul kahf & Turfan & Museumified \\
\hline *Sultan Sutuq & Artush & Museumified \\
\hline
\end{tabular}

Table 1: Status of mazars that once hosted large gatherings of pilgrims (seyla). Asterisks denote the five most sacred mazars in the Uyghur region-my subjective determination based on fieldwork among pilgrims conducted between 2003 and 2018 and historical accounts. Imam Asim is a borderline case. It attracted exceptionally large numbers of pilgrims, but historical sources do not present it as one of the region's most sacred places.

\section{Contemporary Context}

Mazar desecration is part of a larger set of policies that raze the Uyghur built environment, reconfigure Uyghur geography, and eradicate the spatial underpinnings of Uyghur culture. Though a comprehensive enumeration of Chinese spatial reengineering policies is not practicable here-they are simply too numerous-a few examples will demonstrate the extraordinary scope of state efforts to replace Uyghur built environments and uproot geographically embedded expressions of Uyghur culture. As these examples show, almost no part of Uyghur life is untouched by state destruction of the Uyghur built environment, suggesting that state attacks on apical cultural nodes like prominent mazars are part of a larger effort to disconnect Uyghurs' experiences and identities from the landscape.
The recent spate of prominent mosque demolitions and desecrations-including the most important mosques of Karghalik and Keriya-followed a large 'rectification' campaign from late 2016, which 'demolished nearly 70 percent of mosques in the city' of Kashgar, according to Wang Jingfu, the head of Kashgar's Ethnic and Religious Affairs Committee, along with an unknown number of mosques in other parts of Xinjiang (Hoshur 2016). The mosque destructions closely followed the introduction of bans on praying in public, which had left homes and mosques as the only remaining spaces where religious devotions were permitted. This meant that the destruction of mosques has achieved an even greater constriction of religious space than it would have under ordinary conditions.

Both homes and mosques eventually became unsafe for prayer due to the combination of surveillance and arbitrary internment. 
The fanghuiju programme (访惠聚 being an abbreviation of 访民情、惠民生、聚民心， which means inspect the situation of the people, improve the welfare of the people, gather the hearts of the people'), which sent over a million Han Chinese government workers into Uyghur houses, enabled direct monitoring of Uyghurs' religious devotion at home (Byler 2018; Xinjiang United Front Work Department 2017b). Surveillance cameras in mosques further tightened the net on those who prayed. Authorities used the frequency of prayer as an indicator of (un) trustworthiness, ultimately sending people who prayed frequently to the internment and indoctrination camps. One leaked document shows that simply having family members who engage in too many religious activities can lead to internment (Zenz 2020).

Homes were also transformed in more physical ways. Chinese state media outlets have published multiple reports of official efforts to change Uyghur household furnishings. These usually explicitly target the supa (Chinese 土炕), a raised platform, often heated from below, on which many Uyghurs eat meals and sleep. However, many reports also mention other types of furniture throughout the house and complete transformations of household interiors, as part of a 'beautiful courtyard' (美丽庭院) campaign. Because supas are often built into the structure of houses, their removal is labour intensive. In addition to serving as large communal beds, shared by numerous family members, supas are often used for activities that range from hosting guests to doing school homework. The shift to Westernstyle beds dedicated to sleeping in ones or twos substantially changes the everyday interactions within a household. Authorities are aware of this, noting that children and adults will need to sleep separately (Xinjiang Minsheng Net 2018) and commanding Uyghurs to 'abandon the bad customs of laying out carpets, eating and sleeping on the supa, and getting on the supa to do homework' (Zero Distance Awat 2019).
Several ethnic groups across rural areas of northern China, including Han Chinese, use supas, and the province of Gansu has seen its own 'supa reform' (土炕改造) campaign. The different ways that officials both execute and portray 'supa reform' in Gansu and Xinjiang show how Xinjiang officials enlist and reframe wider government policies as tools for transforming Uyghur culture. In Gansu, supa reform is pursued as an environmental policy, designed to reduce emissions from the coal fires that heat the supa (Zheng 2017). In most cases, the goal is to convert coal-heated supas to electric-powered supas, often through subsidies (Gansu Daily Net 2019).

In Xinjiang, on the other hand, the environmental justification is largely absent, and supas are removed rather than converted. Instead, as Timothy Grose (2020) has shown through his analysis of state media reports, officials have adopted a civilising discourse that presents Uyghur household furniture as backward and uncivilised. Xinjiang's highestranking Uyghur official, Shohret Zakir, modelled this attitude in his comments to state media, saying: 'Only by having farmers, especially farmers in poor areas of Southern Xinjiang [where most Uyghurs live], personally experience the benefits of a modern way of life, can we make modern civilised life deeply penetrate farmers' souls ... Grassroots leaders and cadres should ... guide farmers, step by step, to abandon backwards customs and live a modern lifestyle' (Xinjiang Daily 2018).

Meanwhile, in a pattern similar to the museumification of mazars, the state has made a tourist attraction out of the very object that it is destroying in Uyghur villages. Supas, transformed into odd shapes, now stand along the roads of the tourist simulacrum that replaced Kashgar's old city. Before the demolition of Kashgar's Uyghur urban core between 2001 and 2017, typical homes were mostly featureless on the outside, with small windows and little in the way of decoration. The interiors, by contrast, featured lush courtyards, elaborate woodwork, colonnades, and interior 
reception rooms with intricate niches holding display ceramics. The new Kashgar has turned the Uyghur home inside out. Above one of the new roadside supas are shelves holding jars and a teapot. An old column, likely salvaged from a demolished interior courtyard, now stands in front of an exterior door. Supposedly 'backward customs', increasingly off limits for Uyghurs themselves, are now on display for the primarily Han tourists who are driven through the new 'old city' on electric carts.

Between 2000 and 2016, Kashgar was the only historical Uyghur urban core to suffer such wholesale obliteration and replacement. In other towns, piecemeal development slowly transformed and eroded the Uyghur built environment (Kobi 2016), but there was little evidence of state-directed demolition of historical Uyghur neighbourhoods on the scale of Kashgar. However, satellite images reveal that in the years after 2016, authorities oversaw the destruction, in whole or in part, of the old cities of Khotan, Yarkand, Kargalik, and Keriya (Google Earth, 37.1133 ${ }^{\circ}$, 79.9369 ${ }^{\circ}$ [Khotan]; $38.4218^{\circ}, 77.2654^{\circ}$ [Yarkand]; $37.8805^{\circ}, 77.4153^{\circ}$ [Karghalik]; and $36.8501^{\circ}, 81.6706^{\circ}$ [Keriya]). The most common type of replacement building is the multi-storey apartment building.

The example of Kashgar, which has been studied in detail elsewhere, give a sense of what is involved in the replacement of Uyghur neighbourhoods (mahalla) with apartment blocks. Many residents had no choice but to relocate to multi-story apartment buildings outside of the city, and the change has involved disruptions to a wide range of social phenomena, including inheritance practices, life-cycle rituals (funerals, weddings, etc.), elder care, neighbourhood solidarity (mahalladarchiliq), sleeping arrangements, patterns of cohabitation, and networks of reciprocity (Pawan and Niyazi 2016; Liu and Yuan 2019). In short, the move from mahalla to apartment compound represents a shift to an entirely new way of life. Detailed information about demolition and replacement of other old cities from 2016 onward is unavailable as of yet, and research in the affected towns is almost impossible for outsiders. However, the dislocation and cultural disruption that Kashgar's old-city residents have experienced gives a sense of the changes that residents of demolished neighbourhoods in Khotan, Yarkand, Karghalik, and Keriya likely face.

Seen in the context of the comprehensive reengineering of Uyghur spaces, the destruction of prominent mazars represents one extreme on a spectrum. On one end are sites of daily, highly localised, and sometimes mundane interactions with the built environment, for example furniture, house plans, and street layouts. On the other end, famous mazars are sites at which people connect on rare occasions with a transregional, transtemporal, and transcendent community. For those who make pilgrimages in person, forgiveness, merit (sawab), healing, and the interminglings of strangers tie these weighty communitarian meanings to their personal lives. For those who cannot make the pilgrimage, the mazars exert such powers from a distance. Chinese state interventions across the spectrum of the built environment threaten a disruption of Uyghur lifeways and understandings that straddles the symbolic and the practical, the sacred and the mundane, transforming geography and space as they intersect with practices, discourse, and knowledge.

\section{Graveyards}

At graveyards, the widespread state cleansing of intimate spaces with individualised or highly local significance intersects with the mazars' political and symbolic power. Because mazars are most often tombs, the boundary between ordinary graves and mazars is permeable. That line is also blurred by the widespread desire to be buried near a mazar. The tombs of saints, famous and parochial, are often surrounded by the graves of those who were prominent enough in their communities to access prime sacred land for their final resting place. The eminence of these figures, and the 


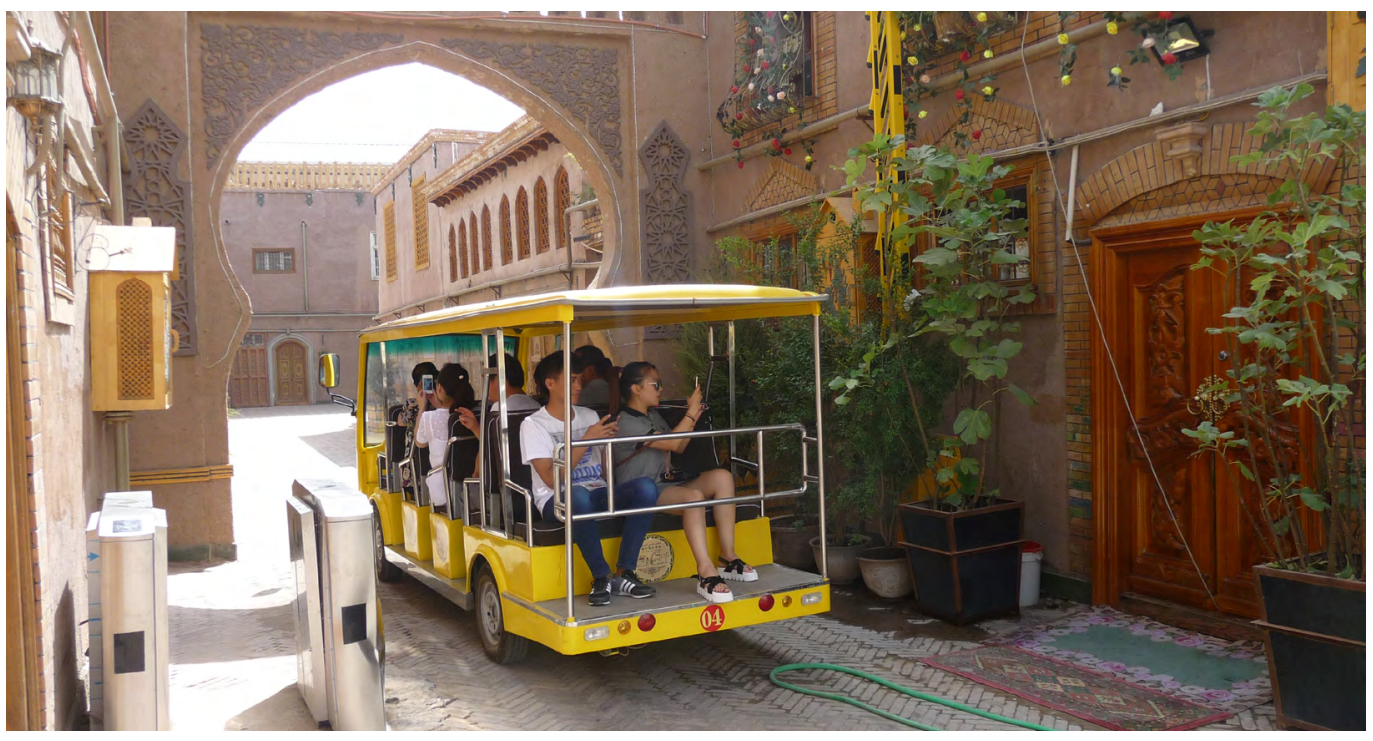

Tourists entering the new Kashgar Old City, 2015 PC: Rian Thum.

prominence of the saints they lie beside, often leads to their graves being treated as parts of the mazars themselves. A grave with a large enough marker, near enough the saint's tomb, will accumulate substantial offerings of its own, even from pilgrims who profess complete ignorance of the tomb's occupant. An inverse phenomenon also appears, which is that physically remarkable graves in a cemetery are often treated as, and thus become, mazars, possibly through the general association between mazars and graveyards.

As discussed above, the most widely renowned mazars appear to have been disproportionately targeted for destruction. However, a large number of very minor mazars have also been destroyed, not because they are mazars, but because they sit in one of over 100 Uyghur graveyards that the Chinese state has demolished since 2017. Many Uyghurs have thus witnessed, in one act of destruction, the simultaneous desecration of their family members' graves and the demolition their local mazars, sites which, despite not attracting substantial numbers of long-distance pilgrims, held similar connections to the divine and to community history at a local level.

For the moment I only have access to the reactions of Uyghurs in exile, but the desecrations appear to have had predictably devastating effects on local communities. Some of these are documented in interviews by journalists and by Bayram Sintash (Rivers 2020; Sintash 2019). The phenomenon is widespread. AFP documented the destruction of 45 cemeteries, and CNN over 100 (Agence France-Presse 2019; Rivers 2020).

Stated reasons for graveyard destructions vary. The central Uyghur graveyard and shrine in Khotan were demolished for the 'city's development' and to create 'open spaces' (Khotan Government 2019). Authorities in the Yili region cited the need for a new fire station as reason for destroying another graveyard (Zero Distance Yining 2019). Much like the case of 'supa reform', the graveyard destructions align with a nationwide programme, in this case 'funeral and burial reform' (殡葬整治) 


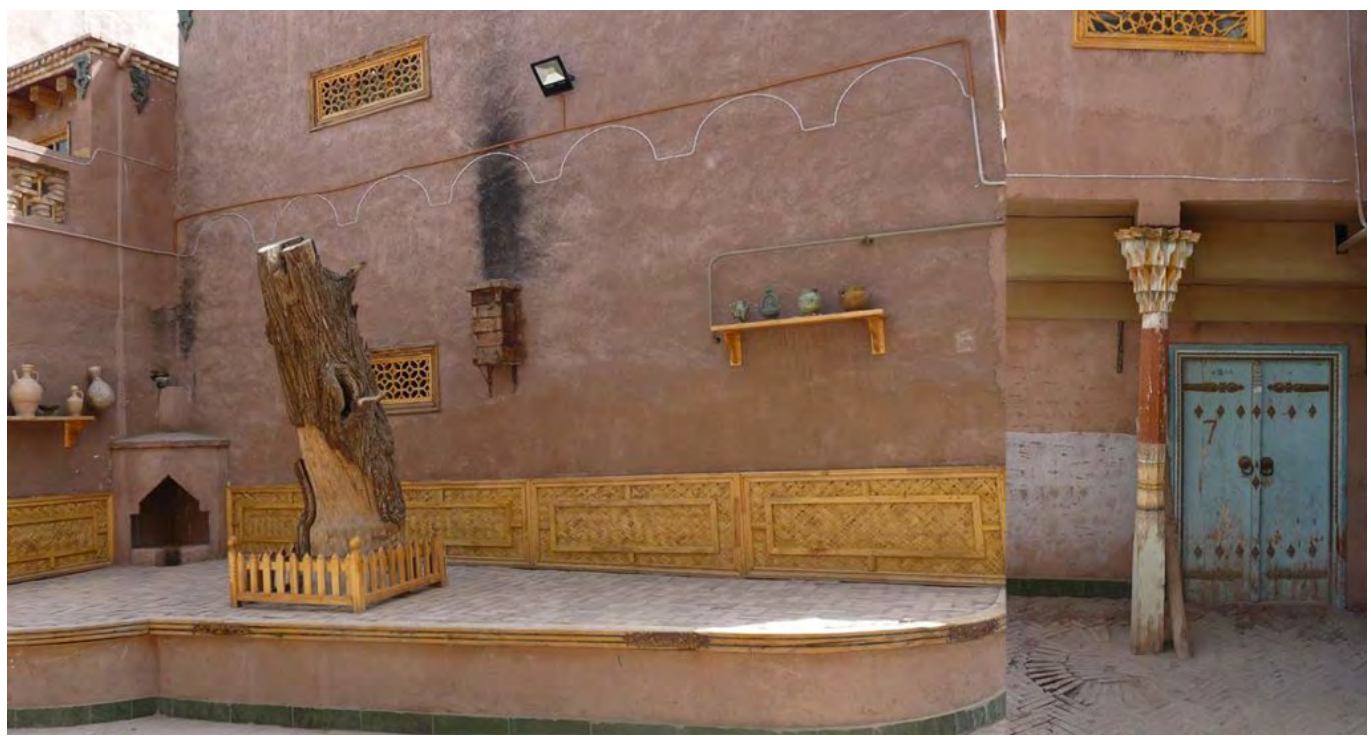

(Ministry of Civil Affairs 2018; Xinjiang Civil Affairs Department 2018). Outside of Xinjiang, this campaign targets the unapproved burial of individuals in forests, the construction of 'luxury' tombs, and the creation of new, unapproved cemeteries. It is often framed as an environmental effort (She County People's Government 2020). On the whole, the national campaign is aimed primarily at controlling the expansion and creation of cemeteries, rather than at destroying longstanding, often historically significant, cemeteries as has happened in the Uyghur case.

The political and symbolic ramifications of this uprooting of Uyghur bodies and history from the land are interwoven into strains of Uyghur historical consciousness that are shared widely today. A story told to me by a young Uyghur man in a southern oasis gives a sense of the significance of death and burial, and the connection they enact between communities and the land.
[Left] Supa-like platform and mock hearth outside houses in the new Kashgar Old City, 2015. [Right] Interior column repurposed for exterior use along a public street in the new Kashgar Old City, 2015. Photos by the author.

Perhat, who is most likely still alive, was an urban and, in the context of his largish oasis town, urbane man in his late twenties when he volunteered a fictional tale he said came from a book. I did not record his telling in audio or written form, thinking that it must be a well-known written tale I would track down later. I asked where he read it, but my subsequent searches in the books he named as possibilities have not turned up a close match. The terminology he used suggested a story from the famous 1996 novel by Memtimin Hoshur, Sand Buried City (Qum Basqan Shahr), which describes the fall of a Uyghur city to a conquering king, but I have been unable to find the tale there. I paraphrase here from memory, hoping that the imprecision of my recall is outweighed by the explanatory value of his recounting. If it does have a written precedent, I hope a reader will inform me:

\footnotetext{
The Sun King desired our homeland. He sent his vizier here. The vizier did not engage in any political machinations, but
} 
instead set up a home, took a wife, and lived a modest life. The people welcomed him, treating him as a guest. Eventually he died and was buried here, in our land. This was, in fact, precisely what the Sun King had hoped for. The vizier's tomb became a foothold for the Sun King, a claim upon the land. Before long the armies of the Sun King followed, and our land became a part of the Sun King's empire. The Sun King had taken the land by sending someone to die here.

This story illustrates not just the political significance of graves, but an awareness of their power to connect living people to the land. The Sun King's soldiers could have conquered the land with or without a grave. But the basis of sovereign ownership preceded conquest, and was effected instead by the linking of death to the landscape. It is a Uyghur story about the primacy of tombs in connecting community and political power to geography.

\section{Different Symbols, Same Grammar}

The rootedness of Uyghur communities in land and the built environment is hardly unique. Though individual phenomena described here may be particular to Uyghurs, and may need some explanation for outsiders, Uyghur geographies are hardly exotic expressions of human relations to land and space. Similar patterns play out across the world. Even the Chinese state shares some Uyghur understandings of space and place. As much as China's settler colonial regime depicts Uyghur-land relationships as backward, it seeks to create analogous interments of its own. Uyghur-style graves are replaced with 'modern' graves that mark the state's control and new, shrine-like monuments to Chinese control are erected, such as the Ban Chao Memorial in Kashgar. This is one message of the Sun King story. The symbols are different, but the grammar is familiar. The actions of the Chinese state suggest that mazars are just as significant as Uyghur pilgrims believe they are.

As the Chinese state works to coopt and disrupt Uyghur geographies, it also embeds itself further in the global history of settler colonial regimes. The desecration of shrines, the forced reordering of household space, and the demolition of cities in the name of modernity, civilisation, and development have all been common tactics of conquering empires and, especially, settler colonial projects around the world. To this list we may add the coerced movement of Uyghurs to factory work outside of Eastern Turkistan. There could hardly be a more literal and explicit example of Tuck and Yang's argument that 'everything within a settler colonial society strains to destroy or assimilate the Native in order to disappear them from the land' (Tuck and Yang 2012, 9). ${ }^{2}$

The Chinese state's programme of arbitrary internment, which has swallowed up a million or more Uyghurs, has no doubt facilitated the cleansing of Uyghur geographies and sacred sites. When Uyghurs can be abducted into camps for activities like refusing to watch state television, using foreign apps, or being related to someone who wanted to travel abroad, protesting the destruction of a mazar is unthinkable. Many of the mazars' constituents were likely already victims of the internment programme, because mazar-related activities have been designated as 'illegal religious activities' or 'signs of potential extremism', sometimes retroactively (Xinjiang United Front 2017a). And the most renowned Uyghur scholar of mazars, Rahile Dawut, has been disappeared since late 2017. Uyghurs are unable to even document the destruction, much less to resist it.

One historically deep strain of Uyghur thought on sacred places offers a possible future for the desecrated and destroyed mazars. In the tazkiras-manuscript texts that act as explanation and sometimes liturgy for famous mazars-the mazar is often figured as an enduring point of significance on the landscape, independent of human-made structures. It can 
even be argued that the sacredness of the place preceded the saint's arrival on the spot (Thum 2014, 126ff.) This increases the likelihood that future generations of Uyghurs, perhaps living in a postcolonial or at least less repressive reality, will return to the dunes of Imam Je'firi Sadiq and Ordam Padishah to build new memorial structures, and that pilgrims will renew their visits, bringing new accretions of offerings. In this possible future the mazars, no less sacred than they were before the Chinese state's attacks, have the potential to again serve as nodes for a Uyghur geography linking Uyghur pasts, presents, and futures to Uyghur lands.

However, this is only one possible future among many. And it is remote from the present reality of destruction. In a 2012 interview, before the shrine demolitions and before her own disappearance, Rahile Dawut described what the erasure we are now witnessing would mean:

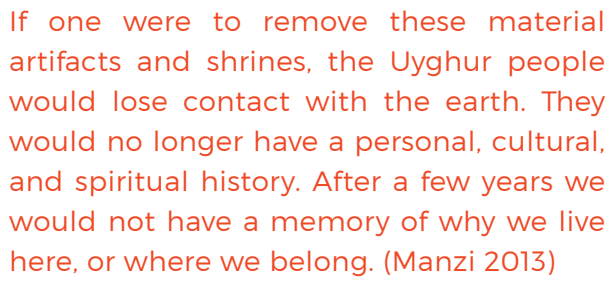

In that interview, Dawut also pointed to the words of a Uyghur beggar she once met: 'When the mazar is at peace, the people are at peace. When the people are at peace, the rulers are at peace.'

[1] This description is based on the author's visit during the pilgrimage festival of 2007. Other shrine descriptions throughout the article are based on the author's fieldwork in 2003, 2004-5, 2007-8, 2010, 2013, 2015, and 2017.

[2] I am grateful to Darren Byler for pointing out this passage. 


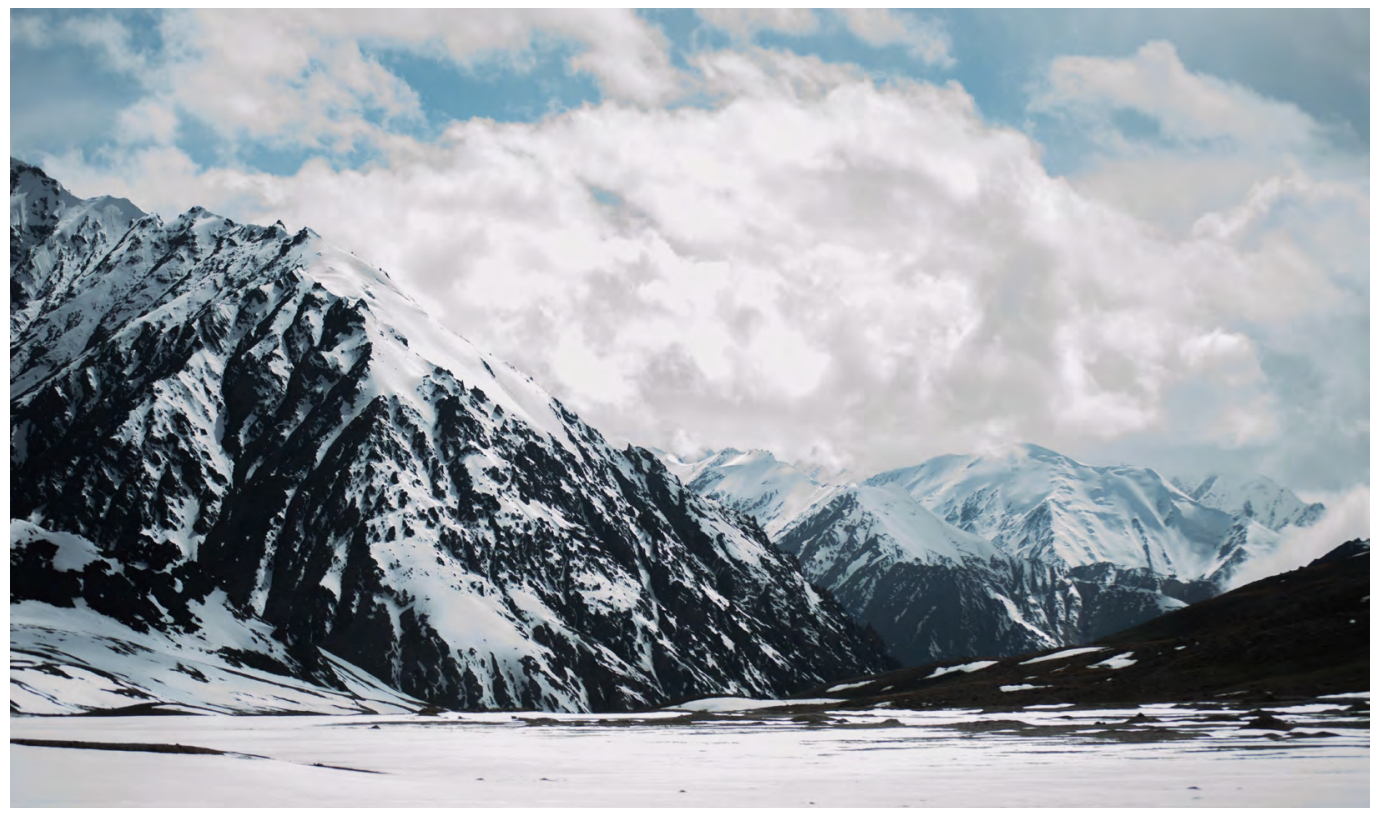

\section{China : Xinjiang :: India : Kashmir}

The Karakorum, at the border between Southern Xinjiang and Kashmir PC: Tahakhan021, Wikimedia Commons.

\section{Nitasha KAUL}

This essay examines the parallels between the two 'rising powers' China and India when it comes to the treatment of the Othered populations, with a specific focus on how this has been experienced by the Muslim majority populations of Xinjiang and Kashmir. It highlights the way in which colonialism has come be understood as a moral wound of the colonised that manipulates imaginaries of pride and futurity by these projects and their leaders.

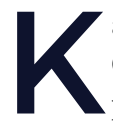
ashmir and Xinjiang share a border. Or, more precisely, the erstwhile princely state of Kashmir that is now divided between India, Pakistan, and China (and officially known as Jammu and Kashmir and Ladakh; Azad Kashmir and Gilgit Baltistan; Aksai Chin, respectively) shares a border with eastern Turkestan and Tibetcurrently officially called Xinjiang and Xizang. In addition to this geographic proximity, Kashmir and Xinjiang are marked by a complex patchwork of ethnic and religious identities, and have borne the weight of contested sovereignty claims throughout most of the modern era.

The specific regions with Muslim-majority populations in Kashmir and Xinjiangthe Kashmiri Muslims are concentrated predominantly in the Kashmir Valley, and 
the Uyghur Muslims in East Turkestan-have witnessed a particular form of political power as exercised by the two rising behemoths India and China. This has included systematic human rights violations in the name of curbing separatism and terrorism. The political relationships of these regions with the Indian and Chinese states reveal important similarities and differences. The similarities are occasioned by the fact that these ethnonationally different Muslim-majority areas have become the focus of assimilation into the evolving Hindu majoritarian nationalism in India and Han majoritarian nationalism in China. Both India and China claim these territories as integral parts of their nationstates.

While Indian Muslims and Hui Muslims in China do not have any overwhelming affinity with the ethnically different Kashmiri and Uyghur Muslim struggles, India and China have still sought to suppress the religious and cultural identities of these peoples by framing them solely as radicalised Muslims; examples include changes to architecture and restricting access to places of worship. This is in line with a broader stigmatisation of their Islamic and ethnic identities as being always already suspect and in need of securitisation. The broader global and regional variants of Islamophobia are an important way to secure justifications for why these people are marginalised (Brophy 2019). The rationale-for putting them into reeducation camps in China, revoking their autonomy without consent in India, imprisoning activists, denying access to the Internet and communications, altering the demography of the region, and prohibiting any meaningful Kashmiri or Uyghur dissent in both the Indian and the Chinese cases-is that all this is being done in order to stamp out terrorism, and to modernise and 'develop' these populations. What this rhetoric has translated into is at best a 'violent paternalism' (Byler 2018), and at worst a prolonged collective punishment of these populations in their own homelands (Anand 2012 and 2019).
Although the purported attempts at modernisation and development have proceeded along somewhat different lines in the two contexts, there is a distinct possibility that in the final instance what China is doing today in Xinjiang may be predictive of the Indian trajectory in Kashmir. In this essay, I will provide a background to the Kashmir region and an overview of some of the recent changes, and then theorise why India and China are able to continue acting in this manner towards those in Kashmir and Xinjiang. I conclude by calling for a greater transregional understanding of these strategies and more solidarity across different contexts.

\section{Kashmir: The Background}

Over the past two centuries, Kashmiris as a people have had their identities constructed out of prolonged experiences of multiple colonisations-from the Mughal to the Sikh empires, Dogra direct rule, British suzerainty, and contemporary Indian and Pakistani control and administrative claims. These rules were legitimised through a mix of treaty provisions, elite bargains, and securitisations (Kaul 2011). While the precise boundaries and jurisdictions of the erstwhile princely state of Jammu and Kashmir shifted over time, the area nevertheless amalgamated a range of different regional, religious, and ethnic populationsall of which are, with different degrees of volition, able to trace one irreducible element of their identity as Kashmiri, even if, in some cases, this simply means being historically bracketed into the territorial bargains of the former state. The three provinces of the state-Jammu (with several districts), Kashmir (with districts in the Kashmir Valley), and the Frontier Districts (Ladakh, Gilgit, Baltistan, and Poonch/Muzaffarabad)-were carved up following the Partition in South Asia, when the independence of British India led to the 


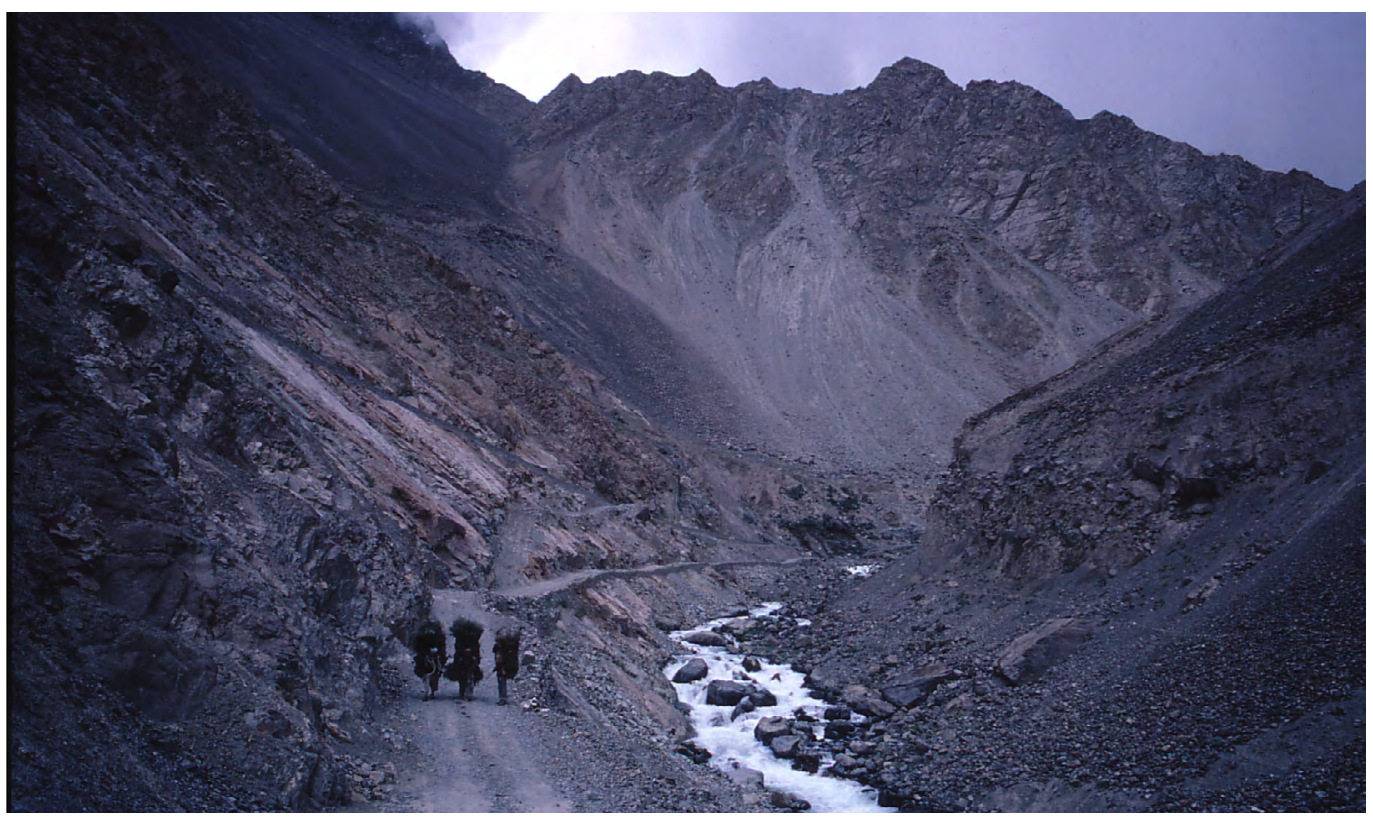

Mountain route in Kashmir, 1983 PC: Ole Holbech.

creation of India and Pakistan. Since their very inception, these two nation-states have been marked internally by the competing and anxious postcolonial nationalisms in their turbulent political dynamics, and externally by the global scenario of the Cold War and its fallout, the ascendant neoliberal consensus, and the protean War on Terror.

Against this setting, Kashmir has remained an unresolved existential issue for India and Pakistan, whose rivalry has played out in a combination of military force, legal impunities, preferred state-centric media framings, cloakand-dagger politics, and strategic alliances on subsets of economic and political issues with powerful, though problematic, entities (such as China, the United States, and the United Kingdom). Only rarely has this confrontation been conducted through artful diplomacy, let alone by showing any human concern for the Kashmiris affected. By the start of the twentyfirst century, with the coming into being of a new global Other via post-9/11 Islamophobia, the rise of Hindu nationalism in India, and following the multiple wars between the two countries, the dominant narrative of the 'Kashmir problem' came to be centred on the Kashmir Valley and its Muslim-majority population. This was in no small measure due to the communalisation of the political dispute because of a number of factors that include: a) the nationalist Indian position being unable to distinguish between a proxy Pakistan-backed armed insurgency and an anti-Indian uprising with popular support fuelled by decades of accumulated resentment; b) Pakistan's twonation theory, which sees Hindus and Muslims as distinct, irreconcilable nations; c) episodes of anti-minority (anti-Kashmiri Pandit) violence carried out by Islamic militants, and the forced exodus of Kashmiri Pandits under threat of violence and with bafflingly little promised protection to stay put in their homeland from the Indian state; and d) the overwhelming and multidimensional violence directed at Kashmiri Muslims, combatants 


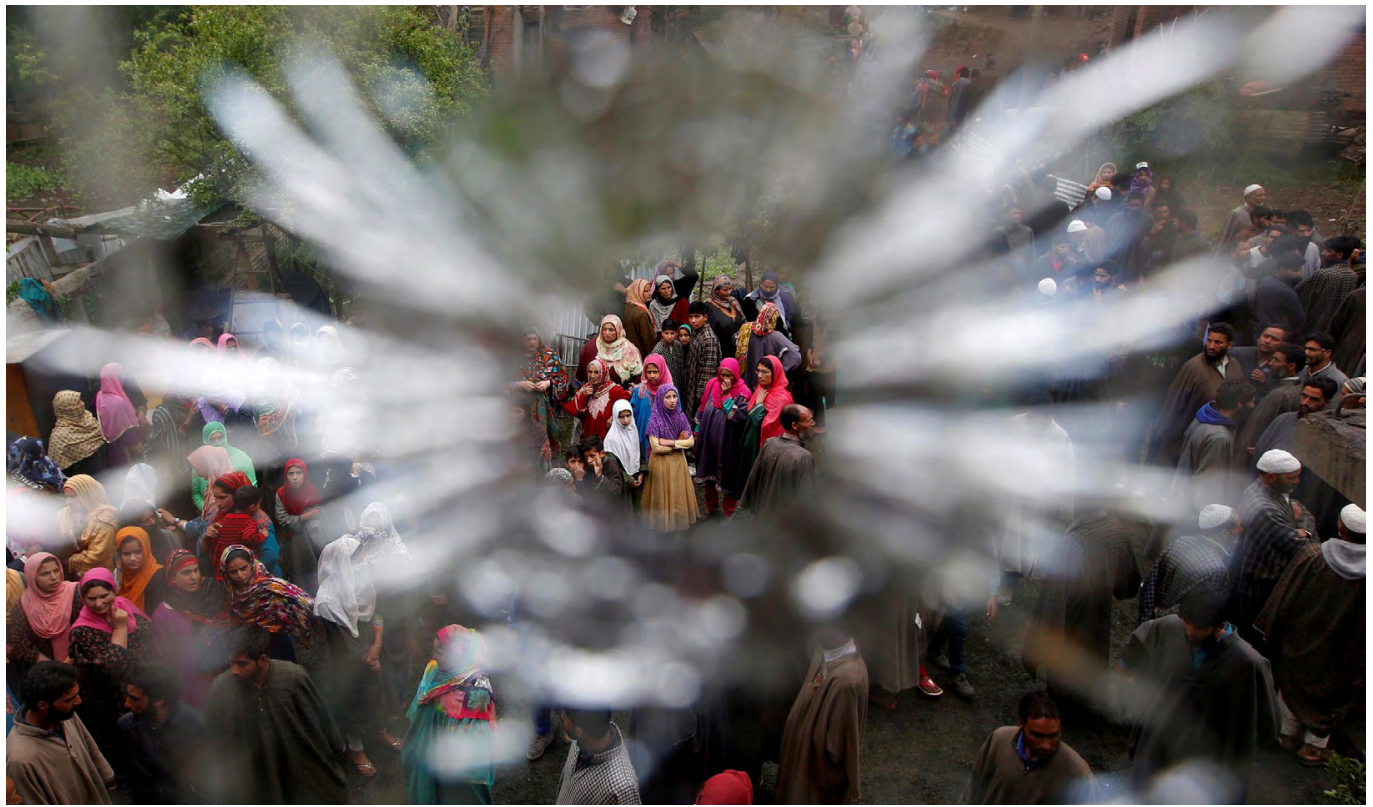

People protest against India in Kashmir,

September 2018. PC: Ubaidsardar, Wikipedia.

and civilians both, by Indian forces, which over the years have killed tens of thousands of Kashmiris, and left thousands victimised through enforced disappearances, torture, mass killings, and mass rapes-all of which has been well documented by human rights organisations.

In the past 10 years, newer chasms have opened up between the global, the national, the macropolitical, and the micropolitical when it comes to the different facets of Kashmiri identity, human rights, and political aspirations in relation to India and Pakistan. At a global level, the prolonged recession in the West and an aggressively marketed discourse of the 'rising powers' have meant the prioritisation of semantics over substance when it comes to India's democratic credentials. This has also involved an alternating mix of threat and awe regarding China's expanding economic and large-scale infrastructural connectivities through the Belt and Road Initiative, including the China-Pakistan Economic Corridor. In this scenario, human rights concerns-whether in Kashmir, Tibet, Xinjiang, Balochistan, or elsewhere-that used to be inserted as a staple into foreign policymaking in the West, and were already suffering from substantial critiques of selectivity and hypocrisy, finally fell prey to the rise of powerful and electorally legitimated right-wing leaders in the West, who quite literally mean only business, largely for themselves and their cronies. At the national level in India, the spectacular consolidation of the dream Hindutva project of the Rashtriya Swayamsevak Sangh (RSS), a powerful right-wing nationwide paramilitary organisation, and the rise of the Bharatiya Janata Party (BJP) led by Narendra Modi, with its particular governmentality of 'postcolonial neoliberal nationalism'-which co-constructs ideas of the economy and nation (Kaul 2019a)have sought to create India, first and foremost, as a Hindu nation akin to a Muslim Pakistan. In these political scripts, the Kashmiris struggling for human rights and/or political 
self-determination have been essentialised as separatist Muslims who need to be subdued by any means possible, because they are not political human beings, but problematic Muslims qua Muslims.

In all of this, the issue of Kashmiri Pandits has been weaponised like never before to justify the Hindutva-motivated Indian actions in Kashmir; the Hindutva idea of India sees only Hindu Kashmiri Pandits as 'true' Kashmiris, just as it sees Hindu Brahman Indians as the ideal subjects of the 'pure' Hindu nation. At the macropolitical level, the distance between the imaginaries and mutual cognition of aspirations in the different regions-Jammu, Kashmir, and Ladakh-has increased significantly as a result of policies that consciously foster selective connectivities and relationalities, and cultivate rival leaderships. At the micropolitical level, the accumulated resentments of the Kashmiri people, especially of the post-1990 generation, have become multilayered metamorphic rocks of grievances, symbolically like the rocks that are pelted by masked youths at the soldiers who are seen as the visible human symbols of an unjust and occupying colonial state.

\section{Kashmir Today}

In 2020, as the world reeled under the impact of the coronavirus pandemic and different countries staggered through various stages of prolonged lockdowns, the people in Kashmir experienced the fallout of a combination of poor health infrastructure and a fractal version of lockdowns within lockdowns as many of the restrictions on telephony and telecommunications put in place in August 2019 had not yet been fully lifted. This was a direct consequence of the events resembling a 'constitutional coup' that took place in the summer of 2019. On 5 August 2019, the Indian government stripped Jammu and Kashmir (J\&K) of its constitutionally guaranteed autonomy by revoking Article 370 of the Constitution, which gave J\&K autonomy over everything except defence, telecommunications, and foreign affairs. In addition to ending autonomy, the statehood of $\mathrm{J} \& \mathrm{~K}$ was also taken away and it was split into two union territories: Jammu and Kashmir as one, and Ladakh as the other.

This occurred overnight, without the consent of the state legislature or the people of the region. To thwart any dissent, all landline and mobile telephony and Internet communications were shut down, curfew-like conditions were imposed, political and civil society leaders from across the spectrum were preventively arrested, no-fly lists were created, and large numbers of people, including children, were imprisoned, sometimes outside the state (Kaul 2019b and 2019c). As the flag of $\mathrm{J} \& \mathrm{~K}$ was removed from buildings and police forces were brought under the control of the Union Home Ministry based in New Delhi, Indian opposition leaders were prevented from visiting the region, and a delegation of far-right European parliamentarians was taken on a tour and photographed against scenic backgrounds in the deserted landscape. Foreign media, critical Indian media, and a US senator were refused access; only state-approved media were permitted to function at media facilitation centres where the chosen few could access the Internet for 15 minutes at a time. This Internet shutdown continued for months, making it the longest ever Internet blockade in any democracy. As of writing, in late autumn 2020, 4G Internet services have still not been restored in spite of the coronavirus pandemic.

Underlying these developments were clear intentions of a transition to full-throated settler-colonialism. As these events were set in motion in 2019, ruling-party politicians in India celebrated the change as something that would allow them to marry 'fair-skinned Kashmiri women'. In the manner of a typical Orientalist fantasy, Kashmir has always been exoticised and feminised in the Indian imagination (Kaul 2018). The Muslim men of Kashmir especially are seen as the cruel Other, latent terrorists who are always already suspect in their politics. So far, 2020 in Kashmir has seen 
further amendments to the law and policies that confirm these settler-colonial intentions. The law was changed so that non-citizens of former J\&K can now receive fast-tracked domicile status based on residency there. In the middle of the coronavirus pandemic, in July 2020, masses of Indian workers were brought into Kashmir to work in brick kilns. Also in the same month, the law was changed to allow the designation of any area as strategic, permitting permanent constructions to be made there for the use of the armed forces. At the same time, housing and urban development policy has been changed to allow the building of hundreds of thousands of different dwellings, ranging from slum redevelopment to integrated townships, through public-private partnerships, for which contracts will be awarded. Kashmiris fear that all these developments taken together will result in overwhelming demographic change the mass settlement of outsiders. That this is not mere doom-mongering is supported by the fact that, in November 2019, the Indian ConsulGeneral in New York was filmed at an event as he comparing the return of Kashmir's Hindu minority to Israeli settlements-in his words: 'If the Israeli people can do it, we can also do it' (Express News Service 2019).

\section{India's Camps}

China plays a complex role in the Indian public imagination and politics-often perceived as a very different Other; India is projected as democratic and China as Communist authoritarian. Yet, China is also seen as worthy of emulation for its economic and infrastructure growth, and in the ability of its leaders to evading the problems of democratic dissent. India's Prime Minister Modi is portrayed as a 'strong' leader, is presented to his masses of followers, someone who can keep democratic noise under control and succeed in the way that China has done.
While sections of the Indian media wonder why China hates its Muslim Uyghur minority, they seem comfortable ignoring the everincreasing and systematic Islamophobic violence in India itself, which is made worse by police inaction or brutality, lack of prompt official condemnation, and inexcusable judicial delays or quietude. It is possible for Indian TV anchors to highlight the plight of the Uyghurs, the lack of religious freedom, and the construction of concentration camps in China; however, the plight of Kashmiri Muslims, the persecution of Indian Muslims, and the construction of detention camps in India receive barely any mainstream attention.

In spite of widespread protests, the recent, controversial Citizenship Amendment Act (CAA) succeeded in creating a religious basis for access to Indian citizenship, but Islam is excluded. Furthermore, the Indian government is planning to establish a National Register of Citizens, and attempts at citizenship verification in certain areas of the country have resulted in the creation of millions of stateless people, often from among those who are already socioeconomically marginalised (for instance, 1.9 million people in Assam, which is 6 percent of the state's population; see Rahim 2019). Much to the chagrin of organisations such as the right-wing paramilitary RSSthe ideological parent of the ruling BJP-a large number of Hindus are among the newly stateless people (Rahim 2019). However, while the new CAA allows these Hindus to find a route back into Indian citizenship, their Muslims counterparts are purposely left in a limbo.

An anti-immigrant and Islamophobic agenda is a key staple of the Modi-led BJP, which has been in power since 2014 and has made no secret of endorsing this agenda by refusing to condemn anti-minority violence and indulging in outright hate-speech against 'Muslims' and 'foreigners'-both of whom are amalgamated into a composite figure by denying the centuries of Mughal history. In 
2014, India's central authorities asked all the provinces to set up at least one detention camp to separate criminals from illegal immigrants or foreigners awaiting deportation after completing their sentences due to the impossibility of confirming their nationality (Kalita 2019). Construction has since begun on a number of detention camps throughout the country, with the process gathering pace over the past couple of years (Sen and Singaravelu 2020; Uniyal 2020). While Modi denied the existence of any such camps, lawmakers have accepted that these exist (IANS 2019). Also, contrary to the claims by the government that the inmates are housed with dignity and not deprived of basic facilities, there have been reports of numerous deaths in the camps in Assam (Krishnan 2020). The resources needed to set up and run these detention camps make them likely candidates to form a blooming 'sunrise industry' (Balakrishnan 2019).

In the context of Kashmir, a different kind of camp is being proposed. In January 2020, General Bipin Rawat, Chief of India's Defence Staff, suggested that Kashmiris could be taken away to 'deradicalisation camps' (Gettleman and Schultz 2020). For many Kashmiris, this echoes the camps in Xinjiang and portends a similar fate awaiting them. The military did not clarify these remarks, but after what was done to Kashmir in the constitutional coup of August 2019, no nightmare is beyond imagination since democratic checks are fast disappearing in the face of a craven judiciary, censored and self-censoring media, targeted attacks on civil society spokespeople and activists, and a wide-ranging Hindu-majoritarian overhaul of the country's historical, social, cultural, and political identities. A hostile attitude towards the Kashmiri population is nothing new. In 2017, the same general-who at that time was army chief-applauded the use of a Kashmiri civilian tied to the front of a military vehicle as a human shield, calling it an 'innovation'; he also expressed the wish that the Kashmiri people would fire weapons instead of throwing stones so that he could do what he wanted with them (Safi 2017).

\section{The Moral Wound of Colonialism and the Postcolonial Error}

Mass internment camps as sites for the deprivation of people's rights and liberties have an inextricable relationship with colonial history and, over the past two centuries, they have been used by a large number of countries across the globe. In fact, governments like those of India and China are only too keen to point to this history of colonial atrocities carried out by Euro-American nations. Added to this is the hypocrisy and selectivity with which 'the West' has pursued its human rights agenda during the period of the Cold War, how it has carried out 'humanitarian intervention' in its aftermath through the invasions of Iraq and Afghanistan, and suppressed the rights and liberties of its own citizens under the guise of the War on Terror. Taken together, this adds up to a convenient nativist discourse that officials in countries like China and India use to justify their own behaviour in Xinjiang, Kashmir, and elsewhere.

When we think about how large and diverse countries such as China and India are able to create consent among their own majority populations, and globally, to support their actions in Xinjiang and Kashmir, we find two important explanatory variables: media censorship and nation-state-centric media coverage of these issues; and how the ignorance and indifference of the wider world to the fate of these oppressed Muslim populations are tied to access to Indian and Chinese markets and global commodity value chains. However, there is a third, equally important way in which Indian and Chinese-and other non-Westernpopulations consent to the treatment of Kashmiri and Uyghur people. This relates to the West/non-West divide in the understanding of the history of human rights, and the role of colonial history in this. This third point is my focus here. 
It is important to analyse the role of colonial history in the present, and I theorise this through what I call the moral wound of colonialism. Let me explain. To begin with, notwithstanding their geographical proximity, or demographic similarity, or strategic treatment, there is a striking paucity of academic work looking at the Kashmir and Xinjiang cases side by side. Such an understanding is often hard to obtain because of the stable sense in which the signifier 'the West' is understood. In the inherited historiography that presents a perennial structuring of colonial power as between 'the haves' of the West and 'the have-nots' of the non-West, there is no place to perceive a colonial exercise of power by the non-West, unless it is only seen only as reflective of the divide-and-rule agenda of the West. This is a significant conceptual problem.

It is sustained by thinking that perceives colonialism as a 'moral wound' to the formerly colonised rather than to the colonisers. To have been colonised in the past is understood as a matter of moral shame and humiliation for the colonised, but there is no dominant equivalent narrative of moral shame and humiliation for having been a coloniser nation. The idea that a state, interpreted as a political community, is justified in acting colonially over territory and peoples that it seeks to control largely goes unchallenged due to the way in which history is taught in teleological and triumphalist terms. Critical challenges to this rarely make it through to the mass media and wider public consciousness and, when they do, it is in the guise of token appreciation of a handful of secular, humanist, liberated, Western-educated, anti-colonial intellectuals. It is certainly the case that what is seen as humiliating is less the carrying out of brutal colonial oppression, and more the inability to have successfully resisted it. In this way, the glory of imperial colonial power is never sufficiently critiqued and the humiliated-yetvirtuous nativist sense of having been colonised is never critically understood either.
This discourse creates the perfect recipe for messianic leaders to manipulate imaginaries of time along the lines of pride and futurity, and promise the future as a return to a glorious past-either of putative precolonial purity in non-Western countries or of imperious and wide-ranging territorial control in Western countries. In each case, the fantasy is predicated on the idea of making a country great again. Manifest in this-what I call a postcolonial error (in both the formerly colonising and the formerly colonised countries)-is the latent potential for a double bind: the non-West can achieve glory along the colonial lines of the historical West by overcoming its past humiliation, but the non-West has a virtuous inability to be a coloniser because of having been previously colonised. Thus, at the same time, a non-Western country, humiliated through previous formal or informal colonisation, seeks to perform economic and political power in the way of the historical West, and yet is immune to the possibility of playing the role of coloniser in its own peripheries. This is effectively the essence of what the moral wound achieves in political terms in the contemporary era.

When India or China is presented as a 'rising power', this is precisely how 'power' is understood and what is meant by its 'rising'. There is, of course, no logical, historical, biological, or empirical reason to sustain the claim that formerly 'humiliated' or colonised non-Western countries are effectively immunised from acting as colonisers themselves. But attempts to highlight the colonial actions of non-Western countries like India and China are usually answered with the retort that these criticisms are just a regressive, Indophobic or Sinophobic, perhaps even racist, ploy to stop these powers from rising because they are not Western. One might further ask what precisely does being nonWestern mean in this context? What is the role of the signifier 'the West' in the idea of 'the non-West'? It certainly does not mean the absence of consumerism, capitalism, and allied infrastructures of conspicuous consumption or urbanisation. When the signifier 'West' is 
raised in this manner, it refers specifically to the question of liberties and rights and, most specifically, human rights.

This, in a single stroke, relinquishes the global legacy of the evolution of human rights-including anti-colonial struggles-to a purported triumphalist West. For the same reason, it also makes the possibility of human rights denial in the West invisible, while enabling the continuation of human rights denial in the non-West to go unchallenged. None of this means that there are not regressive Indophobic or Sinophobic, and even racist, voices in Western countries; in fact, many right-wing voices fit this description. However, this weaponisation of the category 'West' to deny rights in the non-West is fundamentally untenable because of the complexity of history, territory, and identity. Be it China's 'century of humiliation' (Callahan 2004) or the imaginary of the 'Golden Bird' that was India before British colonisation, the postcolonial error of conceptualising the moral wound of colonialism serves a very useful purpose in these countries. The Chinese challenge to global human rights discourse is well recognised (Chen 2019). India is on the same path, with the Indian Home Minister recently referring to the inapplicability of 'Western human rights' in India as the country would have its own expanded human rights linked to Indian values (The Wire 2019). Within this framing, the political aspirations, identities, and rights of minority populations in 'restive' regions cannot be framed as struggles; instead, they are seen as targets of patronising development or the repression deserved by traitorous subjects. What is more, the technologies and infrastructure for this development and/ or repression in China and India are linked to a global network of profitable corporate interests that work along supra and infrastatal pathways, while simultaneously abetting the denial of rights in order to marginalise minority populations in the name of Western politicking.

\section{Highlighting Commonalities}

In both the Indian and the Chinese cases, the uninhibited repression of Muslim-majority regions is aided by the fact that the international community is loath to take any substantive action due to their economic ties with these countries (Ma and Loanes 2019; SupChina 2019). Several Muslim countries refuse to speak up against India and China-for instance, Modi received state honours in the Middle East in August 2019 even as the constitutional coup was under way in Kashmir (Dorsey 2019), and Chinese Belt and Road Initiative investments are having a similar silencing effect on Muslim states. At the same time, statements by the United States are seen as hypocritical given the US's own record of human rights abuses that has only worsened under Donald Trump. The global Islamophobia unleashed in the wake of the War on Terror assists in the collective portrayal of Muslims in India as a threat.

In August 2016, the question 'Should India apply the "Chinese model for Xinjiang" in Kashmir?' on a popular web discussion forum received a variety of responses, revealing two common threads (Quora 2016). The first was that doing so was not possible because China was communist authoritarian and India democratic; the second was that Kashmir's autonomous status was guaranteed by Article 370 of the Indian Constitution. Commencing in July 2016, Kashmir was rocked by a massive anti-India uprising in which mass blindings were carried out using pellet guns. By 2020, Article 370 had been revoked, and there is an accelerated set of legal and policy moves to bring about demographic, environmental, and infrastructural changes in the region. It is conceivable that where Xinjiang leads, Kashmir may follow.

In 2019, The New York Times leaked pages of internal documents of the Chinese Communist Party (CCP)-which the journalists described 
as 'chillingly bureaucratic'-including handbooks with questions and model answers prescribed in order to instruct Uyghur students about their families taken away to camps ( $\mathrm{Ma}$ 2019). Furthermore, video surveillance firmslike Hikvision from China, a 'national AI champion' according to the CCP, and 'either owned or controlled by the Chinese military' according to the US Department of Defense (Dalmia 2020)-have gained increasing prominence in India, including through Indian government contracts under the Make in India initiative. As others have described, there are evident global linkages in the circulation and export of technologies that enable digital authoritarianism in which China's role is ever expanding (Feldstein 2019; Roche 2019).

Even though the relationship between China and India is marred by strategic rivalry over border issues, which periodically translates into clashes and loss of life, the economic ties between the two countries and the resonances between Xi's and Modi's projects to dominate Xinjiang and Kashmir overshadow these confrontations. The ethnonationalist struggles of the Muslim populations in Kashmir and Xinjiang have a long and complex history; indeed, there is even a small minority of Uyghurs who settled in Kashmir as transHimalayan migrants between the 1930s and the 1950s, as Communist China took shape. Kashmir today is not the same as Xinjiang, but many developments over the past year indicate that it might become more and more similar. The people in both these regions have to contend with a political rule that allows them limited rights or ability to dissent and is marked by deprivation of liberties and lack of accountability. Yet, in spite of sharing a historical border, the same religion, and fairly similar challenges, these groups are, if not unaware, at least fairly indifferent to each other's struggles. However, for those of usscholars, policymakers, and activists-who are able to witness the nature of the unfolding political dynamic in the two rising powers of China and India, it is important to highlight the commonalities in terms of strategies, speech acts, and circulations of technology that facilitate such projects. Further and more broadly, as I have argued here, we need to challenge the instrumentalisation of the moral wound of colonialism that translates into a postcolonial error, whereby non-Western countries are able to secure legitimacy and justification for their own exercise of colonial power. 


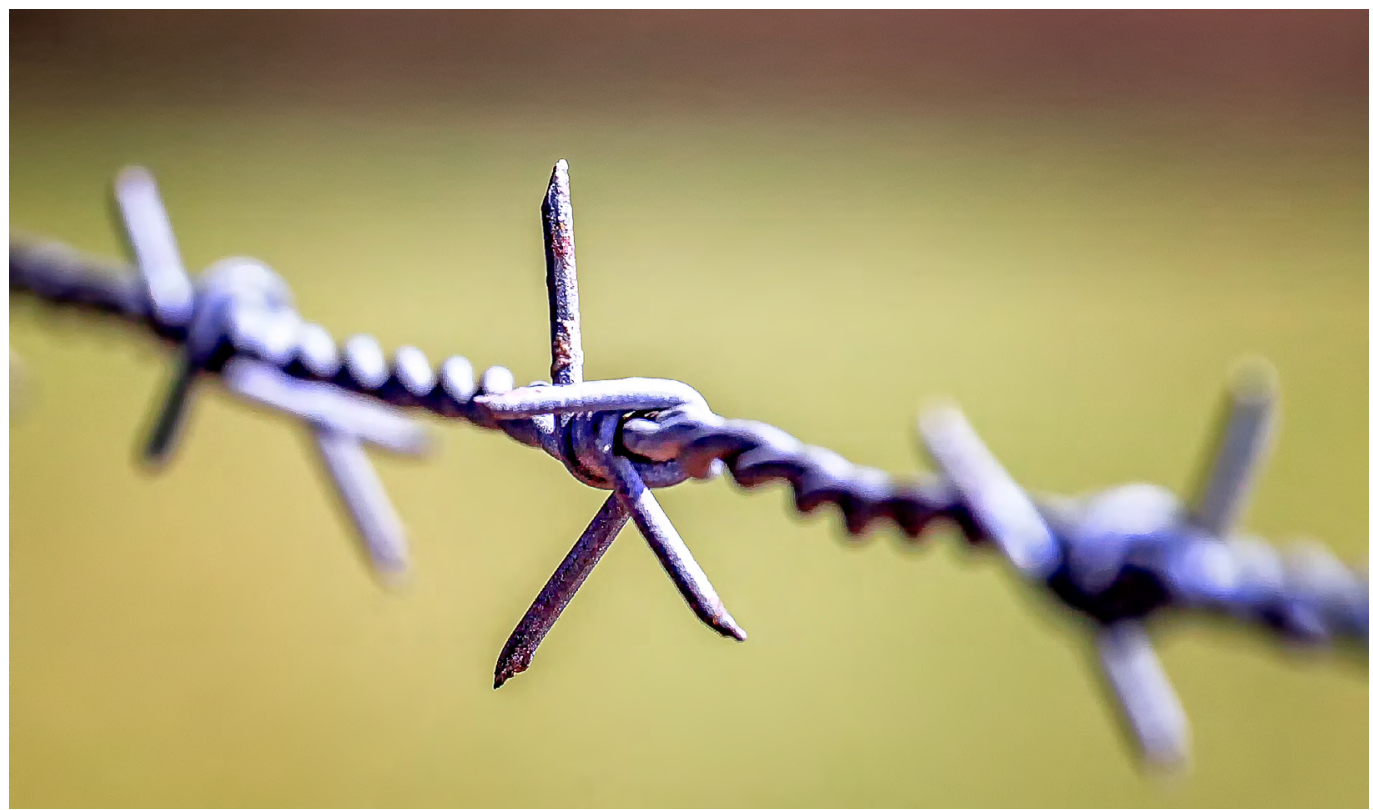

\section{Counterterrorism or Cultural Genocide? \\ Theory and Normativity in Knowledge Production About China's 'Xinjiang Strategy'}

Matthew P. ROBERTSON

A recent high-profile paper classifying the Chinese state's coercive actions against Uyghurs as 'preventive repression' is a window into fundamental questions in the social scientific project. This essay discusses how the concepts we use often carry normative assumptions, arguing that adopting a degree of reflexivity in our scholarship can bring us closer to seeing what they may be.
Barbed Wire Fence. PC: Pat O'Malley.

\section{Wake up! There is something for us to learn here. What they're saying applies \\ to us, even if it was not meant for us. \\ Friedrich Nietzsche, Anti-Education (1872)}

ince 2017, the Chinese Communist Party (CCP) has embarked on a rapid and intense securitisation of the Xinjiang Uyghur Autonomous Region. This has included mass extra-legal internment coupled with coercive thought reform, strict 
surveillance, restrictions on religious life, public struggle sessions, the placement of children in state orphanages, policies for increased Han settlements, limitations on Uyghur births, and much more. What we should call these actions depends on how we think about them, though how we think of them determines what information about them we consider significant. Is it a jobs training programme that went too far? A counterterrorism exercise using indiscriminate target selection and highly intrusive methods? Or is it the destruction of an indigenous Muslim people by a colonial (or totalitarian?) state masquerading as a jobs training programme and counterterrorism exercise?

The recent high-profile paper 'Counterterrorism and Preventive Repression: China's Changing Strategy in Xinjiang' by Sheena Chestnut Greitens, Myunghee Lee, and Emir Yazici, published in International Security (2020) (hereafter referred to as the Xinjiang Strategy paper), provokes exactly these questions, and is an acute demonstration of the centrality of concept formation in our attempts to understand political acts, as well as the unavoidable reflexive and normative dimensions of scholarship when studying how extreme state behaviours affect vulnerable communities.

Greitens et al. put forward a provocative and counterintuitive argument: that the CCP's own justification for its actions in Xinjiang, as a counterterrorism campaign, offers the most compelling explanation for its changed approach to dealing with the indigenous Uyghur Muslims there. The authors assert that this justification has been mistakenly overlooked as an important explanatory factor by extant scholarship, and that it is so significant that countries wishing to alter China's behaviour should adopt the language of counterterrorism rather than human rights. International Security is one of the leading journals in the field of international relations and, while the paper does not uncritically reproduce official formulations of the campaign in Xinjiang, it makes a strong case for the utility of these formulations.

The prominence of the paper and the importance of what is happening in Xinjiang naturally invite dialogue. I think the paper offers a useful starting point for exploring fundamental questions in the enterprise of social science-questions of concept formation, theory, and the role of the social scientist in studying potentially genocidal acts against an indigenous population-which have no easy resolution. This paper puts into sharp relief many of these fundamental lines of enquiry, and by examining them we may be enabled to pursue our vocation with greater reflexivity.

The major problematic raised by the paper is: is what we are observing in Xinjiang a counterterrorism campaign using extreme measures, or a cultural genocide cloaked in the gestures of counterterrorism? Put another way: is the CCP's objective only to prevent further attacks against Chinese civilians by Uyghur militants, or does the Party also seek to end the existence of the Uyghurs as a people? The two goals are not contradictory: if there were no more Uyghurs, there would be no more perceived threat posed by Uyghur militants. Yet we still wish to enquire into what the CCP thinks it is doing. The available data do not allow us to decide whether the CCP's use of a counterterrorism framing for its repression in Xinjiang is driven by instrumental or noninstrumental motives-yet how we approach that dilemma has empirical, conceptual, and normative implications.

My argument proceeds as follows. First, I recapitulate in more detail the movements in the Xinjiang Strategy paper and discuss the empirical and conceptual issues raised. I then turn to the role of concept formation in political science and the undertheorised conceptualisation of terrorism and counterterrorism in the paper. Finally, I look at what light the critical perspective sheds on this problem, and how it can help to illuminate 
the relations we are always involved in when selecting one linguistic formulation or one logic of enquiry rather than another.

\section{The Empirics of Inferring Perceptions}

The Xinjiang Strategy paper begins with an account of China's coercive measures against Uyghurs in Xinjiang-but it is one that is primarily limited to those measures that are consistent with the conceptualisation of the campaign as being primarily aimed at counterterrorism. The authors identify their key contribution, i.e. to demonstrate 'that an overlooked and significant factor that contributed to the CCP's change in internal security strategy in Xinjiang was its desire to prevent terrorism from diffusing into China via radicalized transnational Uyghur networks' (Greitens et al. 2020a, 10).

The next two sections respectively summarise the CCP's repression of Uyghurs in Xinjiang-again only noting acts consistent with counterterrorism-and survey common explanations for those repressive acts, i.e.: increased contention and unrest in Xinjiang, a ramping up of existing assimilationist policies toward minorities, and the rise to leadership of Party chief in Xinjiang Chen Quanguo. They then turn to the favoured explanation, the changing threat of Uyghurs and transnational terrorism, examine the evidence that the CCP expressed concerns over this threat, and on the basis of this evidence argue that this threat has driven the coercive policies against Uyghurs.

Given the central role that CCP perceptions play in supporting this argument, coupled with the inherent vagaries (and perhaps impossibility in any rigorous empirical way) of separating actual CCP perceptions from instrumental CCP propaganda, I argue that more care should have been taken in substantiating their claims about CCP perceptions. ${ }^{1}$
More importantly, the authors do not use the same rigorous standards of analysis to assess the competing explanations for the CCP's Xinjiang campaign against the favoured explanation. The main competitor to the counterterrorism theory is the role of Chen Quanguo in instigating the securitisation drive, which began soon after he assumed the role of Party secretary in Xinjiang (Leibold 2019; Zenz and Leibold 2017). The authors write that assessing Chen's role 'confronts a fundamental empirical challenge: ultimately, we do not have the information necessary to pinpoint the locus of decisionmaking, the set of policy options considered, the process by which the decision was made, or the underlying motivations of the actors whose preferences were decisive. We cannot know for sure whether Chen is a policy entrepreneur, an implementer of central policy, or something in between' (Greitens et al. 2020a, 27-28).

Yet this 'fundamental empirical challenge' posed by the Chen Quanguo explanation applies just as well to the favoured counterterrorism explanation: in that case, the decisionmaking process and actor motives also inhabit a black box.

We observe a series of violent actions by Uyghurs and overseas jihadist groups, claims by Party-affiliated sources that some portion of rural Uyghurs were vulnerable to extremism, and mass detention justified in part, internally and externally, by reference to these threats. It may seem uncontroversial to draw a straight causal line through these events-but we have no criteria for judging what ultimately accounted for the timing and repertoire of coercive choices. Does mere temporal correspondence suffice? If so, the timing of Chen's rise and the crackdown would seem just as compelling. We also do not know whether or not the stated justifications functioned as actual reasons-that is, threats perceived by CCP actors who then took countermeasuresor were constructed as threats by Party actors via their own ideological filters and political 
exigencies. These processes may also be impossible to disaggregate given how theory shapes reality.

The same evidence adduced by the authors could very well account for the security campaign beginning anytime from 2014 onwards, when Xi Jinping visited the region and made the speeches leaked to The New York Times that the authors rely on (Ramzy and Buckley 2019). Xi's comments are again part of a confusing temporal argument in a followup piece by the authors for the Brookings Institution (Greitens et al. 2020b). In it, they refer to contacts between Uyghurs and Islamic militant organisations in Southeast Asia and the Middle East between 2014 and 2016, statements threatening attacks on China by al-Qaeda and ISIS-linked organisations in 2015 and 2016, and note that 'These developments appear to have gotten the CCP's attention'. They then cite The New York Times documents quoting $\mathrm{Xi}$ that 'East Turkestan's terrorists who have received real-war training in Syria and Afghanistan could at any time launch terrorist attacks in Xinjiang'. But The New York Times report indicates that Xi's speeches were made in April and May 2014. The Southeast Asian contacts between Uyghur and Islamic militants were reported between June and September 2014, and the al-Qaeda/ ISIS links one to two years later. Xi could obviously not have been responding to events that took place in the future. Thus, while it is clear that Xi warned about terrorism in 2014, those comments shouldn't be cited as part of a culminating argument, referring to reports months and years after that to show that the timing of the campaign can be primarily explained by 'internal documents appear[ing] to confirm that senior party leaders, including Xi himself, do fear terrorist threats from abroad destabilizing their rule at home' (Greitens et al. 2020b).

The question is not whether the Party expressed concern about terrorist attacks by Uyghurs. The question is that if these concerns were overriding in how the Party was deciding to resolve the Uyghur question, what accounts for the three-year gap between these secret speeches and the timing of the campaign?

Ultimately, how we should understand CCP statements of concern about terrorism depends on how we conceptualise the actions they have taken against Uyghurs.

\section{The Problem of Conceptualisation}

There are no rules in social science for deciding which type of framework, or set of concepts, an investigation should be couched within. All scholarship operates at the tangled intersection of theory and reality. Theory guides what we see because it provides the categories we use to organise data. Better theory is able to account for a larger number of observations, and thus results in fewer anomalies when fitted to our observations; more extensive fact-gathering and greater scepticism about received frameworks allow us greater theoretical discrimination and more rapid knowledge development (Geddes 2003, 17). But how does a scholar know if their theory is wrong? What stops one from emphasising only the evidence that supports a favoured theory, while discounting other evidence?

Ideally, what prevents this within a positivist research paradigm is rigorous hypothesis testing: exposing a conjecture to falsification based on some explicit criteria. But when attempting to evaluate competing explanations for a complex security policy in a closed authoritarian state, it is difficult to test rival explanations for political outcomes in a rigorous way. Typically the most a scholar can do is put forward explanations that are the most consistent with the facts and which are internally coherent. For the most part the authors have adhered to this template.

The authors' imagined cost-benefit analysis for the CCP is straightforward: coercively reeducate almost the entire Uyghur population so as to prevent anyone committing terrorist 
acts, and thus maintain the Communist Party's power. But no evidence is provided showing the CCP in fact considered the isolated acts of terrorism by Uyghur militants to be a genuine threat to its rule, and this proposed core logic of repression has not yet been thoroughly tested in the literature (Davenport 2007, 9).

$\mathrm{I}$ argue that before treating CCP policy in Xinjiang as a case of counterterrorism, the authors should have carefully evaluated what else it may be. An assessment should first establish clear definitions for the concepts of interest, then gather the evidence corresponding to them. We reject the claim that the CCP's Xinjiang strategy is primarily a jobs training programme because this claim cannot account for so many of the repressive acts. When enough anomalies accumulate, we are forced to adopt a new framework.

But if we imagine two columns, with 'preventive repression' being one and 'cultural genocide' the other, we would find that many of the items under each of them would be the same. Mass internment and reeducation are posited as the core of the authors' preventive repression concept; but they could also be a key feature of the elimination of Uyghur identity.

The authors do not mention all of the following, but the Party has: destroyed graves and mosques, forbidden almost all forms of Islamic religious life and expression (failing to discriminate 'normal' from 'extreme'), forbidden the teaching of Uyghur language in schools, systematically denied Uyghurs economic opportunities, expropriated Uyghur lands, encouraged Han settlement, encouraged intermarriage (Han men, Uyghur women), transferred hundreds of thousands of Uyghurs from detention camps to forced labour, and reportedly fostered conditions of mass rape of Uyghur women (Fernando 2019; Hoja 2020; Shir 2019; Stavrou 2019; Tohti 2015; Zenz $2019,2020)$. There are reports of local officials forcing Uyghurs to eat pork and drink alcohol during Ramadan (Long 2019). The secular evangelism of assimilationist Han family quartering campaigns since 2014, involving the careful ferreting out of substantially all religious attitudes and customs in Uyghur private family life (Byler 2018), also reveals a level of care and attention for the inner worlds of Uyghurs that is difficult to square with an instrumentalist political goal. Moreover, the special attention given to crushing Uyghur intellectuals mirrors Zygmunt Bauman's argument that for genocidaires, destroying the traditional elites of the doomed community is key: 'It is hoped that the marked group, once deprived of leadership and centres of authority, will lose its cohesiveness and the ability to sustain its own identity, and consequently its defensive potential' (Bauman 1991, 119).

Whether the campaign as counterterrorism fits all of these observations is dubious. The authors do not mention these acts, though a steel manned version of their argument could claim that some of these policies, like ethnic intermarriage and reeducation, can be understood as being within their definition of preventive repression. In this frame, ethnic cleansing and settler colonialism become not genocidal tools but counterinsurgency strategies (McNamee 2018; McNamee and Zhang 2019). Others, like the assaults on religious belief and destruction of mosques, could also be read both ways: as counterterrorism, intended to cut off connections with the wider Sunni world; or as cultural genocide, motivated by the Party's intent to destroy the Islamic faith of Uyghursan anti-religious ideological goal driven by the perceived threat of these beliefs as such (Zenz 2020).

But when enough of these policies are enacted, when should we stop thinking of the CCP's campaign as a case of extreme counterterrorism, and start thinking of it as cultural genocide?

These problems are archetypal to social science. The philosopher of science Larry Laudan notes that medieval, Renaissance, and seventeenth-century epistemology all shared the core question: 'To what degree, if at all, does a confirming instance of a theory contribute to the cognitive well-foundedness of that theory?' (Laudan 1981, 77). One response 
is to argue that because reality is endlessly narratable, we should adopt narratives that are the most emancipatory. But in that case we seem forced to dispense with any distinction between understanding and action. 'Take the case of a social scientist committed to a revolutionary movement,' Peter Berger writes, 'He may want to shoulder a gun-but others can do this ... in terms of his usefulness to the revolutionary movement, the social scientist will be best employed in the task of objective understanding: what is the situation really like? How can its future course be projected ... All of these are questions of fact, not of value' (Berger 1976, 136-37). Berger defines the ideal of value-freeness as perceiving social reality without being influenced by one's hopes or fears (Berger 1976, 135). This is why we should seek theories that 'carve nature at its joints', and insist that concepts in social science not be coterminous.

If we included in the definition of preventive repression the complete cultural destruction, biological assimilation, and psychological conversion of the Uyghur people, simply because it achieves the goal of stopping Uyghur militants, then cultural genocide would simply have been reinterpreted-or defined out of existence.

By assuming an instrumentalist, neo-realist explanation for the CCP's security actions, the authors limited the evidence they considered to that which could be readily explained by an assumption of instrumentalism. This requires accepting the Party's own explanation at face value-that its own extreme thought reform programme is indeed 'deep preventive counterterrorism work' (Greitens et al. 2020a, 43). It also requires reading against Party discourse and practices that exceed instrumentalist logics, ${ }^{2}$ or failing to recognise how counterterrorism rhetoric is subsumed into the Party's broader dream of (homogeneous) nation-state formation. Absent these considerations, the Party's attitude toward 'religious extremism' becomes merely that it is 'the ideological foundation of terrorism, implying that the only truly effective form of prevention is altering people's thinking' (Greitens et al. 2020a, 43).

The authors' causal chain as proposed is clear, but the conceptualisation struggles to account for many of the CCP's actions in its campaign against Uyghurs. The authors concede that 'China's threat perceptions may be inaccurate, and/or its public rhetoric may be instrumental' (Greitens et al. 2020a, 46), yet suggest that 'those who seek to alter China's treatment of its Uyghur citizens may be more effective if they approach that behavior as grounded in counterterrorism policy, rather than framing objections on human rights grounds' (Greitens et al. 2020a, 46).

But what is at question is precisely the validity and legitimacy of the CCP's threat perceptions. If counterterrorism is indeed being invoked cynically to mask a cultural genocide, or is simply a euphemism for ethnic splittism, the proposed remedies may change considerably. The problem is not simply one of accuracy, but intentionality. Here, questions of normativity intersect with both our means and our ends as students of the political.

\section{Critique, Method, and Meaning}

The hypothesis that the CCP saw a practical problem-Uyghurs being infected by extremist religious ideology and committing acts of terrorism because of it-and sought out a practical if radical solution-mass internment and thought reform-would only be valid if we could be confident that the regime would not have undertaken the campaign, or some version of it, in the absence of terrorism. We cannot rerun history without terrorism and see whether the campaign would have been launched, but we can examine past political campaigns in the People's Republic of China and elsewhere and note the absence of similar motors. The Australian colonialists' violent 
destruction and biological absorption of the Indigenous population, for instance, were driven by ideology and interests and did not require a counterterrorism logic (Ellinghaus 2009; Dirk Moses 2004). Nor were the colonisation of Tibet or the reeducation and destruction of Falun Gong-tactics we see combined in the Uyghur case-driven by concerns over terrorism.

There is also nothing deterministic about a violent action against civilians being coded as 'terrorism'. The act of naming 'carries the ability to constitute other activities and then codify appropriate actions in response' (Featherston $2018,4)$. The CCP is not a passive, reactive participant in its relationship with its Uyghur minority; the Party shapes the playing field. Party theoreticians are aware of this, as when $\mathrm{Li}$ Shulei, director of the Central Commission for Discipline Inspection, instructs that 'language never only reflects reality; it moulds reality ... Language is not a political instrument; it is politics itself' (cited in Sorace 2017, 10).

The tools of critical theory can be helpful in turning upside down and inside out the problems raised by the CCP's Xinjiang strategy. ${ }^{3}$ To begin with, critique can reveal the contingency of and call into question the coherence of terms like 'terrorism', and make claims about who is served by them and in what context; it can reveal how methodological choices are themselves not neutral but instead 'enact' and 'disrupt' worlds by establishing their own criteria for judging significance (Aradau and Huysmans 2014); it can serve to reframe state acts, showing how it may be that a state less passively 'perceives' a threat than it actively constructs one to achieve its ends (hence 'securitisation'). Most pertinently for us, scholars in critical genocide studies have proposed alternative frameworks to account for seemingly incomprehensible political acts. I highlight two of these.

The first theorises genocide as a social process. Here we are encouraged to understand genocide as 'a specific technology of power', a form of 'social engineering that creates, destroys, or reorganizes relationships within a given society', and which establishes 'new social relations and identity models through terror' (Feierstein 2014, 1, 36). Other scholars have studied how genocidal regimes construct their victims through ideological prisms, reading them as transitioning from marginal insiders to outright foreign, a mortal threat, and subhuman (Hiebert 2017, 137-143). This then justifies eliminationist violence. Scholars have begun applying similar frameworks to the CCP's construction of Uyghur identity as deviant, with all that entails (Roberts 2018a; Smith Finley 2019). These theories do not account for the timing of the crackdown either, however, and can appear to read back into events a coherent plan to destroy the Uyghurs.

Jacques Sémelin's notion of 'delusional rationality' provides the clearest account of what is at stake when considering the meaningmaking of genocidaires. The concept can be summarised in a word-'Paranoia'. As Sémelin writes: 'The word fits perfectly, since the structuring of these imaginary representations of the enemy is reminiscent of the descriptions psychiatry ascribes to paranoid personalities. The character traits of a paranoiac can be recognized in a combination of wariness (excessive aggression toward other people), inflexibility (the incapacity to question one's own value system), a hypertrophied Ego (which can go as far as megalomania), flawed judgment' (Sémelin 2007, 44-45).

Sémelin is here worth quoting at length:

A paranoiac's logic is flawed by passion,
whichleads to a delusional interpretation of
reality. Ideas are guided by a preconceived
belief. Doubt is as foreign to the paranoiac
as self-criticism ... The paranoiac reasons
correctly on false premises. The starting
point seems obvious to him because of
a subjective preconception that he is
unable to question. Due to this flaw in
judgment, the paranoiac always skirts the
real problems, seems out of tune with
reality and is impervious to other people's
opinions. Yet his intellectual faculties are
intact. His discourse does draw on reality, 
but gives it an imaginary interpretation. The paranoiac attributes all his difficulties and all his failings to someone else. $\mathrm{He}$ can't call himself into question: the world is all wrong, or people are out to get him. But his interpretations are still plausible, and the paranoiac can enlist their support. (Sémelin 2007, 45; emphasis added)

A notion like 'delusional rationality' resists the kind of precise measurement that positivist methods insist on, because it is founded in an alternative, interpretivist mode of social enquiry. Such theories illuminate an otherwise obscure puzzle: how can we explain the CCP's apparent determination to violently erase the Uyghurs as a people, in response to the paramilitary training of a small number of Uyghur militants and terrorist attacks by a smaller number? The militancy itself can also be interpreted as a desperate response to social conditions created by CCP rule (Tohti 2015). In this reading, the crackdown is revealed as a paranoid reaction to a tiny threat, one that is both counterproductive and non-instrumental. ${ }^{4}$

\section{The Politics of Classification}

The relevance of these frameworks for the inferential problems I identify in the International Security paper is that they can make us alive to the possibility of noninstrumental, or ideological, drivers of state behaviour. In the language of quantitative social science, failure to consider them would be omitted variable bias. Yet, by definition, they cannot be quantified and modelled, since ideology shapes how actors perceive political reality.

Attempts to shortcut the demand to theorise the normative dimensions of political rationality are likely to end up in the quandary proposed by Marxist thinker Louis Althusser, where "what thus seems to take place outside ideology ... in reality takes place in ideology.
What really takes place in ideology seems therefore to take place outside it' (Eagleton 2014, 109). Assuming a single model of rationality can only account for the CCP's Xinjiang strategy when it fails to consider the totality of state action. Reading the campaign as counterterrorism may seem to transform it into a legible problem for policymakers, but we should wish to avoid becoming 'problemsolvers' who believe in methods but not worldviews, as Hannah Arendt (1971) put it.

Though social science should be conducted without any specific policy objective in mind, the way social scientists classify political behaviour has political implications. The stance of the Xinjiang Strategy authors appears to be that there is both a social science case and a favourable policy case (i.e. that it will result in less violence and killing of Uyghurs) for treating the campaign as counterterrorism, if only to open a channel for dialogue with the Party.

But it is far from clear that this is true. The pragmatic adoption of CCP classificatory schema, where it conceals the underlying reality, could also just as well perpetuate the status quo and do little to help Uyghurs. The CCP would probably appreciate its own rhetoric about the campaign taking hold and the normative language of human rights atrocities and cultural genocide being abandoned. In that case, counterterrorism conferences and dialogue sessions for Chinese officials may only end up pseudo-solving a misdiagnosed problem. Critical approaches allow us to see past the CCP's attempts to reframe what is happening in Xinjiang, to flatten the multifaceted destruction of an indigenous people into a pragmatic if extreme counterterrorism exercise. The precise policy implications of this are up for debate. 
I thank Bermond Scoggins, Michael Clarke, Lachlan McNamee, Murray Bessette, Adrian Zenz, and Mustafa Aksu for their comments on drafts of this article. I am grateful to the editors of the Made in China Journal for their attentive editing and feedback. I take responsibility for the arguments and any errors or omissions.

\section{ENDNOTES}

[1] I identify two shortcomings in this regard:

1. After examining the potential terrorist acts of the groups East Turkestan Islamic Movement and the Turkestan Islamic Party between 2001 and 2014, they write: 'Thus, until 2014, CCP perceptions and fears of the links among Uyghurs in China, the Uyghur diaspora, and jihadist militant groups remained a theoretical possibility rather than an operational reality.' This is cited to Raffaello Pantucci in Clarke $(2018,162)$. But the only reference to CCP perceptions there is the author's conclusion that al-Qaeda's 2011 appointment of the leader of the Turkistan Islamic Party as its Pakistan commander 'did not appear to change China's impression of threats from alQaeda'. This conclusion, in turn, cites an article by the Foundation for the Defense of Democracies (Roggio 2011). That article-the ultimate source of the inference about CCP perceptions circa 2014was published in 2011 and notes the appointment while making no reference to CCP perceptions. In terms of the authors' overall argument, this deficit is largely immaterial; it simply shows that we don't know about CCP perceptions in relation to this information.

2. Later in the article, the authors refer to 'CCP thinking in 2017', when Chen Quanguo outlines six principles for combatting terrorism in Xinjiang. Part of this included reducing contacts between Uyghurs in Xinjiang and jihadists abroad. The authors write: 'The rise of this approach was based on the CCP's growing belief that China's Muslim population was more vulnerable to foreign jihadists than previous assessments had indicated.' They write that references to 'infection' began appearing in 2015 in discussions of Xinjiang, and cite two studies as evidence. But they imprecisely report what these studies say. The first comes from a quote in a Phoenix Television Online article in October 2015 by Zhang Yun, the Party secretary of Xinjiang's Department of Justice, who said that in southern Xinjiang 'of those who have been influenced by religious extremism' (受宗教极端思想影响的人群中), 70 percent have been 'dragged along' and 30 percent have been 'contaminated' (Chen 2015). These categories appear to refer to the degree to which these populations have been influenced by religious extremism. Zhang refers to 'a very small number' of others who have committed crimes. The reference, in any case, was to villages in southern Xinjiang, and it did not state what portion of the total population was claimed to have been influenced by religious extremism (of which 70 percent were mildly influenced, and 30 percent heavily influenced). The authors cited his statement as 'explain[ing] that approximately 30 percent of Xinjiang's population [i.e. total population, across the country] had been infected by religious extremism: A similar oversight is committed in the following reference to a study by the sociologist Li Xiaoxia (2016). Li's original paper makes a similar taxonomy of victims of extremism, prefaced with a similar formulation: 'of the communities influenced by “Wahhabism"' (在受 “瓦 哈比” 极端思想影响的群体中). Again we do not know to which subset of the total population this refers. Moreover, Li was referring to the Ili Kazakh Autonomous Prefecture in the north of Xinjiang, and cited a (likely internal Party) document from 2013. The authors write that she 'estimated the number of people [i.e. of the total population, across Xinjiang] contaminated by extremism at around 20 percent'. Moreover, this source is cited to bolster the argument that the Party's concerns with 'infection' were heightened in 2015. The authors conclude that: 'These figures track fairly closely with estimates of the percentage of the population detained for re-education.' Thus, neither of the uses to which these two sources were put quite corresponds with what they said. 
[2] Here I am thinking of works like Leese, Daniel. 2011. Mao Cult: Rhetoric and Ritual in China's Cultural Revolution. Cambidge: Cambridge University Press; DeMare, Brian James. 2015. Mao's Cultural Army. Cambridge: Cambridge University Press; Dutton, Michael. 2009. 'Passionately Governmental: Maoism and the Structured Intensities of Revolutionary Governmentality.' In China's Governmentalities: Governing Change, Changing Government, edited by Elaine Jeffreys, 36-49. London and New York, NY: Routledge; Dutton, Michael. 2004. 'Mango Mao: Infections of the Sacred.' Public Culture 16, no. 2: 161-88; Schwartz, Benjamin I. 1970. Communism and China: Ideology in Flux. New York, NY: Atheneum; Lifton, Robert Jay. 1968. Revolutionary Immortality: Mao Tse-Tung and the Chinese Cultural Revolution. New York, NY: Random House; the work of Christian Sorace, and many others. The point is not that ideology is not also instrumental, but that to regard it as solely instrumental is an unwarranted simplification. As Schwartz $(1970,9)$ argues: 'Those who have possessed power have been quite as prone (if not more so) as others to believe that their power pursuits play a meaningful role in a larger, transcendental order of things. Far from being mutually exclusive, certain types of ideological claims and certain types of power interests reinforce and enhance each other. It is the absolutely pure power-operator who must be regarded as the rare freak.'

[3] Broadly, I have come to think of critique as the ideational equivalent of an illocutionary speech act-'There's a snake under your chair!'-and to perform critique is to make claims on the addressee (Austin 1975, chaps. 8-10; Vuori 2008).

[4] Counterproductive in that, given the predictable and well-established radicalising effects of such extreme and indiscriminate state coercion, it is likely to lead to more militant insurgent responses (Davenport 2007, 9-10; Roberts 2018b). Counterterrorism discourse may then end up being both self-fulfilling and, for the Party's settler-colonialist enterprise, self-exculpatory. The authors partly acknowledge this (Greitens et al. 2020a, 45) but do not seem to fully appreciate its implications for their argument, particularly when it comes to questions of policy. 


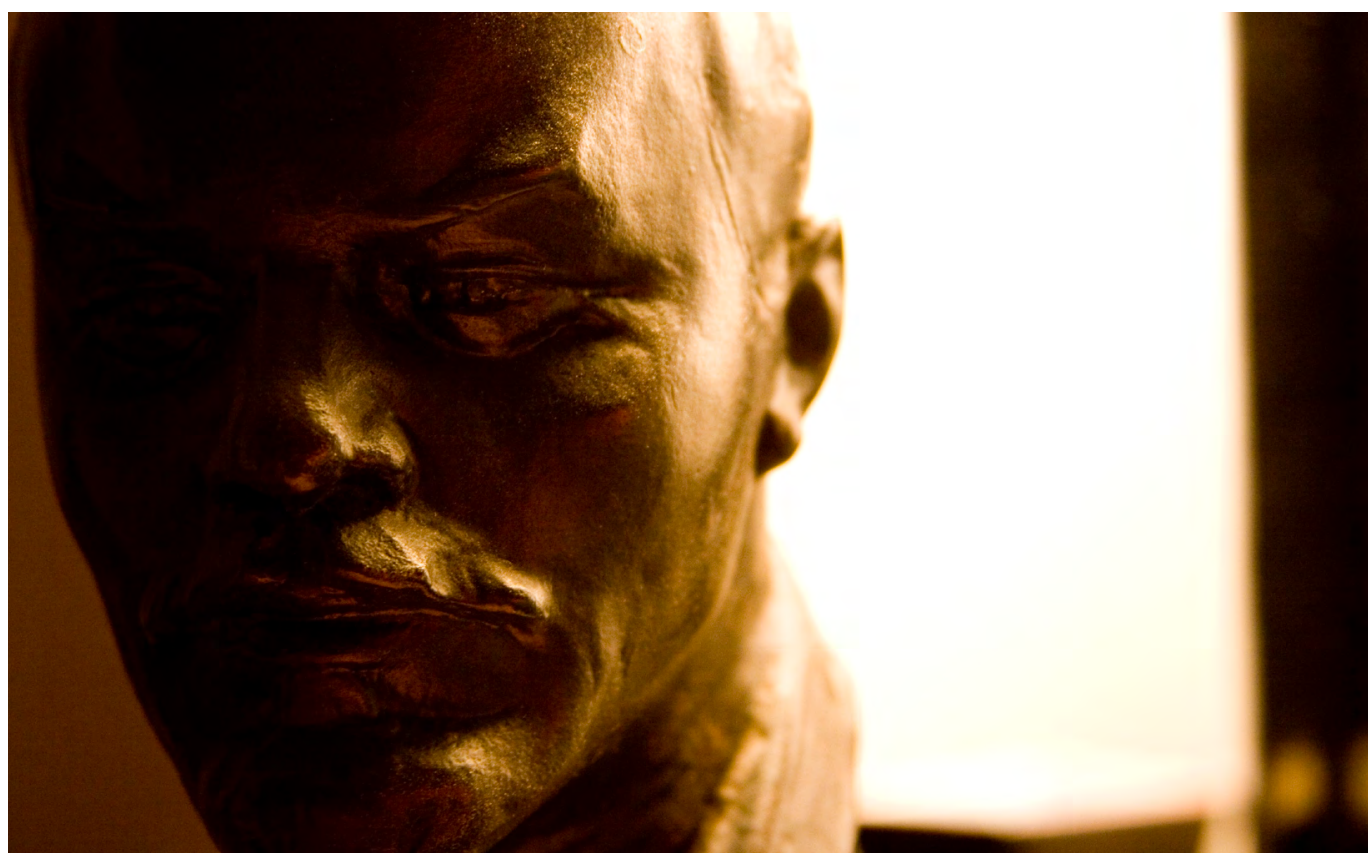

\section{Leninists in a}

Lenin. PC: Enrico Sola.

\section{Chinese Factory:}

\section{Reflections on the Jasic Labour Organising Strategy}

\section{ZHANG Yueran}

Led by Maoist activists, in the summer of 2018, a unionisation drive at the Shenzhen Jasic Technology Co. Ltd led to high-profile confrontation with the employer and the state. This essay examines the decade-long labour organising strategy implemented by the Maoist activists behind the struggle. The making of this strategy was a cause for admiration, but its shortcomings hold equally important lessons for China's labour movement in the future.

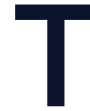

his summer marks the second anniversary of the failed unionisation drive at the Shenzhen Jasic Technology factory, an episode in China's recent history of labour activism that has drawn massive attention from China observers, leftist circles, and media pundits around the world. Compared with other influential instances of contentious labour action in recent years, the Jasic struggle is unique for its militant and combative tactics (including the staging of protests in front of a police station), the prominent role played by young leftist students in solidarity actions, the highly political and Maoist rhetoric, and the unusually harsh and wide-ranging crackdown 
that occurred in its wake. Indeed, in discussing the Jasic struggle, commentators have mostly focussed on these aspects.

However, little attention has been paid to the labour organising strategy underlying the struggle. The labour action at Jasic was by no means spontaneous. Instead, it was the culmination of a quite elaborate and ambitious strategy of labour organising that had been systematically implemented by a group of activists for about a decade before the Jasic struggle broke out. Making clear what this strategy was, and critically reflecting on its achievements and shortcomings, is thus crucial to the charting of future paths of labour organising in China, particularly given the harsh reality labour activists currently face in the country.

The Jasic labour organising strategy has received almost no public attention for two reasons. First, because this strategy was implemented in a rather secretive manner, its existence was not well known at the time when the Jasic struggle gained momentum. Second, in the wake of the severe crackdown, those who had some knowledge of this strategy were reluctant to make it public out of the fear that doing so would politically compromise the detained activists who were involved in the struggle. Partly for these reasons, I opted to not mention this strategy at all in the op-ed I wrote for the Made in China Journal in late 2018, immediately after the large-scale police raid on the Jasic Workers Solidarity Group (佳 士工人声援团).

The situation has changed since then. According to several trusted informants, it is clear that the state has by now accumulated thorough knowledge about this labour organising strategy and dismantled the activist network that had been implementing it. In other words, the main concern that has been giving me pause no longer exists. On the other hand, an open discussion about this strategy is now needed more than ever, since the significantly tightened organising space in the wake of the Jasic struggle has forced labour activists to revisit the question of 'what is to be done' based on a critical reflection of past initiatives.

Drawing on extensive conversations with those who had intimate knowledge of this labour organising strategy, two of whom appeared in an incredibly informative interview (Reignite 2019), as well as with those who had been part of the activist network implementing it, in this essay I offer an overview of this strategy and some preliminary reflections on its accomplishments and the dilemmas those implementing it struggled with.

\section{A Review of the Jasic Struggle}

Before discussing the labour organising strategy leading to the contentious unionisation campaign at Jasic, it might be helpful to give a brief recap of the Jasic struggle itself. In May 2018, several workers at Jasic lodged complaints over a wide range of workplace grievances at the Pingshan district branch office of China's official trade union, the All-China Federation of Trade Unions (ACFTU). While receiving the workers, some local ACFTU officials there suggested unionisation as a possible way to resolve their grievances and informed them of the legal procedure to do so.

In June, a handful of Jasic workers launched a unionisation petition. Within a couple of weeks, about 80 coworkers-roughly 10 percent of the workforce-signed the petition. The employer soon found out about the unionisation drive, and fired the leading worker activists. The fired workers protested outside the factory, during which they were beaten by the police. In response to the violence, they staged protests in front of a local police station, at which point their campaign started to draw wide public attention. As a result, on 27 July a total of 30 individuals, including both Jasic worker activists and their supporters, were detained. 
After the mass detention, dozens of leftist college students and Maoist-leaning activists came to Pingshan to form the Jasic Workers Solidarity Group. In the following month, the group held solidarity actions on a daily basis calling for the release of the detained workers. On 24 August, the police raided the apartment where the solidarity group-whose membership at that point had reached about 50-resided, sending some of the members back home while detaining others.

Subsequent waves of crackdown ensued. About a dozen of the activists who were involved in organising the Jasic struggle and solidarity actions were detained in November 2018. Universities disciplined the students who had joined the Jasic Workers Solidarity Group and severely restricted the activities of the Marxist student associations of which these students were part. Peking University, for example, effectively disbanded its Marxist Studies Society in the name of 'reorganisation' in December 2018. Students who protested these disciplinary actions and restrictions were detained in early 2019; even those who were not formally detained reported experiencing extensive monitoring, harassment, intimidation and physical abuse, as detailed in an account provided by an anonymous Peking University student (Made in China Journal 2019). Later, the scale of the crackdown was also expanded to affect those labour activists who had no personal connections whatsoever with the Jasic struggle, some of whom were detained throughout 2019.

In terms of the number of people detained, the scale of this crackdown was truly unprecedented. More generally, in the wake of the Jasic struggle the Chinese state has adopted an even more hostile stance towards labour activism. As a result, various labour activists and organisations have seen their already limited organising space shrinking even more, leading many to claim that China's labour movement is now at a historic low tide.

\section{The Making of a Labour Organising Strategy}

The Jasic unionisation drive was not an isolated instance of labour activism that 'just happened'. Instead, it represented the climax of a systematic, long-term strategy of labour organising. In the late 2000s, a small group of Maoist activists-some of whom had just graduated from college, whereas others had prior experiences working with antiprivatisation protests by workers in stateowned enterprises-settled in the Pearl River Delta (PRD) and sought to make a systematic intervention in the labour scene there. This strategic decision was informed in part by a political assessment that identified the area as the new frontier of working-class struggles, and also by an optimistic outlook that believed China was on the verge of a breakthrough for leftist politics. If we remember that in the late 2000s Bo Xilai's 'Chongqing Model' greatly increased the political confidence of many Maoist communities in China, workers in state-owned enterprises were still a bastion of militancy, and labour struggles by migrant workers in the PRD were also gaining momentum, it is not difficult to understand where this optimistic outlook came from.

This small group of Maoist activists established close connections with Marxist student associations at several universities that had also adopted a Maoist ideology. Through these student connections, the Maoist activists recruited college graduates to join their ranks. Upon graduation, these students, in turn, would become factory workers and then go on to work themselves as underground labour activists. These recruitment efforts grew over time, and some of the college graduates ended up as core leaders in this Maoist labour activist network in the PRD. The underlying idea was that by abandoning a middle-class career for life-long labour activism, the students would dedicate 
themselves to the revolutionary cause. The experiences of leftist students in the Korean labour movement in the 1980s, particularly as described in Hagen Koo's Korean Workers (2001), were often cited as an inspiration.

These activists usually sought employment in small factories notorious for bad working conditions. They were then expected to agitate their coworkers for some form of collective action as soon as possible, which in some cases resulted in material concessions from the employers. Through this process, the activists were also expected to identify coworkers who were particularly passionate and recruit them to join the activist ranks, while converting these new worker-activists into Maoists along the way. Upon the completion of a collective action, the underground activists would leave the factory and bring with them the newly recruited workers-turned-activists. They would then identify another factory to seek employment in and agitate for collective action there as underground labour activists.

Therefore, this Maoist labour activist network grew by recruiting both college graduates and migrant workers. It was deliberately modelled on a version of the Leninist vanguard party in which the 'petty-bourgeois' intellectuals equipped with revolutionary theory and the most politically 'advanced' elements of the working class combined into an organic whole. In principle, the revolutionary cadre of working-class origins, through political education led by the intellectuals, would become well versed in revolutionary theory (in this specific case, a Maoist politics). Indeed, these activists saw their network as a quasiparty. By gradually increasing the size of this formation and the scale of the collective actions they agitated for, the activists hoped that their network would eventually play a leading role in the burgeoning labour movement in the PRD and guide it towards a revolutionary politics. At the same time, some activists in the network were sent to work in the official trade union or set up community-based NGOs in order to assist the overall organising project as needed.
This strategy met with mixed results. On the one hand, many college graduates were unprepared for life as a worker and underground activist. The physical toll of the gruelling work on the shopfloor was in and of itself overwhelming, leaving little space and energy for organising. Before entering factories, many of them had also been under the illusion that since they were equipped with the 'correct' theory, migrant workers would naturally follow their lead. Very often, this illusion was quickly shattered on the shopfloor. In particular, the Maoist vocabulary-the only vocabulary many student activists knew how to use-failed to connect with rank-and-file workers. Lost, exhausted, and not knowing what to do, many decided to quit. Therefore, even though this Maoist network became ever more successful in recruiting college graduates, the attrition rate was also high.

On the other hand, over the years some activists in the network did successfully organise a few collective actions in the factories they worked in and recruited coworkers to join the ranks of revolutionary activists. Compared with many labour NGOs in the PRD that focussed on 'assisting' or 'advising' workers trying to organise collective actions, the Maoist underground activists, as workers, did not hesitate to lead the fight themselves, personally taking on great political risks. The audacity and sincerity embodied in 'leading by example' enabled some of these activists to win coworkers' trust and recruit a few of those coworkers to become revolutionary cadres. Over more than a decade, this Maoist activist network was able to gain several dozen members.

Around 2015, the growth of this network reached a plateau and stagnated. A sense of demoralisation started to spread among its ranks, which, coupled with the increased hostility from the state towards labour activism, posed nothing short of an existential threat to the endeavour. It was in this context that the leaders of the network found it necessary to agitate for a much more influential collective 
action in a larger factory, in order to both reenergise the demoralised cadres and boost confidence in this organising model. He Pengchao, a graduate of Peking University who became one of the most important leaders in this network, said in a confession video that after surveying several options, the network decided to send underground activists to Jasic in 2016 and started to plan for a largescale confrontational collective action (Jasic Worker Support Group 2019). I have been able to independently verify He's account through other informants.

All of the workers leading the unionisation drive at Jasic in 2018 were in fact underground activists sent in by the Maoist network to agitate, and almost no other Jasic workers participated in the protests organised by the activists. That these activists were able to convince 80 co-workers to sign the unionisation petition within a couple of weeks was a very impressive achievement, but this support base was still not strong enough to anchor a vibrant unionisation campaign and withstand harsh suppression from the employer and the state alike. Unfortunately, the campaign was met with severe and swift repression when the underground worker-activists still lacked widespread and robust support among coworkers. Overall, the engagement from coworkers was limited throughout. This weakness became debilitating after the leading worker-activists were detained on 27 July 2018-at that time, no Jasic workers stepped up to become new workplace leaders to carry the campaign forward, nor did Jasic workers themselves attempt to organise protests or industrial actions in solidarity with the detained activists.

Instead, with the formation of the studentled Jasic Worker Solidarity Group, the centre of action and attention quickly shifted to leftist students. Because of the close connections between the Maoist activist network in the PRD and the Marxist student associations at various universities, leftist students were rapidly mobilised to join the solidarity group en masse. Indeed, the Maoist activist network used this occasion more or less as an educational opportunity to agitate these college students and amplify its call on them to become factory workers and dedicate themselves to the political cause upon graduation.

\section{An Extraordinary Feat}

Despite the tragic ending of the Jasic struggle, the very fact that this sophisticated and multi-layered labour organising strategy had been devised and implemented over more than a decade is in itself an extraordinary accomplishment. For one, this strategy required of its participants-those of both intellectual and working-class origins-an extremely high level of commitment. The fact that several dozen individuals dedicated themselves to such a strategy is a cause for great respect for China's young generation of leftists.

There has been a near-consensus among China's labour activists that the Chinese labour movement has been both fragmented and sporadic. Labour unrest has broken out every now and then in Chinese factories, but it has been hard to imagine how to channel it into some sort of enduring organising project. For Chinese labour activists, therefore, it has been extremely difficult not to feel buried in case-by-case organising, to not lose sight of the forest for the trees, or to formulate any kind of long-term strategic outlook. This challenging task was exactly what the Maoist network in the PRD had accomplished. The Maoist activists were able to connect their immediate organising contexts with a long-term vision of a working-class revolution, however vaguely it was defined, and develop a sense of how the former could lead to the latter. A long-term strategy, despite its flaws, was formulated in a context in which almost no strategic thinking felt possible-and, all the more impressively, this strategy was implemented on the ground.

In order to operate, the many layers which this strategy involved-recruiting college graduates, identifying factories to send activists 
to, agitating for collective action, educating and retaining cadres of working-class origins, etc. - had to be extremely well coordinated. Any breakdown or disconnect between these layers could undermine the entire project. The functioning of this model over more than a decade and the progress it was able to make on these various fronts speak volumes to the organisational acumen of the activists. The problem of coordination was made all the more challenging because, for security reasons, many activists on the ground did not know what the others were doing. Therefore, the internal coordination heavily depended on several central nodes in the network. This, however, also meant the decision-making structure within the network was largely top-down.

In developing and implementing this strategy, the Maoist activists drew heavily upon Marxist classics, especially Lenin's What Is to Be Done (1961). In trying to develop a longterm revolutionary strategy for the Chinese labour movement, the activists attempted to adapt Lenin's insight to a political context that looked very different from the one in which Lenin was situated. As understood by these activists, Lenin provided a crucial way to think about the relationship between revolutionary politics and concrete workingclass struggles. Particularly important was the notion that a vanguard party should provide political leadership to the workers' movement, so as to make sure the latter would not remain confined within reformist tendencies posing no fundamental challenge to the status quo. In this framework, the party should lead the working class, but also remain organisationally distinct from it; the party's political leadership would be primarily realised by developing the most militant and politically conscious workers into revolutionary cadres of the party, who would then lead and agitate other workers. Translating this insight into praxis in a vastly different context required both a great deal of creativity and an engaged analysis of the peculiarities of Chinese labour. Leftist scholars and activists around the globe have long talked about connecting theory to praxis, but serious attempts at it in actual organising have been rare. For this reason, the sincere efforts made by these Maoists to apply classical Marxist insight to on-the-ground organising should serve as an inspiration.

It should also be noted that this strategy was implemented in the presence of a dauntingly repressive state. Similar to what Lenin had envisioned in Tsarist Russia, the organising model embraced by the Maoists in the PRD had to combine some open activity with other, secretive operations. Several layers of the model necessarily remained underground, as did the self-proclaimed long-term revolutionary goal to which this model was supposed to lead. This careful combination of open and underground work posed even more exacting demands on the activists' organisational skills. Nevertheless, they proved themselves to be up to the task.

\section{Lasting Challenges}

It is somewhat ironic that this labour organising strategy seems weakest when it comes to the actual process and art of organising workers-how to have organising conversations with workers, how to build a team of worker leaders on the shopfloor, how to cultivate trust among workers, how to move apathetic and fearful workers towards collective action, etc. Informants who had been part of this activist network reported receiving no training on the nuts and bolts of actual organising-including things as basic as how to approach and talk to fellow coworkers-before being sent into factories. As inexperienced organisers, they operated without guidance on what exactly to do in the factories and had to figure things out on their own. This, in part, explains the high attrition rate among activists who were college graduates. Similarly, relatively little effort was made to develop the newly recruited workersturned-activists into leaders on the shopfloor who possessed the confidence and skills necessary to move coworkers to action, though they received extensive political education 
on Maoist ideology. The lack of systematic accumulation and sharing of knowledge on the concrete skills of labour organising stands in sharp contrast to the extensive knowledge and materials the network developed regarding how to build support bases in universities and recruit college students. This is not to say none of the Maoist activists was a good labour organiser-some were. What was missing, however, was an organisational emphasis on developing good labour organisers.

Therefore, the self-identity of these Maoist activists in the PRD seemed to be that of revolutionary cadre, rather than labour organiser. Faced with a fragmented and sporadic labour movement, this activist network did not seek to build a slate of worker leaders organically embedded in their respective workplaces, who could then be connected to each other in some sort of relatively durable network; this would be one possible way to overcome the fragmentation of the Chinese labour movement. Instead, the Maoist activists sought to give coherence to a fragmented labour movement through a quasi-party political formation expected to not only grow in size but also propagate a Maoist revolutionary politics among the working class; the priority, therefore, was to build the party, rather than the organisational capacity of workers. The problem of this strategy was that this vanguard party could easily become detached from the broader working-class base, because of the lack of organic links with worker leaders.

Part of the problem here seems to originate from the very Leninst model these activists attempted to adapt. In this model, a conceptual and organisational distinction is made between the revolutionary vanguard party and the broader working class-the former is to lead and set the political agenda, whereas the latter is supposed to follow the former's leadership in a rather passive manner. The emphasis was not so much on building the necessary organisational capacity for workers to take massive action as on making sure workers' struggle unfolds in the correct political direction, under the guidance of revolutionary theory. In other words, the role of the party is supposed to be political, not organisational. The Maoist activist network inherited this conception in seeing that their task was fundamentally to recruit workers to revolutionary politics, and organising on the shopfloor was meaningful only insofar as it served this fundamental goal. They were not concerned with strengthening the self-capacity and collective militancy of workers per se. In fact, for the Maoist activists such capacity could be threatening, as the party would then find it much more difficult to control the political direction of workers' struggle.

A crucial contextual difference matters here. When Lenin wrote What Is to Be Done, the Russian labour movement had already gone a long way towards overcoming fragmentation by developing cross-industry, cross-region, and organisationally anchored momentum that was capable of sustaining a militant collective tradition. Therefore, the burning question became what kind of politics this labour movement should espouse. However, in contemporary China, where the labour movement suffers from the very lack of such momentum, the fundamental question of 'how to organise' should be addressed first. By sidelining this question, the Maoist activist network in the PRD failed to provide a workable path to overcome the fragmented and sporadic nature of the contemporary labour movement in China, however admirable their attempt was. Any future endeavours to overcome this challenge, I would argue, will have to put the question of organising front and centre. 


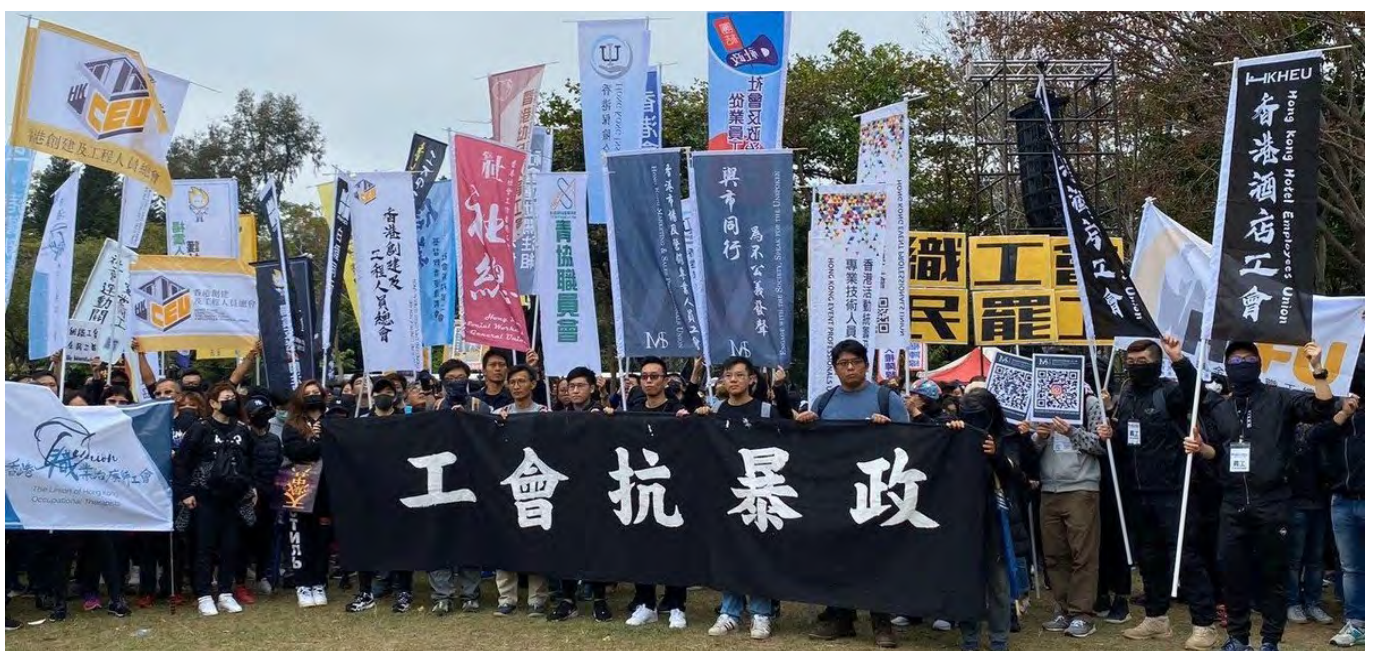

\section{From}

\section{Unorganised} Street Protests to Organising

\section{Unions:}

\author{
The Birth of a New Trade \\ Union Movement in Hong \\ Kong
}

Anita CHAN

Although Hong Kong historically has a weak trade union culture, in early 2020 activists in the protest movement turned to demanding union representation and began forming dozens of small unions from the ground up. Although their future is fraught with challenges, in their first few months of existence these organisations have already successfully mounted an important strike.
Fig. 1: The new unions with their flags forming a united front at the mass rally of 1 January 2020. PC: HKCTU. $\square$ or several months in 2019, the world's news media was front-paging the Hong Kong anti-extradition bill movement almost on a daily basis. However, towards the end of the year, with the street violence subsiding and the fierce battles at two universities ending in the defeat of the students and their supporters, the international media seemed to lose interest. As global attention shifted elsewhere, one might have assumed that the movement had died a natural death. It did not. It is from here that this essay picks up the narrative. It was at that point that the 
movement branched off in a new direction, with activists beginning to set up trade unions and transitioning towards a nascent organised movement.

\section{Solidarity in Disagreement}

In the wake of the Umbrella Movement, which ended in 2015, a whole host of small groups and political parties emerged alongside the 'old' pro-democratic political parties of varied political persuasions. This mushrooming led to competition and fragmentation, which in turn undermined the effectiveness of political activity. Wary of this lesson, the anti-extradition bill movement that began in earnest in June 2019, and eventually drew around one million people on to the streets, has been demonstrating unflinching solidarity to this very day. Differences have been put aside, and the movement has coalesced around three cohesive ideals.

The first can be found in the ubiquitous slogan 'Five Demands, Not One Less', a set of political demands broad enough to accommodate all political leanings. The second was a pact embodied in the saying 'brothers climbing a mountain; each trying one's best' (兄弟爬山, 各自努力), meaning each adopts a strategy they deem best to achieve the goal while not criticising or intervening in the actions and strategies of others. This managed to bring together the two key blocs of the protest movement: the 'Valiant Braves Faction' (勇武派) and the 'Peaceful, Rational, and Nonviolent Faction' (合理非派). The former is made up mostly of students and younger people, all geared and willing to confront the police head on. The latter is composed of people who would not, or could not, engage in violence at the battle front and rather play supporting roles at the rear-for instance, providing material resources, organising or participating in rallies, joining peaceful activities like 'let's lunch together' (和你lunch) or 'let's sing together' (和你sing), raising funds, joining human chains, and taking part in a myriad other innovative actions. To emblemise the unity of purpose of these two souls of the movement, a new Chinese character was even playfully invented, combining elements of the characters for 'peaceful' (禾) and 'valiant' (勇).

The third was an agreement that there is 'no big table', i.e. there are no leaders sitting around a table deciding the direction of the movement. Anyone could put forth proposals-really any idea and type of action-anytime and anywhere through the social media platform Telegram, which requires no real name registration from users. As the slogan goes, this movement was supposed to 'be water'-that is, unplanned, unpredictable, fluid, and spontaneous, a form of urban guerrilla tactics with protesters suddenly popping up and disappearing in shopping malls and subways stations. At the same time, big rallies organised by the pro-democracy parties and well-established organisations continued to be well attended. The two-million-strong march that took place on 16 June 2019 was the largest display of the force of unity.

\section{Trade Unions in Hong Kong}

As months of street actions did not extract any concession from the authorities, a part of the protest movement branched off in a new direction that was more formal and organisedit began setting up as-yet-small independent trade unions.

During three weeks in January, I was in Hong Kong to research these nascent unions. On that occasion, I conducted interviews at several recruitment stands that volunteers of these new unions had set up outside metro stations, at busy street junctions, and at hospital entrances during lunch breaks, after work, and on weekends. I met with newly elected members of some of the new unions' executive (or preparatory) committees, attended a couple of union-organised labour law training sessions, 
and had meetings with Hong Kong academics and labour NGO staff. I also interviewed staff of established union federations in the city. Since January, I have kept abreast of events through social media and online conversations.

Hong Kong is a global commercial hub dominated by free-market beliefs with a relatively weak trade union culture. The largest union federation is the Hong Kong Federation of Trade Unions (HKFTU), with 253 affiliates and 420,000 members. It is well-resourced and largely controlled by the government of mainland China as a counterpart of the official All-China Federation of Trade Unions-a mass organisation subordinated to the Chinese Communist Party and the only trade union legally allowed to exist in the People's Republic of China (PRC). Just like its partner on the mainland, the HKFTU functions like a welfare organisation, doling out money and assistance to its pro-Beijing following. A competitive union grouping that has a long history is the Hong Kong and Kowloon Trades Union Council (HKTUC), which historically had political links to the Kuomintang regime in Taiwan and is now in steep decline. Both these union federations often have acted more like the political arms of their mentors than as unions.

Today, the federation that is most active in organising workers and assisting them in industrial disputes is the Hong Kong Confederation of Trade Unions (HKCTU), which was formed in 1990 and today has 160,000 members in 61 affiliate unions. Inasmuch as it is not directly associated with a political party, it is an independent union federation that politically situates itself in the pro-democracy camp. The new unions have sought help and advice from the HKCTU, though the leaders of the organisation have resisted playing a leadership role over them, as they are hesitant to be seen as intervening in a new, spontaneous trade union movement.

The new unions that have emerged over the past year did not start out as traditional unionising efforts. Instead, they arose from demands for political change in support of the protest movement, without any agenda regarding work conditions or wages. The earliest volunteer organisers emerged from professional sectors such as finance, accountancy, medicine, health, social work, and education. Nurses, doctors, and paramedics, as well as reporters at the front lines of the battles, repeatedly saw protesters getting severely injured due to violence from the police, with members of the security forces even rushing into hospitals demanding to interrogate injured protesters and accessing their personal records. These professionals themselves were often tear-gassed, pepper-sprayed, and beaten up for trying to help the injured and traumatised on the front lines. Some of them were also troubled that at their workplaces, pro-establishment managers harassed those who dared to show support for the pro-democracy camp. Feeling vulnerable, angry, and frustrated, discussing among themselves in person and through social media, they began to seek peer support within their professional ranks, where they could share common experiences and make their voices heard.

\section{From Loose Sand to a United Front}

The call by students and other young people to launch a general strike as part of the protests became the catalyst for forming new unions. Disappointed that their fluidly organised be water' street protests had not extracted any concessions from the Hong Kong government, in early August 2019 they took to social media to implore all of Hong Kong to stage a 'Triple Strike' (三罢), so called because it was supposed to involve workers, students, and businesses. On 5 August, the day chosen for the strike, some 600,000 people joined rallies held in different parts of the city. Supporters participating in the protests refused to turn up for work or called in sick. Once at the rally venues, some of the protesters organised themselves into groups by 


\section{我願意為你擋子彈 你可以為我罷工嗎}

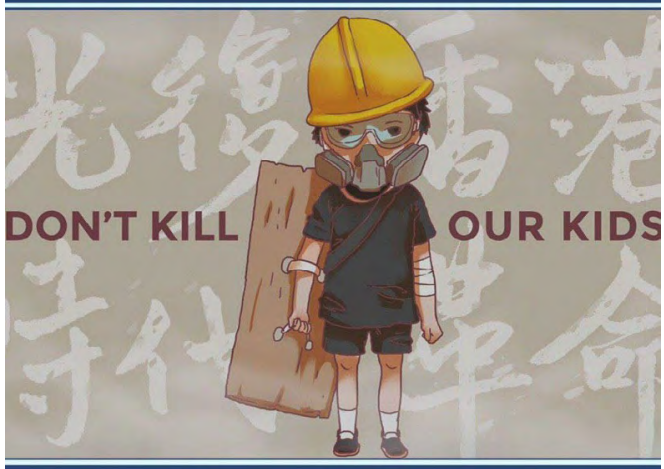

11.11 全港大三罷 黎明來到 要光復這香港

Fig. 2: 'I am willing to take a bullet for you. Are you willing to go on strike for me?'

occupation or trade. This turned out to be an opportunity to discuss among themselves the strategy of participating in the protests by way of their occupational identity.

On 2 September, a second 'Triple Strike' was called, but this time only some 40,000 people turned up for the main rally. The fear of management displeasure had deterred many others. In her speech at the rally, Carol Ng, head of the HKCTU, referred to the disparate groups who attended as 'sectors' (界别) because the idea of forming new trade unions did not yet exist among them. However, some of the attendees began to discuss the possibility of creating a means to protect themselves from managerial harassment and reprisal through the creation of a collective support group. This led to the formation of a 'Cross-sectoral Struggle Preparatory Committee' (跨界别抗争 预备组) and initial talk of forming unions.
At the end of October, after the suspicious death of a Hong Kong University student who had fallen from a multistorey parking lot, angry activists wanted to call another general strike. Posters went up across Hong Kong, including a dramatic one that read: 'I am willing to take a bullet for you. Are you willing to go on strike for me?' (see Figure 2). This third 'Triple Strike' eventually took place on 11 November in many parts of Hong Kong, and ended in roadblocks and violence.

By then, a new umbrella group called the 'Two Million Triple Strike United Front' (二百万三罢联合阵线) appeared on social media posting news about forming unions and sharing new ideas about possible strategies. This time, they argued, a general strike had to be better organised at the workplace level and needed to be large and strong enough to force the hand of the Hong Kong government. Since then, the group has evolved into an umbrella organisation for the new labour movement in Hong Kong.The first urgent task for the nascent trade unions was to recruit more members. To attract more attention from the public, union activists set up 'joint union stands' (联合跨站), each hoisting the flags of their unions. At a mass rally on 1 January 2020 in Wanchai district, the emerging unions coordinated their activities, and representatives from a number of them stood together for a photo, each with their own union's flag and holding a joint banner bearing the slogan 'Trade Unions Resisting Tyranny' (工会抗暴政) (see Figure 1).

As most of the founding members of the new unions had little conception of trade unionism or relevant labour laws, they began to invite labour lawyers and HKCTU leaders to give seminars and training sessions. According to Hong Kong's labour law, political strikes are illegal, so understanding the legality of strikes and how to strategise became a major concern. Moreover, through the training sessions and in the process of registering their unions with the government, organisers were exposed for the first time to various aspects of workplace rights, including trade union rights. Gradually, the motivation for setting up unions became 
multidimensional, rather than a single-minded focus on supporting political strikes. In addition to the five major political demands, trade union leaflets also included demands for shorter work hours, a higher minimum wage, better benefits, fairer bonuses, and, not least, collective bargaining rights.

Unexpectedly, the new unions that first got organised and registered represented whitecollar professions, such as the accountancy union, the financial sector union, the new civil service union, and the health sector unions. When I commented, 'I'm surprised that you are interested in setting up a union since you are from the middle class but not workers,' several interviewees retorted: 'No, we are workers.' One of them even emphasised: 'There are only two types of people-bosses and workers. We are workers.'

Sometimes, without being asked, interviewees poured out their grievances. Housing was a recurring grudge. When apartments of 50 square metres fetch as much as five million HKD, even those with a university degree cannot afford to rent, much less buy a house. Over the past couple of decades, as living costs continued to rise and inequality widened, traditional middleclass professionals have started to take on a working-class identity. A second grievance had to do with occupational health and safety. As the coronavirus began to spread to Hong Kong, staff in the accountancy sector sent by their firms to audit client companies in China had serious complaints about the lack of regard for their occupational safety. Finally, a few complained to me that their own sector of the economy is increasingly dominated by PRCowned businesses, or that at their workplace Hong Kongers have to compete for jobs and promotions with educated immigrants from the mainland, and that their bosses favour the Chinese staff because of their connections with mainland businesses.

\section{Unions Participating in Electoral Politics}

At the end of November, the nascent unions set their sights on a new goal after the prodemocracy camp unexpectedly achieved a landslide victory in the District Council elections, winning 17 out of 18 of Hong Kong's district councils. In the past, the prodemocracy camp had never seriously competed in these local elections, dismissing the councils as powerless and not worth investing time and money in. Since 2007 the councils had been dominated by the pro-establishment camp, but in late 2019, after half a year of street protests, channelling efforts into electoral politics suddenly became an option. The district elections triumph was a big morale booster. If the protest movement had won this election, they might be able to take a meaningful number of seats in the next two selections: first for Hong Kong's partially elected legislative council (LegCo), which is scheduled to take place in September 2020; and second, for the committee that selects the Chief Executive of Hong Kong, which is expected in June 2021.

Some of the seats in both bodies are apportioned to trade unions as one of the 'functional constituencies' that make up their membership. For years, these seats had been dominated by the pro-Beijing HKFTU, which, as stated earlier, has a large number of affiliates. Before 2019, the HKCTU had not put its energy into organising and registering new unions to compete within this functional constituency for a number of reasons. First, it did not have resources to outcompete the HKFTU, and so regarded any attempt as a waste of time. As a union, it preferred to prioritise workplace issues and the protection of labour rights, two aspects that the HKFTU had always neglected. Second, with the territory being dominated by a neoliberal capitalist ideology, Hong Kongers had thus far shown little interest in trade unionism. An HKCTU staff member noted that 
at the beginning of the anti-extradition bill protest movement, few protesters cared to take the handouts she distributed.

Surprisingly, though, the procedure to form a new trade union in Hong Kong is simple. The minimum requirement is that seven people turn up at the Labour Department to apply to register a new union, formed by trade, sector, or occupation. These initial seven organisers have to fill in forms stating the mission of the new union. Getting official approval usually takes a month or two. Once the union is approved, the founders have to hold a general meeting to elect an executive committee and the new union is then formally registered. Organisers assured me that the Labour Department staff were helpful and that they had not encountered attempts to make registration difficult. This ease in registration explains the proliferation of newly registered pro-protest trade unions in a few short months. In fact, some activists started a program called '7 UP' calling on those who could gather seven people to apply to set up a union. The Hong Kong and Chinese governments had been too confident that the pro-Beijing camp would continue to monopolise the labour scene, since Hong Kongers had never expressed much interest in joining unions.

The first of the two forthcoming elections is the Legislative Council election scheduled for September 2020. For the functional constituencies, the labour sector is apportioned three seats out of 35 , which, as I mentioned above, have always been dominated by the proBeijing camp. Since each union is given one vote under a winner-takes-all system, it means that unless the democratic camp increases the number of pro-democracy trade unions, the pro-Beijing camp, having a larger number of unions, will again win the three LegCo seats. Unfortunately, to be eligible to vote, a union has to be set up for at least a year before the election. Since the wave to establish unions did not begin in earnest until October/November 2019 , this means that the new unions will not be allowed to vote in the forthcoming election. In spite of this, from June 2019 to February 2020 there have been 735 applications, followed by another 'tsunami' of requests since then. According to official data from the Labour Department, in the first three months of 2020 there were 1,578 applications as opposed to just 10 to 30 in previous years.

Although many of the new unions will not be able to participate this September, they will be eligible to the vote on the Election Committee in June 2021. The Election Committee, consisting of 1,200 seats, will in turn vote for the Hong Kong Chief Executive in 2022. The labour functional sector will be given 70 seats. Here, too, the more pro-democracy unions there are, the better the chance they have of winning a majority. Sadly for the pro-democrats, the proBeijing camp has also been racing to set up new unions. Whether the pro-democrats can gain a reasonable portion of the 70 seats will depend on whether the various tendencies in the movement can coordinate to avoid running against each other. It is also worth mentioning that alongside setting up new unions, there is also an ongoing, extremely well-organised campaign to increase voter registration.

\section{A Test of Union Solidarity}

The test of whether the leaders of the new unions that sprouted up during the protestspeople who only a few months earlier had little conception of trade unionism-could withstand political and management pressures presented itself at the end of January 2020. The coronavirus was spreading rapidly inside mainland China and beginning to penetrate Hong Kong, which was not prepared to fend off the pandemic. Hospitals were short of beds, personal protective equipment, and personnel. At that time, the newly formed Health Authority Employees Alliance (HAEA), which had been actively recruiting new members and by then had 18,000 union members out of the 80,000 medical and health personnel in the city, called on the government to close the border with China out of concern that the 
territory's hospitals would be overwhelmed, putting medical staff at risk. In other words, the protest was over an occupational health and safety issue, one of the key workplace issues on which trade unions generally focus.

On 31 January, Carrie Lam refused, stating that this would mean discriminating against PRC citizens. The HAEA executive committee, led by a young chair who openly admitted that only half a year earlier she had only cared about enjoying a good life and had no idea about trade unionism, proposed to engage in a two-stage strike. With 3,123 voting yes out of 3,164 ballots cast, the members' vote on 2 February was nearly unanimously in favour of the proposal. More than 50 unions then came forward to support HAEA, and on 3 February, the first day of the strike, 7,000 members participated-i.e., 17 percent of Hong Kong's hospital-related medical sector. The same day, Carrie Lam announced all but three border crossings with the mainland would be shut, with some restrictions on entry by other channels, but refused to budge further.

When the first stage of the strike ended after five days, HAEA called for a second vote on whether to continue the mobilisation. Going on strike always invokes an intense moral dilemma for medical professionals, and this time, with only part of their demands met, of the 7,000 who cast votes 60 percent voted against keeping up the strike, and the action was called off. Nonetheless, we can still say that it was a partial success as Carrie Lam ordered the closing of most of the entry points to Hong Kong from China. The strike was an impressive first action, led by a new generation of trade union leaders who had quickly learned how to organise and, above all, were committed to trade union democracy.

Though compared with other regions Hong Kong has been able to control the pandemic quite well, as the coronavirus continued to spread, street activities in the city declined. The new unions continued to recruit members and to make preparations in sight of the November election. Meanwhile, as suppression continued in workplaces members have swiftly sought help from the unions-particularly in the education sector, where teachers are increasingly under pressure to accept new proPRC curriculums, are harassed, or even fired for supporting the pro-democracy movement and for not discouraging their students from participating. However, this new focus on workplace issues has not changed the political agenda. On 20 June, 30 unions joined hands to organise a referendum to seek members' approval to go on another general strike in protest against Beijing's plan to enact a National Security Law for Hong Kong. A new slogan reflecting the collective identity of the new Hong Kong trade unions appeared: 'To Liberate Hong Kong, Join the Union; Union Revolution to Resist Tyranny' (光复香港加入 工会; 工会革命, 对抗暴政). Of the 9,000 union members who voted, 95 percent said yes. However, given the high abstention rate the strike was called off.

After this, the unions shifted the focus of their activities to the primary election organised by the pro-democracy camp to decide who should stand in the LegCo election in September. On 11 July, 600,000 people cast their votes to elect their favourite candidates for the functional sector to which they belonged. At the time of writing, the votes are still being counted, but there is at least one encouraging sign for the unions. The HAEA Chairperson who had organised the strike in January won by a landslide, receiving 2,165 votes out of 2,856 , against the 186 votes for the current legislator for the health service sector. If allowed to grow and mature, organised collective action could have a future, especially now that the "valiant faction' has lost the prowess that it displayed earlier in the movement.

\section{What Next?}

In sum, when the Hong Kong government did not yield to the pro-democracy protests, a section of the protest movement started a labour movement, building up new small trade 
unions. Unlike the deliberately leaderless movement in the streets, the new shift meant taking an institutional route that requires planning, organisation, and even a link to electoral politics. There are now two strategies running in parallel with each other: the frontline protest movement facing off against the police, and a second aligned movement that is building organised institutional structuresamong them trade unions. This multi-pronged thrust has not created divisions within the protest movement. As the popular slogan 'brothers climbing a mountain, each trying one's best' made clear, all of the trajectories are beneficial to furthering the movement's goals. This climb that began by making strictly nonmaterialist political demands as part of the pro-democracy movement is now gradually also turning to materialist demands such as workplace conditions, wages, bonuses, and occupational politics aimed at securing a voice in the city's flawed political system. However, with the passing of the Hong Kong National Security Law on 1 July, Hong Kong was turned overnight into a lawless society. In light of this latest development, could the emergence of this trade union movement be a mere flash in a pan? 


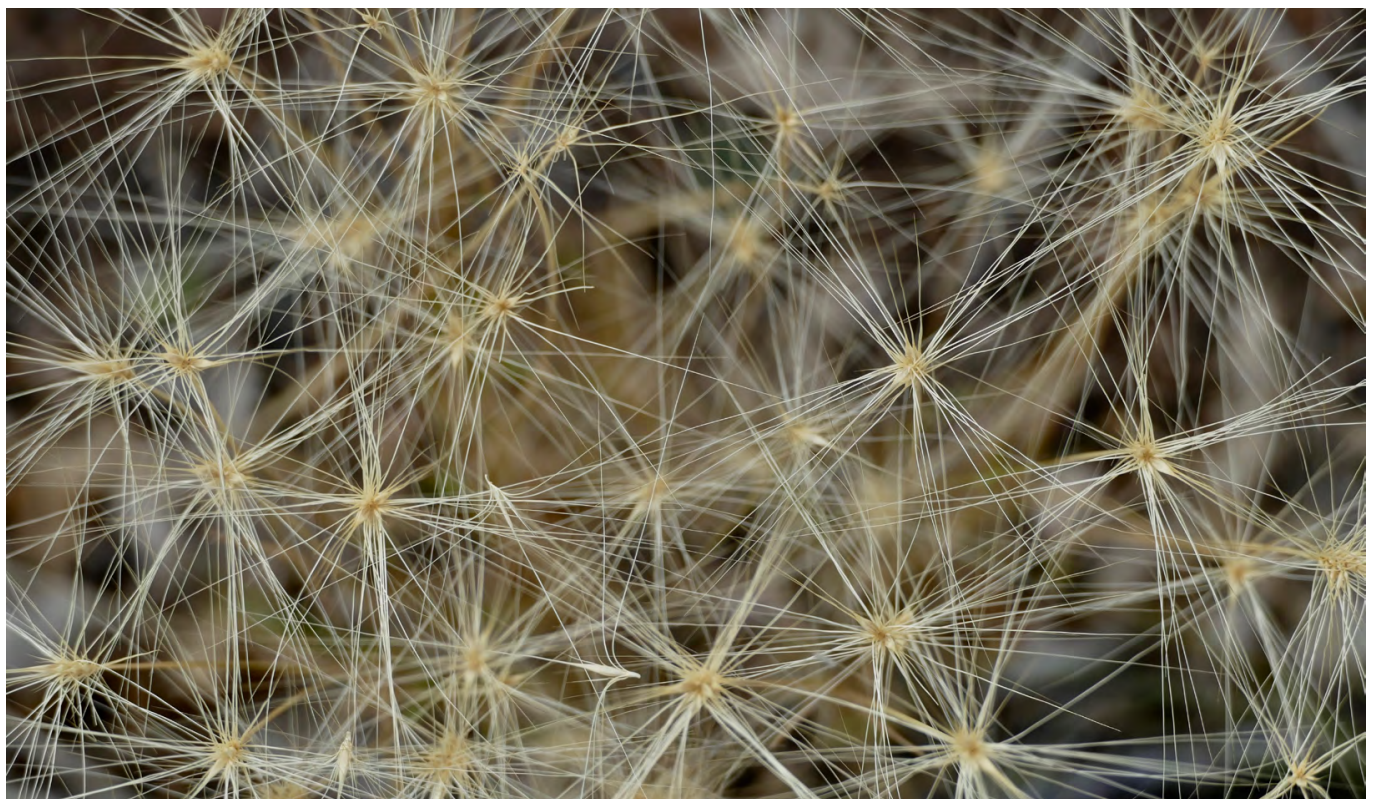

\section{Chinese Diaspora Activism and the Future of International Solidarity}

Mengyang ZHAO

Diaspora activism is frequently perceived as limited to activists' involvement in topics directly related to their homelands, which are often non-democracies with repressive systems. This essay argues that this perception snatches away the agency of diaspora populations, and curbs our ability to imagine the breadth and depth of transnational activism that is taking place today.
Interconncections. PC: Art by Bart, 2019.
Y asmin is an international student residing in a southern US city. A queer activist back in China, she participates in the graduate union campaign in her university and is also a community organiser. She is among a group in the Chinese diaspora who are involved in country-ofresidence social movements, a reality that tends to be overlooked in the landscape of contemporary social movements.

Diaspora activism occupies a strange position in today's social movements. It is at least a century-old phenomenon, with radical 
anarchists and communists transgressing national boundaries to breed revolutions during the early twentieth century being the most notable example (Anderson 2013). The history of Chinese diaspora activism could also date back to the late Qing dynasty, when the diaspora established multiple revolutionary groups overseas (Lai 2010). However, both narratives and practices of diaspora activism underwent a gradual conservative turn with the strengthening of national borders, the end of the Cold War, and the formalisation of social movement theories during the last century that are often strictly confined to national contexts.

Nowadays, stemming from Hirschman's (1978) famous 'exit and voice' framework, public memories of diaspora activism are conspicuously reduced to activists' involvement in topics directly corresponding to their homelands, which are usually nondemocracies with a repressive system (Quinsaat 2013). However, based on my study of Chinese diaspora activism, I argue that such an essentialist tendency frames social movements in non-democracies as antithetical to those in democracies, trivialising the potential interaction and mutual learning between the two fields. Not only does it risk snatching away the agency of diaspora populations, but it also curbs our ability to imagine the breadth and depth of transnational activism that is taking place in today's multi-layered political sphere.

\section{The Case of Chinese Diaspora Activists}

While mobilising for homeland politics constitutes an important and irreplaceable dimension for diasporic communities, it is by no means the only realm and mode of political participation. Diaspora politics also irrevocably intersects with social justice topics in the country of residence, as there are never clearcut boundaries between the two issues. Even mobilisation solely for homeland politics often involves the collaboration with country-of- residence social organisations. Problematising previously narrow presumptions of diaspora is therefore essential, since the processes through which diaspora activists interact with local social movements could not only bring new thoughts and praxes to country-of-residence activism, but also impact activists' subsequent engagement with homeland politics.

From early 2017 to late 2019, I conducted participatory observation of several Chinese diaspora activist communities and conducted repeated interviews with diaspora and nondiaspora activists residing in the United States, Europe, and China. While I chose to concentrate on the Chinese case due to my positionality as a former student activist, more importantly, Chinese diaspora activists are an exemplary case for exposing the problems and contradictions involved in transnational social movement participation.

In the media spotlight, members of the Chinese diaspora are conveniently portrayed as either dissidents against an Orwellian state or loyal trumpeters for a totalitarian government, with both approaches implicitly assuming them to be victims, even though the former is framed in a much more positive light. Such reduction of-or total blindness toward-the agency of those in the diaspora renders its diverse and evolving modes of political participation invisible. The ways in which those in Chinese diasporic communities politically engage are viewed as incongruent with the modes of political participation in liberal democracies, leading many to overlook their potential contributions to social movements in democracies, both intellectually and practically.

Patterns of diaspora activism are embedded in larger historical forces that shape the ebbs and flows of resistance. Since the 1980s, older activist generations have been more likely to be trapped in the dualism of authoritarian versus democracy and to build a closer relationship with political elites in democracies, while younger cohorts have been able to forge stronger ties with progressive social movements in the societies of residence, and 
also have a more critical take on neoliberalism. In fact, nowadays almost all young Chinese activists with a history of involvement in NGOs or more radical actions back home are also keen participants in progressive social movements in their countries of residence, as they tend to have a general fervour for promoting social justice universally, and also have developed transferable expertise via their organising work in China that allows them to navigate the social movement field in a relatively smooth way. Some even play key roles in local movements despite initial difficulties in integrating into the community.

At the same time, it is important to not forget the evolving dynamics of contentious politics in the countries where activists reside. The rise of populist rightist groups in global politics has also contributed to the resurgence of progressive social movements everywhere. The increased visibility of protests inevitably draws many in the diaspora into social movements. For instance, in my study, three activists mentioned Trump's election back in 2016 and the ensuing protests as a crucial period when they palpably felt a strong sense of urgency for direct action. It is in such moments of crisis that diaspora activists earnestly thrust themselves into country-of-residence politics.

\section{Transnational Engagement and Meanings of Resistance}

\footnotetext{
How do Chinese diaspora activists' brave forays into country-of-residence social movements inform and enrich our understandings of social movement transnationalism and global solidarity? Based on my interactions with activists, it is precisely their criticism of, and reflections on, social movements in democracies that have the potential to deepen the meanings and subsequent practice of their resistance.
}

Many activists are disheartened by the fact that social movements in democracies fail to possess the transformative vision they used to imagine before migration. A sneak peek at the languages they use to describe Western social movements reveals the disenchantment. To them, social movements in their host countries are 'formal', 'playful', 'non-confrontational', a 'carnival', 'commercial', and 'bureaucratic', lacking a sense of political urgency to push for real social change. Activists are also quick to discover the mismatch between social movement narratives and practices, as many radical discourses fail to be transformed into concrete and sustainable actions.

Part of the disenchantment results from the divergent contexts of social movements in China and liberal democracies. In China, since openly collective actions are severely restricted, many NGOs have taken up the role of movement coordinators, organising campaigns in a way parallel to social movement organisations in democracies (Pringle 2018). Chinese NGOs also hire members with activist personalities who sometimes organise actions outside of the bounds of normal organisational practice. Such fusion and ambiguity of roles are seldom the case in democracies, where functional boundaries are more clearly set for different social organisations. One unnamed informant even told me her NGO officially forbids its employees from engaging in organised rallies and marches, let alone spontaneous protests.

While activists acknowledge there are highly confrontational and disruptive social movements in liberal democracies, especially those organised by racial minorities and anti-capitalist activists, the general level of movement contentiousness and urgency they encounter pales in comparison with that of China. Back home, many activists fight tooth and nail and are forced to come up with creative strategies every time they organise campaigns around issues such as labour rights, feminism, and the environment, and the best ways to deal with authorities also keep changing. Many 
face illegal harassment and interrogation, eviction from rented houses and confiscation of personal belongings, and some have had experiences of being detained. Paradoxically, a repressive and ever-changing political climate in China produces both intense anxiety and high efficacy as activists feel they are doing transformative activism, while a safer environment in the West makes activism feel more like a set of mundane activities.

These criticisms by diaspora activists are not new to activists and scholars in democracies who live through similar frustrations within movements, especially when they risk reproducing the existing class, race, and gender hierarchies via ostensibly social justice work. The unique positionality of diaspora activists, however, is related to their organising experiences back home, which render them more sensitive to differences in organising models and difficulties of building solidarity. Their comparative insights thus serve as bridges between movements under different political contexts. One activist even mentioned she was able to apply the organising strategies that she had learned back in China to union campaigns in her residence city.

\section{Negative Movement Learning and Disenchantment toward International Solidarity}

Social movement theories have long proposed that commonalities between localities facilitate the diffusion and transfer of social movement knowledge. Yet, stories of Chinese diaspora activists divulge an alternative learning process that I refer to as 'negative learning', as problems of, and differences between, social movements they have observed can also serve as intellectual resources for future actions. Despite expressing sharp criticisms and doubts, activists pointed to many elements they have learned from country-of-residence movements, including both tactical knowledge of organising and, more fundamentally, comparative and intersectional perspectives on resistance and social change. For example, labour union bureaucratisation prompts some to rethink the issue of workers' spontaneity, while internal racism within social movements motivates others to introduce black feminism to a Chinese audience. Such negative learning constitutes a vital process through which movements from different political contexts enrich each other.

Simultaneously, however, direct participation in activism in the country of residence results in the painful realisation by many diaspora activists that social movements in democracies are much more parochial than they previously imagined. The vast majority of social movements are not organised in a way that recognises and cherishes the knowledge of diaspora. As one activist recalled, after joining a radical organisation, he was simply viewed as another newbie who could provide free labour for the activist group. Activists also discover that movement organisations rarely show genuine support for struggles outside of the United States or Europe. One labour activist lamented the lack of a global justice perspective in labour unions, and complained that people who share such sentiments are often marginalised. Even if solidarity is included in a movement's slogan, according to some interviewees, it is merely a rhetorical or symbolic strategy aimed at gaining moral legitimacy, rather than entailing concrete processes aimed at reinforcing forms of joint resistance.

Reckoning with this disappointing reality, some activists start to feel a stronger identification with social movements in China and no longer see themselves as transnational activists. This is not an outright rejection of the value of transnationalism per se, but instead the outcome of a more pessimistic take on the potentials for global solidarity than the often romanticised and tokenised depictions portrayed in the media and within activist communities. In the long run, it is possible that activists will overcome this pessimism and exert 
even more effort in fostering transnationalism despite the unfavourable reality, but at least in the short run this disenchantment could lead to movement burnout and should be taken seriously.

This also implies that the romanticising of global solidarity could backfire once diaspora activists are directly engaged in the convoluted country-of-residence social movements. My comparative analysis of diaspora and nondiaspora activists also shows that before migration, the majority of Chinese activists had no strong preexisting opinions of social movements in the West, as most of them only had limited exposure to social movements in other countries mediated via social media. If they did have preexisting opinions, the general impression tended to be positive. It is direct participation in country-of-residence political activism that reorients their attitudes and produces new activist subjectivities. As one activist reflected after moving back to China, overseas experiences have granted him a much more complicated understanding of social resistance in China and abroad, and it was quite 'liberating' to realise that Western social movements are not necessarily superior.

\section{Pandemic, BLM2020, and the Future of Diaspora Activism}

How can Chinese diasporic activism sustain and develop itself in the shadows of the current pandemic and the resurgence of right-wing nationalism? The increasingly aggressive immigration policies adopted by the US authorities exert a chilling effect on diaspora activists who could now face deportation for participation in protests and assemblies. Compared with native activists, diaspora activists suffer from the 'triple penalty' of simultaneously being activists, immigrants in their residence societies, and activists in their home country. In recent years, the Chinese state has aggressively tightened its grip on all forms of activism, and even diaspora activism might be placed under closer scrutiny under the expansion of transnational repression, especially after the passage of the Hong Kong National Security Law.

The worsening of the US-China relationship is taking another heavy toll on Chinese diaspora activists in the United States, as they are increasingly caught between two ruthless empires demanding loyalty from their own citizens. Not wanting to ally with either side, they have been put into a condition of emotional if not physical exile, with many US diaspora activists expressing deep anxiety over the crisis and their personal safety in both countries.

Starting in May 2020, the Black Lives Matter (BLM) protests have created some silver linings amid these dark times. As a decentralised movement, BLM provides new opportunity for Chinese diaspora activists to unite against racism and rework the meanings of transnationalism in their own way. Chinese diaspora activists have joined the nationwide protests in various cities, organised online forums, established reading groups, conducted public writings, and produced podcasts to divulge and reflect anti-Blackness within Asian communities ( $M a$ 2020). Their timely engagement might not change even a fraction of the whole picture in an era of heightened 'virus nationalism', but such efforts point to viable ways activists could still organise critical interventions in a divided world.

Therefore, it is even more imperative for both the academia and activist communities to interrogate and deconstruct the ideological and ethnic essentialism inherent in analyses of diaspora politics, making visible those efforts that challenge our parochial imagination of transnational social movements. Even social movements purposely mobilised in a local setting could have unintended global impacts, and it is these previously unarticulated transnational lessons that form the radical potential for future activism. 


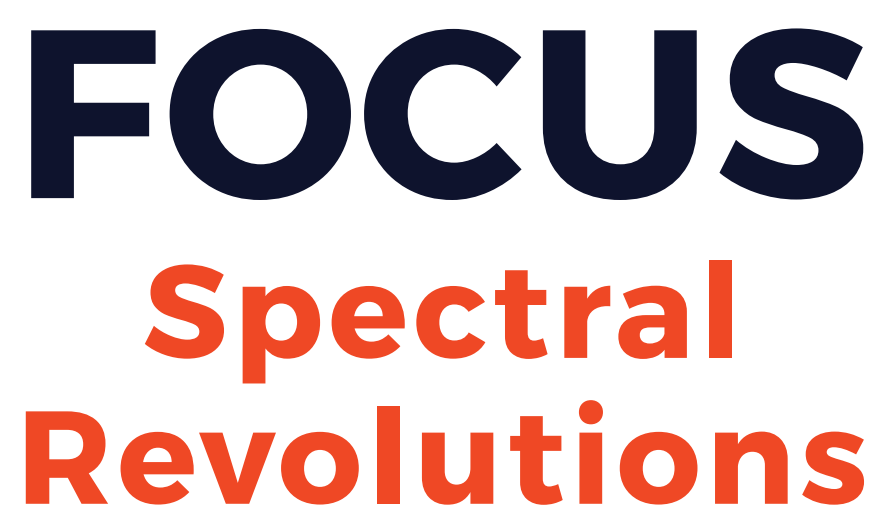

Occult Economies in Asia 


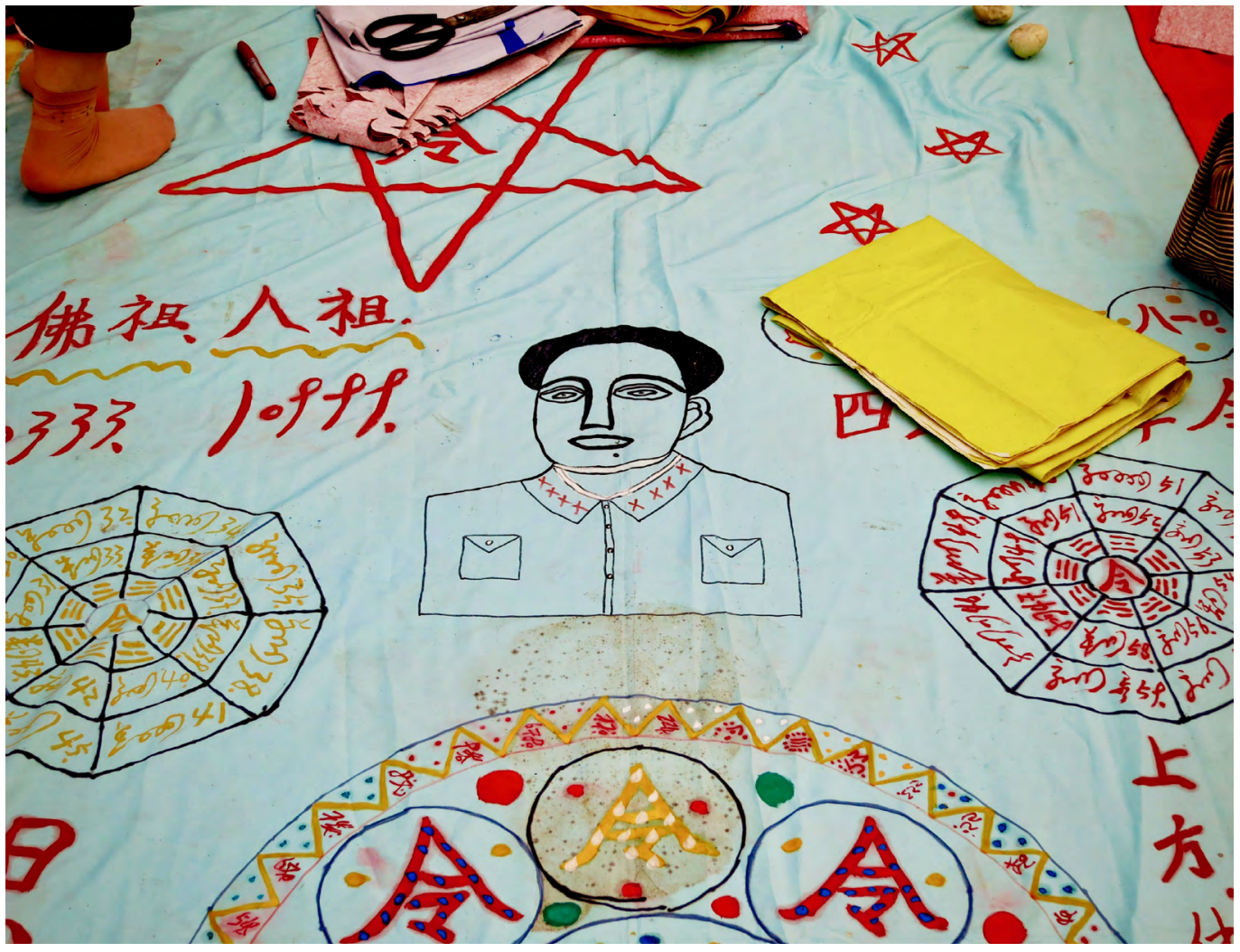

\section{Spectral}

Revolution:

\section{Notes on a Maoist Cosmology}

Emily NG

This essay describes the cosmological role of Mao in ritual and spirit mediumship in rural China. It considers the occulted forces hosted by the Chairman's image and words, across movements of display, concealment, and circulation. Here, the Party-state has a cosmic double, and Maoist anti-religious policies are not what they seem.

The essay features adapted excerpts from the author's book. A Time of Lost Gods: Mediumship, Madness, and the Ghost after Mao (University of California Press 2020).
The Chairman, from the temple square. PC: Emily NG, 2013

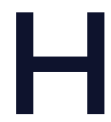
er hand smooths over the face of Mao on the one-hundred-renminbi bill placed atop a stack of blank, beige spirit money. Her fingers lift the edges of the spirit money as the same red renminbi bill is successively pressed on to the next blank sheet. She describes it offhandedly in the language of currency production-to 'imprint it a bit' (印 一下), transferring the vital value of the living yang world to the yin world, the world of that which 'cannot be seen or touched' (看不见, 摸 不着). It was one among many ritual techniques 


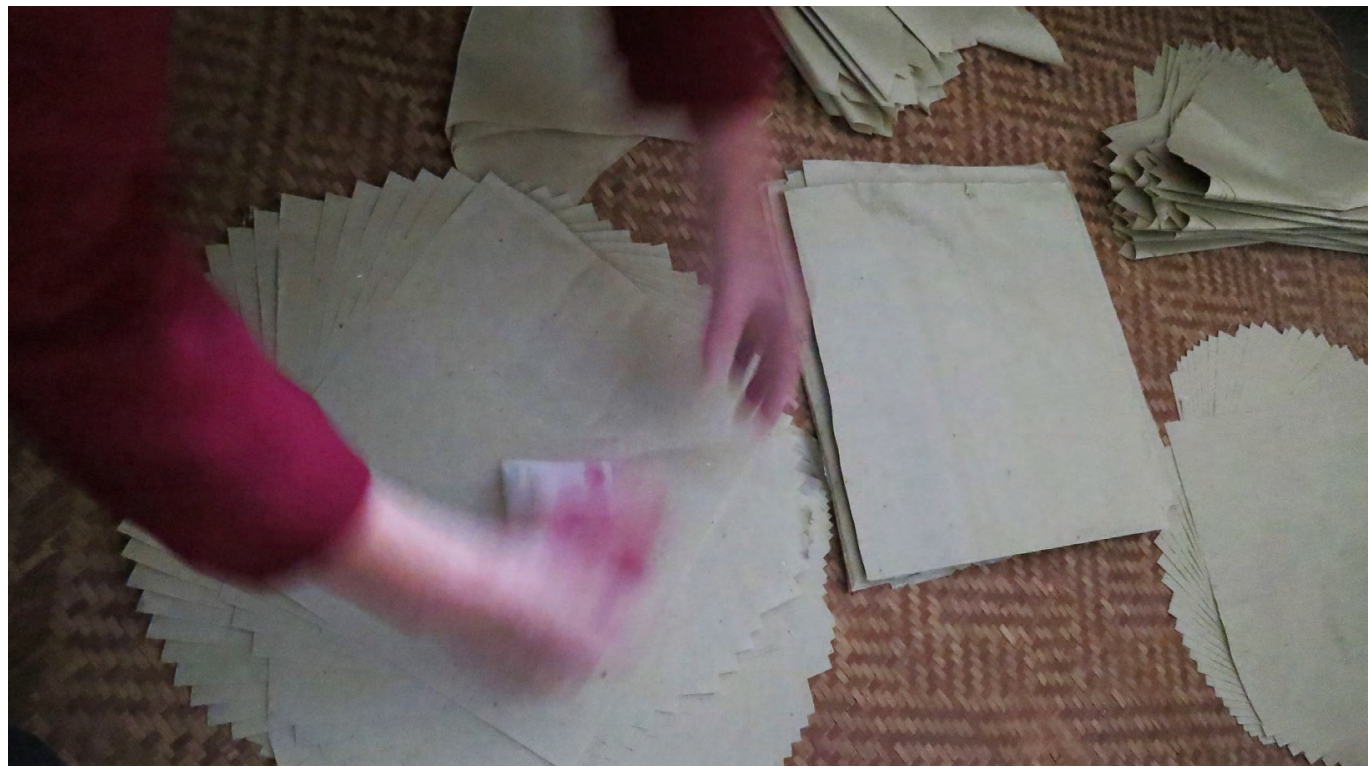

'Imprinting', between yin and yang currencies. Photo by the author, 2012.

used for processing spirit money to ensure an activation of value as it journeys toward the other realm.

On the anniversary of her mother's death, Cai Huiqing (pseudonym) borrows the face of the sovereign to infuse otherworldly currency with value, in the hopes of securing a decent life for her mother in the afterworld. Nestled between her palm and the beige sheets, the Chairman's visage partakes in a haptic intimacy at the crossing of worlds, exceeding apparent paradoxes of communism and the money form, atheism and the ritual-religious form.

Unlike others I met in Hexian, Cai Huiqing did not speak much of Mao, either at that moment or during the time I stayed in her home over the course of my fieldwork. Nonetheless, she knew from local ritual practices that the Chairman exuded a certain potency, which would enable a pivoting between the visible and invisible, living and nonliving. After decades of national, global, and local reproduction and circulation, whether as currency, propaganda, pop art, or otherwise, Mao's image seemed to gather a force at once cosmic and spectral, worldordering and haunting, in its absence-infused presence and presence-infused absence.

In his seminal essay on artwork in an age of technological reproducibility, Walter Benjamin (2008) writes that the aura of early art forms arose from their foundation in ritual. Yet, since the appearance of mechanically reproducible forms-photography and film-art, he suggests, has been emancipated from its previous role in the service of magic and ritual, and finds its basis in a new, revolutionised social function: politics. In the former mode, Benjamin continues, art was only exhibited to humans by happenstance-'what matters is that the spirits see it' $(2008,25)$. The human gaze was unneeded, and indeed at times banished. By contrast, exhibition to the living would become central to modern art forms. Contrasting the 'cult value' of ancient arts with the 'exhibition value' of modern photography, Benjamin pauses on a site of slippage between the two forms of value: the human face. 
As part of this special issue on occult economies, I draw here on the time I spent in 2012 and 2013, and then again in 2018, in a rural county of China's Henan province I call Hexian to consider Mao's role in the contemporary cosmology. In both its adjectival and its verb forms, occult points to questions of presence and perceptibility. In common current usage, it evokes secreted knowledges and practices, magical or otherwise. In earlier scientific writings, it referred to matter and properties not accessible through direct observation. In astronomy, it points to the concealment of one celestial body by the interposition of another, passing by or being in front of it-an eclipse. Taking its cue from Benjamin's reflection on the multiple operations of value potentiated by visual forms, alongside the theme of the occult, this essay considers the significance of and power embodied in the Chairman's image in contemporary Chinese ritual and spirit mediumship, across movements of eclipse and disclosure.

\section{Ten Thousand Years}

On the eve of the lunar year of the dragon, I wandered through the central temple in Hexian, dedicated to Fuxi, the mythological sovereign known as the progenitor of human civilisation. Amid the crowds on the vast square outside the temple gate, I heard a rumbling drum beat. A large circle of onlookers gathered around a small group of middle-aged women and men as they prepared for ritual. They donned matching and seemingly brand-new green Mao-era army coats, topped with brown Soviet-style fur hats, with a single red star at the centre. One woman at the inner edge of the crowd held a tall pole, topped with a large yellow flag with the word ling (令)-in this context referring to divine command-etched in red.

Inside the circle, 18 sheets of yellow fabricused commonly in local rituals and often described at the temple as the colour of the emperor-were laid out in the shape of a fan, flanked by a head of cabbage and two large stalks of scallion. Agricultural goods were often incorporated into ritual spreads on the temple square, sealing symbolic meanings and forces within them, both the commonly shared and the esoteric. Above this was more yellow fabric, every other sheet topped with a bamboo platter-a regional kitchen implement used for drying grains and vegetables. Atop the platters sat paper cuttings of concentric red stars-stars of the Communist Party. On the central bamboo platter, three cigarettes pointed northward, an offering to the gods, I was told. Above the cigarettes, four sticks of incense burned in a golden urn-three for humans, four for ghosts, as the saying went-aside a row of plasticwrapped sausages, 'because gods like to eat too'.

At the very top, farthest north, thus of highest position in the cosmic-symbolic geography, was a large poster of Mao in a red collared shirt, seated and flanked by his generals in blue uniform. On the poster sat some mandarin oranges and three slices of metallic-gold ritual paper-two covered in looping spirit writing, the third with the words 'Through virtue, one gains all under heaven' (德得天下).

As more onlookers gathered around, a man began swinging a three-foot-long necklace of Buddhist beads above his head, then lowered it meticulously atop the poster of Mao and the generals. Two men in Maoist army coats began striking a gong and cymbals, tracing deliberate steps across the spread of ritual offerings. Others joined to walk the perimeter of the encirclement, some singing, some dancing, some plucking offerings off the spread, brandishing them toward the heavens. The percussion gained speed. Cries from the crowd intensified-ayahao! Ayahao!an acknowledgment of the spirited airs and presences (灵气) passing through. A voice bellowed, cutting through the drum and song: 'Ten thousand years! Ten thousand years! Ten thousand years for Chairman Mao!' (万岁! 万 岁! 毛主席万岁! ). 
A woman, standing beneath the yellow flag of divine command, howled at the top of her lungs. In an adjacent ritual circle, the drumming had also reached its peak:

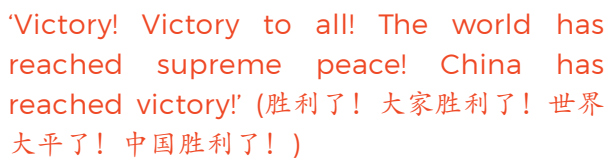

'Ten thousand years, wansui! Ten thousand years, wansui! Tens of thousands of years, wanwansui!' (万岁! 万岁! 万万岁!)

An address reserved for emperors for much of Chinese imperial history, wansui (literally 'ten thousand years of age' and commonly translated as 'long live') gained widespread usage during the Cultural Revolution, after Mao's public mass reception on 18 August 1966, when he took the crowd by surprise with an early morning appearance on Tiananmen Square. As described by the People's Daily,

This morning at $5 \mathrm{am}$, as the sun had just spread its first beams of light from the eastern horizon, Chairman Mao informally appeared on Tiananmen Square ... Chairman Mao wore a grass-green army uniform. On the Chairman's military cap glistened a single red star ... At the moment, the Square boiled over ... Many people clapped their palms until they turned red ... On the Square, tens of thousands of people loudly called: 'Long live Chairman Mao! Long live! Long, long live!'

After this appearance and its press coverage, wansui and its variant wanshou (万寿) were soon incorporated and codified into official Party discourse. By 1968, texts, meetings, speeches, and phone calls often opened with a formal wishing of eternal life and eternal health for the Chairman. During the same period, badges and images of Mao-not unlike those circulating in Hexian at the temple square decades later-also intensified in their mass production and circulation.
While Mao himself was said to have been cognizant of his iconic power and to have curbed the unofficial duplication and distribution of his words and images in the initial post-Liberation years, by the late 1960s, amid the Cultural Revolution, unauthorised media began multiplying at unprecedented speed, launching their circulation and signifying capacities beyond the containment of the state (Leese 2011). Outside of China, in the early 1970s, Andy Warhol would famously reduplicate Mao's portrait, adding another layer of significance to the reproducibility of his image.

In the 1980s and 1990s, after his death and amid major transitions toward economic privatisation, iterations of Mao's image continued to proliferate in China and abroad, now through new waves of contemporary art and kitsch. And in 1999, two years before China joined the World Trade Organisation, RMB bills would, for the first time, begin to deploy Mao's face as their central image. As China continued to rise economically, international news cycles began featuring footage of automated bill counters in China. The Chairman's face appeared again and again, now accompanied by the fluttering sound of paper money, like a flipbook that paradoxically reinstated the staidness of the image through its flickering animation; a filmic still life.

Meanwhile, Mao's words and images have also been used to conjure themes of revolutionary change. Student protestors at Tiananmen Square in 1989, for instance, issued a manifesto that opened with words from an essay by Mao: 'This country is our country, this people our people: if we don't speak out, who will? If we don't take action, who will?' (cited in Davies 2019, 94). Throughout the late 1990s and early 2000s, Maoist slogans and Mao's effigy were a common sight in worker protests following layoffs at state-owned enterprises (Lee 2007), and as late as 2018 Maoist supporters were playing an important role in prominent labour protests in China (Au 2019; see also Zhang Yueran's essay in the present issue). More recently, amid objections 


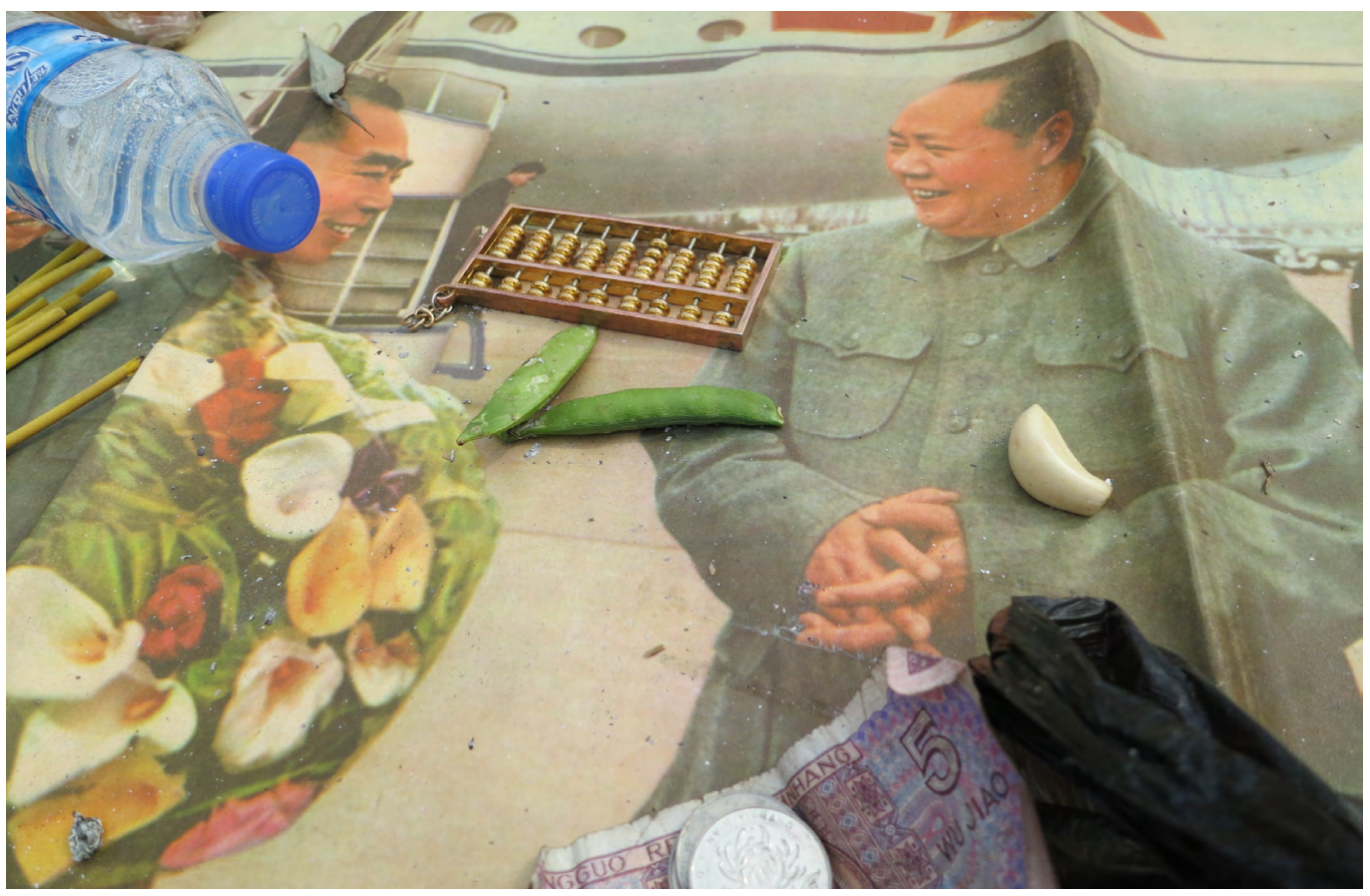

Spectrality, immortality. Mao and Zhou Enlai, at the temple square. Photo by the author, 2013.

in Hong Kong to the increasing encroachment of mainland Chinese rule, Maoist slogans such as 'A revolution is not a dinner party' cropped up in graffiti and on posters, after the prohibition of more straightforward prodemocracy slogans. As one restaurant owner put it: 'If [the police] were to come in and say, "You are breaking the law by posting these [Maoist posters]," I can say, "Well, then you are against the Chinese government"' (Prasso 2020). The Chairman's presence thus allowed for a simultaneous exhibition and concealment, hosting particular forms of speech while, in some cases, momentarily trapping the act of policing in the fissures of language.

In an essay on Maoism and immortality (不朽), Gloria Davies (2019) writes that postMao evocations of Mao are by no means monopolised by the Party. Citing Alexei Yurchak's (2006) work on the Soviet Union, she suggests that these evocations make way for ambivalent forms of overidentification through which endorsement and critique can sometimes become indistinguishable. Through its deployments across art, memorabilia, cash, and protest, the Chairman's image comes to host myriad meanings and powers, from the satirising of state power to the reinstatement of its new forms, from an alignment with the founding spirit of the Party to the (at times simultaneous) ironic turning of the Party's own words against itself. Through its multiplication of ambivalent meanings, Mao's presence seems to take on new modes of life after death.

\section{Cosmic Doubling}

The incorporation of Mao's image in the temple ritual in Hexian may at first strike some as surprising. By most accounts, whether 
popular or scholarly, the Maoist era had been an age of religious repression and the post-Mao market reform era one of religious revival. In such accounts, the Maoist years mark an apex of modern secularisation efforts, intensifying the anti-superstition campaigns of its Republicanera predecessors, culminating in the banning of religion during the Cultural Revolution (1966-76). Market reforms, by comparison, 'opened up' many aspects of life, allowing for a return of previously barred religious practices.

Yet, the spirit mediums I met in Hexian offered a different account of this history, and thus a different account of the present. For them, the ostensibly atheist Maoist campaigns against religion were in fact a matter of righteous, heavenly command, and the appearance of Mao on earth itself signalled a reincarnation determined by otherworldly forces. Conversely, the end of Mao's reign and the advent of market reforms did not mark a return of religion but a return of spiritscorrupt, duplicitous spirits by and large.

The purportedly antireligious campaigns of the socialist state, for the mediums, thus constituted cryptic acts of divine intervention, which in turn allowed the earthly state to misinterpret itself as secular. As Xu Liying (pseudonym), a spirit medium in her midsixties, put it:

\begin{abstract}
When Mao descended to earth, he did not want to. But they insisted, saying he must be sent down ... Once Mao took office, he banned religious faith. After he reincarnated as a human, he smashed all the temples, no? Heavenly command was given from above, telling him to smash them all, keep none of them. They were filled with demonic spirits!
\end{abstract}

While scholars have pointed to the ritualistic quality of the so-called Mao cult both during and after his lifetime, it has often been distinguished from religion proper due in part to Maoism's explicit antireligious stance and policies. Tracing the use of Maoist iconography in (mostly urban) art and kitsch in the 1980s and 1990s, for instance, Geremie Barmé has suggested that this 'new Mao cult' was 'divested nearly entirely of its original class, ethical, and political dimensions', along with the sense of 'moral revival, sanctity, and the general religiosity and fervor that characterized the earlier Cult' (1996, 5, 13). But temple rituals and cosmological accounts in Hexian pointed to a different engagement with the Chairman.

For those in Hexian who dealt with the world of spirits, "the time when Chairman Mao reigned' (毛主席当家的时候)一an everyday phrase there for articulating contrasts with the post-Mao present-marked not only his earthly rule but a cosmic punctuation and rectification, after which the cosmos collapsed into chaos.

In everyday chitchat the phrase usually referred to a time of safety, stability, and fairness. By contrast, with the arrival of the reform era-the ethos of which was seen to be captured by Deng Xiaoping's slogan 'It doesn't matter whether a cat is black or white; as long as it catches mice, it's a good cat'state officials began losing fear and gaining courage, siphoning off increasing amounts of money to the detriment of commoners. While officially taken as a statement of Deng's pragmatic stance toward market economies, the slogan was usually evoked by villagers in Hexian for its moral implications, authorising an era of greed. With the rise of privatisation and labour outmigration to major cities, both the sense of both opportunity and disparity grew, intensifying desire and envy of one's neighbours, leading, I was told, to escalations of theft and corruption. A sense of mutual mistrust deepened among villagers. Even if such mistrust may not have been absent during the Maoist era, day-to-day accounts of the past emphatically distinguished the morally upstanding past from the morally degenerate present.

While sentiments of mistrust and moral decay are not uncommon across Chinese contexts, they strike a particular chord in Henan province, given its place in postreform perceptions. Once part of the 'cradle of Chinese civilisation' and the centre of the 
cosmopolitical universe, this landlocked, heavily agricultural province has been recast through a spatial-temporal mapping of those 'left behind' in a contemporary geography of value. Now, in place of a civilisational centre, Henan is more potent in the national imaginary as a land of poverty, backwardness, charlatans, and thieves, evocative of the famines of the 1940s and 1950s under Nationalist and Maoist rule, and of the HIV scandal of the 1990s, when villagers contracted the virus from blood plasma sales for cash. Reversing Maoist discourses of a revolutionary, future-facing peasantry, rural Henan now appeared as a hollowed space from which one must depart if one wished to seek any semblance of a future.

The contemporary cosmology sketched out by spirit mediums echoed everyday evocations of post-Mao distrust and disintegration in Hexian, centring on the mythohistorical rises and falls of greed, corruption, and fakery across heaven and earth. Indeed, the same official political slogans carried a double function in the invisible yin world. According to spirit mediums in Hexian, given the Chairman's rightful heaven-sent status, ghosts and other spirits did not dare appear during his reign. With his pronouncement 'Sweep away all cowghosts and snake-spirits' (横扫一切牛鬼蛇神), all these spirits vanished-some said they hid in remote mountain caves; others that they disappeared altogether. Originally appearing as the title of an official Party editorial, the phrase became a widespread Maoist slogan during the Cultural Revolution and is generally considered a secular political call for heightened attacks on so-called reactionaries and class enemies. Moreover, it had marked the beginning of some of the most thorough campaigns against religion, including the destruction of icons and temple infrastructure in Hexian.

Yet, in its cosmological rendering, the slogan took on a force of heavenly command beyond earthly statecraft-a call for the banishment of corrupt spirits in a moment of cosmic chaos. Although technically stated in the middle of Mao's rule in earthly historical time, the power of this slogan, in the mediums' usage, came to signify the whole of Mao's reign. For the mediums, this cosmic chaos could be seen in the ongoing warfare with foreign powers in the pre-Liberation period, when Western and Japanese powers occupied various regions of China. In Hexian, memories of Japanese occupation circulated in the oral accounts of elders. Imperialism and occupation, according to the mediums, were not only secular political acts, but also manifestations of demonic forces. Given this scene of demonic intrusion, Mao was sent from the heavens as an act of divine intervention, to save China from full foreign domination.

The earthly state, in other words, had a cosmic double. Heavenly forces deployed purportedly atheist images, words, agents, and acts of the Party-state for purposes beyond its own knowing. The figurehead of Chinese Communist sovereignty was inseparable from an otherworldly sovereignty, and the Communist Revolution, in this rendering, was in fact a divine affair, aimed at rescuing China from demonic imperial forces. Indeed, some mediums said that Mao himself was unaware of his own otherworldly role during his time on earth, and only learned of it after he returned to the heavens.

Bookending the Maoist-era slogan that was said to banish the demonic spirits, the Dengera exhortation on black and white cats was cited by spirit mediums as another moment of transformation in the invisible yin world. As Xu Liying would go on to describe, with a slight twist on colour scheme:

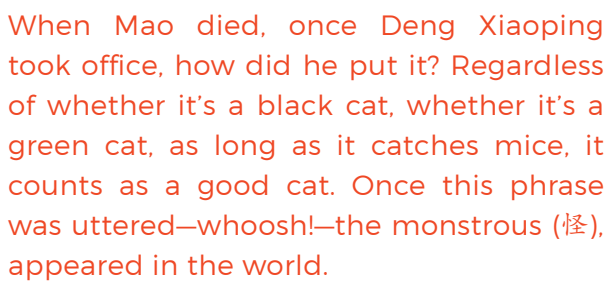

The monstrosity she referred to involved the return of myriad corrupted spirits, including 'fake gods' (假神)-demonic spirits that now masqueraded as deities, duping humans for 
their offerings, vying for wealth and power in the underworld. According to Xu Liying as well as other mediums, this rampant corruption in the heavens has been mirrored on earth. Ever since the Chairman's death, humans and spirits have been driving one another further in their duplicity and greed, resulting in a moral collapse across realms.

Under such circumstances, some spirit mediums described a coming end of the world-a messianic vision in which Mao, or someone like Mao, would someday return, sent by the Future Buddha Maitreya. This messianic return would be accompanied by the annihilation of the current world; the precious few deities and humans who remain virtuous in such chaotic times would be kept, and would repopulate the new world. This new world the mediums described was articulated in both Buddhist eschatological and revolutionary terms: that of a 'true socialism'.

\section{Spectral Revolution}

In Specters of Marx, Jacques Derrida raises questions of inheritance and mourning following the collapse of the Soviet Union. As Christian Sorace $(2020,130)$ put it in a recent contribution to the Made in China Journal, 'the loss of the promise of communism is also a loss of the horizon of future'. For Derrida (1994, 19), to consider place and time 'since Marx', following pronouncements of the triumph of global capitalism, is to consider what remains in the 'non-advent of an event', which carries on in forms secret and ghostly; the very deferral of the event may in turn affirm the sense of a future-to-come.

For the spirit mediums I met in Hexian, the death of Mao and rise of market reforms marked a deferred promise and a haunted present-a moral vacuum filled by swarms of demonic, corrupted spirits. Between visions of Henan's ancient grandeur, memories of pre-Liberation warfare and occupation, and a sense of postreform dispossession, sat an interval of divine sovereignty-one in which the peasantry, as Mao $(1967,23)$ once put it, was poised to 'smash all the trammels that bind them', whether put there by imperialists, warlords, or corrupt officials, and pave the way toward revolution.

Now, as the splendour of the ancient centre and glow of revolutionary horizons come to be eclipsed by new orbits of value, the face of the Chairman interposes itself as a pivot between worlds, hosting multiple forms of power through plays of exhibition and concealment. Occulted forces and signals of the virtuous spirits that remain exude quietly from the state-sanctioned celestial body-the body of the (lost) sovereign.

Through its absent presence, the face of the Chairman gazes over a scene of decay, while animating those who can perceive and decipher his secreted message from the yin realm, urging them to toil for the spectral revolution. Such a sovereign faciality, as Hoon Song (2016) writes of North Korea, lends its own embodied presence to the historical gap and promise of a (Marxist) knowledge to come. For the mediums, in spite of his departure from earthly life, Mao's images and words continue to offer visual and linguistic channels for the passage of spirits-spirits of a true socialism. Meanwhile, for those like Cai Huiqing who may or may not engage with these more elaborate cosmological accounts, the face of the sovereign lends itself to critical transfers between worlds, securing the promise of a good life to come. 


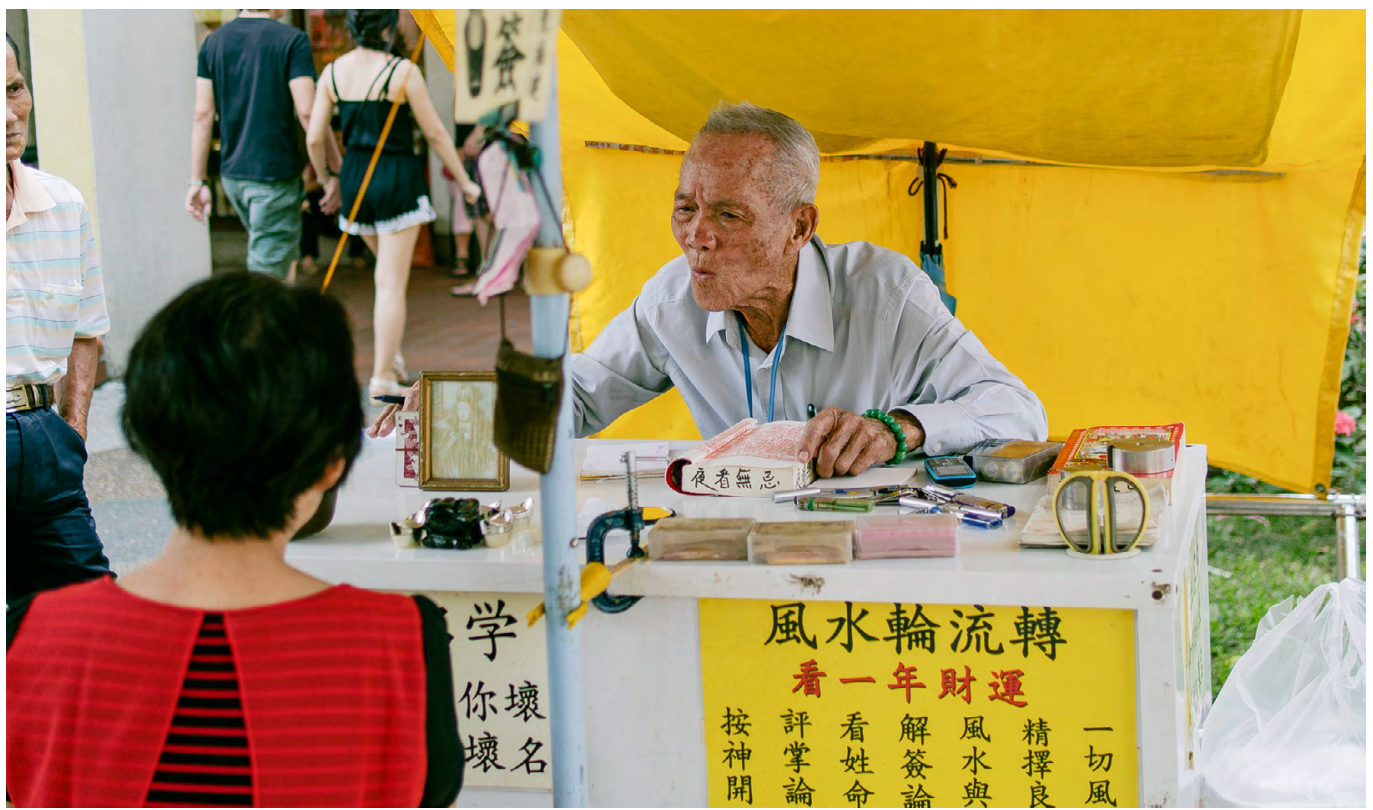

\section{The Yijing Ethic and the Spirit of Capitalism with Chinese Characteristics}

William MATTHEWS

Since the early days of economic reform in the 1980s, China has witnessed a revival of religious beliefs and practices. One of the most pervasive is fortune-telling, which has flourished by offering a means of decision-making in a rapidly changing and uncertain society. This article describes a popular method of fortune-telling using the classical text of the Yijing. It shows how fortunetelling's naturalistic worldview provides an excellent method for people to navigate day-today economic decisions by forecasting fortune in a way that is trustworthy and morally blameless, serving as a compass for uncertain times.
Fortune-teller. PC: Joel Sow.

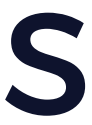
ince the 1980s, alongside the Reform and Opening Up of the Chinese economy and concomitant 'spiritual crisis' (精神危机), China has seen a revival of popular religious practices (Johnson 2017). This has included widespread interest in methods of fortune-telling with the Yijing (易 经), also commonly known as I Ching or Book of Changes, a two-thousand-year-old text on divination and cosmology that has exercised a historical influence in China comparable to that of the Bible in Europe. In fact, this revival of interest has spawned its own proliferation 
of scholarly analyses trying to make sense of China's 'ritual economy'-the resolutely intertwined practices of economic pursuits, religious convictions, kinship ties, and guanxi (关系) networks discussed at length by anthropologist Mayfair Yang $(2000 ; 2020)$ that seem to have put paid to assumptions about the rationalising effects of capitalism. 'Occult economics' indeed-but while other resurgent religious practices may well have something to do with a search for meaning in post-socialist capitalism, fortune-telling with the Yijing does not. Instead, it plays a very practical role in helping people participate in the challenges and opportunities contemporary society presents.

\section{Between Superstition and Science}

The Yijing's own revival peaked in the 'Yijing fever' (易经热 or 周易热) of the 1980s and 1990s, when the publication of new archaeological studies combined with the booming publishing sector to produce a proliferation of books on the subject (Redmond and Hon 2014). This continues today, with new editions of the text, guides adapting it for modern audiences, manuals for using its wisdom to promote good management practices, and, of course, guides to divination. It also remains a focus of scholarly enquiry, both as an object of historical and philosophical significance and as a source of knowledge or wisdom in its own right, the latter institutionalised as 'Changes studies' (易学), a dedicated academic field with its own research institutes as well as amateur associations (Matthews 2017).

However, while scholarship on the Yijing or its use as a source of philosophical 'wisdom' holds political legitimacy, this is not so much the case for its use in fortune-telling-which is where it truly speaks to everyday economic questions. Fortune-telling is considered 'superstition' (迷信) both by the state and by large sections of the public-but practitioners of course do not share this view, and often present it instead as 'scientific' (科学的) and therefore legitimate. As fortune-telling has returned to everyday life in China over the past four decades, it has regained something of the ubiquity it enjoyed before it was pushed underground by Maoism. The majority of people, if they have never consulted a fortuneteller themselves, will doubtless know someone who has, and many who do might well still refer to it as 'superstition' even as it helps them make key life decisions.

In fact, rather than appealing to the 'occult', Yijing divination relies on a very naturalistic explanation of how the world, and fortune-telling, works. This is what makes practitioners' assertions that it is 'scientific' persuasive. The Yijing itself contains 64 'hexagrams' (卦), diagrams of six broken or unbroken lines, which are made by combining eight three-line diagrams (trigrams, also 卦). The Yijing today comprises these, the obscure texts accompanying them, and commentaries, which explain that the sage-king $\mathrm{Fu} \mathrm{Xi}$ created the trigrams by observing patterns in nature, using these observations to derive constant principles of how the world works. Every possible circumstance could therefore be described by combining the trigrams, producing 64 basic kinds of situation. Fortunetellers today will still tell you that because the hexagrams are derived from observing the world, they can therefore be applied to any situation to explain what is going on and what will happen next. This is explained in terms of $q i$ (气), an energy-substance that constitutes everything in the cosmos, including thoughts and emotions. While the idea obviously does not come from physics, there is not a lot of difference between describing everything as being made of $q i$ and everything as being made of matter and energy-one does not need to invoke supernatural forces to subscribe to Yijing divination.

That assumes, though, that people who consult fortune-tellers need to 'believe' in it at all to find it useful. In fact, much of the time clients are reluctant to commit to 'believing' 
(相信) in it; as in forms of divination around the world, many of which do not have any worldviews attached to them at all, clients still use them to help make decisions or resolve conflicts (Boyer 2020). But if clients often do not really 'believe' in it, and it is widely considered superstitious or even fraudulent, why are people from all walks of life willing to spend money and time consulting fortunetellers at all? To understand how it plays a role in the everyday economics of contemporary China, we need to look closer at how Yijing fortune-telling works.

\section{Methods of Divination}

There are various methods of Yijing divination, but all rely on obtaining a hexagram, interpreted as a snapshot of the world from the perspective of the client at a particular point in time and space. This is used to gain information about the client's general circumstances and relationships, which can then be used to diagnose problems and offer advice. Most of my own research on this relates to a technique called 'six lines prediction' (六爻预测), the form of Yijing divination that most people are likely to encounter, typically by temples or large transport hubs-the former being frequented to pray for good fortune, and the latter likely relating to the potential uncertainties and possibilities of travel or labour migration. In a city like Hangzhou, where I did fieldwork, this costs between 20 and 50 yuan, with optional extras such as eightcharacters (八字) horoscopy, face-reading (面相), or even fengshui (风水) consultation. People ask a range of questions, but the most common enquiries relate to marriage, health, personal relationships, work, and money-in short, questions of pressing personal concern that produce difficult decisions or potential uncertainties.

Clients are told not to voice their question until after the procedure has been completed. This involves throwing three coins six times, giving the six lines of a hexagram. The diviner interprets this in terms of the kinds of $q i$ associated with each line, and the kinds of personal relationships that they indicate. Once this is done, the diviner will likely make some general comments on salient relationships revealed by the hexagram, and the client is invited to ask any specific questions. Let's take the enquiry of Mrs $\mathrm{Xu}$ (a pseudonym) as an example (described in detail in Matthews 2018). She got a hexagram that referred to her wealth. Each hexagram has two key lines, one for the enquirer (the 'generation line' 世爻) and one for the subject (the 'resonant line' 应 爻); in this case the generation line referred to 'wives and wealth' (妻财), and the resonant to 'brothers' (兄弟). The resonant line here also corresponded to Earth, and the generation line to Water-according to the cosmology of $q i$, Earth conquers Water. This meant that Mrs Xu's wealth was under threat from financial competitors, 'brothers' referring to people of equivalent social status to the enquirer.

Observing other correlations in the hexagram, the fortune-teller Master Tao noted that Mrs Xu's currently calm attitude to them would be beneficial; correlating the hexagram with Mrs Xu's horoscope based on her date of birth, he was able to give her a forecast. She was moving from a difficult year to two auspicious years, but would need to take care when dealing with these issues in the third year, as it would bring the influence of negative qi. So, Mrs Xu's financial concerns were explained in a way that integrated them closely with other aspects of her life (notably her health), and according to a natural pattern of changing fortune. She was given some responsibility within this-to pay attention to her health and finances in a specific period-but ultimately the ups and downs of her fortune, and the threat posed by outside influences, are explained in terms of the interaction between her own qi and that of the cosmos as a whole. She is granted enough agency to have some positive influence, but at the same time any blame for misfortune is externalised (even the threat from competitors is the product of cosmic forces). 


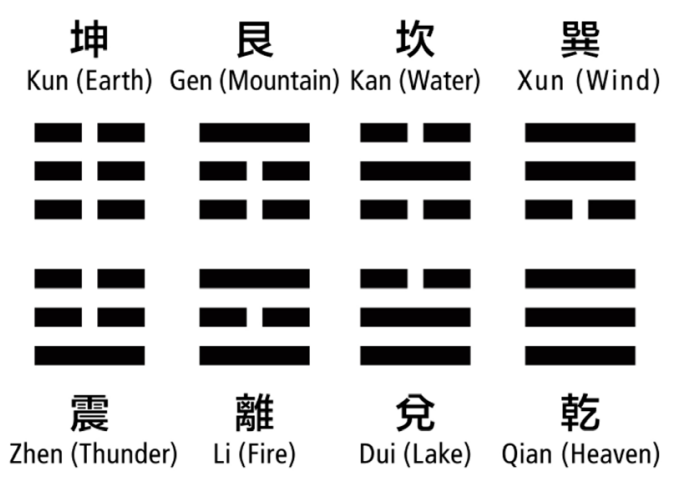

The building blocks of the Yijing, known as trigrams.

Mrs Chen was a small business owner who was interested in whether, and when, she could buy a new shop unit. In this case, Master Tao identified a 'mutually destructive' (相克 的) relationship between the generation line, representing Mrs Chen, and the resonant line, representing the owners of the shop she wanted to buy. In this case, the diagnosis was auspicious-while Mrs Chen explained she had been worrying about whether she could safely sell her old shop, Master Tao said there was no need. The shop would be hers in spite of the mutually destructive relationship-to deal with that, Mrs Chen should be patient, and refrain from discussing acquiring the shop for the next 50 days.

Here, we can again see how the consultation provides a combination of agency and assurance. Notably, both examples involve forecasting future auspicious and inauspicious times-this is crucial. Strictly speaking, sixlines prediction does not give a forecast of what will or will not happen. Instead, by considering the agricultural calendar (农历), based on cycles of qi that follow the same logic as the hexagrams, a client's current fortune can be taken into account in relation to forthcoming qi flows. That is, in both these cases, the client is offered a financial projection of sorts-but one based on cosmic principles rather than the stock market. Indeed, Master Tao would use a simplified version of Yijing divination occasionally to project likely earnings for the day.

\section{A Relational Theory of Economy}

Six-lines prediction has its own theory of economics, one that is well suited to use in the rapidly changing environment of contemporary Chinese capitalism. Considering all the uncertainty, instability, precarity, and opportunity that the current socioeconomic system presents for Chinese people, it is no surprise that a market has emerged to help people make sense of these conditions, which diviners are happy to fill. At the other end of the socioeconomic scale from Master Tao, plenty of fortune-tellers operate as consultants for highpowered business owners and other elites, and charge thousands of yuan for their services. Operating from their own offices or homes, they are less at risk of being moved along by the authorities when the state decides it wants to clear up visible superstition; in Hangzhou, these forced removals have increased since preparations for the 2016 G20 summit and appear to have developed into a general campaign to remove roadside businesses of any kind. Master Tao, for example, was permitted to continue fortune-telling provided he moved to the terrace of a nearby cafe, behind a hedge so he was not visible and would not attract a crowd. The irony of this was that he was forced finally to start using WeChat to communicate with clients, and pre-booked appointments soon filled far more of his schedule than had passing pedestrians.

As mentioned in Mrs Xu's example, 'wealth' in six-lines prediction is part of the category 'wives and wealth', betraying the sexual hierarchy of the context in which the method was developed from the Han dynasty onwards. However, while this means that the categories involved in discussing spousal relations vary for men and women, this does not seem to have 
an obvious impact on clients. The remaining relational categories all describe personal relationships-parents, brothers, children and grandchildren, officials, and ghosts-which can be used to categorise the connection of the client with any particular thing. So pets, for example, come under 'children and grandchildren' as they are dependent on care, and for women, husbands come under 'officials and ghosts' as in Confucian terms they hold authority over their wives.

This means that, in theory at least, women are likely to receive slightly more divinatory diagnoses concerning finances than men; for men, meanwhile, their relationship to their wives is equivalent to that with their money (or vice versa). Either way, though, wealth is an asset over which a client has some degree of control or influence. As we have seen, however, it can be contested. So, a person's relationship with their wealth, and by extension their financial fortune, has to be understood as part of their wider social relations. Economics, from the Yijing's point of view, cannot exist in isolation. Even more than that, one's relation to one's wealth is itself subject to the same wider cosmic forces as one's life circumstances overall, including one's other relationshipsand the nature of hexagram interpretation means it always offers information about other aspects of life as well. This does not mean that positive financial fortune necessarily coincides with, say, good health or luck in love, or indeed auspicious work relationships. But it does mean that all of these things have a common cause in the interaction of a person with cosmic $q i$. Because the forecast provided by a diviner is based on fixed principles about how this qi changes over time, a client's prospects for maintaining, improving, or losing their fortune are constrained. However, the diviner never tells a client what will unequivocally come to pass. Instead, final agency remains with the client-but they now know that if they take a certain course of action, it is more or less likely to improve or endanger their fortune.

\section{A Compass for Uncertain Times}

This tells us something about why the services of fortune-tellers remain in demand, and in fact flourish, in China today despite being labelled 'superstitious'. With so much uncertainty and opportunity in the temperamental context of Chinese capitalism, individuals are confronted with an overwhelming array of decisions, from seeking economic security, to household budgeting, to business ventures, to consumer choices. Fortune-telling helps to contain these decisions, give a limited range of optimal options, and take away an excessive degree of moral culpability by ascribing these conditions to a cosmic order while still allowing the client final agency over their decisions. Significantly, this is not about 'meaning' in the existential sense-the 'spiritual crisis' that popular religion, revived Confucianism, and nationalism have risen partly in response to. While diviners and clients might 'believe in' the cosmology of the Yijing, the fact that that cosmology is naturalistic and ultimately amoral means that any existential meaning must be brought along or read into it by the client. This actually enhances its utility as a way of rationalising decisions and limiting optionsone simply picks an optimum outcome from the paths available.

It is worth considering here something true of divination in general. As I have suggested in passing, and David Zeitlyn has discussed in more detail (2012), there is a genuine similarity between divination and financial forecasting, in that both use models of the world to diagnose features of the past and present and, assuming those models are accurate and constant, to predict future conditions and accordingly offer advice for action. This relates to the key feature of divination that explains why people use it at all: it is intuitively trustworthy. As anthropologist Pascal Boyer explains (2020), a key reason divination is found across societies, and throughout history, is that it produces statements that do not come from an individual 
person. People are constantly on the lookout for cues that they can trust others, or for possible reasons to doubt them-that is, we unconsciously pick up signals about whether or not another person is reliable. In divination, the statements come from the fortune-telling technique-the coins in the case of six-lines prediction, and the fixed referents of the hexagrams. We could say the same thing about the models employed in financial forecasting. This means that a key reason to doubt the statement is removed-clients can see that the fortune-teller has no control over how the coins fall (as a forecaster has no control of the outcomes of a model), so the potential for the statement being deceptive is reduced.

Now, as Charles Stafford points out, in contemporary Chinese society and the ritual economy in which it is enmeshed, a common topic of conversation is 'swindling people' (骗 人). The potential to exploit the trust of others granted by rapid economic liberalisation and the delayed development and poor implementation of protective regulations, coupled with incidents and widespread fears of fraud and con-artistry, have combined to erode levels of public trust in the system, adding to the sense of 'spiritual crisis'. Indeed, diviners themselves, as well as being labelled peddlers of 'superstition', are also subject to accusations of 'swindling people' by taking their money based on false beliefs (and may be prone to accusing others of doing so themselves). Ironically, though, in an environment pervaded by distrust, in which economic decisions must be weighed carefully based on potential ill intent or misinformation, divination offers a method that, in its own way, guarantees trustworthiness.

\section{A New Relevance}

Yijing divination has always been an important part of everyday life in China. That it has been revived over the past four decades is first and foremost to do with the relaxation of state control over 'superstition', but the economic changes of the reform era have created new contexts in which it becomes relevant and valued in people's lives. Diviners themselves have found new opportunities, and while clients embrace divination for the same broad reasons it has always been embraced, they do so to solve day-to-day problems whose nature reflects the specificities of contemporary Chinese capitalism. If $\mathrm{Mrs} \mathrm{Xu}$ or $\mathrm{Mrs}$ Chen and others like them feel they cannot trust the advice of others, particularly in the economic realm, they have the option of a detached fortune-telling technique that, regardless of whether they 'believe' in its cosmology, provides the assurance of neutrality, with the added bonus of blamelessness and just enough agency over one's future. 


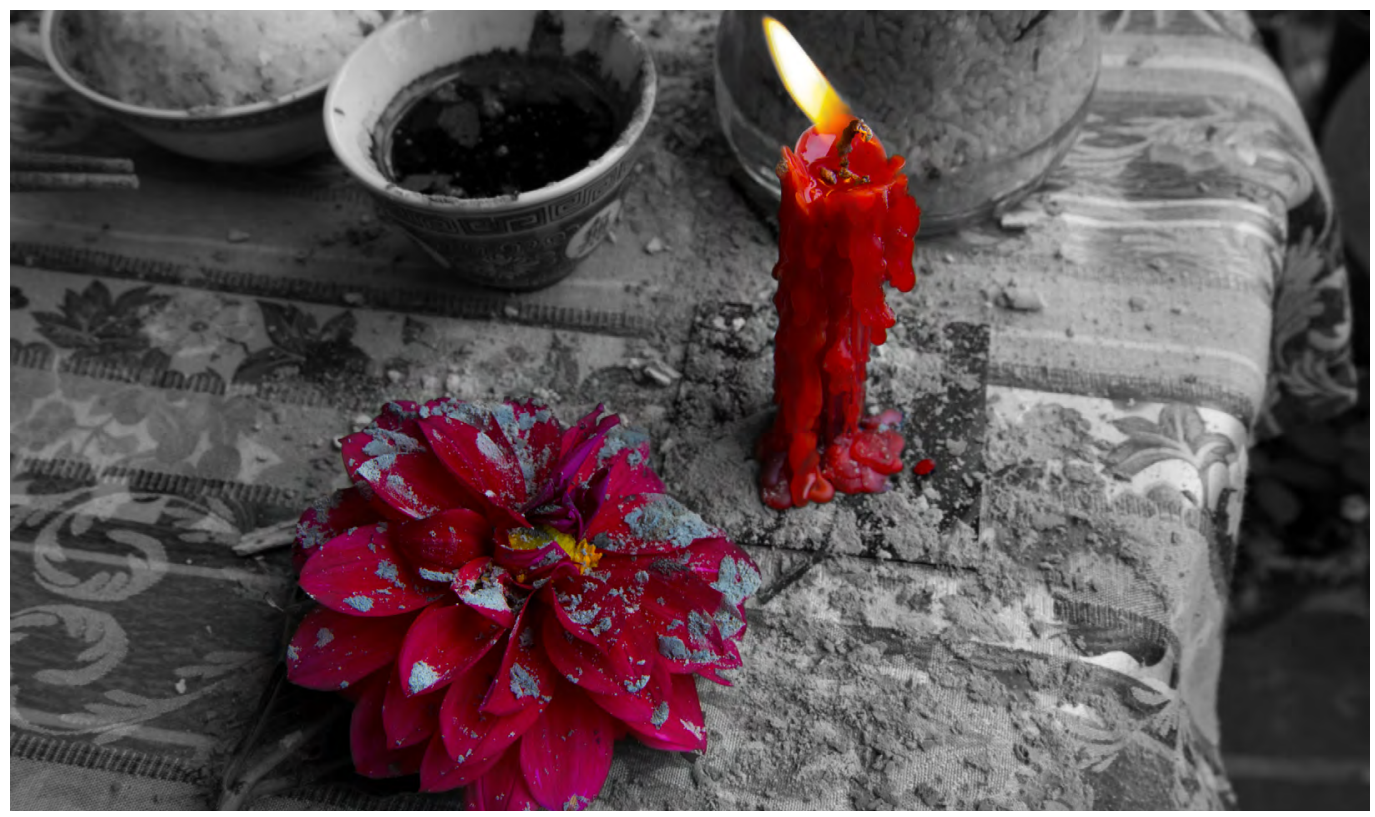

\section{The Macabre}

PC: Slilin.

\section{Affective Labour \\ of Cadavers in \\ Chinese Ghost Marriages}

Chris K. K. TAN

Recently, Chinese newspapers have captured the attention of their readers with stories of criminals robbing graves and murdering people to sell the corpses for use in 'ghost marriages' (yinhun 阴婚). The state casts ghost marriages as 'superstition', but the practice remains as a way for people to attempt to sooth the angst of the spirit of the deceased and its living relatives. In fact, the lifeless corpse used in yinhun must be considered alive during the ritual for the ghost marriage to achieve its spiritual and social efficacies. As such, yinhun cadavers perform a sort of macabre affective labour.

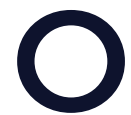
n 30 October 2014, the South China Morning Post reported a most bizarre and macabre crime: the police in Shandong province arrested 11 men for raiding women's graves and selling the corpses for 'ghost marriages' (yinhun 婚, also known as minghun 冥婚) (Luo 2014). Earlier in March that year, the suspects had exhumed a woman's three-month-old corpse, and sold it to a middleman for 18,000 yuan (2,600 USD). Depending on such factors as the age and physical appearance of the deceased, 
her socioeconomic background before death, as well as the freshness of the cadaver itself, a corpse could potentially sell for more than 20,000 yuan. A just-deceased corpse would fetch a far higher price than bare bones. Through the black market, the family of a dead bachelor in neighbouring Hebei province eventually bought the stolen cadaver for 38,000 yuan (5,500 USD). Presumably, after conducting a wedding for the couple, this family reburied the woman next to her new husband. The newspaper article further warned that while the state treats yinhun as outdated and harmless superstition, grave robbery itself is a crime punishable with up to three years of imprisonment. Prices, it seems, have inflated tremendously with the times. A couple of years later, Li (2016) reported, '150,000 yuan (US\$22,000) won't even get you bones'.

Despite its illegality, yinhun persists in the rural areas of Shaanxi, Shanxi, Henan, Hebei, and Guangdong provinces (Luo 2014). In April 2016, three men from Gansu province murdered two mentally disabled women to sell their bodies as ghost brides (Global Times 2016). In a case in late 2016, a woman with multiple physical and intellectual disabilities narrowly escaped being buried alive. Fed powerful sedatives meant to kill her, she nevertheless regained consciousness during the burial, and alerted the horror-struck family who bought her by loudly thumping on her coffin walls. These victims were likely chosen specifically for their intellectual disabilitythey offered less resistance to the violence inflicted on them and were perceived as being 'less human', making it easier to morally justify their murders (Guo 2008). The police have since charged six suspects with abduction, human trafficking, and attempted murder (Gao et al. 2016).

Ghost marriages contradict the state's vision of modernity, so the state discourages their practice. Why, then, does yinhun persist? In this essay, I first discuss how ghost marriages are conducted, then move to examine the motivations behind them. In particular, I argue that because yinhun placates angry ghosts and soothes the anxieties of their living kin, the corpses used in ghost marriages perform a sort of macabre affective labour.

\section{The Ritual}

Historically, an yinhun ritual closely resembled a marriage between living people, albeit with some critical modifications. Unlike the contemporary cases entailing body snatching, the groom's family resorted to a spirit medium-matchmaker to propose the marriage to the bride's family, draw up the list of bride-wealth and dowry items, ritually seek the approval of the deceased for their upcoming union, and then perform the wedding ritual. Depending on the local custom, this ritual took place either at the groom's home or at a local temple. There would be a feast, and the dead could be represented in many forms: a spirittablet inscribed with his/her name, a white cockerel, a bamboo-and-paper effigy meant to be burned later as a funeral offering, or perhaps even the corpse itself.

These modifications are particularly obvious in the description of a Singaporean wedding that Topley $(1955,71)$ provides (see Figure 1). The effigy of the groom had a wad of imitation paper money stuffed into his suit's top pocket. Effigies of servants stood on each side of the couple. The newlyweds were surrounded by accoutrements that they would use in their new spirit home: trunks of clothing, rolls of cloth, furniture, modern electrical appliances, and even a large American-type car-all made of bamboo and paper. The following dawn, after the ceremonies concluded, all of the paper articles-including the newlyweds and their servants-were taken to the backyard. There, the couple was placed in their car, and everything was dispatched to the next world by flame. In cases where corpses represented the couple, an auspicious date and time were then chosen to bury the groom and his new bride. 
Thereafter, the living relatives of both parties became each other's affines. Ghost marriages, like normal marriages, linked two lineages to maintain and enhance family wealth and social status (Jordan 1972; Martin 1991; Topley 1955).

In present times, the yinhun ritual has not undergone significant changes. In October 2016, my research assistant went back home to Hebei province's Guangzong county to interview her fellow villagers who had conducted ghost marriages before. One informant had a younger sister who died of cancer in 2010 at the tender age of 16. Just two days after her death, parents from a neighbouring village came seeking the sister's hand for their high school-educated son who had died in a car accident when he was 20 years old. Knowing that she could not be buried alongside the ancestors, and fearing that her body might be stolen, the informant agreed to the match. The groom's family gave him a symbolic bride price of 4,000 yuan ( 670 USD), and the sister was married off three days later. The entire yinhun ritual took just one day to complete. The informant and his relatives delivered the bride in a coffin draped with festive red cloth. Together with the groom's family, they celebrated with a wedding feast. After the meal, they waited for more than an hour before they were told to go and cry at the burial. The informant remarked:

This wedding was simpler than a regular one. We didn't have the usual steps such as 'formal proposal' (纳采), 'checking for compatible birthdates' (纳吉) and 'delivery of bride-wealth' (纳征). The groom's side prepared all the things for the wedding and the funeral. We just brought along some clothes to be burned at the burial.

As one can see from the example above, the yinhun groom's family provides the bridewealth and the material preparations for the entire ritual, as a living groom would have. However, yinhun lacks the complicated matchmaking rituals of a living marriage. Its secretive nature necessarily means that only the immediate kin of the bride and groom are

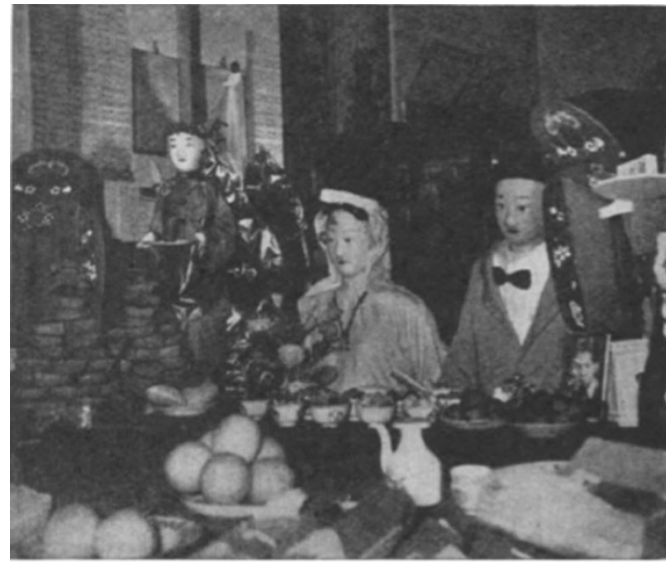

Fig. 1: A ghost wedding feast in Singapore. PC: Topley 1955, 71.

invited. Reflecting also the social awkwardness of an auspicious wedding that is followed immediately by a ritually polluting funeral, this limited number of guests prevents the boisterous liveliness that marks any social event in China as truly successful (Chau 2008).

\section{Soul-soothing Relief for Unsettled Ghosts}

Nevertheless, one question still remains: why would anyone go through a ghost marriage? Since antiquity, the Chinese widely accepted the idea of life after death in the netherworld. In traditional Chinese cosmology, both our earthly domain and the divine realm shared the same social structure. Hence, just as China had the emperor, his imperial court, one's kin, and socially marginal beggars and bandits of this earthly domain, the godly realm had the Jade Emperor, the other gods, one's ancestors, homeless ghosts, and demons (Ahern 1973). As such, the underworld was also believed to have its own king, system of currency, and a China-like social structure. Unsurprisingly, souls had social needs that mirrored those of the living, including the need for marriage. 
In an example from Chinese history, thinking that his favourite but dead son Cao Chong needed companionship, the warlord Cao Cao (155-220 CE) married him to a certain alsodeceased Miss Zhen. Nonetheless, mainstream Confucianism objected to yinhun as something that went 'against human relations' (反人伦). Confucius himself firmly detested human sacrifice and its analogues. Subsequent generations of literati also held that a ghost couple could neither go through all the formal processes that legitimated their marriage nor produce living offspring ( $\mathrm{Gu}$ and $\mathrm{Xu} 2014$ ). The practice waned, especially during the sexually conservative Qing dynasty (1644-1911 CE), which promoted the idea of chaste widowhood (Li 2009), but it never died out completely.

Given the belief that souls had social needs, someone who died unmarried could spell trouble for his/her living relatives. In the past, if a man died without issue, his family could find him a ghost bride, then adopt an heir posthumously (ideally from a relative with the same surname) to extend his patriline. Custom also dictated that senior children should marry before their juniors. A family would arrange a ghost marriage for its eldest son who died prematurely, so that his younger brothers could marry (Martin 1991; Topley 1955). In the case of a woman, she typically married out to contribute to her husband's lineage. She had no right to be enshrined as an ancestor on her natal family's altar. If she died unmarried, nobody would offer her anything to appease her neglected and dissatisfied spirit. Indeed, some Chinese believed that placing the spirit-tablet of an unmarried daughter on the ancestral altar would only provoke the wrath of the other ancestors, and invite disastrous consequences (Wolf 1974). Whether male or female, a lonely and angry ghost might return to visit its living kin with all kinds of misfortune, or it might appear in its mother's dreams to convey its desire for marriage.

A ghost marriage could also occur where only one partner was dead. In dynastic China, a girl might love her fiancé so much that she would carry on with the planned wedding even though he had died. Widowed immediately upon marriage, she would be expected to live chastely in her husband's home thereafter (Mann 1987; Yeung 2003). Although it was applauded as an act of supreme virtue and sacrifice, this move could never have been popular for obvious reasons. Alternatively, a man might 'take a ghost-wife' (娶鬼妻) to fulfil his vow to marry his fiancée who died prematurely. Given the male prerogative to beget heirs, this first marriage would not stop him from remarrying. From the above explanation, one can tell that despite its ghastly reputation, yinhun remains at its core a caring and humane practice that aims to provide soulsoothing relief to unsettled ghosts. Their living families are also relieved, because they hold the menacing spirits in abeyance by incorporating them as honoured ancestors. An otherwiseunpredictable force is hence contained and laid to rest.

\section{Affective Labour}

For ghost marriages to achieve their spiritual and social efficacies, however, the normally lifeless corpse must be treated as if it were alive and capable of affecting living beings during the entire wedding ritual. Therefore, an yinhun corpse is simultaneously dead and alive. This granting of agency to cadavers resonates with the ability of inanimate objects to elicit powerful emotional responses from us living humans that Appadurai (1986), Gell (1998), and other anthropologists have emphasised.

Specifically, yinhun channels the despair, anger, anxiety, and care that the cadaver, the restless ghost, and their living kin express to one another. This care-work to placate the anguished ghost, this outwardly directed 'affective labour' (Hardt and Negri 2004; Ngai 2005), resembles that given by housewives to revitalise their families. Since this revitalisation occurs in private domestic spaces that we often regard as external to capital, affective labour is generally devalued. However, affective labour 
replenishes the housewife's husband-worker for further capitalistic production, making it an integral part of the long chain of capitalist relations (Fortunati 1995; James and Dalla Costa 1975). Similarly, affective labour is also essential to yinhun-without it, it would not have made sense to carry out ghost marriages, and there would have been no reason to rob graves or murder people to obtain yinhun corpses for sale. The key difference lies in how yinhun's affective labour takes on a particular macabre shade because of the ritual's necromantic nature.

Contrary to the criminal associations conjured by media accounts of body snatching, ghost marriage remains by and large a custom untainted by illegal dealings. Robbing graves and murdering people to obtain yinhun corpses severely contradict both national desires to project a modern and socially enlightened image (Rofel 2007) and the general religious reverence for ancestors (Ahern 1973). However, morality in China is more particularistic and relational than its Western counterpart (Pye 1992). In his famous articulation of the 'differential mode of association' (差序格局), Fei Xiaotong (1992) views Chinese society as composed of multiple, categorically different sets of relations, each with their own specific ethical principles. Within this ethical framework, the Chinese treat allegiance to a body of law as foreign, even potentially unethical if it negatively affects one's social relations. The morality of any given act depends on whether the observer stands within or outside the actor's social network (Osburg 2013).

In light of China's subjective ethics, trafficking in yinhun cadavers can be regarded as something positive. During fieldwork, one interviewee reported on a wedding organised for her neighbour's father in 2015. The father worked as a secondary-school teacher, and he had already divorced his wife when he died at 72 years of age. The ghost bride was a 35-yearold housewife from Handan, a city also in Hebei province. She had never attended school, and had died from an illness. The neighbour had wanted to find a new wife for his deceased father for some time, so his classmate helped him via a third party for a sum of 70,000 yuan (12,000 USD). The interviewee did not know anything about the bride's family, as none of them had attended the yinhun ceremony. She said:

\begin{abstract}
The old man taught all his life, but he had a terrible relationship with his old wife. After they divorced 20 years ago, she returned occasionally before abandoning him altogether. She maintained contact with her son (the neighbour), but this son was an unfilial brat. He didn't take good care of his father before his death. I suppose this yinhun was him trying to fulfil his filial duties. He said so himself, so he spent quite a sum on it.
\end{abstract}

Here I suspect that the neighbour might very well have bought a stolen corpse bride. After all, he paid an inordinately large sum of money for her (70,000 yuan, compared with the few thousand that a bride's willing family would normally receive as bride-wealth), and her biological kin were conspicuously missing from the wedding itself. Nevertheless, he might have thought: 'So what if I really bought a stolen corpse? I don't have to know where it came from. If I can provide my deceased father with a wife, then I'm a good son in the eyes of my village. That's all that matters.' Given the role of filial piety, some Chinese may empathise with yinhun practitioners, even if they themselves would never resort to it.

\section{An Unmodern Shadow on Chinese Modernity}

As I conclude this essay, I would like to ruminate on why ghost marriages have taken a criminal turn in recent years. I cannot be certain that the Chinese never committed murder or body-snatching for yinhun purposes in the past, but there is little doubt that China's neoliberalisation has exacerbated the current 
situation. Yan (2009) already observes that decades of hyper-accelerated economic growth have led to greater individualism, and the erosion of genuine love and care. As the state decreases the social welfare benefits it doles out, the Chinese correspondingly develop a greater urgency in their quest for individual economic livelihood. This quest now includes the sale of cadavers for non-medical, marital use, which despite its criminality, ironically reasserts the social importance of affect. The recent resurgence of yinhun in the news highlights the existence of an occult economy that appears coldly modern in its moneycentredness, but is actually an instance of resistance against this inhumane modernity with its emphasis on warm human-centred care. This occult economy highlights the coexistence of pre-modern, modern, and postmodern practices in a rapidly modernising China. In this 'compression of history' (Zhou 2013, 250), yinhun reminds us that the idea of the family is still powerful in contemporary China. As long as kinship remains at the core of a certain kind of Chineseness, yinhun's spectre will likely continue to haunt Chinese modernity as its distinctively unmodern shadow. 


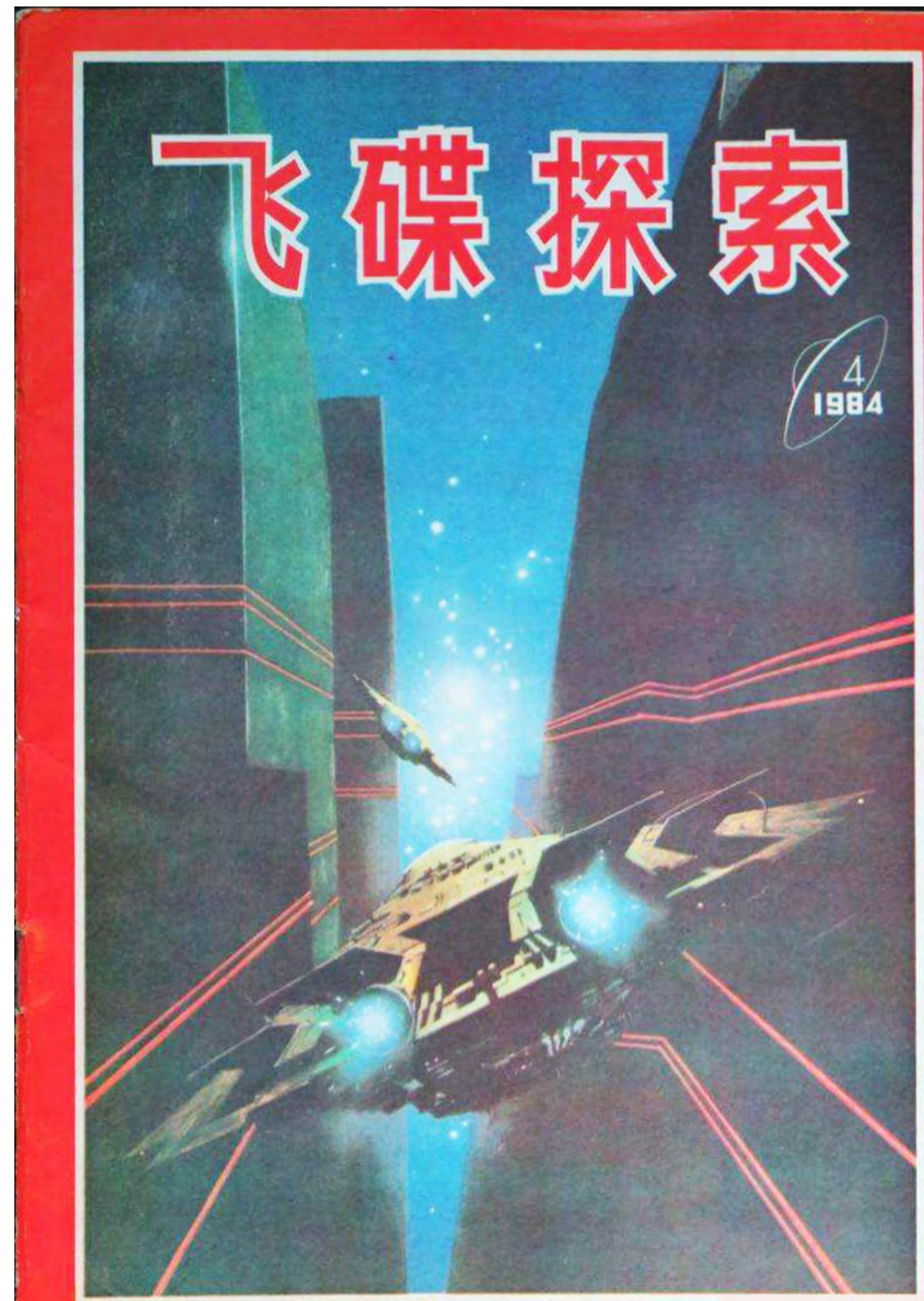

Journal of UFO Research (飞碟探索), ISSUE 4, 1984. PC: kongfz.com. 


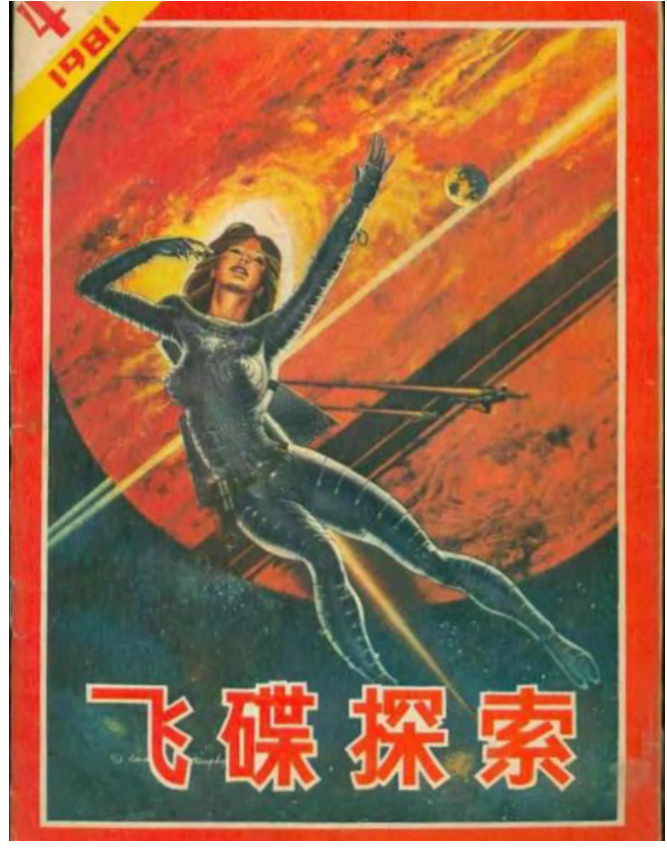

Journal of UFO Research (飞碟探索), ISSUE 4, 1981 PC: kongfz.com.

\section{On UFOlogy with Chinese Characteristics and the Fate of Chinese Socialism}

\section{Malcolm THOMPSON}

From its birth in the late 1970s, Chinese UFOlogy has passed through a series of transformations that are illuminating with respect to certain key interpretive problems around the nature and trajectories of Chinese socialism, the question of tradition and 'Chinese characteristics', and the role of science in China's modernisation. In analysing this history, this essay asks: what is the relationship between UFOlogy and socialism?
'UFO research must have Chinese

characteristics.

Liu Dongjun, 1999

"The navigation system of flying saucers is the Taiji compass.' Jiang Yongqiang, 1995

'UFOs to the people!' Ufologia radicale, 1998

W hat happened to Chinese socialism? This question was most recently asked in connection with this journal in the volume Afterlives of Chinese Communism (2019), along with a series of related questions: What legacies of the socialist tradition in China starting in the $1920 \mathrm{~s}$ still survive into the present? How have various elements of the socialist developmentalist period (1955-c. 1980) continued to shape the dynamics, trajectories, and experiences of the reform period? Where do they do this, and in what senses? How do the temporalities of the economic, political, and cultural domains interact? What do 'continuity' and 'discontinuity' mean in a historical field such as this one? Let us attempt to investigate these questions with reference to Chinese UFOlogy.

\section{The Birth of Chinese UFOlogy}

I will begin by noting a specific discontinuity whose reality is absolutely indisputable: there was no public UFOlogy in China before the reform period, and Chinese UFOlogy and the reform period began at almost exactly the same time. During the first wave of major reforms and the deepening distribution of the problems associated with the Four Modernisationsindustry, agriculture, the military, and science and technology—into the grain of everyday life, 
the China UFO Enthusiasts' Liaison Office (中国 UFO爱好者联络处) was established at Wuhan University on 20 September 1979. By May 1980, it had grown considerably and became the China UFO Research Association (中国UFO 研究会, CURA) with branch organisations in several major cities. The following February, it began publishing the Journal of UFO Research (飞碟探索), and by the mid-1980s had more than 40 branch organisations around the country and thousands of members.

In an at-this-point-unrelated development, in 1981 the All-China Qigong Science Research Association (中华气功科学研究会, QSRA) was established under the All-China Association of Chinese Medicine (中华全国中医学会). The scope and breadth of interest in this topic grew steadily in the following years until in 1986, with the blessing of national leaders like Qian Xuesen, QSRA was established as a nationallevel umbrella organisation for research and qigong practice with hundreds of member organisations. Qian was a key figure in the development of the atomic bomb in China from the mid-1950s, and the 'father' of the Chinese space programme. He was also known as 'the Tsiolkovsky of China', after the Russian rocket scientist whose work inspired not only the Soviet space programme but also numerous Soviet cultural and scientific experiments around spaceflight, biocosmism, and the imagination of a future life in space.

The QSRA immediately became the central institutional locus for paranormal research in China: extrasensory perception, telekinesis, ghosts, and so on. Certainly, as David Palmer notes in Qigong Fever (2007, 107), the 'extraordinary powers' (特异功能) that qigong practice was supposed to engender according to the QSRA were not exactly coextensive with the domain of 'the paranormal', but in seeking to develop and theorise these powers, continuous reference was made to these fields of study, and especially to scientific experiments in these areas in Western countries. Between 1986 and the early 1990s, the organisation changed its name in minor ways and fell from time to time under the supervision of different ministries.
By 1993, it operated as a 'state-level social organisation' (国家一级社团组织) under the Ministries of Health and Civil Affairs.

All of this occurred in exactly the period when the previously uncommon phrase 'with Chinese characteristics' (具有中国特色) was being driven into public discourse, after Deng Xiaoping had used the phrase 'socialism with Chinese characteristics' in his opening speech at the Twelfth National Congress of the Chinese Communist Party on 1 September 1982. It quickly became a central element in the discursive rearrangements that occurred through the 1980s around the problems associated with dismantling many of the social and economic modes of organisation that had characterised the socialist developmentalist period, opening social life to new forms of knowledge and culture from the 'advanced' capitalist countries, developing an 'advanced' culture and economy, and so on. There is little doubt that this had a great deal to do with the end of official Chinese socialist internationalism and the redirecting of attention and desire toward the capitalist world, but the problem of 'Chinese characteristics' also became an important site in which struggles over the legacy and worth of Chinese socialism could take place. The fact that the content of this term often seems unclear was not a function of any deliberate murkiness or basic obscurity, but rather of the fact that it quickly became a central stake in entirely specific and practical struggles. As we will see, this is true in Chinese UFOlogy as well.

\section{Qigong UFOlogy}

By the early 1990s, then-the period immediately following the crushing of the 1989 social movement and the subsequent dismantling of the institutional and discursive resources that pertained to certain forms of protest against the process of reformthe broad project of combining Chinese traditions like qigong with 'high-level science 
and technology' (高阶科技) in the interest of economic development was well-established. It intersected with, and developed alongside, the popular mass movement known at the time as 'Qigong Fever' (气功热), in which, among other things, charismatic Daoist masters would distribute their healing $q i$ to their followers via electronically mediated speech at rallies of thousands or even tens of thousands of people, many of whom fell into collective trances or were healed of injuries or ailments. Traditional Chinese medicine (acupuncture, moxibustion, etc.) had occupied a fairly stable and prestigious place in the apparatus of socialist public health since the 1950 s, but recuperating the religious discourse it had developed with historically, and bringing it into relation with the fourth modernisation, as the QSRA did, created all kinds of new possibilities under the general problem of 'the organic combination of Eastern qigong culture with Western modern science' (东方气功文化与西方现代科学的有机 结合) (Jiang 1995b, 31).

Take, for instance, the book A Summoning to the Idea of the Source of Life (生命源头 的意念呼唤), commonly known as Eastern UFOlogy (东方飞碟学), published by the director of the Guangdong School of Flying Saucer Technology (广东飞碟技术学校) Lin Qingquan in 1993 and favourably reviewed in the magazine China Qigong (中国气功) in 1995. Here, the fundamental principle (基础理论) of Eastern UFOlogy is, precisely, the combination of 'Eastern Yijing principles' (东方易理) with 'Western mathematical formalisation' (西方数 理) (on the Yijing, see also Matthews's essay in the present issue). With the theoretical application (理论应用) of these to the problem of flying saucers and aliens, Lin attains the following:

1. The principle of flight of flying saucers is yin (隐, 'secret', 'hidden') flight. This is similar to the connotation of people with extraordinary powers (特异功能, again). The particular characteristic of yin flight is that the speed of light is controlled by thought, causing the moving body to alternate between empty (虚) and full (实) forms, between the manifest (显) and the hidden (隐).

2. The power source of flying saucers is spiritual thought. Flying saucers rely on controlling the release of the power of thought to set off the internally-produced spin acceleration of their flight system, so that the negative information flow that their thought sends out fires the spin velocity of its particle device, causing it to accelerate its spinning, and in a very short time to surpass the speed of light, so that, by becoming negative, it enters the realm of four dimensional space.

3. The navigation system of flying saucers is the Taiji compass (太极罗盘). In the boundlessness of space, where is the destination? How is navigation accomplished? One must use the Taiji compass to go out to interstellar space distances and time intervals, to pass through the conversion of time and space into four-dimensional pure negativity, which is the time-tunnel between the starting point and the destination.

4. Aliens, like the qigong masters of Earth, can directly absorb the yin capacities of the universe and are thus able to avoid the necessity of eating and dressing; they can reside anywhere, refusing grains year in and year out to attain immortality, without suffering from freezing or being susceptible to cold diseases. The aliens live in all sorts of simple saucer-shaped flying machines, roaming about freely, floating endlessly in time and space. (Jiang 1995b, 31)

Setting the particular content aside for the moment, the condensation of previously-and perhaps 'properly'-separate vocabularies and concepts into a single text that we find here would not, in and of itself, have seemed very 
strange within the terms of qigong discourse in the 1990s. But that is not to say that it was satisfactory to everybody.

The China UFO Research Association had been affiliated with the QSRA since January 1988 as a 'second-level study society' (二级 学会), and by this route had acquired legal standing as an organisation. But this led to all kinds of 'internal contradictions' (内部矛 盾) between the 'materialist' UFOlogists and the qigong tendency (Jiang 1995a, 213-215). This came to a head at CURA's fourth national congress in Beijing in May 1992, at which many members became frustrated by the infiltration of 'pseudoscience' (伪科学), leading the organisation to reiterate its commitment to 'the dialectical-materialist guiding principle' (辩证唯物主义指导原则) (Xinhua 1992).

\section{Dispersal and Reconstitution}

The most famous element of the popular qigong-UFOlogy matrix described here is, of course, the Falun Gong, which entered the QSRA with its leader Li Hongzhi in July 1993. It is unclear what role this event had in further dividing UFOlogy into what can only be described as a two-line struggle, but it would certainly lead to major problems for the movement. Li's own beliefs about aliens and UFOs are relatively well-known, but the question here is how the Falun Gong's involvement in the broader qigong movement affected the UFOlogists.

In the post-1989 context, close watch was kept on developments within the organisations that broadly constituted 'civil society' in China, with Party members often joining groups or creating Party branches within them. Being thus regularly apprised of what they considered the increasingly strange developments within the qigong movement-and particularly in the Falun Gong-and as Qian Xuesen's political influence over science in China began to wane, sections of the Party began a media campaign against pseudoscience in 1995, which continued and intensified over the following years. The Falun Gong withdrew from-or was thrown out of, accounts differ-the QSRA in March 1996, but this in no way saved the latter and the broader movement from continuing to experience internal struggles and problems with the state.

In September 1997, as a result of what contemporary UFOlogists call its 'implication in extraordinary political events in China', CURA lost its status as a second-level study society under the QSRA and was 'compelled to disband', after which branch organisations survived independently and more or less underground, 'wandering about like lost children with no home, totally unsure of what to do' (ICUA 2019). The Dalian branch took the initiative in reconstituting an umbrella organisation, and in September 1998 a conference was held there with delegates from all over the country. Out of the discussions that took place there emerged plans for a new organisation, which was established in April 1999 as the International Chinese UFO Association (世界华人UFO联合 会, ICUA), registered in Hong Kong. This is the largest organisation of Chinese UFOlogy today, though it is certainly not the only one.

\section{Maoist UFOlogy?}

This is the situation in which we discover a very different kind of recuperation of Chinese traditions for the accomplishment of national goals, for instance in the article 'UFO Research Must Have Chinese Characteristics' (UFO 研 究必须具有中国特色) by Liu Dongjun, which appeared in the October 1999 issue of the popular science monthly Scientific Chinese (科学中国人). The principles of UFO research here have nothing whatsoever to do with qigong modes of explanation, and its methods resemble nothing so much as a socialist developmentalist-era mass campaign: 
1. We must adhere to the materialist point of view, use the scientific method and strategy of seeking truth from facts, discard the false and retain the true, and seriously explore causes and laws of transformation. In the boundless universe, nothing is so bizarre that it cannot exist. But no matter how magical it is, as long as it is an objectively existing substance, there will necessarily be laws of transformation for its emergence, development, and decline. Only by using the materialist standpoint and method can we reach conclusions that accord with objective reality and the nature of science. We must put an end to the idealist conception of history, and refrain from unrealistic fantasies or deliberate mystification.

2. We must achieve the unity of experts and the masses, set up observation points widely, establish an observational and information network, and lay out a tight nationwide network concentrated on observation and capture. Whether a UFO phenomenon is an atmospheric or photoelectric phenomenon or an emissary from the stars or anything else, if we wish to reveal its true face, we must adopt the method of the unity of experts and the masses. Every province, every city, every region, even every county, and especially remote and fortification areas-all of these require the setting up of observation points and the presence of observation personnel.

3. We must have the spirit of perseverance, devotion, and life-long struggle. Tackling key problems for science and being devoted to humanity-this is the spirit of the age, the sacred duty of the descendants of Yan and Huang, a lofty and glorious enterprise. Every comrade who is earnest about UFO exploration and research should possess this spirit of tenacious struggle and dedication. This way, we will walk at the forefront of the world's nations in UFO exploration and research and achieve amazing results that will attract the attention of the world. (Liu 1999, 78)

In this obviously aspirational text-it would be inane to point to this aspect of it as a shortcoming-the legacies of Chinese socialism have a great deal to offer not only to UFOlogy but also to science as a global enterprise and, further, to the preparation of the ground for imagining a future in which the coordinates of human endeavour are cosmic rather than merely terrestrial. Here, the elements of 'Maoist' forms of epistemology, practice, and personal commitment are conjoined to a form of science that is, at least in principle, open to any possible future.

\section{The End}

Unfortunately, perhaps, this document carries no sign of having been at all influential. The form of UFOlogical discourse that has been dominant in China since the formation of the ICUA-which one can follow in the pages of The Journal of UFO Research or in the conference reports that appear on the association's website, or in its newsletter, UFOlogy (飞碟报)一is exclusively concerned with cataloguing encounters, breathlessly excavating possible references to UFOs and aliens in 'ancient times' in China and elsewhere, compiling reports from global UFOlogy, and ruminating harmlessly on the possible nature of an 'interstellar civilisation' (星际文 明). A bleak seriality of endless, untheorised repetition, as the Italian collective Men in Red put it in its magazine Ufologia radicale in 1998 (7-8), devoted to no programme beyond establishing the reality of the phenomenon, and no longer really committed to even that beyond the community of people who already accept it. Chinese UFOlogists in the 1990s, like many other fields of social activity, attempted to establish a UFOlogy with Chinese 


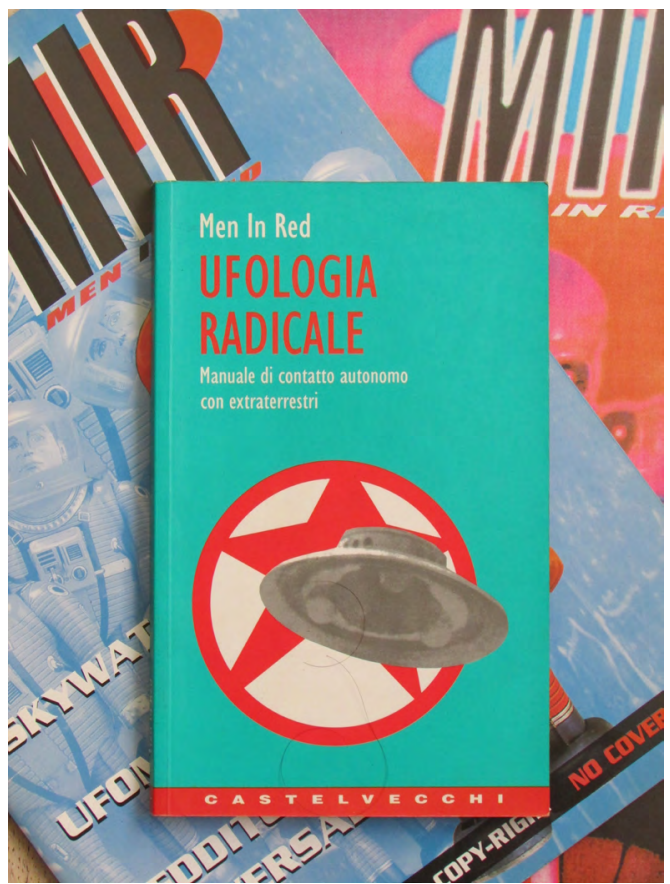

Ufologia Radicale, by the Italian Collective Men in Red.

characteristics in very different ways. But with the stamping out of radical qigong thought and the disappearance of mass mobilisation in the field of science, Chinese UFOlogy, insofar as it officially exists, ceased to differ from the UFOlogy of the History Channel or the glossy UFO magazines in any discernible way. But another UFOlogy was possible.

Where manifestations of alien contact do appear that may involve something more than this, the agents (official and unofficial) of the China Anti-cult Association (中国反邪 教协会), created in October 1999 precisely in the suppression of the Falun Gong, are ever vigilant and waiting to expose them. This happened, for instance, last year when Liu Boyang, a PhD student in astrophysics at the National Astronomical Observatory under the Chinese Academy of Sciences, launched a public campaign to denounce online cult tendencies around aliens (Chen 2019a), which prompted Chen Xingqiao of the China Buddhist Association to write the lengthy 'Study of the Cult Teachings of “Alien Systems”' (“外星”系邪 说研究) on behalf of the Anti-cult Association, currently posted on the website of the People's Government of Jinghe county, Xinjiang (Chen $2019 b$ ). With so much of the state apparatus today committed to policing and preventing the emergence of new things and actually existing UFOlogy in China in such a moribund condition, we are far away now from the possibilities that existed in the 1990s for either a Chinese UFOlogy or a socialist UFOlogy. 


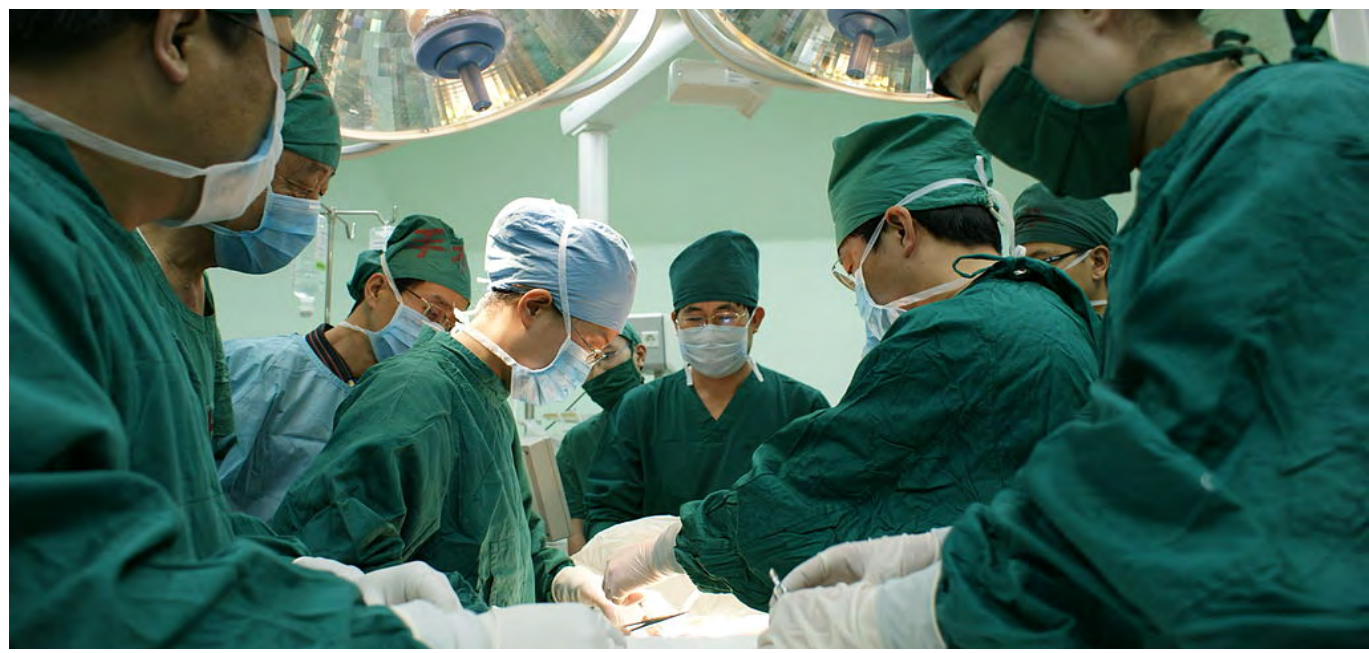

\section{Shared Visions: The Gift of The Eye}

Organ transplant. PC: CMSRC.

Sylvia J. MARTIN

Organ transplantation as discussed in the occult economies literature is associated with illicit activities and uncanny circumstances, and is fuelled by socioeconomic disparity. Discussing corneal transplantation as depicted in the Hong Kong-Thai film The Eye, this essay reflects on the symbolic and affective aspects of gifting the organ that helps us to mediate the world and which is associated with personal identity. It argues that through the genre of horror, cultural meanings of corneal transplantation are heightened that include the notion of tethering individuals through premonitory visions. In its portrayal of corneal donation and reciprocity, The Eye offers a warning about predictive knowledge.
W alking around Hong Kong during the seventh month of the lunar calendar, in the weeks leading up to the annual Hungry Ghost Festival, or Yue Laan Jit (孟兰节), it is not unusual to come upon local residents casually engaging with the supernatural. With little fanfare, and as pedestrians rush past, individuals burn incense, paper money (referred to as 'hell money', 陰司 紙), candles, and other items in a tin bucket on the sidewalk or edge of the street, often with prepared foods and fruits, in a TaoistBuddhist ritual of appeasing lingering spirits after the Gates of Hell open. Operas are staged in various neighbourhoods not just for living audiences, but for spectral ones as well in an effort to pacify and entertain the ghosts who wander the city. According to popular Chinese religion, 'hungry ghosts' (餓鬼) are unsettled spirits of people who met unfortunate deaths, and the festival is devoted to feeding and placating these roaming ghosts (Constable 1994, 111; Guang 2011). Burning incense and 
paper money for Yue Laan Jit does not preclude a person's affiliation with, or participation in, other religions. A designated time once a year in which the worlds of the living and unliving are set to collide is not unlike Western Europe's All Hallows' Eve, or its predecessor Samhain (Santino 1983, 5).

Yet, making preparations for expected visitors from the supernatural world at ritualised times is one thing; being confronted with unsolicited shadows and spirits from that world in daily life is another. While conducting research on the production processes of the Hong Kong film industry, I found that throughout the year actors claimed to occasionally see ghosts, or were rumoured to be possessed by them while they were working. These supernatural encounters were more common if they were filming late at night in remote areas, and even more so when filming ghost movies or films with violent scenes (Martin 2017). Ghosts were understood to be mischievous and attracted to performance activity and enactments of danger, especially by actors and stunt workers who hailed from Cantonese opera troupe traditions. Production management would often offer lai see (利是, or 'red packets') as a token of appreciation to performers for engaging in dangerous activity. Starting the day's filming by burning incense to appease any lingering ghosts and consulting with astrologists for an auspicious filming schedule were other practices that linked the occult and the film industry.

But, taking it one step further, what if seeing ghosts in the ordinary landscape of the city while going about one's business during the daytime was a common occurrence, for instance when standing at a traffic light on a busy street, or while eating at a noodle shop? Or what if one saw images that foretold imminent death? The 2002 Hong Kong-Thai film The Eye (Gin Gwai) explores those very experiences through its telling of a story about corneal transplantation. I argue that through the genre of horror, cultural meanings of vision are highlighted and heightened that go beyond the political economic analysis of extraction

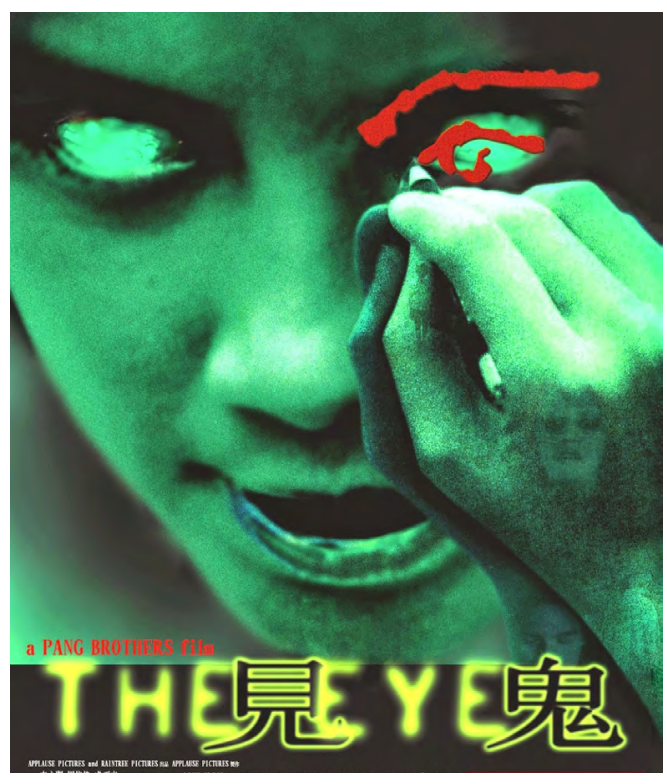

The Eye (Gin Gwai), 2002.

and exchange. In my discussion of corneal transplantation in The Eye, I account for the symbolic and affective aspects of acquiring such an evocative body part.

In the film, a young Hong Kong woman, Mun, who has been blind for most of her life, receives a double cornea transplant. Soon after her operation, she is confronted with disturbing visions: ghosts, and dark, shadowy figures that surround people who will die shortly after. Mun's family becomes concerned over her behaviour as she becomes agitated and withdrawn, and as they see her talk to herself, they start to suspect that Mun is possessed. It becomes increasingly apparent that what Mun referred to in the opening scene as 'fresh eyes' are no ordinary corneas, thus raising doubts about their origins. At the encouragement of a Daoist priest, and accompanied by her psychotherapist, Mun travels to Thailand to seek out more information about the source of the corneas.

The ability to see ghosts or signs of impending doom is not celebrated or commodified in The Eye; rather, through 
the plot device of transplantation, the film depicts the burden of foresight, the lonely responsibility of premonition. In a time when predictive technologies are increasingly valued despite their biases-not just in the health sector, but also in politics, policing, finance, job performance, and educational achievementand individuals revise and refine their actions accordingly, The Eye resists the endeavour of all-seeing, all-knowing capability.

\section{The Occult Economies of Transplantation}

With globalisation having primed the conditions for the dis- and re-embedding of organs from the Global South to the Global North, from East to West, a prominent issue in the social science literature on organ transplantation is trafficking (see Cohen 2003; Comaroff and Comaroff 1999, 2000; ScheperHughes 2000, 2007, 2009). In their exploration of occult economies, Jean and John Comaroff (1999, 280-81) offer the case from South Africa of a man arrested for attempting to sell a pair of eyes in a shopping mall as an example of a neoliberal environment in which 'scams and stratagems ... flow from a promiscuous mix of scarcity and deregulation'. 'This traffic,' Scheper-Hughes $(2009,8)$ explains, 'is fueled by a neo-liberal economy that values humans as commodities and the "self" as a market mechanism-suppliers, brokers, buyers, sellers, and processors-of re-usable body parts, pushing human agency and hyperindividualism to their extreme limits.' ScheperHughes (2000) focussed on the circulation of kidneys, which are considered more desirable if sourced from living donors/sellers, in many cases extracted under dubious terms from vulnerable, debt-ridden people whose consent is underinformed and whose access to healthcare is limited. The plundering of such 'medical material' is especially prevalent in India, South America, and South Africa (Scheper-Hughes 2009, 13). Correspondingly, the film plays up the fear of circulating corneas as a possibly ill-gotten gain, mirroring what Comaroff and Comaroff $(2000,317)$ describe of occult economies as 'the use of the bodies of some for the empowerment of others'.

In fact, organ trafficking has thrived in the face of widespread socioeconomic upheaval and insecurity stemming from privatisation, with even national governments implicated in such schemes (Comaroff and Comaroff 1999, 291). Occult economies are premised upon an uneasy convergence of 'magical technologies and mysterious modes of accumulation' (Comaroff and Comaroff 1999, 284), and the Comaroffs $(2000,316)$ point to ScheperHughes's research on organ trafficking in Latin America and elsewhere as part of a broader phenomenon in which the commodification of body parts relies upon 'forms of power/ knowledge that transgress the conventional, the rational, the moral'. Illicit and occult activities thus intersect amid growing socioeconomic inequality. Scheper-Hughes's (2007) work on organ transplantation also contributes to a valuable literature on the ethical and social dimensions of defying disease and death through the circulation of kidneys not just across the globe but also within families, revealing cases of kidneys given under the 'tyranny' of pressured family relationships-particularly 'sacrificial' female kin-and, likewise, the weight of receiving such an outsized gift.

Yet, corneal transplantation brings its own, mediating complications, as corneas help enable vision, and vision is one of the five senses used to perceive the world(s) around us; studies and social commentary attest to crosscultural ideas that sight is for many the primary and privileged sense (Enoch et al. 2019; Aldama 2017). While the kidneys that Scheper-Hughes focuses upon provide what donor organisations refer to as the 'gift of life', imperative as they are for the maintenance of bodily health they nevertheless serve internal needs; corneas, however, are external features that help sustain sight (and in the case of the film, also 'the gift of second sight', or clairvoyance), and literally 


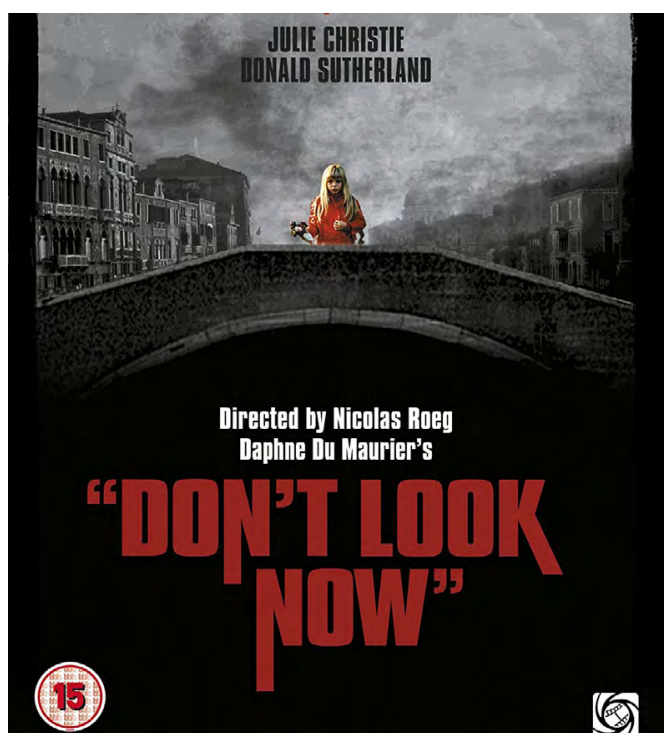

shape one's outlook on the world(s)-occult and ordinary. Eyes are also associated with personal identity, as a study on donor relatives illustrates (Sque and Payne 1996), as well as with identification and surveillance, which makes corneal transference from one person to another more provocative than with most internal organs. Corneal transplants also imply notions of 'shared vision'. The film plays upon the uncanniness of receiving someone else's eyes-of tethering individuals through frightful visions. Finally, I suggest that in its depiction of cornea donation and an act of reciprocity, we can take from The Eye a warning about predictive knowledge.

\section{'The Thing Given Is Not Inactive'}

Supernatural films such as the UK/Italy movie Don't Look Now (1973) and Hong Kong's My Left Eye Sees Ghosts (2002) have utilised the association of eyes with second sight, with visions of the occult; The Eye spawned

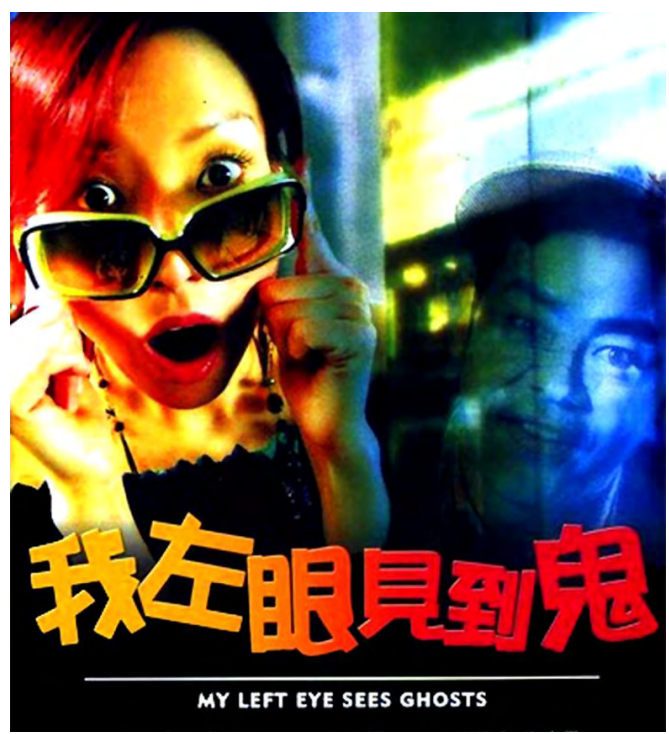

Don't Look Now (1973) and My Left Eye Sees Ghosts (2002).

numerous sequels and a Hollywood remake. The beginning of The Eye seems far from the world of underground organ transplants, and we learn that Mun has led a seemingly full life prior to her transplant-she moves about the city with apparent ease, she enjoys performing violin with an orchestra for the blind, and she lives with her sister and her grandmother, with whom she seems close. After her transplant in a calm, sterile Hong Kong hospital environment (the source of her corneas not yet revealed), Mun is assigned a psychotherapist, Doctor Wah, to help her adjust to seeing and acquire what he refers to as a 'visual vocabulary'she must learn to identify objects on sight, as opposed to touching them first. Yet Mun's postoperative world shifts in other, uneasy ways: she starts to sense that the paranormal and premonitions she sees are not seen by others, while at the same time, she is dismissed from her reassuringly familiar orchestra community because she is no longer blind-a loss that she had not anticipated.

According to a study on adolescent corneal transplantation, recipients can experience depression, anxiety, despair, and fear as well as 
feelings of guilt towards the organ donor, and it is likely that adults share some of these same reactions (Tong et al. 2009). Authors of a study on the impact of corneal transplantation on adults in Iran note of recipients, 'the fact that they have part of another person's body, does not escape them, leading to complex moral and psychological problems for the patients. The multiplicity of potential factors affecting the individual psyche is that such an experience can be beyond individual tolerance' (Amiri et al. 2017, 4056). There may be, after all, a quality of unnaturalness (or, supernaturalness) in lifting 'medical material' from a corpse and transferring it into a live being, activating it into use, which the film exploits. In Magical Interpretations, Material Realities, Henrietta L. Moore and Todd Sanders (2002, 1-2) note that science and the occult have long been entwined, such as the popularity of nineteenthcentury spiritualism alongside the advances of Victorian science, and contemporary social scientific literature notes the ontological complexity of what it means to look out at the world with eyes other than one's own. In a British psychological study on donor relatives, some family members interviewed said that they could not go through with the deceased's wish to donate their eyes, the reasons including that the deceased 'would need them in an afterlife'. Indeed, the authors further note that '[a]ttached to the precise feelings about the eyes are contemporary images in horror films of empty eye sockets' (Sque and Payne 1996, 1364).

While she focussed on kidneys, not corneas, Scheper-Hughes draws from the work of French sociologist and anthropologist Marcel Mauss to invoke the spiritual aspect of organ donation. She employs Mauss's notion of gift exchange to underscore the 'tyranny' of receiving such an indebting gift from a family member, and also the pressure on family members (especially females) to sacrifice an important organ for the benefit of another person (see also Fox and Swazey 1978). More importantly in the case of The Eye, Scheper-Hughes adapts Mauss's $(1990,11)$ emphasis on the Maori concept of hau ('spiritual power') to describe the spiritual dimension of gift exchange. The gift, Mauss explains, impels its recipient to reciprocate. In Maori law, Mauss (1990, 12 with italics added) identifies that obligation as stemming from

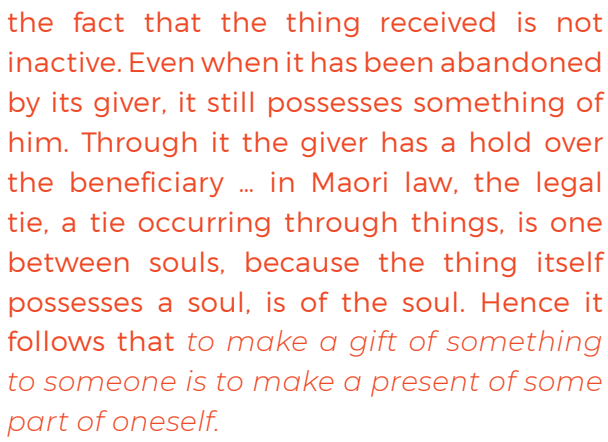

In Mauss's application of Maori law, Mun's corneas therefore contain some essence of her donor, who was a young woman named Ling who committed suicide. Mun realises that when she looks in the mirror she in fact sees a different woman than who others see-Ling, it turns out. Mun and Ling are inextricably linked, and Mun comes to realise through the advice of a Daoist priest that in order to free herself from these disturbing visions of ghosts and warnings of death, she must not only thank Ling, but reciprocate in some way.

\section{Shared Vision}

In leading up to the act of reciprocity, Mun begs Doctor Wah to help her address the frightening visions, and starts to keep her bedroom lights off and immerse herself in darkness. Her grandmother and sister seek assistance of a more spiritual nature, first burning money outside their building at night, and later inviting the Daoist priest to perform an exorcism in Mun's bedroom. Earlier in the film, the priest conferred with Mun's neighbours, whose son had committed suicide, his ghost repeatedly appearing to Mun after her transplant. After Mun's therapist convinces 
her eye surgeon to divulge information about Mun's donor, he and Mun travel to Thailand, where the donor, Ling, lived.

Thailand provides cheap resources and labour for Hong Kong (see also Knee 2009). Besides the country's beaches offering a budget vacation destination, Thai women contribute a steady supply of labour for Hong Kong's foreign domestic worker scheme in unstable and sometimes abusive conditions that help animate Hong Kong's prosperity. Mun and Doctor Wah find out that Ling was a Thai-born Chinese who even as a child was harassed and shunned by the local villagers for her ability to foresee death. 'From time to time, she would weep outside someone's door. Afterwards, a person in that house would pass away, a childhood acquaintance tells them. Eventually, as a young woman, Ling foresaw a fire that would kill 300 people. Flashback footage shows Ling's distress in trying to frantically warn villagers of her vision. They scorn her, and in the aftermath of the disaster, Ling, who apparently is tormented by her foreknowledge and her inability to change the future, hangs herself.

The movie does not clarify if it had been Ling's wish to donate her corneas, or if her surviving mother decided for her. Nevertheless, voiceover from the Daoist priest iterates Mun's obligation to Ling: 'We believe that the very last consciousness of a person just before they die becomes the consciousness of the ghost ... The woman whom Ms. Wong [Mun] keeps seeing after resuming her sight, we have to resolve her problems so that she can move on.' Mun meets Ling's mother, who is embittered over Ling's suicide, resentful that her daughter 'gave up' on herself. Mun asks to spend the night in Ling's bedroom after their long journey, and in Ling's bed, Mun says aloud: 'I know you've wanted me to come here all this time. Well, here I am now. What do you want to tell me?'

At 3am, Mun hears Ling calling her mother for help, and realises that the dead girl wants that she bring her mother to her. Mun then begs Ling's mother to come up to Ling's room where she hanged herself, telling the mother:
'Since she killed herself, she's been trapped in a time warp ... constantly repeating her suicide.' The mother refuses to cooperate, insisting that she cannot forgive Ling for giving up on herself. Mun runs back to Ling's room, and finally the mother, hearing Ling's voice calling for her help, runs to Ling's room. There, Ling appears alive, lying on the floor, cut down from the sheet with which she hanged herself. Sobbing, Ling apologises to her mother, who in turn lovingly offers her the forgiveness that her daughter desperately sought. They clasp hands, and Ling's face, finally at peace, morphs into Mun's. It is now Mun lying on the floor, Ling nowhere in sight. Mun did what the priest suggested: resolve Ling's problem so that she could move on. Mun merged her entire body with Ling's, sharing the same form, to stage this final farewell with the mother. She thus, symbolically at least, reciprocated Ling's gift.

The film seemingly concludes with this act of reciprocity. Yet while stuck in traffic on her way to the airport, Mun discovers to her horror that shadows swarm the street around her, and she realises death must be impending. Panicked, she runs through traffic to try to warn everyone around her to run, but no one believes her. Intercut with this footage are flashback images of Ling running through her village begging everyone to leave because she foresaw a deadly disaster, highlighting their twin experiences of foresight to no avail. In Mun's time, a mass explosion occurs, killing dozens of the people she tried to warn. She is saved by Doctor Wah, but not before shards of glass fly into her corneas, blinding her.

The film finally ends with Mun looking calm amid the busy ferry pier of Hong Kong, meeting Doctor Wah, who now is her love interest, with her serene voiceover that Ling has left her. She states that she holds no resentment towards Ling: 'Since I saw and experienced the same pain that she did.' Evidently, even after Mun and Ling's exchange, those corneas remained enchanted. Mun, in a less drastic manner than Ling, was relieved of the burden of premonitions and predictions, and the tormented aftermath of helplessness. The two 
women shared not only ocular tissue, but also a vision of haunted beings and forewarnings of death. Foresight in particular can be isolating and as Ling's story showed, alienating. Yet, in Mun's act of reciprocity, she essentially embodied Ling, fusing them even more fully, a conscious act of recipient/donor solidarity.

\section{Eyeing Empathy}

Receiving a cornea transplant differs from transplantation of unseen internal organs especially given the various meanings and functions associated with the eye. Eyes signify a person's identity and authenticity; they also ostensibly enable vision, and vision is what conveys so much of the world to us. The eyes thus bring the world in to the observer and at the same time, communicate something outwards of the observer. A kidney, while so imperative to our body's functioning, does not mediate between us and the world(s). The Eye offers an East and Southeast Asian imaginary of transplantation and gifting-appropriately enough, its writers include a set of Hong KongThai twin brothers-that may be dismissed as technophobic, although it is also a positive portrayal of someone living with a sensory impairment (e.g. a loving family, a social life, a budding romance). But the film illustrates the empathy that an organ recipient can feel for their donor; in this case, quite literally seeing the world through their eyes, binding them together.

While strands of popular culture urge people to identify and nurture their individual 'superpower', Mun's reluctance to be 'an extraordinary person', as she terms it, is refreshing. 'I don't want to be terrified every night,' she told her therapist. Refusing visions of the future, which suggests a critique of predictive knowledge, may actually leave room for new potentialities. As Faye Ginsburg and Rayna Rapp (2020, S7) note in their work on disability: "Beyond "victimology" lies disability's world-making creativity.' 


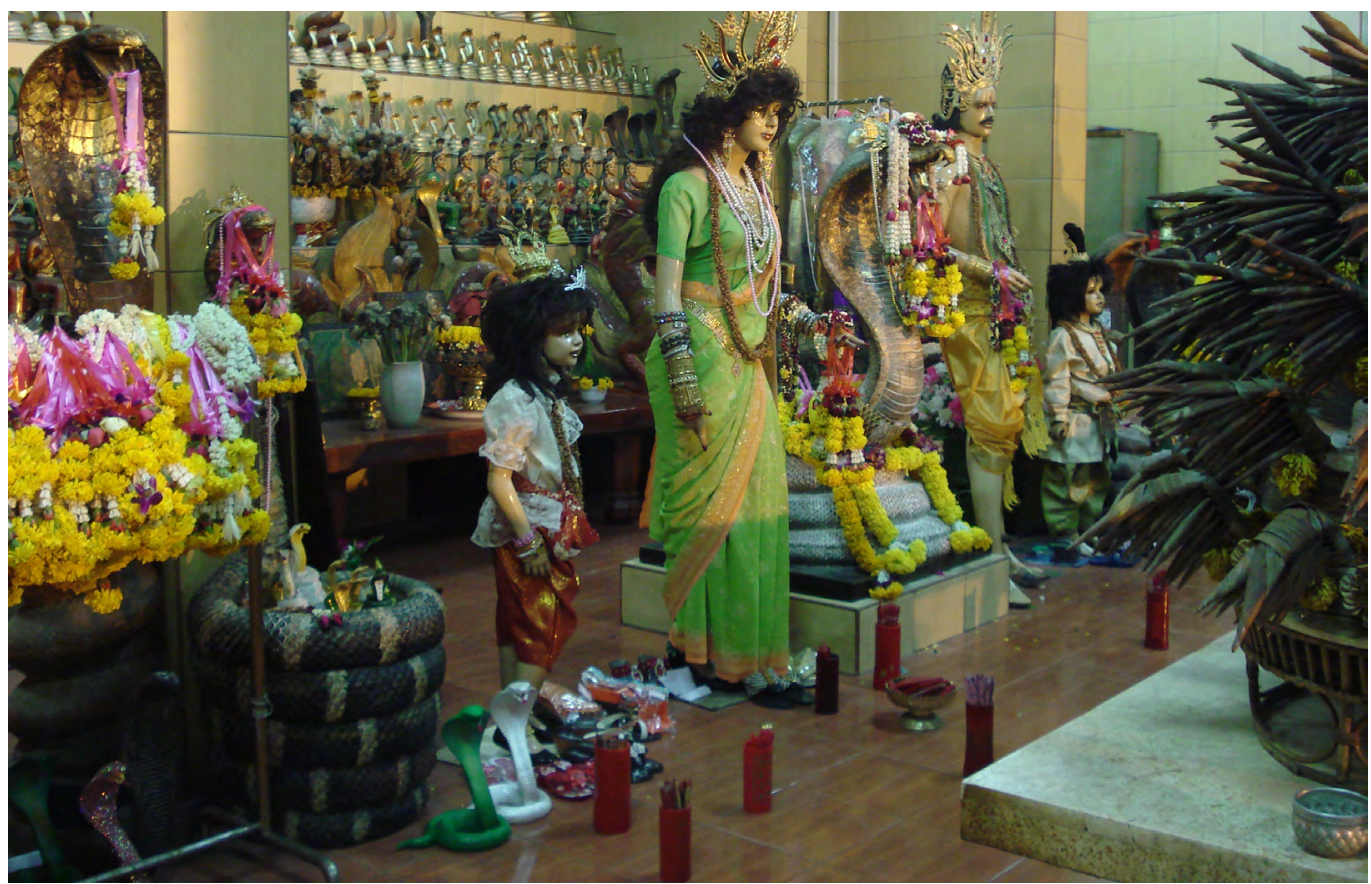

\section{Accidents and Agency}

\author{
Death and Occult Economies \\ in Thailand
}

Andrew Alan JOHNSON

With new economic regimes, new infrastructure, and increased 'development' also come new religious movements. Whereas earlier scholars assumed that modernity would disenchant, this has, time and again, proven not to be the case. But why? While one popular explanation-the 'occult economy'-attributes this increasing (decentred) religiosity to the vicissitudes of new economic regimes, this essay interprets it as an acknowledgement of a shared world in flux, with humans and nonhumans alike struggling to come to terms with what existing in a changed present might mean.
Fig. 1: Lady Mother King Cobra Shrine. PC: A.A. Johnson.
$\mathrm{T}$ here are ghosts on the roadside in Bangkok, but not always those of people. A shrine to the spirits of a dead tree marks a place where a 'Lady Mother' (jao mae) threatens drivers with deadly accidents, but also promises winning lottery numbers (Figure 1). A water dragon (naga) dies entombed in a riverbank but reemerges to give job leads to potential migrants (Figure 2). Spectres are haunting Thailand, spectres that speak to issues of causality and accident, human and other-than-human networks, and, above all, the question of agency. For some anthropologists, the occult becomes a frame through which 


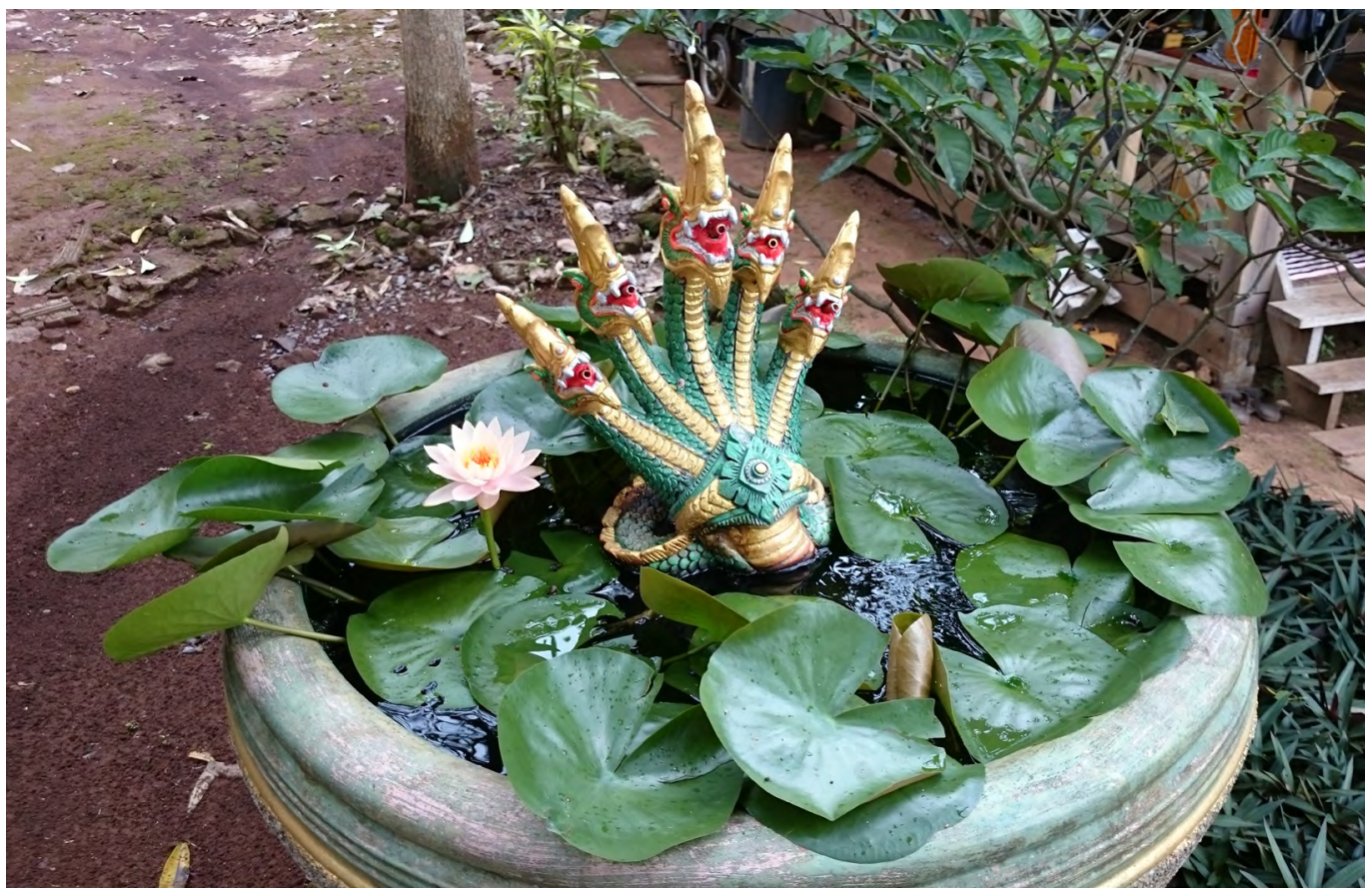

Fig. 2: Naga decoration at Ban Buek. PC: A.A. Johnson.

one can look at the hidden, malevolent, and profitable aspects of increasingly precarious economic conditions-an 'occult economy'.

In this essay, I critique this concept via three vignettes taken from my fieldwork, moments of change in the (after)lives of migrant workers as well as the spirits with which they interact. Whereas other anthropologists have presented these worlds as either nightmares given birth by new capitalist conditions or functionalist means of 'dealing with' such disruptions, instead, I explore these old/new spirits of capitalism by looking at spirits as another entity in a social network that includes human, nonhuman, and what might be termed 'inhuman' (Johnson 2020) worlds, and how these spirits help to resolve the excess of agency that chaotic times bring about. I do so via the stories of three interlocutors: Gamrai, Lek, and Mon.

\section{Gamrai}

A street vendor, Gamrai, pushes her cart on the margin of a deadly highway in western Bangkok (see Johnson 2016). Here, a flyover funnels cars down to Rama II Road, making a chaotic traffic pattern with a bad reputation for deadly high-speed accidents. Indeed, it was the inordinate amount of traffic deaths that caused people living nearby to try to find a cause-the local neighbourhood hired a medium who, in a trance, related the story of a mother cobra killed during the road's construction and whose ghost was now furious at the passing cars. The neighbourhood in turn put a shrine up to this spirit, the Lady Mother King Cobra (jao mae joong ang).

And here, just where the highway is worst, just by the shrine, is where Gamrai is struck by a passing truck. She awakens in the hospital 
and is visited by an apparition: a woman in a dazzling traditional Thai outfit, who smiles at her. At the woman's feet are her children-at least, they are children sometimes. Sometimes, the family are cobras.

Gamrai recognises the woman as the Lady Mother. 'I knew it was her who did this to me,' Gamrai tells me, but then adds: 'She is so kind.' In the following nights, Gamrai becomes the cobra ghost's 'daughter', bringing it nightly offerings and asking in return for success in her business. The violence of the crash has opened a channel where such a connection between spirit and human becomes possible.

\section{Lek}

In the yard of a large house on the eastern outskirts of Bangkok, a banana tree produces a flower shaped like a human head. Migrant workers, most of them Lao speakers from Thailand's northeast, come to the yard to ask the flower for lottery numbers, whereupon the owner of the house chops the tree down and flings it into a vacant lot. The lot, in turn acquires a host of ghosts: the tree spirit adopts an abandoned 'Burmese' aborted foetus (kumanthong), and the spirits of the pradu trees flanking the lot join the community. The crowds, too, grow.

Lek is a factory worker who has moved to Bangkok from the provincial capital of Roi Et. One night, his girlfriend dreams of a woman in green. The next day, as he is driving past the banana tree shrine, Lek crashes his motorcycle and is severely injured. The following night, his partner comes to understand that the crash was the result of the tree spirit's love for Lekwere he to die, his ghost might inhabit the shrine and he would become the spirit's lover. Lek and his partner then go there to offer their apologies-Lek cannot be the banana tree's lover, but he is flattered. Thus, he seeks to change his relationship with the spirit from one of a potential romantic partner-and therefore in danger of being murdered-to, like Gamrai, a mother and child. In so doing, Lek can count on gifts of luck and fortune from the spirit, instead of possessive romantic love.

\section{Mon}

The riverbank behind a fisherman's compound-in fact, just outside of where I am living-collapses. Here is a site where a naga has been seen in the past, a sometimes benevolent but potentially violent being that could be asked to provide fish for nets. But as the riverbank crumbles under the weight of new concrete bulwarks built to counter recent dramatic floods which came as a result of Chinese dam projects far upstream, Mon, the fisherman, suspects that the serpent has been crushed in its underground lair. In the wake of the naga's physical destruction, a new, ghostly naga emerges, no longer promising fish but instead offering lottery numbers and cash. Here, too, it is very much like the previous ghosts-a physical being destroyed by the expansion of the city into its land, then reemerging as a patron of a different sort. Mon-and I-leave offerings out on the sand to the serpent, asking it for luck in job interviews, travel, and the lottery.

The riverbank occasionally sends dreams as well. One night, I dream that the island across the way has sprung a spring of clear, thick, nearly gelatinous water. I bring the dream to Mon's sister, who has a penchant for interpretation (which she usually uses to play the lottery), and she speculates that something has sent it to mewhether the naga, or a heretofore unidentified spirit, she did not know. But, perhaps, did I see any numbers in my dream?

\section{Occult Economies and Their Discontents}

Here, then, are three ghosts-the destroyed cobra, the uprooted tree, and the naga. They are strikingly similar. Each one comes at a moment 
of dislocation and change for the humans around it, when disaster creates a rupture across various worlds: human, nonhuman, and inhuman. This rupture rises from the sources of precarity in the lives of those who come to follow the spirits: a deadly road becomes the medium through which the cobra mother and the banana ghost act; and the Mekong that flows past the naga's lair, a river that has been devastated by Chinese and Lao hydropower projects upstream, gives birth to the ghostly dragon. How might we make some kind of sense of these new spectres, anthropologically speaking? Or is making sense not the right term?

In an influential essay from the 1990s, Jean and John Comaroff (1999) introduced the idea of 'occult economies' to try to tease through very similar disruptions and dislocations in South Africa. The Comaroffs describe in a series of vignettes (similar to the ones I introduced above) new fears and monsters that arose in the wake of South African liberation. As promised prosperity did not in fact trickle down to all, for many, the natural conclusion was that it had been stolen by those with special-occult-abilities. Thus the proliferation of phenomena that the Comaroffs (1999, 281) describe-lake monsters, Satanic cults, the creation of zombie workers-'flow from a promiscuous mix of scarcity and deregulation'. The end of apartheid meant the end of barriers, but this also meant the inflow of predatory financial practices from the outside. In this rush, some profited; many did not. And ... this was liberation? Where did the promise that individual Black South Africans would feel liberated in apartheid's wake go?

Via the lens of occult economies, the Comaroffs $(1999,295)$ call for anthropologists to focus on the 'production ... of compound political, economic, and cultural forms', to see how these 'create community', and 'fabricate social realities'. But questions immediately arise. Here, political economy seems to be the active force: as the Comaroffs write, the economy is the one producing, creating, fabricating. Those following and believing in the phenomena have little agency-not to mention the question of the 'agency' of the spirits themselves.

But is the present moment that unique? While events such as the end of apartheid or mass labour migration might be new in scale, economic shocks are not. Returning to Thailand, in the wake of Bangkok's early twentieth-century transformation into a modern nation-state with a vast royal bureaucracy and sovereignty defined by borders (see Thongchai 1994; Strate 2015), prophets arose in the Lao-speaking northeast from time to time, promising a radical disruption in the world order (Toem 1987). These 'men of merit' ( $p$ hu mi bun) declared that gravel would turn to gold, that a wind would sweep away anyone not holding lemongrass, that money would turn into excrement, and that animals would turn into demonic mermaids. These proclamations came just as everything else seemed to fall apart-Europeans seized a Laos that had been just a few decades prior destroyed by Bangkok, and local lords were curtailed in favour of direct rule from Bangkok. Many-from local officials down to farmers-slaughtered their animals, planted lemongrass around their house, and stockpiled gravel, awaiting the coming of the new era. It may be easy to see this panic as arising (produced, created, fabricated) from a mystification of the very real changes in the political economy of the region or, indeed, as a semi-instrumental exercise of peasants fed up enough and desperate enough to destroy their own livelihoods to spite the state. But these 'occult economies' seem to be engaging in much more than acting out mystifications of, or actively combatting, new economic regimes. Perhaps golden gravel and cannibal mermaids are not just symbols emerging from an incomplete understanding, but ways of understanding in and of themselves.

This is precisely Bruce Kapferer's (2003) point. He critiques the Comaroffs' notion of occult economies as presenting the new ghosts of the new economy as a kind of mystification of the real issue, which, for the Comaroffs, is the pervasive expansion of neoliberal capital. 
Such a model presents the ghosts of capitalism as dreams and the anthropologist as the psychoanalyst, interpreting a fundamentally meaningless symbolic content in order to discover the 'real' source of the woes. Instead, Kapferer argues that social and cultural content matters, as ways of understanding and dealing with such shocks are deeply socially and historically situated. In Kapferer's work on sorcery, it is sorcery's dynamism that makes it relevant to modernity as it incorporates foreign symbols, modern tropes, as well as individual improvisations. In addition, sorcery is always concerned with human agency (Kapferer 2003, 105). In the suniyama, the anti-sorcery Sri Lankan rite that Kapferer $(2003,119)$ describes, the victim of sorcery is called to reset him/ herself, to reorient and adapt to a changeable and often hostile world. Thus, sorcery appears in moments of shock not because these moments are opaque to a naïve subject, but because it is itself already a tradition that addresses the unexpected shocks of existence. Rites such as the suniyama break the individual from the grip of an outside force; they are, in essence, the opposite of a Comaroffian occult economy: they provide clarity and agency when it has been taken away.

Here, then, we have a debate: occult economies as pathologies arising from the shocks and disruptions of the market, or occult economies as a means towards resolving these very disruptions. But an element present in the three examples that I provide at the opening of this essay is lacking in both models: the spirits themselves. For the Comaroffs, a witch is identified in the form of a baboon, a lake monster is reported in the papers as a curiosity, investors start a pyramid scheme, and reports of occult organ trades shock local newspapers. The subjectivity of the witch, monster, and organ trader are not investigated. For Kapferer, the sorcerer does not make an appearance. But it is the relationships between agents that are central to Gamrai, Lek, and Mon and the ghosts of new economies.

Here, then, I turn to this notion of ghosts as other agents, and to the question of accident.

\section{Accident}

The snake, the tree, and the naga each recall questions of accident and agency: traffic accidents signify the presence of the Lady Mother and the banana ghost, but also give rise to them; the naga dies owing to an accident but also promises happy accidents to its devotees. And agency is at the heart of the distinction between Kapferer's and the Comaroffs' takes on occult economies: are such practices ways to actively engage with, or passive reactions to, economies? Agency and accident are tied together-an accident is an accident because there is no agency. 'It was an accident' and 'I chose to do it' are separated by a world of difference, but agency and accident are bound together.

Trais Pearson (2020) notes how the term 'accident' (ubatihet) is a relatively new one in Thai, arriving in dictionaries around the turn of the twentieth century. An accident is a misfortune without a cause, an unhappy confluence of events that leads to tragedy. As Siam's legal code modernised, it was the state that filled the gap to arbitrate agent-less accidents.

But in Pearson's account, the intervention of the state is not absolute, nor is it always invoked. When a famous Thai actress kills a police officer in a traffic accident, a number of factors emerge to complicate what might be a simple process where the state determines fault and sets penalties: the officer's ghost emerges asking that she be forgiven; the officer's family asks for money directly, out of the realm of the courts. While police point towards an authorless accident, or at least to themselves as the arbiters, social and supernatural forces emerge to complicate the new system.

Accident, then, creates an excess of fault, and, for Kapferer, it is fault-dosa in Kapferer's Sinhala, with the same root as thos in Thai-that characterises the occult. Agency and causality move beyond material limits. Here, models that reduce occult economies to purely political economic roots risk missing that excess, and 
risk overlooking the paradoxical question of agency that runs throughout-who is the author of this accident? Who regulates the unregulated?

\section{Divine Excess}

'Of course,' the sceptical reader will say, 'we cannot treat Lady Mother King Cobra as an agent. She is a cultural manifestation. Cobra spirits don't exist.' But let us stay with this for a moment: assuming that the economy does a thing and a spirit does not assumes a particular kind of evidentiary regime-one invisible hand exists, and the other does not. Elizabeth Povinelli (2016) details the animist qualities of the market-that realm where we can posit something we can never see ('value' or an idealised commodity) and then talk about its effects. We claim the dollar is strong or weak today, when the slip of paper remains just as flaccid as it was yesterday. To see 'the market' function, we have to point towards its effectsmuch as we do with ghosts.

Mon reports that 'people see naga all the time'. Here, he means a broader evidentiary regime. He means not only people seeing shapes emerging from the water or on the riverbank, but also dreams-seeing in dreams constitutes a kind of direct experience of a divine being, and certainly so if one's vision is confirmed by a surprising event (a miraculous recovery, a car accident, a winning lottery ticket).

The excess of agency suggested by accident opens up the space for ghosts, and a broader evidentiary regime allows for these ghosts to emerge. Such ghosts have always been present in Thailand, but they flourish when questions of agency are in flux-during the early 1900s, in the case of the phu mi bun, and they flourish now. As Claudio Sopranzetti (2017) shows, the lure of migrant work in Bangkok is not because of the (questionable, rare) economic benefit of such work, but the 'freedom' it provides.

Independence, as Sopranzetti points out, is a desired state but also a state of precarity, and it is into this mix that new spirits arrive.
In Vietnam, Philip Taylor (2004) notes how the fickle and often vindictive $\mathrm{Ba}$ Chua $\mathrm{Xu}-$ the 'lady of the realm', her cult booming in popularity since Vietnam's doi moi reforms-is seen not as a hostile manifestation of capitalism, but rather as an agent whom individuals can petition. The Lady gives her devotees a form of 'insurance', acting as their advocate in an unfamiliar, dislocating realm (Taylor 2004, 93). Thus, for those in new, volatile professions or, as Sopranzetti (2017) puts it, 'framed by freedom', overflowing with their own agency, ghosts absorb some of this potential, becoming patrons for those without.

But Gamrai, Lek, and Mon approach spirits as other beings in the world, and it is vital to be faithful to their perspective. The ghosts I detail here are co-sufferers, not echoes of or cures for the present moment. They, too, have undergone transformations. The snake has died, the banana tree has been cut down, the naga has suffocated. In the shared recognition of suffering, there is a link. The truck that hit Gamrai is an echo of the bulldozer that hit the Lady Mother. The withering Mekong reflects the withering of Mekong-region fishermen. Here, ghosts are things of a similar order as humans-both possessing their own agency subject to the same dislocations and disruptions that their devotees face. Indeed, the language used for spirits is that of familiarity: mothers (mae), fathers (pho), children (luk, e.g. the kumanthong). And here is where the idea of occult economies falls short in the context of Southeast Asia-while spirits, like strangers, can be hard to understand (Sprenger 2018), they are ultimately fellow agents in the world: full of their own potential and agency, and subject to their own disasters. 


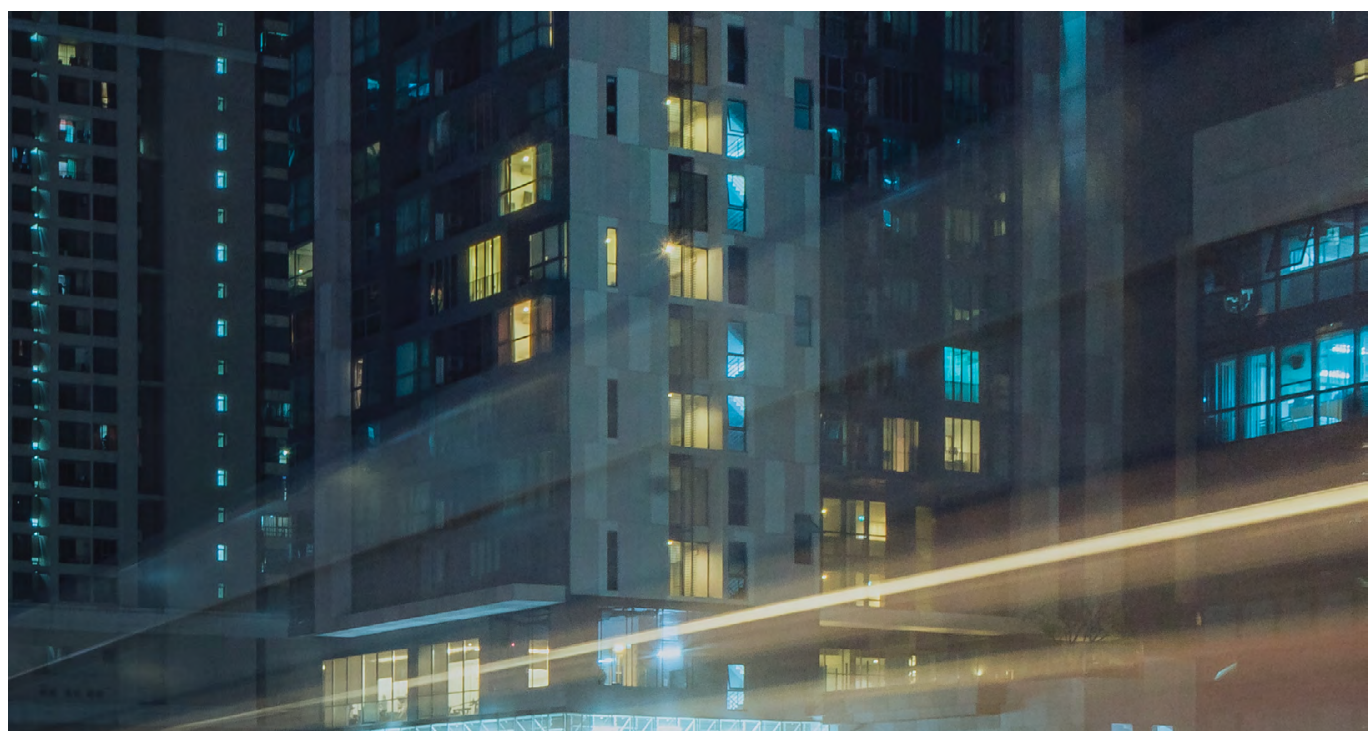

\section{The Diviner and the Billionaire:}

Bangkok Lights. PC: Anton Strogonoff.
Wealth as Mystery in

Buddhist Thailand

\section{Edoardo SIANI}

A Bangkok roadside diviner examines two luxurious skyscrapers along the river. He believes that they were erected by Thailand's largest corporation, the CP Group (Zheng Da in Chinese), on the instructions of their formidable in-house diviners. The master replicates a Buddhist discourse, according to which wealth flows naturally to those who can unlock the secrets of the cosmos.
$\mathrm{T}$ he roadside diviner ( $m o d u$ ) raises his eyes from the scribble of astrological calculations. He stares into the night sky: beyond the pointy roof of a shrine, beyond the slow dance of traffic lights suffused in exhaust, beyond the confusing smile of a young woman on the backlit sign of a massage parlour. He conjures up two elegant skyscrapers erected a few kilometres away on the west bank of the Chao Phraya River. One contains full-service apartments reminiscent of suites of luxury hotels; the other, condominiums for sale. Both buildings are very 'hi-so', the diviner reassures me, with state-of-the-art fitness facilities and swimming pools overlooking the river. Topped by golden spires that light up at night, they glitter brighter and higher than any other building on the same skyline. 
The property, among the most luxurious in Bangkok, is not only a masterpiece of engineering, stresses the master. Inaugurated on an auspicious day and time, it is also the result of brilliant divination. In fact, in his narrative, good architecture and good divination are two sides of the same coin. Working in tandem, they direct the flow of wealth into the pockets of landlords and tenants alike.

'Have you ever seen the towers?' he asks. They are not straight like ordinary skyscrapers. Instead, they are round, slightly pointed. The shape, he argues, is a clever innovation designed to keep all 'bad things' (sing mai di) away, leaving those who own or live in the buildings unscathed. I ask if this logic replicates the round mirrors that people hang outside houses and shops facing three-way junctions (sam yaek)-notorious crossroads of evil spirits (phi). The mirrors, with their round surfaces, bounce the spirits back on to the streets, preventing them from entering. The master nods. All of this, he declares, is good 'huang jui' (fengshui), a divinatory technique imported by Teochew Chinese immigrants (Wasana 2019).

Keeping bad influences away is not enough, however. Good divination must also generate wealth. Thus, the skyscrapers were built on a tiny piece of land, referred to by those in the know as the 'belly of the dragon' (thong mangkon). In that precise spot, the Chao Phraya River darts like the unruly dragons of Chinese mythology, creating the belly, evocative of abundance. Promotions feature images of the Chao Phraya River as a flow of golden lava, swelling to the base of the complex, streaming upwards to inundate the towers. This is a paradise of wealth-a far cry from the muddy riverbanks below, where tourists snap selfies against a backdrop of wooden shanties.

\section{Corporate Divination}

'Some people say divination ( $k a n$ du duang) is not true,' states the master, smiling. 'They say it's superstition (gnom gnai)! But look at the owner of the towers: the CP tycoon (jao sua si $p i)$. He is the richest man in Thailand, and he uses the services of diviners all the time!' The man continues, his speech getting more heated. 'He is not stupid (mai go). All of the richest men in Thailand use the services of diviners. And they are not stupid.'

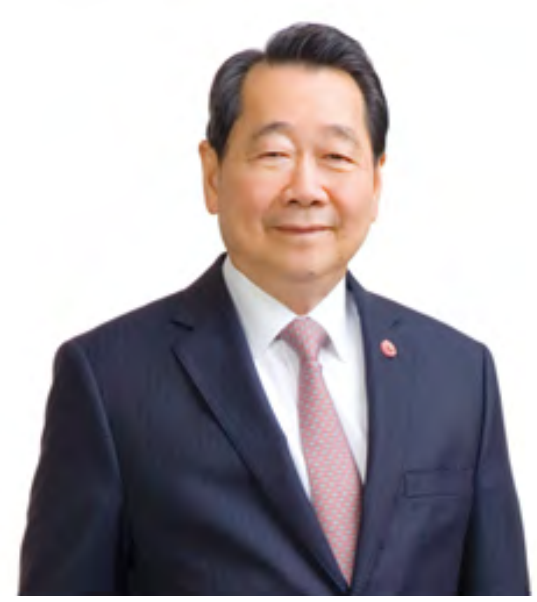

Dhanin Chearavanont, Senior Chairman of Charoen Pokphand Group Co. Ltd. PC: cpgroupglobal.com.

The tycoon's name, too powerful for a roadside diviner to utter in full (Gray 1992), is Dhanin Chearavanont. Of Chinese descent, Dhanin does not precisely own the skyscrapers as the master would have it. Senior chairman of the Charoen Pokphand Group (CP), a corporate conglomerate of truly unimaginable wealth (see Backman 1999, 65-79; Handley 2003), he remains, however, the wealthiest businessman in Thailand (Forbes 2020). CP, the country's largest private corporation (The Business Times 2018), is a household name. It dominates the market of primary goods from poultry to pork, operates more than 10,000 7-Eleven stores (Bangkok Post 2017), controls the telecommunications giant True Group, and much, much more (Handley 2003). A top world conglomerate, $\mathrm{CP}$ has investments in 21 countries, including China. Known locally as 
'Zheng Da' (正大), it proudly holds the Chinese corporate registration number '0001' (Charoen Pokphand Group, n.d.).

In Thailand, rumours of CP's extraordinary use of divination abound. As would be expected of a Thai firm doing business of such magnitude, astrologers (nak horasat) clearly set the most auspicious dates and times for the corporation's calendar of events. CP's hires, it is said-including those at managerial levels-are decided by human resource officers paired with a select team of diviners. Astrologers check candidates' birthdates, compiling profiles on their true character, abilities, and future potential. Specialists in ngo heng, a Chinese divinatory discipline based on the reading of physiognomy, sit in on job interviews so as to observe the candidates' facial features, a master's score above 80 percent being necessary to make it to the next stage of recruitment.

\section{Fortune-Telling and the Quest for Money}

Confirmed in part by Thananurak Jarusakul, a diviner who claimed to work for CP (Sutthikhun 2008), these rumours may not be entirely true. That said, they are credible enough to be repeated. Unstated but taken for granted, Thailand's wealthiest consult obsessively with diviners. Newspapers routinely feature stories of notable businesspeople, politicians, and media personalities following the often deliciously eccentric advice of some trusted master. The intent of these articles is to elicit surprise-hilarity, even-at the extent to which the powerful believe in divination. Yet, the same reports also spark interest in what the practice seems to achieve in the realm of accumulation, reinforcing its appeal to people from all walks of life.

Scholars argue that, as neoliberal policies exacerbate precarity worldwide, the accumulation of wealth becomes a mystery (Comaroff and Comaroff 2001). Puzzled by an unpredictable economy, apparently governed by obscure laws and entities, people resort to the familiar occult to achieve stability. Operating in new realms of the unknown, religious practitioners in turn respond by marketing adhoc ritual services. Invoking special powers, secret knowledge, and privileged access to divinity, they promise to fulfil the financial ambitions of the truly faithful in exchange for a fee.

The Thai market of the occult has been visibly on the rise since the end of the Cold War (Jackson 2014). Still known to tourists by the eyebrow-raising catchphrase the 'land of smiles', the kingdom, after all, is plagued by the biggest income gap in the world, with 1 percent of the population controlling 66.9 percent of the country's wealth (Macan-Markar 2019). In Buddhist temples, saffron-clad monks, the assumed epitome of religious orthodoxy, specialise in the production of amulets ( $\mathrm{phra}$ khrueang) that attract cash to their lucky owners. In slums, spirit mediums (rang song) become possessed in order to reveal winning lottery numbers to fervent disciples (luk sit). Along roadsides, diviners proliferate at night, aspiring to make their way to the marbled hallways of companies like CP. A thriving economic sector in its own right, divination boasts astronomic figures: according to a study conducted by Kasikorn Bank, in 2005, Thai people spent 4,000 million baht (roughly 132 million USD) on fortune-telling, excluding related ritual services (Kasikorn Research Center 2005). The same amount was spent, earlier in 2020, to move all overhead electricity cables underground in some areas of Bangkok: a public project hailed as the fifth most expensive of the year (Thailand Government Spending 2020).

\section{Buddhist Wealth}

International discourse generally depicts the accumulation of wealth as being in opposition to Buddhist morality. Yet this is a gross 


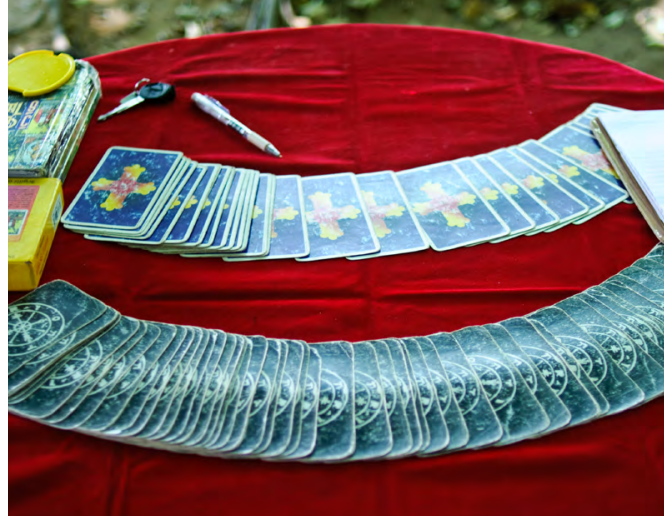

A Thai fortune-teller's table. PC: Thaths.

simplification if not outright Orientalism. Dominant Thai discourse is that wealth, along with all other good things, flows naturally to moral people (see Lotus Happiness 2017), those whose actions (kan kratham) align with the Dharma (thamma). Particularly since Thailand's entry into the war against communism in Indochina, success in capitalist domains-very much like the Protestantism of Max Weber (1958)-has crystallised as a sign of elevated moral standing, the 'fruit' (phon) of meritorious past action (bun barami) (Gray 1986). The late King Bhumibol Adulyadej (r. 1946-2016), worshipped as 'thammaracha' (a monarch who rules in accordance with the Dharma) and regarded as the most meritorious being in the kingdom, thus became, as it turned out, the world's richest royal (Puangchon 2018). Enormous wealth flowed to him from obscure sources indeed, as if by magic (Handley 2006, 363-93).

In Theravada Buddhism, the Dharma, i.e. the Buddha's teachings and the reality they describe, is the ultimate cosmic law. Because the cosmos is believed to be subject to impermanence (anijja), the rules that govern it are in a state of flux, requiring constant study to identify new formations (Siani 2018). It is here that diviners come into play. As morally suspect figures, with their abstruse calculations, they seek to unlock the secrets of a fluctuating cosmic-cum-economic order, the prescriptions they offer up to clients (luk kha) addressing the most efficacious ways to 'make merit' (tham bun) under always uncertain circumstances: specific prayers, say, rather than exotic rituals. The Dharma constituting at once a moral and natural law, these prescriptions align action with the natural/supernatural, identified as the course of celestial bodies and auspicious moments.

\section{A Roadside Master Learns, Then Teaches}

Roadside practitioners view more distinguished colleagues with a mix of admiration and envy, analysing their work in the hopes of gaining insight into distinct tricks and techniques. Diviners who help billionaires make money, it is reasoned, must necessarily know more of the perfect alignment of action and cosmos than those who advise mere labourers and white-collar workers. Hence, for an ambitious roadside master, two skyscrapers on the Chao Phraya River become the ultimate case study. A former monk, he is always on the lookout for new ways to satisfy his customers.

Some might think that what he doesadvising others on how to make money-is quite lowly; improper, even, for one who used to don the saffron robes. From his perspective, however, things look quite different. 'People assume diviners are only here to tell people's fortunes,' he concludes, referencing a discourse common among his colleagues. 'In fact, what we teach is the Dharma.' 


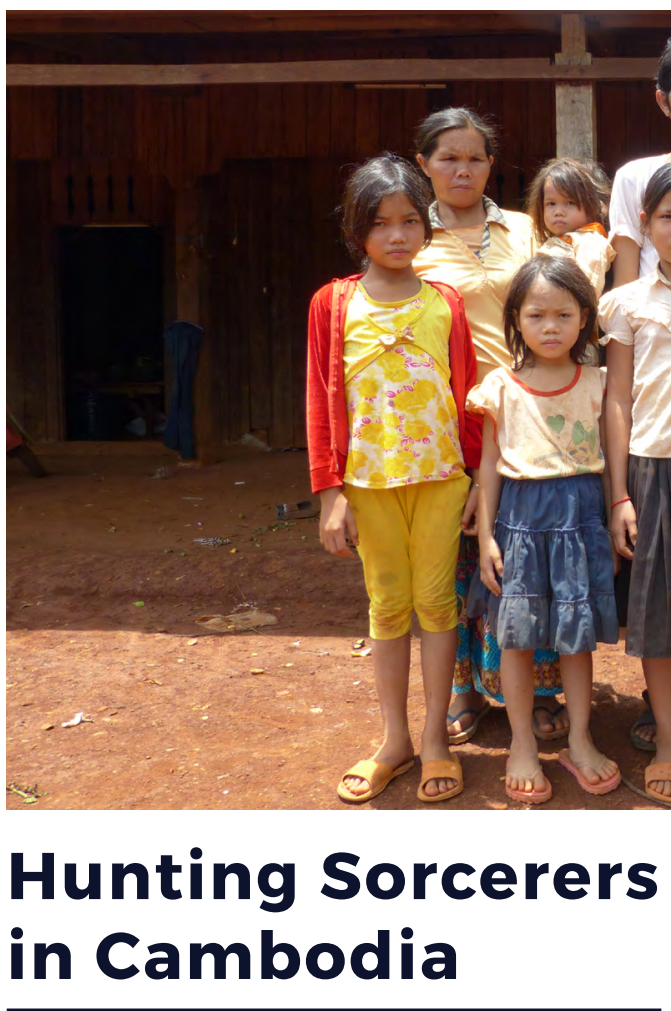

Ivan FRANCESCHINI
'Sorcerer' Rocham Kin with his family in front of the makeshift accommodation that the local police had put at their disposal. Borkeo district, Ratanakiri, 2015.PC: Ivan Franceschini.
Over the past decade, Cambodia has seen dozens of witchcraft-related cases in which people were harassed or even killed because their neighbours suspected them of engaging in black magic. Through interviews with survivors and family members of the victims, this essay traces some of these cases and argues that such occurrences are linked not only to poverty and exclusion, but also to a more fundamental collision between two worlds. n January 2014, I had been in Cambodia for only a few weeks when a headline in a local newspaper attracted my attention: 'Mob Decapitates 55-year-old Accused of Sorcery' (Eang 2014). It was a fairly short article that recounted how, a couple of days earlier, a traditional healer called Khieu Porn had been hacked to death in the middle of the night, while on his way back home from the celebrations for the rice harvest festival in his village. According to the reporter, the man had been stabbed no less than 10 times and then beheaded, his head thrown far away from the body. Apparently, his fellow villagers suspected him of being a sorcerer (thmup) and had decided to take matters into their own hands.

Having spent almost a decade in relatively secular Beijing, I often had that kind of nagging feeling of disenchantment that the 
Italian journalist Tiziano Terzani (2010, 236) describes in his diaries from New York, another global city: 'I feel more and more how this civilisation is foreign. I walk in the streets and there is never any sign of the divine, never any procession, never any celebration, any god passing by. Never a sign of anything that goes beyond the absurd appearances.' At once horrified and curious, I immediately hired a translator and set off for the village where the murder had taken place. I did not think too much about what I would do there-my main hope was to have a glimpse into that 'something' that goes beyond appearances.

Trapaing Chuk was an anonymous hamlet in Kompong Speu province, not too far from Phnom Penh. It was a little cluster of wooden houses dispersed amid the same dusty roads, palm trees, rice fields, and wooden houses with which I would become familiar in the following years, but being my first foray in the Cambodian countryside, everything was brimming with promise. When we arrived, the funeral of the victim had just ended and the whole family was assembled. Khieu's son took it upon himself to accompany us to the scene of the crime. There, in a quiet clearing hidden by some trees, he pointed at a long stretch of grass muddied by a dark-brown stain of dried blood, a stark contrast with the surrounding greenery. Bending down, he picked up a couple of white fragments that lay hidden among the stalks and casually handed them to me-they were a tooth and a fragment of the skull of his father. In this way I found another part of the story that had gone unreported: not only had the man been beheaded, but the head had also been split in two parts, one of which had not been retrieved yet.

On that day, I managed to talk to a few more villagers. Most of my interviewees agreed that Khieu had been a practitioner of black magic and were happy that he had been killed. Lorng Youm, an elderly woman with gums stained by betel, had no doubt that the man had been a sorcerer who had caused the sudden death of many people in the village: 'A man died the day after he had read his hand, another one soon after meeting him.' Despite people's hopes, the murder had not done much to rid the villagers of their problem. Quite the opposite-now they had to reckon with the ghost (khmauch) of the dead sorcerer, who was roaming the village at night looking for his missing head. People were terrified to go out after dark and monks had been called to place protective spells around some houses, but the effectiveness of such measures remained to be seen.

\section{At the Intersection of Field and Forest}

This was my first brush with the world of the supernatural in Cambodia, a fascination that I have kept up-although not in a systematic manner-ever since. I was interested in how the supernatural permeated all aspects of everyday life there, and, in particular, I was attracted by the dark side of these beliefs, in all their manifestations. There were so many trails I could have followed. As Philip Coggan $(2015,37)$ wrote in his popular book on spirits in Cambodia:

\begin{abstract}
True black magic exists, everyone [in Cambodia] knows it. The most horrific forms involve nails from coffins, oil distilled from corpses and foetuses torn from the wombs of living women. These confer powers on the owner, the dead bound to the will of the living. The black magician can cause razor blades and needles to enter the body of an enemy, or a buffalo skin that will swell up in the stomach. The person so attacked becomes ill, and will die if not helped by white magic.
\end{abstract}

More generally, I was curious about how these traditional beliefs played out in a rapidly modernising country such as Cambodia. In his extraordinary study of Khmer funeral rituals, Erik Davis (2016, 83) has argued 
that in Cambodia the relationship between spirits and people-as well as between people themselves-is determined by the perception of the surrounding nature as fundamentally hostile:

\section{The Khmer imagine the world into distinct and opposed geographic and moral spheres-the field and the forest, sruk and brai (a.w. srok and prei). The violence of historical relationships between upland and lowland and the dialectical relationship that lowlanders have with the forests marks them as places of death and rebirth, dangerous places of spiritual transformation and seemingly limitless but uncertain moral potency.}

It is the remnant of this metaphoric forest that I set out to explore.

In the months that followed my visit to Trapaing Chuk, Cambodian media regularly reported stories of villagers getting murdered for alleged sorcery. The most dramatic instance occurred in April 2014, when Pov Sovann, a traditional healer in Prey Chonlounh village, Takeo province, was lynched by a mob of several hundred people (Kim 2014). When I managed to visit the place in July 2015, villagers were eager to share what had happened that fateful day. According to the village chief, an elderly man named Kae Yaw, Sovann had a history of erratic behaviour, which culminated in his decision to set up a ceremonial altar at home. At the end of April, faced with his refusal to remove the altar-which many in the village held he used to practice black magic-the villagers had had enough and several of them converged on his house, where they started shouting abuse and throwing stones at the man. The news spread like wildfire on Facebook and people from neighbouring villages started streaming in, with the crowd rapidly growing to a mob of several hundred people. An ambulance arrived at the scene but was not allowed to intervene; the police were also present but could not-or, according to some, would not-do anything. In the evening, after an ordeal of eight hours, the tragic epilogue: Sovann was thrown out of his house and beaten to death by the rabid crowd, heedless of the desperate pleadings of his aunt and a few other relatives.

While the village chief was telling us this story, a couple dozen villagers gathered around me and my interpreter. They were mostly women and children, but there were also some young men carrying long knives-an ordinary view in a Cambodian village, but which assumed disquieting connotations in that specific context. We asked them if, with the benefit of hindsight, any of them had any regret about Sovann's fate, but nobody responded. Only one woman in her thirties broke the silence to say that he had it coming, to which the onlookers expressed general approval. At that point, the situation took a worrying turn. The villagers pleaded with us to help them with the ongoing police investigation-a request that turned out to be superfluous, considering that the only two people who had been detained in relation to the massacre would be released within a couple of months-and, seeing my hesitation, began to openly question whether we were siding with them or with their victim.

Eventually, one woman in the crowd agreed to take us to the scene of the crime, which was only a few hundred metres away. Although we had been assured that all the family had left the village after the murder, once there, we found that several of Sovann's relatives were still living nearby, with the exception of the widow, who had moved to Phnom Penh to work in a garment factory. They were still assiduously fighting for justice, but held out very little hope of ever receiving redress. Tired of reliving the tragedy every day, Sovann's father-in-law by then had demolished the old house where the man had been besieged. With barely suppressed fury, glaring at the woman who accompanied us, he relayed all the threats he had received from the villagers in his quest for justice for his slaughtered relative and complained: 'They told me that nothing prevents them from targeting another one. There is no justice in this country.' 


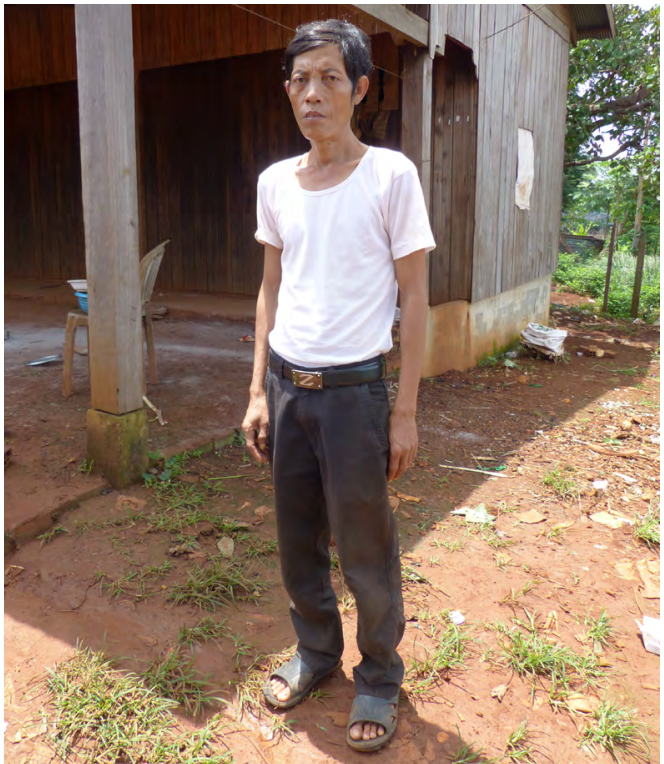

\section{Survivors}

Not all 'sorcerers' get murdered-some of them manage to escape from their villages, leaving behind their land, possessions, and occasionally even their family. Over the years, I encountered a few of these survivors. In the summer of 2015, I travelled to Ratanakiri, a once-remote province on the border with Vietnam and Laos. Populated by ethnic minorities that maintain strong animistic beliefs, the area is often taken as the epitome of that metaphoric 'forest' that looms so large in the Cambodian imaginary-although in reality the jungle today has almost completely disappeared, replaced with the uniform rows of rubber trees of Vietnamese and Chineseowned plantations.

In Ratanakiri, I learned how exiled 'sorcerers' represent a political problem in Cambodia. Years earlier, the Cambodian media had reported about Saleav, an entire village

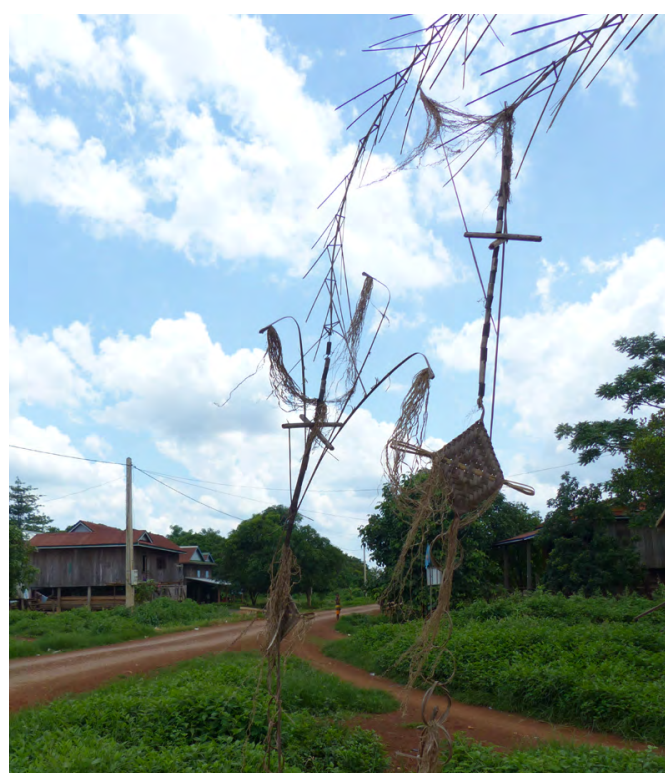

(Left) Rocham Kin. (Right) An amulet protecting the village from which Rocham Kin had to escape after being accused of sorcery. Chrung village, Borkeo district, Ratanakiri, 2015. PC: Ivan Franceschini.

in Borkeo district where, for a quarter of a century, 'sorcerers' banished by their fellow villagers had settled (May and Boyle 2012). When I visited in 2015, I could not locate the village and verify this story, but representatives of local NGOs confirmed that the provincial government was indeed trying to find a location to resettle all the exiled 'sorcerers'-the only problem was that land was in high demand and it was nearly impossible to find a suitable location. In the course of my inquiries, I also managed to unearth a couple more tragedies.

In a miserable hut in the back of the police station in Borkeo, I met Rocham Kin, a man of Jarai ethnicity who was then in his midforties. In early April he had escaped from his village after his neighbours had accused him of killing six people with a magical plant that he had picked up in the forest. For two weeks, he had survived alone in what was left of the jungle, an experience he would rather forget: 'I didn’t have any rice, water, blankets, mosquito 


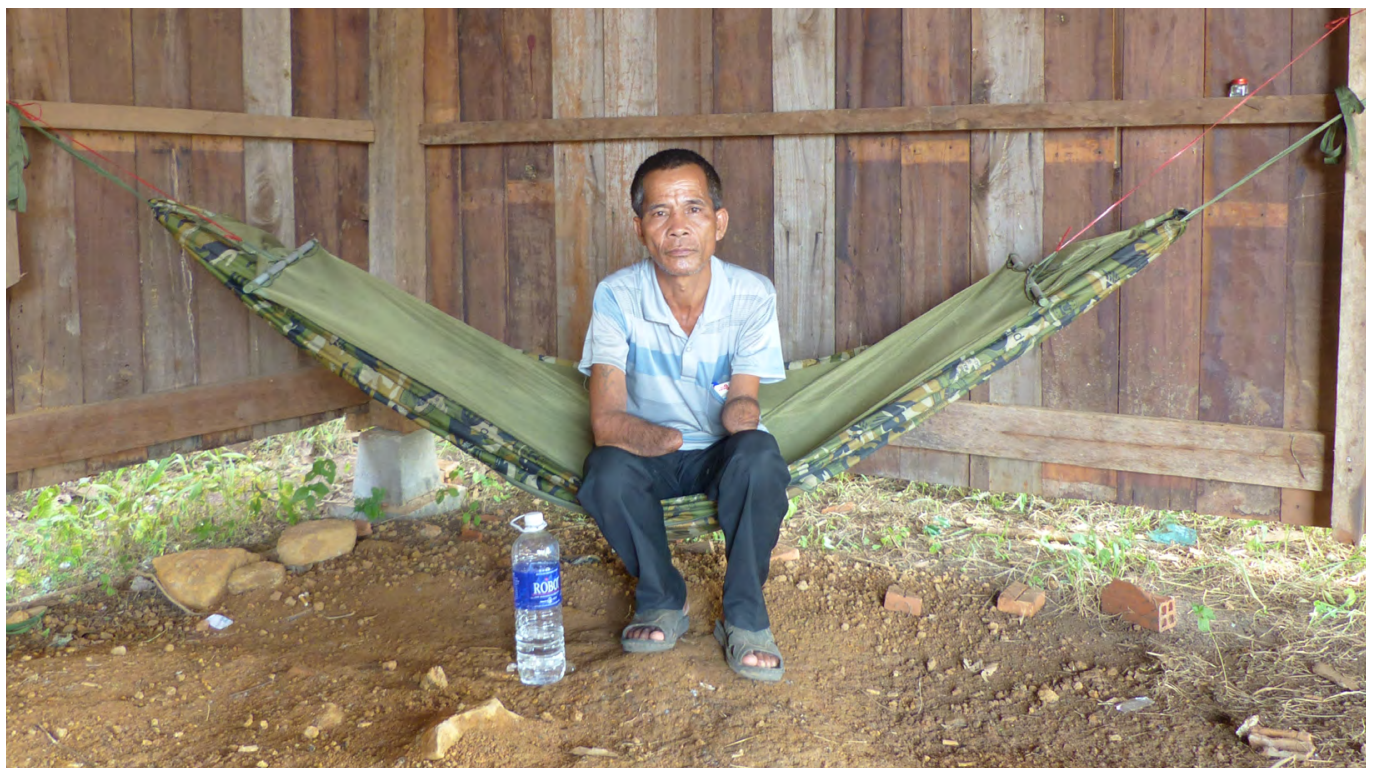

'Sorcerer' Sovann Thy in his temporary shelter on the grounds of the local police station. Oyadav district, Ratanakiri, 2015. PC: Ivan Franceschini.

nets, food, or cigarettes.' It was then that the head of the local police had taken pity on him and offered him, his wife, and eight of their children a temporary place to stay. In spite of the early involvement of national media (Cuddy and Phak 2015), finding safe accommodation had proven much harder than expected-word travelled fast from village to village and nobody wanted to have a sorcerer for a neighbour. I stayed in touch with Kim, and one year later he was still living at the police station, scared to leave the safety of his shelter lest he be killed. After that, he changed his phone number and I lost all contact.

Through word of mouth, I discovered that another 'sorcerer' had found refuge in a shed in the police station of Oyadav district, near the Vietnamese border. Sovann Thy, himself Jarai, was around 50 years old and had lost both arms in a mine explosion decades earlier. One day, while drunk, he had made an infelicitous joke about spirits, and his fellow villagers had begun suspecting him of being a sorcerer. One month earlier, they had forced him to leave the village. 'They threatened to kill my sister and my niece,' he told us, but not his wife and their six children, who had stayed behind in the family house, siding with the people who had banished him. Only in September that year, after months of negotiation between the police and the villagers, would he be granted permission to move on to a piece of land that he owned not too far from the village. While his life was no longer in danger, in the process he had lost his family and all his possessions.

\section{A Glimpse into Cambodian Society}

While the hounding and killing of sorcerers in Cambodia appear to be decreasing, the phenomenon remains relatively common. In a report on 'popular justice' released in 2019, the Office of the United Nations High 
Commissioner for Human Rights (OHCHR) documented 49 witchcraft-related cases in Cambodia between 2012 and 2018, among which 35 involved killings and 14 attempted killings or harassment (OHCHR 2019, 10). These episodes constituted the largest part of 73 reported cases of mob violence in the same period, which had resulted in a total of 57 people being killed. That the phenomenon remains fairly common is demonstrated by the fact that between January 2017 and June 2019, the Cambodian Ministry of the Interior reported no less than 16 cases of mob violence and eight killings following accusations of practising witchcraft (OHCHR 2019, 5).

Stories such as these provide grim insights into Cambodian society. Facing the impossibility of ascertaining how many of these cases are related to venal matters such as disputes over land ownership-NGO activists in Ratanakiri pointed out to me at least one case in which sorcery had been used as a pretext to exile a family and strip them of their land, and the case of Sovann Thy himself seemed fairly dubious in this regard-usually the emphasis falls on the social causes of the killings. The OHCHR report underlines how these murders might be linked to poverty and exclusion, with 'cases [happening] more in specific geographical locations linked to a lower level of economic and social development or that are less accessible' (OHCHR 2019, 14). Indeed, visiting those villages, it is hard not to reach the conclusion that poor sanitary conditions, lack of access to proper health services, and low levels of education play a fundamental role in creating the conditions for these tragedies.

However, the roots of the matter run far deeper than immediate material deprivation. I remember my befuddlement when, in Phnom Penh in 2014, I attempted to discuss the matter with a young university graduate who had studied abroad and was then working in an organisation that promoted the education of rural children. When I asked him what he thought the Cambodian authorities should do to prevent these killings, his response was that they should have trained teams of
Buddhist monks to travel from village to village to teach villagers how to collect proper evidence of sorcery to hand over to the police for prosecution according to the law. No matter the level of education or prosperity of my interlocutors, on several occasions I found myself facing similar responses that-each one in its own way-betrayed the adherence to worldviews very different from my own.

According to Somchan Sovandara, a professor at the Royal University of Phnom Penh who has conducted extensive research on traditional healers in Cambodia, all these killings hark back to the primordial conflict between fields and forests that underlies much of Cambodian culture. When I interviewed him in January 2014, he stressed how sorcery had roots in both the real and the metaphorical forest: 'Thmup (sorcerers) have always existed in Cambodia. In the past, they retired in the forest and lived isolated from the rest of the community. Whomever needed to curse someone just went into the wild and asked for their assistance.' The problem is that with the forests rapidly succumbing to economic developmentCambodia lost almost 2.2 million hectares of tree cover between 2001 and 2018, with an annual rate of loss increasing almost threefold in the same period (Kresek 2019)-sorcerers, witches, and other supernatural beings now have no place left to go.

In light of all this, one might argue that it is the perverse dynamics of deforestation and exploitation of natural resources that are causing a collision between two worldsthe magic one of the forest and the 'civilised' one of the fields. If we accept this view, the murders of Cambodian 'sorcerers' then provide a glimpse into such a primordial clash. It is in this conflict that that much-craved 'something' that goes beyond appearances spills out into the everyday life of both victims and executioners, wreaking havoc in a final act of defiance in the face of the onslaught of 'civilisation'. 


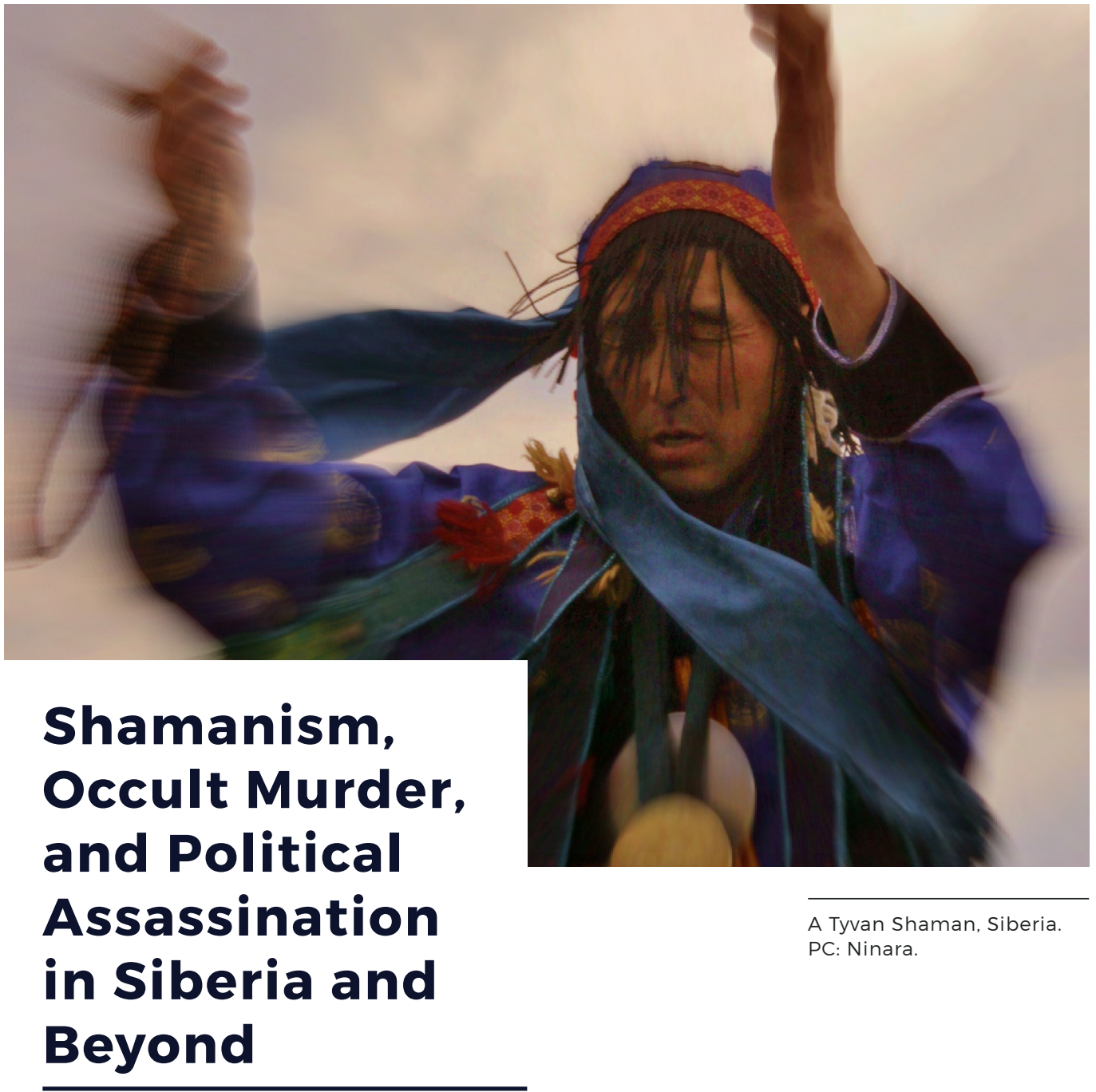

\section{Konstantinos ZORBAS}

This essay examines the revival of shamanism in a Siberian city and analyses the political dimensions of rituals for reversing the effects of sorcery assault. Drawing on fieldwork exploring an epidemic of occult violence in Kyzyl, Tyva Republic, the essay identifies a new type of shamanic detective and entrepreneur, whose techniques of countercursing cut across the state's operations of security and justice.
$1 \mathrm{~s}$ it is well known, shamans are associated with prescient or anticipatory knowledge about unpleasant occurrences, as well as with personal 'abilities' in divining and detecting hidden aspects of significant events. In making a diagnosis about an illness or a misfortune, shamans often perform rituals for reversing negative effects attributed to witchcraft and occult malignity. In this essay, I will revisit my 
fieldwork with shamans in the Siberian city of Kyzyl, the capital of the Russian Republic of Tyva, offering some insights into an epidemic of curses and sorcery as an expression of a universal, and currently prevalent, phenomenon-namely collective hopelessness and the fear of impending doom.

To begin, I shall present an example of a shaman's (after-the-fact) divination about 9/11. This shaman, a specialist himself in countercursing, was a key informant on the subject of 'curses' (kargysh in Tyvan) during my fieldwork in a religious organisation in Kyzyl in 2003. In one of our conversations, he offered the following testimony about the course of events leading to $9 / 11$ :

\section{Did you watch these two airplanes, which the (suicide) terrorists hijacked in order to strike the Towers in New York? This was a curse affliction too. Several years earlier. when the United States had invaded Iraq, a Muslim priest cursed the US President from his mosque in Baghdad. The priest's curses were revealed in this form, in retaliation for this invasion.}

This provocative statement by a native leader of shamanic (religious) revival in Kyzyl illustrates an intriguing aspect of remedies for illnesses in an 'Association of Shamans' that runs a clinic in Kyzyl. The shamans of this clinic attributed their clients' problems to curses that had been cast against them by various enemies due to envy or unjustifiable hostility. This (perceived) proliferation of curses marked a striking reversal of earlier accounts by classical Tyvan ethnographers, whose books include stories of people encountering spirits or falling ill after walking through dangerous locales in the wilderness. In contrast to these accounts, which involve religious offences and violations as a cause of illness, the materials of the present study document the proliferation of a new sort of curse paranoia.

And this is not the only difference with past traditional explanations for misfortune. Consultations about how to deal with curse afflictions were sought after by individuals who attempted to solve tensions and conflicts associated with the legal system. In this context, rituals of healing and retaliationthe focus of this essay-address complex synergies of real and occult violence, which are ungovernable by the Russian law. I argue that procedures of divination and counter-cursing can be analysed as a grassroots operation of cultural (or shamanic) justice, which is coextensive with the state's institutions. In other words, the strand of shamanic retaliation that this essay documents functions as a rational alternative to the expression of motives channelled through overt violence and murder in this specific society of south Siberia.

\section{The Soviet Cultural Revolution in Tyva}

The ethnographic data of this study were collected over the course of fieldwork in one of the four religious organisations for the revival of shamanism that functioned in Kyzyl during the time of my fieldwork. A region in south Siberia approximately the size of Greece and bordering Mongolia, Tyva is the home of ancient traditions of nomadic pastoralism and horse-breeding (Soyan-Peemot 2020; Vainshtein 2009). Following the establishment of the Autonomous Republic of Tyva in 1990, it has also become the site of a renewal of local religions. While for more than two decades (1921-44) the polity known as the People's Republic of Tannu-Tyva was part of the United Nations as a nominally independent state (although in essence it was under Soviet rule), in 1944 this territory was formally annexed by the Soviet Union.

As Galina Lindquist $(2011,72)$ has shown in her works on the history of religions in Tyva, in the first years of the Stalinist administration in this territory during the 1920s the Soviets relied on the literate Buddhist clergy for the establishment of an independent state. Nonetheless, as happened throughout 


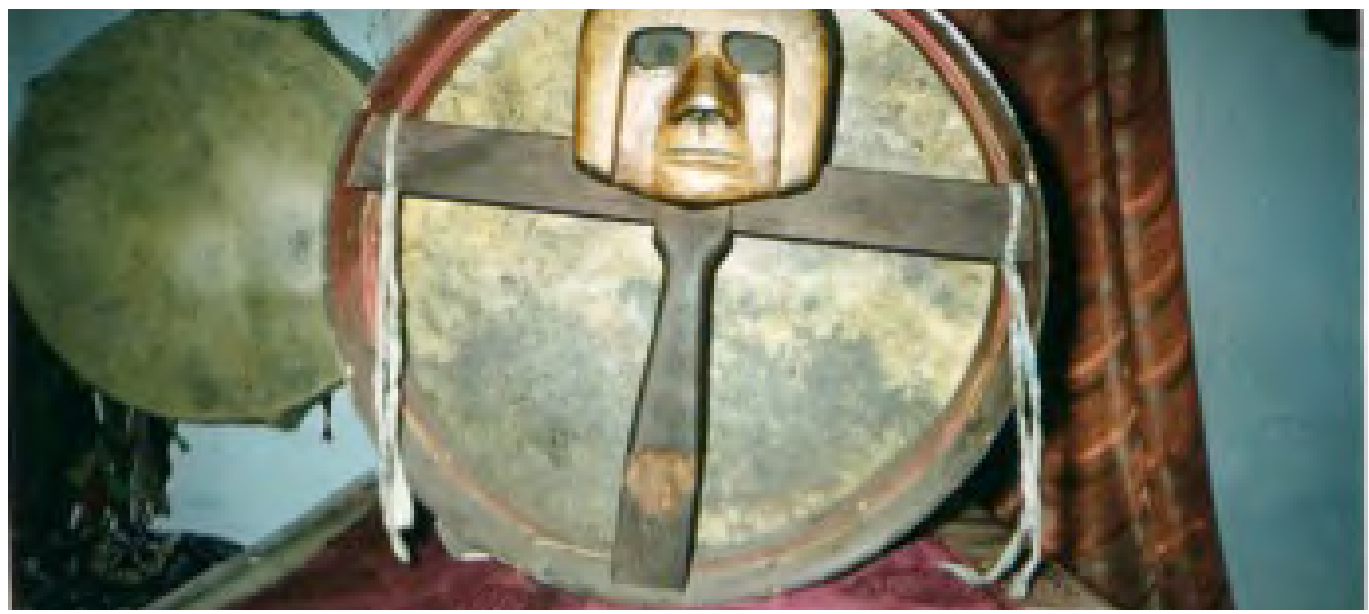

Siberia in the 1930s, religious devotees and practitioners (denigrated as 'cult officials' in the Soviet parlance) were relentlessly repressed by a Tyvan state elite, which represented one of the fiercest Bolshevik regimes of Asia and the Far East (Lindquist 2011, 72-73; for an eyewitness account see Mänchen-Helfen 1931). While the practitioners became extinct by the 1960s due to the anti-religious mobilisations and expanding medical facilities and boarding schools, some rituals survived in clandestine forms among isolated and remote herder camps (aaldar in Tyvan).

In his magisterial 2007 book The Beauty of the Primitive, Andrei Znamenski notes a fascinating and rather undocumented aspect of pan-Siberian adventures of religious survival throughout the Soviet 'Cultural Revolution'. As he writes, within this intolerable sociointellectual atmosphere, dominated by zealots of Stalinist modernisation and their enthusiasm for eradicating shamanism, the indigenous nations of Siberia reinvented their sacred customs in forms almost unnoticeable by outsiders. While shamanic drums and attire were being confiscated or even placed in museum collections for Russia's 'nationalities', the natives in the Altai, Tyva, and Evenkiya practised ritual healing with tools that occupied ancillary functions in the original shamanic rituals, such as branches, bows, and arrows. My informants recalled another ingenuous
A private collection of drums: The figure in the cross-pieces of the brown drum represents god Mars. This drum is used for counter-cursing rival shamans. The 'white' (ak in Tyvan) drum on the left is used in healing rituals. PC: Kostantinos Zorbas.

practice that substituted for shamanic drums, namely, the ringing of tiny bells, a technique which at that time was politically less dangerous than trance rituals that involved an audience (Shirokogoroff 1935). Remarkably, indigenous inventiveness encompassed also 'imaginary drums', i.e. drawings of drums on various materials for ritual use, as well as the custom of waving white fabrics next to a 'sacred tree' (tel'yash in Tyvan) in order to summon the spirits of a locality and ward off the spirits of illnesses (Znamenski 2007, 342-43).

\section{Shamanism and Ethnic Integration}

Soviet socialist scholarship and its 'struggle' (bor'ba in Russian) against the 'fraudulent and exploitative' religious faith of shamans provide a crucial background to the present analysis of shamanic assassins operating on the margins of the law and the state in the town of Kyzyl. Kyzyl-a Tyvan word that means 'red' and stands as a signifier of Soviet enlightenment 
and progress-is a town of approximately 110,000 residents in the geographical centre of the Tyva Republic. Throughout the 1990s, it was known as one of the poorest and most crime-ridden provincial towns of post-socialist Russia.

In a way evocative of Morten Pedersen's 2011 study of Darhad shamanism as an 'ontology of transition', which emerged in north Mongolia after the meltdown of socialist institutions, the first official guilds (or societies) of 'shamans' (shamany in Russian; khamnar in Tyvan) in the 1990s addressed the consequences of the socioeconomic disintegration of the Soviet polity (Zorbas 2015). In her pioneering work on shamanic and Buddhist revitalisation in Tyva, Galina Lindquist (2011) examines whether this organisational form of state-sponsored shamanic activities was antecedent to the 'juridical confessionalisation' of shamanism as a religion on a par with Buddhism and Russian Orthodoxy. Interestingly, she argues that the official restoration of shamanism as a 'traditional confession' in the Autonomous Republic of Tyva derived from scholarly theories of shamanism as the Ur (Paleolithic) religion (Lindquist 2011, 76; Vitebsky 1995).

Nonetheless, while this image of shamanism as an indigenous tradition has sustained Tyvan ethnonationalism-even including assertions of separatism and rejection of any ties with Moscow in the early 1990s-it is, rather, Buddhism, as a national religion, represented by the local sangha (monastic order), that unites the Tyvan nation with a (Buddhist) transnational 'ecumene' whose centre is in Tibet (Lindquist 2011). My research also provides an additional standpoint for challenging some of the above assumptions about shamanism as a key feature of ethnic integration or nationalism in Tyva. It does so by highlighting how some kinds of shamanic redress are isomorphic with (or relevant for) methods in organised crime and political assassination.

A brief theoretical extension in support of this argument is necessary. In his classic 2001 study Stratagems and Spoils, the anthropologist of South Asia Frederick Bailey argues that political decision-making acknowledges the tensile co-presence of normative and pragmatic rules; it is the practical wisdom and expediency associated with the latter set of rules are crucial for winning in contests ranging from elections to competing claims in the criminal underworld (2001). For Bailey (1994), the manipulation of normative rules as a means of manning the barricades against opponents underpins every forum for competition: the Parliament, the Cosa Nostra (where 'anarchy' is fenced off by rules or a code of revenge), or an Indian village council launching a witch trial against a wealthy villager.

The relevance of this theory for conceptualising the shifting roles of shamans as the catalysts of 'cultural crimes' and as 'ministers of justice' will emerge in several intriguing cases below. Here, the focus is on a rather similar analysis by political scientist Charles Tilly (1985, 175), who argues that protection rackets 'share a home with their upright cousins in responsible government'. For Tilly, whose theory of war-making and state-formation presents an alternative to Enlightenment ideas of the social contract, governments have organised protection rackets with the advantage of legitimacywhich is basically the only way they differ from racketeers.

\section{Shamanic Justice}

Let us see how these propositions illuminate some rather undocumented aspects of shamanic practices in Kyzyl. Crucially, the picture of shamanism that emerges from the data on counter-cursing consultations that I collected differs from official (and scholarly) perceptions of an ethnic religion. While my sample of clients includes Russians, Kazakhs, and other Russian-speaking nationals of Central Asian origins who were treated for curse affliction, the majority were ethnic Tyvans. 
One case concerned a businessman from Ulanbaatar, who unexpectedly arrived at the Association of Shamans with a swollen face and seeking a meeting with the Headman. The latter was a self-designated 'Great Shaman' (Ulug Kham in Tyvan), who acquired his abilities after birth sometime in the 1950s, when his shaman-grandmother washed him in a river in a symbolic act of 'cutting' the deadly impact of an evil spirit. This Mongolian businessman claimed that he had been terribly beaten by a gang some days after he arrived at Kyzyl. The beating was a warning; they would let him live only if he paid them off. After the client left, the Headman mentioned to me that his knowledge of the landscape in Tyva would assist this client in his escape, but I do not know if this was only an empty boast as I have no further information about the client's fate. What is significant here is that the client did not seek official intervention, for instance by going to the police or to the Mongolian consulate in Kyzyl. This suggests that trust in agencies of law enforcement has been transferred to the shamanic detective and entrepreneur, who exemplifies an intimate bond between religiosity and rational risktaking in the privatised economy of Russia, a bond that in Tyva is predominantly expressed in Buddhist acts of merit-making.

The parameter of rational risk is important for making sense of the above transference of trust to supernatural forces. What stories like this one actually reveal is that a similar motive can be channelled by means of two substantively different structures: namely, pragmatic and 'occult' agencies for special protection. Undoubtedly, shamanic incantations for spiritual 'protection' (kamgalal in Tyvan) do not produce the same outcomes expected from security agencies. Nonetheless, shamans may fulfil protective roles that allow the victim to avoid the consequences and unpleasant risks associated with seeking police mediation (for instance, the possibility of being kidnapped for ransom).
The stories that I collected lead to the conclusion that shamanic rituals are a vehicle for the expression of non-traditional motives, which bear some relevance to the operations of justice in Tyva. Consider, for instance, the following case, in which a legal dispute between ex-spouses over the ownership of property brings occult threats to life. The woman, a Russian whose young son had unexpectedly lost his life, had sued her exhusband for selling a house that they coowned. During a consultation, the Headman used his 41 stones to divine the cause of her son's death. According to him, the boy's vitality had been stolen by a sorcerer who transplanted it to the aging father, so that the latter would be able to take advantage of it to be with his young mistress.

The client herself, who was waiting for three years for a court hearing, was steadfast in her desire to fend off her ex-husband's sorcery and to punish him in a deserving manner via a shamanic ontology of immediate returns (for a related ethnography of strategies for deflecting curses in a Mongolian context, see Swancutt 2012). The Headman cleansed her from the curses with juniper incense and chanted his ritual invocation (algysh in Tyvan) for summoning his assistant spirits in a 'trance ritual' (khamnaashkyn). During this performance, he beat his drum and swung it around himself like a 'whirlwind' (kazyrgy) in a movement of sweeping away the enemy's curses. Here, the Headman's divination of a murder by means of 'soul-harvesting' is in itself a manifestation of a planetary social diagnostics characteristic of post-revolutionary societies. As the Comaroffs (1999) have famously argued, it becomes, one may say, a 'shamanic mask', i.e. an impersonation or an echo of a magically killed young man, who resembles the South African social nightmare of 'ghost [zombie] workers', abducted by the rich and elderly witches and bereft of both voice and agency (Comaroffs 1999, 289). 
This pattern of occult economy, based on notions of illegitimate extraction or exploitation, emerges also in another consultation at the Association of Shamans. This case, which features splenetic feelings of workplace abuse and of abandonment by a partner, involved an ethnic Tyvan woman, who resigned from her post as an accountant after unsuccessfully filing a petition against her employer, a middle-aged Tyvan woman who had allegedly hired magicians to curse her. Yet, the Headman's khamnaashkyn revealed several strands of curse affliction-in addition to curses by her employer, this young woman had also been magically assaulted by a female sorcerer of Armenian nationality. This magician had been hired by a Buryat woman resident in Tyva, who hoped to get this client's office job for one of her own relatives. This kind of dynamic, involving occult specialists as paid assassins for rational and pragmatic purposes, can be perceived as a variant form of a logic of retribution that is present in both post-traditional societies (i.e. Tyva) and modern nation-states or global power blocs. I adopt the notion of 'retributive logic' from anthropologist Garry Trompf, who in his 2004 book Payback delineates a universal pattern of 'rationally justified recrimination'. As he notes, religious systems have a legal validity of their own, since they explain 'eventualities too personal or profound to be covered by the law' (2004, 3-9). This is also reflected in the cases of shamanic redress against afflictions with sorcery that are documented in this paper.

A final example from the Headman's caseload illustrates the novel appropriations of shamanic power for purposes associated with political offices. Allegedly, the Headman once travelled by helicopter to a local politician's headquarters, where he performed a ritual so the politician could outdo his opponents and secure his victory in the elections. This is one more piece of evidence that shamanism is reconstituted as an autonomous field, whose purposes and specialisms overlap with motives associated with both crime and politics. As in the previous case study, we find in this shamanic narrative a synergy between occult strands of violence and rational motives related to competitiveness. The data on countercursing practices evince a reorientation of modern shamanic practice toward contexts of insecurity, which are the object of state law and governance.

\section{Shamanic Revivals and State Power}

The ethnographic documentation of shamanism as an alternative to physical and pragmatic mechanisms of harming an opponent has important implications for analysing religious revivals in ethnic societies with active strands of occult violence, but also with a background of past (or present) political repression. As we saw, the criminal figure of shamans as hired killers and quasientrepreneurs, who work in the margins of the state's surveillance, descends from a dialectic confrontation between Soviet modernisation and native religious legitimacies (the latter ones surviving the persecutions through oftentimes unrecognisable and ingenuous symbolic forms).

The sample of consultations, which involves both occult and physical threats, leads us to another crucial implication about statesponsored shamanic revival as an expression of ethnic integration and nationalism in postSoviet Tyva. Although shamanism is a powerful signifier of ethnic identity, the data of this study identify several unofficial strands of the shamanic complex, which overlap with the operations of state protection and justice. In probing cases that involve aspects of occult and physical conflict, the Headman has reinvented his ancestors' ritual acts of defying state power.

Fieldwork in Tyva to conduct this research was supported by an individual grant from the Wenner-Gren Foundation. 


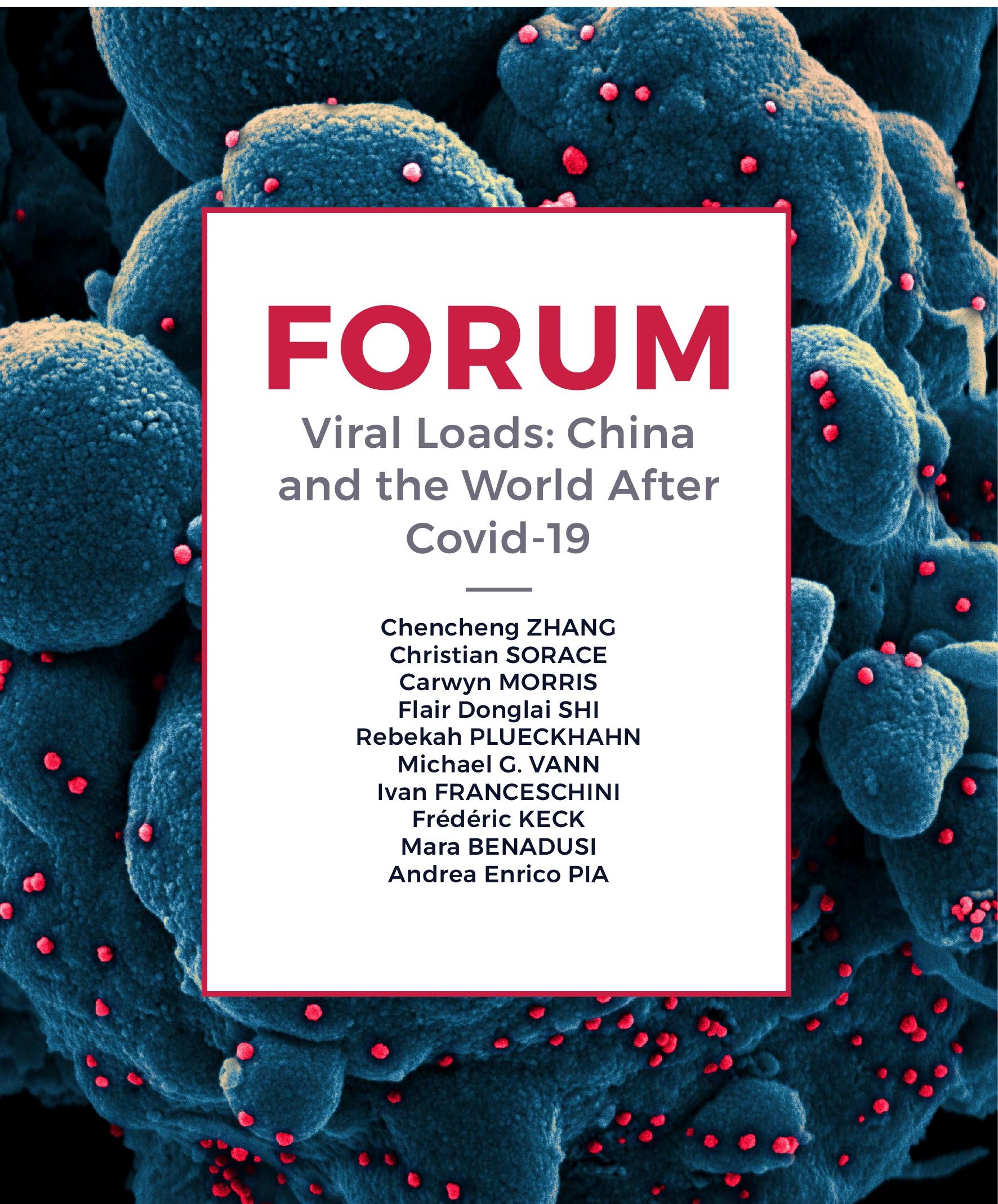




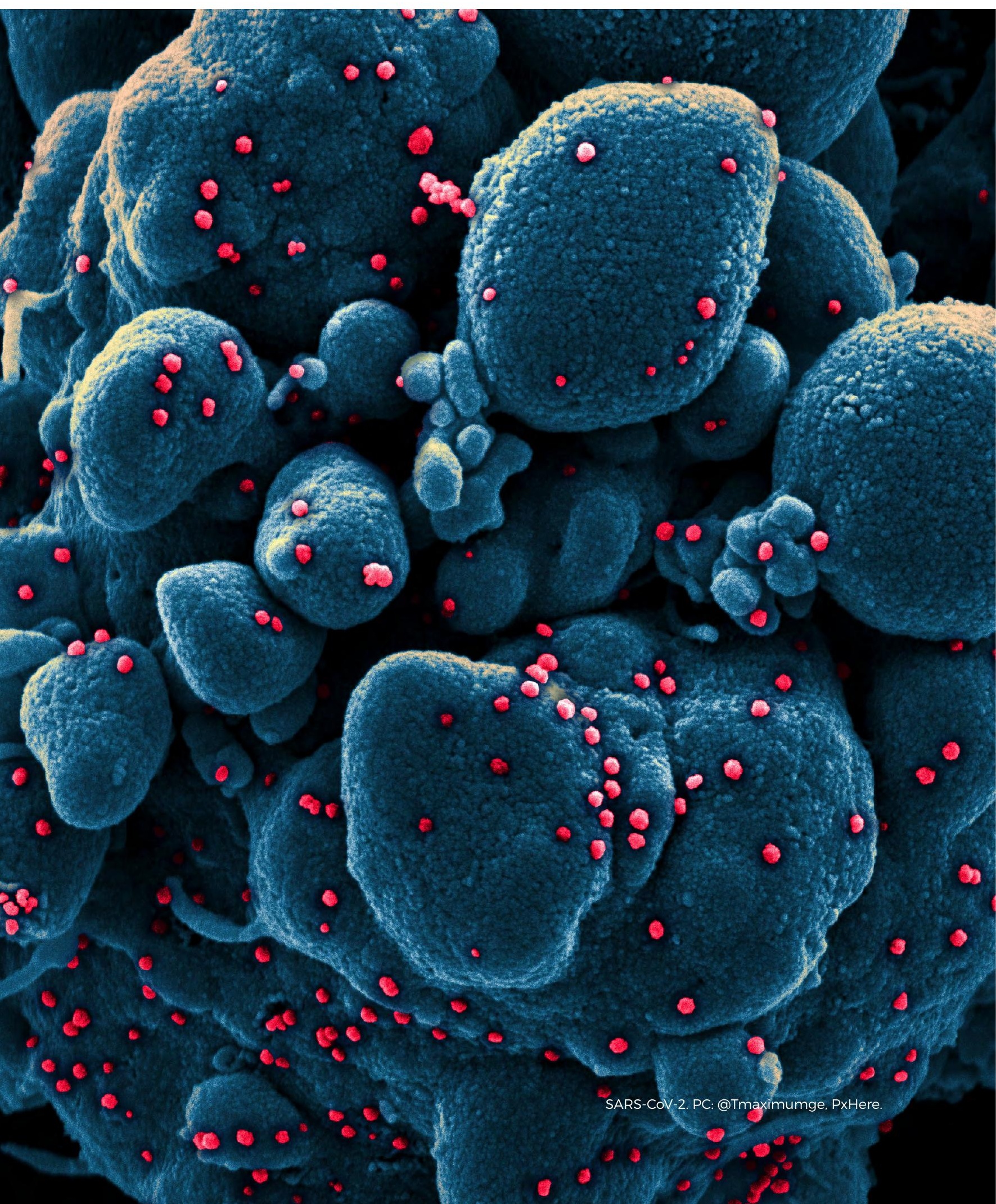




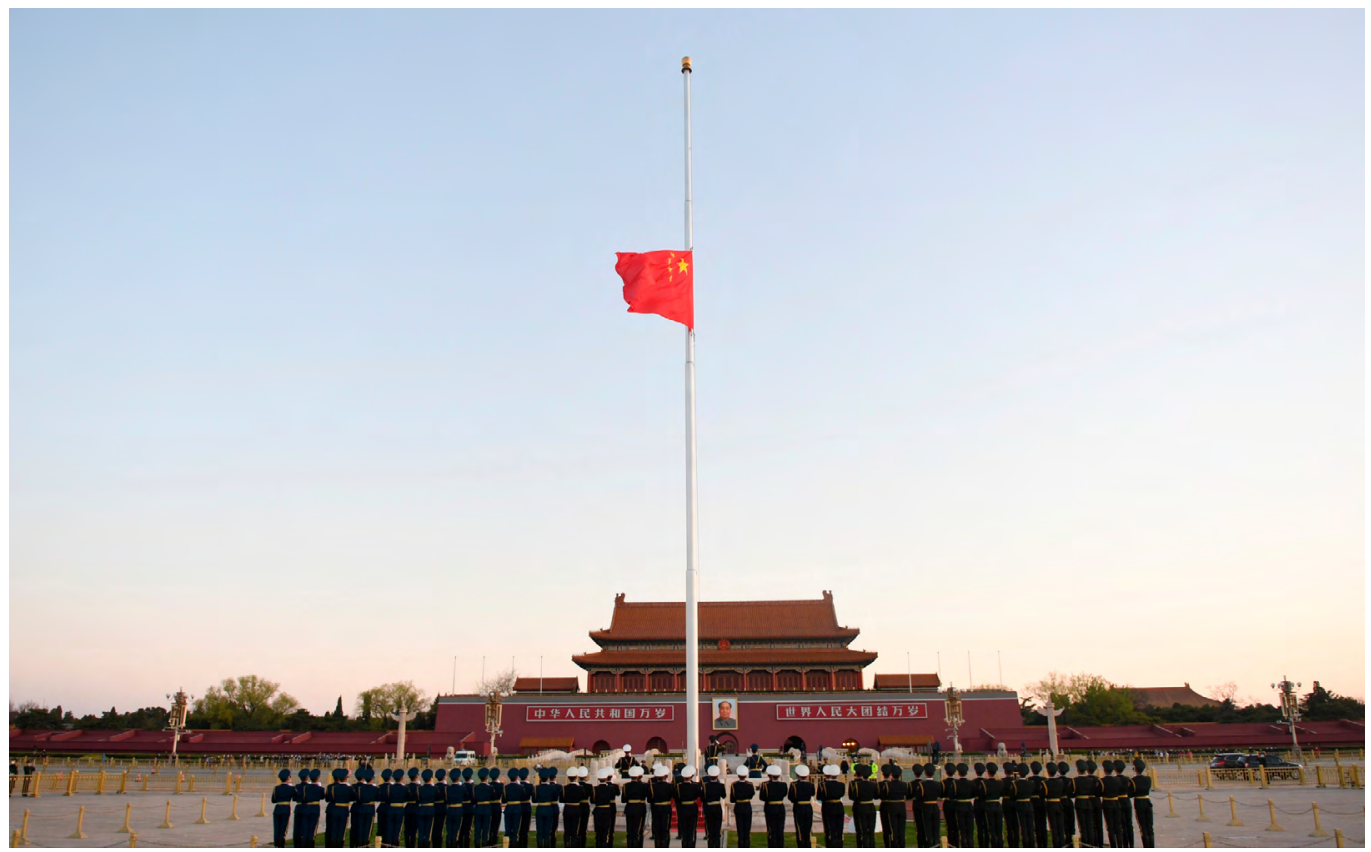

\section{Covid-19 in China From 'Chernobyl Moment' to Impetus for Nationalism}

Chenchen ZHANG

W hen Dr Li Wenliang died from Covid-19 on 7 February, the Chinese Internet saw an unprecedented outpouring of grief and anger. The universal mourning for the reprimanded doctor, who had warned his colleagues about a potentially infectious coronavirus in late December and had been silenced by authorities, was also an expression of the public anxiety and dissatisfaction with government responses that had accumulated over the few weeks since the outbreak began. The missteps and failures that had triggered widespread outrage ranged from the official downplaying of the risk of humanto-human transmission in the earliest days, to the shortage of personal protective equipment for medical workers; from the scandal of

\begin{abstract}
Flag at half-mast in Tiananmen Square on 4 April 2020 to commemorate those who died in the fight against Covid-19. PC: Ju Huanzhong, Xinhua.
\end{abstract}

the Wuhan Red Cross in mismanaging the distribution of donated medical supplies, to the skyrocketing numbers of new cases and victims.

The situation was so grim and criticism from ordinary citizens so prevalent that some observers dubbed the crisis China's 'Chernobyl moment' (Shih 2020b). However, as the epidemic has-at least for now-been brought under control, critical voices also seem to be fading away, even though anger lingers in Wuhan, where some dissidents are still fighting to resist the official victorious narrative (Kuo 2020; Weinland 2020). To be sure, it is difficult to know if and how the pandemic has influenced regime support in a country that regularly censors criticism, but discontent with 
epidemic responses has been largely subdued and nationalist sentiments have become more prominent. This holds true especially in those parts of China that have been much less impacted by the coronavirus -97 percent of all Covid-19 deaths in China occurred in Hubei province, where the epidemic started, while the rest of the country, with a population of over 1.3 billion, has recorded 121 deaths as of 30 April.

The relatively successful and prompt flattening of the curve, however, is not the only factor that contributed to the transformation of public sentiment. As in past crises that also evoked mounting criticism by exposing structural problems in the political system, the Chinese Party-state employs a set of 'hard' and 'soft' tools to suppress dissent and overcome the trust crisis. These include censorship, crackdowns on dissidents, bureaucratic and technocratic adjustment, and a tried-andtested propaganda formula that I would call 'disaster nationalism'. Yet unlike past disasters, such as the Sichuan earthquake of 2008, the global development of the pandemic and international power dynamics have also played a significant role in how Covid-19 has become an impetus for nationalism.

\section{Authoritarian Resilience and Disaster Nationalism}

Political scientists use the concepts of authoritarian resilience or responsive authoritarianism to describe the ways in which the Chinese regime allows a certain degree of participation and responsiveness without democratisation (Nathan 2003; Qiaoan and Teets 2020). In times of crisis is one, this responsiveness could mean rapid personnel changes to shift blame from the political system itself to individual local officials, technocratic improvement such as the reform of the epidemic control system following SARS, and strategies of political communication that respond to and incorporate public sentiments (Repnikova 2020).

The Party-state, for example, wasted no time in joining the public to pay tribute to Dr Li Wenliang, going as far as to officially recognise him as a 'martyr' (烈士). Right after his death, a technology company based in Beijing submitted a public sentiment analysis report to the government and offered recommendations on how to respond to the online outrage (Shih 2020a). The National Supervisory Committee sent a special team to Wuhan to investigate the matters related to $\mathrm{Dr}$ $\mathrm{Li}$, and they unsurprisingly made the decision to revoke the reprimand and hold the relevant police officers accountable (Xinhua 2020). The pattern of punishing individual and local actors to ease anger and distract attention from structural problems within the system itself persists. Top Hubei and Wuhan officials were replaced in mid-February. After a prison in Shandong province was found to have covered up an outbreak, several figures-from the prison warden to responsible officials in the provincial government-were removed from office.

In terms of technocratic adjustment, there has been an ongoing debate on improving the epidemic response system and the management of public health crises, which has mostly focussed on legislation. The National Expert Panel on Covid-19 at the National Health Commission recruited two legal scholars in February (Fudan Public Health School 2020). In addition to calls for amending the existing Law on the Prevention and Treatment of Infectious Diseases, 17 other legal instruments in the field of public health will be amended or adopted (Wang 2020; NPC Observer 2020).

The particular mode of messaging and emotional mobilisation that the propaganda machine deploys in times of crises is one of disaster nationalism. It is epitomised by a phrase former premier Wen Jiabao famously wrote on a school blackboard in Beichuan, the epicentre of the 2008 Sichuan earthquake: 'Disasters regenerate a nation' (多难兴邦). Narratives of 
disaster nationalism focus on heroic sacrifices of individuals as well as the cohesion of the national community. State media also celebrates the contribution of ordinary citizens more than usual, indicating a more human-centred and participatory approach that scholars have termed 'authoritarian participatory persuasion' (Repnikova and Fang 2018). People's Daily, for example, launched a series called 'Thank You, Every Ordinary Chinese citizen' (谢谢每一个平 凡的中国人) on its social media channel, which quickly became a trending hashtag on Weibo, with over 570 million views at the end of April.

The idea of 'being together in this'-shared feelings of pain, sadness, love, and inspirationcan be channelled towards reinforcing the sense of belonging to the imagined community (Anderson 2006). In his study of the responses to the Sichuan earthquake, Bin Xu (2009) notes how the event became a 'televised spectacle of distant suffering'. With Covid-19 being the first pandemic in the age of social media, the spectacle of suffering, compassion, solidarity, and even boredom is mass produced in a much more personal, decentralised, and spontaneous way. While some videos get censored, there are many others that can serve the purpose of promoting national solidarity, which are quickly picked up by the propaganda apparatus-from moving love stories of dispatched medical workers to the beautiful moment where an elderly patient and a young doctor watch the sunset together. By curating social media content it is possible to add a humane touch to the grand narrative of the 'war' against the epidemic. Through the daily (re)telling of heroic and compassionate stories, and the constant chanting of the slogan 'China, add oil!' (中国加油!), dissatisfaction with the government becomes subordinate to pride for the nation, of which the Party monopolises the representation.

The staging of a national mourning day on 4 April was a crystallisation of disaster nationalism. Having momentarily witnessed the power of mourning after the death of Dr Li Wenliang, what better way to tame this power than by turning it into an official ritual with members of the Politburo joining the rest of the country in mourning together at a designated time of a designated day? At that moment, mourning was no longer destabilising, but patriotic. Meanwhile, other subversive forms of remembering, such as the creation of digital archives of censored articles, continue to be suppressed (Li 2020).

\section{The Perils of Binary Thinking}

The relative success of the Chinese authorities in containing the outbreak in China and the mishandling of the pandemic in other countries, especially in Western democracies, have created an opportunity for the Chinese Party-state to change the narrative both domestically and globally-achieving more success with the former than the latter. In fact, when the Chinese government's efforts to sell its preferred story on the international stage backfired, suspicion and hostility from the West further enhanced nationalism at home.

It comes as no surprise that a hostile international environment boosts nationalism. The Chinese public often assumes that accusations from Western governments are in bad faith, especially when such international actors were silent while many in China were themselves furiously criticising the government for cover-ups and incompetence in late January and early February. The online backlash against the scheduled publication of Fang Fang's Wuhan Diary in English and German is a perfect example of how the debate quickly became distorted by binary thinking, i.e. the assumption of a binary opposition between a homogeneous China and a homogeneous 'West' (The Economist 2020). Netizens who attack her ruthlessly claim that even though some part of the diary might be true and fair, the translation of her work for a Western audience means betrayal and cozying up to 'foreign hostile forces' (境外敌对势力) - a term frequently used by both state media and 
the general public in China to delegitimise local social movements and grassroots activism as stemming from foreign influence.

My previous research on right-wing populist discourse on Chinese social media also highlights this strategy of 'externalising the domestic and internalising the international' in official and popular communications (Zhang 2019). When binary thinking dominates the discussion, any criticisms of the government can be dismissed as intentionally or unintentionally 'helping the enemy'.

The nationalist right in Western societies are informed by the same binary thinking that views the pandemic as a power game with a set of winners and losers. Some resort to xenophobia and racism, which not only hurt Asian communities in those societies, but also help the Chinese government and 'wolf warrior' nationalists to perpetuate the narrative of foreign hostile forces (Shi and Liu 2019). While hawks on both sides feed into each other by scapegoating the foreign other for domestic failures, progressive politics everywhere must resist subjecting democratic struggles against inequality, injustice, and state violence to the logics of right-wing nationalism and geopolitical competition.

Lastly, although nationalistic sentiments now appear to be prevalent in discussions about Covid-19 in China, the diversity of opinions and the creative expression of criticism despite strict censorship should never be underestimated. Representing the country as a monolithic whole and disregarding the agency of its citizens are key components of the binary thinking critiqued above. 


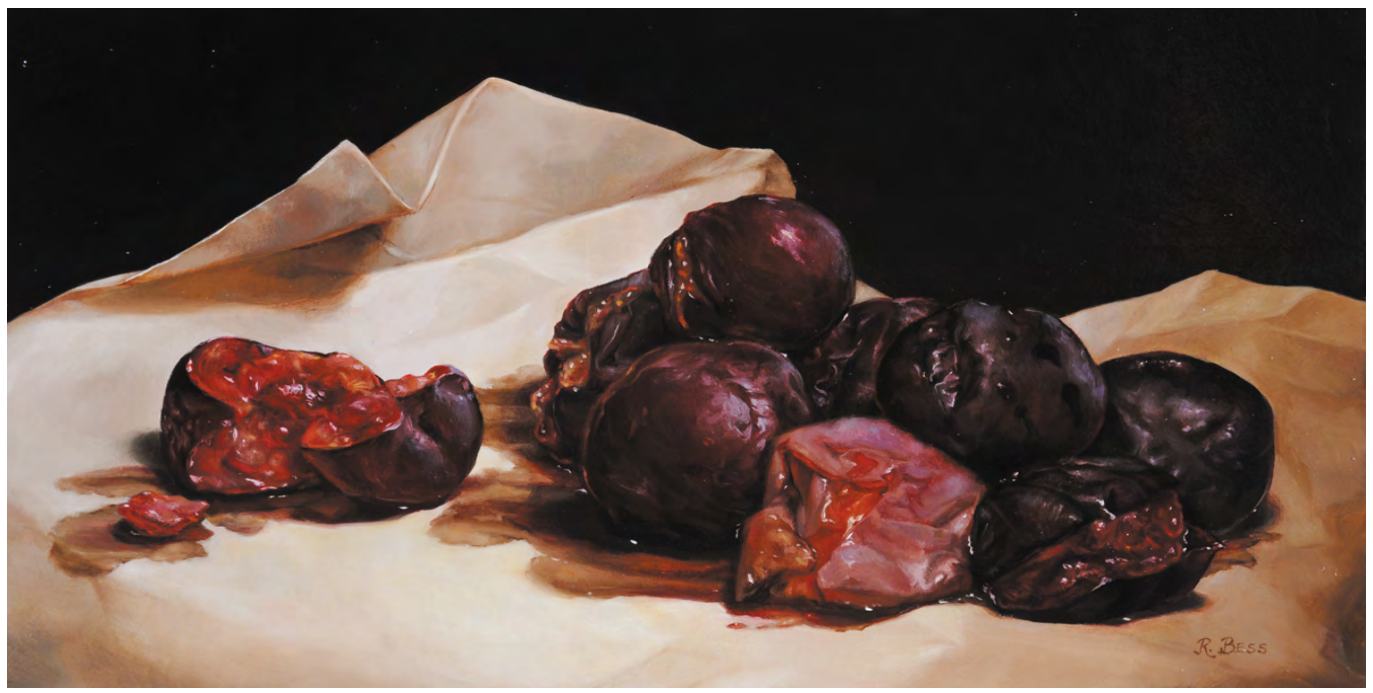

\section{Gratitude \\ The Ideology of Sovereignty in Crisis}

Christian SORACE

$\mathrm{n}$ the midst of the pandemic, expressions of gratitude are everywhere. The appreciation of frontline workers can be heard from the balcony singing of Northern Italy to the nightly applause across New York City rooftops. Even the wolves of my own state of Colorado seem to be contributing their evening howls (Gruenauer 2020). Meanwhile, mental health experts encourage us to remain 'grounded' through gratitude meditations. Psychology Today lists the life-affirming benefits of 'Gratitude in a Time of Pandemic' (Alti 2020), while the Mayo Clinic (2020) enjoins us to 'Discover Gratitude' as a strategy to preserve our mental and physical health. But what is gratitude, and why is it having a moment right now?

Gratitude is the appreciation of our vulnerability and dependence on others. Covid-19 reminds us that no person is an island; we exist in webs of dependence and chains of production that connect us to the immigrant worker who harvests produce, the truck driver who delivers it, and the local cashier at WholeFoods. When these threads-so often taken for granted-become frayed, gratitude is an attempt to symbolically repair them.

\section{Gratitude as an Alibi}

While gratitude appears, on the face of it, to be a constructive response to the current crisis, it can also be an affective alibi for what Saidiya Hartman (2020) refers to as the 'gratuitous violence' of racialised and unequal societies and geopolitical relations-we are not all in this together. As a public discourse, gratitude can easily slip from a recognition of individuals to an acceptance of the systems that reproduce their exploitation. Can one really be grateful for 
a world in which blood samples with Covid-19 antibodies are sold for astronomical prices and the lives of low-wage workers are being risked and sacrificed to maintain corporate profits under the guise of keeping the economy running, rather than imagining what it would take to build a post-capitalist economy that will not destroy the planet? Instead of gratitude for the world as it is, I prefer to think of the risks we take and care we give to each other as instances of solidarity and comradeship in the fight for the world as it could be (Dean 2019).

But to glimpse that world, we need to see through the mystifications of this one. Although gratitude is praised as an ethical disposition, the politics of gratitude ensnares us in a complicated logic of sovereignty, indebtedness, and de-politicisation. Behind its warm edges lies the moralising and silencing accusation of being ungrateful. What does it mean when gratitude is no longer a spontaneous emotional response but something that is asked from us?

\section{Petty Politics}

In the United States, Donald Trump delayed Covid-19 relief cheques, which are critical for many people who have lost their jobs and health care, because he insisted that his signature be on them (Rein 2020)-a tacky reminder of the sovereign giver behind the gift. With a blatant disregard for the temporalities of life and death, he demanded that state governors express their gratitude to him in return for the distribution of life-saving medical resources, such as ventilators and personal protective equipment (Mackey 2020). 'All I want them to do-very simple-I want them to be appreciative. I don't want them to say things that aren't true. I want them to be appreciative. We've done a great job.'

This is also how Trump mercurially conducts foreign policy. Other countries are not grateful enough to the United States for its role and investment in propping up the global order. Lest we are tempted to dismiss this as a quirk of Trump's narcissism and not a feature of American imperialism, recall-recently rehabilitated in public opinion-George W. Bush complaining in 2007 that the Iraqis whose lives he destroyed do not feel sufficiently grateful (Kaplan 2007): 'I think the Iraqi people owe the American people a huge debt of gratitude. I mean ... we've endured great sacrifices to help them ... [and] wonder whether or not there is a gratitude level that's significant enough in Iraq.' As Mimi T. Nguyen (2012) has shown, this is a broader pattern of American culture; after being granted citizenship in the United States, refugees from areas devastated by US imperialism are expected to show 'gratitude' for the 'gift of freedom'.

\section{China as Antithesis?}

While many Americans were rightfully outraged and scandalised by the hysterical demands of our petty sovereign, as a scholar of Chinese politics, I had an uncanny moment of déjà-vu. In my book on the aftermath of the 2008 Sichuan earthquake, I wrote about how Chinese Communist Party officials demanded gratitude from the disaster victims and even launched gratitude education campaigns in the earthquake zone (Sorace 2017). In May 2018, the tenth anniversary of the earthquake was celebrated as a 'day of gratitude' (感恩日).

More recently, on 7 March 2020, the newly appointed Wuhan Communist Party secretary Wang Zhonglin encouraged local residents embarking on their third month of quarantine to 'carry out gratitude education among the citizens of the whole city, so that they thank the General Secretary [Xi Jinping], thank the Chinese Communist Party, heed the Party, walk with the Party, and create positive energy'-a demand that met with outrage and ridicule and was swiftly removed from the municipal government's official WeChat page (Bandurski 2020). 
China's demand for gratitude and recognition for its 'heroic steps to fight the virus' (Wong and Mozur 2020) and aid to foreign countries that are in dire need of medical equipment has also become a new feature of Chinese soft power and global diplomacy (Repnikova 2020). In some cases, China's plea for gratitude has been requited, in scenes such as when the Serbian president kissed the Chinese flag as he welcomed a shipment of medical supplies on the tarmac' (Allen-Ebrahimian 2020). In others, it has caused alarm and furthered antiChina sentiment (Erlanger 2020).

The US government urges Americans to think of so-called Communist China as the antithesis of the United States. It seems to be the one thing the Democratic and Republican parties can agree on, especially as the 2020 presidential election promises to be a spectacle of cockfighting over who is tougher on China (Beinart 2020). But perhaps this discussion of gratitude can provide an occasion to consider the irrationality and absurdity of what we accept as normal in mainstream political discourse. For starters, why, in the midst of this unprecedented political, economic, epistemic, and health crisis, are both of the world's superpowers demanding gratitude?

\section{Popular Sovereignty}

Although it may not be immediately apparent from the other side, in both political systems, the people are sovereign and do not owe the government any gratitude whatsoever. The government rules only at the behest of and on the basis of the consent of the governed. The Chinese writer Fang Fang articulates this point with disarming clarity in the following lines from her blog about life under quarantine: 'The government is the people's government; it exists to serve the people ... Government, please take away your arrogance, and humbly be grateful to your masters-the millions of people of Wuhan' (Bandurski 2020).
In both countries, however, consent is mediated through liturgical rituals of power rather than actively given. In the United States, studies have shown that ordinary citizens have almost zero impact on policy formulation and decision-making (Gilens and Page 2014). In China, the Communist Party governs in opaque secrecy while being occasionally responsive to popular opinion and protest. What no one wants to admit is that both Chinese and American citizens live under the residual aura of the promise of popular sovereignty. As Partha Chatterjee $(2019,113)$ puts it, the people, in other words, were sovereign, without exercising sovereign power.'

One of the ways that aura is maintained is through affective compensation. While $\mathrm{Xi}$ Jinping promises to 'rejuvenate the great Chinese nation', which is really a Chinese version of 'Make America Great Again', Trump seduces Americans into believing that he embodies their stolen sovereignty. The difference between these fantasies of reclamation is that they are carried by opposite trajectories. Trump's demand for gratitude is the expression of an empire in decline, whereas China's demand for gratitude registers the insecurity of the not quite.

Despite their differences, in both China and the United States, gratitude is the ideology of sovereignty in crisis. It calls on us to emotionally accommodate the world on offer, while insinuating that it might be gone tomorrow. Don't ask for a better life, be grateful for what you have. These hysterical demands reveal the insecurity of sovereign power.

\section{Beyond Refusal}

In the poetic lines of a nurse working in one of the makeshift hospitals in Wuhan, gratitude is refused: 'Please don't decorate me in garlands / Don't give me applause / Spare me recognition for work injury, martyrdom, or any other merits' (Wei 2020). Aware of how 
her work at the frontlines feeds back into the Communist Party's self-adulation, the nurse demands to be left alone so she can have a good night's sleep. Her poem is a refusal of the political instrumentalisation of duty, risk, and courage. This sentiment is being echoed among health care workers in the United States who 'don't want glory. We just want our jobs to be protected-in every sense' (Khan 2020).

This refusal allows the poet to 'breathe undisturbed' for a precious moment and makes the sound of 'slogans' and 'propaganda' ring hollow. We can hear the anxious voice of the sovereign calling on us to be grateful. But for how long before its fragility is drowned out in what Fred Moten $(2018,149)$ describes as the 'noisy parallel track to American military/ corporate power' that mistakes itself for a public sphere? Or, silenced in the shrill jubilation of Chinese state-nationalism?

When one is drowning, gratitude can feel like a life vest. To survive the perils of floating in deep ocean, it is natural to conjure and fixate on a shore that brings a horizon into focus-a feeling of anticipation and gratitude for when this will be over, and life can return to normal. But what if normalcy is only a mirage? Sovereign power smells blood in the water, it preys on vulnerability. It extends a hand to the shipwrecked overboard on the condition of reciprocated gratitude. Although we should refuse this call and take what already is collectively ours, not only is refusal dangerous, but it is also not enough.

The problem with refusal alone is that it is an aesthetic gesture which, at most, makes a temporary cut in ideology. But the skin of ideology heals quickly. Refusal, without an organised politics behind it, barely scratches the surface. 


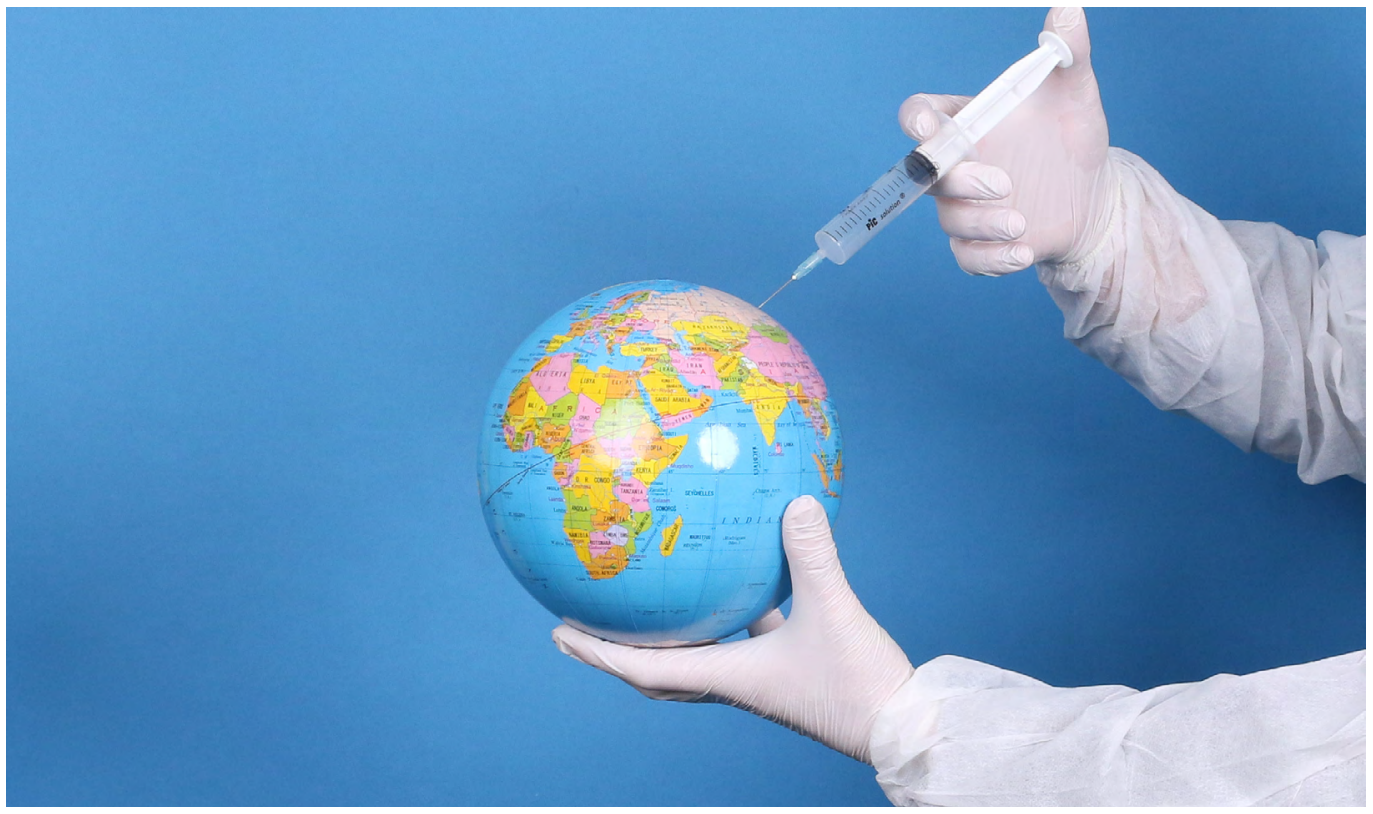

\section{The Surveillance}

\section{Vaccine}

\author{
Surveillance, Censorship, and \\ the Body under Covid-19
}

PC: Jernej Furman.

\section{Carwyn MORRIS}

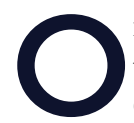

ne of my companions throughout the Covid-19 lockdown has been Gushi.FM (故事FM, storyfm.cn), a podcast that is an oral historical archive, a diverse digital memory bank with stories of poverty, exploitation, coming out of the closet, and much more. At its heart, Gushi.FM is about giving people a voice. The podcast's coverage of Covid-19-related events began on 26 January with the episode 'The Lockdown Diaries of Five Wuhaners' (五个武汉人的封城日记). Over the following 30 episodes, 14 were explicitly about Covid-19, each one of them telling several stories. During this period, Gushi.FM went from being an archive exploring the past to engaging in future-oriented memory work.
By mid-March, I had already heard of foreign friends and students leaving the United Kingdom of their own volition or under pressure from parents due to worries over the British response to Covid-19. Although many people I spoke to feared the journey home and would miss their lives in England, they still left. This 'should I stay or should I go' dilemma was at the heart of episode 341 of Gushi.FM (Kou 2020). The final story of the episode was that of Maoxiaoqian, a student studying in Scotland who by then had returned to China. When Covid-19 began spreading, she 'didn't think it was a big problem' and 'decided not to go back' as she did not imagine 'it was going to go crazy'. Only after the British authorities discussed 
'herd immunity' as a viable strategy did Maoxiaoqian decide to flee to China. Speaking from quarantine in Shanghai, she said:

To be honest, I don't regret coming back to China, because right now the UK government is just, a bit ... terrifying. So, I feel that coming back to China [despite the danger, and sitting close to someone confirmed with Covid-19 on the flight] is a bit safer really. After these two weeks of quarantine are over then ... everything will go back to normal!

Maoxiaoqian had something to say to others who found themselves in a similar situation:

To those fellow students in other countries, I hope they can look after themselves; be careful ... and I hope other countries can take knowledge-based approaches to combatting this problem. I also hope that in China we can get better soon, we're almost at the end of the pandemic. I hope we can add oil and defeat the pandemic!

In the following months, the idea of China being a safer space than the United Kingdom as Covid-19 spread gained considerable currency among broader circles. In another instance, a British evacuee from Wuhan named Matt Raw, who had returned to the UK on a celebrated evacuation flight in late January, had to say: 'It feels a little bit like out of the pot, into the fire' (Murray 2020a). Raw noticed a blasé attitude to Covid-19 in the United Kingdom, and soon felt that they 'made the wrong decision coming back' and 'should have stayed in China', which has done 'everything right' (Murray 2020b). Raw believed that the British government was 'slow to act', that it could have done so much more, and that it 'really only has itself to blame for the situation'. In short, Raw felt he had 'made a bad choice', resulting in him being cared for by 'the same government that wanted us to take public transport back home after the flight [from Wuhan] landed' (CGTN 2020).

\section{Overt Surveillance, Biopolitics, and Ethics}

To help think through Maoxiaoqian's and Raw's experiences and desires, this essay will discuss surveillance, biopolitics, and social imaginaries related to governmental responses to Covid-19. In doing this, I hope to consider why, in a period where virus and censorship converged to create a legitimacy crisis for the Chinese government, technologies that may otherwise be considered repressive came to be desired as technologies of 'vaccination' (Esposito 2008). In this short essay, I do not dispute a responsive-or even reactiveauthoritarianism thesis, nor do I condone mass surveillance, but I wish to consider how governmental responses are interpreted by individuals and eventually gain their support, even if they involve enhanced surveillance. The essence of my argument is that governmental responses to Covid-19 that heavily survey the body-and thus life-are imagined to possess an ethics of care. While individuals may protest against and critique malignant forms of surveillance, the effect of life being saved through surveillance seems to override feelings of anxiety.

In considering this, I start with the idea of surveillance imaginaries. According to David Lyon (2018, 33), 'surveillance imaginaries provide the sense of what living with surveillance entails'. These imaginaries are related to 'shared understandings about certain aspects of visibility in daily life, and in social relationships, expectations and normative commitments. They provide a capacity to act, to engage in and to legitimate surveillance practices' (Lyon 2018, 43). They influence how people-including legislators, surveillants, and those surveilled-imagine what surveillance is and its uses. The key point is that technologies that can be used for surveillance can be imagined in multiple ways. When thought of positively, such technologies are rarely understood in terms of surveillance-they 
become technologies of surveillance only when imagined negatively. The move from covert to overt surveillance is central to a change in imaginaries, and it is when surveillance stops being covert that anxieties emerge. Covid-19 surveillance bucks this trend, with surveillance as surveillance embraced as something that helps the human flourish and that therefore should be embraced-good gaze surveillance.

To think through overt surveillance as a desired practice of governance, it is helpful to consider it as an overt form of 'biopolitical' governance. Biopolitics is concerned with how governance becomes involved in the giving, preservation, and flourishing of lifewhat Foucault $(2003,241)$ calls 'the right to make live and to let die'. Biopolitical practices are often diffuse, performed by a number of institutions and at different scales. Family planning is perhaps the most famous example of biopolitical governance in China, a system supported by neighbourhood surveillance (Fong 2016). In the case of China's Covid-19-related surveillance, the multi-scalar government, tech corporations, gatekeepers, and the self all play a role in this. While not the first case of overt biopolitical governance in China, Covid-19 is affecting the entire population regardless of gender, ethnicity, or class, and has resulted in life-sustaining practices of governance becoming impossible to ignore.

However, China is not exceptional. Overt biopolitical governance is occurring simultaneously around the world and taking heterogeneous forms, with different policy decisions being enacted regionally, nationally, and sub-nationally. This heterogeneity is obvious to anyone following mainstream or social media, and for many people evaluating success is relatively simple: where are people living and where are they dying? Based on these evaluations, ethical judgements can be made on how life is and is not preserved. Judging the ethics of a strategy may also lead to revising one's evaluation of the institution implementing the strategy-often governments. For some individuals, such as Raw and Maoxiaoqian, choices can then be made with regard to which overt biopolitical regime to live under. From this we can begin to understand what ethical positions are emerging during the pandemic.

\section{Good Gaze Surveillance}

For both Maoxiaoqian and Raw, the pandemic meant dealing with the British government. In the early period of the crisis, the British authorities went from being unresponsive to having an unusual response-a strategy of 'herd immunity'. This strategy would let the virus spread in a somewhat controlled way-atrisk groups were told to self-isolate-in order for the population to develop widespread immunity. The hope was that this would enable the country to move beyond Covid-19, protect the people against a 'second wave' through immunisation, and enable the economy to return to normal. This strategy came into place alongside a failed attempt at 'track and trace', the positive name given to Covid-19 surveillance measures.

Both strategies were openly panned by those within and outside of the United Kingdom, and experts doubted whether immunity would even develop (Basu 2020). Not only was there heterogeneity of 'expert knowledge' within the country, but the World Health Organisation (WHO) was also providing its own guidance, and people like Maoxiaoqian and Raw had access to scientific discussions from within China as well. By March, the expert knowledge provided to citizens within China was relatively uncontested (unlike in the UK), and the WHO had publicly supported the approach taken by the Chinese authorities. This is reflected in Maoxiaoqian's and Raw's comments that other governments follow evidence-based approaches. Transnational individuals such as Maoxiaoqian and Raw make decisions about which expert knowledge and state strategies to trust. While uncontested knowledge may play a role in decision-making, it is clear that both Maoxiaoqian and Raw found the British strategy of herd immunity unsettling. As 
individuals, an approach built on the principle of 'letting die', where the death of an individual is fine, could be considered harmful. Either one of them could be the herd's sacrificial lamb. More broadly, in a herd immunity strategy with very little 'track and trace' surveillance, care for the individual seems totally absent. The individual body, and the life it holds, is imagined not to matter to the shepherd.

The British herd immunity approach differs significantly from the Chinese government's strategy, which focuses on surveillance, mobility management, and contact tracing (CCTV 2020). In this strategy, the individual's body takes centre stage, an intimate surveillance that resonated with both Maoxiaoqian and Raw. This way, the individual body comes under intense scrutiny through a number of surveillance systems, including those experienced everyday, such as QR-code and smartphone-based surveillance, as well as systems rarely experienced but extolled in the media, like contact tracing. Chinese health surveillance controls everyday mobility through algorithmic sorting of those most likely to be infected, creating a constant reminder of the body being cared for and human life being extended. In extreme cases, such as lockdowns or quarantines, the body is not just under scrutiny-it is taken control of for the safety of the individual and the rest of society. This is a form of bodily governance both Maoxiaoqian and Raw seem happy with.

These two strategies have different affective dimensions to them, as we can see from Raw's and Maoxiaoqian's responses. Even after failure in January and February, the Chinese response inspired a desire to be seen by the good gaze surveillance apparatus. The British response, on the contrary, inspired fear and regret, and a desire to flee. These strategies for combatting Covid-19 are unequivocally governmental, and they result in Raw's and Maoxiaoqian's antipathy towards the British government and implicit admiration for the Chinese government's response. This admiration is widespread within China, according to recent surveys by $\mathrm{Wu}$ (2020). Furthermore, recent surveys by the Manchester China Institute suggest that this sentiment is shared across a group generally more critical of the government, i.e. international students (Fan et al. 2020; Peter Gries, personal communication on 9 July 2020). Survey responses show that Chinese students in Manchester feel grateful to the Chinese government for their handling of Covid-19, and that they consider Western political systems to be less effective in fighting the pandemic. In other words, the saving of life during Covid-19 made overt surveillance practices something to be desired, not feared, a reversal that in turn influenced how respective governments are imagined.

\section{Censorial Anxieties}

In January and February 2020, covert censorship of social media and social communications-censorship built on surveillance-became overt. A central figure in this was Wuhan-based doctor Li Wenliang. By mid-January, Doctor Li had already shared information that a SARS-like disease had been discovered. Screenshots of his warnings had spread and Doctor Li had been interrogated by agents of the public security, who had demanded he sign a statement admitting to 'rumourmongering'. As the virus spread, Li's fame as a whistleblower who tried to save lives grew, as did anger over how he was treated. Before the end of January, Doctor Li had been admitted to the hospital and diagnosed with Covid-19. On 7 February he died of the disease, leading to mourning and anger across the nation. As the health crisis worsened, messages, posts, and pictures related to both the virus and Doctor $\mathrm{Li}$ (as well as other whistleblowers) were being censored in increasingly obvious ways, and Weixin accounts were being suspended at an unprecedented rate. These events made the censorial system and its malignant foundations impossible to ignore. After all, what had been censored as 'rumours' were unequivocally 'truths', and surveillance-enabled censorship 
was stopping the communication of potentially lifesaving information. In this case, surveillance was hurting, not helping, people.

So impossible was this censorship to ignore that citizens came together to create archives of Covid-19-related censorship, using archival spaces outside of China's digital territory to guarantee the safety of these memories. For the archivists, this memory activism was not to remember their past, but to help those in the future remember their present-an attempt to create a memory of that which was violently erased through a system of surveillance and censorship. As one Chinese memory activist repository notes:

As the censorship in China, no one can conduct free speech right. People will forget something.

This little project remind us, maybe just me, not forget this disaster which CCP (China Communist Party) should take much more responsibility than anyone.

All reports from mainstream media, which some will be erased by CCP someday. But the INTERNET never forget. (Lestweforget 2020)

The practices involved in this memory activism resemble those that I researched in 2017, when data on the forced evictions of Beijing's so-called low-end population（低端人 口) were recorded by hundreds of volunteers and stored outside of China for safekeeping (Morris 2020). In a long-image (长图)-i.e. an article transformed into a scrolling pictureshared on Weibo, the organisers of the 2017 memory project explained that they were doing this because the 'biggest characteristic of this era' is 'the collective amnesia of event after event, some make themselves forget, and others are forced to forget'. They believed that people need 'to put just a tiny bit of effort into keeping these memories alive'. In both 2020 and 2017, when violence towards the body and the violence of censorship became impossible to ignore, any illusions of care were shattered. In both cases, when violent governance was impossible to rationalise away and the illusion of care shattered, spaces for countermovements emerged, which in turn prompted the authorities to detain those involved in memory activism projects ( $\mathrm{Li} 2020$ ).

The surveillance-enabled censorship of early 2020 stopped the spread of information about a deadly disease, rather than stopping the spread of the disease itself. Surveillance and censorship went from being actions that happened far away or to bad 'rumour-mongers', to becoming part of an overt biopolitics that was causing harm. In this case, the harmful censorial practices made the government an unethical institution malignant to life, and censorship came to be seen as a biopolitical practice to be contested. During this potential 'Chernobyl moment' (Zhang 2020), the rationale for surveillant intrusion into daily life became more difficult to articulate. Due to this, a space for political change appeared, with some commentators suggesting that an emerging crisis of legitimacy could rock the $\mathrm{Xi}$ Jinping administration (Haass 2020; Pei 2020). In the end, aided by the detention of those engaged in contentious politics, this space was not filled by reformers or revolutionaries, but rather by ethical surveillance practices. Through these practices-alongside largescale opinion management-the palpable anger of January and February was alleviated, government legitimacy increased, and algorithmic, application-based governance further normalised.

\section{The Surveillance Vaccination}

In his reflection on the relationship between Nazism and homicide, Roberto Esposito (2008) uses the language of immunisation. Esposito argues that for the Nazis homicide was an instrument of regeneration, a practice that became essential to saving and renewing the vital forces of Germany. This was a horrific vaccine for an imagined disease. Vaccines are 
hostile forces brought into the body to protect it against disease and make it stronger. But, there is a chance that vaccines can turn against the host and cause harm, eventually leading to the death of the body. The Chinese case is not nearly as entrenched in the biological as Nazi Germany-although the biological has been a key part of governance, and biological metaphor has been creeping into recent urban policy (see Sorace 2017; Haas 2017; Tu et al. 2019)but Esposito's ideas can still be productive in understanding the surveillance described above. The 'body' being protected may be the intimate scale of the human body, the city, the nation, or even the institutional body, such as the Chinese Communist Party. In this case, the government is using the vaccine of surveillance on the body-the Chinese society-of which it is a part.

In the above cases, surveillance is a vaccine for a number of bodily problems, and imagining surveillance as ethical or malignant depends on the body's reaction to it. Successful vaccination can keep the government in power, but the vaccine can also produce an autoimmune response. Both of these reactions occurred in China during the Covid-19 crisis. Surveillance eventually enabled human life to flourish in the face of death, resulting in increased governmental legitimacy, but, before that, malignant surveillance was central to a 'Chernobyl moment' that possibly threatened the very survival of the Party-state. Through censorship, the vaccination produced an autoimmune response. Why did this occur? One reason is that through this inoculation, the government came to perceive a greater viral threat within its body, i.e. viral politics. Viral politics is a dormant virus that could become active and potentially result in the death of its host, i.e. the government. Censorship is designed to keep this virus dormant, but this may result in other viruses spreading. In January and February 2020, what were believed to be symptoms of viral politics-rumour and discontent-were eliminated through the surveillance vaccination. However, due to overt censorship, malignant censorial practices became obvious to many. Impossible to ignore or rationalise, these practices were instead contested.

Following this, and perhaps unintentionally, a successful short-term vaccine for viral politics was found-good gaze surveillance. The vaccine included a lifesaving gaze towards the individual's body and life desired by both Maoxiaoqian and Raw, stopping both Covid-19 and viral politics. Thus, the space for political change that emerged due to malignant surveillance was filled by an ethics of care. My research on the contested evictions of the 'lowend population' in 2017 showed that malignant surveillance can bring an end to (memory) activism, but the case of Covid-19 shows that a good gaze surveillance vaccine can also halt viral politics. The long-term effects of an ethical surveillance vaccine are still unknown, though ongoing research by Wang (2019) suggests that individuals are supportive of surveillance systems deemed to have ethical dimensions, such as social credit systems. Still, the effects of the malignant censorship that cost lives in January and February 2020 have not been dealt with. This malignant censorship affected many, and the long-term impact it will have on how surveillance and the government are imagined remains to be seen. 


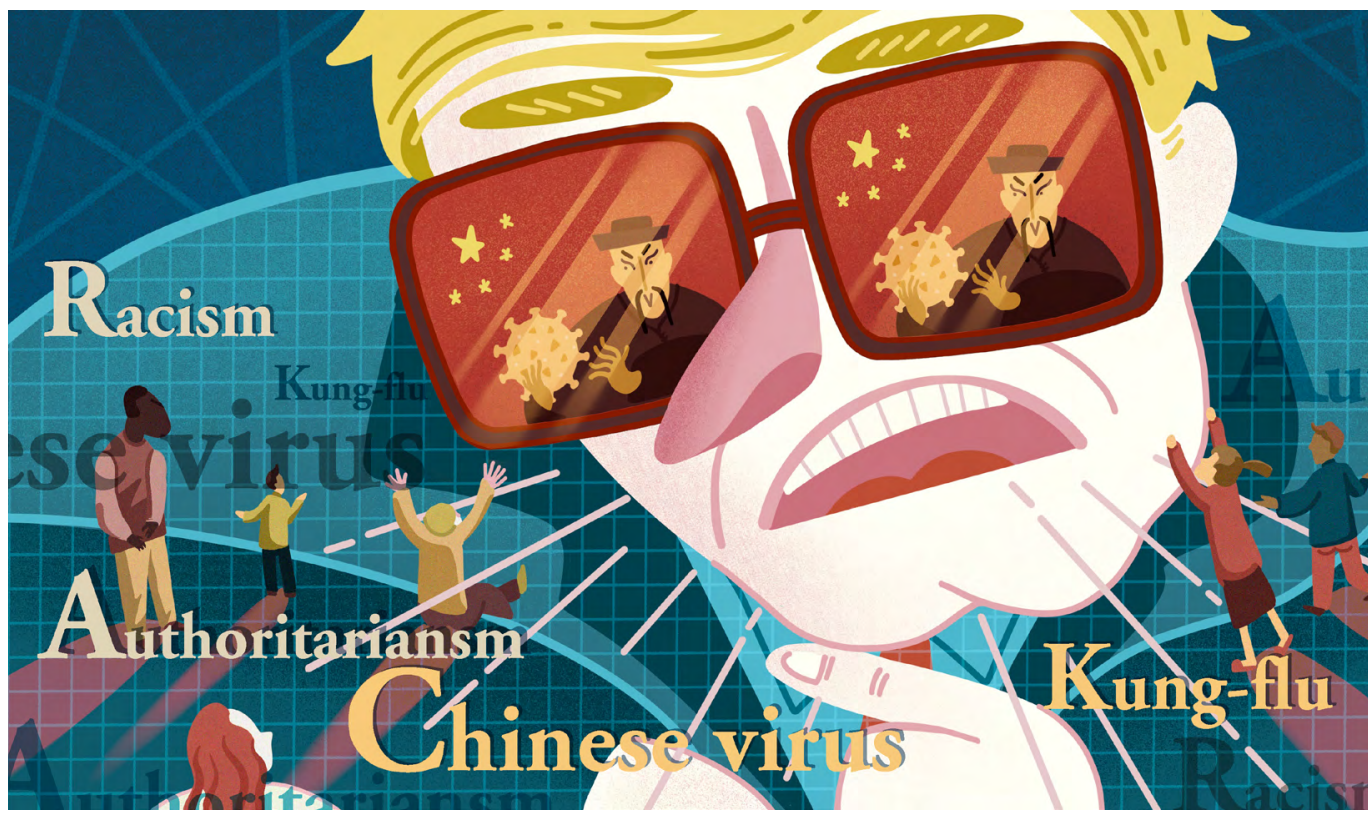

\section{Sinophobia} Will Never Be

the Same after Covid-19

Flair Donglai SHI
Artwork by the illustrator Qin Chuichui (秦垂垂) specially commissioned by the author to accompany this article. PC: @andrea._q (Instagram) $\checkmark$ ust hours before I started writing this article, US President Donald Trump hit the headlines again for calling Covid-19 'the Chinese virus' and 'Kung-flu' at a campaign rally in Tulsa, Oklahoma (The Guardian 2020). He has been using such racially codified terms in public appearances and on Twitter since March, right after Covid-19 became much more than just a viral outbreak in China (VialaGaudefroy and Lindaman 2020). Although there has been major backlash against him in Asian American communities, as well as from Asian countries and communities around the world, a major distinction between these two groups, which are often lumped together under the racialised category of 'Asian' in US media and public discourses, is that while US citizens of Asian ancestry can vote, Asians without citizenship (including permanent residents) cannot. Trump's tactic for appeasing Asian Americans inevitably capitalises on this very fact. On 12 May, he tweeted: 'Asian Americans are VERY angry at what China has done to our Country, and the World. Chinese Americans are the most angry of all. I don't blame them!' (Yam 2020). What he attempts to do in this statement is drive a wedge between Asian Americans and non-American Asians, purporting to speak on behalf of the former. He wants his Asian American voters to be nationalistic according 
to his exclusive definition, and to distance themselves from China. In other words, Chinese Americans may strive to become the good exception within populations racialised as 'Chinese' by constantly emphasising their Americanness. This is the Trumpian vision of an ideal, well-behaved Asian America and some of the very few politically visible figures from that community, such as Andrew Yang, the social entrepreneur who ran as a candidate in the 2020 Democratic presidential primaries, do not seem to-or dare to-disagree (Zhou 2020).

If Chinese Americans reject this Trumpian tactic and reaffirm their commonality and solidarity with their families and friends in China, they risk confirming and perpetuating the stereotypes of the Chinese being inscrutable, unassimilable, and untrustworthy perpetual foreigners whose allegiance is fundamentally questionable (Tuan 1998). If, conversely, they adopt the Trumpian framing, they go down the unavoidable path of performative nationalism, which means being pressured to make endless assertions of American exceptionalism and superiority over other-especially non-white-nations whenever they participate in discussions about the virus. Such a loyalist dilemma is not limited to Asian Americans. Chinese diasporas living in most white-majority Western societies constantly face similar suspicions. For most of us living in a range of different diasporic conditions, including many of the international students studying in the West, the renunciation of our racialised connection to the 'foreign'in this case Asia or China-and the subsequent unapologetic declaration of a seemingly de-racialised form of Western nationalism are inherently reductive and self-defeating choices to make. After all, the majority of racist incidents targeting 'Chinese' peoples in the West have been based on superficial phenotypical distinctions rather than the victims' nationalities, which is why we often see reports about East and Southeast Asians with no connection to China also suffering from the discrimination and violence brought about by Sinophobic sentiments since the onset of the pandemic (Iau 2020; Boonlert 2020). If racists see no national distinctions but only a generalised and imagined 'Chinese look', why should anti-racist struggles against Sinophobia be confined within the boundaries of white-majority nations in such an a priori fashion? For this reason, I wish to put forward an internationalist proposal: the perpetual foreigner stereotype is worthy of preserving and perpetuating for diasporic groups no matter where they are, because there is nothing wrong with being foreign.

\section{Embracing the Foreign}

The mutual harms of racism should not be overlooked just because its purported targets are foreign rather than local. The spread of Covid-19 has been accompanied by a surge of racist incidents around the world, and people who 'look Chinese/Asian' are among the most attacked. Wikipedia (2020) even has a whole page documenting these incidents and the list is still expanding. Considering how the physiognomic and biologic discourses of 'Mongoloid' and 'Yellow Peril' have been declared 'mere relics of a bygone era' in most Western societies as they take pride in their progressive and multicultural appearances, this surge of crude phenotypical racism may seem like a surprising retrogression (Lynteris 2018, 54). However, for most East and Southeast Asians living in the West, Covid-19 has merely brought to the surface beliefs that had always been lurking in the racialised social structures of their everyday experiences.

For instance, back in February, when my Chinese British friends and I were spat on for walking down the streets wearing face masks, the aggressor certainly did not care whether we had a British passport, a Chinese passport with the right to permanent residency in the United Kingdom, or a brand-new Singaporean passport without stamps. The colour 'yellow' may be rarely used nowadays as a racialised 
designation, but its reductive racist effect is well preserved and demonstrated in such antiAsian incidents based on an imagined 'Chinese look'. It was this perceived foreignness that lumped us together on that occasion, and it is in these moments of heightened antagonism that the affective and political bonds of panAsian or even pan-people-of-colour solidarity can be formed and cultivated. This is also why I cannot help but feel a strong sense of double alienation and disappointment whenever I join academic panels or general discussions on anti-racist struggles and find that the Chinese British or Asian American commentators often begin their arguments by saying: 'I was born in this country.' On such occasions, I often find myself asking, rhetorically: 'I was not born here, and I do not and probably will never have a British passport. Does this mean I should simply go back to my own country when the racists on the street tell me to?' If the legitimacy of anti-racist struggles has always to be built from such birth qualifications and national identity confirmations, they can easily fall back into a narrow-minded nationalist framing that excludes many other groups victimised by the same Sinophobic sentiments, and thus forecloses possible solidarities across national and racial divides.

In other words, a nationalistically conditioned multiculturalism is inadequate in tackling pervasive Sinophobia that sees no national boundaries and distinctions. On the one hand, there are certainly similarities between the nineteenth-century sentiments related to the Yellow Peril and the Sinophobic assaults on Asians following the Covid-19 outbreak, as they both manifest as daily practices of physical attack and verbal abuse targeting Asians regardless of their ethnic background or country of origin. On the other hand, Sinophobia at the discursive level will never be the same in the post-pandemic era as far as the People's Republic of China (PRC) is concerned, since the nation is no longer a semi-colonised empire in decline but a rising technological and economic superpower. The kind of multiethnic American nationalism instigated by the Trumpian vision of a divided Asia/America means that, in practical terms, foreign countries and peoples can be blamed and attacked without worrying about accusations of racism, since a seemingly progressive American exceptionalism could always justify itself by citing support from a related hyphenated community at home in opposition to external nation-states and the populations they encompass (Andersen 2018).

Therefore, contemporary Sinophobia in the West is, in essence, a specific form of xenophobia-a tactic of fear- and hatemongering targeting the foreign. Based on this important recognition, my advocacy is this: since nationalism does not build a genuine and effective coalition against racism, Chinese communities in different kinds of diasporic conditions, together with their local and international allies and friends, must embrace the foreign. Embracing the foreign is not in conflict with efforts at localisation. On the contrary, it is based on the recognition that the foreign is part of the local, and local politics do affect and are affected by the foreign living among us. Moreover, embracing the foreign does not mean becoming unconditional apologists for all the decisions made by the Chinese government, but it does require us to stop treating anti-Chinese sentiments and incidents as merely domestic issues in the West and be more sensitive and attentive to the international aspects of Sinophobia, especially those seemingly progressive discourses around China, the specifics of which I discuss in the following sections.

\section{Ruptures and Continuity}

When I say that Sinophobia will never be the same following the Covid-19 outbreak, I do not intend to mark 2020 as presenting any kind of deterministic rupture from all the antagonistic sentiments and discourses against China and the Chinese in the West since the late Qing period. To be more precise, it is the liberal 
disavowal of Sinophobia that will not be the same as the pandemic exposes liberalism's long tradition of complicity with xenophobia and modern empire-building (Lowe 2015). There is certainly a discontinuous yet interconnected genealogy of dominant Sinophobic tropes in the West-from the Yellow Peril of a decaying dynasty, to the Red Scare of a brainwashing Communist regime, to the neo-Orientalist struggle against an authoritarian superpower (Yang 2010; Gries 2014; Ooi and D’Arcangelis 2018; Visco 2019). With this genealogy in mind, I would suggest that Covid-19 has intensified a preexisting trend of Cold War ideological opposition to China to the degree that dominant-both conservative and progressiveliberal-discourses in the West have stopped expecting the country 'to be normal like us', which Daniel Vukovich $(2012,23)$ calls 'the becoming logic'.

This logic operated in Western-centric expectation and hope: the hope was once that market reforms would entail political reforms, leading to the eventual collapse of the authoritarian one-party state and China's transformation into a multiparty liberal democracy (Anderlini 2013). However, the fact is that, since the Opium Wars, China has never been more powerful than it is today, and there is now an increasing sense of recognition both in China and abroad that the country will not only keep exploring its own model of political and economic development but may as well surpass the West in many aspects of modern life-infrastructure, technology, e-commerce, cultural industries, etc.-regardless of or, even more scarily for Western liberals, because of its sociopolitical organisation and management. In other words, rather than becoming the silent and conformist 'model minority' in the international order dominated by Western liberal democracies, China's rise is seen through the stereotype of the Chinese as 'unassimilable' foreigners who will always cause disruptions in the West as well as to Western governance and blueprints of the world. In other words, as the becoming logic fails to realise its promises and predictions, its reversal, the century-old idea of immutable Orientalist difference, is staging an alarming comeback.

In this sense, the Trumpian advocacy for Asian American nationalism is but a preemptive move that renders Sinophobic attacks against China politically correct for a range of his constituencies across the conservative/liberal divide in American society, or even morally justified in universalist terms when the Chinese government or specific sociopolitical events in China become the primary targets of criticism, albeit always tainted with subtle racialised undertones. Even without Trump, the conservative and liberal camps in the United States and the United Kingdom already tend to be united in their consensus that it is definitely not racist if the China blame game is played by focussing on issues of censorship, racist incidents within China, and Chinese hegemony towards other Sinophone territories (Promise $\mathrm{Li}$ 2020). While these are complex issues that certainly warrant grounded analyses and targeted criticism, Western critical discourses surrounding these sensitive areas should not be exempt from (self-)reflections on Orientalism and critiques against Sinophobia, especially if they manifest in totalising languages that may easily escalate into a new Cold War that demands or dismisses ideas purely based on a binary logic of incommensurable political allegiances-e.g. either 'pro-China' or 'antiChina', either the 'West' or 'China', either 'Sinophone' or 'Chinese'.

Against an already-risen powerful PRC championing globalisation coupled with a much more authoritarian mode of domestic governance, the resurgence of Sinophobia following the Covid-19 outbreak has acquired new legitimacy through its integration into sophisticated layers involving international and inter-racial politics. If diasporic communities are serious about standing together with the foreign to tackle this new wave of Sinophobia, always starting the anti-racist conversation with 'I was born here' is counterproductive. The first step towards embracing the foreign is 
to become aware of the international aspects of racism involving political judgements against other countries. In the case of Sinophobia, the analyses of systemic racism should not be confined to the presentation of the sufferings of individual Chinese people living in the West but must be extended to the examination of biased Western discourses and images of the nation of China. In the rest of this essay, I describe and explain three prominent ideological slippery slopes that constitute this new post-Covid Sinophobia, which have made it increasingly difficult to separate Western anti-racist, anti-authoritarian discourses from their own Orientalist tendencies and effects.

\section{The Wane of Western Triumphalism}

Firstly, post-Covid Sinophobia has finally exposed the unproductive and hypocritical aspects of the dominant form of anti-PRC rhetoric built on the neo-Cold-War binary of democracy versus authoritarianism. As the 'Coming Collapse of China' thesis keeps collapsing year after year (Chang 2001, 2011, and 2020), Western triumphalism following the end of the Cold War has inevitably started to wane, being replaced with the increasing sense of unease and fear that the Chinese Communist Party's authoritarian control will actually prove to be a working method of modernisation and development, eventually spilling over and contaminating the democratic 'Free World' (Human Rights Watch 2020).

From late January to mid-March, when most cases of Covid-19 were still confined to mainland China, numerous articles appeared in mainstream Western media lambasting Chinese authoritarianism and censorship as the cause of the outbreak (The Economist 2020; Tufekci 2020). Not only did they highlight the silencing of $\mathrm{Dr} \mathrm{Li}$ Wenliang, they also criticised the unprecedented method of large-scale lockdown as 'violating human rights', continuously doubting its efficacy (Buckley et al. 2020; Eve 2020). The subtext was clear: Covid-19 would never have happened in the democratic West, and even if it did, it would have been handled much more effectively and humanely than it was in authoritarian China. Such positional superiority was taken for granted until the turn of events since March quickly proved the opposite. This is what Belinda Kong (2019, 380) terms 'bio-Orientalism', which had already manifested thoroughly during the SARS outbreak in 2003, when Western media and public discourses portrayed China as 'the site of exotic and unhygienic culinary traditions as well as authoritarian secrecy, a lethal combination' threatening to break 'the boundary between first-world health and third-world contagion'. As Marius Meinhof (2020) points out in a poignant summary, such dominant bio-Orientalist discourses:

(1) perceived events through the framework of liberal/authoritarian, (2) read the outbreak as a proof of the inevitable failure of the non-liberal, (3) delegated the virus into the sphere of the authoritarian other, (4) muted Chinese voices by making all statements from within China suspicious: Official Chinese case numbers, death rates, reports on successful containment strategies-always there would be someone to suspect manipulation by the authoritarian regime, which made it difficult to act upon these information.

This bio-Orientalist Sinophobia's unreflective totalisation of a preconceived antiauthoritarian ideology did a huge disservice to everyone living in Western societies, not just the Chinese diasporas. The blind faith in idealised versions of liberal democracy bolstered by this conjecture of the authoritarian Other has weakened Western vigilance against the virus, and in extreme cases, resulted in blatant racism that designates the virus as 'only affecting people of the yellow race' (Kang 2020; The Storm Media 2020). The complacency has 
also hampered much-needed scientific as well as political collaboration with China, and the unwillingness to take seriously Chinese methods of containing and treating the virus backfired in cataclysmic proportions (Zhang and $\mathrm{Xu} 2020$ ).

Rejecting the authoritarian/democratic binary embedded in post-Covid Sinophobia does not mean that we cannot criticise the Chinese government's policies and actions. On the contrary, a much more nuanced case-bycase method of critique is urgently needed in order to avoid distorting the purpose or effect of critique into self-indulgent mystification of Western superiority. In other words, to steer clear of such Sinophobic tendencies, we must constantly ask ourselves: are we critiquing China because we have the best interests of people in China at heart, or because we just want to make ourselves feel good that we are not Chinese or not living in China? Common Asian American reactions based on birthplace and political allegiance can hardly confront this sophisticated anti-authoritarian Sinophobia, and we must learn to defuse and re-appropriate the Othering nature of many of the dominant China-watching discourses in order to avoid traps of hypocrisy, which can be so enticing in their superficial tone of enlightenment and progressiveness.

\section{Triangulations of Anti- racist Competitions}

Secondly, post-Covid Sinophobia is not confined to the racial binary of white versus yellow anymore, and actively incorporates antiBlackness into a complex triangulation of (anti-) racist competitions that set the postcolonial, progressive, and multicultural West apart from racist, backward, and monolithic China. In such a racial triangulation, the Chinese are often presented as trapped in the West's own racist past without any historical contextualisation of their own history of contact with people of African descent. Put more simply, one of the popularised Sinophobic arguments is now this: not only are the Chinese very racist against Black people, their racism also manifests in abhorrent ways that we in the white-majority societies have long overcome.

Nothing illustrates how this sophisticated anti-racist Sinophobia-how oxymoronic!works better than many of the progressivesounding Western media reports on the problematic treatment of African migrants in Guangzhou in April. Toward the end of March after the domestic situation was more or less brought under control, the Chinese government shifted its focus on to international border control to prevent Covid-19 from travelling back to China. This shift certainly brought much pressure on local governments in cities like Guangzhou, which hosts a significant foreign population, especially African nationals. Therefore, when news and images started circulating on social media showing Black residents being evicted from their flats by their Chinese landlords, Guangzhou McDonald's putting out notices of 'No Blacks shall enter', and anti-Black hate speeches proliferating on the Chinese Internet, the outrage was expected, understandable, and much needed (BBC 2020; Hangwei Li 2020). Make no mistake here: these incidents were motivated by xenophobia and must be condemned as such. It is well documented and researched that anti-Black sentiments in the PRC date back to the 1970s, and Africans in Guangzhou continue to face racism, while the most outrageous racist attacks have been posted online by nationalistic Chinese netizens who do not live anywhere close to the Black communities (Sautman 1994; Cheng 2011; Lan 2017; Huang 2020). What is troubling is how these issues concerning the welfare of Africans in China are often picked up by Western media to demonise the PRC as an outstandingly racist nation mired in exceptionally backward interracial cultural politics.

For example, a video explaining these anti-Black incidents in Guangzhou went viral on Facebook in May, in which the host puts forward the thesis that "planet China is 
racist' (Project Nightfall 2020). Instead of historicising anti-Black ideologies in China as part of the nation's race to become modern after being forcibly incorporated into a racially stratified system run by Euro-American imperialism (Dikötter 2015; Lan 2017), the video presents a bricolage of racially codified cultural phenomena in contemporary Chinese society to emphasise both the pervasiveness and the severity of Chinese anti-Black racism. They include animalising images, Blackface performances, and the literal whitewashing of Black bodies in commercial advertisements. As a result, this portrayal of a hyper-racist country is totalised into 'planet China'. The accusatory agenda of the video's anti-racist critique is achieved by instigating kneejerk reactions of shock and shame from its Anglophone audiences, which are evoked by the indelible historical memories of similar racist practices in Western societies. The effect is almost immediate: it confirms the belief that 'planet China', despite its political clout and economic development, is culturally stuck in 'our' past, and unlike 'us' in the multicultural progressive West, the Chinese offer no compassion for, or solidarity with, Black people. Rather than pointing out the obvious fact that Blackface and whitewashing in contemporary China may have a different genealogy and produce different social-still harmful and offensiveeffects than in, say, the antebellum American South (Castillo 2016; Black Livity China 2018), the video foregrounds Chinese anti-Blackness as not only anachronistic but also particularly unforgivable given the progressive camp's antiracist criticisms against anti-Asian sentiments within Western societies. Similar to the rush to condemn authoritarianism, Western media discourses tend to grab every opportunity to claim the moral high ground over the PRC around topics of race and racism.

The proliferation of such biased media discourses may affect their readers' reallife perceptions and interactions with PRC nationals as well, who are often expected to speak and explain for 'their country'. To offer a personal example, when I shared reports on anti-Asian incidents in London or articles supporting the Black Lives Matter movement on social media, some of my British friends responded by sending me videos and reports from the $B B C$ and The Guardian on racism against Blacks in China (Burke et al. 2020). They said, in an offended reaction of white fragility and whataboutism, that they found it funny that a Chinese person would accuse the West of being too racist against Blacks while China is 'colonising' the entire African continent with the Belt and Road Initiativeanother totalising claim long challenged by scholars working on issues related to the Chinese presence in Africa (Yan and Sautman 2017; Yan 2020). Since most of the grassroots reports and organisational materials calling for Chinese support for Africans in Guangzhou can only be found in Chinese, I could not show them that many Chinese people disagree with such xenophobic practices as well and are doing all they can to offer concrete help to their African neighbours and friends on the ground (Douban 2020). There is also a host of African voices sharing their experience about living in China, including YouTubers like Wode Maya and Fyjo Molly, but they are rarely commented upon by Western scholars and critics, and are generally ignored in the major media outlets. When Sinophobia takes on anti-racist tones in the post-pandemic era, it is more important than ever that those of us seeking to build diasporic and pan-coloured solidarities equip ourselves with the knowledge and critical capability to contextualise each criticism of racism. Whataboutism does not help with addressing the multiple and intersecting systems of oppression at hand (see Franceschini and Loubere's op-ed in the present issue). antiBlack incidents in China should not be cited to excuse anti-Chinese incidents elsewhere and vice versa. As paradoxical as it may sound, the contextualisation of racism and criticism against racism is necessary to build solidarity across racial and national divides regardless of one's location and identity. 


\section{Sinophobia in Sinophone Communities}

Finally, just as anti-Blackness is not confined to white majority societies, Sinophobia can be found in abundance in Sinophone communities outside of mainland China. Despite Western media's portrayal of Sinophone regions like Hong Kong and Taiwan as perpetual victims of Chinese hegemony, the complex cultural politics manifested in these places cannot be reduced to another binary of oppressive centre versus marginalised peripheries (Shi, forthcoming 2020). Sinophone mockeries and racialised memes against China proliferated online following the outbreak in Wuhan. Anti-mainlander YouTube channels such as Hong Kong Golden Music (高登音悅台), which had been a key driving force in the 'anti-locust' campaigns in the city throughout the last decade-with 'locusts' (蝗虫) being a derogatory term for mainland Chinese in Hong Kong (Yan and Sautman 2015; Ong and Lin 2017; Carrico 2018)-enjoyed a revivalist surge of popularity after producing parodic songs like 'New Pneumonia, Countrymen Dying' ( 新型肺炎国人渐已死) and 'Little Nigger' (小 尼哥) targeting both the PRC and the World Health Organisation (HKGolden Music 2020a and 2020b). In Taiwan, an adaptation of Jolin Tsai's hit song 'Wonder in Madrid' (马德里不 思议) titled 'Mother Pneumonia Wonder' (马的 肺炎你真不思议) includes the line 'China has always been sick' (中国本来就有病) and has had over 1.5 million views on YouTube (Caiyiling 2020). Not surprisingly, when Jolin Tsai released a new song, 'Fight as One', with Hong Kong singer Eason Chan, they were widely lampooned by Hong Kong and Taiwanese netizens for participating in brainwashing Chinese propaganda (Chan and Tsai 2020). Since the establishment of the Communist government on the mainland, Hong Kong and Taiwan's cultural similarity and affinity with the PRC have always been overwhelmed by the political and ideological divide between China and the liberal West, whose anti-authoritarian assertions of progressive superiority often materialise in highly inflammatory and discriminatory terms on these Sinophone frontlines (Law 2000; Chen 2010; Li 2019). Such neo-Cold-War divides will only intensify in the post-Covid era, making Sinophobic sentiments and discourses ever more difficult to detect and challenge.

\section{Building New Coalitions}

The anti-authoritarian, anti-racist, and Sinophone aspects of post-Covid Sinophobia demand transnational awareness and crosscultural sensitivities that cannot be nurtured in any single nationalistic mode of thinking. The concept of ethnic/racial minority is usually defined in relation to nation and sovereignty as given concepts and lived experiences, but minority subjects also travel across national boundaries and in this process become the 'foreign'. For example, when Chinese Americans travel back to China, they cease to be ethnic minorities in that context and thus may need to reflect on their own complicities with the dominant structures and discourses around them, or they may encounter new intersectional situations that afford them unexpected means of coalition-building based on more cosmopolitan outlooks, such as solidarity with other 'foreigners' who are not born in China and do not speak Chinese well. The exploration of innovative ways of responding to the new wave of Sinophobia has just begun, and embracing the foreign, in China, the West, and anywhere else shall serve as a constant reminder against nationalism in all of its forms, conservative or liberal. 


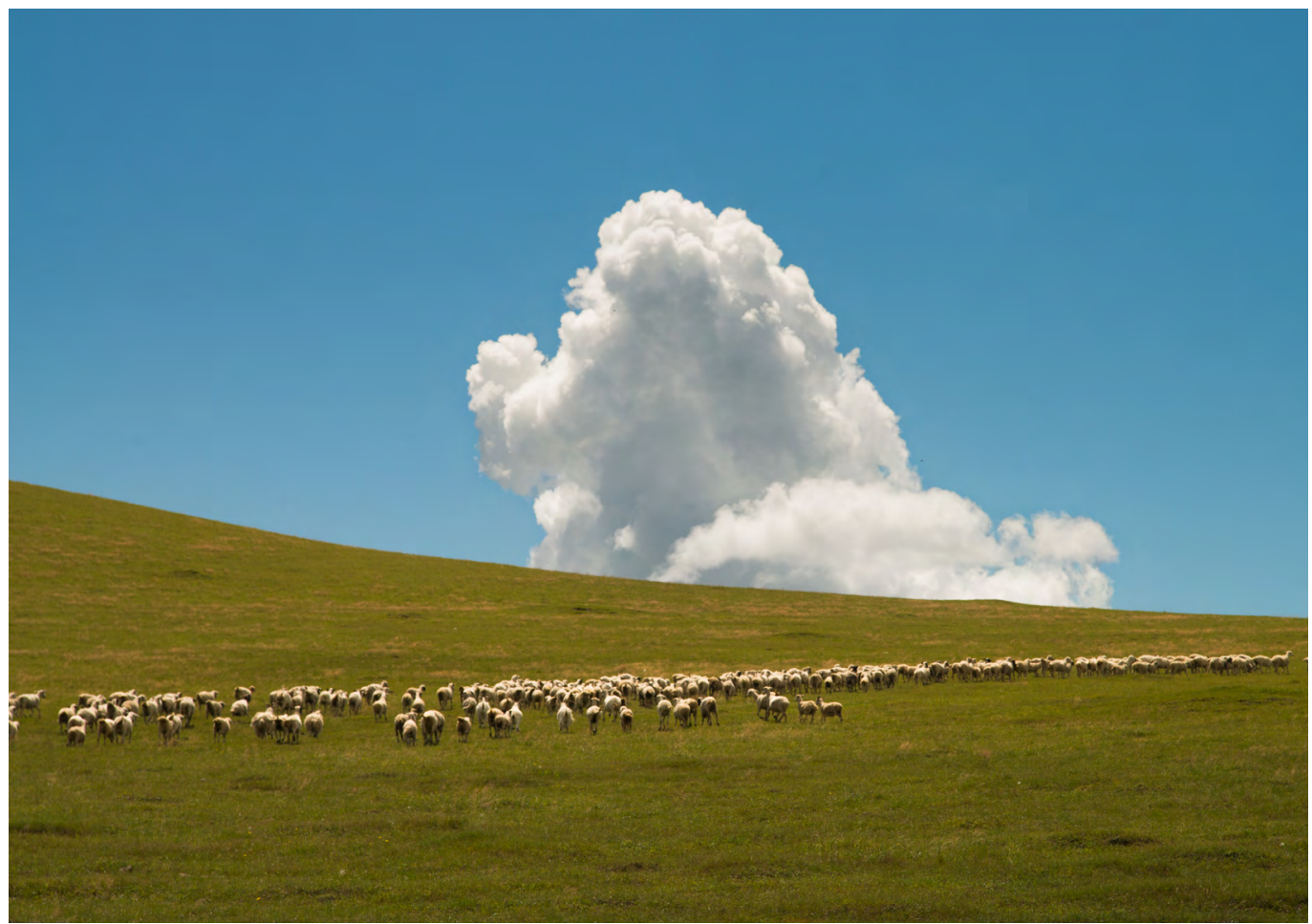

\section{Breathing What Air?}

Cloud and Sheep, Inner Mongolia. PC: Jonathan Kos-Read.

\section{Reflections on Mongolia Before and After Covid-19}

\section{Rebekah PLUECKHAHN}

T he rush of government responses to curb the spread of Covid-19 throughout different parts of the world has highlighted existing inequalities in stark terms, as well as facilitating the emergence of new ones. In urban areas, lockdowns, while very much effective in reducing the spread of the virus, have formed a rapid, unprecedented, and unforeseen (in most spheres) rupture. Lockdowns, as Arundhati Roy (2020) writes, have 'worked like a chemical experiment that suddenly illuminated hidden things'. For many, though, these 'hidden' inequalities were well known before Covid-19 began to spread. In most places, certain segments of the population, including those in precarious work, insecure housing, or with existing health conditions, have borne the brunt of the effects of the virus on the body, as well as many of the reverberating effects of the implementation of responses adopted to curb its spread (Fassin 2020). The diffusion of Covid-19 has demonstrated-if 
it had not already been evident-the need to invest in equitable health and other essential infrastructures and services in preparation for major crisis events.

Focussing on legacies of inequality opens up a longer durée-the 'before' Covid-19, as well as a wider perspective on the many rapidly changing events now unfolding each day. While there will possibly be new paths opened by these virus-eliminating strategies that may reshape our political spheres, our senses of a collective social responsibility, or government welfare programmes, it has yet to be seen whether the weights of 'previous' unequal wealth distributions and infrastructural provision will be too cumbersome to reshape at times of such rapid change. In the meantime, there is a chance to zoom out, as it were, to consider what kinds of 'life' are being preserved by, or neglected in, attempts to combat the virus. In the examples I refer to here, drawing from ethnography in Ulaanbaatar, Mongolia, and reflections on recent developments in Australia and elsewhere, the lungs and surrounding air are paramount. So, too, is the preserving of life. But whose life, and what air remain striking questions both 'before' and 'after' this current age. These questions, like the virus itself, emerge from the hyper-connectivity and diverse types of accumulation that form some of the inherent features of late capitalism.

\section{Rethinking Hyper- connectivity and Isolation}

Between 2009 and 2013, mobility and connectivity were reshaping Mongolia's economy. Flows of investment into mining infrastructure in southern Gobi Desert regions gave rise to heightened investment in secondary industries and construction in the urban capital, Ulaanbaatar. Longplanned-for systems of housing finance were launched. Trucks laden with coal barrelled one after another through the desert on open stretches of road towards Mongolia's southern border with China, fuelling China's need for coking coal and helping to support booms in urban construction. Connectivity formed types of economic stimulus that opened new possibilities, giving rise to complex forms of financialisation and boosting personal ambitions and profits.

This connectivity was also an impedimentMongolia's economy was extremely sensitive to a subsequent downturn in commodity prices, China's lessening need for coal, and a withdrawal of different forms of financial investment. Conducting ethnography during those years of economic flux highlighted the seductive distraction of 'boom and bust' narratives. It also revealed the rupture effect of discourses of crisis or hyamral (in Mongolian), fuelled by an environment of steepening personal and public debt (Bonilla 2016). At the same time, tracing experiences of economic flux also exposed fundamental senses of time that stretched well before any kind of postsocialist economic 'boom'. Visions of what might be possible in an unclear future shaped people's creative strategies in finding new solutions in the present strategies that drew from past familial networks and entrepreneurial techniques (Empson 2020).

On a global scale, Covid-19 has similarly called into question some of the contradictory outcomes of hyper-connectivity. It has, as Roy (2020) further writes, unlike flows of capital, sought proliferation, not profit, and has in many ways 'reversed the direction of the flow'. Since January 2020, there has been a reshaping of what it means to be a so-called success-one that is far more linked to health outcomes, rather than the economy-centric understandings of success that have shaped so much of geopolitical power relationships for a long time. Success stories, such as New Zealand with zero new cases in June and July, are those with the ability to successfully isolate. Staying apart, as an Australian government slogan goes, keeps us together and saves lives-messaging that people in Victoria, 
Australia, see emblazoned on freeway message boards and Facebook ads as we live through another, more stringent lockdown due to a significant rise in community transmission of the virus. Success stories now are those that avert disaster-an economy that is more shut off, protecting people's health and the health systems that support them.

However, as noted by Minnegal and Dwyer (2020), there are reverberating ironies to isolation and attempts to curb the spread of Covid-19. One irony is that reducing the spread of Covid-19 has given rise to new vulnerabilities and is having cascading effects that are likely to outlast the virus. Some of these reverberating effects will be something that people living in less infrastructurally equitable urban environments have long experienced.

\section{Managing Air Pollution in Ulaanbaatar}

As I walked up an uneven dirt track with Saraa (pseudonym) towards her home in Ulaanbaatar in October 2019-well before there was knowledge of Covid-19-the wind whipped against our bodies. We pressed ahead, passing through a narrow walkway between two fenced parcels of land and emerging out on to a crest of a hill. The land plots on this newer part of a district of Ulaanbaatar were more sparsely placed. The fences closely hugged this narrow, unpaved road that arched away from the city. From this crest of the hill, the city lay below us in a sweeping panorama-clusters of apartment buildings, both old and some very new, lay surrounded by rolling mountains.

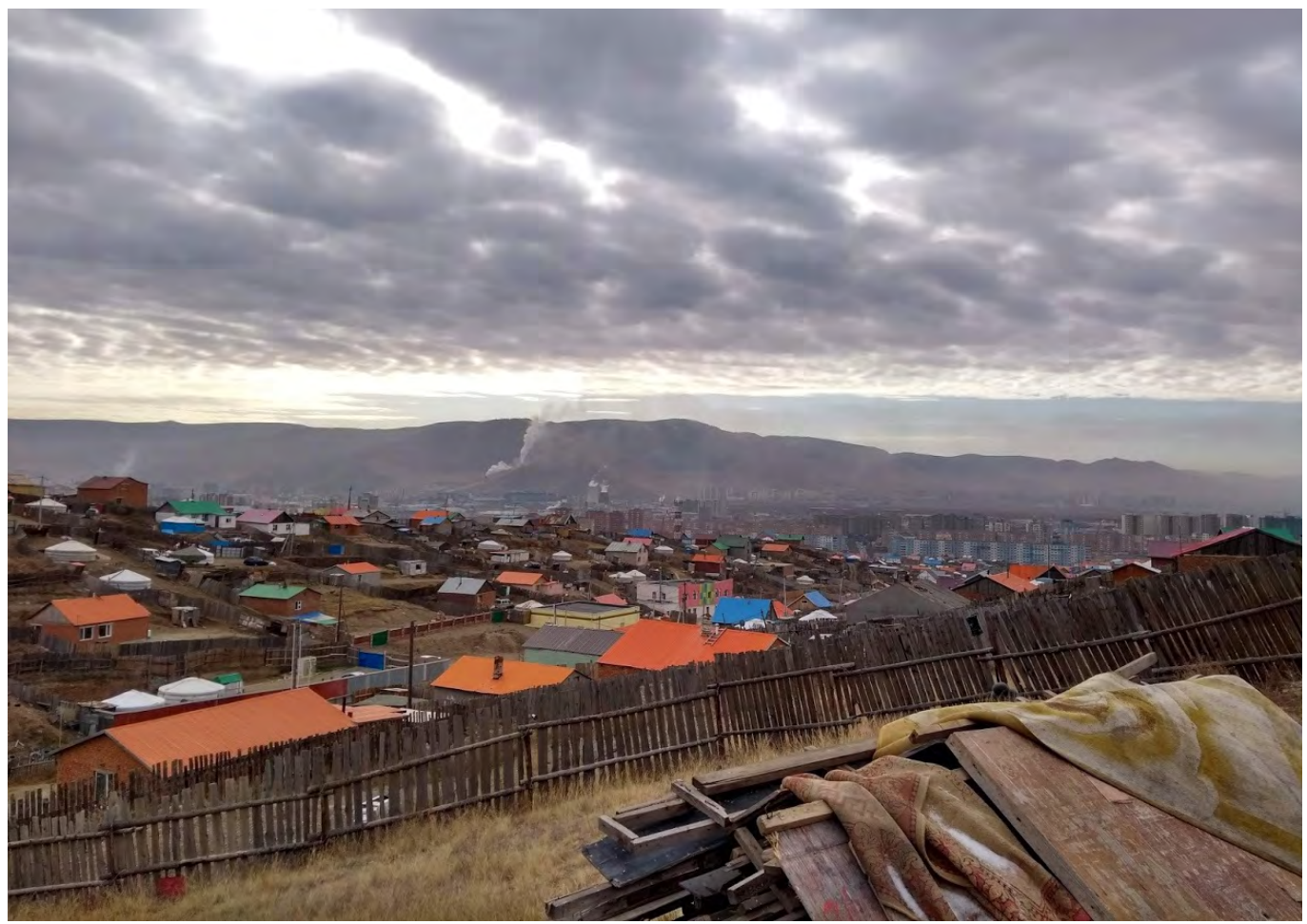

Ger districts and Ulaanbaatar's centre, October 2019. PC: Rebekah Plueckhahn. 
In the late afternoon autumn sun, plumes of smoke rose up from Power Plant No. 3 to our right-the thermal power plant that partially heats Ulaanbaatar's District Heating Service, supplying heating to the city's apartment and commercial buildings. Expanding out from this centre of Ulaanbaatar were land plots like Saraa's-fenced parcels containing self-built homes or ger, the collapsible felt dwellings used by Mongolia's many mobile pastoralists. These ger districts, as they are known, constitute a significant amount of Ulaanbaatar's urban land mass, and are not connected to the city's heating service, running water, or sewerage.

Since the early 2000s and until that autumn, Ulaanbaatar had experienced severe seasonal winter air pollution, as a result of households burning low-grade raw coal to keep warm in the ger districts. These continuing seasonal experiences of severe pollution, as coal smoke settles over the city trapped by its surrounding mountains, had been culminating in a perpetuating sense of environmental and political crisis. This context directly arises from legal and political processes that have shaped Ulaanbaatar's postsocialist experience (Sorace 2018). As a larger response to continued air pollution, when I visited Saraa last October the Ulaanbaatar municipal government had just initiated a programme whereby the burning of raw coal for heating was banned and residents were required to only burn new 'smokeless' briquettes called 'sainjruulsan tülsh' or 'improved fuel'. These are 'tablets', or shahmal, consisting of a type of compacted, washed coal powder. In these early weeks of the programme, the sky had been noticeably clearer, arguably a watershed moment in Ulaanbaatar's postsocialist environmental history. However, as this was happening, other stories were emerging. This new fuel source, it was rumoured, burnt differently, using up different levels of oxygen compared with the raw coal that people were used to (Bayartsogt 2019). Several people had unfortunately died, purportedly from carbon monoxide (CO) poisoning, and the company producing the new tablets had been urging people to keep their stoves clean in order to minimise risks (Bayartsogt 2019).

As I researched in this district that month as part of a project examining public transport access, I travelled with several municipal workers as they conducted an active educational public health campaign that consisted of visiting households one by one from $5 \mathrm{pm}$ into the evening, communicating with them on the need to keep more air flowing through gers and houses in order to avoid CO poisoning. While CO poisoning had also previously occurred due to burning raw coal in households, this new fuel required adjustments, education, and adaptation.

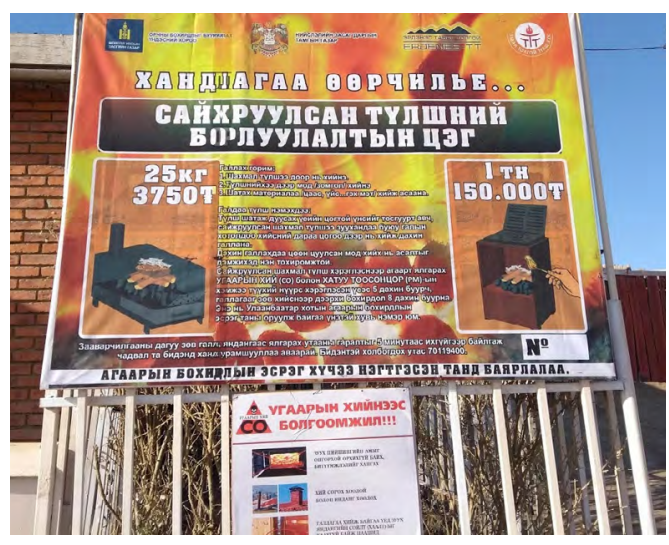

A sign informing people of the new fuel as well as providing instructions on how to burn it safely. PC: Rebekah Plueckhahn.

As I spent time in this ger district, I reflected on the inequities emerging through this fuel transition. Changing the fuel did not address the underlying need for a more sustainable, comprehensive form of heating infrastructure throughout the ger districts. While it has been reported that there was a subsequent improvement in particulate matter pollution that winter in Ulaanbaatar (Ganbat et al. 2020), the coal briquette solution-arguably a lot cheaper to implement than centrallysupplied heating infrastructure-offset the costs on to ger district residents. 
Watching the different events around the world over the past few months caused me to reflect on the unfolding of the new coal programme and seeing Ulaanbaatar residents grapple with government policies that had reverberating effects. People around the world have now needed to significantly adjust, withdraw, and compromise to limit the spread of Covid-19. It has given rise to vulnerabilities that span beyond and within existing power relationships-every body is vulnerable to this novel virus. The virus has, to quote Judith Butler (2016, 25), highlighted vulnerability, not as a subjective disposition, but as a relation between a body 'to a field of objects [and] forces ... that impinge on or affect us in some way'.

Saraa in Ulaanbaatar did not describe herself as someone who struggles. She articulated resourceful ways she was attempting to negotiate the physically and infrastructurally uneven landscape around her. Our very first discussion was about her plans to set up a playground using land within her fenced plot so that nearby children have somewhere to gather. She had devised clever ways of minimising the cost of the more expensive private taxis in getting her two children to school up and down arduous unpaved roads, with one child sitting on another's lap in order to save on taxi fare. These strategies required work-the intermittent nature of the informal 'taxi' service required her to vigilantly watch for her children every afternoon after school, as she was not sure when they would arrive exactly. These strategies created possibility, but also required the labour of hypervigilance.

\section{Coping with Seismic Shifts}

Mongolians have demonstrated time and time again their ability to move through and adapt to seismic shifts. The transition from socialism to a market economy after 1990 saw the proliferation of different kinds of enterprise and diverse economies, as well as the sequestering of wealth into the hands of a minority through uneven processes of privatisation (Byambabaatar 2018). In recent years, new strategies have emerged as Mongolia has grappled with considerable economic flux (Empson 2020; Plueckhahn 2020).

Understanding the very real risk of health catastrophe that this virus could bring, the Mongolian government implemented lockdowns at the very beginning of Covid-19, suspending flights to and from China on 1 February and all flights to and from South Korea and Japan by the end of the month (Munkhbat 2020). A long-term closure of schools and universities followed, along with non-essential businesses shutting down or shifting to work-from-home arrangements (Krusekopf and Mendee 2020). The restricting of flights continues to this day, even severely limiting the ability of many Mongolian citizens currently abroad to return, as government evacuation flights are few and demand outstrips supply (Walker et al. 2020). While there are some programmes of repatriation, this lack of wholesale government-organised return of citizens has been criticised by many Mongolians stuck abroad. In the lead-up to national parliamentary elections in June 2020 , the national government declared that international arrivals will be restricted until a vaccine is available.

Overall, such efforts to lock down the country have been described as a success, albeit a bittersweet one (Krusekopf and Mendee 2020). In April, a video was posted on Facebook that included a renamed $\mathrm{Mr}$ Bean sketch where Mr Bean (aka 'Mongolia') vanquished a Judo opponent (aka 'Covid-19') by sneaking up behind him, pushing him over, rolling him up in the martial arts mat and sitting on him rather than fighting with him directly (Düürenbayar 2020). This appropriated comedic sketch rings true-the numbers of confirmed cases have remained small, with 310 total cases occurring from returned travellers as of 5 September 2020 and no evidence of community transmission. 
However, like many other places around the world right now, such 'success' has come at an economic cost. Claims for unemployment have increased within Mongolia, and businesses and individuals reliant on freight or large and smallscale cross-border trade have been severely affected (Odbayar 2020). Many borrowers have requested the deferral of mortgage repayments (Krusekopf and Mendee 2020). As seen during other periods of local economic hardship, such as the economic downturn and flux that spanned 2014-16, there is a tendency towards buying locally produced foods and gifts, especially in the lead-up to this year's Tsagaan Sar, or Lunar New Year celebrations, in February (Bayarsaikhan 2020).

Many people within the ger districts rely on sourcing goods from China to sell locally, as well as working as traders at Ulaanbaatar's train station. While there is no doubting the effectiveness of the lockdown, like many places around the world, those who have been affected most acutely are often those who have been shouldering the greatest levels of economic precarity well before the spread of Covid-19.

\section{Realignments}

Like the briquette programme introduced last winter in Ulaanbaatar, attempts to create infrastructures of improvement or containment that lessen the impact of both air pollution in Ulaanbaatar and the spread of Covid-19 have had considerable social repercussions. Hyperconnectivity and increasing urbanisation, both forming conditions of late capitalism, have given rise to the adverse effects of increasing air pollution (Abrahms-Kavunenko 2019), and easy pathways for this virus to spread. Those most vulnerable are often asked to bear the brunt of attempts to alleviate these environmental and health crises, creating complex reverberating types of responsibilities borne by those without safety nets. While the new fuel programme in Ulaanbaatar allowed the air to be clearer for all, ger district residents needed to adapt to a new fuel that, for some, had devastating consequences. While we all may be vulnerable to the virus, or to air pollution, attempts to curb its spread are felt very differently.

Covid-19 has created new alignments in the distribution of economic precarity on a global scale and the types of power relationships that underpin them. It is definitely 'more than a virus' (Roy 2020). However, this has happened at such a fast rate and there is no way of knowing whether such revisioning or realigning is temporary or not. Covid-19 has also given rise to significant temporal shifts. While it came on extremely quickly, we do not know how long we will need to adapt. Whether or not this ends soon or over a number of years, people like Saraa will need to navigate uncertain urban landscapes, strategising ways to incrementally alleviate different kinds of infrastructural 'gaps' that existed long before lockdown.

Sections of this paper draw from research conducted in 2019 as part of the Ulaanbaatar Accessibility Appraisal (UNAA) Project funded by a University College London Grand Challenges for Sustainable Cities Award. I would like to thank Munkh-Orgil Lkhagva for assistance with the ethnographic research and Sanchir Jargalsaikhan for providing me links to some of the secondary source material cited in this article. I would also like to thank Benjamin Hegarty for providing comments on an earlier draft of this paper. 


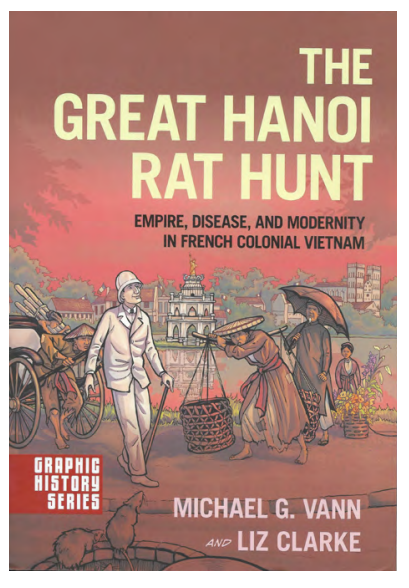

The Great Hanoi Rat Hunt: Empire, Disease, and Modernity in French Colonial Vietnam (Oxford University Press 2018).

\section{The Great Hanoi Rat Hunt}

\author{
A Conversation with Michael G. Vann
}

Ivan FRANCESCHINI

In The Great Hanoi Rat Hunt: Empire, Disease, and Modernity in French Colonial Vietnam (Oxford University Press 2018), historian Michael G. Vann tells the darkly humorous story of how the French colonial state unsuccessfully attempted to impose its vision of modernity upon the colonial city of Hanoi, Vietnam, focussing on a long-forgotten episode that took place in 1902, in the context of the third global plague pandemic. A hybrid scholarly volume and graphic novel-with one hundred pages in the comic format beautifully drawn by artist Liz Clarke-the book offers a praiseworthy case study in the history of imperialism, highlighting the racialised economic inequalities of empire, colonisation as a form of modernisation, and industrial capitalism's creation of a radical power differential between 'the West and the rest'. Unforeseen to the author at the time of writing, it now also offers valuable parallels and lessons regarding the current Covid-19 pandemic and its fallout in terms of disease control, surging nationalism, and anti-Asian racism.

Ivan Franceschini: The Great Hanoi Rat Hunt is unlike most scholarly books. It is part of Oxford University Press's graphic history series. In other words, it is a comic book; or at least one hundred pages are in the comic format with an equal number of supporting essays and documents. Why did you decide to write a graphic history?

Michael Vann: I originally published a journal article on Hanoi's rats and the Frenchmen who wanted to kill them in 2003. I assumed a few dozen colleagues read the piece and kind of forgot about it until I got a phone call from the producers of Freakonomics in 2012. They asked me if I would come on the show to speak about my research as it illustrated the principle of 'perverse incentives', a concept totally new to me at the time! After talking with them and doing the interview I found my article was being cited by quite a few economists and business journalists. I then decided to expand the piece into a 
monograph. But as I revived my rat research, I wanted to reach a larger audience than a traditional academic monograph and I remembered that Oxford had this series that takes unusual and quirky historical research and puts it into comic form. I knew my project would be a great fit as it is a pretty quirky story.

But there were other reasons for publishing The Great Hanoi Rat Hunt as a graphic history. The book engages urban history, the history of disease, and world historical patterns of imperialism, economics, and migration. These are all topics that really need illustrations. Most editors at academic presses cringe when authors ask to include large numbers of images, but graphic histories are based on images. Working with the amazing artist Liz Clarke, I designed maps showing the spread of disease, Chinese migration, and colonial expansion. We also developed pages that could contrast the Vietnamese sections of Hanoi with the new French neighbourhoods. As sewers play an important role in the story, we also illustrated them and created pages with cross sections' of buildings to show the urban infrastructure. Perhaps most importantly, Liz Clarke was able to create the feel of the city. Her art is really just gorgeous.

\section{IF: Did you face any pushback or criticism from other historians?}

MV: Yes, I did get a few raised eyebrows and some sceptical remarks. But, hey, I'm a full professor! What's the point of tenure if you aren't taking a few risks? But more seriously, I think anyone who reads the book will see that the historical research that went into it is serious and understand that The Great Hanoi Rat Hunt could have easily been a traditional academic monograph. Fortunately, the vast majority of the responses have been very positive, including rave reviews in several leading journals.

IF: In the preface, you describe your book as a 'fascinating case study that illustrates the ironic and tragic ways in which modernisation projects can have unintended consequences (xiv)' How did you come across this unusual history?

MV: What I have come to call the 'Great Hanoi Rat Hunt' was a hilarious but very insightful bit of history I discovered in the French colonial archives in Aix-en-Provence, France. My encounter with it was entirely by chance. While doing my doctoral research on the urban history of Hanoi under French colonial rule in the mid-1990s, I lived in Aix. On the one hand, I'm lucky to have my main archival collection located in such a beautiful and fun town. One the other hand, it is really depressing to walk past the charming Cours Mirabeau with its cafés and past the lovely fountains and parks that fill Aix to go sit quietly inside the Centre des Archives Section d'Outre-Mer. 
Far too many afternoons I found myself not focussing on the archival documents but staring out the window at the beautiful Provençal sunlight. In order to keep myself entertained-and in the archives-on lovely spring days I would call up strange or humorous-sounding files. I would save these as a little 'pick me up', an amusing diversion to keep me going.

One day I opened a file called 'Destruction of Animals in the City', which I chose because of its morbid title. This dossier was unlike anything else I found in the archives. It contained about one hundred identical forms listing the numbers of rats killed in the first and second arrondissements (districts) of Hanoi. The dates started in April 1902 and finished in July. In the first few days the files reported a few hundred rats killed, but the numbers quickly jumped into the thousands. It was not uncommon to see between 7,000 and 14,000 rats killed in a single day. On the worst day for Hanoi's rodent residents, over 20,000 rats were reported killed. Yet, after slaughtering hundreds of thousands of rats, the death toll dropped. One day it was a few thousand, the next day a few hundred, then a few dozen. On the last page of the dossier it reported no rats killed. And there was nothing in the dossier to explain any of this information. At the time, the spring of 1995, I did not know what this all meant, but I decided I would try to solve this mystery. I had a historian's hunch that this event could serve as a micro-history to explore the larger issues at play in colonial Vietnam. This led to me to over two decades of research on this campaign to kill Hanoi's rats. After combing through the colonial archives in Aix, visiting various collections in Paris, and then a series of research trips to Hanoi between 1997 and 2014, I was able to piece together the story, a story which revealed the important power relationships of this colonial city.

MV: The short version of the Great Hanoi Rat Hunt is as follows. When the French seized the city in the 1880s, they immediately set about rebuilding it. Pagodas and temples were torn down to make space for a new French city of straight and wide avenues, home to large office buildings for the new colonial administration and spacious villas for the newly arrived colonists. In sharp contrast to the French Quarter's European ambiance, the so-called Old Quarter, a neighbourhood of 36 streets, was preserved as the domain of the city's Vietnamese and Chinese communities. There, roughly 90 percent of Hanoi's population was crammed into one-third of its surface area. The French Quarter and an administrative and military district to the west made up the other two-thirds of the city but only housed some 10 percent of its residents. The result was a classic 
colonial dual city. Following the imperialist logic of the Mission Civilisatrice-the French analogue of the White Man's Burdenthe colonial authorities justified their urban renovation as essential to combatting disease. In the 1890s, the French put in state-of-the-art sewers and a freshwater system. However, colonial Hanoi was a classic dual city with a racial divide between white and Asian access to the benefits of the city's new urban infrastructure. While French villas had running water and flush toilets, most of the Vietnamese and Chinese residents of the Old Quarter had to collect water from public fountains and pre-dawn night-soil collectors removed human waste in buckets. This part of the city really only had gutter drains, not proper sewers.

While these moves helped fight cholera, a disease brought to Hanoi by the French expeditionary forces coming from Algeria, the new sewers created a different health crisis. At the same time that the French were rebuilding Hanoi, a Bubonic Plague epidemic in Yunnan made its way to Canton and Hong Kong. From there it struck British India. American troops brought it to Manila when they invaded the Philippines in the SpanishAmerican War. It struck Honolulu, leading to the burning down of Chinatown, before hitting San Francisco, where municipal authorities quarantined that Chinatown and discussed a 'Honolulu Solution'. French researchers such as Alexandre Yersin in Hong Kong and Paul-Louis Simond in Bombay made crucial discoveries about rat fleas being the vector in the spread of the plague bacillus. As fate would have it, Governor-General of French Indochina Paul Doumer ordered Yersin to Hanoi in 1902 to found a medical school. Yersin and other medical experts in the city were concerned about the plague arriving from southern China on the newly established steamship lines and the railway to Yunnan.

The situation became more serious when French residents reported an infestation of rats in the French Quarter. It seems that brown rats arrived on ships and trains from China. This invasive species discovered that the new sewers were an ideal ecosystem and quickly colonised the colonisers' urban infrastructure. The situation was so bad that there were reports of rats climbing up the outflow pipes and then out of toilets in French homes. This was unpleasant enough, but the realisation that these rats could be carrying plague threw the public health officials into a panic. Using their new knowledge, the colonial public health officials began a campaign of rat eradication. I guess we could call it e-rat-ication. 
MV: Right, problems began almost immediately. First, the Vietnamese sewer workers refused the unpleasant task of hunting rats in sewers and went out on strike. When the city officials put out a bounty on rats, paying a few cents for each rat tail delivered to the police station, hundreds of thousands of rats seemed to be killed. However, after three months of this programme they discovered the local community was farming rats, cutting off their tails to collect the bounty, and then letting them go free to breed more rats. They also found a smuggling network bringing rats and other rodents from all over Tonkin to the city of Hanoi. In the end, the French authorities realised that very intense and invasive public health measures such as quarantining the sick in lazarettes, burning the belongings and often homes of the sick, and seizing corpses were more effective. However, these measures angered the local population.

IF: Why is rediscovering this episode so important today? What relevance does it have to our current pandemic?

MV: The relevance of this case study in the Covid-19 era is threefold. First, large cities and industrialised transportation will lead to disease outbreaks. Our modern infrastructure creates the potential for epidemics. We see this with the growth of Chinese cities and the way in which they push into wetlands that are a seasonal home to migratory birds. Many of these birds encounter influenza in Siberian ponds and lakes in the summer and bring it back to central and southern China and Southeast Asia in the fall. As many industrial poultry production centres are near these wetlands, it is easy for zoonotic diseases like influenza to jump from animal hosts into the human population. Dramatic breakthroughs in transportation-be it the Pax Mongolica on the Silk Roads, cholera on nineteenthcentury British shipping, or low-cost air travel today-allow for such diseases to spread through human communities around the world, becoming a pandemic. The Bubonic Plague, SARS, and Covid-19 are all zoonotic diseases that arose from human contact with animals.

Second, public health measures are always disruptive and unpopular. The people of Hanoi hated seeing their belongings and homes destroyed and their loved ones, be they ill or deceased, taken by the French authorities. Today we see cantankerous Americans resisting sound public health measures such as wearing masks as a threat to their freedom. But let me say that I have much more sympathy for colonial 
subjects frustrated with the injustices of imperialism than for red-hatted Trump supporters comparing the governors of California and Michigan to Adolf Hitler.

Third, there is a long history of Sinophobia and pandemic disease. As with anti-Semitism during the Black Death, scapegoating Chinese bodies and China as a whole was a factor then and now.

IF: Rats are one of the main characters in your book. You explain that while these animals are often reviled and associated with filth, they can be considered the 'totem animal of modernity' and a 'symbol of the era of imperialism' at the dawn of the twentieth century (80). How is that the case? And how does the negative image of the rat during that period relate to that of the much-reviled bat today?

MV: Rat and human histories are closely intertwined. Any discussion of the Anthropocene should consider the symbiotic relationship between rats and people. Rats, especially brown rats, made use of the global changes in human infrastructure at the turn of the twentieth century. If industrialisation changed the world for human beings, it also created new opportunities for their furry neighbours. Expanding cities and long-distance trade networks offered rats new habitats and new ways to travel distances far greater than they could with just their stubby little legs. As with humans, these technological changes resulted in a demographic explosion. I'm not sure if we breed like rats or they breed like people. It is impossible to know the exact rat population, but scientific estimates indicate that these rodents currently outnumber human beings by several billion. I find it fascinating that as humans went through an unprecedented population boom from 1800 to the present, rats, which most people consider a pest, increased in number as a direct consequence of human actions.

Hanoi during the French colonial occupation (1884-1954) is an excellent case study for illustrating the relationship between humankind and its rodent neighbours; maybe roommates is a better term. Hanoi's rat problem frustrated French colonial administrators, who believed that Western modernity with its emphasis on science would solve supposedly backwards Asia's alleged health problems. Ironically, with European imperialism facilitating the spread of the plague. The French created an entirely new public health crisis in the streets of Hanoi, with rats playing a central role. Just as Europeans invaded and colonised Southeast Asia, brown rats that stowed away on Western steamships and railcars also invaded and colonised the region, begging the question of who the real invasive species was. When crafting The Great Hanoi Rat Hunt as a graphic 

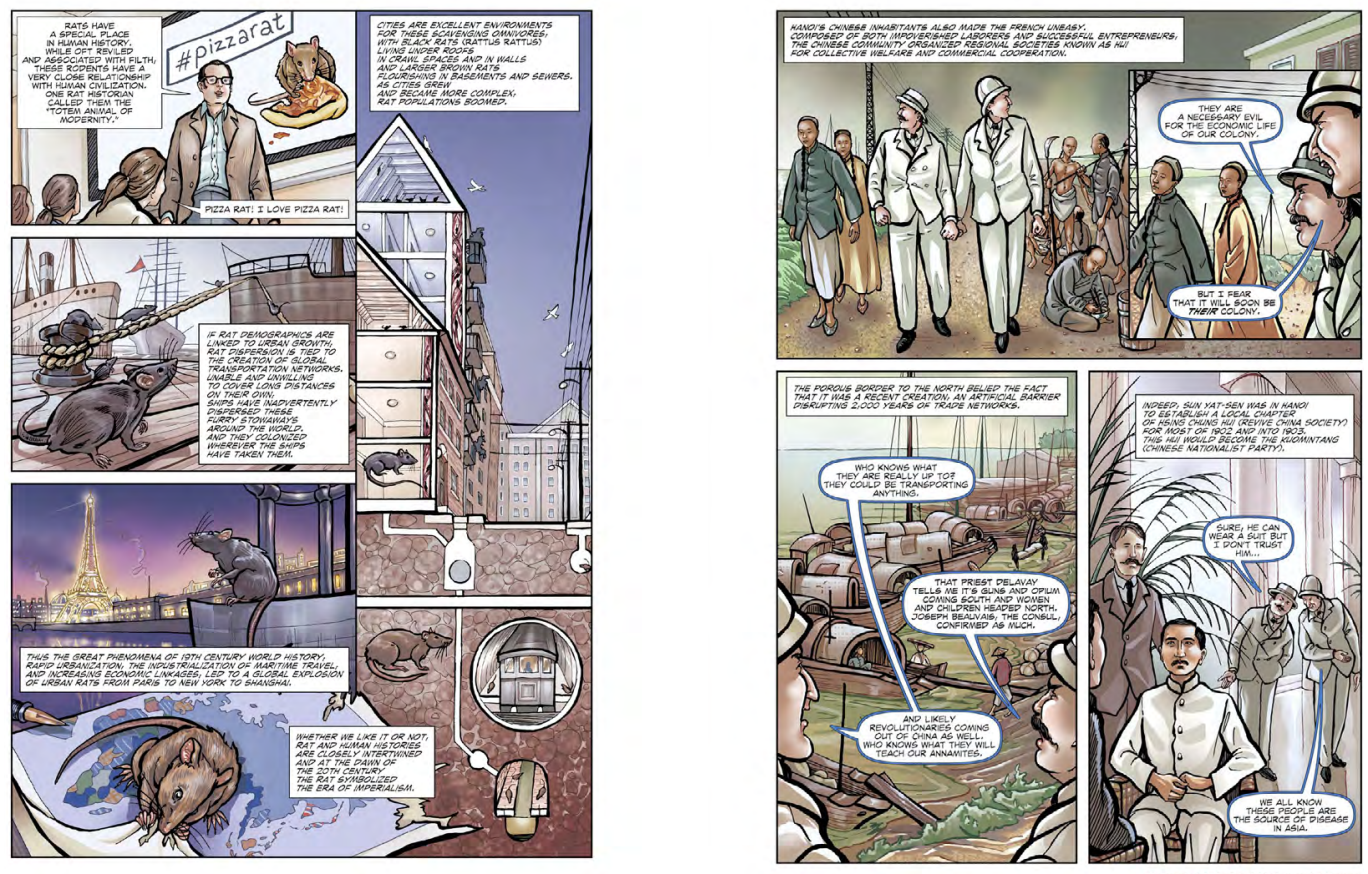

Copyright Oxford University Press

history, I took inspiration from Art Siegelman's Maus. While I refused to anthropomorphise the rats, they serve as a metaphor not only for French colonisation but also Vietnamese resistance.

As for bats, well I won't make a Dark Knight joke, but they can also play an important metaphoric role in helping us understand humanity's relationship with the animal world during the Anthropocene. My father was an immunologist at the University of Hawai'i medical school. He was also a very adventurous traveller and quite the gourmand. When I first started going to Southeast Asia in 1990, he told me to try every food I could find except for bats and monkeys as they were potential disease vectors. He also warned me not to explore caves with bat colonies and not to get bit by monkeys. In my 35 years in Southeast Asia, aside from an unfortunate encounter with a flying fox inside our villa in Yogyakarta, I've kept my bat exposure to a minimum, but I have been bitten by three monkeys. While the origins of Covid-19 remain a bit of a mystery, it is likely a zoonotic disease that jumped from an animal reservoir into the human population. Thus, yes, there are some clear analogies to rats and their fleas spreading the plague over a century ago. As we are coming close to eight billion people on this small planet, we are increasingly encroaching on animal habitats. While this is disastrous for our fellow species-Richard Leakey warned us in the 1990s that we are entering into a sixth 
mass extinction event-it is dangerous for us as well, as seen in the increase in zoonotic disease events. Mike Davis has termed the threat of pandemic diseases coming from our pressures on the natural world 'the monster at the door'. While bats and rats are kind of scary to most of us, we should be truly terrified of the pathogenic threats they might be carrying.

IF: Racism, and in particular Sinophobia, is a central topic in your book. Sun Yat-sen makes a brief appearance in your story, as he was in Hanoi for most of 1902 and into 1903, trying to set up a chapter of his Revive China Society. When you portray him you have two anonymous French colonists-a recurrent presence throughout the bookcommenting: 'Sure, he can wear a suit but I don't trust him ...' 'We all know these people are the source of disease in Asia' (65). On the following page, your alter ego says: 'While the colonial troop movements of the French invasion and pacification campaigns were a primary culprit in moving diseases around Asia and around the world, it was more politically expedient to blame vulnerable Chinese coolies.' These words are extraordinarily relevant today-for instance, I remember how some scholars, without any evidence whatsoever, blamed the arrival of the virus in north Italy on the influx of workers from China. In the book you also describe how, when the disease appeared in Hawai'i in 1900, the white supremacist government blamed the Chinese community, sealed off Chinatown, and set fire to the homes of the infected, eventually burning down the entire neighbourhood, as they could not control the flames (75). How did this Chinese association with disease come to be uncritically accepted at that time and, in your opinion, why is it that this discourse remains so strong to this day?

MV: I'm very happy you picked up on that. I tried to do a number of things with The Great Hanoi Rat Hunt; the graphic format is very well suited for including sub-plots and references. I find Sinophobia to be one of the great cultural forces of the past two centuries and it is a force alive and well today.

It is more than an understatement to note that the West has a very complicated relationship with China. In this book, I noted that it was the wealth of China that lured France into Asia. Vietnam, Cambodia, and Laos were seized in several stages as the French looked for a backdoor to China, specifically a river route to Yunnan, which was imagined to be an El Dorado with silk instead of gold. As fate would have it, by the time the French established a rail link from Yunnan to Hanoi to the port of Haiphong, the demand for silk had waned. But Yunnan was also a source of opium production and under the leadership of Governor-General Paul Doumer (1897-1902), French Indochina played a crucial role in supplying opium to the French Concession in Shanghai. Doumer essentially created a narcostate and put the colony's previously precarious finances firmly in the black. However, all this was predicated upon the French empire's economic interdependence with China. Chinese goods, Chinese merchants, and Chinese labourers were really the life blood of the French Indochinese Federation. The Gallic 
conquerors knew this and hated it. Some mused that neither they nor the Vietnamese ran the colony. Others called the Chinese 'the Jews of Asia'-and in the era of the Dreyfus Affair this was no compliment. They were also very nervous about Chinese revolutionaries, be it Sun Yat-sen's Guomindang or the Chinese Communist Party after 1921. When I found out Sun was in Hanoi during the rat hunt, I had to include him in the story, if only because we are both graduates of 'Iolani high school in Honolulu, Hawai'i.

This created a generalised anxiety about China and the Chinese. When French medical experts and public health authorities realised that Yunnan was the source of the plague epidemic, vilifying China and Chinese bodies came quite naturally. This Sinophobia spread like a virus to the American empire, with Manila, Honolulu, and San Francisco all seeing various manifestations of anti-Chinese sentiments, policies, and violence. The burning of Chinatown in my hometown is the most shocking example, but San Francisco's Chinatown was quarantined, and city leaders discussed a 'Honolulu Solution'.

IF: Your story takes place during the third global plague pandemic. The disease started in Yunnan in 1855 and went on to kill over 80,000 people in Guangzhou without raising much alarm abroad. Global panic started only in 1895, when people in British Hong Kong began to get sick. It was then, as you write, that journalists used telegraphs and trans-oceanic cables to report the panicked flight of tens of thousands of Chinese. As British authorities scrambled to enact public health measures and reassure the community, newspapers published photographs of workers hauling bodies through empty streets' (73). At that point, you say that the race to investigate and find a solution for the plague 'took on aspects of nationalist competition' (74). How did that competition play out then and what lessons can we draw from that experience for the current pandemic?

MV: Keep in mind that this was the era of intense nationalism, a toxic nationalism that had already fuelled the absurd and blood-soaked expansion of the colonial empires and would soon lead to the horrors of the First World War. Everything, even scientific research, became infected (pardon the pun) with nationalist rivalries. Patrick Deville covers this in his fictionalised biography of Alexandre Yersin, Plague and Cholera (2012). In Europe, Louis Pasteur and Robert Koch and their students competed with each other. It is no coincidence that one was French and the other German. Nationalist tensions turned scientific competition into something much more serious. That both men founded institutes that trained scores of the world's leading researchers meant that Franco-German tensions could be exported to the far corners of the world and kept alive in proxy-wars. 
We see this in the response to the plague in Hong Kong. As the disease ravaged the city, the French government and the Institut Pasteur sent Alexandre Yersin to join the international team of plague fighters. However, the British authorities in Hong Kong gave Yersin a very frosty welcome and denied him access to their laboratory facilities. Yersin built his own wood and thatch hut and resorted to bribing guards at the morgue for samples from corpses. His ill-treatment can be chalked up to AngloFrench rivalries. That Yersin, Swiss by birth but a naturalised French citizen, had studied with Koch in Germany only to take a position with the Pasteurians aggravated the situation. As fate would have it, the British had brought in a Japanese researcher, Kitasato Shibasaburō, who just happened to have been a Koch protégé who studied in Berlin when Yersin was there. Clearly there was no love lost between these two men. But the truly despicable treatment Yersin received should be understood as part of this international rivalry (homophobia directed at Yersin likely played a role as well). When Yersin discovered the plague bacillus, the British authorities dismissed his findings and promoted Kitasato as the hero of the day. We now know that Yersin was right, but it was not until after his death that the bacteria was named Yersinia pestis in his honour. This rivalry continued as Yersin and Paul-Louis Simond studied the plague in Bombay and Karachi. In 1898 Simond identified the role rats and their fleas play in the propagation of the disease. That a French researcher working in the Raj bested British scientists again was embarrassing and led to the English being slow to recognise these important findings.

A hundred and twenty years later and we still have similar issues regarding nationalism and scientific research. In March 2020 journalists confirmed that the Trump administration offered large sums of money to Tübingen-based CureVac to make sure any potential vaccine would only go to the United States. The German government and public opinion were incensed at the move, with one member of parliament declaring that capitalism must have limitations. In July, America, Canada, and the United Kingdom accused China of vaccine espionage. In a stunning move, Trump ordered the closure of Houston's Chinese Consulate. Setting aside Trump's odious Sinophobia and his deliberately provocative use of the term 'China Virus', some of us wondered what exactly was the problem. What was China going to do? Give the vaccine away? Sell it at a discounted price and hurt the profit margins of the American pharmaceutical industry? We are a long way from Jonas Salk, who dismissed patenting and profiting from his polio vaccine with the famous words: 'There is no patent. Could you patent the sun?' 
MV: The French colonial archives are full of reports filled with statistics, all of which should be taken with a grain of salt. One the one hand, Peter Rabinow and others have shown that the French colonial state saw itself as a modern technocratic administration. These bureaucrats, inspired by France's nineteenth-century engineering triumphs such as the Suez Canal and the Eiffel Tower, sought to become social engineers in the colonies. Urbanists and public health officials saw themselves as manifesting la Mission Civilisatrice. On the other hand, there is the problem of the numbers. Technocrats require data, but the data were unreliable. Everything from the city's population to the number of plague cases to the daily count of dead rats was really a best guess. Thus, while the French state presented itself as in control, the reality was that the colony was a Potemkinville.

And again, we see similar things happening today. Without reliable systems of widespread testing for both infections and antibodies, epidemiologists are flying blind. We don't know who has the virus and where the next outbreak will be. Nonetheless, Trump gives interviews and press conferences where he points to charts and cites various statistics. But as with the French colonial bureaucrats, these data are just not reliable.

IF: One last question. In commenting on the aggressive public health measures adopted by the authorities, including forced field-testing of vaccinations on local people, the two anonymous colonists have this conversation: 'I guess the interests of public health override all other concerns.' 'Yes, and fortunately here in the colonies we don't really have to take public opinion into account. Try to get this done back home in the chaos of the Third Republic. These experts could never overcome the various obstacles. But here in the empire, we can see the modern state in action. Maybe at some point in the future we can bring these techniques of social control back to France' (93). This fictitious discussion raises some fundamental questions of biopolitics that have gained even more currency these days. Can you tell us more about the debate that took place back then and the lessons we can draw from it for today?

MV: In the French empire, a large number of technocrats found an ideal situation to engage in widespread social experiments. Again, much of this was in the areas of urbanism and public health. They were inspired by the work of figures like Georges-Eugène Haussmann, who served as prefect of Seine (1853-70) under Emperor Napoleon III and completely rebuilt much of Paris. Not everyone was happy with Haussmannisation. His critics called him 'the demolisher', as he tore down old neighbourhoods and pushed poor and workingclass Parisians out of the city centre. Baron Haussmann was 
able to do this because he served the Second Empire (1852-70), an authoritarian regime that embraced technocracy. When the government collapsed and was replaced by the progressive Third Republic (1870-1940), many of these technocrats were frustrated by the new democratic constraints placed upon them. Thus, they often turned to France's growing colonial empire where their power was not restricted, they did not have to listen to public opinion, and they could use the military to suppress any opposition. Unsurprisingly, when the Third Republic fell during the Nazi invasion, many technocrats from the colonies happily served the quasi-fascist Vichy regime.

The disturbing reality is that authoritarian regimes seem to be better suited to face public health crises. This was true in colonial Vietnam and it is true in today's Vietnam. After the 1902 rat hunt failed, the French authorities employed very invasive and draconian public health measures that seem to have helped weaken the impact of the pandemic. Today, the Vietnamese Communist Party has a much better track record fighting Covid-19 than the United States. The widespread flaunting of public health measures-often by citizens citing their special freedom as Americans-that we see in the United States would be unthinkable in Vietnam. In terms of biopolitics, personal liberties stand in the way of the collective good. This is a frightening conclusion and I'm not at all happy about the political implications, but it's where we are at in 2020 . 


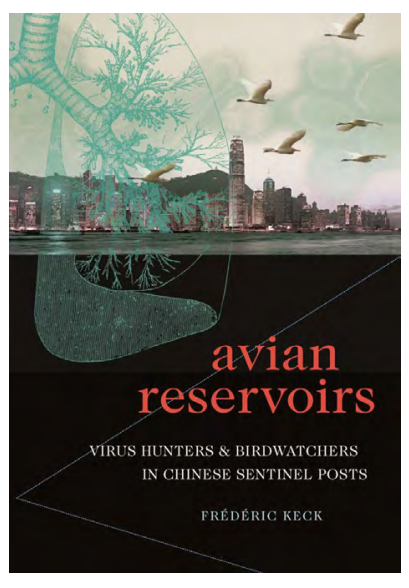

Avian Reservoirs: Virus Hunters and Birdwatchers in Chinese Sentinel Posts (Duke University Press 2020)

\section{Asian Reservoirs A Conversation with Frédéric Keck}

\author{
Mara BENADUSI \\ Andrea Enrico PIA
}

The Covid-19 pandemic has brought the whole world to its knees. Yet, this coronavirus is only the latest in a number of zoonosis events originating in different parts of the globe, and especially within Asia, over the last 20 years. For this reason virologists commonly refer to places like China, Hong Kong, or Singapore as reservoirs of potential viral threats. The combination of advanced logistic infrastructures, industrial farming, and the progressive disappearance of wild ecologies in these places arguably facilitates animal-to-human transmission of zoonotic diseases. In Avian Reservoirs: Virus Hunters and Birdwatchers in Chinese Sentinel Posts (Duke University Press 2020), Frédéric Keck challenges the idea of zoonosis as an Asian problem, and shows us how attending to the wild and domesticated behaviour and physiology of birds reveal the multiple and often contradictory ways in which virologists and citizen scientists make sense of epidemics and inform their policy advice.

Andrea Enrico Pia: Let's start from the end. All of us have been subjected to differently graded forms of sanitarian intervention for the past two or three months. Extremely coercive measures, including complete lockdowns, have been put in place globally to bring Covid-19 under control. The way in which these lockdown have been socialised, though, has brought to the fore the pastoral powers-to borrow one of the key analytics of Avian Reservoirs-of public shaming, surveillance, and mutual accusations in a concerted effort to curtail the infection through the micro-policing of individual behaviour. This has often occurred at the expense of investigating real sites of contagion, such as hospitals and shop-floors. In a way, public health-minded citizens have become the real 'sentinels' against the propagation of the virus. In your book, you analyse a different kind of 'sentinel'-birds-and varying ways of being alert to contamination that do not resort to pastoral power or coercion. Can you tell us a bit more about why the concept of the 'sentinel' is important for the study of pandemics? 
Frédéric Keck: Sentinels can be defined as devices to perceive early warning signals of an upcoming disaster. It is a military technology-sentinels are soldiers going to the frontline to raise the alarm when the enemy approaches-transferred to environmental concerns: there are sentinels for hurricanes, earthquakes, floods, species extinction, nuclear accidents, chemical pollution, and emerging infectious diseases. The sentinel perceives the threat before it can be measured, it makes visible the invisible signs of danger, it is attentive to the weak noises announcing a disaster. Non-human animals have been configured as sentinels because they are physiologically close to humans and more sensitive, such as chickens for bird flu or clams for chemical pollution. But we can conceive that robots or plants could be used as sentinels as well. In Avian Reservoirs, I argue that sentinel devices are cynegetic techniques-i.e. related to hunting-because they allow human experts to communicate with birds through images of viruses or numbers of species extinction, in the same way as shamans communicate with animals in hunting societies. By contrast with pastoral power, which is organised from above to decide which animal in the flock can be saved and which must be sacrificed, cynegetic power is horizontal and reversible: it starts from a shared vulnerability to environmental disasters, but also from a prey-predator relationship in a common habitat. For Covid-19, because of the failure of early warning signals in Europe, we had to use the costly techniques of lockdown to avoid deciding on triage and sacrifice, but now that the peak of the epidemic is behind us, sentinel devices are used to control the spread of the virus, for instance by detecting its prevalence in the sewerage system or training dogs to smell SARS-Cov2 in human tissues.

Mara Benadusi: In your book, you encourage us to see pathogens from the perspective of animals themselves. Now that several countries are moving towards a 'phase two' in response to the pandemic, a debate is emerging around how to 'live with' the virus. It is on this phrase, 'live with', in the sense of coexistence, that I would ask you to dwell a bit more. How can the current pandemic help us to reframe concepts of causality and relatedness, reflecting different modes of coexistence between humans and viruses, humans and animals, and humans and the environment more generally? Is it possible to imagine a phase of real 'coexistence' in this broader sense and how could taking the perspective of a bat-or a pangolin-help with making it more viable?

FK: Responses to pandemic in 'phase one' rely on a simple concept of causality: identify the chains of transmission to predict the number of casualties and reduce this number by cutting the chain of transmission. But in 'phase two', we realise that the causality is more complex: if we shut down wet markets in central China, animals trafficked for the growing demand for materials used in Chinese traditional medicine will be smuggled, 
and viruses transmitted by bats will take another road. So we need to prepare for future pandemics coming from animals with a much broader view of our interactions with them, and of our interactions with microbes that cause immunological panics when viruses jump from wild animals. Taking the perspective of bats-or pangolins, or whatever animal has been the intermediary vector in Chinese wet markets, or dromedary camels in the transmission of MERS-Cov-is how virologists simulate the spread of future pandemics, by imagining methods of transmission that have not occurred yet but that could have catastrophic consequences. This is the reason why I argue that preparedness relies on a holistic view of relations between humans, animals, and microbes, while precaution relies on a much more linear view. This is the ambivalence of the notion of animal reservoir: either as something to know and imagine, or as something to control and eradicate.

AEP: Let me turn your attention to the People's Republic of China for a moment. In the West, China has been accused of 'coronavirus diplomacy'-the political sleight of hand of hiding the country's role in the early spreading of Covid-19 by overplaying its commitment to international medical aid and cooperation. In the attempt to control the narrative of the post-pandemic world to come, many are now commenting, often in flatly racist terms, on the supposed Asian propensity to live in what you call 'spaces of contagion'-sites where humans and animals live in too close proximity with one another. In your research on the H5N1 avian flu, for instance, you visited many such 'wet', 'poultry', and 'bird' markets. Are these special places to consider when thinking about the origin of the current pandemic, or do they represent just one of the sites along a food supply chain where (potentially zoonotic) encounters between humans and animals are staged?

FK: Wet markets are very special places for social anthropologists because they are sites of intense relations between humans, animals, and microbes. I spent a lot of time in wet markets in Hong Kong-'wet' refers to the fact that markets must be cleaned every day to avoid contamination-to understand why consumers want to buy a chicken or a fish 'fresh' to carry back home after it has been killed, and how retailers perceive such a risky activity as exposing themselves daily to the slaughter of potentially infected chickens. I also followed Buddhist practitioners who bought birds or fish in wet markets to release them as a gesture producing 'merits' (放生), and who were criticised by environmentalists because the release often led to the death of animals. There is so much life and death in these markets that they are perfect sites for the observation of biopolitics in the making. In my next ethnographic project, I will study how the regulation of these wet markets in Hong Kong and Singapore over the last 20 years will be applied in central China. China wants to appear as a 'clean state' after the 
pandemic, and yet people will continue buying food in these wet markets because they don't trust the safety and quality of meat in supermarkets.

MB: One of your main interlocutors in Asian Reservoirs is Malik Peiris from Sri Lanka, Chair Professor at the Department of Microbiology at the University of Hong Kong and Scientific Director of the HKU-Pasteur Research Centre at Hong Kong. Professor Peiris is a renowned virologist and is most notable for being the first person to isolate the SARS virus. In the West, experts' handling of the Covid-19 pandemic has been largely criticised for its mixed messages and internecine animosity. Can you tell us more about the role played by 'experts' from Asia in the 'hunt' for viruses? Has their scientific authority in managing viral outbreaks ever been subjected to similar criticism? Could you help us reconstruct a genealogy of these Asian professionals and the political reception of their work leading up to the current pandemic?

FK: Virologists in Hong Kong became heroes after SARS because they helped society survive an epidemic that was about to collapse the economy. The fear of SARS-Cov2 can only be explained as a global extension of the fear experienced by Hong Kong society during the SARS crisis: a liberal economy that relies on the circulation of commodities and persons can collapse if an infectious agent blocks the chain of production. Virologists in Hong Kong acted as mediators in the sense of Bruno Latour-they attenuated the violent tension between production, circulation, and consumption by controlling the mutations of infectious agents. In that sense, I argue that they worked as shamans in hunting societies. Virologists tamed wild animals by transforming them into sentinels so that they would not take 'revenge' against humans. Now this shamanicheroic role in the chains of domestication is also configured by the techniques of the global war against terrorism. SARS was conceived as Asia's 9/11, the virus hijacking cells and taking planes to travel around the globe, causing panic after circulating silently. SARS heroes are controlling 'nature as a bioterrorist threat': that is why there is so much consensus around their role in preparing Hong Kong for future pandemics. By contrast, virologists in France have been caught in the traps of the precautionary principle. Is the government doing too much or too little? Do we have enough masks, vaccines, drugs, tests to protect the population? The Hong Kong government does not face these questions because it is rich and liberal. The only question it has to face is the following: is the government going to protect us from a Chinese invasion? As I show in my book, SARS heroes answered this question through the sophisticated language of viruses. 
AEP: In your book, you spend considerable time thinking about the categories of preparedness and prevention. From animal husbandry to birdwatching, from the study of viruses to the stockpiling of vaccines, societal-wide anticipation of future pandemics is key to responsiveness to outbreaks. In this sense, Covid-19 has thrown the 'unpreparedness' of Western countries into stark relief and shown the extent to which Western societies and economies may have to change to accommodate the threat of future epidemics. A debate is now raging between those interested in only minimally tweaking our current system to preserve the usual paths of capitalist accumulation and those who see in a 'pandemic shock' an unprecedented opportunity to consolidate the infrastructure of data-driven capitalism. Lastly, environmental justice campaigners wish this crisis could build momentum towards changing our dysfunctional relationship with the wild and the non-human. What lesson about 'being prepared' is there to be learnt from the Chinese 'sentinel' posts you have studied?

FK: The anthropologist Andrew Lakoff has taught us that when scenarios of preparedness meet the reality of disasters, we discover that we have always been unprepared. The lack of preparedness is precisely the motor that drives contingency planners to put more effort into imagining future disasters. What interests me is how these global scenarios are implemented in different locations based on various relations between humans and non-humans. In China, the fear of a pandemic was oriented less by the anticipation of a bioterrorist attack than by the fear of the emergence of a flu virus in poultry farms or wet markets; a pandemic was not conceptualised as a sign of godly apocalypse, but rather as a transformation in the heavenly mandate. The idea of being unprepared or that one may fail to perceive early warning signals of disasters takes on different meanings if one thinks that 'Nature' behaves like God, that is as an essence capable of talking to you directly, or if it is conceived of as an interpretable force that can be understood through its indirect forms of mutation. When I worked with virologists and ornithologists, I studied their understanding of a 'false alarm'. This could either mean that their target was wrongly interpreted as a vector of a potential epidemic, or that signs of an impending 'spill-over' were not leading to the right kind of prevention and mitigation response. In that sense, I was interested to see how Chinese societies perceived questions of environmental justice without sharing the Western theological separation between nature and culture and based on a different ontology of early warning signals, or sentinels.

MB: Following on from the last question, I wanted to ask your opinion about the social techniques of anticipation we encounter in your book. We are now witnessing a flurry of speculation relative to how to anticipate hypothetical future outbreaks and thus envision consequential public measures. However, this enormous effort of anticipation is not a neutral process. It distributes unequally the capabilities required by social actors to effectively influence their future. In circumstances of extreme uncertainty, 
such as those described in your book, the question is not only whose life is to be protected', but also 'what form of life we abandon or let die'. In your experience, what is the role assumed by pandemics in shaping the ways we think about our future as a society?

FK: This is another way to raise the question of social and environmental justice in the time of pandemics, and how preparing for future pandemics will allow us to build more solidarity and equity, or lead us to more competition, looting, and violence. I think that the first virtue of pandemic preparedness is to force us to include animals in the concern for vulnerability and care in a world we have transformed and damaged-call it the Anthropocene, if geologists agree. But of course, this is not a step forward if it results in us sacrificing some parts of the human population to meet the demands of preparedness. However, I don't think we have to make a choice between protecting humans and animals, and choosing which lives should be protected in a situation of emergency. This is one of the effects of the distinction between pastoral power and cynegetic power. Pastoral power is ready to sacrifice some parts of the flock for the wellbeing of the whole; cynegetic power takes the perspective of all living beings in a predatory situation, and death occurs almost as an accident that shouldn't be talked about. Preparedness is violent, the world in which we are entering is more favourable to predatory relations than to pastoral care, but hunting societies were more respectful of their environment, and taking their perspective might help us to think about the ecological challenges we have to face. 


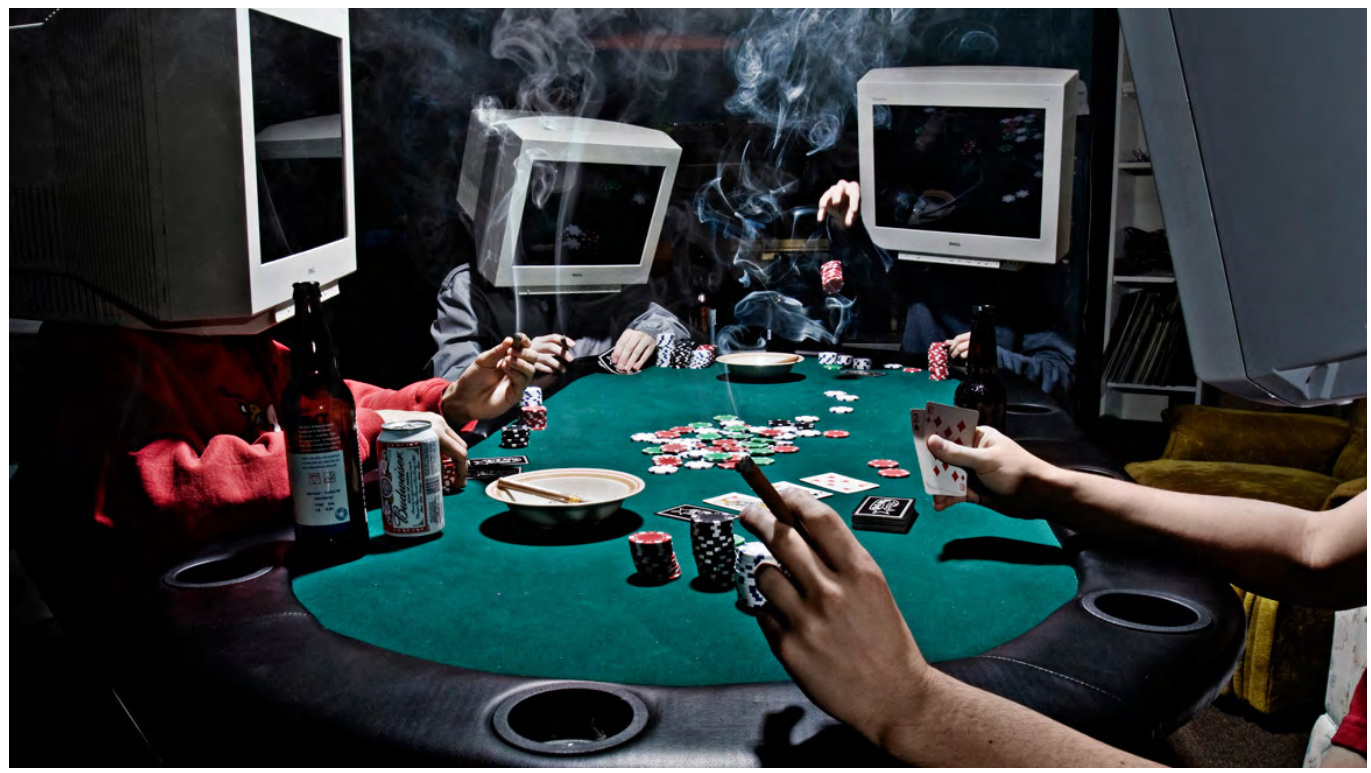

\section{Between}

\section{Economic and}

\section{Social Exclusions}

\author{
Chinese Online Gambling \\ Capital in the Philippines
}

Alvin CAMBA

Under Rodrigo Duterte's administration, Chinese capital has increasingly flowed into the Philippines. Much of this new investment has been in online gambling firms-a peculiar type of capital that is not involved in the Belt and Road Initiative (BRI) and is even criminalised by the Chinese state. Drawing from field research in Metro Manila, this essay interrogates the anti-Chinese sentiments among Filipinos that have been stoked by online gambling firms. In examining the broader social reverberations of Chinese capital on Philippine society, it argues that Chinese online gambling capital generates specific forms of economic and social exclusions.
Online Gambling. PC: Dan McClanahan.

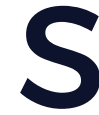
ince the early 2000s, Philippine elites have limited Chinese capital in major economic sectors, such as infrastructure, construction, and many others. During Benigno Aquino III's term (2010-16), no major investment from Chinese state-owned enterprises (SOE) or development aid agencies came in because of the conflicts in the South China Sea. In stark contrast to his predecessor, upon his accession to the presidency in 2016, Rodrigo Duterte signed a Memorandum of Understanding (MoU) with the Chinese government worth 24 billion USD, comprising 15 billion USD in foreign direct investment (FDI) and 9 billion USD in aid. Although these 
streams of FDI and aid have barely materialised since then, in the past few years Chinese capital has nonetheless increased in the Philippines, a growth that is largely related to the online gambling industry. Online gambling not only has indirectly benefitted from the Belt and Road Initiative (BRI) through the inflow of Chinese tourists, which has become a pathway for illegal workers, but has also led to an overall increase in the number of Chinese investors supplying the mushrooming online gambling sector.

Chinese online gambling firms have been controversial, purchasing office space across Metro Manila, importing hundreds of thousands of workers, and increasing subcontracting arrangements with Chineseinvested firms in other sectors. Anti-Chinese sentiments among Filipinos have increased, generating tensions between Metro Manilans and the Chinese migrant community. There have been calls for banning, relocating, and expropriating online gambling firms. These anti-Chinese feelings are unusual because Chinese online gambling firms constitute a peculiar type of capital that is not involved in the BRI and is even criminalised by the Chinese state. Yet, Filipinos have felt wronged by the online gambling investments. Analysing the workings of this type of capital resonates with Ching Kwan Lee's arguments in The Specter of Global China (2017), where she discusses Chinese state capital's distinctiveness from private global capital. Building on Lee's work, I look at one crucial question: what are the reverberations of Chinese capital in the host society? By examining the consequences of the expansion of Chinese online gambling firms in urban areas in the Philippines, especially in Metro Manila, I hope to identify the sources of Filipino animosity against the influx of Chinese online gambling outfits.

In her book, Lee draws on the theoretical frameworks of Karl Polanyi and Max Weber to explain the embedded and contested dimensions of China's state investment, racial relations between Chinese and Zambians, and the global situatedness of China-in-Africa.
Following these theoretical traditions, I argue that Chinese online gambling capital generates specific forms of economic and social exclusions, and illustrates the broader social reverberations above and beyond the capital investments. Polanyi $(1944,37)$ proposes that commodification disembeds the 'fictitious commodities' of land, labour, and money from the host state's social relations, leading to social dislocation or the 'eventual annihilation of society'.

Though commodification has been a historical process, Chinese online gambling firms have further disembedded fictitious commodities. In 2016, online gambling firms started buying entire condominium buildings or floors in Metro Manila, outbidding the socalled call centres, which provide back-office services to major Western multinational companies, and Filipino buyers. Hundreds of thousands of illegal and semi-legal Chinese speakers migrated to work in newly established online gambling firms (Bureau of Immigration 2019). The sheer magnitude of these changes contributed to the increase of real estate prices and quite possibly other basic goods (Bloomberg 2018). As business process outsourcing (BPO) is priced out, fewer longterm jobs are created for Filipinos. Coupled with the lack of infrastructure development and stagnation of real wage growth, this situation has had a major impact on the livelihoods of many Filipinos.

To understand how actors react to such a process, I use Weber's concept of social closure to illustrate the ways in which individuals draw group boundaries around commonly identifiable traits. In the eyes of some Chinese firms and workers, Filipinos are predatory, targeting them for bribes. For many Filipinos, the racialised imaginary of a 'Chinese invasion' colours their view of how Chinese firms and workers reshape the labour market and the commercial sectors. This essay briefly discusses how the Chinese and Filipinos construct or racialise one another through online gambling firms, their affiliates, and the auxiliary consumption industries that follow. 


\section{Market and Social Exclusions}

Polanyi theorises that the market society emerged through what he calls a 'double movement'. The first movement occurs when states attempt to disembed markets from societies through the process of commodification, which he defines as the freedom to produce goods for the purpose of sale without political or social barriers (Polanyi 1944, 37 and 187). In order to actualise a market society, states need to commodify land, labour, and money, or what he calls 'fictitious commodities' (Polanyi 1944, 137). However, because land, labour, and money are always embedded in social relations, a fully self-regulating market is impossible (Polanyi 1944, 172). As such, disembedding fictitious commodities from one set of social relations generates social dislocations.

To prevent society's eventual annihilation, Polanyi argues that a second movement emerges to reembed the market in social relations (Polanyi 1944, 137). Social dislocations caused by commodification lead to different counter movements in the three fictitious commodities, specifically: workers in labour (Polanyi 1944; 105); the landlords and peasantry in land (Polanyi 1944, 94); and the business class in money (Polanyi 1944, 113). He suggests that in the end these groups will eventually transcend their narrow goals, protecting society as a whole, and reembedding the fictitious commodities back into society (Polanyi 1944, 139 and 151).

While Polanyi elaborates on commodification, the non-economic dimensions of the process are better explained by Max Weber. Weber uses the concept of social closure to explain capital's social impact. According to him, social closure is the process of drawing subjective boundaries and forming particular identities with the aim of monopolising economic and social opportunities. He first defines open and closed relationships. A relationship is open if the system of order does not deny participation to anyone who wishes to join and is actually in a position to do so', while it is closed if according to the 'subjective meaning and binding rules, participation of certain persons is excluded, limited, or subjected to conditions' (Weber 1978a, 343).

Because social closure acts to curb competition, Weber argues that there is often 'one group of competitors [that] takes some externally identifiable characteristic of another group of (actual or potential) competitors-race, language, religion, local or social origins, descent, residence, etc.as a pretext for attempting their exclusion' (Weber 1978a, 342). He also adds that it 'does not matter which characteristic is chosen in the individual case: whatever suggests itself most easily is seized upon' (Weber 1978a, 342). As Weber puts it, 'the purpose is always the closure of social and economic opportunities to outsiders'. These resources are not open to outsiders, and if they acquire the opportunities normally conferred upon insiders, then the 'old monopolistic association is doomed' (Weber 1978a, 343).

\section{The Rise of Online Gambling Capital in the Philippines}

President Rodrigo Duterte gave up claims on the South China Sea in exchange for better relations with China and increased access to its capital (Camba 2017). Online gambling constitutes a major aspect of Chinese capital expansion in the Philippines. After taking office in June 2016, Duterte instituted the 'Philippine Offshore Gambling Operations' (POGO) scheme, a new regulation that enables online gambling firms to set up shop in major cities, such as Makati, Pasay, and Paranaque (IBON 2020). Before the POGO scheme, online gambling firms could only open in the areas managed by the investment promotion agencies, which were often located in export 
processing zones or special economic zones (SEZ) away from the cities. Although there is no direct link between giving up the South China Sea and the influx of online gambling capitalsome firms already existed during the previous Aquino III administration, which resisted China's maritime claims, and the Chinese state actively discourages host countries from accepting online gambling-a Chinese official pointed out to me in an interview in 2018 that the Philippines' decision to forgo claims on the South China Sea has limited China's ability to pressure the Philippines into banning online gambling. Additionally, the improved relations between the two countries generated larger Chinese tourist and foreign direct investment inflows, which allowed online gambling firms to expand their labour supply and contract other non-gambling Chinese firms for their services (Camba and Magat 2020, 12). Today, Duterte continues to protect online gambling firms as current and former Chinese nationals pour billions into the industry. The online gambling industry is an ideal case to examine Chinese capital in the Philippines because the sector's massive profit margins, new technologies, and dozens of legal jurisdictions demonstrate how differences in geography, sector, commodity, network, and timing all play a role in shaping the dynamics of capital.

The Philippine Amusement Gambling Corporation (PAGCOR), a government company tasked with regulating gambling in the country, has recorded 60 online gambling firms operating within the POGO investment scheme (PAGCOR 2019). Most of the investors came from offshore financial centres such as the British Virgin Islands, Cayman Islands, and the Isle of Man. However, drawing from a dataset that I created on the basis of information from the Security Exchange Commission (SEC) that houses the records of millions of firms, in August 2020 I could find at least 69 online gambling firms outside the POGO scheme (Camba 2020, 987). Of the 60 firms in the POGO list, only 16 appeared in my dataset. This shows that, although the SEC should have records for all the firms setting up operations in the Philippines, companies can deliberately fudge their information. Alongside the expansion of online gambling, the number of newly registered firms with Chinese investors continues to increase across multiple industries in the domestic consumption sector (Camba and Magat 2020).

Defined as gambling that occurs through computer-mediated communication and new electronic media, online gambling was first offered by Antigua and Barbados-domiciled firms in 1994 (Banks 2017, 225-37). While online gambling started as an 'add-on' to clients within onsite casinos, the sector rapidly took advantage of the transformation of Internet, programming, and currency transfer technologies. Customers today can choose to play in an online casino, engage in sports betting, and shop across hundreds of games in a relatively anonymous manner. The existence of the sector is made possible by millions of workers, thousands of servers, and hundreds of buildings linked across continents, countries, and cities. Thanks to advances in the relevant technologies, studies estimate that online gambling firms only need 5 percent of the capital outlay of onsite casinos in order to achieve the same level of profits (Banks 2016, 44).

In the early 2000s, Chinese nationals started investing in and creating their own firms, capitalising on the access to Chinese labour and networks across the Global South. According to investors I interviewed, today East and Southeast Asian markets comprise 20 percent of the worldwide online gambling market, and Chinese investors-including both current and former Chinese nationals-and their partners in Taiwan and Hong Kong control 15 percent of the global market. My interviews also indicate that online gambling generally-Chinese or otherwise-has been a major conduit of money laundering, allowing Internet-based operators to illicitly transfer money. 


\section{Disembedding Labour, Land, and Money}

As mentioned above, gambling in the Philippines is partly regulated by the state. Oligarchs and domestic conglomerates work with foreign investors to operate more than 50 onsite casinos-25 of which are in Metro Manila. During the mid-to-late 2000s, online gambling did not constitute a major portion of the global gambling sector because of limited technology (Rivas 2019b). In the Philippines, SEZs housed a fair number of Chinese online gambling firms. Before Duterte opened the country to foreign investment in the sector, the operation of online gambling outside the SEZs was monopolised by PhilWeb-a firm owned by one of former president Aquino III's oligarch supporters (Camba 2019). PhilWeb focussed on online gaming programmes for Filipinos, banning non-Filipinos from playing and limiting access for those outside the Philippines. The Filipino online gambling industry did not require a Mandarin-speaking labour force since its operations were limited to the domestic market. When Duterte liberalised online gambling in October 2016, PhilWeb lost the monopoly and the PAGCOR ultimately inherited the power to oversee the sector (Rivas 2019a). Subsequently, Chinese online gambling firms that catered to a Mandarinspeaking audience started entering the country in droves, requiring Mandarin speakers for their operations.

Access to workers was difficult because of regulations. While there are legal procedures to acquire work permits, these are too slow and difficult to get. As a result, members of the Philippine bureaucracy began issuing work permits illicitly in order to profit on the side-a fact that some of them were ready to admit to me in interviews. Some in the Philippine Immigration apparatus even sold work permits and/or passwords in bulk to the online firms. A 'safe entry' that allowed workers to get into the country without getting recorded or scanned was also available for sale (Peralta 2019). More extreme examples include the smuggling of workers to the SEZs, which are operated by local politicians, as one local mayor told me in an interview in April 2019. This kind of disembedding of labour control from the Philippine central government to the informal networks of the Philippine bureaucracy allowed a significant influx of Mandarinspeaking workers into Metro Manila.

This influx of firms and workers also created massive demand for real estate. Some online gambling firms purchase buildings, but most firms typically buy half a dozen floors for their operations and to house workers. The need for space led to a massive increase in demand, causing property market values to skyrocket in major Philippine cities (Bloomberg 2018). Several CEOs of construction companies whom I interviewed in February 2019 told me that before Duterte opened online gambling further, real estate companies and property developers predicted that the bubble in the Philippine property market was about to burst. In 2015, commercial real-estate debt ballooned, call centre demand slowed, and real estate purchases from overseas Filipino workers dropped. However, thanks to a massive influx of online gambling firms, fears of a bubble have since dissipated. Online gambling firms began to acquire entire buildings and floors in the outlying districts of Metro Manila, such as Novaliches, Pasay, and Paranaque.

As a planning manager in one of the Philippines' largest real estate companies told me, instead of building condominium units for call centres or housing, major real estate companies have started to tailor more offices for online gambling firms. At the same time, online gambling firms have also started purchasing unused buildings to provide accommodation to most of their labourers. However, specialised staff, management, and those workers who cannot get accommodation still need to find housing in the city and compete with Filipino demand. 
As the online gambling sector exerts pressure on the supply of office space in the city, the price of real estate continues to increase, and has eventually become too expensive for most Filipinos. Since 2015, real estate prices have shot up by 172 percent (Venzon 2020). According to my interviews with local property developers, the select Filipino middle class who used to be able to purchase housing in prime areas have started to look elsewhere, resorting instead to the 'township' properties in nearby provinces, such as Cavite, Tarlac, and Laguna. Golden Bria Company, one of the biggest real estate firms specialising in townships properties, has seen its stock prices spike from 2017, largely because of the influx of Filipino buyers.

Online gambling firms are able to outbid call centres. Since starting in late 2016, online gambling firms have acquired one million square metres of office space in Metro Manila. Across the country, they own an additional 700,000 square metres (Valdez 2020). According to a real estate broker I interviewed in February 2019: 'The Chinese would buy six to seven floors at a time, while call centres would get one or two at most ... The locals would just buy a unit or two and the latter usually have problems with payments.' Real estate companies would rather sell to Chinese firms because they buy units in bulk. Furthermore, online gambling firms have been buying up the units that were previously owned by Filipino residents, offering to purchase the mortgages and deeds from people who are struggling to repay their bank loans. However, there have also been reports that Filipinos end up moving elsewhere when the neighbouring units are used as offices or 'barracks' for Chinese workers.

Chinese nationals have become the biggest international buyers of real estate, accounting for large proportions of the international sales of leading firms-e.g. 34 percent of Ayala Land, 10 percent of SM Prime Holders, 60 percent of DMWAI, and 50 percent of DMCI in 2017 (Bloomberg 2018). In 2018, Ayala Land and SM Prime Holders sold 90 and 50 percent of their units to Chinese nationals or firms respectively (Venzon 2020). The number of new BPOs and the sector's contribution to job creation have started to decrease because these multinational companies are getting outbid by online gambling firms (Venzon \& Turton 2019). Significantly, while BPOs took 65 percent of the office space in Manila in 2016, the following year the share had shrunk to 39 percent. According to my interviewees in the call centre sector, this has resulted in a thousand fewer projected jobs for Filipinos in the BPO industry.

Finally, the disembedding of money occurs through the special provision that the Philippine government gives to online gambling firms under the POGO scheme. The Bureau of Internal Revenue, the Philippine agency in charge of taxation, does not interface directly with the online gambling firms (Ibarra 2018). Under the current system, online gambling firms pay PAGCOR an application fee of 50,000 USD for e-casinos and 40,000 USD for betting licences. Following receipt of the approval, the firms pay a franchise fee ranging from 200,000 USD for e-casinos to 150,000 USD for betting (Venzon 2016). After granting approval, PAGCOR continues to earn from these firms through a monthly levy of 5 percent of the firms' total profits, which makes PAGCOR the most profitable state enterprise in the Philippines. However, this system lacks transparency, making it impossible to know how much firms have earned and whether or not they are paying the correct amount of taxes. As it stands, online gambling firms only need to report their earnings to PAGCOR by submitting a minimum number of documents before paying the yearly levies (Ibarra 2018).

The Philippine government has decided to tax the service providers of the online gambling firms, but not the firms who have set up shop in the Philippines themselves. These moves have led to a crackdown on service providers that have not paid income taxes (Venzon 2020). Nevertheless, there is confusion with regard to this policy, as many service providers feel that the Duterte administration has reneged on its initial agreement. Furthermore, in many 
ways there is little distinction between the two since both the actual firms and their service providers carry out a lot of the necessary functions of the operation. Although service providers usually have minority shareholders in the form of Filipino, Chinese, and Hong Kong nationals, the actual technology used by the service providers is owned by the firms.

\section{Social Exclusion}

Capital infusion redraws group boundaries and access to resources through a process of social exclusion. First, restaurants and stores that cater to online gambling firms continue to expand across the city. These establishments often pop up in units in the condominium buildings or floors that online gambling firms bought, or they replace existing establishments that were bought out. As these establishments do not offer English or Filipino translation, they exclude non-Mandarin speakers by default (Malasig 2019). Besides being used by online gambling firms, these businesses cater to the newly emerging cohort of Mandarinspeaking workers. When online gambling firms open, other auxiliary services targeting the workers, ranging from restaurants and canteens to grocery shops or hair salons, follow suit (Camba 2020, 987). What is crucial is that, while previous establishments exclude by social class, or the inability to hold sufficient economic power to partake in the service, de facto Chinese-only establishments exclude via language, skin colour, or looks.

Second, since online gambling firms constitute the largest investment in the Philippines since 2016, a process of boundary formation has occurred, creating a divide between the Chinese and their partners, and everyone else. The online gambling sector needs suppliers, services, and partners. Interviews with several Chinese managers in online gambling firms that I conducted in 2019 suggest that they use their Chinese networks in the Philippines to link up with other Chinese investors in construction, retail, or retrofitting services. They prefer to work with Chinese firms because they know what to expect, but choosing which firms to partner with is more related to who their networks refer them to and expediency. In the past few months, the media narrative on online gambling, which paints the Chinese as villains, has made these firms more wary. If the product or service requires a Filipino partner, the managers stated that they would rather work with Filipino Chinese, Filipinos with some degree of Chinese ancestry (the so-called 'Chinese mestizo'), or firms owned by Filipino partners of other Chinese companies. The Filipino business community in various forums has stated that online gambling firms have begun to reshape the business environment in Metro Manila, resulting in the Filipino and non-Chinese foreign firms feeling slighted.

Third, since the surge of Chinese migrant workers in 2017, social closure inside and outside the online gambling firms has started to emerge. According to my observations and interviews with people in these firms, Filipino staff members are often relegated to the role of security guards, cooks, or building administrators. Some people are also hired to liaise with the local government and resolve matters with the police. Filipino women find employment hosting gambling tables. While Mandarin-speaking workers are paid more, they are also more vulnerable to exploitation. Inside the firm, Filipino security staff I have interviewed indicated that they are used to discipline or keep the Chinese workers in line. The firm separates Filipino and Chinese employees into different functions, a divide and conquer strategy to keep workers in line. Additionally, according to some Chinese employees I spoke to in February 2019, online gambling firms threaten their Chinese migrant workers with deportation to ensure compliance.

Outside the firm, Mandarin-speaking workers who are not provided accommodation need to rent in clusters across Metro Manila, either sharing one unit or renting units on a single 


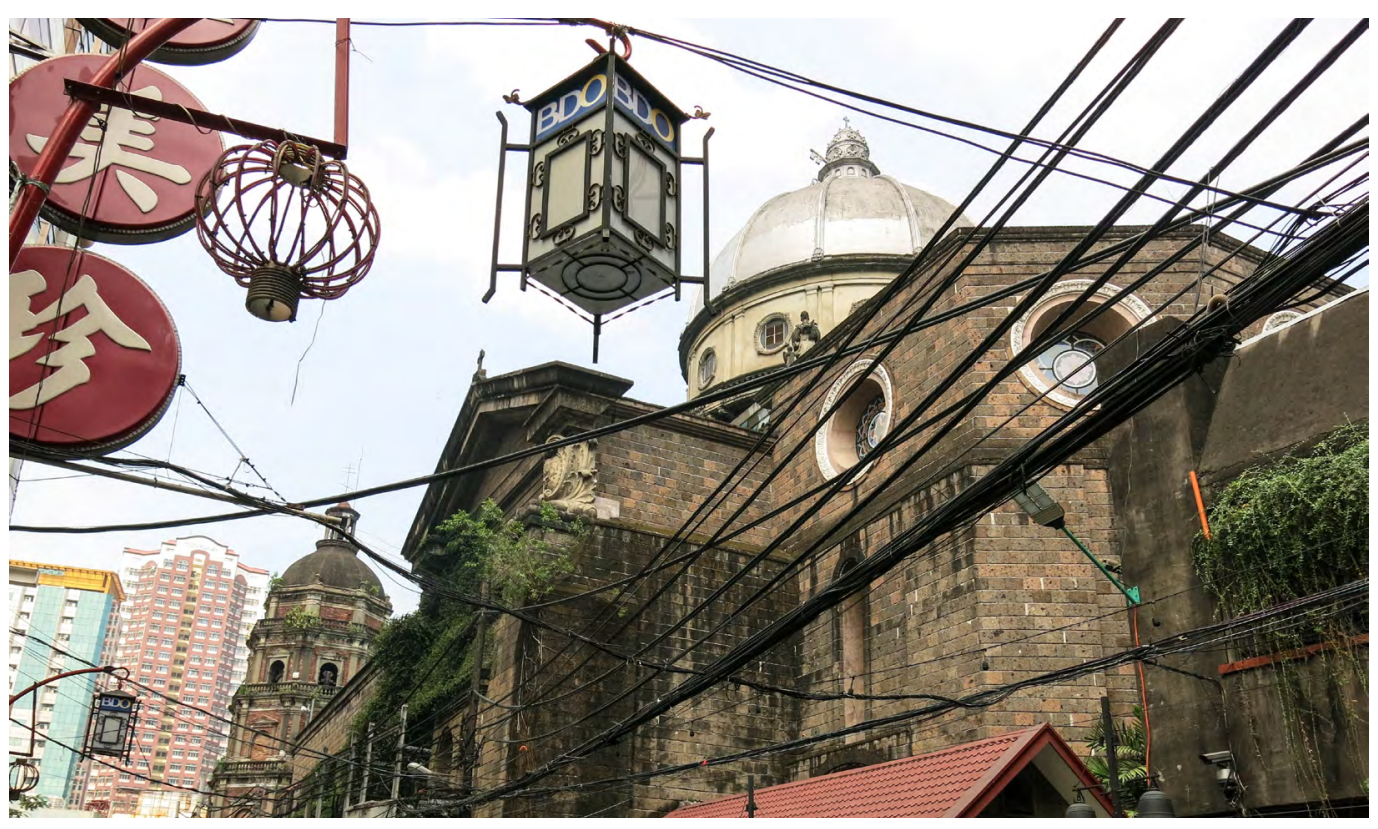

Manila. PC: @deortiz.

floor. Filipinos make sense of the clustering through the lens of a 'Chinese invasion' and Duterte kowtowing to Xi Jinping (see Malasig 2019). From local barangays to condominium units, the Chinese workers have encountered resistance or dismay from Filipinos. Targeted by government officials during their entry and shunned by local people, some Chinese workers have expressed suspicion of Filipinos. For Filipinos, Chinese workers have changed the city, populating condominiums, regularly breaking rules, and overcrowding Metro Manila's malls. Makeshift online gambling satellite offices have proliferated across the lucrative residential areas, drawing the anger of Metro Manila's elites. Mall of Asia, one of the largest malls, in Asia located in Metro Manila, has regularly become a place where online gambling workers hang out on Sundays, causing widespread racialised complaints about Chinese workers' lack of civility: spitting on the ground, cutting in lines, and talking loudly.
Finally, online gambling has partially contributed to a surge in kidnappings inside and outside the firms. As PSA Philippines Consultancy (2019) notes, no Westerners were kidnapped in 2018, which was corroborated by interviews with officials at the American and Australian embassies; most Westerners in the Philippines are elderly people relying on limited pensions provided by their governments, but the Japanese, Korean, and Chinese nationals are often investors or wealthy tourists. Online gambling firms have become investors in new onsite gambling locales, resulting in new gambling facilities such as Okada Manila, City of Dreams, NayonLanding, and Solaire North. These sites have started to draw in East Asian gamblers, including Chinese nationals, Hong Kongers, or Taiwanese who have been targeted for kidnapping and other forms of extortion. Furthermore, there have been cases of Chinese nationals held by onsite gambling firms for incurring high levels of debt. Some cases have been reported to be violent, but most have 
been involuntary detention. Outside the firm, targeted kidnapping has already increased. For the kidnappers, who are often former or current Philippine police moonlighting on the side, 'Chinese-speakers' are easy targets for 'making a quick buck' because their government will not intervene anyway. These syndicates target frequent visitors to the casinos, relying on their perception of Chinese looks or language to choose their targets.

\section{Online Gambling Capital's Broader Reverberations}

This essay interrogated the anti-Chinese sentiments among Filipinos that have been stoked by online gambling firms-a peculiar type of capital outside the purview of the Chinese state. Using Polanyi and Weber, I illustrated how online gambling firms generated specific forms of economic and social exclusions. For what concerns economic exclusion, online gambling firms were marketising land, labour, and money. The disembedding of these three 'fictitious commodities' allowed online gambling firms to expand in the Philippines. At the same time, this disembedding fuelled anti-Chinese sentiments by the Filipinos due to rising real estate prices, the surge of Chinese migrant workers in a context of high unemployment, and the limited government taxation of the firms. Social exclusion occurred through social closure within and outside the firm, specifically the process of choosing business partners among online gambling firms and the selective commercial targeting of the migrant Chinese networks by non-gambling Chinese firms. Combined, all these processes have had broader social and economic impacts on Philippine society.
While Lee's study of Chinese state capital opened new ways to look at the varieties of Chinese capital, her analysis was limited to the 'hidden abodes of production'. However, capital inflows do not just stay contained in one sector or geographical area-rather, they have broader reverberations across the whole of the host society. This essay presented a preliminary framework that can be employed to attend to some of the ramifications of Chinese capital, deepening Lee's approach to studying Global China by examining how Chinese capital inflows intersect with commodity-specific features, history, geography, ownership interests, timing, mode of investment, and sectoral variation. 


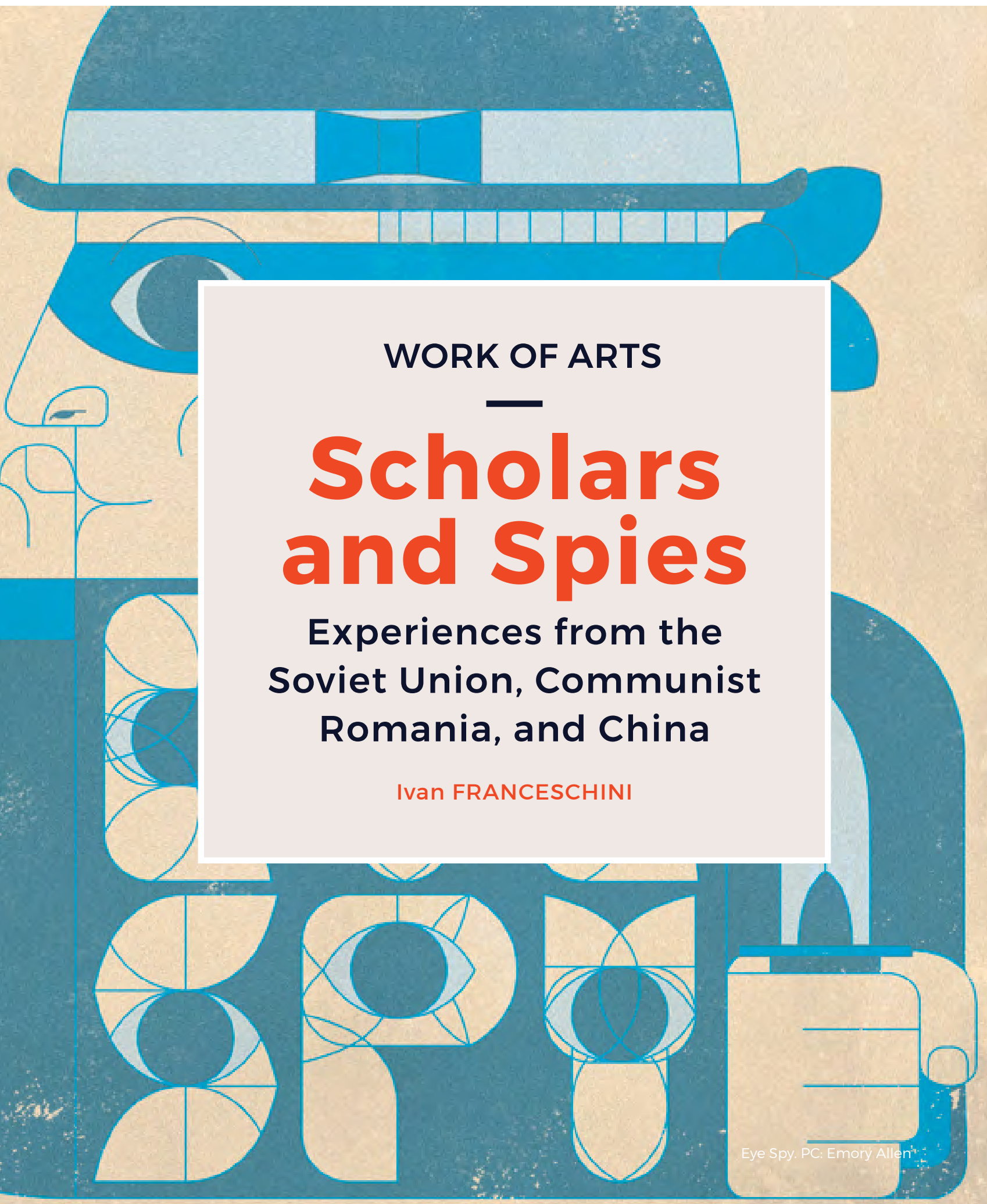


Scholars and Spies

\section{Experiences from the Soviet Union, Communist Romania, and China}

Ivan FRANCESCHINI

$\mathrm{n}$ response to the renewed emphasis of the central government on national security, in November 2015 the authorities of Jilin province, in northeast China, introduced a hotline to report possible spies. The dilemma was how to recognise a spy. Local officials instructed concerned citizens to look out for eight revealing signs (Yang 2015). First, spies never explained their work with clarity, wore different professional hats at the same time, and had plenty of funding at their disposal. Second, at gatherings they often came up with controversial topics then withdrew in the shadows to observe how people reacted in order to select contacts to develop. Third, foreign correspondents, journalists writing about foreign affairs, missionaries, or people involved with NGOs were all likely to be spies. Fourth, spies had proper business cards, but worked irregular hours and the information on the card did not hold up to closer scrutiny. Fifth, people who had studied abroad in many different countries or whose history of studying overseas did not match their age were most likely spies. Sixth, spies enjoyed asking sensitive questions, especially on politics, military affairs, public opinion, and trade. Seventh, they held regular meetings in this or that place to exchange materials and documents. Finally, they could be found at academic conferences and business meetings, where they often gave reactionary speeches and exaggerated the positive aspects of foreign countries.
As a foreign researcher/NGO consultant/ occasional journalist who at that time had been based in China for a decade, reading these tips made me uneasy. Just like the archetype of the spy described by the Chinese authorities, I was never clear about my professional identity, enjoyed discussing controversial topics, kept very irregular work hours, and went around with lousy business cards that struggled to accurately describe my many identities. I did not participate in academic conferences very often, but I guess that could have been held against me as well, perceived as a ploy not to attract too much attention. The uneasiness worsened a few months later, when on 15 April 2016, on the occasion of the first National Security Education Day, the authorities of Xicheng district in Beijing publicly displayed the panels of a comic warning Chinese women not to date foreigners because they might turn out to be spies (Horwitz 2016). The posters told the story of a female Chinese public servant who had fallen in love with a red-haired foreigner claiming to be a 'visiting scholar engaged in research on Chinese issues'. As the two grew to know each other, the foreigner persistently asked for internal materials from the woman's workplace, just to vanish right after he got the documents he wanted. Later, state security officials informed the girl that he had been a foreign spy.

Since then, the position of foreign researchers in China has become increasingly precarious. While those early warnings could still be read as a bad joke, in recent years the Chinese state security has taken to detaining researchers on unsubstantiated charges of espionage or threatening state security. One does not have to think only about the politically charged cases of Michael Kovrig and Michael Spavor, the two Canadian consultants/researchers detained since December 2018 in retaliation for the arrest of a high-level Huawei executive in Canada, nor what happened to Feng Chongyi, a Chinese-born Australian professor who in 2017 was prevented from leaving China and 
was interrogated for an entire week by state security agents. More recently, two professors from a Japanese university were involved in equally disturbing but less-publicised cases. In 2019, Nobu Iwatani, a Japanese historian at Hokkaido University who specialises in research on the Chinese Nationalist Party during the Second Sino-Japanese War, was detained in China for over two months for possessing a 'forbidden book' (Fischetti and Roth 2019). He had travelled to the country on the invitation of the Chinese Academy of Social Sciences and was detained upon his arrival at the hotel designated by his hosts. In June the same year, Yuan Keqin, a professor of East Asian political history at the same university and a permanent resident of Japan, also went missing after leaving for China to attend a family funeral and to this day, more than one year later, there is still no news about him (Kyodo 2020).

Vague and terrifying as their definition of espionage might be, the Chinese authorities are not an aberration in looking at foreign scholars as a threat. In recent years, in contexts as diverse as Australia, the United States, and Europe, the rhetoric of Chinese students at Western universities as potential spies in the classroom, ready to report on both their classmates and their teachers, has prompted fears about threats to academic freedom. In 2018, the United States Department of Justice inaugurated a controversial China Initiative that purports to tackle the problem of the theft of intellectual property by targeting, among others, established scholars who join China's 'talent programmes' and students participating in university research projects (Barr 2020; Lewis 2020). In Europe, in February 2020 the European Commission circulated among national authorities and universities in Europe a draft 'concept note' that invited them to appoint civilian spy-catchers to stop China and others from stealing secrets. These would be special 'individuals' or 'groups' in each university who would 'liaise' with real counterintelligence officers from national security services 'interested in dealing with issues of foreign infringement' (Rettman 2020). This followed the denial in October 2019 of a residence permit to Song Xinning, former director of the Confucius Institute at the Vrije Universiteit in Brussels, whom Belgian authorities accused of being a spy (Lo et al. 2019). As I write, China scholars are discussing the arrest of a Chinese student at the University of Michigan and two associates for allegedly taking illegal photos of military installations at the US Naval Air Station in Key West (Lolo 2020).

All these cases raise fundamental questions about the relationship between academia and espionage-are these simple manifestations of paranoia on the side of the authorities? Or is there more to it? The problem of theft of technology is undoubtedly real, and so are the ties that bind many academics to intelligence services-one just has to think of David Price's (2016) account of the influence of the American security state on anthropology since the Second World War or Gregory Afinogenov's (2020) recent study of the role of scholars in spying on China on behalf of the Russian empire from the seventeenth century onward. However, the question goes far beyond these aspects. Even if we do not steal any technology and do not formally cooperate with any intelligence service, how do social scientists differ from spies? Two recent books-Sheila Fitzpatrick's A Spy in the Archives (2013) and Katherine Verdery's My Life as a Spy (2018)-grapple with this dilemma from the vantage point of decades of engagement with the authoritarian contexts of the Soviet Union under Brezhnev and Communist Romania under Nicolae Ceaușescu. Written from the perspectives of respectively an historian and an anthropologist, these two volumes excavate the inner conflicts that underlie the activities of social scientists, offering insights that go beyond the specific realities in which the authors operated and providing lessons that well apply to the herewherever that is-and now. 


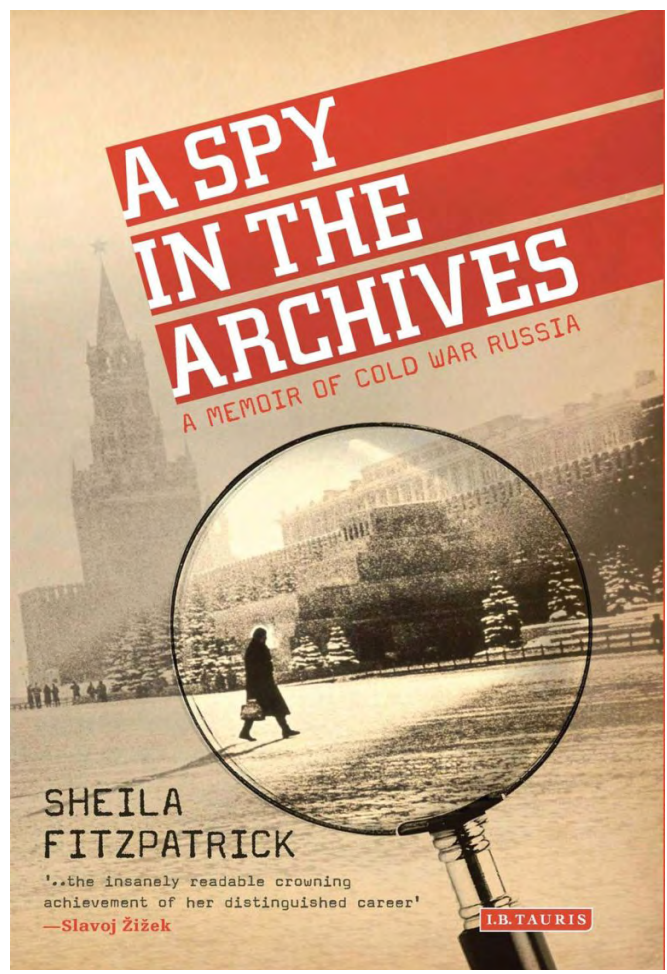

Cover of the 2015 edition of A Spy in The Archives: A Memoir of Cold War Russia, by Sheila Fitzpatrick. Published by I.B. Tauris.

\section{A Spy in the Archives}

A pioneer in the field of Soviet history, Sheila Fitzpatrick more than anyone else has brought nuance to our understanding of how common people lived in Stalin's Russia, challenging the sweeping generalisations and binary views subsumed under the 'totalitarian' framework. Using a warm, autobiographical style, in A Spy in the Archives she looks back at the beginning of her career. She first travelled to the Soviet Union for a three-week study trip in the spring of 1966, then returned in September for a longer stay as a foreign exchange student at Moscow State University, planning to research Anatoly Lunacharsky, the first Commissar to Enlightenment of the newly established Soviet state and a major figure in contemporary debates on culture and education. In spite of all the small and big inconveniences that the young Fitzpatrick had to put up with during her stay, all went well enough until one day in June 1968, when a national Soviet newspaper outed her as an 'ideological saboteur', 'one of those scholars who pretend to be doing scholarly research but are actually putting out disinformation, the way intelligence agents do' (1). In other words: a spy.

Fitzpatrick did not hear about this immediately-she did not read that newspaper, which was very conservative, nor did any of her Russian friends or anyone from the British Embassy-so the incident did not have any major repercussion for her life at that time. However, in retrospect this became one of the defining events of those years for her, to such an extent that espionage frames her whole memoir. In fact, she admits to having a certain familiarity with espionage even before she went to the Soviet Union, something related to her 'growing up in a left-wing family in Melbourne in the Cold War' (5). As a teenager, she followed the convolutions of the trial of the Rosenbergs in the United States and then the political throes that followed the defection of an attaché of the Soviet Embassy in Canberra. After completing her undergraduate studies in Australia, she enrolled at St Antony College, Oxford, a place that was often referred to in both the Soviet Union and the West as a 'spy college', due to the number of its staff who had worked in British intelligence. Although Fitzpatrick regarded herself as 'apolitical', 'paying almost no attention to international politics but ... sceptical of whatever seemed to be the dominant opinion on what I thought of as the woolly left' (21), in such a politically loaded context she could hardly avoid getting enmeshed in the general paranoia of the Cold War years.

At that time, spy scandals filled the newspapers in Britain. Fitzpatrick remembers the cases of Oleg Penkovsky and George Blake, two famous spies who worked respectively for the Western and Soviet sides and had the 
misfortune of getting caught. There was also the case of art historian Anthony Blunt, who was unmasked as a double agent and yet kept working as Surveyor of the Queen's Pictures-a story that has recently been presented to audiences in the hit TV show The Crown. Scholars and students attracted high levels of scrutiny. In 1963, newspapers all over the world reported the sensational story of Frederick Barghoorn, an American professor of political science and Sovietologist at Yale who was arrested on the street in front of his hotel in Moscow after a stranger had walked up to him and shoved some papers in his hand. Brought to the Lubyanka, he was released only after the intervention of President Kennedy (43). Two years earlier, an exchange student named Edward Keenan was caught wandering around restricted areas in Central Asia and the Caucasus and expelled as a spy (44). The year of Fitzpatrick's first visit to the Soviet Union, a British student from the London School of Economics named Peter Reddaway was expelled from Moscow for having alleged connection to the British intelligence; and while she was still in Russia, a British teacher of Russian language named Gerald Brooke was arrested on a tourist trip and accused of smuggling leaflets, ending up in a labour camp for three years (45).

Such was the climate in which Fitzpatrick's first visits to the Soviet Union took place. In the book, she describes the briefing she had to take part in at the Foreign Office before she left for Moscow:

Everybody we met in the Soviet Union would be a spy, we were told. It would be impossible to make friends with Russians because in the first place, they were all spies, and, in the second, they would make the same assumption about us. As students we would be particularly vulnerable to Soviet attempts to compromise us because, unlike other foreigners resident in Moscow and Leningrad, we would actually live side by side with Russians instead of in a foreigners' compound.
Detailed instructions were offered about how to avoid getting into trouble with the KGB. We should be particularly careful not to be entrapped in sexual liaisons which would result in blackmail (from the Soviet side) and swift forcible return to Britain (from the British side). If any untoward approach was made to us, or if we knew of such an approach to someone else in the group, we should immediately inform the embassy. (82)

According to Fitzpatrick's account, such ominous warnings were met with scepticism by the prospective exchange students. As she notes: 'There must have been quite a lot of silent scepticism in the room about the briefer's claim that it would be impossible to make friends with Russians ... I certainly thought the briefer was out of date, and was a bit surprised at the strength of the Cold War message' (83). In spite of this, at the same time 'it was hard not to shiver at the cloak-anddagger atmosphere and the speakers' emphasis that if you got into trouble in the Soviet Union, it could be real trouble' (83).

After she arrived in Moscow, Fitzpatrick had to put up not only with the awkward interactions with her neighbour in the university dorm, clearly entrusted with keeping an eye on her, but also with clumsy approaches of young people whom she surmised had been sent by the KGB to spy on her. In one surreal instance, an unknown young man knocked on her door one evening, asking to borrow a screwdriver (104). He introduced himself only as Misha, and never explained how he had got into a building where only pass-holders were admitted. Fitzpatrick accepted his invitation to visit a painting exhibition in the following days and, on that occasion, the two bonded. Towards the end of their outing, Misha suddenly became nervous, 'seemingly torn by some kind of conflict, and saying "I don't know, I don't know" rather comically in English' (107). After one week, he went off on a business trip to the Ukraine and disappeared from Fitzpatrick's life. To justify the sudden departure, she made up a romantic 
story in which Misha had been sent by the KGB but had then realised that he really liked her and felt it dishonourable to keep deceiving her. In this concocted intimacy, it is possible to discern the inner conflicts involved in living as a stranger in a society where everything foreign is at the same time secretly admired and kept at bay. The craving for a meaningful personal connection also represents the dilemmas and difficulties that a foreign researcher faces in relating to the society that is the target of his or her studies as something more than a simple object of knowledge.

The constant uncertainty about the real intentions of the people surrounding her led young Fitzpatrick to question her own identity and motives. This emerges with remarkable clarity from a chance meeting that she had one day with a schoolgirl in Volgograd:

\footnotetext{
'Are you a spy (ty shpionka)?' was the ingenuous question asked me by a schoolgirl in Volgograd. I said no, but in my own mind the answer wasn't absolutely clear-cut. No, I was not a spy: that is, I was not on the payroll or working unpaid for any national or émigré intelligence agency. But I knew some spies, broadly construed: my Oxford college, St Antony's, was full of them, admittedly mainly retired ... How close did a connection have to be to become culpable? ... No doubt it was a symptom of our collective paranoid obsession with spying that such thoughts would even come into my mind. In the unlikely event that I had wanted to be absolutely honest in replying to the Volgograd girl's question, I might have said, 'Not intentionally.' But even that might not have been fully accurate, since in my capacity as a historical researcher, I wanted to find out things the Soviet authorities wanted to hide, and they counted that as spying. Given my status as hunter out of secrets, I never felt totally innocent-but perhaps nobody did in the Soviet Union. The most accurate answer to
}

the Volgograd question might have been: 'I don't think so.' Or even 'I hope not.' (2013, 85-86)

Compared with this kind of deep selfquestioning, the accusations of being a spy levelled at Fitzpatrick by a national newspaper seem like a trivial matter. The real undermining of her self-perception took place on a daily basis in the ordinary human interactions that constituted the basis of her everyday life in the Soviet Union.

Fitzpatrick's entry points into Soviet society were her friendship with members of Lunacharsky's family and her archival work. Early in her stay, she befriended Irina Lunacharskaya, Lunacharsky's stepdaughter and self-appointed guardian of his intellectual legacy, as well as her uncle Igor Alexandrovich Sats, Lunacharsky's brother-in-law and personal secretary. In particular, as an editor at the literary magazine Novy Mir-which at that time was looked upon as a liberal beacon in the Soviet Union-Igor Sats granted Fitzpatrick privileged behind-the-scenes access to the highest-level intellectual debates of that period, the stuff that would have made headlines in foreign newspapers if only she had chosen to divulge it. However, her real breakthrough came thanks to her work in the State Archives. Overcoming a host of challenges at a time when it was almost impossible for a foreigner from a capitalist country to get access to Soviet archives, Fitzpatrick was allowed to explore the internal documents of the Narkompros, the People's Commissariat for Education, which Lunacharsky had presided over for a while. Through her archival research, she was able to gain extraordinary insight into the functioning of the Soviet state that challenged the then-dominant idea of the Party-state as a monolith. It was an exhilarating feeling for a budding young scholar: 'Some days, I felt completely carried away by the sense that I now understood how the Soviet system worked AND NOBODY ELSE DID because they had never seen a soviet state archive' (184). 
Her hard work even gained her some secret friends. A few years later, she was given one file on convict labour, a taboo subject in the Soviet Union of those years. At that time, Fitzpatrick had thought it was a fortuitous accident, but during perestroika she reports that she met an archivist who greeted her as an old friend and told her: 'Weren't you pleased when you got that file on convict labour I sent you? It was my little gift to you, you were such a hard worker' (209). At the same time, her work in the archives did nothing but reinforce the suspicions of the authorities that she was engaged in espionage, resulting in a string of uncomfortable incidents. One day, she surprised a stranger secretly taking her photo while she was ordering food at the university cafeteria (197). Another time, she found herself in real danger, facing a botched attempt at a honey trap set up by an unknown 'East German scholar' with the assistance of her neighbour (200). It was this event that finally led Fitzpatrick to visit the British Embassy to seek help from the British cultural attaché, who in an unlikely turn of events was a relative by marriage of Ian Fleming, the creator of James Bond.

While reading as an enjoyable memoir and a lively description of what life was like for a foreigner in Brezhnev's Soviet Union, A Spy in the Archives is also a powerful reflection on the challenges involved in doing research in authoritarian contexts and on the inner conflicts of social scientists. Reflecting on the beginning of her career with the benefit of half a century of hindsight, Fitzpatrick reaches the same conclusion as her younger self on that distant day when she had met the schoolgirl in Volgograd:

The Soviets were not totally stupid in thinking that historians like me were essentially spies ... We were trying to get information they didn't want us to have, and we were prepared to use all sorts of ruses and stratagems to get it. It's true that we wanted the information for ourselves, not for a spymaster. On the other hand,

\begin{abstract}
'ourselves' included a Western scholarly audience; it was not purely for our private satisfaction. If we found something explosive in the archives, we were going to use it in our work, without any sense of obligation to the archives, still less loyalty to the Soviet state. (210)
\end{abstract}

For this reason, as she writes in the final pages of the memoir, she 'never felt completely innocent in the Soviet Union' (341). Nor did she feel much welcome in the United States, where she moved in the 1970s, as rumours started swirling that she had got into Soviet archives because her father was a big Communist apparatchik in Australia-he obviously was not-and she had come to Columbia University as a KGB spy. The silver lining in her American experience was that, although she felt 'victimised and scared', at least she did not have to feel guilty (341).

\section{My Life as a Spy}

Questions related to the identity of the researcher are also central to Katherine Verdery's My Life as a Spy, albeit with some fundamental differences. Whereas Fitzpatrick's historical work in the Soviet Union largely revolved around archival documents, Verdery's research in Communist Romania was mostly ethnographic, involving actual people in communities she lived in. In addition, while Fitzpatrick wrote a memoir mostly based on personal recollections, her diaries, and letters written to her mother, Verdery could count on an additional source: the secret police files that the Romanian Securitate had kept on her from her first visit to the country in 1973 to the fall of the Ceaușescu regime in 1989. These files contained an extraordinary-and overwhelming-amount of information. As Verdery writes: 
I arrived in the reading room to see on a table three huge stacks of yellowing dossiers plus a fourth small one. There were eleven volumes in all. Each stack contained multiple volumes of 300-400 pages apiece, covered in cardboard and bound with string. I began to read, spending several hours going through them and completely forgetting about lunch. When I finally came up for air, I looked at the people around me and found myself thinking they were all secret police informers rather than objects of surveillance reading their files, like me (10).

Reading her own files was a life-altering experience for Verdery, as it exposed the extent of the surveillance to which she had been subject, the network of informants even among her closest friends, and the lies that had been fed to her. It was also alienating in that the self that emerged from the files was at the same time familiar and completely foreign, those actions and words that she still remembered twisted to appear in a sinister light. To further complicate her self-perception, all people named in the files were assigned pseudonyms-Verdery was referred to as 'VERA', but also 'VIKY, 'VALY', 'KORA, 'KITTY', 'KATY', 'VANESSA', 'VADU', and 'VERONA' (14). Throughout the book, Verdery refers to these alter egos as her 'spy doppelgangers', but instead of ridiculing the point of view of her hidden controllers, she concedes that their portrayal of her was not totally unreasonable. Wasn't it true that many embassy personnel and scholars visiting the Soviet bloc had intelligence connections? What kind of foreigner came alone and settled in a single village for over a year to conduct ethnographic research on folklore, as she did in 1973? And what about her habit of dressing modestly to mingle with local people or to hide her identity as a US citizen when taking the train? Wasn't that the kind of thing a spy would do? Even more troubling for Verdery was the realisation that there were uncanny parallels between her own ethnographic practices and those of intelligence work:
[The officers] recognize me as a spy because I do some of the things they do-I use code names and write of 'informants', for instance, and both of us collect 'sociopolitical information' of all kinds rather than just focusing on a specific issue. So what are the similarities and differences between these two different modalities of information gathering: spying and ethnography? When I read in the file that I 'exploit people for informative purposes', can I deny that anthropologists often do just that, as Securitate officers do? Isn't this part of the critique of my discipline that likens it to a colonial practice? (18)

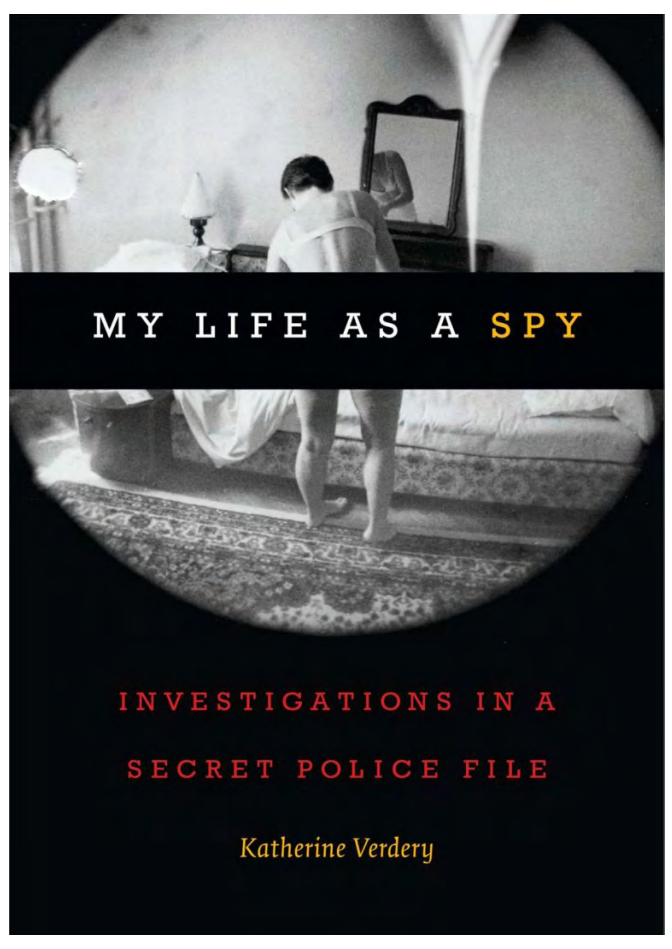

My Life as a Spy: Investigations in a Secret Police File, by Katherine Verdery. Published by Duke University Press (2018). 
Particularly haunting is the epiphany that these officers might have just used her to do their own work 'discovering things they might have missed concerning what people thought about the regime. The Securitate made me its tool-perhaps another reason why they did not throw me out' (276). Of course, it took Verdery decades of experience and the trauma of reading of her own police files to become aware of these dynamics. Just like Fitzpatrick, Vedery also remembers feeling sceptical as a young student when she heard the warnings by embassy personnel about the extent of the surveillance she would be subject to:

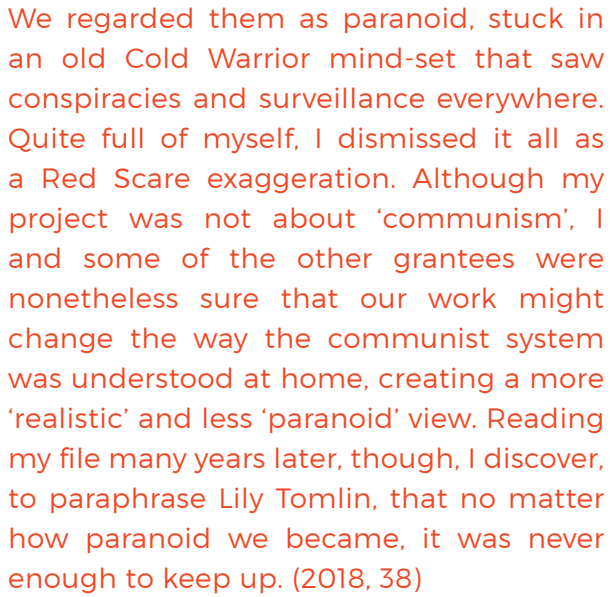

In Communist Romania-as elsewheresurveillance relied on both a human infrastructure and cutting-edge technologies. Verdery tells us that estimates about the number of informers in Romania at that time range from under a million to three million, depending on whether the count includes those working with the regular police or only those collaborating with the Securitate, plus an additional 15,000 full-time Securitate employees (208). If these numbers seem staggering in relation to the size of the Romanian population at that time (around 23 million), so was the task at hand, if we consider that in 1968 the Securitate had determined that fully 50 percent of the adult population was suspicious and should be under surveillance (208). To carry out their work, the Romanian state security could count on new surveillance technology, in particular the recording equipment called Tehnica Operativa, which included video cameras as well as various other means of interceptions and which security officers affectionately referred to as 'Teo' (114). Judged from today's standards, Teo seems quite rudimentary. Not only did it require significant work and planning to set up, but it also often malfunctioned and could be easily fooled by the proximity of something loud, like a television (137-38). Also, Teo could not operate alone, but constantly needed human assistance, for instance to transcribe the audio recording as tape was in short supply and often needed to be reused-nothing compared with the ease of today's 'smart' technology. In spite of these limitations, Teo remained a very intrusive tool at the disposal of the Securitate, as the cover photo of My Life as a Spy demonstrates-an image of the author in her underwear secretly taken in a hotel room in 1985.

Due to these technological constraints, the system was overall tilted towards greater reliance on informers. As a former Securitate officer told Verdery many years later: 'The CIA relies too much on technology and doesn't get good intelligence because it doesn't use informers enough' (260). The greater strength of Verdery's book indeed lies in the way the author manages to highlight the complexities of the relationship between informers, their handlers, and their targets. Instead of simple condemnation, Verdery tries to understand. Informers did not inform on their targets only out of fear of repercussions for themselves and their families, but for a whole range of other reasons. In fact, through the reading of her file and her interviews with former informers, she discovers that far from being invisible, the Securitate was present in the daily life of ordinary Romanian people: '[P]eople could see the officers responsible for their work unit, or the guys hanging out in places where potential "dissidents" might congregate. Secus were known as the 'boys with the blue eyes' ... The Securitate thrived not just on invisibility 
but on its dialectic with the visible' (284-85). It was only to her as a foreigner researcher, an outsider to Romanian society, that the Securitate remained invisible, as she explains in this poignant passage:

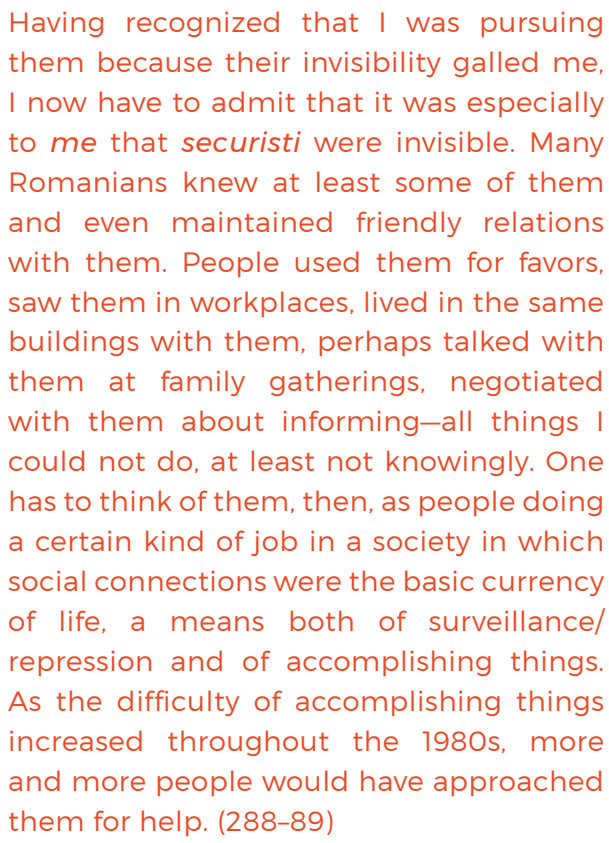

Only this proximity could explain the otherwise inexplicable manifestations of friendship between informants and their handlers, as when one of the Securitate officers Verdery managed to interview told her that he had been one of only three people outside the family who had showed up at the funeral of an informant who had spied on her many years earlier (269).

The increasing awareness of being under constant surveillance over the years took a heavy toll on Verdery's mental health. She relates that after spending one year in Romania in 1984-85, she felt traumatised for months. Even at home in Baltimore, she found herself constantly worrying about microphones in her apartment, and panicked when a friend began telling her on the phone about another friend who was doing something with cocaine, as she was convinced that her phone was bugged and the police would overhear it (165). An even harder blow came years later, when reading her files, she found that some of her closest friends had regularly reported on her and even that some men she had sexual liaisons with had been sent by the Securitate. While anybody would find this terribly destabilising, Verdery proves considerable detachment and analytical skill in arguing why what all these people did should not be considered a betrayal:

\begin{abstract}
My relations with various Romanians who arguably 'broke my trust' have to be placed in the context of the larger set of relationships in which they are embedded, which these people may be trying to shelter when they agree to inform on me. For me to see their abandonment as betrayal would be to insist that I be more important to them than those others. To put the problem in this way is to diminish the force of 'betrayal', for clearly it is absurd for me to imagine that I will be more important to my friends than their own families, friends, and ongoing livesrelations having much greater longevity for them than does ours, and which their reports on me protect. (227)
\end{abstract}

Here again we find that constant feeling of being an outsider with which social scientists doing research in a foreign context have to grapple. It is due to this substantial estrangement that researchers are every so often looked upon as spies and, in such circumstances, it is not hard to see how the spy doppelganger ceases to be a mere manifestation of paranoia and ends up assuming a life of its own.

\section{Continuity and Change}

While the Soviet Union and Communist Romania ceased to exist three decades ago, social scientists conducting research in authoritarian systems today continue to face 
challenges and dilemmas similar to those described by Fitzpatrick and Verdery. The context, however, is obviously very different. My experience in China over the past 15 years provides some insight into these changes. I have described elsewhere the non-consequential brushes that I had with Chinese state security (Franceschini 2017). When I visited the offices of labour NGOs, it occasionally happened that some unintroduced stranger was sitting there in silence, simply taking notes of what we were saying. On one occasion, while I was abroad, some state security officials tracked down one of my former collaborators and interrogated him at length about my activities and whereabouts. They were particularly interested in my spending habits: Did I often rent expensive cars? Did I like to throw money around? He protested that I was so stingy that I always insisted on taking public transportation even when doing interviews in some faraway suburb-which was true-and the matter ended there. At that time, I had little reason to fear the possible consequences of these encounters: I was worried about the wellbeing of my local collaborators, but I thought that being a foreigner the worst consequence I could face would have been a visa denial or being expelled from the country. Of course, this was before the Chinese authorities began detaining foreigners with links to local and international NGOs.

As Fitzpatrick and Verdery, at the beginning of my stay in China-at least in the first few years of it, before surveillance became so obvious that it was impossible to ignore it any longer-I did not take seriously all the warnings about the possibility that my communications and movements might be monitored. In my dealings with Chinese labour NGOs, I also became increasingly aware of the ambiguous relationship that bound my contacts in Chinese civil society to the state security apparatus, a topic which I have written about elsewhere (Franceschini and Nesossi 2018). Just like Verdery was surprised at hearing that a Securitate officer had participated in the funeral of one of his informants, I remember my befuddlement one day when an activist friend of mine candidly told me how his handler in the state security had visited him at the hospital after he had surgery to bring him flowers. I have no doubt that some of my contacts in NGOs informed not only on mewhich I totally understood and considered unavoidable-but also on each other. In a couple of cases, I even found myself dealing with people in the civil society organisation I worked with who threatened to report me to their contacts in the state security if I did not become more compliant in approving their proposed expenses.

I do not have access to any documentation that the Chinese state security might have compiled on me, so I am unable to assess the thoroughness of state surveillance in today's China. However, I find the very idea of the existence of mysterious 'files' that the Chinese authorities might be keeping on me haunting like a ghost both intimate and strange. What I can say is that the few dealings that I had with the Chinese state security are most likely just the tip of the iceberg, the only visible part of a much more pervasive high-tech surveillance system that remains invisible to the naked eye. As surveillance comes to rely on new, sophisticated technologies, the occasional meetings with agents sent by the authorities to spy on us described by Fitzpatrick and Verdery are becoming remnants of another era, when states mostly relied on actual people to keep an eye on the comings and goings of their citizens and of foreigners within their territories. This human infrastructure of surveillance is unlikely to be dismantled anytime soon, but as high-tech surveillance becomes more and more pervasive and efficient, state apparatuses will rely less and less on an army of controllers to keep people in check. This way, surveillance is becoming at the same time less visible and more pervasive, as the National Security Agency scandal of recent years proves all too clearly.

The implications of this shift remain to be seen. Verdery emphasises the effects that intrusive surveillance embedded in her social network had on her identity. As the Romanian 
Securitate demanded that her friends and acquaintances report on her and did not hesitate to spread rumours about her evil purposes, she found herself doubting the very foundations of her perception of reality and wondering whether she has been delusional all along. On the contrary, high-tech surveillance 'does not rely on undermining people's social relationships to control them but instead simply maps those relationships to discern potentially treacherous patterns. It does not instrumentalize people's social relationships in the same way as does Securitate surveillance' (293). The one thing that the two forms of surveillance share, according the Verdery, is the constant need to identify new enemies in order to ensure their own survival: 'In both [systems], a bureaucracy exists to find enemies-spies, terrorists-and to ferret out secrets. If in the Securitate's case this meant that all foreigners became spies and the atmosphere of suspicion somehow invited people to produce secrets and transgressions, does high-tech surveillance too help to produce the very threat it seeks to obliterate?' (294).

The relationship between surveillance technology and manual labour-and between new surveillance techniques and mental health-need further exploration. However, although the rules of the game are rapidly changing, the relationship between academia and espionage remains as fraught with contradictions as always. Fitzgerald and Verdery both challenge the idea that there exists a clear-cut boundary between the identity of the researcher and that of the spy. This holds true not only in authoritarian contexts such as the Soviet Union, Communist Romania, or the People's Republic of China-countries ruled by party-states largely shrouded in secrecy-but also in Western liberal democracies, which are ruled by political classes that often have an interest in obscuring uncomfortable truths. As social scientists, as far as we attempt to unearth information that the authorities of the countries we work in would rather keep buried, we are all 'spies'. We are supposed to talk to people, conduct surveys, and dig in the archives to challenge established narratives and present uncomfortable truths. Moreover, many of us receive significant funding from government grants or publicly sponsored universities, which makes us even more dubious in the eyes of the authorities of the places we focus on. Unable as we are to outrun the shadow of the political, it comes as no surprise that our intentions are constantly questioned. 


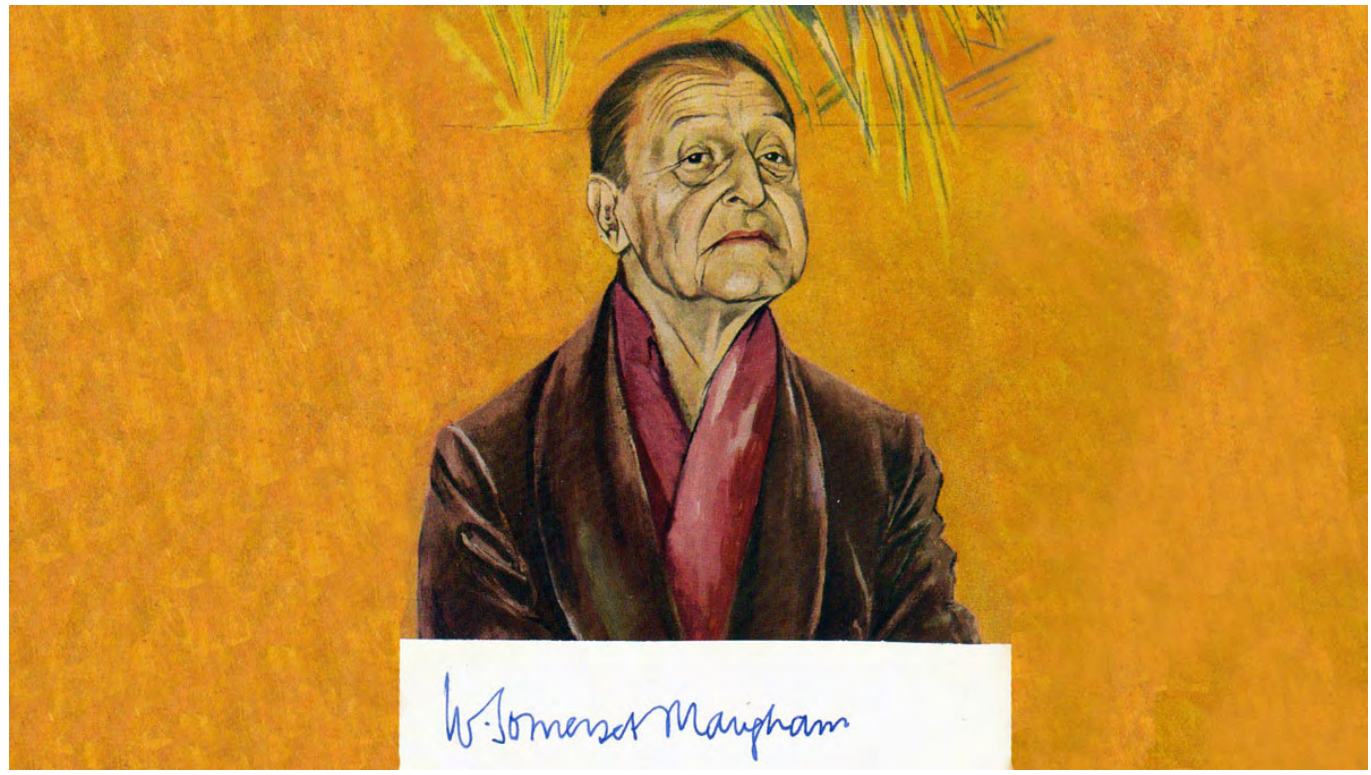

\section{Experiences of the Soul \\ On William Somerset Maugham's Far Eastern Writings}

W. Somerset Maugham, from an original portrait by Graham Sutherland, 1978.

Ivan FRANCESCHINI

W illiam Somerset Maugham is probably one of the most commercially successful but least critically appreciated writers of the twentieth century. If today he is remembered mostly for his 1915 masterpiece Of Human Bondage and a few other outstanding novels, back in his time readers looked upon him as the cantor of the decadence of the British Raj, particularly in the Malay archipelago. Although he was in Malaya for only six months in 1921 and four months in 1925 , he managed to write two collections of short stories-The Casuarina Tree (1926) and Ah King (1933)-that played a huge role in shaping the Western imaginary of the East, just as Rudyard Kipling had done for India. His literary engagement with Asia and the Pacific was not limited to Malaya. In 1916-17, he travelled to Hawai'i, Tahiti, and other islands in the Pacific, which he then used as the backdrop for several short stories collected in The Trembling of a Leaf (1921), as well as the novels The Moon and Sixpence (1919) and The Narrow Corner (1932). In the second half of 1919 he visited a China in turmoil, an experience he drew on when writing On a Chinese Screen (1922), a semi-forgotten collection of sketches that in his words constituted 'not a book, but the material for a book', and The Painted Veil (1925), a novel of adultery and revenge set 
between Hong Kong and the mainland. In 1922, he undertook an adventurous journey in Myanmar, Thailand, Cambodia, and Vietnam, which he then described in the travelogue The Gentleman in the Parlour, released in 1930. Finally, in 1944 he published the novel The Razor's Edge, part of which was set in India, where he travelled in 1938.

As it often happens when an established author dares to write about foreign context that they have visited but are not particularly familiar with, his writings were highly controversial. While readers loved his Far Eastern tales and travelogues, opinions among British colonial administrators, settlers, and scholars were more mixed. One criticism was that he did not indulge the Orientalist gaze of the public, showing very little interest in the local populations and focussing instead on the inner worlds of the foreigners living in remote outposts of the Empire. For instance, when, in 1937, Philip Fogarty, then Commissioner in charge of the Shan States, was trying to convince Maurice Collis to visit this forgotten corner of the British Empire and write a book to showcase the achievements of the colonial administration in the area, he explained how he should pitch the idea to his publishers in these terms: 'Look here. Put it like this to them. Say the Shan States are fresh ground. And it's a literal fact, what's ever been written about them? Somerset Maugham went down one road there on mules ten years ago, but he's not interested in Asiatics. While you-well, that's your particular line' (Collis 1938, 20).

Another criticism was that his tales and travelogues did not have an explicit political dimension, quite unlike the writings of George Orwell (1903-50), who was working as a policeman in Burma in the early 1920s, just as Maugham was travelling through the country. While George Orwell's stay in Burma resulted in the masterpiece Burmese Days (1934) and several essays highly critical of British rule-to understand the critical verve of his work one just has to think of passages like 'Mr. Macgregor stiffened at the word "nigger", which is discountenanced in India. He had no prejudice against Orientals; indeed, he was deeply fond of them. Provided they were given no freedom he thought them the most charming people alive. It always pained him to see them wantonly insulted' (Orwell 1974, 30)-Maugham only wrote a couple of travelogues that were largely composed of his own existential and literary musings, and a handful of short stories set on rubber estates and remote outstations. In these, he largely limited himself to the description of the lowly passions of the British side of colonial society-their loneliness, boredom, drunkenness, lust, and madness. As Maugham's biographer Selina Hastings (2009, 295-96) wrote: 'Orwell portrayed the colonial oppressors at worst vicious, at best stupid and dull: a dull people, "cherishing and fortifying their dullness behind a quarter of a million bayonets". He clearly foresaw the end of Empire, while Maugham appeared not so much unaware of as indifferent to the subject.'

\section{Burgess's Hit Job}

The strongest indictment of Maugham's writings on the Far East comes from Anthony Burgess (1917-93), another heavyweight of contemporary British literature. Burgess spent five years in the 1950 s as a teacher and education officer in the British Colonial Service in Malaya, gaining fluency in written and spoken Malay language and authoring no less than three novels set in the country, the so-called The Malayan Trilogy (2000). Given his deep emotional attachment to Malaya, it is not surprising to discover that Burgess considered Maugham little more than an interloper. While in an obituary he praised Maugham's collections of Malayan stories as containing some of the finest examples of writing in English, with a 'width of observation [that] was something new in English fiction, as was the willingness to explore moral regions then regarded as taboo' (Burgess 1965, cited in 


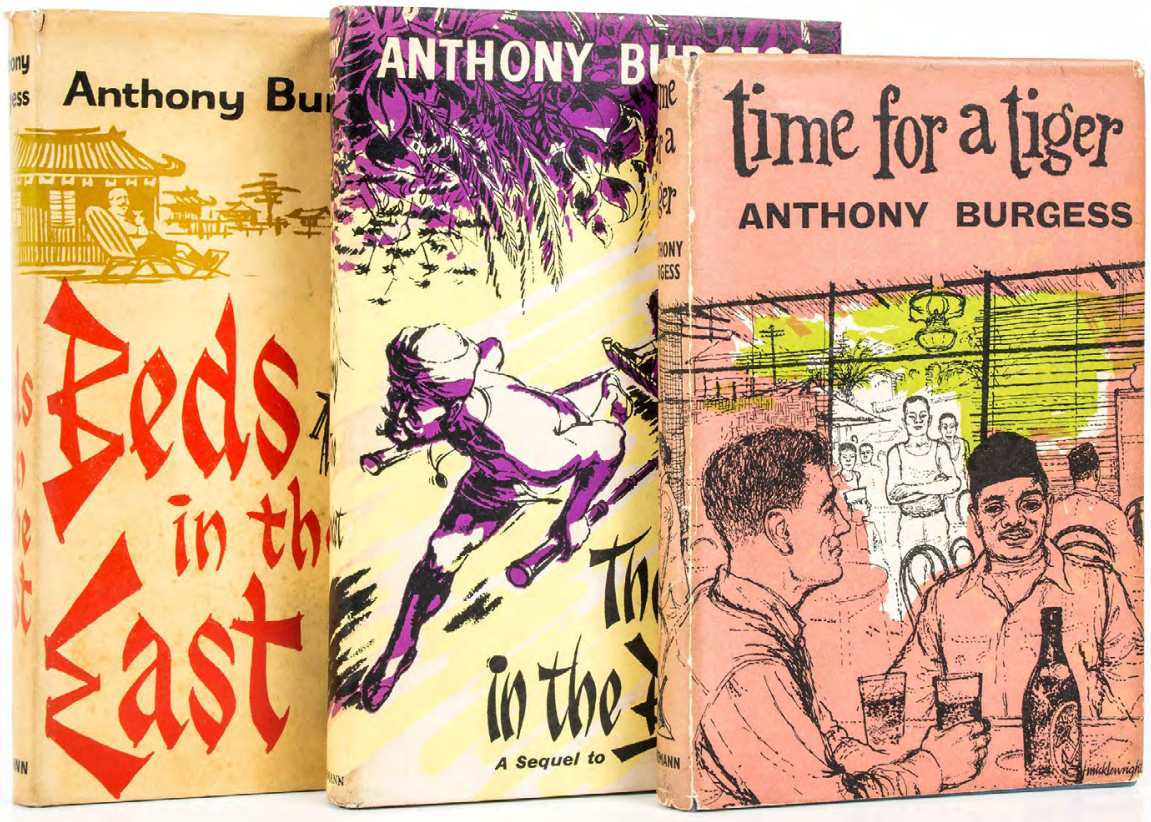

Hastings 2009, 329), in an introduction that he wrote in 1969 for a new edition of these same stories that he himself had prepared, he was much more dismissive:

He stayed in no one place very long, but he usually managed to absorb something of the atmosphere of each town, village or rubber estate he visited, and he always made quick contact with the local residents. These residents were invariably Europeans-planters, colonial officials, businessmen, or just men living in exile to escape from trouble or sadness at homeand there is little evidence that Maugham gained, or wished to gain, any direct knowledge of the lives and customs of the native peoples of the East. This must be disappointing to present-day Malay and Indian and Chinese and Eurasian readers of his stories, but we have to remember that (apart from the fact that Maugham had no time to learn Malay or Chinese or
An old edition of Anthony Burgess's Malayan Trilogy.

Tamil) the Western attitude to the Far East was very different in Maugham's time from what it is today. (1969, xv)

Burgess's animosity towards Maugham fully emerged one decade later, when he published Earthly Powers (1980), a novel in which the main character-81-year-old writer Kenneth Toomey looking back at his life-is nothing but a barely hidden parody of the deceased writer. In fact, it has recently come to light that in earlier drafts of the book the main character was named Kenneth Markham Toomey, a name much closer to Maugham's, and that the author changed it at a very late stage of writing, probably not to offend the nephew of the deceased writer, whom Burgess had recently met and befriended (Biswell 2012). While undoubtedly a minor masterpiece, Earthly Powers was a castigation of Maugham for both his bubbling private lifethe memorable opening line read: 'It was the afternoon of my eighty-first birthday, and I was 
in bed with my catamite when Ali announced that the archbishop had come to see me'-and his inability to overcome his reputation as a second-rate, commercial writer. The novel even includes a few chapters set in the East. It is here that Burgess brings to light what he really thinks about Maugham's fame as a cantor of colonial Malaya and, more broadly, the East. A dialogue between Toomey and his agent sets the general tone:

[Agent:] 'Now the next thing is a travel book. Becoming very popular with the world opening up again. Scribner's man Jeffrey's was here, we had lunch, he paid of course, he was keen on that. That would be jest fahn ah gayess. He insisted on taking me to the Lucullus, Wembley. The British Empire, he was very struck with the British Empire. India, Ceylon, the Federated Malay States. Now then, here's my idea. You do that, and you also do some so to speak travel stories. Memsahibs committing adultery, planters' wives murdering their Chinese lovers, district officers going down with DTs.'

[Toomey:] 'A rather limited image of the British Empire.

[Agent:] 'Well, out east, you know. Eard the heast a-cawwing. You know Collier's? I don't mean those dirty poetic men in D. H. Lawrence, I mean the magazine. Thought you did. One thousand dollars per story. They'll arrange a contract for twenty stories, half and half for foreign rights, then perhaps another twenty if all goes well. Really short ones, two and a half of their pages with a big illustration-you know the sort of thing, the memsahib in her camisole threatening a leering muscular coolie with a broken gin bottle. Anyway. it's two birds. You end up with two books, one throwing harsh tropical light on the other. Toomey's East. Damn and blast.' That was the cigarette. (Burgess 1980, 211)
Toomey/Maugham, we are told, is in it just for the money, his writing nothing more than a heist aimed at taking advantage of the gullibility of the public. The sarcasm becomes even more explicit a few pages later, when the character is in Singapore and engages in a striking act of dissociation from his real-life alter ego, which, incidentally, is also the only occasion in which Maugham is explicitly cited in the book: 'Singapore duly smelt of boiling dishrags and catpiss. I stayed at the Raffles Hotel which Willie Maugham, under their later notepaper heading, was to laud as breathing all the mystery of the fabled East. The mystery lay perhaps in the provenance of the meat for the curries' (Burgess 1980, 230).

The criticism becomes slightly more articulate with the introduction of Philip, a young British doctor with whom Toomey falls in love, reciprocated. Philip happens to be in Malaya because he felt the urge to heed the 'call of the East' after reading a book by Joseph Conrad, but is now disillusioned. When he tells Toomey about this, Philip is sarcastic: 'I take it you'll be writing about the East now. And then some medical student will read you and say ah adventure and go for an interview in Great Smith Street. A big responsibility.' 'So it's not like Conrad.' 'Conrad left out the hookworm and the malaria and the yaws' (Burgess 1980, 235). To make his point clear, when the following day dawns, Philip takes Toomey to his hospital, where they visit the ward of patients with deformities due to tropical diseases. When Toomey cannot stand the sight and is about to vomit, the doctor quips:

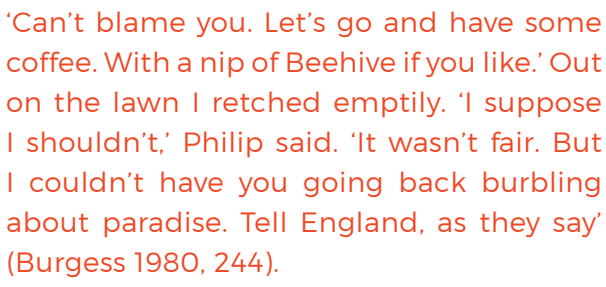

Allowing himself plausible deniability by not naming him explicitly, through the character of Toomey, Anthony Burgess 


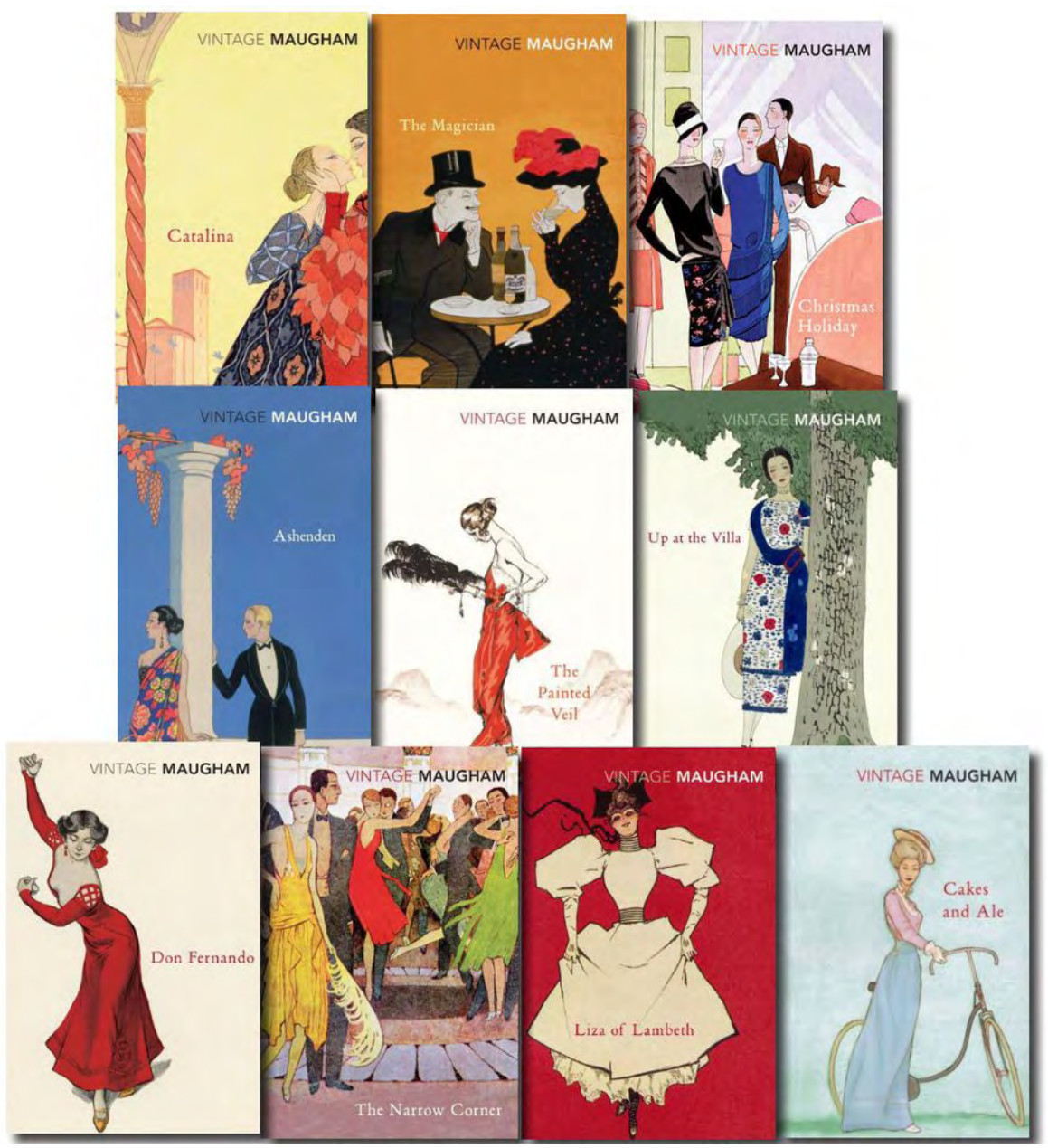

The Vintage edition of some of William Somerset Maugham's books.

manages to assassinate Maugham's character. Not only is the writer denied agency-after all, he produces his tales only for money upon the suggestion of his agent-but he is also described as completely unaware of the reality he purports to portray. So much for Burgess's praise of Maugham as the author of some of the finest examples of writing in English.

\section{Flights of Fancy}

It is undeniable that Maugham's fascination with the East was prone to flights of fancy and had a strong Orientalist flavour. If we skim through his oeuvre, we discover that traces of this attraction can be found from his early 
works, which long predate his trips to Asia and the Pacific. Some of the earliest examples are in The Magician, a short novel published in 1908 in which Maugham experiments with the topic of the supernatural through the eyes of Oliver Haddo, a character based on notorious occultist Alesteir Crowley. Just like many of his contemporaries, Maugham saw the occult as indissolubly linked to the East. These are the words with which the young writer describes the moment when Margaret, a young woman with an artistic temperament, is seduced by Haddo thanks to his magical powers:

[Oliver Haddo] began to talk with that low voice of his that thrilled her [Margaret] with a curious magic. He spoke not of pictures now, nor of books, but of life. He told her of strange Eastern places where no infidel had been, and her sensitive fancy was aflame with the honeyed fervour of his phrase. He spoke of the dawn upon sleeping desolate cities, and the moonlit nights of the desert, of the sunsets with their splendour, and of the crowded streets at noon. The beauty of the East rose before her. He told her of many-coloured webs and of silken carpets, the glittering steel of armour damascened, and of barbaric, priceless gems. The splendour of the East blinded her eyes. He spoke of frankincense and myrrh and aloes, of heavy perfumes of the scent-merchants, and drowsy odours of the Syrian gardens. The fragrance of the East filled her nostrils. And all these things were transformed by the power of his words till life itself seemed offered to her, a life of infinite vivacity, a life of freedom, a life of supernatural knowledge. (Maugham 2000c, 113)

This passage is a perfect example of Orientalist writing. The opulent, exuberant, and mysterious Oliver Haddo comes to embody the fabled East, which seduces Margaret, an innocent maiden who would otherwise be destined to an ordinary, boring bourgeois life as the wife of a famous surgeon. In the book,
Maugham let it be understood that Haddo does really have magical powers, but one cannot avoid thinking how much stronger and more relatable the writer's message might have been if the 'magician' had managed to seduce the girl simply using the leverage of her fascination with the East.

A few years later, in Of Human Bondage (1915), the protagonist Philip Carey, a young student of medicine clearly modelled on Maugham himself, dreams of travelling to the East as soon as his training is over: 'As soon as I've got through my hospital appointments, I shall get a ship; I want to go to the East- the Malay Archipelago, Siam, China, and all that sort of thing-and then I shall take odd jobs. Something always comes along-cholera duty in India and things like that. I want to go from place to place. I want to see the world. The only way a poor man can do that is by going in for the medical' (Maugham 2000d, 356). This is how Carey/Maugham imagined the East: 'He wanted to go to the East; and his fancy was rich with pictures of Bangkok and Shanghai, and the ports of Japan: he pictured to himself palm-trees and skies blue and hot, dark-skinned people, pagodas; the scents of the Orient intoxicated his nostrils. His heart beat with passionate desire for the beauty and the strangeness of the world' (Maugham 2000d, 537). Although the dream of Asia appears only in these two passages in the whole novel, Philip's story in Of Human Bondage can also be read as a tale of fascination with the exotic, which leads him to live in an imaginary future and let the present flow by. In this disgruntlement with the ordinariness of bourgeois life, Philip's character presents significant assonances with those of Margaret in The Magician. However, while Margaret succumbs to her tragic destiny, Philip never visits the East and, in the final pages of the book, we find him giving up for good on this dream to start a family. This decision to set aside his wanderlust and settle down in England assumes the character of an epiphany: 


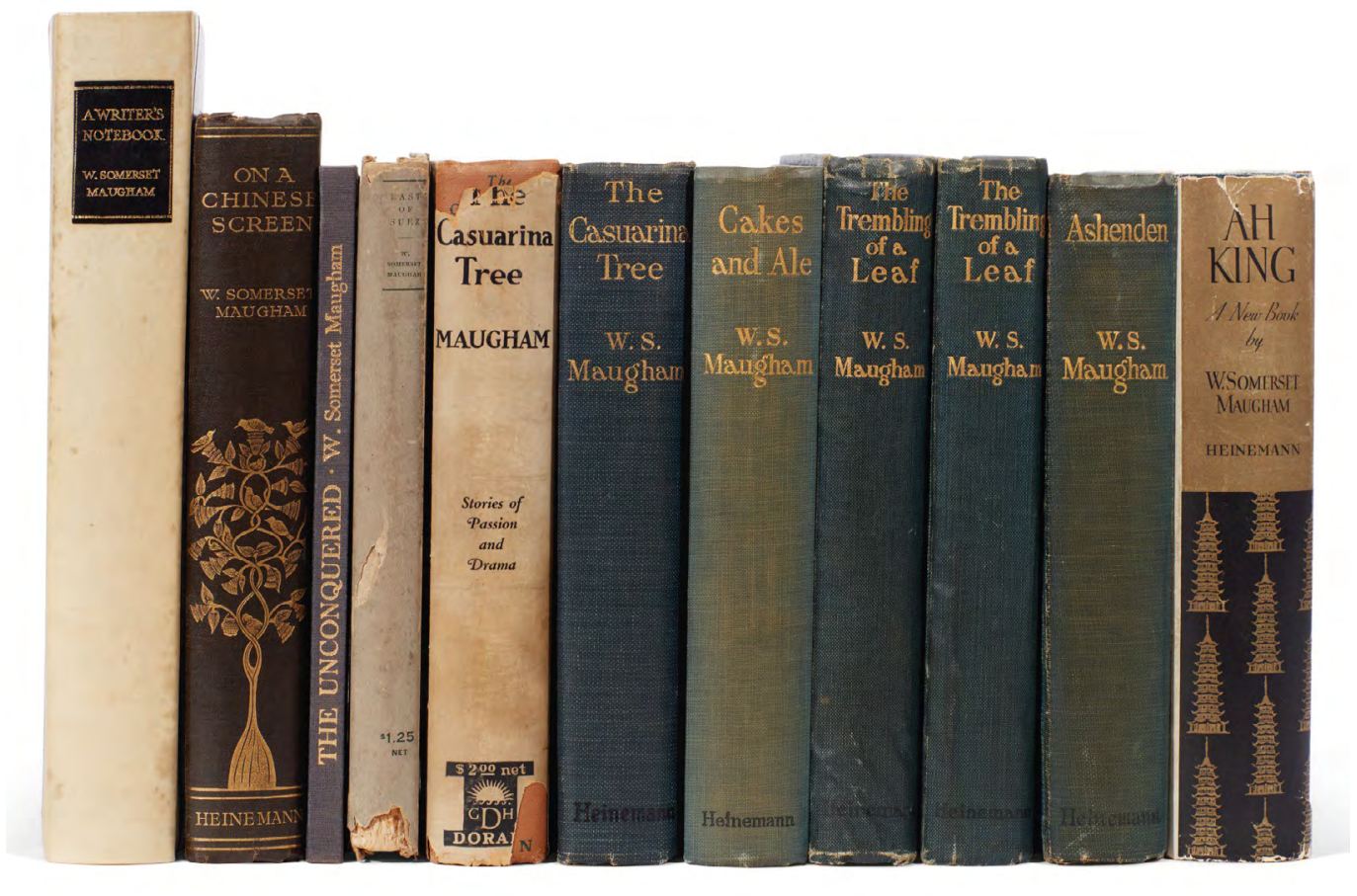

A Collection of 11 works of William Somerset Maugham from the 1920s to the 1940s. From the Library of Christian Heuer (sothebys.com).

What did he care for Spain and its cities, Cordova, Toledo, Leòn; what to him were the pagodas of Burma and the lagoons of South Sea Islands? America was here and now. It seemed to him that all his life he had followed the ideals that other people, by their words or their writings, had instilled into him, and never the desires of his own heart. Always his course had been swayed by what he thought he should do and never by what he wanted with his whole soul to do. (Maugham 2000d, 699)

If we consider how Maugham's later writings played a fundamental role in shaping the imaginary of the East among the Western public and pushing innumerable people to "live by the [his] ideals'-something that clearly bothered Anthony Burgess-this passage assumes a tone of clairvoyant self-deprecation.

The fascination of the East plays a fundamental role even in Maugham's following masterpiece, The Moon and Sixpence, which he published in 1919, on the eve of his journey to China. This novel tells the story of an artist named Charles Strickland-a fictional character clearly inspired by Paul Gauguinwho finds his fulfilment as both painter and human being in Tahiti. The imaginary to which Maugham resorts in this book is still informed by Orientalism. For instance, we are told that ' $\mathrm{t}]$ he Pacific is more desolate that other seas; its spaces seem more vast, and the most ordinary journey upon it has somehow the feeling of 
an adventure. The air you breathe is an elixir which prepares you for the unexpected. Nor is it vouchsafed to man in the flesh to know aught that more nearly suggests the golden realms of fancy than the approach to Tahiti' (Maugham 1999, 156-57). In some ways, Strickland's existential trajectory is exactly the opposite of that of Philip Carey. Unlike Philip's carefully planned but never executed trip, Strickland travels to the East without any plan and, when he arrives in Tahiti, settles down in a hut in the jungle. It is there that, before meeting a tragic death, he realises his artistic aspirations on the walls of his hut. Unfortunately, nobody will know about his accomplishments as after his demise the place is set on fire upon his request.

What all these early writings have in common is that they describe the fascination that a legendary East exerts on Western characters. In these novels, Maugham presents the East as an exciting alternative for bourgeois characters disgruntled with their life prospects, an idealised Other where they believe they have a chance to find fulfilment. While, as we will see, the travelogues and short stories that he wrote in the 1920s and 1930s in the wake of his first journeys to the East are more complex, there is curiously a recrudescence of the Orientalist imaginary in The Razor's Edge, his 1944 novel. In it, we meet Larry Darrell, a middle-class American on a spiritual quest to find meaning in his life, travelling to India and encountering a series of individuals who awaken his curiosity towards Hinduism. In particular, he is astonished to meet a local politician, the Oxford-educated minister of finance in one of the smaller northern states of the country, who tells him that in one year, when he reaches the age of 50 , he is 'going to resign his profitable position, dispose of his property to his wife and children, and go out into the world as a wandering mendicant' (Maugham 2000f, 287)-all of this with the support of his friends and colleagues, who in all this see something totally natural. Through these meetings, Larry eventually lands in an ashram in southern India, where he has the first mystical experience of his life. While this sounds very clichéd, one cannot but be amazed by Maugham's clairvoyance in anticipating cultural trends that would take hold in the West only two decades later.

\section{Challenging Orientalist Tropes}

While not devoid of merit, the criticisms of Somerset Maugham as an inveterate Orientalist painting an idealised picture of the East while completely disregarding the local population and the politics involved in the British Raj are ungenerous. After his first trips to Asia in the early 1920s, Maugham clearly realised the fancifulness of his conception of the East as a 'mysterious' and untouched Other, and became much less prone to those flights of fancy that appeared in his early writings. In particular, in his Asian travelogues it is possible to discern a dawning awareness of how he had succumbed to the Orientalist imaginary of the East. As he wrote in The Gentlemen in the Parlour (2001b, 8):

Though I have travelled much I am a bad traveller. The good traveller has the gift of surprise. He is perpetually interested by the differences he finds between what he knows at home and what he sees abroad. If he has a keen sense of the absurd he finds constant matter for laughter in the fact that the people among whom he is do not wear the same clothes as he does, and he can never get over his astonishment that men may eat with chop-sticks instead of forks or write with a brush instead of with a pen. Since everything is strange to him he notices everything, and according to his humour can be amusing or instructive. But I take things for granted so quickly that | cease to see anything unusual in my new surroundings. 
In On a Chinese Screen, he recounts a meeting with a certain $\mathrm{Dr}$ Macalister, a medical missionary who had come to China 30 years earlier. His account provides a sobering indictment of any Orientalist fantasy:

'I often laugh when I think of my first impressions of China,' he said. 'I came out expecting to undergo hardships and privations. My first shock was the steamer with ten-course dinners and first-class accommodation. There wasn't much hardship in that, but I said to myself: Wait till you get to China. Well, at Shanghai I was met by some friends and I stayed in a fine house and was waited on by fine servants and I ate fine food. Shanghai, I said, the plague spot of the East. It'll be different in the interior. At last I reached here. I was to stay with the head of the mission till my own quarters were ready. He lived in a large compound. He had a very nice house with American furniture in it and I slept in a better bed than I'd ever slept in. He was very fond of his garden and he grew all kinds of vegetables in it. We had salads just like the salads we had in America and fruit, all kinds of fruit; he kept a cow and we had fresh milk and butter. I thought l'd never eaten so much and so well in my life. You did nothing for yourself. If you wanted a glass of water you called a boy and he brought it for you.' (Maugham 2000e, 48-49)

If it is true that in his writings Maugham chose not to focus on 'Asiatic' characters, this was arguably not because he lacked interest, but rather an act of humility based on his explicit admission to be unable to portray realistically a personality rooted in a context totally alien to him. He was fully aware of his limitations in imagining the Other, and never hid it. As

[1] I wish to thank Annie Ren for bringing this episode to my attention. he explained in a letter that he wrote in 1951: 'I felt that all the depictions that had been made of either Chinese, Indians, or Malays were merely superficial impressions combined with a lot of conventional prejudices. It is very nearly impossible for an English author to create a French character so that French readers would accept him as real. How much more difficult then would it be for an English writer to create a Chinese the Chinese would accept as plausible' (cited in Hastings 2009, 324-25). This is consistent with Maugham's general attitude towards creative writing. His stories always have a semi-autobiographical component-in most novels, he even inserts a fictionalised version of himself as a narratorand over and over again in his writings he emphasises how he feels uncomfortable using characters that stray from his familiar milieu. In The Razor's Edge, he even felt the need to justify his choice to use American characters:

It is very difficult to know people and I don't think one can ever really know any but one's own countrymen. For men and women are not only themselves, they are also the region in which they were born, the city apartment or the farm in which they learnt to walk, the games they played as children, the old wives' tales they overheard, the food they ate, the schools they attended, the sports they followed, the poets they read, and the God they believed in. It is all these things that have made them what they are, and these are the things that you can't come to know by hearsay, you can only know them if you have lived them. You can only know them if you are them. And because you cannot know persons of a nation foreign to you except from observation, it is difficult to give them credibility in the pages of a book. (Maugham 2000f, 2-3)

If he had such qualms in describing a character hailing from a culture with which he had such affinities, one can easily understand why in his writings on the Far East he chose 
to focus on British characters. In one of those rare instances in which he attempted to give voice to a Chinese intellectual, the result indeed left much to be desired. ${ }^{1}$ In a sketch entitled 'A Student of the Drama' included in On a Chinese Screen (Maugham 1955, 118-20), Maugham describes how during his trip to China he encountered a young Chinese lecturer on the art of the drama, a young man who had studied in Europe, could express himself fluently in English, French, and German, and had written a book in French on the Chinese theatre. Unfortunately, the portrait of this scholar that emerges from these pages is far from flattering. When asked what books he recommended his students read in order to learn about the literature of the day, the man could not respond as his narrow interests did not extend beyond the art of drama; his literary tastes appeared very questionable; and his approach to the art of the drama was over-intellectual and mechanistic. When he insisted that Maugham-who was a master of the genre-reveal to him the secrets of his craft, the writer simply shrugged his questions off: 'If you can't write a play no one can teach you, and if you can it's easy it's as falling off a log.'

While Maugham did not mention the name of the scholar, four decades later the son of the man came forward and published an essay in which he provided some additional context to the meeting (Soong 1974). It turned out that the 'student of the drama' was Sung Ch'un Fang (1892-1938), an influential scholar who had played a fundamental role in introducing Western drama in China while also advocating for the preservation of a 'national' theatre on the grounds that European and American cultural imports could undermine traditional values and lead to social corruption (Chen 2001, 852). His son, an accomplished scholar himself, remembered how 30 years earlier his father had strongly encouraged him to read the works of Somerset Maugham along with those of Oscar Wilde and how, one day, he had found a copy of On a Chinese Screen on a shelf in his father's office, with a pencil mark against the chapter 'A Student of the Drama'. Only years later, after his father's death, he learned that his father had indeed met Somerset Maugham and he was the one portrayed in the essay. He was also told that his father had felt that 'at many points Maugham had made deliberate exaggerations with a rather unfair attitude' (Soong 1974, 84). From that, he proceeded to dissect Maugham's account of the meeting, providing necessary context to explain the nuances of his father's point of view that had been lost in the fictional portrayal. Without animosity, he then concluded with a reflection on how Maugham's work might have served a political agenda:

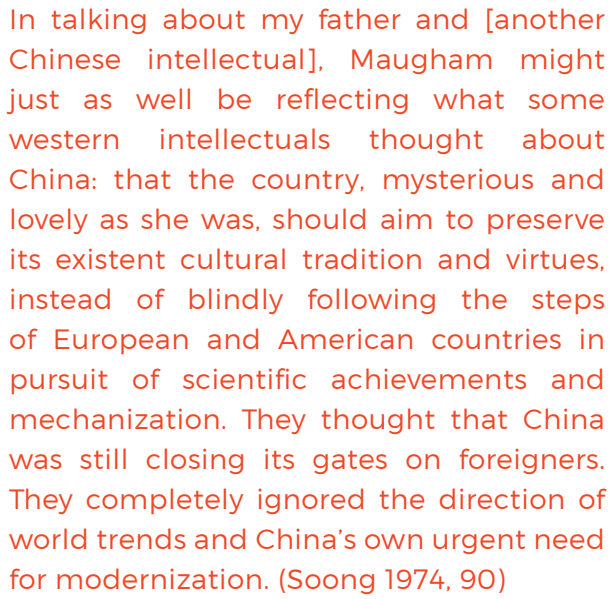

Indeed, while on the surface apparently apolitical, Maugham's writing on Asia was in fact very political. Although Sung Ch'un Fang's son limited himself to musing on the relevance of Maugham's writings for debates on Chinese politics, there is a broader point to be made here about the writer's depiction of the most remote corners of the Raj, providing a most powerful indictment of the provinciality, narrowness, wastefulness, and pointlessness of colonial society. As I mentioned above, Maugham's colonial characters are often drunk and depressed, pathetic and morally bankrupt, which hardly portrays an edifying picture of the British colonial enterprise. For instance, in 'God's Truth', one of the sketches in On a Chinese Screen, we find one Mr Birch, an envoy 
of the British American Tobacco Company stationed in a little town in inner China. It was a place with 'only two or three streets of shops', which he knew by heart, and interminable winding alleys which presented a monotonous expanse of wall broken only by solid closed doors. These were the Chinese houses and these were as impenetrable to one of his colour as the life which surrounded him' (Maugham 2000e, 53). Birch was very homesick-we are told that he had not spoken to another white person in three months-so when a missionary who was passing by refuses his hospitality he completely loses it and attacks the man. 'Birch seized the missionary's let and jerked it out of the stirrup; the missionary nearly fell off and he clung in a somewhat undignified fashion to the pony's mane. Then he half-slipped, halftumbled to the ground' (Maugham 2000e, 54). Two Chinese men on a cart presumably carrying the missionary's belongings witness the whole scene 'with indolent curiosity', but are not given a voice. The missionary threatens to report Birch to his chief, leaving Birch alone and at that point 'anger left him and a sob broke unwillingly from his lips' (Maugham 2000e, 55).

This is only one variation in the broad gallery of colonial characters that appear in Maugham's pages. Portraits such as this did not earn Maugham any friends in colonial society. Just like George Orwell incurred the extreme displeasure of members of the British administration in Burma after the publication of Burmese Days, Maugham similarly became persona non grata in Malaya. His biographer Selina Hastings $(2009$, 279) reports that a member of the Malayan Civil Service wrote that Maugham's passage 'was clearly marked by a trail of angry people. The indignation aroused by his play, The Letter [a story of adultery and murder set in colonial society] ... was still being voiced in emotional terms when I came by. It was also charged against him that he abused hospitality by ferreting out the family skeletons of his hosts and putting them into his books.' To this Maugham responded with a postscript that he added to the American edition of The Casuarina Tree, one of the collections of short stories that drew from his trips in Malaya:

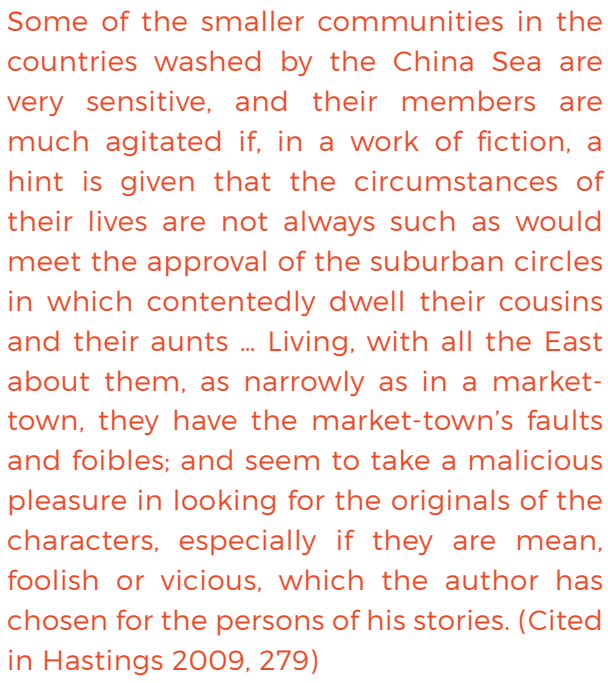

While the immediate display of anger might indeed have been related to Maugham bringing to light some 'skeletons in the closet', it is impossible to deny how the portrayal of colonial society that emerges from Maugham's writing is generally unflattering and might lead readers to question the British colonial endeavour.

However, the greatest merit of Maugham's writing is in how he challenged Orientalist tropes that had asserted themselves in European literature over the years, in particular through the influence of giants like Rudyard Kipling and Joseph Conrad. In particular, Maugham more than anybody else dispelled the myth of the East as a dark and silent jungle, filled with unspeakable threats. This imaginary is far from unique to Anglophone literature. We find it, for instance, also in Italy in the books of Emilio Salgari, who, although he had never set foot in Asia himself, wrote an extremely popular series of books about the adventures of a group of rebel pirates fighting against the British and Dutch colonial powers from their base in Malaysia. Significantly, the first book in 
the series was entitled The Mystery of the Black Jungle (1895). It is exactly these kinds of tropes that Maugham explicitly challenges in his short stories and travelogues from the Far East, and there is no doubt that it is a conscious effort. In a short story titled 'Before the Party'-the tale of an alcoholic husband murdered by his wife-that was included in his 1926 collection The Casuarina Tree, he wrote:

Next day they went up stream in a prahu. From the novels she had read she expected the rivers of Borneo to be dark and strangely sinister, but the sky was blue, dappled with little white clouds, and the green of the mangroves and the nipahs, washed by the flowing water, glistened in the sun. On each side stretched the pathless jungle, and in the distance, silhouetted against the sky, was the rugged outline of a mountain. The air in the early morning was fresh and buoyant. She seemed to enter upon a friendly, fertile land, and she had a sense of spacious freedom. They watched the banks for monkeys sitting on the branches of the tangled trees, and once Harold pointed out something that looked like a log and said it was a crocodile. (Maugham 2000a, 160)

Similar words recur in another story in the same collection, 'The Force of Circumstance', in which newlywed Doris, who only recently arrived in Malaysia to join her husband, discovers with horror that he has already fathered several children with a local woman:

Of course she had read novels about the Malay Archipelago and she had formed an impression of a sombre land with great ominous rivers and a silent, impenetrable jungle. When the little coasting steamer set them down at the mouth of the river, where a large boat, manned by a dozen Dyaks, was waiting to take them to the station, her breath was taken away by the beauty, friendly rather than awe-inspiring, of the scene. It had a gaiety, like the joyful singing of birds in the trees, which she had never expected. (Maugham 2000a, 253)

And yet again, in 'Neil Macadam', a short story included in the 1933 collection Ah King that tells the tragic tale of the seduction of a young British assistant curator by the Russian wife of his boss, we find this discrepancy between the imagined East narrated by Conrad and the reality.

Now they were steaming up the river. At the mouth was a straggling fishermen's village standing on piles in the water; on the bank grew thickly nipah palm and the tortured mangrove; beyond stretched the dense green of the virgin forest. In the distance, darkly silhouetted against the blue sky, was the rugged outline of a mountain. Neil, his heart beating with the excitement that possessed him, devoured the scene with eager eyes. He was surprised. He knew his Conrad almost by heart and he was expecting a land of brooding mystery. He was not prepared for the blue milky sky. Little white clouds on the horizon, like sailing boats becalmed, shone in the sun. The green trees of the forest glittered in the brilliant light. Here and there, on the banks, were Malay houses with thatched roofs, and they nestled cosily among fruit trees. Natives in dug-outs rowed, standing, up the river. Neil had no feeling of being shut in, nor in that radiant morning, of gloom, but of space and freedom. The country offered him a gracious welcome. (Maugham 2000a, 190)

In writing these lines, it is almost as if Maugham was attempting to assuage the concerns that Philip, the young doctor in Burgess's Earthly Power, would express to his literary alter ego Toomey decades later. Generally speaking, it is undeniable that Maugham's vision of the East is very different from that of Kipling and Conrad. In his writings, the East appears bright and warm, which 
contrasts even more with the inner darkness of the foreign characters who populate his pages, almost all of whom cannot adapt to the life in the East. It might be possible to argue that in these depictions Maugham simply swapped one form of Orientalism with another, but his focus on the psychology of the foreigner in the colonial setting represents a fundamental departure from his predecessors. It is in this gaze into the inner dimension of ordinary people engaged in the colonial enterprise that his everlasting legacy lies.

\section{Experiences of the Soul}

In conclusion, what should we make of William Somerset Maugham's writings on the Far East? Should we discard them as a mere Orientalist fantasy by a representative of the British colonial class, or does his work contain deeper insights into the colonial experience? In his depictions of Asia, especially in the early writings that precede his travels, Maugham indeed tended to portray an idealised image of the East that often deployed tropes typical of Orientalist writing. However, while he never really abandoned the idea of the East as an idealised Other, in the oeuvres that he produced after his earliest journeys to Asia and the Pacific, his approach became increasingly complex. Not only did he begin criticising the imaginary of the East as a dark and threatening place that had been promoted by the likes of Kipling and Conrad, but he also shifted his gaze to the inner life of members of British colonial society stranded in the farthest corners of the Empire.

If we follow Edward Said's $(2003,123)$ lead and consider Orientalism as a 'systematic discipline of accumulation' that 'far from ... being exclusively an intellectual or theoretical feature ... tends fatally towards the systematic accumulation of human beings and territories', then Maugham's writings definitely do not fit the bill. While lacking the openly critical verve of George Orwell, his stories on the
Far East do not present an idealised view of colonial rule-quite the opposite. By depicting misfit, adulterous, drunk, and murderous British subjects hardly at ease in their foreign context, Maugham actually undermined the myth of racial superiority that underpinned the British colonial endeavour. It is exactly in this depiction of the moral bankruptcy of British colonial society at a time when the Empire was already in full decline that the value of Maugham's writings on the Far East resides. It is true that he did not even attempt to give a voice to local people-and managed to upset at least one of the 'Asiatics' he portrayed in his books-but this, I believe, should be interpreted as a display of humility on his part rather than a form of contempt. As a passerby in the Far East, he simply felt out of his depth in dealing with the complexities of local societies and preferred to focus on the maladies of the categories he knew best, i.e. British officials, businessmen, and adventurers.

In one of the sketches included in On a Chinese Screen, Maugham recounts a meeting with a man who had travelled far and wide, working his way from London to South America and from there to Tahiti and eventually China. He had led an incredibly adventurous life, and had written a couple of dozen articles on his experiences. Still, Maugham found him extremely dull and insipid: 'I sought to discern how the variety of his experience had affected him; but though he was full of anecdote, a jovial, friendly creature, willing to talk at length of all he had seen, I could not discover that any of his adventures had intimately touched him ... The oddities of life amused him. He had an insatiable curiosity. But I think his experiences were merely of the body and were never translated into experiences of the soul. Perhaps that is why at bottom you felt he was commonplace' (Maugham 2020e, 7). The opposite could be said of Maugham: he might not have had that much experience of the body, but his Far Eastern writings show that he definitely was not lacking experience of the soul. 

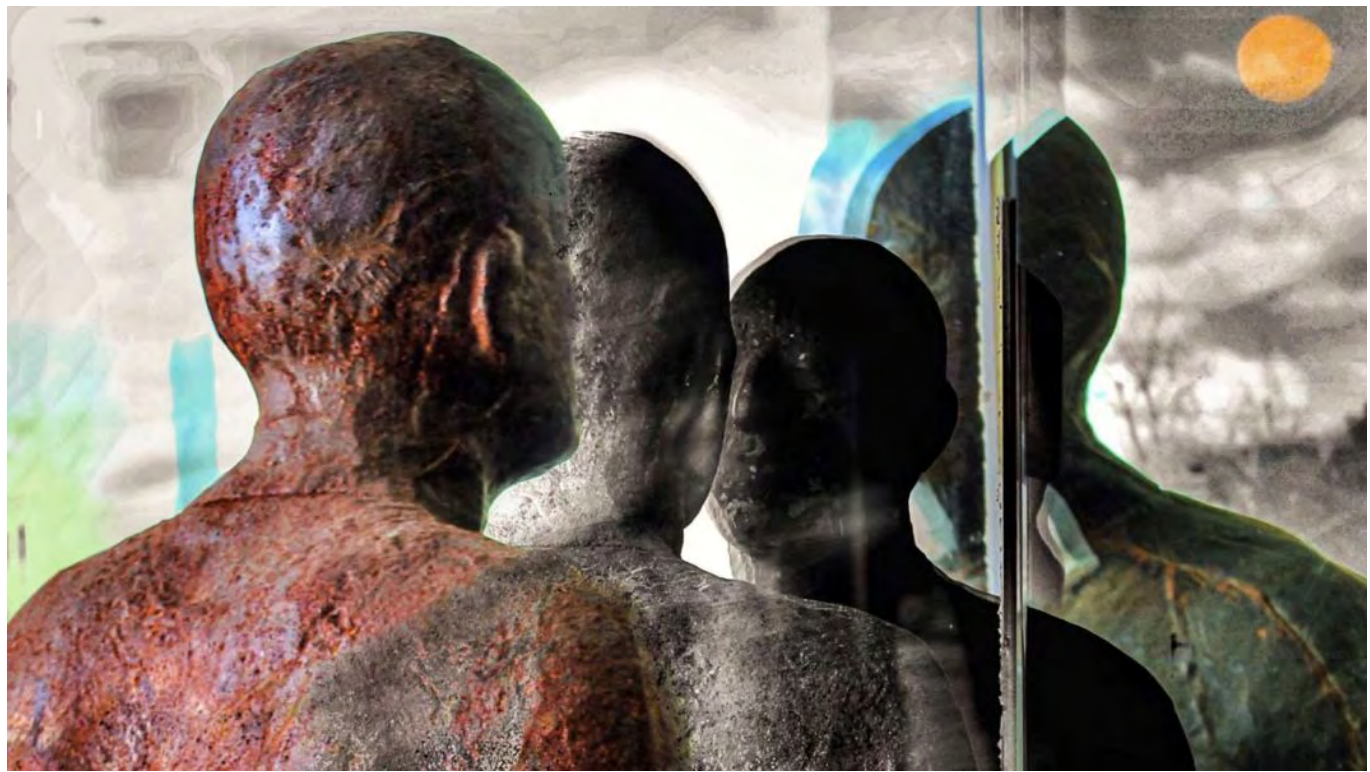

\title{
Zombies of Capital
}

\author{
On Reading Ling Ma's
}

Reflections, by Robert Laliberte. From Antony Gormley, Reflections II. DeCordova Museum, Lincoln, MA.

Severance

Ivan FRANCESCHINI

Capital is dead labour, that, vampire-like, only lives by sucking living labour, and lives the more, the more labour it sucks. The time during which the labourer works, is the time during which the capitalist consumes the labour-power he has purchased of him. Karl Marx, Capital Volume One (1867)

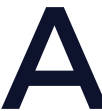
s a true man of his times, Marx liked to pepper his writings with analogies from the gothic imaginary (Steven 2018). Ghosts, vampires, and undead monsters all make their appearances in his work-one just has to think about the incipit of the Manifesto of the Communist Party (1848), where readers are told that 'a spectre is haunting Europe: the spectre of communism.' And, as Umberto Eco (2002) pointed out, we should remember that this was a time when 'we were still close to the preromantic and romantic flourishing of the gothic novel, and spectres were entities that had to be taken seriously'. Far from being considered curious aberrations, these preternatural metaphors have given rise to a whole literature on spectral capitalism. Jacques Derrida is probably the most famous intellectual who engaged with this aspect of Marx's oeuvre, in his Spectres of Marx (1993), but we should not forget Chris Harman with his Zombie Capitalism (2009), and David McNally's Monsters of the Market (2012). In Mark Fisher's Capitalist Realism $(2009,15)$, we find this memorable passage: 
The most Gothic description of Capital is also the most accurate. Capital is an abstract parasite, an insatiable vampire and zombie-maker; but the living flesh it converts into dead labor is ours, and the zombies it makes are us. There is a sense in which it simply is the case that the political elite are our servants; the miserable service they provide from us is to launder our libidos, to obligingly represent for us our disavowed desires as if they had nothing to do with us.

Despite being a novel, Ling Ma's Severance (2018) clearly belongs to this intellectual tradition. The book is narrated by Candace Chen, a young woman from a family of Chinese immigrants in the United States who finds herself in the middle of a pandemic that mutates most of mankind into zombies. After escaping from New York, she joins a small group of survivors as they make their way to a mysterious 'facility' on the outskirts of Chicago, looting houses and killing their undead occupants along the road. Unlike the dominant zombie trope in popular culture, Ling Ma's undead are not aggressive creatures and do not crave human meat-they are just doomed to repeat ad infinitum those actions that defined them during their life, until their body is completely consumed and falls apart. This meekness is loaded with meaning. When one survivor from the group that Candace joins remarks that their life feels like a horror movie, 'like a zombie or vampire flick', Bob-the selfappointed leader of the group and villain of the novel-objects that the narratives attached to the two creatures are completely different. While vampires are intrinsically individualistic creatures and the danger with them lies in their intentions, which might be either good or bad, that is not the case with zombies:

[With zombies] it's not about a specific villain. One zombie can be easily killed, but a hundred zombies is another issue. Only amassed do they really pose a threat. This narrative, then, is not about any individual entity, per se, but about an abstract force: the force of the mob, of mob mentality. Perhaps it's better known these days as the hive mind. You can't see it. You can't forecast it. It strikes at any time, whenever, wherever, like a natural disaster, a hurricane, an earthquake. (29)

By introducing meek zombies, Ling $\mathrm{Ma}$ portrays a humanity so alienated that even in its non-existence, as zombies, it remains neutered. Tamed in life, these human beings become even more so in death.

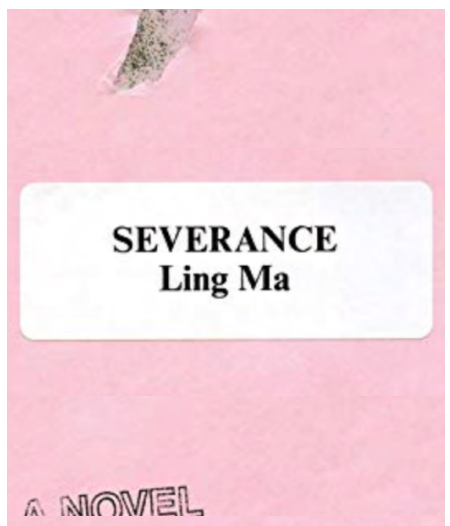

Severance, by Ling Ma. Published in 2018 by Farrar, Straus and Giroux.

\section{Zombie Labour}

The image of the zombie is the perfect vehicle for any Marxist critique of contemporary capitalist society. As Tyler Malone (2018) pointed out, the zombie as a Marxist metaphor is threefold: it simultaneously represents capital itself, which reproduces itself only by consuming living labour; the capitalist worker, who is so alienated to become a zombified living dead; and the everyday consumer trapped in an endless cycle of consumption. It is mainly in this third manifestation that the trope of 
the zombie has emerged in popular Western culture, from George Romero's 1968 classic The Night of the Living Dead and its 1978 sequel, Dawn of the Dead, which is almost entirely set in a shopping mall besieged by the undead, to Jim Jarmusch's recent The Dead Don't Die (2019), in which zombies are seen repeatedly engaging in the same consumerist behaviour that characterised them in life.

While also an indictment of consumerism, Severance has a stronger focus on labour. While the book includes some explicit reflections on how globalisation has affected labour, a few descriptions of the reality of alienated work in the publishing sector, and a couple of poignant meetings between the protagonist and disgruntled Chinese and American workers, the whole novel is really a metaphor for the alienation of labour in contemporary capitalist society. In Severance, the 'Shen Fever' pandemic that ends humanity originated in the factories of Shenzhen. As Candace tells us: 'The reigning theory, first disseminated by a prominent doctor in the Huffington Post, was that the new strain of fungal spores had inadvertently developed within factory conditions of manufacturing areas, the SEZs in China, where spores fed off the highly specific mixture of chemicals' (210). Its physical and psychological symptoms are virtually indistinguishable from those that we might find in some worker toiling day and night in a sweatshop or in front of a computer screen. In its initial stages, the disease is difficult to detect, as its early signs include memory lapse, headaches, disorientation, shortness of breath, and fatigue. Later-stage symptoms include signs of malnourishment, lapse of hygiene, bruising on the skin, and impaired motor coordination (148-49). Eventually, the infected patients lose consciousness and end up in a liminal space between life and death in which they are only able to repeat over and over again the action that defined them during their life.

Two passages in severance beautifully illustrate this association between zombies and the alienation of labour in late capitalism.
In the first episode, Candace films a zombie saleslady inside a deserted clothes shop in New York. These lines are worth quoting in full:

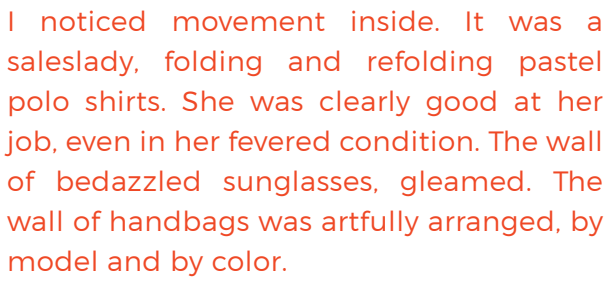

The subsequent post was a thirty-second video of the saleslady folding T-shirts. I tried to show it from a distance; I didn't want the video to be too graphic. Half her jaw was missing. But the way she folded each garment, with an economy of movement, never breaking pace, generated a sense of calm and ease. (258)

The contrast between capitalist plenty and the alienation of labour could not be made clearer, but even as the social order of capitalism is falling apart, not everybody is willing to open their eyes to the inherent absurdity of the system. As Candace publishes the video on her blog, which is followed by a dwindling number of survivors all over the world, it immediately becomes her most popular post but also brings her criticism for 'posting disaster porn'.

The second encounter is with Eddie, a taxi driver. While the pandemic is already well under way, Candace occasionally takes his cab to go to work, but after a while he stops getting her calls and she forgets about him. One day, while trying to find a way to leave the now deserted New York, she sees a single cab driving slowly down the street, swerving across lanes. Unsure whether that is just a hallucination, she hails it. The car surprisingly slows and inside she finds Eddie, looking straight ahead, unresponsive just like a zombie. When Candace pulls him out of the vehicle and drives away with his car, he does not provide any resistance. Only later is she assailed by the 
doubt that maybe Eddie was not fevered after all, that maybe he had just been trying to get out of the city like she was and had stopped to help her. By describing this, the author seems to be telling us that the alienation of labour in our society is so pervasive that sometimes it is not possible to distinguish between our working selves and a zombie.

Reading Severance, one cannot but think about another illustrious literary precedent. In House of the Dead, his 1862 semi-autobiographical memoir from a Siberian labour camp, the great Russian writer Fyodor Dostoevsky draws from his experience as an inmate to offer a timeless reflection on the malady of labour as an action repeated over and over again without any real purpose:

It once came into my head that if it were desired to reduce a man to nothing-to punish him atrociously, to crush him in such a manner that the most hardened murderer would tremble before such a punishment, and take fright beforehandit would only be necessary to give to his work a character of complete uselessness, even to absurdity.

Hard labor, as it is now carried on, presents no interest to the convict; but it has its utility. The convict makes bricks, digs the earth, builds; and all his occupations have a meaning and an end. Sometimes the prisoner may even take an interest in what he is doing. He then wishes to work more skillfully, more advantageously. But let him be constrained to pour water from one vessel into another, to pound sand, to move a heap of earth from one place to another, and then immediately move it back again, then I am persuaded that at the end of a few days, the prisoner would hang himself or commit a thousand capital crimes, preferring rather to die than endure such humiliation, shame, and torture. $(2004,17-18)$
Although the title House of the Dead referred to the spiritual death and subsequent awakening of the main character of the novel, if read in the light of the passage above, the image of the 'dead' easily assumes a very peculiar, quasi-Marxian meaning that clearly resonates with Ling Ma's zombies. That this passage is relevant for our understanding of labour in contemporary society has also been highlighted by anthropologist David Graeber (2018, 15-16), who finds in Dostoevsky's words a key to interpreting the proliferation of 'bullshit jobs' today.

\section{A System That Refuses to Die}

Of course, Severance remains first of all a novel-and a very enjoyable one at that. If the mere narrative skills of the author were not enough, the eerie similarities with the current Covid-19 pandemic make this book surprisingly relatable. Just like in the current pandemic, the fictional Shen Fever also originates in China, where the government initially reacts by hiding the real numbers of infected in order not to scare investment away. To prevent the spread of the fungus through the migrations of people and merchandise, various countries, including the United States, impose travel bans. At some point, Candace even finds herself wondering whether the pandemic has made humanity more stupid: 'Who knew what was true. The sheer density of information and misinformation at the End, encapsulated in news articles and message-board theories and clickbait traps that had propagated hysterically through retweets and shares, had effectively rendered us more ignorant, more helpless, more innocent in our stupidity' (31).

Severance is also the story of a family of Chinese immigrants to the United States, and their inner tension as the mother would like to go back to China and the father to stay. If we focus exclusively on Candace's trajectory, the book is the opposite of a bildungsroman. 
She starts off as a budding photographer trying to develop a project on the decline of the American rustbelt-another reminder that the book is really about labour-wanders for months around the streets of New York taking photos for her blog, then progressively gives up her artistic pretensions as she takes on a corporate job that involves managing the manufacture of Bibles. It takes the pandemic to make her retrieve some of her passion for photography. Candace makes it clear that she holds no illusion towards her job, and at some point even informs her boss that she wants to quit, only to change her mind immediately thereafter. She considers leaving New York with her boyfriend, but once again she chooses not to quit her job because she would feel lost without it. Even in the middle of the pandemic, as all her colleagues die or leave, she decides to keep working in exchange for a huge amount of money promised by her boss. She moves into the office and keeps sending emails and coming up with useless tasks just to fill the time. Only on the day when her contract finally expires, by mistake she locks herself out of the premises and is finally free-just to discover that at that point money had lost all its value.

While working at all these levels, Severance functions at its best as the story of a system that refuses to die. With this novel, Ling Ma has provided a graphic commentary on Frederick Jameson's famous remark that 'it is easier to imagine an end to the world than an end to capitalism' (Fisher 2009). The futility of any present endeavour to reimagine capitalism is highlighted by the fact that the story takes place in 2011, at the height of the Occupy Wall Street Movement. Candace tells us that with the onset of the pandemic, Zuccotti Park came to resemble a deserted refugee camp, littered with abandoned tents, tarps, and pieces of clothing, not to mention the occasional discarded protest signs: 'PEOPLE BEFORE PROFITS. DEPRIVATIZE DEMOCRACY. WE ARE THE 99\%. EAT THE RICH' (214). While this last attempt at resisting the capitalist system was miserably failing, the ridiculousness of life under late capitalism continued unabated. Candace describes how, even while the pandemic was already critical, the New York Fashion Week was still being held, with models sent down the runway in face masks, gloves, and even scrubs, many branded with designers logos (211). It took the collapse of the hidden infrastructure of essential human labour that sustained it for society to finally break down for good. However, even then, as the undead took over, capitalism found a way to survive in the mechanical actions of people's soulless bodies. 


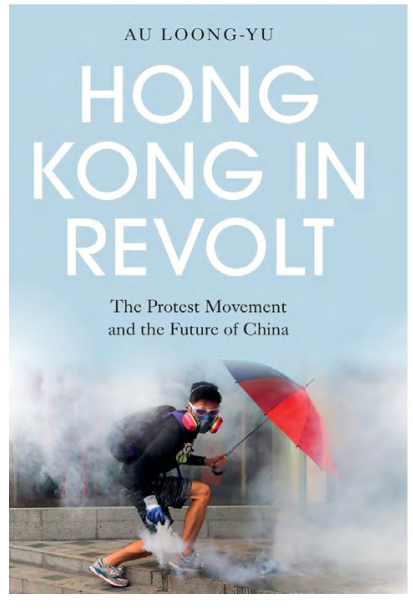

Hong Kong in Revolt: The Protest Movement and the Future of China (Pluto Books 2020).

\section{Hong Kong in Revolt A Conversation with Au Loong-Yu}

Ivan FRANCESCHINI

For the past year and a half, Hong Kong has been in turmoil, with a new generation of young and politically active citizens mobilising to protest Beijing's tightening grip over the city. In Hong Kong in Revolt: The Protest Movement and the Future of China (Pluto Books 2020), prominent Hong Kong leftist intellectual $\mathrm{Au}$ Loong-Yu retraces the development of the protest movement in his place of birth over the past two decades, setting it within the context of broader political trends in mainland China and beyond. Published after the Chinese authorities enacted a new draconian National Security Law that effectively signalled a new stage in the crackdown, this book provides a perfect opportunity to reflect on the events of the past months, dispel some myths, and, possibly, draw a few early lessons.

Ivan Franceschini: Looking back at the protests over the past year and a half, and further back to the other mass movements that have taken place in the city over the past decade, is it possible to find a single thread that unified all these instances of civic unrest? In other words, what was it all about?

Au Loong-Yu: One can summarise all the main protests in the past decade in one word, namely 'disillusion'. Increasingly, Hong Kong people have been disillusioned with Beijing's empty promises of 'Hong Kong people running Hong Kong' and universal suffrage. In 2010, under pressure from the pandemocrats' for universal suffrage, Beijing made the concession of granting five more directly elected seats in the Legislature. However, this was rejected by the radical democrats because the increase in directly elected seats was to be balanced by an equal number of indirectly elected seats, which would facilitate Beijing's manoeuvring. The Basic Law of Hong Kong, unless Beijing revises it, is only valid for 50 years. In 2010 one-fourth of this validity period had passed, but universal suffrage was still nowhere to be seen. Since then, Beijing has begun to roll out a greater offensive against Hong Kong's autonomy. Firstly, in 2012 they made the Hong Kong government push for compulsory 'national education' to promote their version of 'Chinese identity'. This was followed by the imposition of Mandarin as a teaching medium in Chinese language lessons, 
which amounted to denying local students the right to use their mother tongue-Cantonese. This was bitterly resented by students, and the most radical of them, led by Joshua Wong, founded Scholarism to oppose the new policy. Even parents organised themselves to support the students. Both campaigns succeeded in stopping the government from implementing its plan. Beijing's offensive has served to convince the more radical democrats and the young generation that they must act quickly and resolutely to fight for universal suffrage, which eventually led to the 2014 Umbrella Movement. This was the first time in post-war Hong Kong that there was such a massive and peaceful civil disobedience, and it started with the high hope that if it could win the support of local people, then Beijing would have to listen. The movement did indeed get massive support, but Beijing refused to listen, and this broke the hearts of many, who felt deeply that their 79-day occupation had ended with nothing. Behind this lay a deep disillusionment with Beijing as well. A mixture of anger, demoralisation, and despair descended upon the young generation.

The protesters would not have been able to launch a second big wave of protests if in 2019 Beijing had not started another round of offensives, this time with the Extradition Bill. The protests, with millions of participants and the young at the forefront, were larger, sometimes violent, and lasted much longer than the 2014 movement, continuing for eight months until the onset of the pandemic. They knew the bill implied the end of Hong Kong's autonomy and hence the term 'end game' (终局之战) repeatedly appeared among protesters.

But there is another dimension of 'disillusion'. The last decade saw a growing disillusionment in relation to the pandemocrats, firstly among young people, followed by a significant section of the pan-democrat's traditional supporters, either middle or lower-class people who once believed in moderate politics-that we should not push Beijing too hard, that civil disobedience was too radical, etc. Most pan-democrat parties had been so pacified by the (partial) electoral politics that they had lost sensitivity to how common people felt about Beijing and also lost the appetite for confrontational actions. Their poor performance in 2014 made the young despise them. The largely spontaneous and leaderless 2019 Revolt was a response to their impotency in initiating a movement from below. It signifies the death of the old politics and the (difficult) birth of a new one. 
ALY: I think that if a strong dose of pessimism, at least in the short term, is warranted, it is more because of the reason for the defeat rather than the defeat itself. We were defeated simply because of a severe imbalance of power-in this type of confrontation we would never be able to match the monolithic state. The absolute majority of protesters, although very sympathetic, continued to stand by and watch 'the braves' (勇 武派) physically confronting the police without ever joining their fight. There is a rationale here. Even common people know by intuition that a successful revolution in a single city was inconceivable. The vanguard of the movement, the '1997 generation', themselves had no answer to this question. Herein lies the greatest weakness of the Revolt-the lack of a strategic outlook. The movement was very good at tactics, but not so much at strategy.

In my view, the Hong Kong movement must seek its allies not only internationally but also, more importantly, in mainland China as well. We also have to admit that Hong Kong's freedom is a long-term struggle. This implies that the Hong Kong movement has not been able to resolve the tensions in its relationship with mainlanders, and needs to figure out how to avoid alienating mainland Chinese, including those who immigrate here.

My book discusses one big protest on 7 July 2019 that aimed to approach mainland visitors to persuade them about the cause. The activist who called for this march expected only 2,000 protesters, but 230,000 people turned out. They went to the terminal of the high-speed train that runs between Hong Kong and the mainland so as to meet mainland visitors. While the police expected clashes, it was amazing to see protesters approach mainland visitors in a friendly way. Therefore, we can say that seeking allies in the mainland was still in the minds of many. As a whole, however, while it was natural for the movement to seek allies in the West and Japan, this was not the case for finding allies in the mainland, hence the voices advocating for the former were always much stronger than those for the latter. Surely this should not be a choice of either the former or the latter, we could, and should, do both. But as a whole the movement failed to pursue a conscious alliance 
with mainland Chinese people and groups. If it had done that, whatever the direct result, it would still have been beneficialless in the sense of any immediate success, more in the sense that we could have avoided making mistakes such as tolerating the right-wing localists' attack on all Chinese as supporters of the Chinese Communist Party (CCP), and it would have fostered longer-term potentials for solidarity. Beijing jumped to seize the opportunity to attack the whole movement as antiChinese so as to alienate mainlanders from the movement and stop them from sympathising with Hong Kong protesters. To a certain extent it succeeded.

The movement did have a loose strategy, or its 'vision of Hong Kong', reflected in the slogan of gong zung keoi gaak (港中区隔) or 'segregation of Hong Kong from China'. Behind the slogan is also a pro-West sentiment. All the evil comes from Beijing and all the sympathy for our struggle against Beijing comes from the West or from Japan-this is what many have felt. The role of mainland Chinese does not appear in this political formula at all. There are rationales to this sentiment, but since it was, and is, not backed by any serious analysis, with no clear boundaries ever laid down, it often plays into the hands of the right wing, who have tried, sometimes successfully, to channel certain protests into potentially Sinophobic attitudes and openly proUS establishment sentiments. Unless we can come up with a clear strategy to seek an alliance with the mainland Chinese as well, Hong Kong people will remain isolated.

The rationale for optimism in the medium term is that people do learn over the course of struggle. Since 2014 the Hong Kong people, for the first time, have been greatly politicised and have mobilised to take back what has been owed to them. From a historical point of view, this is just the first stage in a new era of popular re-awakening. The movement's 'five demands' speak for this. In terms of party politics, although the right wing has been more vocal, neither they nor other opposition parties are big. This implies that all political tendencies visible in the 2019 Revolt are far from consolidated. The struggle for a progressive course of actions is still in front of us.

IF: With the benefit of hindsight, do you think there was ever any chance that Beijing would ease up and heed the demands coming from the people in Hong Kong? What lessons would you draw from this whole experience?

ALY: I did not subscribe to the idea that Beijing would really accommodate Hong Kong people's wishes to run their own domestic affairs. What it has done since the handover of Hong Kong in 1997 is a clear indication. Six years after the handover it tried to impose the National Security bill on us. We defeated it. For a while it was a bit quiet but actually its offensive only 
took a more concealed form. More than a decade ago I noticed two things that symbolised the new offensive. Firstly, Beijing began to organise thugs to confront the Falun Gong people here, whereas previously it just ignored them. Actually, not many people were attracted by their beliefs, but with the rapid increase of mainland visitors to Hong Kong, Beijing now seemed to be concerned that these people might be converted by the Falun Gong, hence a change of tactic. Secondly, Beijing began to coordinate between its Hong Kong Party machinery and mainland local governments to found hundreds if not thousands of 'Fellow Villagers Associations' (同乡会) to rope in those who had migrated from the mainland to Hong Kong. These organisations proved to be vital in getting votes for proBeijing parties. The pan-democrats hoped to soften up Beijing's autocracy through closer ties, but what happened is that it is we who were changed.

Similarly, Western countries had pursued 'engagement' with Beijing, in the hope that they could give mainland China a push towards political liberalisation through more trade. In general, I have never been optimistic about this. I describe Beijing's regime as overly rigid in its version of 'Chinese characteristics', which is essentially a return to the political culture of imperial China. Xi Jinping's 2017 speech about power having to be passed down to people with 'red genes' (i.e. the second red generation), is a manifestation of that practice. Fei-Ling Wang's 2017 book The China Order: Centralia, World Empire, and the Nature of Chinese Power well captures the pre-modern aspect of this regime, but he left out the modern aspect of the CCP, namely its ambition to modernise China, or in Mao's words 'surpassing first Britain and then the United States' (超英赶 美). Behind its faith in its pre-modern values also lies a very modern, very material thing, namely the fundamental interest of its rule. It combines both the coercive power of the state, armed with the most modern weapons and technologies, and the power of its industrial and financial capitalism. It succeeds by running simultaneously on two sets of rules, the law and the hidden rules of the bureaucracy, with the latter always overriding the former. Its rulers find this regime serves their interests well. From the top to local level, Party officials have enriched themselves tremendously because of this. The more they do this, the dirtier secrets arise that they need to hide. This, in and of itself, is a reason why the Party officials cannot tolerate dissident views. The Party requires the construction of an Orwellian state in the mainland and, imperatively, this must expand to Hong Kong as well. I believe that the rigidity of the hard core of the Party-state, formed and hardened through 
its particular type of revolutionary history, its return to the imperial political culture, and its entrenched interest in a total state, makes it impossible for a self-reform to occur.

To sum up, in order to have a less erroneous appraisal of Beijing's regime, instead of just looking at the appearances of the CCP or its top leaders at the time, we have to have a holistic point of view accompanied by historical and relational approaches. The bright side of my narrative is that the CCP, in the course of its modernising China even further, has also fundamentally changed the initial set of relationships of forces within China. For the past 70 years, all other classes and social groups within China have been at the mercy of this monolithic Party-state. In appearance this remains unchanged, but its actual composition has greatly changed. In addition to this, a big portion of the Chinese upper middle class, the new working class, and those exploited sweatshop workers, are economically connected to the global markets as well. The breaking up of the relationship between China and the United States now puts the Orwellian state to a difficult test, making its situation increasingly fluid. Will a new domestic political force arise out of this fluidity and begin to challenge the hard core of the CCP? That is the riddle of this new stage.

IF: In your book, you also spend considerable energy explaining what the mobilisation was not about. A couple of misconceptions you try to dispel are that the protest were racist, targeting mainland Chinese, and that they were about demanding independence. Why have these ideas taken hold among the public and why should they be rejected?

ALY: First, we must remind ourselves that today's media corporations are all very powerful in shaping the so called public opinion. At the beginning of the Revolt last year, when individuals waved the independence flag, other protesters who were not in favour of it would try to convince them to stop by reminding them that the movement was about the five demands, not about independence. In some cases, the persuasion might work. However, both Western media and pro-Beijing media loved focussing on people waving the flag instead-although for quite opposite reasons-ignoring the fact that most protesters did not wave it. This is how a small minority of protesters became emboldened by the media, while the majority, feeling discouraged, chose to remain silent at later protests.

The wonderful thing about this Revolt is that it had hundreds of big and small protests exhibiting great diversity and contradictions. What unified these diverse protests were the five demands, not any other requests. There were only a few protests which were potentially targeting mainland immigrants or visitors here, but they were much smaller in size and also 
only took place in more remote areas-as such, they cannot represent the movement. But it is also true that most people, who did not approve of the right-wing localists, often chose to remain silent about them. I argue that without an organised progressive force consciously fighting for an inclusive Hong Kong identity, this will continue to be the case, unfortunately.

IF: Finally, you criticise a certain idea that has taken root in some leftist circles in the West: that the Hong Kong protests were right wing and manipulated by foreign imperialists. What is your response to these insinuations?

ALY: Just as the media loves to put a spotlight on protesters waving pro-independent flags, it also loves to do the same to protesters waving pro-US flags. Yet few people are aware that protesters also waved the Catalonian flag, and once held a proCatalonian independence rally. Those pro-US forces tried to stop the holding of such a rally because 'Spain is a US ally'-an argument that was rebutted. This piece of news went largely unnoticed, however.

Last year, I was at a Berlin conference where a participant condemned the movement as being manipulated by the United States by referring to protesters waving the US flag. My response was that her condemnation itself might be seen as manipulated as well, only this time by the media, as she uncritically accepted the media's preference for the flag-waving minority.

The pan-democrats have always had strong ties to the US and British establishments, but they were marginalised in this most recent Revolt. There were organised pro-US forces, but they were small. The mass movement is led by no one. Most young people waving the US flag did not belong to any political party, they were generally new hands in the social movement and only wanted to call for international support.

That said, the problem with last year's Revolt was that most protesters did not have any idea of 'left versus right', and everything in their world is squeezed into a worldview of 'either Beijing or us'. For this reason, they just accept any foreigners with some power to help, without ever asking the question 'are they your real friends?' This lack of understanding allows protesters to occasionally be depicted as part of the proTrump current, which is then magnified by the media.

We must be aware of another facet of this discussion on 'foreign forces', though. Western governments, with the United Kingdom and United States at their head, are being recognised as legitimate stakeholders by no one other than the CCP itself, as enshrined in the Basic Law. This law lays down in detail that Hong Kong people would be able to keep their own British law, enjoy the right to the British passport, and even allows foreigners to be employed as civil servants, from the lowest to 
the highest ranks (except for the very top), including foreign judges, and so on and so forth. This should have given both the United States and United Kingdom a lot of leverage, at least for the remaining 27 years before the Basic Law expires, unless it is further revised. With the Extradition Bill, Beijing did nothing less than break its promise in both the Sino-British Joint Declaration and the Basic Law. I never endorsed these two documents. Actually, Hong Kong people have always been excluded from negotiations over their fate, but if Beijing wants to decolonise Hong Kong's colonial legacy, it should replace it with even better protection of human rights, and honour its promise of universal suffrage for the city, not replace it with its own even worse legal system or annihilate the city's autonomy. If the US government is not our real friend, right now Beijing is our real enemy. That is what matters.

IF: In the book, you explain how the youth have played a fundamental role in the mobilisation. What makes the '1997 generation' so different from those who came before?

ALY: Now Beijing wants to take full control of Hong Kong's education to make sure the young would not be influenced by dangerous ideas. This is laughable, and actually counterproductive. I was a secondary school teacher for nearly 20 years. I failed terribly in trying to instil a spirit of rebellion against the colonial education among my students. The time simply had not come yet. Only with the coming of the '1997 generation' did a significant section of society begin to stir.

It is a generation that is full of anger and hope. They are angry because they felt lied to by Beijing. Since their birth, they have been hearing about Hong Kong people challenging Beijing to honour its promise of universal suffrage. As they grew up, the suffrage was nowhere to be seen, and Beijing launched wave after wave of attacks on Hong Kong's autonomy, hence the anger. On the other hand, they think there is still hope, if only they are radical-or at least more radical than the pan-democrats. A new way of fighting back must be found, and they found it 'by any means necessary', by 'being water', 'being brave', etc. If civil disobedience and occupying major streets in 2014 were not enough to make Beijing yield, then let us fight the police and occupy the legislature! Their bravery also came from their 'end game' mentality-this will be our last struggle for our autonomy so let's spare no effort!

Another factor at play was the relative liberties the new generation enjoyed while growing up. Under British colonial rule, our generation grew up in quite a repressive atmosphere and learned to be apolitical to avoid trouble. Hence the 30-yearold democratic movement was always very timid, so you see how 
different the new generation is from the old. The young were inexperienced, but this also enabled them to think outside the box of the pan-democrats. Now they have seen with their own eyes that even a Revolt as massive as last year's did not make Beijing yield to them; on the contrary the latter now retaliated with an even more lethal weapon, the National Security Law. The young now finally understand that it is going to be a very long struggle, and there is no such thing as an 'end game'. It is going to be a very hard fight as well, because Beijing's agenda is to destroy this generation. They did it before, in 1989.

To sum up, one may say that the contribution of the young is that they, like the boy who pointed out loudly that 'the emperor has no clothes on!', were able to identify where the real problem lies. They also tried to fix it, even if events proved that it was a task for which they were not yet fully prepared.

IF: This issue includes an article by Anita Chan about the extraordinary mushrooming of trade unions in Hong Kong over the past year. You also dedicate part of your book to this phenomenon. Can you please delve a bit more into the role of the workers during the protests? What are the prospects for this nascent labour movement under the New Security Law?

ALY: If one compares last year's Revolt with the Umbrella Movement then one witnesses a step forward for labour. The pro-democracy Confederation of Trade Unions (CTU) was founded in 1990 and nowadays it claims to have 95 affiliated unions representing 190,000 members. It always follows the pan-democrats' political line and this eventually alienated the young generation, which is one of the reasons why it played nearly no role at all during the Umbrella Movement. It called for a strike, but I used to say that only two and a half unions heeded the call, because the teachers' union was only half-hearted about it. It was a reflection of the fundamental weakness of the labour movement in Hong Kong at that time. Last year, when the movement had just begun in early June and right after the two-million-strong march, the CTU called for another strike but was unsuccessful. History seemed to be repeating itself. But no, the young did not allow that. The following months saw an ever-stronger mobilisation, but the young were increasingly aware that they alone would not be able to make Beijing yield, so they repeatedly called for a general strike.

This was also the moment when a new segment of young employees began to emerge as activists. Together with the CTU, the allied forces were able to call a successful general strike, for the first time in many decades, on 5 August 2019. Among others, pilots and flights attendants responded en masse, and half of all flights were grounded, leaving air traffic in chaos. Although later strike calls were unsuccessful after Beijing 
retaliated by forcing Cathay Pacific to sack a few dozen of its strikers, the August strike went into the memory of many as a proof of the power of labour. This also laid the foundation for a new union movement where dozens of new unions were founded. The spread of the Covid-19 pandemic gave a chance to the newly founded Hospital Authority Employee Union to test its strength. The union accounts for 20 percent of the workforce of 80,000, and in February 2020 it went on strike for five days to demand that the government temporarily close the borders between Hong Kong and mainland China to stop the pandemic from spreading further in the city. The upside of this strike is that one witnessed that the new leadership has the guts to fight, which is very rare among local trade unions. The downside, though, is that on several occasions it seemed that the membership was not ready to take a more militant line.

With Beijing retaliating with its National Security Law, this new union movement now faces the greatest challenge since its founding. Unions may not be Beijing's top target, but the mainland authorities definitely dislike a militant union movement. I hope that the young unionists will have enough time to consolidate themselves before Beijing starts its next offensive.

IF: One aspect that I don't find mentioned often in media coverage is how the National Security Law will likely impact civil society on the mainland. For three decades, Hong Kong has been the funding gateway for a wide array of civil society organisations in mainland China, including labour NGOs, human rights lawyers, and other kinds of activist groups. With Chinese civil society already under unprecedented assault, will Hong Kong still be able to play such a role?

ALY: Right now, it is already very difficult. Some Hong Kong groups that have been supporting Chinese labour have had to either shut down their operations or significantly scale down and lay low. The more severe the economic crisis and the more the conflict with the United States is escalated, the more likely Beijing will be to seek the total obliteration of labour groups in the mainland, especially those with ties to Hong Kong. I remember a dozen years ago we rented a bus in Shenzhen and took a whole bunch of German grassroots labour activists to visit factories where strikes had occurred. We did not dare step outside the bus though, but the German activists were still impressed with the stories we told and happy about being able to see the factories. This is unimaginable today. The narrow but real space for NGO activism in the Pearl River Delta is long gone.

We still have another form of leverage, however. For decades, the picture of Hong Kong people standing up for their rights has inspired many in the mainland. In this new period of 
repression, Hong Kong could still promote a movement from below in the mainland in an indirect way, i.e. through its own struggle for autonomy and democracy. This is important as Hong Kong's advantage lies in its 'soft power' rather than the non-existent 'sharp power' which certain 'braves' were looking for. Making the city unwelcoming to mainland Chinese is suicidal. Unfortunately, in last year's Revolt, Beijing made full use of the right-wing localists' presence to depict the whole Revolt as being about independence and China-bashing, not to mention pro-Trump. This alienated potential mainland allies. The problem for Hong Kong lies less in the existence of right-wing localists, however, and more in the lack of a strong labour left wing, which, if present, could put the right wing under check. The good news is that with the new trade union movement there is now a whole new group of labour activists to win over to a labour left wing, although it will take time.

Secondly, the seeds sown by mainland and Hong Kong labour activists in the past two decades will continue to grow in the future. Twenty years ago, most rural migrant workers did not have any idea of their legitimate rights. Through their own struggle, plus some help from NGOs, today many of them are much more informed and ready to demand their rights. In 2018, for instance, more than a hundred silicosis victims from Hunan spontaneously organised to go to Shenzhen (where they had contracted the occupational disease while working) to petition for compensation. Under harsh repression, workers cannot do any long-term organising, but through these kinds of defensive struggles they are still able to be partially empowered.

ALY: Since you sent me these questions, the Hong Kong situation has been further worsening, day by day. The absolute asymmetry of power between Beijing and Hong Kong implies that we will be in a dire situation for years to come, unless the mainland situation takes a surprising change of direction. Some protesters are now celebrating the success of their so called scorched earth tactic after the United States nullified Hong Kong's special status. I don't subscribe to their idea of 'success' because turning Hong Kong into a battlefield between Beijing and Washington is going to make things worse, not easier. I do not intend to place too much blame on these 'scorched earth' advocates though, as from the very beginning Hong Kong has been too small to play any leading role in shaping its own fate. Sadly, its fate is always determined by outside forces. No matter how flawless our resistance, once Beijing makes up its mind to finish our autonomy, we are done in this regard. Daily resistance 
to stop things worsening is still necessary, but we have to prepare for the day when organised opposition will be barred from elections altogether if not totally wiped out. Local people are aware of this coming catastrophe and are hence looking forward to more international support. However, as a small city this may also imply that the fight to defend our autonomy has slipped away from our own hands.

Precisely because of Hong Kong's uniqueness-small but significant in its geopolitics and international finance statusinternational pressure is vital for us. But it has to be the right kind of pressure. We all know too well that governments are more an establishment force than an engine for progressive changes. It is just too dangerous to leave the solidarity campaign with mainland and Hong Kong democratic movements to foreign governments alone, not to mention ceding it to Trump. We need international progressive labour and civil associations and individuals to press their governments to do the right things while stopping them from doing wrong things. The prerequisite of this endeavour is to grasp the actual situation going on here. My suggestion is that we should be guided less by ideology and more by objective investigation and simple empathy-and here I mean ideology in the sense of a 'socially necessary illusion' which is divorced from reality. What unified the massive movement was the five demands, with four related to the opposition to the Extradition Bill, the fifth being universal suffrage. How can anyone who claims to be left or progressive not support these demands? 


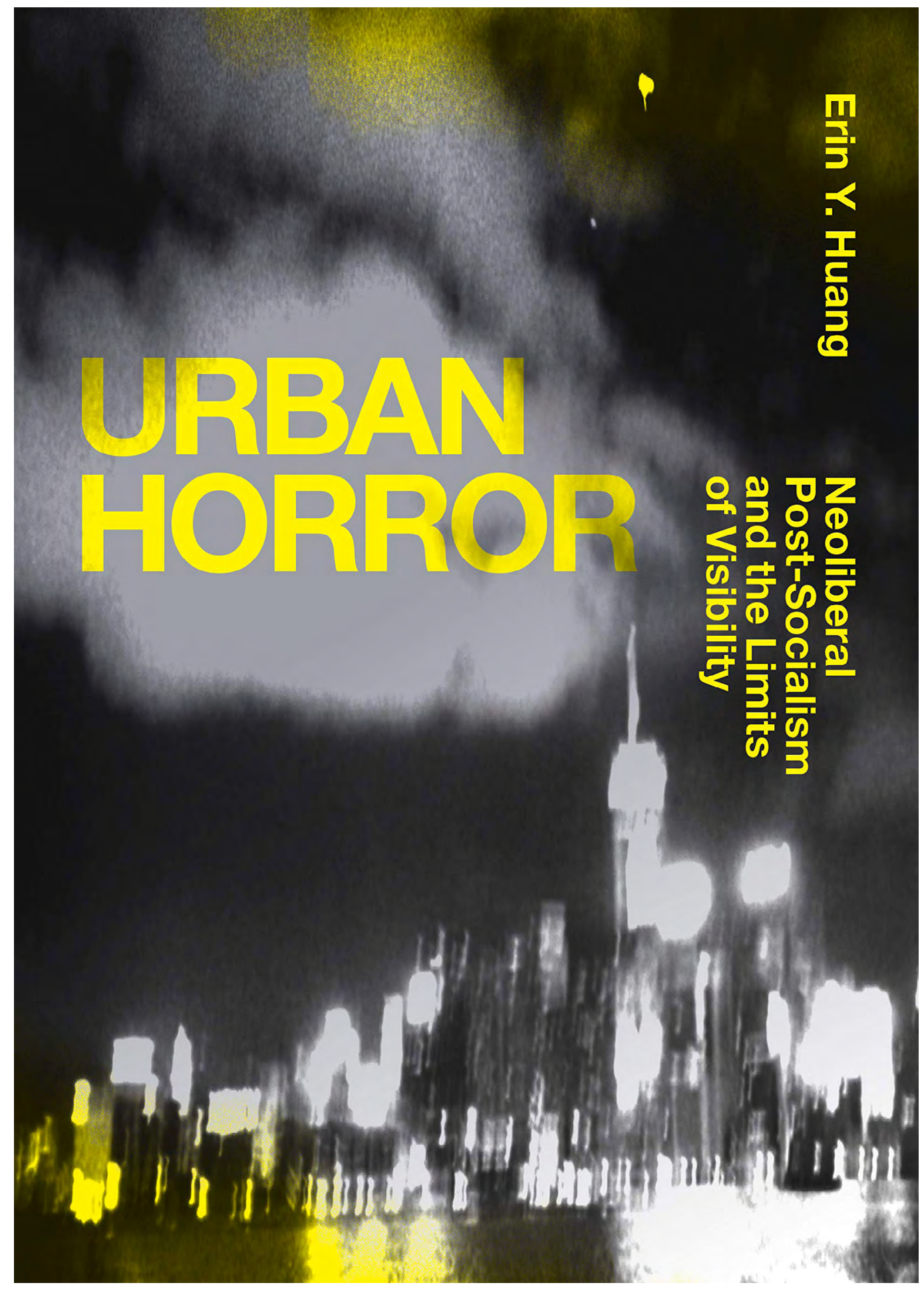




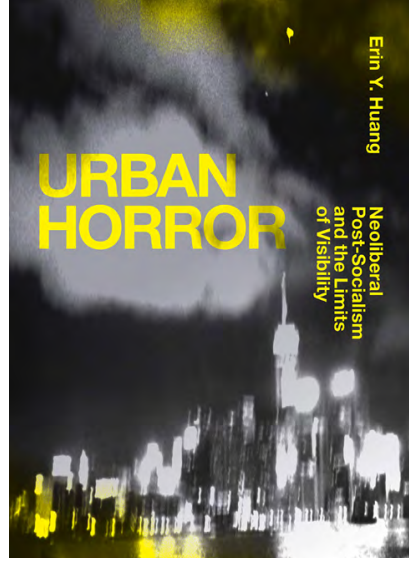

Urban Horror: Neoliberal PostSocialism and the Limits of Visibility (Duke University Press 2020).

\section{Urban Horror \\ A Conversation with Erin Y. Huang}

Christian SORACE
As dystopic environments become reality, Erin Y. Huang's Urban Horror: Neoliberal Post-Socialism and the Limits of Visibility (Duke University Press 2020) examines how cinema can help us comprehend the incomprehensible and navigate our own disorientation. For Huang, the scale, speed, and intensity of violence that circulates throughout the neoliberal world exceeds our frames of cognition and overwhelms our political vocabularies. The result is a diffuse sense of horror. The filmmakers from the Sinophone world that Huang engagesincluding Huang Weikai, Li Shaohong, Fruit Chan, and Tsai Ming-Liang among many others-are sensitive to the different sensory, affective, and political dimensions of what Huang calls 'urban horror', which no matter how bleak, also contains glimpses of alternative futurities.

Christian Sorace: In the introduction, you define horror as a historical mode of perception arising when the perceived external reality exceeds one's internal frame of comprehension'. Can you give an example for our readers to explain why this gap can be so horrifying?

Erin Huang: We live in a world of horrors, where the techniques and technologies of war and extraction continue to evolve and devastate. The present era, which I explore as the emergence of the post-X era, wherein the present can only be understood through the hyphenated and residual relationship with capitalism and socialism, has seen the unimaginable expansion of atrocities, humanitarian crises, economic extractions, and environmental degradations, in an expanding list that continues to grow each day. And as an accompanying phenomenon, we have never been more exposed, in an intimate fashion, to the images, sounds, and sensory transmissions of violence, whether distant or near, in the saturated media environment that now structures our everyday life. Therefore, the question that confronts us in the era of hypermediatised horror is never the lack of adequate examples of catastrophe, but the overabundance of images that overwhelms and paralyses feelings and actions, fatiguing rather than accelerating the reimagination of shared common wealth. 
For this reason, in a counterintuitive way, the horror that permeates art and cinematic productions of the post-Cold War Sinophone Asia is not the appearance of new (Asian) monsters, serial killers, or ghosts, belonging to the genre of commodified horror in existing Western literary and film conventions. Rather, the horror addressed in this book speaks to a paradox of vision, where body-centred horror that mirrors a specific mode of representing capitalism in its early stage-for example, in the aesthetic genres of vampires and zombies-can no longer speak to the disappearance of an identifiable agent of horror in the neoliberalising world. In fact, it is precisely the visible that has become the incomprehensible. For example, when filmmaker Chan Tze-woon moves his camera in Yellowing, which documents the 2014 Umbrella Movement in Hong Kong, the camera's gaze wavers between the firework show in the sky celebrating China's National Day, and the police teargassing demonstrators on the ground. The sounds and smoke of explosion from above and below become contiguous, proposing a deterritorialised post-socialist reality that is hypervisible, but for which no adequate frame of comprehension exists. The affect lingers, suggesting a mixture of emotions that persist and are recorded as excesses that do not dissipate. They open up, rather than closing down, a new path of affective communication and connection. This horror is frightful and evokes the sentiment of resistance, but it is representative of a newly emergent feeling belonging to the era the book examines. Tracing the dissemination of a Marxian horror in the postsocialist and post-capitalist world, the 'horror' in the book tells the affective history of transterritorial neoliberal capitalism that grows and transforms along with the geopolitics of postCold War global economy.

CS: You have some beautiful passages in the book devoted to the 'future of the image' and the 'history of affective rehearsals of revolutions that cannot otherwise be told'. Can you elaborate on the revolutionary potentiality of cinema?

EH: The future of the image is a question that French philosopher Jacques Rancière asks. Reflecting on scholarly discourses of the 'image', often treated as the passive site of inscription, fetishism, and commodification, Rancière's question arrives at the moment when the image has become the ubiquitous basis of our understanding of reality. Yet the relationship between image and reality has still not been solved, regardless of the image's transition of medium specificity from literature to painting, photography, film, and computer software. This is an intriguing question for me to consider, writing a book that covers the media landscape from the 1990s 
onward when the image is said to have lost its transformative power due to market commodification and deepening self and political censorship under the neoliberal post-socialist regime.

When the expression of public dissent becomes increasingly difficult, and when the image seems to have lost meaning, the film texts collected in this book suggest a fundamental rethinking about the post-Cold War media environment and the power of the image. For readers who are searching for the familiar tropes of ghosts, monsters, and spectres that are representative of the return of the repressed-the resurgence of past traumas and violence that continue to haunt the present-the urban horrors presented in this book frustrate expectations, yet for a specific reason. Different from the Freudian theorisation of repressions and returns that provides an account of the psychological mechanisms of memories and symptoms, urban horror is derived from Friedrich Engels's industrial horror, where the sentiment of horror is evoked in correspondence to an anticipated future and the possibility of an aggravated calamity. The emphasis is on the speculation of the future that is reshaping the legibility of the present. Produced during the decades after the demands for democracy were foreclosed in post-Cold War China, the films in this book collectively rehearse different realities, setting in motion the potentialities of a different future, every time an additional viewer encounters the image.

\section{CS: Since the publication of your book, it would seem that we are even more enveloped in the logic of urban horror. Would you recommend any films that help us reflect on the current pandemic as a form of urban horror?}

EH: This pandemic has made visible the systematic management of not life, but death across specific racial, minoritised, and vulnerable groups. This phenomenon not only exists in the United States but is a part of an expanding global circuit of neoliberal economic practice that is built on the foundations of old and new colonial relations. One specific practice we can consider here is the world's dependence on the post-socialist Chinese Special Economic Zones (SEZs) that fuel the global economy through state-managed supply of low-cost labour. For several decades since the Chinese state's experiment with SEZs-exception zones that allow for the state's strategic participation in the global economy without disrupting its political regime-the growth of Chinese SEZs has transformed the relationship between East and West, and socialism and capitalism. As the trade war between the United States and China intensifies, the pandemic spotlights the transcontinental global logistics chain that stretches the conventional factory to different parts of the world and makes visible newly emergent 
neoliberal spaces that rarely draw public attention. These include container ports, special economic zones, transit and processing centres, and logistics cities-all of them spaces that accelerate the spread of the virus. These logistical spaces constitute the transmission routes of Covid-19, proposing a different world map created under the neoliberal post-socialist condition. A recent cultural text that comes to mind is actually not a film but a novel, Ling Ma's Severance-reviewed by Ivan Franceschini in this issue of the Made in China Journalthat details post-apocalyptic New York, destroyed by a virus that spreads from Shenzhen Special Economic Zone and the neoliberal trade routes to the entire world. Written shortly before the current pandemic, the novel is already rehearsing the discomforts, anxieties, and soft critiques of racial injustices of offshore Chinese labour from the perspective of a Chinese American writer. There are a few films from my book where a virus setting opens up an affective landscape of resistance addressing necropolitical economic precarity and encroaching colonialism. For example, Tsai Ming-liang's The Hole (1998), and Fruit Chan's The Midnight After (2014).

CS: We would love to have a preview of your new research on the 'visual mapping and infrastructural development of oceanic urbanisation'. What is catching your eye here?

EH: The ocean is the forgotten space. 'Out of sight, out of mind', as maritime photographer and filmmaker Allan Sekula said. Yet despite the common belief that we have entered the age of instant telecommunication and transaction, the ocean continues to be the material basis of global capitalism. As container ships slowly but persistently travel across oceans and continents, the growing demand for mega-ships, deep water ports, artificial islands, inland highways, and train tracks is illustrative of an infrastructural revolution reconfiguring the relationship between land and sea, continental and oceanic empires, and for my specific interest, the expansion of Sinocentric neoliberal post-socialism beyond socialist China that is affecting the entire world. One can immediately think of China's recent Belt and Road Initiative (BRI) that dreams of the revitalisation of the land and maritime Silk Road in the twentyfirst century. Reconfiguring the infrastructural connections between Asia and Europe while transforming the South China Sea into a militarised transit ocean between East and West, the BRI has generated abundant study of the economic, political, and environmental impacts and the future of infrastructure. Yet for my interest, the BRI is one of the most visible media events in the past decade, generating state-sponsored YouTube channels, documentaries, science films, and satellite photography that have not been carefully considered. 
Often characterised as free, open, and expansive, the ocean plays an important role in the discourse and imagination of oceanic neoliberalism and requires a new theory of contemporary oceanic imperialism. Racialised, gendered, and fraught with conflicting territorial claims, the ocean is generative of romantic associations with freedom although it in reality occupies the primary locus of international conflict, militarisation, and labour exploitation. I am curious to see how to propose an ocean-based and archipelagically expanding theory of critique that revises the land-based concept of capitalism. Starting with the artificial desert islands in the South China Sea, where European, Japanese, Chinese, and Southeast Asian (neo)colonial histories collide, I hope to reimagine and uncover an oceanic Asia that is the site of violence, remembered and reenvisioned by a growing number of thinkers concerned with economic, indigenous, feminist, and environmental justice. 


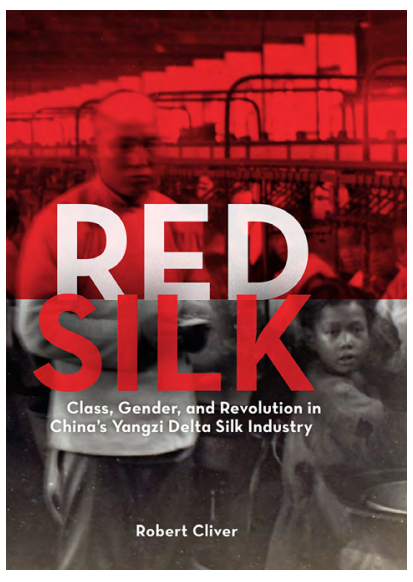

Red Silk: Class, Gender, and Revolution in China's Yangzi Delta Silk Industry. (Harvard University Press 2020).

\section{Red Silk \\ A Conversation with Robert Cliver}

Ivan FRANCESCHINI

In Red Silk: Class, Gender, and Revolution in China's Yangzi Delta Silk Industry (Harvard University Press 2020), Robert Cliver reconstructs the history of Chinese silk production in the Yangzi River Delta during the wars, crises, and revolutions of the twentieth century. Based on extensive research in Chinese archives and focussed on the 1950s, the book tells the stories of male silk weavers in Shanghai factories, who enjoyed close ties to the Party-state and benefitted greatly from socialist policies after 1949, and the young women toiling in silk thread mills or filatures, without powerful organisations or ties to the new regime. Both groups of workers and their employers had to adapt to rapidly changing circumstances, and their actions compelled the Party-state to adjust its policies, which in turn produced ever-new challenges. The results, though initially positive for many, were ultimately disastrous. By the end of the 1950s, there was widespread conflict and deprivation among silk workers and, despite its impressive recovery under Communist rule, the industry faced a crisis worse than either war or revolution.

Ivan Franceschini: Since the publication in the 1960s of Jean Chesneaux's seminal book on the Chinese labour movement, there has been a burgeoning literature on the history of labour in China. How has the field of Chinese labour history changed over the decades and how does Red Silk fit into this scholarly tradition?

Robert Cliver: It has been such a pleasure to participate in the field of historical studies of the People's Republic of China (PRC), which has become so vibrant and exciting over the past 30 years. When I first applied to graduate schools in 1992, I contacted Frederick Wakeman at Berkeley to ask about studying PRC history there. He replied that this was a field for sociologists and political scientists and that I should go into one of those departments. But I love history and historical methods, and some of my favourite political scientists who study modern China, such as Elizabeth Perry, write like historians. So, I went to the University of Hawai'i at Manoa to study with Stephen Uhalley in the history department there. Years later, in 2004, when I was first researching my dissertation, I participated in a workshop on PRC history at UC San Diego and Professor 
Wakeman was a participant, writing on the transition to Communist rule in the Shanghai police. Of course, he did not remember my letter, but we remarked on how far the field had come in a decade, especially the ability to conduct archival research in the PRC.

This is really the key development in this field-access to archival documents in China. Considering the Chinese Communist Party's (CCP) proletarian pretensions, there is surprisingly little scholarship on industrial workers in the PRC. A few works produced in the 1970s and 1980s depended on either published sources like newspapers or interviews with Chinese out-migrants in Hong Kong. From the 1990s, however, as access to Chinese sources for social history opened up, Western scholarship expanded beyond studies of ideology and international relations to include social and business history, and histories of workers.

Two of my favourite recent books on Chinese workers are Workers at War (2004) by Joshua Howard, and Eating Rice from Bamboo Shoots (2009) by Jacob Eyferth. I was very fortunate to have these two excellent labour historians working as reviewers for my manuscript with the Harvard University Asia Center. Their efforts made this a much better book than I could have produced on my own and I am very grateful to them. Where my book differs from theirs, and other scholarship on Chinese workers, is the focus on gender and women workers. While I look to Chesneaux and Dirlik and other pioneers in this field, I am really following in the footsteps of scholars like Emily Honig, Elizabeth Perry, and Gail Hershatter, whose studies of Chinese workers focus on gender as an important axis of analysis. Delia Davin's Woman-Work (1976) was an excellent starting point for me, and I hope that I have continued to explore the same themes through archival research. One of the most important conclusions I came to in writing Red Silk is that gender was hugely important in determining the experiences of different groups of workers in China's Communist revolution. I hope that my book pushes the boundaries of labour history in China and encourages us to look at the intersectionality of people's experiences in China's mid-century revolution.

IF: In the book, you look into the lived experiences of workers in the silk weaving industry in Shanghai and silk thread production in Wuxi. What are the main axes of your analysis?

RC: The main axes of analysis in Red Silk are class, gender, industry, and locality. Obviously, these are all interconnected, so the intersectional approach is key. In this book and an earlier article on 'democratic management' (民主管理), I found that one of the most important factors in determining which workers 
were able to gain access to the benefits of revolution-such as improved working conditions and welfare-and to participate in management was gender. Male workers were generally better able to achieve these benefits than women workers, even in the same industry or the same factory. Gender discrimination wasand is-built-in to Chinese systems of labour management, and proved very difficult to overcome even in the revolutionary context of the 1950s. There was successful resistance to CCP policies by the brutal, violent male supervisors in silk filatures, who managed to perpetuate their position well beyond the moment of Liberation.

It is not as simple, however, as male workers benefitted while female workers did not. About half of the silk weaving workforce in Shanghai was comprised of women-mostly employed in the poorer-paying jobs but also including many weavers. These women workers, and women employed in Shanghai filatures (thread mills), won much the same benefits as their male counterparts because they belonged to the same unions, which enjoyed close ties to the Communist Party, a strong position vis-à-vis their employers, and the political and economic resources of the city of Shanghai, which was able to provide much better welfare benefits for women workers than the city of Wuxi, where the majority of filature workers lived. Similarly, although many male workers in steel or textiles industries in Wuxi were able to gain welfare benefits and participatory forms of management, female filature workers were not, even in thread mills administered directly by the Party-state from 1949. Although it can be difficult to generalise about the experiences of Chinese workers during the revolution, we can draw some conclusions from these kinds of comparative case studies. In general, men and women experienced different revolutions, as did workers in different industries and different localities. Obviously, proletarians and capitalists experienced the revolution in different ways also-although under some circumstances, such as the 'socialist transformation of industry and commerce' in 1956, they could find common cause in challenging the Party-state.

IF: While focussing mostly on the 1950s, you also look into the decades that preceded the Chinese Revolution. Was the year 1949 really a watershed moment for the workers in the industries you examine? Was there any change in how they perceived their position in the workplace once they supposedly became the 'masters of the enterprise'?

RC: This is a very complex question that is hugely important for the field of PRC studies. The CCP has emphasised the utter transformation of everything, like the break of dawn, with Liberation in 1949. Even the archives are organised around this principle-pre-Liberation and post-Liberation-and scholars in 
China and abroad have focussed on the radical changes brought about under Communist rule, or the limitations of such changes. These days, we tend to emphasise continuities across the 1949 divide, as in a marvellous conference I attended in London in 2018 titled 'How Maoism Was Made'. In my presentation, I looked at continuities in government administration of the silk industry from the Japanese occupation of 1937 to 1945, through the post-war Guomindang years and into the 1950s. Although there were strong continuities, there were also some dramatic changes, such as the expansion of state administration to all parts of the economy and the penetration of the Party-state to the level of the village, neighbourhood, and factory. We thus see a complex mix of change and continuity, and great divergence in the outcomes of the revolution. For example, while Shanghai silk weavers won institutions for democratic management, health insurance, and job security, Wuxi filature workers got production campaigns and stricter workplace controls, mainly because the same brutal supervisors were still in charge for years after 1949. For those workers, it was like Liberation was something that happened to other people and they saw little improvement in their own situation until 1953 or even later.

Some fascinating examples of how these workers perceived the revolution in their own contexts appear in archival documents, mainly union reports on workers' attitudes during the 1950s. These reports quote workers making statements such as: 'Mao Zedong and Chiang Kai-shek are pretty much the same-whoever gives me a higher wage is better.' Or a statement recorded during the Great Leap Forward in 1959: 'In the past, working 12 hours was exploitation. Now what do we call working 12 hours?' The question remains at the centre of historians' studies of revolutionary change-what changed and what remained the same, and why? Where were revolutionary initiatives successful and where did they fail? One of the answers that Red Silk offers is that conditions varied in different industries and localities, and among different groups of people. Outcomes of revolutionary policies varied similarly, indicating that we need to look beyond the ideology of the leaders or the decisions made in Zhongnanhai to understand the Chinese revolution.

IF: The topics you explore in Red Silk are of interest not only to historians, but also to anyone who follows issues related to labour and gender in China today. In the book, you briefly mention how contemporary social divisions have grown out of those of the Maoist period. Can you elaborate on that?

RC: I mentioned some of the Chinese labour historians that have inspired me. The same is true of my colleagues in anthropology, sociology, and political science who also study 
Chinese workers-scholars like Pun Ngai, Ching Kwan Lee, Anita Chan, Leslie Chang, Bill Hurst, and Steve Philion. Their studies reveal the same divisions within the Chinese working class as we find throughout the twentieth century. Privileged male workers in ageing state industries use different tactics for protest than young women workers in the capitalist export industries serving the global economy. There are differences in locality between township enterprises in the hinterland and international firms based in South China. Another important divide today is between groups of workers who enjoyed substantial benefits under socialism and now see those benefits threatened, and those who must struggle to achieve any kind of fair treatment under restored capitalism. These divisions not only pre-date the restoration of capitalism in China in the past 40 years, but even predate the 1949 revolution. Perhaps this is an indication that divisions according to locality, industry, and gender are common among all modern workers, but this may be too much of a generalisation for this context.

IF: I was also intrigued by another analogy that you touch on but do not fully elaborate, that between the experiences of Chinese workers in the 1950s and those of their Soviet counterparts in the heyday of the Russian Revolution. What does such a comparison tell us?

RC: Another important influence on my work is S. A. Smith, one of the premier social historians of China and Russia. I wish I could have made these kinds of comparisons more prominent in my book, but I had so much rich material just on Chinese workers, with all of their diversity, that introducing another axis of comparison seemed overly complex. Some important differences just off the top of my head include standards of living (Soviet workers were richer than their Chinese counterparts and had better access to consumer goods), efforts to implement political production campaigns and democratic management were stronger and more sustained in China (I think partly due to China's relative poverty-political incentives are cheap, as is having workers do the work of administrators and engineers), China's position in the global economy was different (more isolated) than that of the Soviet Union, and, as much as Chinese production technologies developed in the 1950s and 1960s, China continued to make use of traditional technologies (such as medieval iron smelting furnaces) much more than the Soviet Union. There are many other comparisons worth making, but I am straying beyond my specific area of expertise and will instead point readers to the works of Professor Smith and others who are more proficient in both of these fields. 



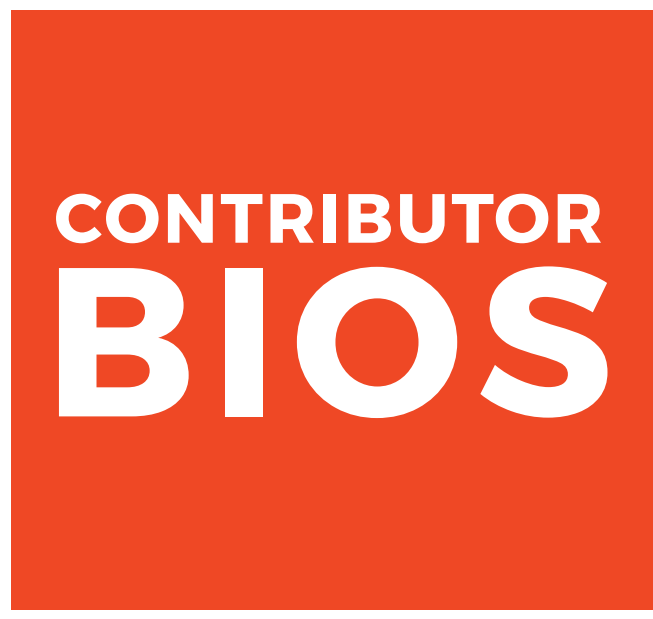

AU Loong-Yu is a writer based in Hong Kong. His first book China Rise: Strength and Fragility, was published by Merlin Press in 2012. His latest book, Hong Kong in Revolt: The Protest Movement and the Future of China, was published by Pluto Books in August 2020.

Mara BENADUSI is Associate Professor in Anthropology at the Department of Political and Social Sciences at the University of Catania, and current President of the Italian Society for Applied Anthropology. Her research interests focus on vulnerability, resilience, and risk related to disasters and environmental crises; as well as on humanitarian intervention, and the social and political consequences of liberalisation of nature and green grabbing. She has carried out long-term fieldwork on the post-2004 Tsunami reconstruction in Sri Lanka and more recently on the ecological frictions affecting a large petrochemical corridor on the northern coast of Siracusa, Sicily. She is the recipient of the 2013 Mary Fran Myers Scholarship of the Natural Hazards Center at the University of Colorado Boulder.

Alvin CAMBA is a PhD Candidate in sociology at Johns Hopkins University. He works on elite relations around new capital, illicit capital inflows, and the political economy of natural resources. More information about his work can be found on his website (alvincamba.com).
Anita CHAN is Visiting Fellow at the Political and Social Change Department, The Australian National University. Prior to that, she was Research Professor at University of Technology Sydney. Her current research focuses on Chinese labour issues. She has published widely on Chinese workers' conditions, the Chinese trade union, and labour rights. She is the co-editor of The China Journal with Jonathan Unger.

Robert CLIVER is a Professor of History at Humboldt State University in California, where he has lived for 13 years. He grew up in Massachusetts and earned his BA in history at Tufts University. After spending some time in Beijing working as a translator, he continued his education with an MA at the University of Hawai'i and a PhD at Harvard University. He has also taught at the Foreign Affairs University in Beijing and Oxford University in England.

Ivan FRANCESCHINI is a Postdoctoral Fellow at the Australian Centre on China in the World, The Australian National University. He has been working on Chinese labour activism for over a decade and his current research mainly focuses on China's presence in Cambodia. He co-edits the Made in China Journal.

Erin Y. HUANG is Assistant Professor of East Asian Studies and Comparative Literature at Princeton University. She is an interdisciplinary scholar and comparatist specialising in Marxist geography, postcolonial theory, feminist theory, cinema and media studies, and Sinophone Asia. Since the publication of her first book, she has been working on a second project that examines the geopolitics of oceanic China, consisting of military bases, artificial islands, and megacontainer ports that amplify the continued struggle between land and sea. 
Andrew Alan JOHNSON received his $\mathrm{PhD}$ from Cornell University in 2010. He has taught at Columbia University, Princeton University, and Yale-NUS College, among other places. He is currently a Visiting Scholar at the Center for Southeast Asian Studies, University of California, Berkeley, and a writer for Firaxis Games's Civilization series. He is the author of Ghosts of the New City (2014) and Mekong Dreaming (2020).

Nitasha KAUL is a novelist, economist, poet, and Senior Lecturer in Politics and International Relations at the Centre for the Study of Democracy, University of Westminster. Her books include Imagining Economics Otherwise (Routledge 2007); Future Tense (Harper Collins 2020); Residue (Rainlight 2014, shortlisted for the Man Asian Literary Prize); and Can You Hear Kashmiri Women Speak? (Kali for Women Press 2020). Links to all works can be found at www. nitashakaul.com.

Frédéric KECK is Senior Researcher at the French National Centre for Scientific Research (CNRS), director of the Laboratory for Social Anthropology in Paris, co-editor of The Anthropology of Epidemics (Routledge 2019), and author of several books in French. His research investigates contemporary relations between human and non-human beings as they are mediated by microbes. After studying zoonotic pathogens in the context of avian influenza in Asia, he now explores relations between the living and the dead through a collaboration with African museums on the microbiome in human remains. He is generally interested to understand how microbes act as signs of environmental changes, and how non-human beings act as sentinels when they carry these microbes.

James LEIBOLD is an Associate Professor and Head of the Department of Politics, Media, and Philosophy at La Trobe University. His research explores the politics of ethnicity, race, and national identity in modern China, with a current focus on ethnic policymaking and implementation in contemporary China.
Nicholas LOUBERE is an Associate Senior Lecturer in the Study of Modern China at the Centre for East and South-East Asian Studies, Lund University. His research examines socioeconomic development in rural China, with a particular focus on microcredit and migration. He co-edits the Made in China Journal.

Sylvia J. MARTIN received her $\mathrm{PhD}$ in Anthropology from the University of California, Irvine, and is an Assistant Professor at the University of Hong Kong. Recent work examines the convergence between the US state and Hollywood imagineering. She is the author of the monograph Haunted: An Ethnography of the Hollywood and Hong Kong Media Industries (2017) and articles in the journals Visual Anthropology Review and Media, Culture \&t Society.

William MATTHEWS is Fellow in the Anthropology of China at the London School of Economics, where he teaches on the MSc China in Comparative Perspective. He researches divination and cosmology in contemporary and early China, with a view to understanding what these tell us about belief, reasoning, cultural transmission, and the politics of legitimate knowledge.

Carwyn MORRIS recently completed a PhD in Human Geography at the London School of Economics and is an incoming Postdoctoral Research Associate at the Manchester China Institute; His ethnographic research, funded by the Economic and Social Research Council and the Chiang Ching-kuo Foundation, examines space as the medium of control in China's physical and digital spaces. Connect with him on Twitter@carwyn. 
Emily NG is a Postdoctoral Researcher at the Amsterdam School for Cultural Analysis, University of Amsterdam. Her ethnographic work in China has addressed cosmopolitical imaginations in contemporary spirit mediumship and charismatic Christianity, as well as intergenerational experiences of mind and madness in psychiatric and religious settings. Recently, she has been exploring cultural-aesthetic figurations of the rural as part of the project 'Imagining the Rural in a Globalizing World' (RURALIMAGINATIONS, 2018-2023), which received funding from the European Research Council (ERC) under the European Union's Horizon 2020 research and innovation programme (grant agreement No 772436).

Andrea Enrico PIA is Assistant Professor in Anthropology at the London School of Economics. Since 2007, Andrea has been engaged in a long-term, multi-sited ethnographic study of China's unfolding water crisis, paying particular heed to questions of environmental justice, social control, and prefigurative rural politics. His next project looks at the internationalisation of the Chinese water industry and the politicalecological transformations now affecting the transboundary riverine communities located along the Mekong. His work has appeared on PoLar: Political and Legal Anthropology Review, The Journal of the Royal Anthropological Institute, and Cultural Anthropology, among others. His first book is forthcoming with Johns Hopkins University Press.

Rebekah PLUECKHAHN is a McArthur Research Fellow in Anthropology at the University of Melbourne. She has published on topics including the anthropology of capitalism in Mongolia, flexible land possession and bureaucracy, residential experiences of changing urban environments, Mongolian musical sociality, causality, and morality.
Matthew P. ROBERTSON is a PhD student at The Australian National University and a Fellow in China Studies at the Victims of Communism Memorial Foundation. His doctoral research, using computational methods and process tracing, focuses on the organ transplantation industry in the People's Republic of China. It is concerned both with empirical questions and the political logic of state control over citizen bodies. His broader research interests include political violence, biopolitics, genocide studies, and social thought.

Gerald ROCHE is an anthropologist and Senior Research Fellow in the Department of Politics, Media, and Philosophy at La Trobe University. His research on Tibetan language politics has led him to an interest in contemporary colonialism, resistance by Indigenous and minoritised peoples, and transnational social movements.

Flair Donglai SHI (施東來) is completing his $\mathrm{PhD}$ in English and Comparative Literature at the University of Oxford and has been working at Warwick University as Associate Tutor in Translation and Cultures since 2018. Based in the English Faculty, his thesis is entitled 'The Yellow Peril Discourse in Anglophone and Sinophone Literatures and Cultures, 1895 to the Present: Mutations, Reactions, and Reincarnations'. His articles on postcolonial feminism, Chinese literature, and world literature have been published in several academic journals, including Comparative Critical Studies, Women: A Cultural Review, Chinese Literature: Essays, Articles, Reviews, and Comparative Literature \& World Literature. His latest publication is the edited volume World Literature in Motion: Institution, Recognition, Location (Ibidem 2020).

Edoardo SIANI writes about power in Buddhist Thailand. Assistant Professor of Southeast Asian Studies at Ca' Foscari University of Venice, he holds a PhD in Anthropology and Sociology from SOAS, University of London. He has resided in Bangkok since 2002. 
Christian SORACE is an Assistant Professor of Political Science at Colorado College. He is the author of Shaken Authority: China's Communist Party and the 2008 Sichuan Earthquake (2017). $\mathrm{He}$ is also the co-editor of Afterlives of Chinese Communism: Political Concepts from Mao to Xi (2019). His current research focuses on the crisis of democracy, air pollution, and urbanisation in Mongolia.

Chris K. K. TAN is an Associate Professor in the School of Social and Behavioural Sciences at Nanjing University, China. His current research focuses on how affects intersect with technology in China. He previously published in Information, Communication \& Society, Journal of Consumer Culture, and Urban Studies. He is currently writing a monograph on national belonging among Singaporean gay men.

Malcolm THOMPSON is a historian of China based in Vancouver, Canada. He holds a $\mathrm{PhD}$ from the University of British Columbia (UBC) and has taught there and at the University of Toronto. He has held postdoctoral fellowships at the Institute of Asian Research at UBC and at the Fairbank Center, Harvard University.

Rian THUM is Senior Research Fellow at the University of Nottingham. His research and teaching are generally concerned with the interpenetration of China and the Muslim world. Since 1999, he has regularly conducted field research in Xinjiang and other areas of China with large Muslim populations, both Uyghur and Chinese-speaking. His book The Sacred Routes of Uyghur History (2014) was awarded the Fairbank Prize for East Asian history (American Historical Association) and the Hsu Prize for East Asian Anthropology (American Anthropological Association). Thum's current book project, Islamic China, is a reexamination of Chinese Islam that takes full account of the numerous Persian and Arabic sources that Chinese-speaking Muslims have used and written.
Michael G. VANN earned his PhD from the University of California, Santa Cruz, in 1999. He is currently a Professor of History at California State University, Sacramento, where he teaches surveys of world and Southeast Asian history, as well as courses on imperialism, genocide, and disease. While most of Vann's work has been on the French colonial empire in Southeast Asia and Algeria, his current book project compares the representation of Cold Warera mass violence in Vietnamese, Cambodian, and Indonesian museums. Vann has taught at Universitas Gadjah Mada, East China Normal University, Paññāsāstra University of Cambodia (Siem Reap), and Metropolitan Business College (Hanoi). Vann is not actually a fan of rats.

Chenchen ZHANG is a Lecturer in Politics and International Relations at Queen's University Belfast. Her research interests lie broadly in international relations, political theory, and political geography. Connect with her on Twitter@chenchenzh.

ZHANG Yueran is a doctoral student in sociology at the University of California, Berkeley. His research focuses on political economy, (de)mobilisations, and the interaction between states and class forces in the Global South. He has also been involved in labour and left organising in both China and the United States.

Mengyang ZHAO is a doctoral student in sociology at the University of Pennsylvania. Her research interests include digital labour, precarious work, and social movements. Having volunteered for several NGOs and social movement networks in China and the United States, she hopes to contribute to transnational organising via activist scholarship.

Konstantinos ZORBAS is an Associate Professor at the Department of Anthropology, Shandong University, China. His main research focuses on shamanic rituals to deal with an epidemic of curses in the Tyva Republic, Russia. Currently, he is completing a monograph on shamanism and post-socialism in Tyva. 


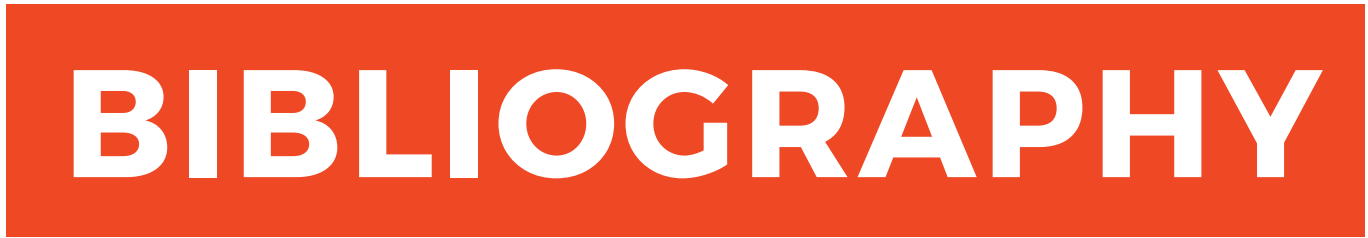

\section{What about Whataboutism? Viral Loads and Hyperactive Immune Responses in the China Debate (IVAN FRANCESCHINI AND NICHOLAS LOUBERE)}

Amy, Jean-Jacques and Sam Rowlands. 2018. 'Legalised Non-consensual Sterilisation: Eugenics Put into Practice Before 1945, and the Aftermath. Part 1: USA, Japan, Canada and Mexico.' The European Journal of Contraceptive \& Reproductive Health Care 23, no. 2: 121-29.

Backer, Larry Catá. 2019. 'And an Algorithm to Bind Them All? Social Credit, Data Driven Governance, and the Emergence of an Operating System for Global Normative Orders.' SSRN. papers. ssrn.com/sol3/papers.cfm?abstract_id=3182889.

BBC. 2020. 'China Forcing Birth Control on Uighurs to Suppress Population, Report Says.' BBC, 29 June. www.bbc.com/news/world-asia-china-53220713.

Benns, Whitney. 2015. 'American Slavery, Reinvented.' The Atlantic, 21 September. www.theatlantic. com/business/archive/2015/09/prison-labor-in-america/406177/.

Brophy, David. 2019. 'Good and Bad Muslims in Xinjiang.' Made in China Journal 4, no.2: 44-53.

Byler, Darren. 2019a. 'How Companies Profit from Forced Labor in Xinjiang.' SupChina, 4 September. supchina.com/2019/09/04/how-companies-profit-from-forced-labor-in-xinjiang.

Byler, Darren. 2019b. 'Preventative Policing as Community Detention in Northwest China.' Made in China Journal 4, no. 3: 88-94.

Byler, Darren. 2020. 'The Global Implications of “Re-education” Technologies in Northwest China.' Center for Global Policy, 8 June. cgpolicy.org/articles/the-global-implications-of-re-educationtechnologies-in-northwest-china.

Carney, Matthew. 2018. 'Leave No Dark Corner' ABC News, 18 September. www.abc.net.au/ news/2018-09-18/china-social-credit-a-model-citizen-in-a-digital-dictatorship/10200278.

Chelwa, Grieve and Sean Muller. 2019. 'The Poverty of Poor Economics.' Africa is a Country, 17 October. africasacountry.com/2019/10/the-poverty-of-poor-economics.

Cliff, Tom. 2016. Oil and Water: Being Han in Xinjiang. Chicago, IL: University of Chicago Press.

Clover, Charles. 'China: When Big Data Meets Big Brother.' Financial Times, 20 January. www.ft.com/content/b5b13a5e-b847-11e5-b151-8e15c9a029fb. 
Darrowby, James. 2019. 'Intellectual Property, Artificial Intelligence, and Ethical Dilemmas: China and the New Frontiers of Academic Integrity.' Made in China Journal 4, no. 1:24-29.

Daum, Jeremy. 2017. 'China Through a Glass, Darkly.' China Law Translate, 24 December. www.chinalawtranslate.com/en/china-social-credit-score.

Daum, Jeremy. 2019. 'Untrustworthy: Social Credit Isn’t What You Think It Is.' Verfassungblog, 27 June. verfassungsblog.de/untrustworthy-social-credit-isnt-what-you-think-it-is.

Dirlik, Arif. 2017. Complicities: The People's Republic of China in Global Capitalism. Chicago, IL: Prickly Paradigm Press.

Greitens, Sheena Chestnut, Myunghee Lee, and Emir Yazici. 2020. 'Counterterrorism and Preventive Repression: China's Changing Strategy in Xinjiang.' International Security 44, no. 3: 9-47.

Harney, Alexandra. 2019. 'Risky Partner: Top U.S. Universities Took Funds from Chinese Firm Tied to Xinjiang Security' Reuters, 13 June. www.reuters.com/article/us-china-xinjiang-mit-techinsight/risky-partner-top-u-s-universities-took-funds-from-chinese-firm-tied-to-xinjiang-securityidUSKCN1TE04M.

Hu, Krystal and Jeffrey Dastin. 2020. 'Amazon Turns to Chinese Firm on U.S. Blacklist to Meet Thermal Camera Needs.' Reuters, 29 April. www.reuters.com/article/us-health-coronavirus-amazoncom-cameras/exclusive-amazon-turns-to-chinese-firm-on-u-s-blacklist-to-meet-thermal-cameraneeds-idUSKBN22B1AL.

Loubere, Nicholas. 2018. 'Indebted to Development: Microcredit as (De)marginalisation in Rural China.' Journal of Peasant Studies 45, no. 3: 585-609.

Loubere, Nicholas and Stefan Brehm. 2018. 'The Global Age of Algorithm: Social Credit and the Financialisation of Governance in China.' Made in China Journal 3, no. 1: 38-42.

McNeill, Sophie, Jeanavive McGregor, Meredith McGriffiths, Michael Walsh, and Echo Hui. 2019. 'UTS, Curtin Unis Announce Reviews Over Links to Surveillance Tech Used by Chinese Government.' $A B C$ News Four Corners, 16 July. www.abc.net.au/news/2019-07-16/australian-unis-to-review-linksto-chinese-surveillance-tech/11309598.

Monbiot, George. 2020. ‘Boris Johnson Says We Shouldn’t Edit Our Past. But Britain Has Been Lying about It for Decades.' The Guardian, 16 June. www.theguardian.com/commentisfree/2020/jun/16/ boris-johnson-lying-history-britain-empire.

Nemser, Daniel. 2017. Infrastructures of Race: Concentration and Biopolitics in Colonial Mexico. Austin, TX: University of Texas Press.

Ordonez, Victor. 2019. ‘Erik Prince's Company Plans Business in China Province Under Human Rights Scrutiny According to Financial Disclosure.' ABC News, 10 October. abcnews.go.com/ International/erik-princes-company-plans-business-china-province-human/story?id=66139535. 
Palin, Megan. 2018. 'China’s “Social Credit” System Is a Real-life "Black Mirror” Nightmare.' New York Post, 19 September. nypost.com/2018/09/19/chinas-social-credit-system-is-a-real-life-blackmirror-nightmare.

Patton, Dominique. 2016. 'Xinjiang Cotton at Crossroads of China's New Silk Road.' Reuters, 12 January. www.reuters.com/article/us-china-xinjiang-cotton-insight-idUSKCNOUQ00320160112.

Pitzer, Andrea. 2018. One Long Night: A Global History of Concentration Camps. New York, NY: Little, Brown and Company.

Reisinger, Don. 2015. 'Why Facebook Profiles are Replacing Credit Scores.' Fortune, 2 December. fortune.com/2015/12/01/tech-loans-credit-affirm-zest.

Rivlin-Nadler, Max. 2019. 'How ICE Uses Social Media to Surveil and Arrest Immigrants.' The Intercept, 23 December. theintercept.com/2019/12/22/ice-social-media-surveillance.

Robertson, Matthew. 2020. 'Counterterrorism or Cultural Genocide? Theory and Normativity in Knowledge Production About China's "Xinjiang Strategy". Made in China Journal, 12 June. madeinchinajournal.com/2020/06/12/counterterrorism-or-cultural-genocide.

Roche, Gerald. 2019. 'Transnational Carceral Capitalism in Xinjiang and Beyond.' Made in China Journal 4, no. 1: 13-15.

Rollet, Charles. 2019. 'Influential US Scientist under Fire for Xinjiang Links.' Coda, 12 September. www.codastory.com/authoritarian-tech/influential-us-scientist-under-fire-xinjiang-links.

Teng, Biao 滕彪. 2020. '中美比较如何成为一种病毒 [How Comparisons between the United States and China Became a Virus]. 纽约时报中文网 [The New York Times Chinese Website], 28 May. cn.nytimes.com/opinion/20200528/coronavirus-china-us-pandemic.

The Economist. 2016a. 'China's Digital Dictatorship.' The Economist, 17 December. www.economist. com/leaders/2016/12/17/chinas-digital-dictatorship.

The Economist. 2016b. 'China Invents the Digital Totalitarian State.' The Economist, 17 December. www.economist.com/briefing/2016/12/17/china-invents-the-digital-totalitarian-state.

The Economist. 2016c. 'Test of Character.' The Economist, 29 September. www.economist.com/ finance-and-economics/2016/09/29/tests-of-character.

Wee, Sui-Lee. 2019. 'China Uses DNA to Track Its People, With the Help of American Expertise.' The New York Times, 21 February. www.nytimes.com/2019/02/21/business/china-xinjiang-uighurdna-thermo-fisher.html.

World Bank. 2015. World Development Report 2015: Mind, Society, and Behavior. Washington D.C.: The World Bank. 
Xu, Vicky Xiuzhong, Danielle Cave, James Leibold, Kelsey Munro, and Nathan Ruser. 2020. 'Uyghurs for Sale: “Re-education”, Forced Labour and Surveillance beyond Xinjiang.' Australian Strategic Policy Institute website, 1 March. www.aspi.org.au/report/uyghurs-sale.

Yi, Xiaocuo. 2019. 'Blood Lineage.' In Afterlives of Chinese Communism: Political Concepts from Mao to $\mathrm{Xi}$, edited by Christian Sorace, Ivan Franceschini, and Nicholas Loubere, 17-22. Canberra, London, New York, NY: Anu Press and Verso Books.

Zeng, Meg Jing. 2018. 'China's Social Credit System Puts Its People under Pressure to Be Model Citizens.' The Conversation, 24 January. theconversation.com/chinas-social-credit-system-puts-itspeople-under-pressure-to-be-model-citizens-89963.

Zhang, Chenchen. 2020. 'Governing (Through) Trustworthiness: Technologies of Power and Subjectification in China's Social Credit System.' Critical Asian Studies.

\section{China's Second-generation Ethnic Policies Are Already Here: What China's History of Paper Genocide Can Tell Us about the Future of Its 'Minority Nationalities' (GERALD ROCHE AND JAMES LEIBOLD)}

Atwood, Christopher. 2020. 'Bilingual Education in Inner Mongolia: An Explainer.' Made in China Journal, 30 August. madeinchinajournal.com/2020/08/30/bilingual-education-in-inner-mongoliaan-explainer.

Axelsson, Per. 2010. 'Abandoning "The Other": Statistical Enumeration of the Swedish Sami, 1700 to 1945 and Beyond.' Berichte zur Wissenschaftsgeschichte 33: 263-79.

Baioud, Gegentuul. 2020. 'Will Education Reform Wipe Out Mongolian Language and Culture?' Language on the Move, 30 August. www.languageonthemove.com/will-education-reform-wipe-outmongolian-language-and-culture.

Bulag, Uradyn. 2019. 'Nationality.' In Afterlives of Chinese Communism: Political Concepts from Mao to $X i$, edited by Christian Sorace, Ivan Franceschini, and Nicholas Loubere, 149-54. Canberra, London, and New York, NY: ANU Press and Verso Books.

Byler, Darren. 2019. 'Xinjiang Education Reform and the Eradication of Uyghur-language Books.'

SupChina, 2 October. supchina.com/2019/10/02/xinjiang-education-reform-and-the-eradication-ofuyghur-language-books.

Deerinwater, Jen. 2019. 'Paper Genocide: The Erasure of Native People in Census Counts.' Rewire. news, 9 December. rewire.news/article/2019/12/09/paper-genocide-the-erasure-of-native-peoplein-census-counts.

Kidwai, Ayesha. 2019. ‘The People’s Linguistic Survey of India Volumes: Neither Linguistics, Nor a Successor to Grierson's LSI, but Still a Point of Reference.' Social Change 49, no. 1: 154-59.

Leibold, James. 2013. Ethnic Policy in China: Is Reform Inevitable? Honolulu, HI: East-West Centre. 
Leibold, James. 2014. 'A Family Divided: The CCP's Central Ethnic Work Conference.' China Briefs, 7 November. jamestown.org/program/a-family-divided-the-ccps-central-ethnic-work-conference.

Leibold, James. 2015. ‘China’s Ethnic Policy under Xi Jinping.' China Brief, 19 October. jamestown. org/program/chinas-ethnic-policy-under-xi-jinping.

Leibold, James. 2016. 'Preferential Policies for Ethnic Minorities in China.' In Handbook on Ethnic Minorities in China, edited by Xiaowei Zang, 165-88. London: Edward Elgar.

Leibold, James. 2019. 'Planting the Seed: Ethnic Policy in Xi Jinping's New Era of Cultural Nationalism.' China Brief, 31 December. jamestown.org/program/planting-the-seed-ethnic-policy-inxi-jinpings-new-era-of-cultural-nationalism.

Mullaney, Thomas. 2011. Coming to Terms with the Nation: Ethnic Classification in Modern China. Oakland, CA: University of California Press.

Qiao, Long. 2020. 'Ethnic Mongolian Parents Strike over China's New Language Policy in Schools.' Radio Free Asia, 28 August. www.rfa.org/english/news/china/mongolia-language-08282020105851. html.

Ramirez, Renya K. 2007. Native Hubs: Culture, Community, and Belonging in Silicon Valley and Beyond. Durham, NC, and London: Duke University Press.

Roche, Gerald. 2019. 'Articulating Language Oppression: Colonialism, Coloniality, and the Erasure of Tibet's Minority Languages.' Patterns of Prejudice 53, no. 5: 487-514.

Roche, Gerald. 2020. 'Tibetan Language Rights and Civil Society in the People's Republic of China: Challenges of and for Rights.' Asian Studies Review, online first. doi.org/10.1080/10357823.2020.1758 033.

Vincent, Eve. 2017. Against Native Title: Conflict and Creativity in Outback Australia. Canberra: Aboriginal Studies Press.

Upton, Janet L. 2000. 'Notes Towards a Native Tibetan Ethnology: An Introduction to and Annotated Translation of dMu dge bSam gtan's Essays on Dwags po (Baima Zangzu).' The Tibet Journal 25, no. 1: $3-26$.

Wong, Edward. 2010. 'Tibetans in China Protest Proposed Curb on Their Language.' The New York Times, 22 October. www.nytimes.com/2010/10/23/world/asia/23china.html.

Wu, Da. 2015. 'Three Tongues and Two Identities: A Case Study of Ersu Ethnic Identities in Sichuan, China.' Cultural Diversity in China 1: 44-67.

Xu, Shixuan. 2013. 'Language Endangerment.' In The Language Situation in China, edited by Yuming Li and Wei Li, vol. 1, 26170. Berlin and Boston: De Gruyter. 
Zhou, Viola. 2020. “'Don’t Try to Tame Me”: Mongols in China Protest Plan to Teach in Chinese.' Inkstone, 31 August. www.inkstonenews.com/society/dont-try-tame-me-mongols-china-protestplan-teach-chinese/article/3099606.

\section{Undoing Lenin: On the Recent Changes to China's Ethnic Policy (CHRISTIAN SORACE)}

Anderson, Benedict. 2016. Imagined Communities: Reflections on the Origin and Spread of Nationalism. London and New York, NY: Verso Books.

Atwood, Christopher. 2002. Young Mongols and Vigilantes in Inner Mongolia's Interregnum Decades, 1911-1931. Leiden: Brill.

Atwood, Christopher. 2004. Encyclopedia of Mongolia and the Mongol Empire. New York, NY: Facts on File, Inc.

Atwood, Christopher P. 2020. 'Bilingual Education in Inner Mongolia: An Explainer' Made in China Journal, 30 August. madeinchinajournal.com/2020/08/30/bilingual-education-in-inner-mongoliaan-explainer.

Baioud, Gegentuul. 2020. 'Will Education Reform Wipe Out Mongolian Language and Culture?' Language on the Move, 30 August. www.languageonthemove.com/will-education-reform-wipe-outmongolian-language-and-culture.

Barmé, Geremie R. 2011. ‘The Children of Yan'an: New Words of Warning to a Prosperous Age.” China Heritage Quarterly, no. 26. www.chinaheritagequarterly.org/features.php?searchterm=026_yanan. inc\&issue $=026$.

Bulag, Uradyn E. 2003. 'Mongolian Ethnicity and Linguistic Anxiety in China.' American Anthropologist 105, no. 4: 753-63.

Bulag, Uradyn E. 2010. Collaborative Nationalism: The Politics of Friendship on China's Mongolian Frontier. Lanham, MD: Rowman \& Littlefield Publishers, Inc.

Bulag, Uradyn E. 2012. 'Good Han, Bad Han: The Moral Parameters of Ethnopolitics in China.' In Critical Han Studies: The History, Representation and Identity of China's Majority, edited by Thomas S. Mullaney, James Leibold, Stéphane Gros, and Eric Vanden Bussche, 92-109. Berkeley, CA: University of California Press.

Bulag, Uradyn E. 2019. 'Nationality.' In Afterlives of Chinese Communism: Political Concepts from Mao to Xi, edited by Christian Sorace, Ivan Franceschini, and Nicholas Loubere, 145-51. London and New York, NY: Verso Books.

Chan, Wilfred. 2020. 'Did US Lobbying Efforts Backfire for Hong Kong's Pro-Democracy Movement?' The Nation, 14 September. www.thenation.com/article/world/hong-kong-china-jeffrey-ngointerview.

Cherry Society 樱桃社. 2020. “打倒大汉族主义! [Down with Great Han Chauvinism!]. Telegram post, 4 September. telegra.ph/han-09-04md. 
Coulthard, Glen Sean. 2014. Red Skin, White Masks: Rejecting the Colonial Politics of Recognition. Minneapolis, MN: University of Minnesota Press.

Dunbar-Ortiz, Roxanne. 2015. An Indigenous Peoples' History of the United States. Boston, MA: Beacon Press.

Estes, Nick. 2019. Our History Is the Future: Standing Rock Versus the Dakota Access Pipeline, and the Long Tradition of Resistance. London and New York, NY: Verso Books.

Estes, Nick. 2020. Tweet on 8 August. twitter.com/nickwestes/status/1292211928748691456.

Friedman, Eli. 2020. Tweet on 19 September. twitter.com/EliDFriedman/ status/1307357424525991936

Heqiyeletu, Se. 贺其业勒图.色. 2020. “乌兰夫同志在语言政策执行层面上以法规化措施推进民族 语文工作常态化的经程及运作模式研究 [Comrade Ulaanhuu on Aspects of the Implementation of Language Policy: Research on the Methods, Path, and Measures to Legalise and Advance the Normalisation of Ethnic Literature and Language Work].' WeChat post, 30 August. mp.weixin. qq.com/s/rL5jRGK6OiX8pBeZWlso7g.

Hioe, Brian. 2020. 'The Qiao Collective and Left Diasporic Chinese Nationalism.' New Bloom, 22 June. newbloommag.net/2020/06/22/qiao-collective-nationalism.

Humphrey, Caroline and Uradyn E. Bulag. 2020. 'Letter: China's Mongol Region Wants to Stick to the Script.' Financial Times, 13 September. app.ft.com/content/f9378802-90c5-41bb-88c7-90eb9ab62dd5.

Hu, Lianhe胡联合and Angang Hu鞍钢胡. 2011. “国外是如何处理民族问题的 [How the Nationalities Question Is Handled Outside of China]. 爱思想 [Aisixiang], 14 November. www.aisixiang.com/ data/46493.html. English translation by David Ownby for Reading the China Dream, www. readingthechinadream.com/hu-and-hu-nationalities-question.html.

Jankowiak, William R. 1988. 'The Last Hurrah? Political Protest in Inner Mongolia.' The China Journal 19/20: 269-88.

Lausan Collective. 2019. 'Hong Kong Human Rights and Democracy Act: A Critical Analysis.' Lausan, 15 September. lausan.hk/2019/hong-kong-human-rights-and-democracy-act-critical-analysis.

Lenin, Vladimir I. (edited by Robert C. Tucker). 1975. The Lenin Anthology. New York, NY: W.W. Norton and Company.

Lenin, Vladimir I. and Slavoj Žižek. 2017. Lenin 2017: Remembering, Repeating, and Working Through. London and New York, NY: Verso Books.

Lewin, Moshé. 2005. Lenin's Last Struggle. Ann Arbor, MI: University of Michigan Press.

Li, Narangoa. 2020. 'Concerned Parents Opposed to Proposed Changes to Mongolian Language Texts, Inner Mongolia.' MongolInk, 21 September. mongoliainstitute.anu.edu.au/mongolink/2020/09/21/ concerned-parents-opposed-to-proposed-changes-to-mongolian-language-texts-inner-mongolia. 
Liu, Xiaoyuan. 2006. Reigns of Liberation: An Entangled History of Mongolian Independence, Chinese Territoriality, and Great Power Hegemony, 1911-1950. Stanford, CA: Stanford University Press.

Ma Rong 马戎. 2019. ‘中国民族区域自治制度的历史演变轨迹 [The Historical Evolution of China's System of Autonomous Ethnic Regions ]. 民族研究 [Ethnic Studies]: 92-109. Introduction and translation by David Ownby for Reading the China Dream, www.readingthechinadream.com/marong-ethnic-regional-autonomy.html.

Prashad, Vijay. 2020. Speech at Progressive International's 2020 Summit, 18 September. www. youtube.com/watch?v=h7YiBIj2k0M\&feature=youtu.be.

Qiao Collective. 2020. 'On Inner Mongolia and Bilingual Education in China.' Qiao Collective website, 10 September. www.qiaocollective.com/en/articles/inner-mongolia-bilingual.

Red Horse Reading Club 红马读书会. 2020. “关于当前内蒙古自治区蒙古语授课教育遇到困境的反映 [Reflections on the Difficulties Currently Faced by Education through Mongol Medium in the Inner Mongolia Autonomous Region]. Available upon request.

Simpson, Audra. 2014. Mohawk Interruptus: Political Life Across the Borders of Settler States. Durham, NC: Duke University Press.

Sinica. 2019. 'Tashi Rabgey and Jim Millward on China's Ethnic Policy in Xinjiang and Tibet.' Sinica Podcast, 15 February. supchina.com/2019/02/15/sinica-podcast-tashi-rabgey-and-jim-millward-onchinas-ethnic-policy-in-xinjiang-and-tibet.

Sorace, Christian P. 2017. Shaken Authority: China's Communist Party and the 2008 Sichuan Earthquake. Ithaca, NY: Cornell University Press.

Xi Jinping. 2017. 'Full Text of Xi Jinping's Report at 19th CPC National Congress.' China Daily, 18 October. www.chinadaily.com.cn/china/19thcpcnationalcongress/2017-11/04/content_34115212.htm.

Yang, Haiying 楊海英 (translated by Liu Yingbo 刘英伯 and Liu Yanzi 刘燕子). 2014. 没有墓碑的草原: 内蒙古的文革大屠杀实录 [The Steppe Without Headstones: A Record of Cultural Revolution Slaughter in Inner Mongolia]. Taipei: Baqi Wenhua.

\section{The Spatial Cleansing of Xinjiang: Mazar Desecration in Context (RIAN THUM)}

Abdu Vali Akhon. 1905. 'Māzārlārgha Bārādūrghānlārnīng Ya nī Ziyāratgāhnīng Bayāni [On Those Who Go to Mazars, That Is to Say, on Pilgrimage Sites].' Gunnar Jarring Collection, Lund University Library.

Agence France-Presse. 2019. “No Space to Mourn”: The Destruction of Uygur Graveyards in Xinjiang.' South China Morning Post, 12 October. www.scmp.com/news/china/politics/ article/3032646/no-space-mourn-destruction-uygur-graveyards-xinjiang.

Brophy, David and Rian Thum. 2015. 'Appendix: The Shrine of Mulammad Sharīf and Its Qing-Era Patrons.' In The Life of Muhammad Sharif: A Central Asian Sufi Hagiography in Chaghatay, edited by Jeff Eden, 55-76. Vienna: Verlag der Österreichischen Akademie der Wissenschaften. 
Byler, Darren. 2018. 'China's Government Has Ordered a Million Citizens to Occupy Uighur Homes. Here's What They Think They're Doing.' ChinaFile, 24 October. www.chinafile.com/reportingopinion/postcard/million-citizens-occupy-uighur-homes-xinjiang.

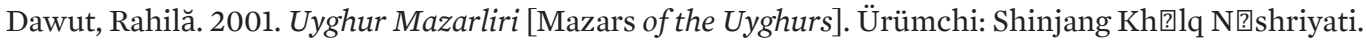

Dūghlāt, Mīrzā Haydar (translated by W. M. Thackston). 1996 [1543]. Mirza Haydar Dughlat's Tarikh-i Rashidi: A History of the Khans of Moghulistan. Cambridge, MA: Harvard University, Department of Near Eastern Languages and Civilizations.

Gansu Daily Net. 2019. “平川 区完成土炕改造2563铺 [Pingchuan District Completes Reform of 2,563 Kangs]' 每日甘肃网 [Gansu Daily Net], 21 January. by.gansudaily.com.cn/ system/2019/01/21/017124756.shtml.

Google Earth. 2020. 'Satellite Image Showing Former Location of Ordam Padshah Mazar.' Google Earth. earth.google.com/web/@38.91253865,76.65675727,1614.22900131a,0d,35y,-0.0105h,28.7197t,0r.

Grose, Timothy. 2020. 'If You Don't Know How, Just Learn: Chinese Housing and the Transformation of Uyghur Domestic Space.' Ethnic and Racial Studies, doi.org/10.1080/01419870.2020.1789686.

Harris, Rachel and Rahilä Dawut. 2002. 'Mazar Festivals of the Uyghurs: Music, Islam and the Chinese State.' British Journal of Ethnomusicology 11, no. 1: 101-18.

Hoshur, Shohret. 2016. 'Under the Guise of Public Safety, China Demolishes Thousands of Mosques.' Radio Free Asia, 19 December. www.rfa.org/english/news/uyghur/udner-the-guise-of-publicsafety-12192016140127.html.

Jarring, Gunnar. 1935. 'The Ordam-Padishah-System of Eastern Turkistan Shrines.' Geografiska Annaler 17: 348-54.

Kemal, Ahmet. 1925. Çīn Türkistān Hatıraları [Memoir of Chinese Turkistan]. Izmir: marifet matbaası.

Khotan Government. 2019. 'Notice Regarding the Removal of Sultanim Mazar and Graveyard.' See author's Twitter thread at twitter.com/RianThum/status/1255146071258349574.

Kobi, Madlen. 2016. Constructing, Creating and Contesting Cityscapes: A Socio-Anthropological Approach to Urban Transformation in Southern Xinjiang, People's Republic of China. Wiesbaden: Harrassowitz Verlag.

Kuo, Lily. 2019. 'Revealed: New Evidence of China's Mission to Raze the Mosques of Xinjiang.' The Guardian, 7 May. www.theguardian.com/world/2019/may/07/revealed-new-evidence-of-chinasmission-to-raze-the-mosques-of-xinjiang.

Lesté-Lasserre, Christa. 2020. 'Scientists Are Leading Notre Dame’s Restoration-and Probing Mysteries Laid Bare by Its Devastating Fire.' Science, 12 March. www.sciencemag.org/news/2020/03/ scientists-are-leading-notre-dame-s-restoration-and-probing-mysteries-laid-bare-its. 
Liu, Tianyang and Zhenjie Yuan. 2019. 'Making a Safer Space? Rethinking Space and Securitization in the Old Town Redevelopment Project of Kashgar, China.' Political Geography 69: 30-42.

Manzi, Su. 2013. 'An Interview with Rahilä Dawut.' In Living Shrines of Uyghur China by Lisa Ross, 121-23. New York, NY: The Monacelli Press.

MarcelTraveller. 2018. 'Imam Asim's Tomb, Hotan.' Review on Tripadvisor, June. www.tripadvisor. com/Attraction_Review-g528737-d8705159-Reviews-Imam_Asim_s_Tomb-Hotan_Xinjiang_Uygur. html.

Millward, James. 2009. Eurasian Crossroads: A History of Xinjiang. New York, NY: Columbia University Press.

Ministry of Civil Affairs. 2018. ‘政部等9部门联合发文部署开展殡葬领域突出问题专项整治行动 [The Ministry of Civil Affairs and Nine Other Departments Jointly Issue a Document Launching a Special Rectification Campaign for Outstanding Problems in the Field of Funerals and Burials].' Ministry of Civil Affairs of the People's Republic of China website, 2 July. www.mca.gov.cn/article/ $\mathrm{xw} / \mathrm{tzgg} / 201807 / 20180700009909 . \mathrm{shtml}$.

Pawan, Sawut and Abiguli Niyazi. 2016. 'From Mahalla to Xiaoqu: Transformations of the Urban Living Space in Kashgar.' Inner Asia 18, no. 1: 121-34.

Rivers, Matt. 2020. 'More Than 100 Uyghur Graveyards Demolished by Chinese Authorities.' CNN, 2 January. www.cnn.com/2020/01/02/asia/xinjiang-uyghur-graveyards-china-intl-hnk/index.html.

She County People’s Government. 2020. ‘殡葬整治工作半年总结 [Mid-year Summary of Funeral and Burial Rectification Work].' She County People's Government website, 3 July. www.ahshx.gov.cn/ BranchOpennessContent/show/1745160.html.

Sintash, Bahram. 2019. 'Demolishing Faith: The Destruction and Desecration of Uyghur Mosques and Shrines.' Washington, D.C.: Uyghur Human Rights Project.

Sugawara, Jun. 2016. 'Opal, a Sacred Site on the Karakoram Highway.' In Mazar: Studies on Islamic Sacred Sites in Central Eurasia, edited by Sugawara Jun and Rahile Dawut, 153-74. Tokyo: Tokyo University of Foreign Studies Press.

Thum, Rian. 2014. The Sacred Routes of Uyghur History. Cambridge, MA: Harvard University Press.

Tuck, Eve and K. Wayne Yang. 2012. 'Decolonization Is Not a Metaphor'. Decolonization: Indigeneity, Education \& Society 1, no. 1: 1-40.

Wang, Jianping. n.d. 'Islam in Kashgar in the 1950s.' Unpublished paper.

Xiao, Eva and Pak Yiu. 2019. 'China Disturbs Even the Uighur Dead in “Development” of Xinjiang.' The Japan Times, 11 October. www.japantimes.co.jp/news/2019/10/11/asia-pacific/social-issues-asiapacific/death-uighurs-long-reach-china. 
Xinjiang Civil Affairs Department. 2018. 和静县召开殡葬领域突出问题专项整治动员大会 [Hejing County Held a Special Rectification Mobilisation Meeting for Prominent Issues in the Area of Funerals and Burial].' Xinjiang Civil Affairs Department website, 2 September. mzt.xinjiang.gov.cn/ xjmca/dfxx/201809/5ae7347ed0344a92adc955205ba99b3c.shtml.

Xinjiang Daily. 2018. “雪克来提·扎克尔到喀什开展“四同”活动时强调: 深入促进各族干部群众交往交 流交融打牢新疆社会稳定和长治久安的坚实基础 [When He Went to Kashgar for the “Four Sames” Activities, Shohret Zakir Emphasised: Thoroughly Promote the Intermingling and Communication between Cadres of All Ethnic Groups and the Masses in Order to Establish a Firm Base for Social Stability and Long-term Security in Xinjiang]. 新疆日报 [Xinjiang Daily], 14 February. wap.xjdaily. com/xjrb/20180214/99479.html.

Xinjiang Minsheng Net. 2018. ‘工作队引导村民建设美丽庭院 [Work Team Guides Villagers in Constructing Beautiful Households]. 新疆民生网 [Xinjiang Minsheng Net], 5 June. www.xjmsw.cn/ xxzl/20180605/2018060548831.html.

Xinjiang United Front Work Department. 2017a. ‘非法宗教活动的26种表现 [26 Manifestations of Illegal Religious Activities].' Xinjiang United Front Work Department website, 19 June. www.xjtzb. gov.cn/2017-06/19/c_1121167392.htm.

Xinjiang United Front Work Department. 2017b. ‘新疆启动民族团结结亲周百万千部职工分批下基层 [A Million Cadres and Workers Go to the Grassroots as Xinjiang Kicks Off the "Weeklong Becoming Family” Campaign for Ethnic Unity].' Xinjiang United Front Work Department website, 19 December. web.archive.org/web/20180521023148/http://www.zytzb.gov.cn/tzb2010/S1824/201712/029ea48103 254b359c754152e005c302.shtml.

Xu, Qian 许倩. 2018。喀什盘索城免费开放各地游客争相一睹班超风采_西域 [Kashgar's Pantou City Opens Free of Admissions Charges: Tourists from Everywhere Fall Over Each Other to Get a Glimpse of Ban Chao's Elegant Bearing].' 新疆晨报 [Xinjiang Chenbao], 28 August. www.sohu. com/a/250604268_100034331.

Zenz, Adrian. 2020. 'The Karakax List: Dissecting the Anatomy of Beijing's Internment Drive in Xinjiang.' The Journal of Political Risk 8, no. 2. www.jpolrisk.com/karakax.

Zero Distance Awat. 2019. “【乡村振兴】阿克切克力片区召开群众宣传教育暨美丽庭院”建设现场工 作推进会_生活 [Village Revitalisation: Akeqiekeli Area Held a Propaganda and "Beautiful Courtyard” Construction Work Promotion Meeting]. 阿瓦提零距离 [Zero Distance Awat], 31 Mach. www.sohu. com/a/305042908_752235.

Zero Distance Yining. 2019. 【公告】伊宁县墩麻扎镇墩麻扎村坟墓搬迁事宜公告_墓地 [Announcement of the Removal of Graves at Dunmaza Village, Dunmaza Town, Yining County]. 伊宁 县零距离 [Zero Distance Yining], 8 May. www.sohu.com/a/312763996_120056900.

Zhang, Shicai. 2016. 'The Waqf System and the Xinjiang Uyghur Society from the Qing Dynasty to the Republic of China Period.' In Mazar: Studies on Islamic Sacred Sites in Central Eurasia, edited by Sugawara Jun and Rahile Dawut, 127-40. Tokyo: Tokyo University of Foreign Studies Press. 
Zheng, Chaohua 郑朝华. 2017. “土炕”改“电炕”干净又节能 - -甘州区农村改炕工作纪实 [Changing Earthen Kangs to Electric Kangs Is Clean and Energy-saving: An Account of Kang Reform Work in Rural Gansu].' Ministry of Agriculture of the People's Republic of China website, 1 December. jiuban. moa.gov.cn/fwllm/qgxxlb/qg/201712/t20171201_5959814.htm.

China : Xinjiang :: India : Kashmir (NITASHA KAUL)

Anand, Dibyesh. 2012. 'China and India: Postcolonial Informal Empires in the Emerging Global Order.' Rethinking Marxism: A Journal of Economics, Culture \& Society 24, no. 1: 68-86.

Anand, Dibyesh. 2019. 'Colonization with Chinese Characteristics: Politics of (In)security in Xinjiang and Tibet.' Central Asian Survey 38, no. 1: 129-47.

Balakrishnan, Paran. 2019. 'Detention Camps as Growth Model.' The Hindu Business Line, 20 September. www.thehindubusinessline.com/opinion/columns/from-the-viewsroom/detentioncamps-as-growth-model/article29460978.ece.

Brophy, David. 2019. 'Good and Bad Muslims in Xinjiang.' Made in China Journal 4, no. 2: 44-53.

Byler, Darren. 2018. 'Violent Paternalism: On the Banality of Uyghur Unfreedom.' The Asia-Pacific Journal 16, no. 4: 1-15.

Callahan, William A. 2004. 'National Insecurities: Humiliation, Salvation, and Chinese Nationalism.' Alternatives: Global, Local, Political 29, no. 2: 199-218.

Chen, Yu-Jie. 2019. 'China’s Challenge to the International Human Rights Regime.' NYU Journal of International Law and Politics 51: 1179-222.

Dalmia, Vinayak. 2020. 'China's Hikvision Controls India's Surveillance Market: Modi Needs to Do More than Ban Apps.' The Print, 1 July. theprint.in/opinion/chinas-hikvision-controls-indiassurveillance-market-modi-needs-to-do-more-than-ban-apps/452014.

Dorsey, James M. 2019. 'Diverging Gulf Responses to Kashmir and Xinjiang Reflect Deep Divisions.' Begin-Sadat Center for Strategic Studies website, 25 September. besacenter.org/perspectives-papers/ gulf-states-kashmir-xinjiang.

Express News Service. 2019. 'Indian Diplomat Compares Return of Kashmiri Pandits with Israeli Settlements, Sparks Row.' Indian Express, 28 November. indianexpress.com/article/india/indiandiplomat-compares-return-of-kashmiri-pandits-with-israeli-settlements-sparks-row-6140271.

Feldstein, Steven. 2019. ‘The Global Expansion of AI Surveillance.' Carnegie Endowment for International Peace website, 17 September. carnegieendowment.org/2019/09/17/global-expansionof-ai-surveillance-pub-79847.

Gettleman, Jeffrey and Kai Schultz. 2020. 'Indian General Talks of "Deradicalization Camps” for Kashmiris.' The New York Times, 17 January. www.nytimes.com/2020/01/17/world/asia/indiakashmir-camps.html. 
IANS. 2019. 'Modi Says No Detention Camps, Minister Accepted 6 in Assam.' Outlook India, 23 December. www.outlookindia.com/newsscroll/modi-says-no-detention-camps-ministeraccepted-6-in-assam/1692393.

Kalita, Prabin. 2019. 'India's Biggest Detention Centre to House "Foreigners" by 2020.' The Times of India, 8 September. timesofindia.indiatimes.com/city/guwahati/indias-biggest-detention-centre-tohouse-foreigners-by-2020/articleshow/71030993.cms.

Kaul, Nitasha. 2011. 'On Loving and Losing Kashmir'. India International Centre Quarterly 37, nos. 3/4: $42-53$.

Kaul, Nitasha. 2018. 'India’s Obsession with Kashmir: Democracy, Gender, (Anti-)nationalism.' Feminist Review 119: 126-43.

Kaul, Nitasha. 2019a. 'The Political Project of Postcolonial Neoliberal Nationalism.' Indian Politics \&t Policy 2, no. 1: 3-30.

Kaul, Nitasha. 2019b. 'Kashmir Is Under the Heel of India's Colonialism.' Foreign Policy, 13 August. foreignpolicy.com/2019/08/13/kashmir-is-under-the-heel-of-indias-colonialism.

Kaul, Nitasha. 2019c. 'Written Testimony for Hearing on Human Rights in South Asia: Views from the State Department and the Region, Panel II.' US House of Representatives, Committee on Foreign Affairs, 22 October. docs.house.gov/meetings/FA/FA05/20191022/110143/HHRG-116-FA05-WstateKaulN-20191022.pdf. For the oral testimony see www.youtube.com/watch?v=b-S8xynlcgY.

Krishnan, Vidya. 2020. “Gov't Killed My Husband”: Why Are Detainees Dying in Assam?' Al Jazeera, 3 March. www.aljazeera.com/features/2020/03/03/govt-killed-my-husband-why-are-detaineesdying-in-assam.

Ma, Alexandra. 2019. 'China Tells Uighur Muslims They Are Abducting Their Families so They Can Cleanse Their Brains Like They Have a Disease, Leaked Documents Show.' Business Insider, 18 November. www.businessinsider.com/china-uighur-detention-camps-cleanse-religion-leakeddocuments-nyt-2019-11? r=US\&IR=T.

Ma, Alexandra and Ellen Loanes. 2019. 'China and India Are Using the Same Playbook to Trample on Their Minorities, and the Rest of the World Is Too Powerless to Stop Them.' Business Insider, 23 November. www.businessinsider.com/china-uighur-india-kashmir-assam-oppression-parallels2019-11? $r=U S \& I R=T$.

Quora. 2016. 'Should India Apply the "Chinese Model for Xinjiang” in Kashmir?' Quora, accessed on 1 October 2020. www.quora.com/Should-India-apply-the-Chinese-model-for-Xinjiang-in-Kashmir.

Rahim, Zamira. 2019. 'India Builds Detention Camps for Up to 1.9m People "Stripped of Citizenship" in Assam.' The Independent, 11 September. www.independent.co.uk/news/world/asia/assam-indiadetention-camps-bangladesh-nrc-list-a9099251.html.

Roche, Gerald. 2019. 'Transnational Carceral Capitalism in Xinjiang and Beyond.' Made in China Journal 4, no. 1: 13-15. 
Safi, Michael. 2017. 'India Army Chief Defends Soldiers Who Tied Man to Vehicle and Used Him as a Human Shield.' The Guardian, 29 May. www.theguardian.com/world/2017/may/29/india-army-chiefkashmir-protests-man-tied-to-vehicle.

Sen, Sumant and Naresh Singaravelu. 2020. 'Data: Where Are Detention Centres in India?' The Hindu, 1 January. www.thehindu.com/data/data-where-are-detention-centres-in-india/article30451564.ece.

SupChina. 2019. 'Is Kashmir the Next Xinjiang?' SupChina, 21 October. supchina.com/2019/10/21/iskashmir-the-next-xinjiang.

The Wire. 2019. 'Western Standards on Human Rights Can't Be Blindly Applied to India: Amit Shah.' The Wire, 13 October. thewire.in/politics/western-standards-on-human-rights-cant-be-blindlyapplied-to-india-amit-shah.

Uniyal, Ruchika. 2020. 'What Are Detention Centres?' The Times of India, 12 February. timesofindia. indiatimes.com/india/what-are-detention-centres/articleshow/72975067.cms.

\section{Counterterrorism or Cultural Genocide? Theory and Normativity in Knowledge Production About China's 'Xinjiang Strategy' (MATTHEW P. ROBERTSON)}

Aradau, Claudia, and Jef Huysmans. 2014. 'Critical Methods in International Relations: The Politics of Techniques, Devices and Acts.' European Journal of International Relations 20, no. 3: 596-619.

Arendt, Hannah. 1971. 'Lying in Politics: Reflections on The Pentagon Papers.' The New York Review of Books, 18 November. www.nybooks.com/articles/1971/11/18/lying-in-politics-reflections-on-thepentagon-pape.

Austin, John Langshaw. 1975. How to Do Things with Words. Oxford: Clarendon Press.

Bauman, Zygmunt. 1991. Modernity and the Holocaust. Cambridge: Polity.

Berger, Peter L. 1974. Pyramids of Sacrifice: Political Ethics and Social Change. New York, NY: Anchor Press/Doubleday.

Byler, Darren. 2018. 'Violent Paternalism: On the Banality of Uyghur Unfreedom.' The Asia-Pacific Journal 16, no. 24: 4.

Chen, Fang 陈芳. 2015. ‘独家重磅：新疆去极端化调查 [An Investigation of De-radicalisation Efforts in Xinjiang].' Phoenix Television Online, October 2015. news.ifeng.com/mainland/special/xjqjdh.

Clarke, Michael. 2018. Terrorism and Counter-terrorism in China: Domestic and Foreign Policy Dimensions. Oxford: Oxford University Press.

Davenport, Christian. 2007. 'State Repression and Political Order.' Annual Review of Political Science 10, no. 1: 1-23. 
Dirk Moses, A. 2004. Genocide and Settler Society: Frontier Violence and Stolen Indigenous Children in Australian History. New York, NY: Berghahn Books.

Eagleton, Terry. 2014. Ideology. London and New York, NY: Routledge.

Ellinghaus, Katherine. 2009. 'Biological Absorption and Genocide: A Comparison of Indigenous Assimilation Policies in the United States and Australia.' Genocide Studies and Prevention 4, no. 1: $59-79$.

Featherston, Donnie. 2018. 'Living Through Terror and Terror Through Living: The Biopolitical Dimensions of Religion, Security, and Terrorism.' PhD dissertation, University of Denver. digitalcommons.du.edu/etd/1434/.

Feierstein, Daniel. 2014. Genocide as Social Practice: Reorganizing Society under the Nazis and Argentina's Military Juntas. New Brunswick, NJ: Rutgers University Press.

Fernando, Gavin. 2019. 'Chinese Government Slammed Over “Mass Rape” Program.' News.com.au, 19 December. www.news.com.au/world/asia/this-is-mass-rape-china-slammed-over-program-thatappoints-men-to-sleep-with-uighur-women/news-story/ed45cd065e39690354b6402d02904557.

Geddes, Barbara. 2003. Paradigms and Sand Castles: Theory Building and Research Design in Comparative Politics. Ann Arbor, MI: University of Michigan Press.

Greitens, Sheena Chestnut, Myunghee Lee, and Emir Yazici. 2020a. 'Counterterrorism and Preventive Repression: China's Changing Strategy in Xinjiang.' International Security 44, no. 3: 9-47.

Greitens, Sheena Chestnut, Myunghee Lee, and Emir Yazici. 2020b. 'Understanding China's "Preventive Repression” in Xinjiang. Brookings Institution, 4 March. www.brookings.edu/blog/ order-from-chaos/2020/03/04/understanding-chinas-preventive-repression-in-xinjiang.

Hiebert, Maureen S. 2017. Constructing Genocide and Mass Violence: Society, Crisis, Identity. London and New York, NY: Routledge.

Hoja, Gulchehre. 2020. 'Subsidies for Han Settlers "Engineering Demographics” in UyghurMajority Southern Xinjiang.' Radio Free Asia, 13 April. www.rfa.org/english/news/uyghur/ settlers-04132020172143.html.

Laudan, Larry. 1981. 'Hume (and Hacking) on Induction.' In Science and Hypothesis: Historical Essays on Scientific Methodology, by Larry Laudan 72-85. Dordrecht: D. Reidel Publishing Company.

Leibold, James. 2019. 'The Spectre of Insecurity: The CCP's Mass Internment Strategy in Xinjiang.' China Leadership Monitor, 1 March. www.prcleader.org/leibold.

Li, Xiaoxia 李晓霞. 2016. ‘新疆宗教极端思想传播特点及抵御政策分析 [Analysis of the Special Characteristics of Transmission of Religious Extremism in Xinjiang and a Resistance Policy]. 民族社 会学研究通讯 [Sociology of Ethnicity], no. 213. www.shehui.pku.edu.cn/upload/editor/file/20180829/ 20180829124750_8488.pdf. 
Long, Qiao. 2019. 'Chinese Officials Force Muslims to Drink, Eat Pork at Festival.' Radio Free Asia, 6 February. www.rfa.org/english/news/uyghur/festival-02062019140637.html.

McNamee, Lachlan. 2018. 'Mass Resettlement and Political Violence: Evidence from Rwanda.' World Politics 70, no. 4: 595-644.

McNamee, Lachlan and Anna Zhang. 2019. 'Demographic Engineering and International Conflict: Evidence from China and the Former USSR. International Organization 73, no. 2: 291-327.

Nietzsche, Friedrich Wilhelm. 2016 (1872). Anti-Education: On the Future of Our Educational Institutions. New York, NY: New York Review Books.

Ramzy, Austin and Chris Buckley. 2019. “Absolutely No Mercy”: Leaked Files Expose How China Organized Mass Detentions of Muslims.' The New York Times, 16 November. www.nytimes.com/ interactive/2019/11/16/world/asia/china-xinjiang-documents.html.

Roberts, Sean R. 2018a. 'The Biopolitics of China's "War on Terror" and the Exclusion of the Uyghurs.' Critical Asian Studies 50, no. 2: 232-58.

Roberts, Sean. 2018b. 'The Narrative of Uyghur Terrorism and the Self-Fulfilling Prophecy of Uyghur Militancy.' In Terrorism and Counter-Terrorism in China, edited by Michael Clarke, 99-128. Oxford: Oxford University Press.

Roggio, Bill. 2011. ‘Al Qaeda Appoints New Leader of Forces in Pakistan's Tribal Areas.' FDD's Long War Journal, 9 May. www.longwarjournal.org/archives/2011/05/al_qaeda_appoints_ne_2.php.

Sartori, Giovanni. 1970. 'Concept Misformation in Comparative Politics.' The American Political Science Review 64, no. 4: 1033-53.

Sémelin, Jacques. 2007. Purify and Destroy: The Political Uses of Massacre and Genocide. New York, NY: Columbia University Press.

Shir, Rustem. 2019. 'A Language under Attack: China's Campaign to Sever the Uighur Tongue.' Hong Kong Free Press, 18 June. hongkongfp.com/2019/06/18/language-attack-chinas-campaignsever-uighur-tongue.

Smith Finley, Joanne. 2019. 'Securitization, Insecurity and Conflict in Contemporary Xinjiang: Has PRC Counter-Terrorism Evolved into State Terror?' Central Asian Survey 38, no. 1: 1-26.

Sorace, Christian P. 2017. Shaken Authority: China's Communist Party and the 2008 Sichuan Earthquake. Ithaca, NY: Cornell University Press.

Stavrou, David. 2019. ‘A Million People Are Jailed at China's Gulags. I Managed to Escape. Here's What Really Goes On Inside.' Haaretz, 17 October. www.haaretz.com/world-news/.premium. MAGAZINE-a-million-people-are-jailed-at-china-s-gulags-i-escaped-here-s-what-goes-oninside-1.7994216. 
Tohti, Ilham (translated by Cindy Carter). 2015. 'Present-day Ethnic Problems in Xinjiang Uighur Autonomous Region: Overview and Recommendations.' China Change, 22 April. chinachange. org/2015/04/22/present-day-ethnic-problems-in-xinjiang-uighur-autonomous-region-overviewand-recommendations-1.

Vuori, Juha A. 2008. 'Illocutionary Logic and Strands of Securitization: Applying the Theory of Securitization to the Study of Non-democratic Political Orders.' European Journal of International Relations 14, no. 1: 65-99.

Zenz, Adrian. 2019. 'Beyond the Camps: Beijing's Long-term Scheme of Coercive Labor, Poverty Alleviation and Social Control in Xinjiang.' Journal of Political Risk 7, no. 12.

Zenz, Adrian. 2020. 'The Karakax List: Dissecting the Anatomy of Beijing's Internment Drive in Xinjiang.' The Journal of Political Risk 8, no. 2. www.jpolrisk.com/karakax.

Zenz, Adrian and James Leibold. 2017. 'Chen Quanguo: The Strongman Behind Beijing's Securitization Strategy in Tibet and Xinjiang.' China Brief, 21 September. jamestown.org/program/ chen-quanguo-the-strongman-behind-beijings-securitization-strategy-in-tibet-and-xinjiang.

\section{Leninists in a Chinese Factory: Reflections on the Jasic Labour Organising Strategy (ZHANG YUERAN)}

Jasic Workers Solidarity Group. 2019. ‘认罪视频文字整理 [Transcript of a Confession Video]. 佳士工 人声援团网 [Jasic Workers Solidarity Group Website], 2 March. jiashigrsytl.github.io/rzspneww.

Koo, Hagen. 2001. Korean Workers: The Culture and Politics of Class Formation. Ithaca, NY: Cornell University Press.

Lenin, Vladimir I. 1961 (1902). What Is to Be Done? In Lenin's Selected Works, 347-530. Moscow: Foreign Languages Publishing House. www.marxists.org/archive/lenin/works/1901/witbd.

Made in China Journal. 2019. 'Orwell in the Chinese Classroom.' Made in China Journal website, 27 May. madeinchinajournal.com/2019/05/27/orwell-in-the-chinese-classroom.

Reignite. 2019. “對話大陸工人鬥爭參與者：佳士學生進廠的工作思路批評 [A Conversation with Participants in Workers' Struggle in Mainland China: A Critique of the Approach to Labour Organising by Jasic Students]. 懷火 [Reignite], 4 June. www.reignitepress.com/post/佳士左翼毛派學 生運動工運組織者工學聯盟.

Zhang, Yueran. 2018. 'The Jasic Strike and the Future of the Chinese Labour Movement.' Made in China Journal 3, no. 3: 12-17.

\section{Chinese Diaspora Activism and the Future of International Solidarity (MENGYANG ZHAO)}

Anderson, Benedict. 2013. The Age of Globalization: Anarchists and the Anticolonial Imagination. London and New York, NY: Verso Books. 
Hirschman, Albert O. 1978. 'Exit, Voice, and the State.' World Politics 31, no. 1: 90-107.

Lai, Him Mark (edited by Madeline Y. Hsu). 2010. Chinese American Transnational Politics. Urbana, IL: University of Illinois Press.

Ma, Chris. 2020. 'At the Margins of a Movement, Forging a Common Language.' Sixth Tone, 16 June. www.sixthtone.com/news/1005802/at-the-margins-of-a-movement,-forging-a-common-language.

Pringle, Tim. 2018. 'A Solidarity Machine? Hong Kong Labour NGOs in Guangdong.' Critical Sociology 44, nos. 4-5: 661-75.

Quinsaat, Sharon Madriaga. 2013. 'Migrant Mobilization for Homeland Politics: A Social Movement Approach.' Sociology Compass 7, no. 11: 952-64.

\section{Spectral Revolution: Notes on a Maoist Cosmology (EMILY NG)}

Au, Loong-yu. 2019. 'The Jasic Mobilisation: A High Tide for the Chinese Labour Movement?' Made in China Journal 3, no. 4: 12-16.

Barmé, Geremie. 1996. Shades of Mao: The Posthumous Cult of the Great Leader. Armonk, NY: M.E. Sharpe.

Benjamin, Walter. 2008. The Work of Art in the Age of Its Technological Reproducibility, and Other Writings on Media. Cambridge, MA: Harvard University Press.

Davies, Gloria. 2019. 'Immortality.' In Afterlives of Chinese Communism: Political Concepts from Mao to Xi, edited by Christian Sorace, Ivan Franceschini, and Nicholas Loubere, 89-95. Canberra: ANU Press.

Derrida, Jacques. 1994. Specters of Marx: The State of the Debt, the Work of Mourning, and the New International. New York, NY, and London: Routledge.

Lee, Ching Kwan. 2007. Against the Law: Labor Protests in China's Rustbelt and Sunbelt. Berkeley, CA: University of California Press.

Leese, Daniel. 2011. Mao Cult: Rhetoric and Ritual in China's Cultural Revolution. Cambridge: Cambridge University Press.

Mao, Zedong. 1967. Selected Works of Mao Tse-Tung, Volume 1. New York, NY: Foreign Languages Press.

Prasso, Sheridan. 2020. 'Hong Kong's Yellow Movement Turns Chinese Propaganda on Its Head.' Bloomsberg, 5 August. www.bloomberg.com/news/articles/2020-08-05/hong-kong-s-yellowmovement-turns-chinese-propaganda-on-its-head.

Song, Hoon. 2016. 'North Korea’s “Succession” of Marxism.' Boundary 2 43, no. 3: 79-104. 
Sorace, Christian. 2020. 'Poetry After the Future.' Made in China Journal 5, no. 1: 130-35.

Yurchak, Alexei. 2006. Everything Was Forever, Until It Was No More: The Last Soviet Generation. Princeton, NJ: Princeton University Press.

\section{The Yijing Ethic and the Spirit of Capitalism with Chinese Characteristics (WILLIAM MATTHEWS)}

Boyer, Pascal. 2020. 'Why Divination? Evolved Psychology and Strategic Interaction in the Production of Truth.' Current Anthropology 61, no. 1: 100-23.

Johnson, Ian. 2017. The Souls of China: The Return of Religion After Mao. London: Penguin.

Matthews, William. 2017. 'Making "Science” from "Superstition”: Conceptions of Knowledge Legitimacy among Contemporary Yijing Diviners.' Journal of Chinese Religions 45, no. 2: 173-96.

Matthews, William. 2018. 'Reducing Uncertainty: Six Lines Prediction in Contemporary China.' Manuscript submitted for publication.

Redmond, Geoffrey and Tze-Ki Hon. 2014. Teaching the I Ching. Oxford: Oxford University Press.

Stafford, Charles. Undated. 'Deception, Corruption and the Chinese Ritual Economy.' Asia Research Centre Working Paper 3, The London School of Economics \& Political Science. www.lse.ac.uk/ asiaResearchCentre/_files/ARCWP03-Stafford.pdf.

Yang, Mayfair Mei-hui. 2000. 'Putting Global Capitalism in Its Place: Economic Hybridity, Bataille, and Ritual Expenditure.' Current Anthropology 41, no. 4: 477-509.

Yang, Mayfair Mei-hui. 2020. Re-enchanting Modernity: Ritual Economy and Society in Wenzhou, China. Durham, NC: Duke University Press Books.

Zeitlyn, David. 2012. 'Divinatory Logics: Diagnoses and Predictions Mediating Outcomes.' Current Anthropology 53, no. 5: 525-46.

\section{The Macabre Affective Labour of Cadavers in Chinese Ghost Marriages (CHRIS K. K. TAN)}

Ahern, Emily. 1973. The Cult of the Dead in a Chinese Village. Stanford, CA: Stanford University Press.

Appadurai, Arjun, ed. 1986. The Social Life of Things: Commodities in Cultural Perspective. Cambridge: Cambridge University Press.

Chau, Adam Yuet. 2008. 'The Sensorial Production of the Social.' Ethnos 73, no. 4: 485-504.

Fei, Xiaotong. 1992. From the Soil, the Foundations of Chinese Society: A Translation of Fei Xiaotong's Xiangtu Zhongguo. Berkeley, CA: University of California Press.

Fortunati, Leopoldina (translated by Hilary Creek). 1995. The Arcane of Reproduction: Housework, Prostitution, Labour and Capital. New York, NY: Autonomedia. 
Gao, Zhiqiang 高志强, Niu Jingfang 牛静芳, and Cui Shouyue 崔守跃. 2016. “一户人家娶“鬼妻”：正 下葬时棺材里传出拍击声 [A Family Takes a “Ghost Bride”: Thumping Came from the Coffin During Burial].' 大河报 [Dahebao], 9 December. hlj.people.com.cn/n2/2016/1209/c338553-29438547.html.

Gell, Arthur. 1998. Art and Agency: An Anthropological Theory. Oxford: Oxford University Press.

Gu, Chunjun and Keqian Xu. 2014. 'Netherworld Marriage in Ancient China: Its Historical Evolution and Ideological Background.' Journal for the Study of Religions and Ideologies 13, no. 38: 78-109.

Guo, Jinhua. 2008. 'Stigma: Social Suffering for Social Exclusion and Social Insecurity from Mental Illness to HIV/AIDS in China.' PhD dissertation, Harvard University.

Hardt, Michael and Antonio Negri. 2004. Multitude: War and Democracy in the Age of Empire. New York, NY: Penguin Books.

James, Selma and Mariarosa Dalla Costa. 1975. The Power of Women and the Subversion of the Community. Bristol: Wages for Housework.

Jordan, David K. 1972. Gods, Ghosts and Ancestors: The Folk Religion of a Taiwanese Village. Berkeley, CA: University of California Press.

Li, Quanping 李全平. 2009. “山西雁北区当代阴婚现象研究 [Contemporary Ghost Marriages in Yanbei, Shanxi]. 民俗研究 [Folklore Studies], no. 2: 242-53.

Li Teng 李腾. 2016. ‘中国阴婚现象调查：“15万元连骨头都买不到” [A Survey of Chinese Ghost Marriages: 150 Thousand Yuan Won’t Even Get You Bones]. 中国新闻周刊 [China News Weekly], 12 May. mp.weixin.qq.com/s?_biz=MjM5MDU1Mzg3Mw==\&mid=2651196263\&amp;idx=1\&amp;sn= 2bf64b42f19988421df6c7be17c803al\&.

Luo, Chris. 2014. '11 Arrested for Tomb-raiding and Selling Women's Corpses for "Ghost Marriage' Rituals.” South China Morning Post, 30 October. www.scmp.com/news/china-insider/ article/1628204/shandong-police-arrest-11-over-dead-bodies-sold-ghostmarriage.

Mann, Susan. 1987. 'Widows in the Kinship, Class and Community Structures of Qing Dynasty China.' Journal of Asian Studies 46, no. 1: 37-56.

Martin, Diana. 1991. 'Chinese Ghost Marriage.' Journal of the Anthropological Society of Oxford Occasional Paper 8: 25-43.

Ngai, Sianne. 2005. Ugly Feelings. Cambridge, MA, and London: Harvard University Press.

Osburg, John. 2013. Anxious Wealth: Money and Morality Among China's New Rich. Stanford, CA: Stanford University Press.

Pye, Lucian. 1992. The Spirit of Chinese Politics, New Edition. Cambridge, MA: Harvard University Press. 
Rofel, Lisa. 2007. Desiring China: Experiments in Neoliberalism, Sexuality and Public Culture. Durham, NC, and London: Duke University Press.

Topley, Marjorie. 1955. 'Ghost Marriages Among the Singapore Chinese.' Man 55: 29-30.

Topley, Marjorie. 1956. 'Ghost Marriages Among the Singapore Chinese: A Further Note.' Man 56: 71-72.

Wolf, Arthur P. 1974. 'Gods, Ghosts and Ancestors.' In Religion and Ritual in Chinese Society, edited by Arthur P. Wolf, 131-82. Stanford, CA: Stanford University Press.

Yan, Yunxiang. 2009. 'The Good Samaritan's New Trouble: A Study of the Changing Moral Landscape in Contemporary China.' Social Anthropology 17, no. 1: 9-24.

Yeung, Alison Sau-Chu. 2003. 'Fornication in the Late Qing Legal Reforms: Moral Teachings and Legal Principles.' Modern China 29, no. 3: 297-328.

Zhou, Yongming. 2013. 'Branding Tengchong: Globalization, Road Building and Spatial Reconfigurations in Yunnan, Southwest China.' In Cultural Heritage Politics in China, edited by Tami Blumenfield and Helaine Silverman, 247-59. New York, NY: Springer.

\section{On UFOlogy with Chinese Characteristics and the Fate of Chinese Socialism (MALCOLM THOMPSON)}

Chen, Xi. 2019a. 'Enlightenment Through Contacting Aliens? Chinese Astrophysics PhD Student Debunks Cult-themed Social Media Accounts.' Global Times, 18 January. www.globaltimes.cn/ content/1136219.shtml.

Chen, Xingqiao 陈星桥. 2019b. “外星”系邪说研究 [Study of the Cult Teachings of “Alien Systems”]. Website of the People's Government of Jinghe County, Xinjiang Province, 16 May. www.xjjh.gov.cn/ info/1718/114153.htm.

Editorial Board of the Journal of UFO Research. 2006. 飞碟探索25周年典藏本1981-2006 [Twentyfifth Anniversary Collection of the Journal of UFO Research, 1981-2006]. Gansu: Gansu Kexue Jishu Chubanshe.

International Chinese UFO Association. 2019. “团结奋进、披荆斩棘、走向辉煌一世界华人UFO联 合会20周年史记 [Advance Together, Overcome Difficulties, Head for Glory: Twenty Years of the International Chinese UFO Association].' International Chinese UFO Association website, 23 April. www.hrufo.com/show.asp?id=634.

Jiang, Huangrong 江晃榮. 1995a. UFO: 飛碟示警與外星人之謎 [UFO: The Warning of Flying Saucers and the Riddle of Aliens]. Taipei: Yuhu Wenhua Chubanshe.

Jiang, Yongqiang 蒋永强. 1995b. ‘碟探索的气功思路一介绍林清泉的东方飞碟学 [The Qigong Thought of the Journal of UFO Research: An Introduction to the Eastern UFOlogy of Lin Qingquan].' 中国气功 [China Qigong], no. 7: 31-32. 
Liu, Dongjun 刘东军. 1999. 'UFO研究必须具有中国特色 [UFO Research Must Have Chinese Characteristics]. 科学中国人 [Scientific Chinese], no. 10: 78.

Men in Red. 1998. Rivista di ufologia radicale 2._archive.org/stream/ufologia-radicale-page/n3/ mode/2up.

Palmer, David. 2007. Qigong Fever: Body, Science, and Utopia in China. New York, NY: Columbia University Press.

Sorace, Christian, Ivan Franceschini, and Nicholas Loubere (eds). 2019. Afterlives of Chinese Communism: Political Concepts from Mao to Xi. Canberra, London, and New York, NY: ANU Press and Verso Books.

Xinhua. 1992. "China UFO Society Meets; to Continue Scientific Study.” 13 May. Translation included in CIA FOIA Collection, www.cia.gov/library/readingroom/document/0000112346.

\section{Shared Visions: The Gift of The Eye (SYLVIA J. MARTIN)}

Aldama, Zigor. 2017. 'China's Myopic Epidemic: Why a Simple Solution is Being Ignored.' South China Morning Post, 8 April. www.scmp.com/magazines/post-magazine/long-reads/article/2085125/ chinas-myopia-epidemic-why-simple-solution-being.

Amiri, Fardin, Shahrzad Ghiyasvandian, Elham Navab, and Masoumeh Zakerimoghadam. 2017. 'Corneal Transplantation: A New View of Life.' Electronic Physician 9, no. 4: 4055-63.

Cohen, Lawrence. 1999. 'Where It Hurts: Indian Material for an Ethics of Organ Transplantation.' Daedalus 128, no. 4: 135-65.

Comaroff, Jean and John Comaroff. 1999. 'Occult Economies and the Violence of Abstraction: Notes from the South African Postcolony.' American Ethnologist 26, no. 2: 279-303.

Comaroff, Jean and John Comaroff. 2000. 'Millenial Capitalism: First Thoughts on a Second Coming.' Public Culture 12, no. 2: 291-343.

Constable, Nicole. 1994. Christian Souls and Chinese Spirits: A Hakka Community in Hong Kong. Berkeley, CA: University of California Press.

Enoch, Jamie, Leanne McDonald, and Lee Jones. 2019. 'Evaluating Whether Sight is the Most Important Sense.' JAMA Ophthamalogy 137, no. 11: 1317-20.

Fox, Renee C. and Judith P. Swazey. 2002. The Courage to Fail: A Social View of Organ Transplants and Dialysis. $2^{\text {nd }}$ Edition. London and New York, NY: Routledge.

Ginsburg, Faye and Rayna Rapp. 2020. 'Disability/Anthropology: Rethinking the Parameters of the Human.' Current Anthropology 61, supplement 21: S4-S15.

Guang, Xing. 2011. 'Yulanpen Festival and Chinese Ancestor Worship.' Journal of Buddhist Studies 9: $123-43$. 
Knee, Adam. 2009. 'The Pan-Asian Outlook of “The Eye”.' In Horror to the Extreme: Changing Boundaries in Asian Cinema, edited by Jinhee Choi and Mitsuyo Wada-Marciano, 69-84. Hong Kong: Hong Kong University Press.

Martin, Sylvia J. 2017. Haunted: An Ethnography of the Hollywood and Hong Kong Media Industries. New York, NY: Oxford University Press.

Mauss, Marcel (translated by W. D. Halls). 1990 [1950]. The Gift: The Form and Reason for Exchange in Archaic Societies. New York, NY: W. W. Norton.

Moore, Henrietta and Todd Sanders. 2002. Magical Interpretations, Material Realities: Modernity, Witchcraft and the Occult in Postcolonial Africa. London and New York, NY: Routledge.

Santino, Jack. 1983. 'Halloween in America: Contemporary Customs and Performances.' Western Folklore 42, no. 1: 1-20.

Scheper-Hughes, Nancy. 2000. 'The Global Traffic in Human Organs.' Current Anthropology 41, no. 2: 191-224.

Scheper-Hughes, Nancy. 2007. 'The Tyranny of the Gift: Sacrificial Violence in Living Donor Transplants.' American Journal of Transplantation 7, no. 3: 507-11.

Scheper-Hughes, Nancy. 2009. 'The Tyranny and the Terror of the Gift: Sacrificial Violence and the Gift of Life.' Economic Sociology: The European Electronic Newsletter 11, no. 1: 8-16.

Sque, Magi and Sheila A. Payne. 1996. 'Dissonant Loss: The Experience of Donor Relatives.' Social Science Et Medicine 43, no. 9: 1359-70.

Tong, Allison, Rachel Morton, Kristen Howard, and Jonathon C. Craig. 2009. 'Adolescent Experiences Following Organ Transplantation: A Systematic Review of Qualitative Studies.' The Journal of Pediatrics 155, no. 4: 542-49.

\section{Accidents and Agency: Death and Occult Economies in Thailand (ANDREW ALAN JOHNSON)}

Comaroff, Jean and John Comaroff. 1999. 'Occult Economies and the Violence of Abstraction: Notes from the South African Postcolony.' American Ethnologist 26, no. 2: 279-303.

Johnson, Andrew Alan. 2012. 'Naming Chaos: Accident, Precariousness, and the Spirits of Wildness in Urban Thai Spirit Cults.' American Ethnologist 39, no. 4: 766-78.

Johnson, Andrew Alan. 2016. 'Ghost Mothers: Kinship Relations in Thai Spirit Cults.' Social Analysis 60, no. 2: 82-96.

Johnson, Andrew Alan. 2020. Mekong Dreaming: Life and Death along a Changing River. Durham, NC: Duke University Press.

Kapferer, Bruce. 2003. Beyond Rationalism: Rethinking Magic, Witchcraft and Sorcery. New York, NY: Berghahn. 
Pearson, Trais. 2020. Sovereign Necropolis: The Politics of Death in Semi-colonial Siam. Ithaca, NY: Cornell University Press.

Povinelli, Elizabeth. 2016. Geontologies: A Requiem to Late Liberalism. Durham, NC: Duke University Press.

Sopranzetti, Claudio. 2017. 'Framed by Freedom: Emancipation and Oppression in Post-Fordist Thailand.' Cultural Anthropology 32, no. 1: 68-92.

Sprenger, Guido. 2018. 'Buddhism and Coffee: The Transformation of Locality and Non-human Personhood in Southern Laos.' Sojourn: Journal of Social Issues in Southeast Asia 33, no. 2: 265-90.

Strate, Shane. 2015. The Lost Territories: Thailand's History of National Humiliation. Honolulu, HI: University of Hawaii Press.

Taylor, Philip. 2004. Goddess on the Rise: Pilgrimage and Popular Religion in Vietnam. Honolulu, HI: University of Hawaii Press.

Thongchai Winichakul. 1994. Siam Mapped: A History of the Geo-body of a Nation. Honolulu, HI: University of Hawaii Press.

Toem, Wiphakphotchanakit. 1987. Prawattisat Isan [History of Isan]. Bangkok: Thammasat Press.

The Diviner and the Billionaire: Wealth as Mystery in Buddhist Thailand (EDOARDO SIANI)

Charoen Pokphand Group. n.d. 'Milestones.' www.cpgroupglobal.com/about/Milestones.

Comaroff, Jean and John Comaroff (eds). 2001. Millennial Capitalism and the Culture of Neoliberalism. Durham, NC, and London: Duke University Press.

Fredrickson, Terry. 2017. 'Now More Than 10,000 7-Eleven Stores in Thailand.' Bangkok Post, 17 August. www.bangkokpost.com/learning/advanced/1307966/now-more-than-10-000-7-elevenstores-in-thailand.

Forbes. 2020. 'Thailand's 50 Richest.' Forbes. www.forbes.com/thailand-billionaires/list.

Gray, Christine. 1986. Thailand: The Soteriological State in the 1970s. PhD thesis, University of Chicago.

Gray, Christine. 1992. 'Royal Words and Their Unroyal Consequences.' Cultural Anthropologist 7, no. 4: 448-63.

Handley, Paul. 2003. 'De-mythologizing Charoenpokpant: An Interpretative Picture of the CP Group's Growth and Diversification.' In Ethnic Business: Chinese Capitalism in South East Asia, edited by Jomo Kwame Sundaram and Brian C. Folk, 153-81. London: RoutledgeCurzon.

Handley, Paul. 2006. The King Never Smiles: A Biography of Thailand's Bhumibol Adulyadej. New Haven, CT, and London: Yale University Press. 
Jackson, Peter. 2014. 'Ascendant Doctrine and Resurgent Magic in Capitalist Southeast Asia: Paradox and Polarisation as 21 $1^{\text {st }}$ Century Cultural Logic.' DORISEA Working Paper Series, no. 6: 3-18.

Lotus Happiness. 2017. '10 Buddhist Billionaires of Asia.' Lotus Happiness, 4 June. www.lotushappiness.com/10-buddhist-billionaires-asia.

Kasikorn Research Center. 2005. 'Thurakit Mo Du Pi 48 [The Fortune Telling Business in 2005].' Kasikorn Research Center website, 10 March. kasikornresearch.com/th/analysis/k-econ/economy/ Pages/4840.aspx.

Macan-Markar, Marwaan. 2019. 'The 99\% Election: Thais Are Worse Off After Five Years of Military Rule.' Nikkei Asian Review, 6 March. asia.nikkei.com/Spotlight/Cover-Story/The-99-election-Thaisare-worse-off-after-five-years-of-military-rule.

Puangchon, Unchanam. 2018. 'Kasat Kradumphi: Moradok Thang Prawatsat Jak Rachakan Thi 9 Haeng Rachawong Jakri [The Bourgeois King: The Historical Legacy of the Ninth King of the Chakri Dynasty].' Fa Diaw Kan [Same Sky] 16, no. 1: 7-71.

Siani, Edoardo. 2018. 'Stranger Diviners and Their Stranger Clients: Popular Cosmology-making and Its Kingly Power in Buddhist Thailand.' South East Asian Research 26, no. 4: 416-31.

Sutthikhun, Kongthong. 2008. 'Truat Sob Ngo Heng Kon Khao Tham Ngan CP Ajan Thananurak Jarusakun Sin Sae Khu Jai Jao Sua Thanin Jiarawanon [Checking Ngo Heng Before Working at CP: Master Thananurak Jarusakun, Tycoon Dhanin Chaerawanont's Favourite Chinese Diviner].' OK Nation Blog, 9 February. oknation.nationtv.tv/blog/sutku/2008/02/09/entry-3.

Thailand Government Spending. 2020. 'Information of 31/05/2020.' Digital Government Development Agency website. https://govspending.data.go.th/dashboard/1.

The Business Times. 2018. 'Thailand's Largest Company CP Group Signs 224.5b Baht Rail Deal.' The Business Times, 25 October. www.businesstimes.com.sg/transport/thailands-largest-companycp-group-signs-2245b-baht-rail-deal.

Wasana, Wongsurawat. 2019. The Crown and the Capitalists: The Ethnic Chinese and the Founding of the Thai Nation. Seattle, WA: University of Washington Press.

Weber, Max (translated by Talcott Parsons). 1958. The Protestant Ethic and the Spirit of Capitalism. New York, NY: Charles Scribner's Sons.

\section{Hunting Sorcerers in Cambodia (IVAN FRANCESCHINI)}

Coggan, Philip. 2014. Spirit Worlds: Cambodia, the Buddha and the Naga. Oxford: John Beaufoy Publishing.

Cuddy, Alice and Seangly Phak. 2015. 'Witch Hunt in Ratanakiri.' The Phnom Penh Post, 8 May. https://www.phnompenhpost.com/post-weekend/witch-hunt-ratanakkiri. 
Davis, Erik. 2016. Deathpower: Buddhism Ritual Imagination in Cambodia. New York, NY: Columbia University Press.

Eang, Mengleng. 2014. 'Mob Decapitates 55-year-old Accused of Sorcery' The Cambodia Daily, 20 January. english.cambodiadaily.com/news/mob-decapitates-55-year-old-accused-of-sorcery-50890.

Kim, Sarom. 2014. 'Villagers Stone "Sorcerer" to Death.' The Phnom Penh Post, 29 April. www.phnompenhpost.com/national/villagers-stone-'sorcerer'-death.

Kresek, Kai. 2019. 'What's Happening in Cambodia's Forests?' Global Factory Watch, 26 September. blog.globalforestwatch.org/data-and-research/whats-happening-in-cambodias-forests.

May, Titthara and David Boyle. 2012. 'Cambodian “Sorcerers” Damned to Exile.' The Phnom Penh Post, 19 June. www.phnompenhpost.com/national/cambodian-sorcerers-damned-exile.

OHCHR. 2019. 'People's Court Preventing and Responding to "Popular Justice" in Cambodia.' Office of the United Nations High Commissioner for Human Rights. cambodia.ohchr.org/sites/default/files/ report/other-report/OHCHR Report EN.pdf.

Terzani, Tiziano. 2014. Un’idea di destino. Milan: Longanesi.

\section{Shamanism, Occult Murder, and Political Assassination in Siberia and Beyond (KONSTANTINOS ZORBAS)}

Bailey, Frederick. 1994. The Witch-Hunt, or, The Triumph of Morality. Ithaca, NY: Cornell University Press.

Bailey, Frederick. 2001. Stratagems and Spoils: A Social Anthropology of Politics. Boulder, CO: Westview Press.

Comaroff, Jean and John Comaroff. 1999. 'Occult Economies and the Violence of Abstraction: Notes from the South African Postcolony.' American Ethnologist 26, no. 2: 279-303.

Lindquist, Galina. 2011. 'Ethnic Identity and Religious Competition: Buddhism and Shamanism in Southern Siberia.' In Religion, Politics \& Globalization: Anthropological Approaches, edited by Galina Lindquist and Don Handelman, 69-90. New York, NY: Berghahn Books.

Mänchen-Helfen, Otto. 1992 [1931]. Journey to Tuva: An Eye-witness Account of Tannu-Tuva in 1929. Los Angeles, CA: Ethnographics Press (University of Southern California).

Pedersen, Morten Axel. 2011. Not Quite Shamans: Spirit Worlds and Political Lives in Northern Mongolia. Ithaca, NY: Cornell University Press.

Shirokogoroff, Sergei. 1935. The Psychomental Complex of the Tungus. London: Kegan \& Paul.

Soyan Peemot, Victoria. 2020. 'Emplacing Herder-Horse Bonds in Ak-Erik, South Tyva.' In Multispecies Households in the Saian Mountains: Ecology at the Russia-Mongolia Border, edited by Alex Oehler and Anna Varfolomeeva, 51-71. Lanham, MD: Lexington Books. 
Swancutt, Katherine. 2012. Fortune and the Cursed: The Sliding Scale of Time in Mongolian Divination. New York, NY: Berghahn Books.

Tilly, Charles. 1985. 'War Making and State Making as Organized Crime.' In Bringing the State Back In, edited by Peter Evans, Dietrich Rueschemeyer, and Theda Skocpol, 169-91. Cambridge: Cambridge University Press.

Trompf, Garry. 1994. Payback: The Logic of Retribution in Melanesian Religions. Cambridge: Cambridge University Press.

Vainshtein, Sevyan. 2009 [1980]. Nomads of South Siberia: The Pastoral Economies of Tuva. Cambridge: Cambridge University Press.

Vitebsky, Piers. 1992. The Shaman: Voyages of the Soul, from Siberia to the Amazon. Boston, MA: Little, Brown and Company.

Znamenski, Andrei. 2007. The Beauty of the Primitive: Shamanism and the Western Imagination. Oxford: Oxford University Press.

Zorbas, Konstantinos. 2015. 'The Origins and Reinvention of Shamanic Retaliation in a Siberian City (Tuva Republic, Russia).' Journal of Anthropological Research 71: 401-22.

\section{Covid-19 in China: From 'Chernobyl Moment' to Impetus for Nationalism (CHENCHEN ZHANG)}

Anderson, Benedict. 2006. Imagined Communities: Reflections on the Origin and Spread of Nationalism. London and New York, NY: Verso Books.

Fudan Public Health School. 2020. “全国新冠肺炎专家组调整 [National Expert Panel on Covid-19 Readjusted].' Fudan Public Health School’s website, 24 February. sph.fudan.edu.cn/a/1962.

Kuo, Lily. 2020. “People Have Been Awakened”: Seeking Covid-19 Answers in Wuhan.' The Guardian, 20 April. www.theguardian.com/world/2020/apr/20/people-have-been-awakened-seeking-covid-19answers-in-wuhan.

Li, Jane. 2020. 'Chinese Internet Users Who Uploaded Coronavirus Memories to GitHub Have Been Arrested.' Quartz, 27 April. qz.com/1846277/china-arrests-users-behind-github-coronavirusmemories-page.

Nathan, Andrew. 2003. 'Authoritarian Resilience.' Journal of Democracy 14, no. 1: 6-17.

NPC Observer. 2020. 'Translation: NPCSC's New Public Health Legislative Plan in Response to COVID-19.' NPC Observer, 29 April. npcobserver.com/2020/04/29/translation-npcscs-new-publichealth-legislative-plan-in-response-to-covid-19.

Qiaoan, Runya and Jessica C. Teets. 2020. 'Responsive Authoritarianism in China: A Review of Responsiveness in Xi and Hu Administrations.' Journal of Chinese Political Science 25, no. 1: 139-53. 
Repnikova, Maria. 2020. 'Does China’s Propaganda Work?' The New York Times, 16 April. www.nytimes.com/2020/04/16/opinion/china-coronavirus-propaganda.html.

Repnikova, Maria and Kecheng Fang. 2018. 'Authoritarian Participatory Persuasion 2.0: Netizens as Thought Work Collaborators in China.' Journal of Contemporary China 27, no. 118: 763-79.

Shi, Wei and Shih-Diing Liu. 2019. 'Pride as a Structure of Feeling: Wolf Warrior II and the National Subject of the Chinese Dream.' Chinese Journal of Communication, online first. doi.org/10.1080/17544 750.2019.1635509.

Shih, Gerry. 2020a. 'As Anger Explodes Over Doctor's Death, Beijing Firm Gives Chinese Government Advice.' The Washington Post, 8 February. www.washingtonpost.com/world/as-anger-explodes-overdoctors-death-beijing-firm-gives-chinese-government-advice/2020/02/08/6899e3e6-4a52-11ea9164-d3154ad8a5cd_story.html.

Shih, Gerry. 2020b. 'In Coronavirus Outbreak, China's Leaders Scramble to avert a Chernobyl Moment.' The Washington Post, 29 January. www.washingtonpost.com/world/asia_pacific/incoronavirus-outbreak-chinas-leaders-scramble-to-avert-a-chernobyl-moment/2020/01/29/ bc4eb52a-4250-11ea-99c7-1dfd424la2fe_story.html.

The Economist. 2020. 'A Diarist in Wuhan Faces Fury for Sharing Her Story with the West.' The Economist, 16 April. www.economist.com/china/2020/04/16/a-diarist-in-wuhan-faces-fury-forsharing-her-story-with-the-west.

Wang, Qi. 王琦. 2020。 强化公共卫生法治保障：我国今明两年拟制定修改17件相关法律 [Reinforce Legal Protection for Public Health: In These Two Years China Will Draft and Amend 17 Relevant Laws]. 新华网 [Xinhua], 27 April. news.china.com.cn/2020-04/27/content_75982970.htm.

Weinland, Don. 2020. 'Inside Wuhan: China's Struggle to Control the Virus-and the Narrative.' Financial Times, 23 April. www.ft.com/content/61ec68d8-8432-11ea-b872-8db45d5f6714.

Xinhua. 2020. “关于群众反映的涉及李文亮医生有关情况调查的通报 [Notice on the Investigation of Issues related to Dr Li Wenliang]. 新华网 [Xinhua], 19 March. www.xinhuanet.com/politics/202003/19/c_1125737457.htm.

Xu, Bin. 2009. 'Durkheim in Sichuan: The Earthquake, National Solidarity, and the Politics of Small Things.' Social Psychology Quarterly 72, no. 1: 5-8.

Zhang, Chenchen. 2020. 'Right-wing Populism with Chinese Characteristics? Identity, Otherness and Global Imaginaries in Debating World Politics Online.' European Journal of International Relations 26, no. 1: 88-115.

\section{Gratitude: The Ideology of Sovereignty in Crisis (CHRISTIAN SORACE)}

Allen-Ebrahimian, Bethany. 2020. 'Beijing Demanded Praise in Exchange for Medical Supplies.' Axios, 6 May. www.axios.com/beijing-demanded-praise-in-exchange-for-medical-supplies-16f5183e589a-42e5-bc25-414eb13841b0.html. 
Alti, Zachary. 2020. 'Gratitude in a Time of Pandemic.' Psychology Today, 25 March. www. psychologytoday.com/us/blog/the-mental-hygienist/202003/gratitude-in-time-pandemic.

Bandurksi, David. 2020. 'Thank You, No Thank You.' China Media Project, 7 March. chinamediaproject.org/2020/03/07/thank-you-no-thank-you.

Beinart, Peter. 2020. 'The Utter Futility of Biden's China Rhetoric.' The Atlantic, 20 April. www.theatlantic.com/ideas/archive/2020/04/futility-bidens-china-hawkery/610285.

Chatterjee, Partha. 2019. The People: Reflections on Popular Sovereignty Today. New York, NY: Columbia University Press.

Dean, Jodi. 2019. Comrade. London and New York, NY: Verso Books.

Erlanger, Steven. 2020. 'Global Backlash Builds Against China Over Coronavirus.' The New York Times, 3 May (updated 11 May). www.nytimes.com/2020/05/03/world/europe/backlash-chinacoronavirus.html.

Gilens, Martin and Benjamin I. Page. 2014. 'Testing Theories of American Politics: Elites, Interest Groups, and Average Citizens.' Perspectives on Politics 12, no. 3: 564-81.

Gruenauer, Jason. 2020. "How Denver Got Its Howl-and What It Means to Those Fighting Coronavirus on the Front Lines.” The Denver Channel, 28 April. www.thedenverchannel.com/news/ coronavirus/how-denver-got-its-howl-and-what-it-means-to-those-fighting-coronavirus-on-thefront-lines.

Hartman, Saidiya. 2020. ‘The Death Toll.' Los Angeles Review of Books, 14 April._lareviewofbooks.org/ article/quarantine-files-thinkers-self-isolation.

Kaplan, Fred. 2007. 'A Debt of Gratitude: Why Is Bush So Obsessed with Ungrateful Foreigners?' Slate, 13 March. slate.com/news-and-politics/2007/03/why-is-bush-so-obsessed-with-ungratefulforeigners.html.

Khan, Musaub. 2020. 'The Problem with Heroizing Health Care Workers Like Me.' The New Republic. newrepublic.com/article/157354/problem-heroizing-health-care-workers-like.

Mackey, Robert. 2020. 'In Exchange for Aid, Trump Wants Praise from Governors He Can Use in Campaign Ads.' The Intercept, 28 March. theintercept.com/2020/03/28/exchange-aid-trump-wantspraise-governors-can-use-campaign-ads.

Mayo Clinic. 2020. 'Discover Gratitude.' www.mayoclinichealthsystem.org/gratitude.

Moten, Fred. 2018. Stolen Life. Durham, NC: Duke University Press.

Nguyen, Mimi Thi. 2012. The Gift of Freedom: War, Debt, and Other Refugee Passages. Durham, NC: Duke University Press. 
Rein, Lisa. 2020. 'In Unprecedented Move, Treasury Orders Trump’s Name Printed on Stimulus Checks.' The Washington Post, 14 April. www.washingtonpost.com/politics/coming-to-your-1200relief-check-donald-j-trumps-name/2020/04/14/071016c2-7e82-11ea-8013-1b6da0e4a2b7_story.html.

Repnikova, Maria. 2020. 'Does China's Propaganda Work?' The New York Times, 16 April. www. nytimes.com/2020/04/16/opinion/china-coronavirus-propaganda.html.

Sorace, Christian. 2017. Shaken Authority: China's Communist Party and the 2008 Sichuan Earthquake. Ithaca, NY: Cornell University Press.

Wei, Shuiyin. 2020. 'Please Don’t Disturb.' MCLC Blog, 20 February. u.osu.edu/mclc/2020/02/27/ poems-from-a-wuhan-nurse.

Wong, Edward and Paul Mozur. 2020. 'China's “Donation Diplomacy” Raises Tensions with U.S.' The New York Times, 14 April. www.nytimes.com/2020/04/14/us/politics/coronavirus-china-trumpdonation.html.

\section{The Surveillance Vaccine: Surveillance, Censorship, and the Body under Covid-19 (CARWYN MORRIS)}

Basu, Arindam. 2020. 'The "Herd Immunity" Route to Fighting Coronavirus Is Unethical and Potentially Dangerous.' The Conversation, 17 March. theconversation.com/the-herd-immunity-routeto-fighting-coronavirus-is-unethical-and-potentially-dangerous-133765.

CGTN. 2020. “We Should've Stayed”: Briton Evacuated from Wuhan Regrets Leaving China.' CGTN, 7 May. newseu.cgtn.com/news/2020-05-07/-We-should-ve-stayed-Brit-evacuated-from-Wuhanregrets-leaving-China-QhrStoy8yk/index.html.

Esposito, Roberto. 2008. Bíos: Biopolitics and Philosophy. Minneapolis, MN: University of Minnesota Press.

Fan, Yingjie, Jennifer Pan, Zijie Shao, and Yiqing Xu. 2020. 'How Discrimination Increases Chinese Overseas Students' Support for Authoritarian Rule.' SSRN Scholarly Paper ID 3637710. Rochester, NY: Social Science Research Network.

Foucault, Michel. 2003. Society Must Be Defended: Lectures at the Collège de France, 1975-76. New York, NY: Picador.

Haas, Benjamin. 2017. 'China's Shanghai Sets Population at 25 Million to Avoid "Big City Disease". The Guardian, 26 December. www.theguardian.com/world/2017/dec/26/chinas-shanghai-setspopulation-25-million--big-city-disease.

Haass, Richard. 2020. 'Why the Coronavirus Should Change the Way We Think about China.' The Washington Post, 11 February. www.washingtonpost.com/opinions/2020/02/11/how-coronaviruscould-change-china. 
Kou Aizhe. 2020. 'E341: 我在美意英, 疫情肆虐下我的生活在这样继续 [E341: Stories from America, Britain, and Italy as the Pandemic Wreaks Havoc, and How We Continue].' Gushi.FM, 23 March. storyfm.cn/episodes/e341-i-am-in-the-united-states-italy-and-the-united-kingdom-and-my-lifecontinues-like-this-under-the-epidemic.

Lestweforget. 2020. 'Lestweforget/Wuhan2019.' GitHub, 30 June. https://github.com/lestweforget/ wuhan2019.

Li, Jane. 2020. 'Chinese Internet Users Who Uploaded Coronavirus Memories to GitHub Have Been Arrested.' Quartz, 27 April. qz.com/1846277/china-arrests-users-behind-github-coronavirusmemories-page.

Lyon, David. 2018. The Culture of Surveillance: Watching as a Way of Life. Hoboken, NJ: John Wiley \& Sons.

Morris, Carwyn. 2020. 'Life under Chai: Spatial Governmentality and Practices of Resistance in the Digital and Physical Spaces of Beijing, China.' PhD dissertation, The London School of Economics and Political Science.

Murray, Jessica. 2020a. 'British Family's Fraught Escape from Wuhan and Coronavirus.' The Guardian, 6 February. www.theguardian.com/world/2020/feb/06/british-familys-escape-fromwuhan-fraught-with-obstacles.

Murray, Jessica. 2020b. 'Britons Evacuated from Wuhan Regret Coming Home.' The Guardian, 10 April. www.theguardian.com/world/2020/apr/10/britons-evacuated-from-wuhan-regret-cominghome-coronavirus.

Pei, Minxin. 2020. 'China's Coming Upheaval.' Foreign Affairs, 17 July. www.foreignaffairs.com/ articles/united-states/2020-04-03/chinas-coming-upheaval.

Sorace, Christian. 2017. 'Communist Party Immunology.' In China Story Yearbook 2016: Control, edited by Jane Golley, Linda Jaivin, and Luigi Tomba, 99-107. Canberra: ANU Press.

Tu, Ming 涂铭, Mengda Wu 梦达乌, and Chang Lv 畅鲁. 2019. “治理“大城市病”，北京今年要出 哪些招? [To Heal the “Big City Disease”, What Measures Will Beijing Take This Year?]. Xinhua, 14 January. www.xinhuanet.com/politics/2019-01/14/c_1123988971.htm.

Wang, Xinyuan. 2019. 'Hundreds of Chinese Citizens Told Me What They Thought about the Controversial Social Credit System.' The Conversation, 17 December. theconversation.com/hundredsof-chinese-citizens-told-me-what-they-thought-about-the-controversial-social-credit-system-127467.

Wu, Cary. 2020. 'How Chinese Citizens View Their Government's Coronavirus Response.' The Conversation, 5 June. theconversation.com/how-chinese-citizens-view-their-governmentscoronavirus-response-139176. 
Zhang, Chenchen. 2020. 'Covid-19 in China: From "Chernobyl Moment” to Impetus for Nationalism.' Made in China Journal, 4 May. madeinchinajournal.com/2020/05/04/covid-19-in-china-fromchernobyl-moment-to-impetus-for-nationalism.

\section{Sinophobia Will Never Be the Same after Covid-19 (FLAIR DONGLAI SHI)}

Anderlini, Jamil. 2013. 'How Long Can the Communist Party Survive in China?' Financial Times, 20 September. www.ft.com/content/533a6374-1fdc-11e3-8861-00144feab7de.

Andersen, Kurt. 2018. 'How to Talk Like Trump.' The Atlantic, March. www.theatlantic.com/ magazine/archive/2018/03/how-to-talk-trump/550934.

BBC. 2020. 'China McDonald's Apologises for Guangzhou Ban on Black People.' BBC News, 14 April. www.bbc.co.uk/news/world-asia-china-52274326.

Black Livity China. 2018. 'Racism-with Chinese Characteristics: How Blackface Darkened the Tone of China's Spring Festival Celebrations.' Black Livity China, 16 February. blacklivitychina. com/2018/02/16/racism-with-chinese-characteristics-how-blackface-darkened-the-tone-of-chinasspring-festival-celebrations.

Boonlert, Thana. 2020. “'Racist” London Attack on Thai.' Bangkok Post, 18 February. www.bangkokpost.com/thailand/general/1859664/racist-london-attack-on-thai.

Buckley, Chris, Raymond Zhong, Denise Grady, and Roni Caryn Rabin. 2020. 'As Coronavirus Fears Intensify, Effectiveness of Quarantines Is Questioned.' The New York Times, 26 January. www. nytimes.com/2020/01/26/world/asia/coronavirus-wuhan-china-hubei.html.

Burke, Jason, Emmanuel Akinwotu, and Lily Kuo. 2020. 'China Fails to Stop Racism Against Africans Over Covid-19.' The Guardian, 27 April. www.theguardian.com/world/2020/apr/27/china-fails-tostop-racism-against-africans-over-covid-19.

Caiyiling 才艺零. 2020. '马的肺炎你真不思议 [Mother Pneumonia Wonder].' YouTube, 25 March. www.youtube.com/watch?v=HLTGBlmZC2Q.

Carrico, Kevin. 2018. 'Swarm of the Locusts: The Ethnicization of Hong Kong-China Relations.' In Yellow Perils: China Narratives in the Contemporary World, edited by Franck Billé and Sören Urbansky, 197-220. Honululu, HI: University of Hawai'i Press.

Castillo, Roberto. 2016. 'Racist Ad.' AfricansInChina.Net, undated. africansinchina.net/compilationopinion-and-analysis-pieces-about-the-notorious-racistchinesead.

Chan, Eason and Jolin Tsai. 2020. 'Fight as One.' YouTube, 3 April. www.youtube.com/ watch?v=Zi6xM0qJiic.

Chang, Gordon G. 2001. The Coming Collapse of China. New York, NY: Random House.

Chang, Gordon G. 2011. 'The Coming Collapse of China: 2012 Edition.' Foreign Policy, 29 December. https:/foreignpolicy.com/2011/12/29/the-coming-collapse-of-china-2012-edition. 
Chang, Gordon G. 2020. 'Collapse of China Explained by Chinese American Lawyer.' Valuetainment (YouTube Channel), 11 April. www.youtube.com/watch?v=IYjeO_n9vQw.

Chen, Kuan-hsing. 2010. Asia as Method: Toward Deimperialization. Durham, NC: Duke University Press.

Cheng, Yinghong. 2011. 'From Campus Racism to Cyber Racism: Discourse of Race and Chinese Nationalism.' The China Quarterly 207: 561-79.

Dikötter, Frank. 2015. The Discourse of Race in Modern China (2 ${ }^{\text {nd }}$ Edition). London: Hurst \& Company.

Douban. 2020. “广州招募志愿者帮助黑人解决吃饭住宿问题 [Call for Volunteers in Guangzhou to Help Black People Get Food and Accommodation].' Douban, 15 April. www.douban.com/group/ topic/171519628.

Eve, Frances. 2020. 'China's Reaction to the Coronavirus Outbreak Violates Human Rights.' The Guardian, 2 February. www.theguardian.com/world/2020/feb/02/chinas-reaction-to-thecoronavirus-outbreak-violates-human-rights.

Fyjo Molly. 2020. 'Africa• China • Love.' YouTube Channel Playlist, 9 February. www.youtube.com/ watch?v=M3j6hXW13Uc\&list=PLYAqgh9QhI9N9Dgki3rC8s1xa3QjcP3HB\&index=22.

Gries, Peter Hays. 2014. "Red China” and the "Yellow Peril”: How Ideology Divides Americans Over China.' Journal of East Asian Studies 14: 317-46.

Huang, Kun. 2020. “'Anti-Blackness” in Chinese Racial-nationalism: Sex/Gender, Reproduction, and Metaphors of Pathology.' Positions: Politics/Praxis, 29 June. positionspolitics.org/kun-huang-antiblackness-in-chinese-racial-nationalism-sex-gender-reproduction-and-metaphors-of-pathology.

HKGolden Music 高登音悅台.2020a. ‘小尼哥 [Little Nigger].' YouTube, 17 April. www.youtube.com/ watch?v=utEUOCgcxqQ.

HKGolden Music 高登音悅台. 2020b. ‘新型肺炎国人漸已死 [New Pneumonia, Countrymen Dying]. YouTube, 26 January. www.youtube.com/watch?v=vcsrCBpTjpU\&t=107s.

Human Rights Watch. 2020. 'China's Global Threat to Human Rights.' Human Rights Watch, undated. www.hrw.org/world-report/2020/country-chapters/global.

Iau, Jean. 2020. 'More Shock than Anger: S'porean Student Opens Up About Covid-19 Racist Attack on London.' The Straits Times, 3 March. www.straitstimes.com/singapore/singaporean-student-inlondon-seeks-eyewitnesses-after-coronavirus-related-taunt-and.

Kang, Yufei 康㻦霏. 2020. “纽约州长「曾假设新冠病毒只攻击黄种人! [New York Governor "Hypothesised that Coronavirus Only Affects Yellow People”!]. Ctwant, 4 April. www.ctwant.com/ article/44402. 
Kong, Belinda. 2019. 'Pandemic as Method.' Prism: Theory and Modern Chinese Literature 16, no. 2: 368-89.

Lan, Shanshan. 2017. Mapping the New African Diaspora in China: Race and the Cultural Politics of Belonging. London and New York, NY: Routledge.

Law, Wing-sang. 2000. 'Northbound Colonialism: A Politics of Post-PC Hong Kong.' positions: East Asia Cultures Critique 8, no. 1: 201-33.

Li, Audrey Jiajia. 2019. 'The Xenophobic Undercurrents of the Hong Kong Protests.' Inkstone, 11 October. www.inkstonenews.com/opinion/xenophobic-undercurrents-hong-kong-protests/ article/3032492.

Li, Hangwei. 2020. 'Mistreatment of Africans in Guangzhou Threatens China's Coronavirus Diplomacy.' The Conversation, 17 April. theconversation.com/mistreatment-of-africans-inguangzhou-threatens-chinas-coronavirus-diplomacy-136348.

Li, Promise. 2020. 'No to Chinese Authoritarianism, No to "Yellow Peril".' Democratic Socialists of America, 20 January. www.dsausa.org/democratic-left/no-to-chinese-authoritarianism-no-toyellow-peril.

Lowe, Lisa. 2015. The Intimacies of Four Continents. Durham, NC: Duke University Press.

Lynteris, Christos. 2018. 'Yellow Peril Epidemics: The Political Ontology of Degeneration and Emergence.' In Yellow Perils: China Narratives in the Contemporary World, edited by Franck Billé and Sören Urbansky, 35-59. Honolulu, HI: University of Hawai'i Press.

Meinhof, Marius. 2020. 'Othering the Virus.' Discoversociety, 21 March. discoversociety. org/2020/03/21/othering-the-virus.

Ong, Jonathan and Tony Lin. 2017. 'Plague in the City: Digital Media as Shaming Apparatus Toward Mainland Chinese "Locusts" in Hong Kong.' In Communicating the City: Meanings, Practices, Interactions, edited by Giorgia Aielle, Kate Oakley, and Matteo Tarantino, 149-63. Oxford: Peter Lang.

Ooi, Su-Mei and Gwen D'Arcangelis. 2018. 'Framing China: Discourses of Othering in US News and Political Rhetoric.' Global Media and China 2, nos. 3-4: 269-83.

Project Nightfall. 2020. 'How Covid-19 Exposed Racism in China: The Story of Shocking Racism.' Facebook post, 17 May. www.facebook.com/ProjectNightfall/posts/1315012455362382.

Sautman, Barry. 1994. 'Anti-Black Racism in Post-Mao China.' The China Quarterly 138: 413-37.

Shi, Flair Donglai. 2020 (forthcoming). 'Reconsidering Sinophone Studies: The Chinese Cold War, Multiple Sinocentrisms, and Theoretical Generalization.' International Journal of Taiwan Studies.

The Economist. 2020. 'Li Wenliang's Death Exposes the Costs of China's Authoritarianism.' The Economist, 13 February. www.economist.com/china/2020/02/13/li-wenliangs-death-exposesthe-costs-of-chinas-authoritarianism. 
The Guardian. 2020. 'Donald Trump Calls Covid-19 "Kung flu” at Tulsa Rally.' The Guardian, 21 June. www.theguardian.com/us-news/2020/jun/20/trump-covid-19-kung-flu-racist-language.

The Storm Media. 2020. ““新冠肺炎是黄种人的病! ”日本副首相麻生太郎爆料：欧洲人原本不关心 疫情，义大利代表还呛“我们不会得” ““Coronavirus Pneumonia is Only for Yellow People!” Japanese Vice-Prime-Minister Tarō Asō Reveals: The Europeans Do Not Care about the Epidemic at All, the Italian Representative Even Rebutted that "We Won't Get it"]. The Storm Media, 25 March. www. storm.mg/article/2446543.

Tuan, Mia. 1998. Forever Foreigners or Honorary Whites? The Asian Ethnic Experience Today. New Brunswick, NJ: Rutgers University Press.

Tufekci, Zeynep. 2020. 'How the Coronavirus Revealed Authoritarianism's Fatal Flaw.' The Atlantic, 22 February. www.theatlantic.com/technology/archive/2020/02/coronavirus-and-blindnessauthoritarianism/606922.

Viala-Gaudefroy, Jérôme and Dana Lindaman. 2020. 'Donald Trump's “Chinese Virus”: The Politics of Naming.' The Conversation, 21 April. theconversation.com/donald-trumps-chinese-virus-thepolitics-of-naming-136796.

Visco, Stephen Del. 2019. 'Yellow Peril, Red Scare: Race and Communism in National Review.' Ethnic and Racial Studies 42, no. 4: 626-44.

Vukovich, Daniel F. 2012. China and Orientalism: Western Knowledge Production and the PRC. London and New York, NY: Routledge.

Wikipedia. 2020. 'List of Incidents of Xenophobia and Racism Related to the COVID-19 Pandemic.' Wikipedia._en.wikipedia.org/wiki/List_of_incidents_of_xenophobia_and_racism_related_to_the_ COVID-19_pandemic - China.

Wode, Maya. 2017. 'Being Black in Asia.' YouTube Channel Playlist, 21 May. www.youtube.com/watch ?v=UPSyEorCQG0\&list=PLUA2bFez9e8TRkaqNNNPFpnmqPoA4Nki4

Yam, Kimmy. 2020. 'Trump Claims Asian Americans Are Angry at "What China Has Done” to U.S.' NBC News, 12 May. www.nbcnews.com/news/asian-america/trump-claims-asian-americans-areangry-what-china-has-done-n1205356.

Yan, Hairong. 2020. 'We Wanted to Know if Chinese Migrants in Africa Self-segregate. What We Found.' The Conversation, 4 June. theconversation.com/we-wanted-to-know-if-chinese-migrants-inafrica-self-segregate-what-we-found.

Yan, Hairong and Barry Sautman. 2015. Localists and 'Locusts' in Hong Kong: Creating a Yellow-Red Peril Discourse. Baltimore, MD: Carey School of Law, University of Maryland.

Yan, Hairong 严海蓉and Barry Sautman 沙伯力. 2017. 中国在非洲：话语与现实 [China in Africa: Discourses and Reality]. Beijing: Shehui Kexue Wenxian Chubanshe. 
Yang, Jui-sung 杨瑞松. 2010. 病夫、黄祸与睡狮：「西方」视野的中国形象与近代中国国族论述想像 [Sick Man, Yellow Peril and Sleeping Lion: Chinese Images from Western Perspective and the Discourses of Modern Chinese National Identity]. Taipei: Zhengda Chubanshe.

Zhang, Yunpeng and Fang Xu. 2020. 'Ignorance, Orientalism and Sinophobia in Knowledge Production on COVID-19.' Tijdschrift voor economische en sociale geografie/Journal of Economic and Social Geography, online manuscript. onlinelibrary.wiley.com/doi/abs/10.1111/tesg.12441.

Zhou, Li. 2020. 'Andrew Yang Told Asian Americans to Prove Their Americanness. Here's Why That's Wrong.' Vox, 3 April. www.vox.com/2020/4/3/21206760/andrew-yang-washington-post-asianamericans-opinion.

\section{Breathing What Air? Mongolia Before and After Covid-19 (REBEKAH PLUECKHAHN)}

Abrahms-Kavunenko, Saskia. 2019 Enlightenment and the Gasping City: Mongolian Buddhism at a Time of Environmental Disarray. Ithaca, NY: Cornell University Press.

Bayarsaikhan, Dulguun. 2020. 'Coronavirus Starts to Take Toll on Mongolian Economy.' The UB Posts, 13 February. theubposts.com/coronavirus-starts-to-take-toll-on-mongolian-economy.

Bayartsogt, Khaliun. 2019. 'Mongolia’s New “Cleaner” Fuel Linked to Deaths, Illness.' Phys Org, 19 November. phys.org/news/2019-11-mongolia-cleaner-fuel-linked-deaths.html.

Bonilla, Lauren. 2016. 'Internalizing External Debt.' Emerging Subjects Blog, 24 February. blogs.ucl. ac.uk/mongolian-economy/2016/02/24/internalizing-external-debt.

Butler, Judith. 2016. 'Rethinking Vulnerability and Resistance.' In Vulnerability in Resistance, edited by Judith Butler, Zeynep Gambetti, and Leticia Sabsay, 12-27. Durham, NC: Duke University Press.

Byambabaatar, Ichinkhorloo. 2018. 'Collaboration for Survival in the Age of the Market: Diverse Economic Practices in Postsocialist Mongolia.' Central Asian Survey 37, no. 3: 386-402.

Düürenbayar, Düüree. 2020. 'Mongolia vs Corona.' Video on Facebook, 1 April. www.facebook.com/ duurenbayar.ulziibayar/videos/1283818725157961.

Empson, Rebecca. 2020. Subjective Lives and Economic Transformations in Mongolia: Life in the Gap. London: UCL Press.

Fassin, Didier. 2020. 'An Unprecedented Health Crisis: Didier Fassin on the Global Response to the Covid Pandemic (Interview by Joanne Lipman).' Institute for Advanced Study website, 3 June. www. ias.edu/ideas/fassin-covid-global-response.

Ganbat, Gantuya, Tseren-Ochir Soyol-Erdene, and Batbayar Jadamba. 2020. 'Technical Note: Recent Improvement in Particulate Matter (PM) Pollution in Ulaanbaatar, Mongolia.' Aerosol Air Quality Research, online first. doi.org/10.4209/aaqr.2020.04.0170. 
Krusekopf, Charles and Mendee Jargalsaikhan. 2020. 'Mongolia's Bittersweet Covid-19 Success.' East Asia Forum, 27 August. www.eastasiaforum.org/2020/08/27/mongolias-bittersweet-covid-19-success.

Minnegal, Monica and Peter D. Dwyer. 2020. 'Communication, Privilege and the Ironies of Isolation: From Melbourne to Papua New Guinea.' Medical Anthropology at UCL website, 17 April. medanthucl. com/2020/04/17/communication-privilege-and-the-ironies-of-isolation-from-melbourne-to-papuanew-guinea.

Munkhbat, Sainbuyan. 2020. 'Mongolia's Challenges in Returning Nationals Stranded Abroad during Covid-19.' Asia Pacific Foundation of Canada website, 5 May. www.asiapacific.ca/publication/ mongolias-challenges-returning-nationals-stranded-abroad.

Odbayar, O. 2020 'Covid-19 ba Mongolyn Ediin Zasag [Covid-19 and the Mongolian Economy].' Ikon, 7 May. ikon.mn/opinion/lval.

Plueckhahn, Rebekah. 2020. Shaping Urban Futures in Mongolia: Ulaanbaatar, Dynamic Ownership and Economic Flux. London: UCL Press.

Roy, Arundhati. 2020. ‘The Pandemic Is a Portal.' Financial Times, 4 April. www.ft.com/ content/10d8f5e8-74eb-11ea-95fe-fcd274e920ca.

Sorace, Christian. 2018. 'Ulaanbaatar, City of the Future.' Made in China Journal 3, no. 1: 82-85.

Walker, Shaun, Lily Kuo, Hazem Balousha, and Oliver Holmes. 2020. 'The People that Covid-19 Has Cut Off from Home.' The Guardian, 3 August. www.theguardian.com/world/2020/aug/03/thepeople-that-covid-19-has-cut-off-from-home.

Waters, Hedwig Amelia. 2016. 'Living on Loans.' Emerging Subjects Blog, 22 January. blogs.ucl.ac.uk/ mongolian-economy/2016/01/22/living-on-loans.

\section{Between Economic and Social Exclusions: Chinese Online Gambling Capital in the Philippines (ALVIN CAMBA)}

Banks, James. 2016. Online Gambling and Crime: Causes, Controls and Controversies. London and New York, NY: Routledge.

Banks, James. 2017. Gambling, Crime and Society. London: Palgrave Macmillan.

Bloomberg. 2018. 'Chinese Money Triggers a Dizzying Rally in Manila Property.' Bloomberg News, 3 May. www.bloomberg.com/news/articles/2018-05-03/in-china-s-new-gambling-hot-spotproperty-prices-are-on-a-tear.

Bureau of Immigration. 2019. 'Tourists and Special Work Permits.' Bureau of Immigration, Department of Justice of the Philippine Government, Manila.

Camba, Alvin. 2017. 'Inter-state Relations and State Capacity: The Rise and Fall of Chinese Foreign Direct Investment in the Philippines.' Palgrave Communications 3, no. 41. 
Camba, Alvin. 2019. 'Inside a Chinese Gambling Entity: What Happens, Who Works, How?' ABSCBN News, 9 May. news.abs-cbn.com/spotlight/05/09/19/inside-a-chinese-gambling-entity-whathappens-who-works-how.

Camba, Alvin, 2020. 'The Sino-Centric Capital Export Regime: State-backed and Flexible Capital in the Philippines.' Development and Change 51, no. 4: 970-97.

Camba, Alvin and Janica Magat. 2020. 'How Do Chinese Investors Respond to Territorial Disputes? Evidence from the Philippines and Implications on Economic Strategy.' The Singapore Economic Review. doi.org/10.1142/S0217590819500681.

Ibarra, Richard. 2018. 'The Rise of POGOs: A New Landscape in e-Casinos and Sports Betting.' BusinessWorld, 17 September. http://www.bworldonline.com/the-rise-of-pogos-a-new-landscape-ine-casinos-and-sports-betting.

IBON. 2020. 'POGO Locations in the Philippines.' IBON website, 5 March. www.ibon.org/pogolocations-in-the-philippines.

Lee, Ching Kwan. 2017. The Specter of Global China: Politics, Labor, and Foreign Investment in Africa. Chicago, IL: University of Chicago Press.

Luna, Franco. 2020. “'Women for Order”: Hontiveros Slams Chinese Prostitution Dens in POGO Industry.' Philippine Star, 28 January. www.philstar.com/headlines/2020/01/28/1988465/ womenorder-hontiveros-slams-chinese-prostitution-dens-pogo-industry.

PAGCOR. 2019. List of Philippine Offshore Gaming Operators. Manila: PAGCOR, Offshore Gaming Licence Department.

Peralta, Janine. 2020. 'Witness: 90\% of Immigration Bureau Personnel Involved in "Pastillas" Scheme.' CNN Philippines, 20 February. www.cnnphilippines.com/news/2020/2/20/pastillasscheme-immigration-personnel-involved.html.

PSA Philippines Consultancy. 2019. Philippines Kidnapping Overview 2018. Metro Manila: PSA.

Polanyi, Karl. 1944. The Great Transformation (Vol. 2). Boston, MA: Beacon Press.

Rivas, Ralf. 2019a. 'A Chinese Online Gambling Worker's Plight in Manila.' Rappler, 12 June. www. rappler.com/newsbreak/investigative/232508-life-chinese-online-gamblingworkers-manila.

Rivas, Ralf. 2019b. ‘Online Gambling: Good for Whose Business?' Rappler, 14 June. www.rappler.com/ newsbreak/in-depth/232985-online-gambling-good-for-whose-businesschinese-philippines.

Valdez, Denise. 2020. 'China’s POGO Crackdown, Coronavirus May Dampen PHL Office Space Demand.' BusinessWorld, 27 February. www.bworldonline.com/chinas-pogo-crackdown-coronavirusmay-dampen-phl-office-space-demand. 
Venzon, Cliff. 2016. 'Philippines Invites Foreign Gamblers, Cracks Whip on Locals.' Nikkei Asian Review, 14 September. asia.nikkei.com/Economy/Philippines-ropes-in-foreign-gamblers-as-it-cracksthe-whip-on-locals.

Venzon, Cliff 2018. 'Chinese Appetite for Manila Condos Grows with Warmer Ties, Weaker Peso.' Nikkei Asian Review, 29 March. asia.nikkei.com/Business/Markets/Property/Chinese-snap-upManila-condos-amid-strong-diplomatic-ties-weak-peso.

Venzon, Cliff. 2020. 'Chinese Eye Bigger Slice of Manila as Real Estate Prices Tank.' Nikkei Asian Review, 5 June. asia.nikkei.com/Business/Markets/Property/Chinese-eye-bigger-slice-of-Manila-asreal-estate-prices-tank.

Venzon, Cliff and Shaun Turton. 2019. 'Philippines Halts New Online Casinos as China Urges Crackdown.' Nikkei Asian Review, 3 August. asia.nikkei.com/Business/MediaEntertainment/ Philippines-halts-new-online-casinos-as-China-urges-crackdown2.

Weber, Max, 1978. Economy and Society: An Outline of Interpretive Sociology (Vol. 1). Berkeley, CA: University of California Press.

\section{Scholars and Spies: Experiences from the Soviet Union, Communist Romania, and China (IVAN FRANCESCHINI)}

Afinogenov, Gregory. 2020. Spies and Scholars: Chinese Secrets and Imperial Russia's Quest for World Power. Cambridge, MA: Harvard University Press.

Barr, William P. 2020. 'Attorney General William P. Barr Delivers the Keynote Address at the Department of Justice's China Initiative Conference.' Website of the US Department of Justice, 6 February. www.justice.gov/opa/speech/attorney-general-william-p-barr-delivers-keynote-addressdepartment-justices-china.

Fischetti, Andrea and Antoine Roth. 2019. 'Why Did China Detain a Japanese History Professor?' Tokyo Review, 30 December. www.tokyoreview.net/2019/12/why-did-china-detain-a-japanesehistory-professor.

Fitzpatrick, Sheila. 2013. A Spy in the Archives. Melbourne: Melbourne University Press.

Franceschini, Ivan. 2017. 'Meet the State Security: Chinese Labour Activists and Their Controllers.' Made in China Journal 2, no. 1: 34-37.

Franceschini, Ivan and Elisa Nesossi. 2018. 'State Repression of Chinese Labour NGOs: A Chilling Effect?' The China Journal, no. 80: 111-29.

Horwitz, Josh. 2016. 'From Red-haired Foreigners to Soviet Grandpas: A Look at Chinese Cartoons about Spies.' Quartz, 21 April. qz.com/666513/from-red-haired-foreigners-to-soviet-grandpas-a-lookat-chinese-cartoons-about-spies. 
Kyodo. 2020. 'Chinese Academic at Japan University Detained by China for Spying.' South China Morning Post, 26 March. www.scmp.com/news/asia/east-asia/article/3077138/chinese-academicjapan-university-detained-china-spying.

Lewis, Margaret K. 2020. 'Criminalizing China.' Journal of Criminal Law and Criminology 111, no. 1. papers.ssrn.com/sol3/papers.cfm?abstract_id=3600580.

Lo, Kinling, Simone McCarthy, Stuart Lau, and Keegan Elmer. 2019. 'Chinese Professor Accused of Spying by Belgium, Barred from Entering Schengen Area.' South China Morning Post, 30 October. www.scmp.com/news/china/diplomacy/article/3035627/chinese-professor-accused-spying-belgiumbarred-entering.

Lolo, Sabrina. 2020. ' 3 Chinese Nationals Sentenced to Prison for Illegal Photography at Key West Naval Base.' CBS12 News, 5 June. cbs12.com/news/local/3-chinese-nationals-sentenced-to-prisonfor-illegal-photography-at-key-west-naval-base.

Price, David H. 2016. Cold War Anthropology: The CIA, the Pentagon, and the Growth of Dual Use Anthropology. Durham, NC: Duke University Press.

Rettman, Andrew. 2020. 'Universities in EU on Alert to China Spy Threat.' EUobserver, 23 April. https://euobserver.com/foreign/148164.

Verdery, Katherine. 2018. My Life as a Spy: Investigations in a Secret Police File. Durham, NC: Duke University Press.

Yang, Hengjun 杨恒均. 2015. Weibo post, 1 November. www.weibo.com/u/1220546491.

\section{Experiences of the Soul: On William Somerset Maugham's Far Eastern Writings (IVAN FRANCESCHINI)}

Biswell, Andrews. 2012. 'The Earthly Powers Manuscript.' The International Anthony Burgess Foundation website, 1 July. www.anthonyburgess.org/blog-posts/the-earthly-powers-manuscript.

Burgess, Anthony. 1965. 'W. Somerset Maugham: 1874-1965.' The Listener, no. 1917, 23 December.

Burgess, Anthony. 1969. 'Introduction'. In Maugham, William Somerset, Malaysian Stories, vi-xvii. Singapore and Hong Kong: Heinemann Educational Books (Asia) Ltd.

Burgess, Anthony. 1980. Earthly Powers. New York, NY: Penguin Books.

Burgess, Anthony. 2000. The Malayan Trilogy. New York, NY: Vintage.

Chen, Xiaomei. 2001. 'Twentieth-century Spoken Drama.' In The Columbia History of Chinese Literature, edited by Victor Mair, 848-77. New York, NY: Columbia University Press.

Collis, Maurice. 1938. Lords of the Sunset. London: Faber and Faber Limited.

Hastings, Selina. 2009. The Secret Lives of Somerset Maugham. London: John Murray. 
Maugham, William Somerset. 1955. The Travel Books. Melbourne, London, and Toronto: William Heinemann Ltd.

Maugham, William Somerset. 1999 (1919). The Moon and Sixpence. New York, NY: Vintage.

Maugham, William Somerset. 2000a. Far Eastern Tales. New York, NY: Vintage.

Maugham, William Somerset. 2000b. More Far Eastern Tales. New York, NY: Vintage.

Maugham, William Somerset. 2000c (1908). The Magician. New York, NY: Vintage.

Maugham, William Somerset. 2000d (1915). Of Human Bondage. New York, NY: Vintage.

Maugham, William Somerset. 2000e (1922). On a Chinese Screen. New York, NY: Vintage.

Maugham, William Somerset. $2000 f$ (1944). The Razor's Edge. New York, NY: Vintage.

Maugham, William Somerset. 2001a (1925). The Painted Veil. New York, NY: Vintage.

Maugham, William Somerset. 2001b (1930). The Gentleman in the Parlour. New York, NY: Vintage.

Maugham, William Somerset. 2001c (1932). The Narrow Corner. New York, NY: Vintage.

Orwell, George. 1974 (1934). Burmese Days. New York, NY: Harcourt Inc.

Said, Edward W. 2003 (1978). Orientalism. London and New York, NY: Penguin.

Soong, Stephen C (translated by Diana Yu). 1974. 'My Father and Maugham.' Renditions, Autumn: 81-90.

\section{Zombies of Capital: On Reading Ling Ma's Severance (IVAN FRANCESCHINI)}

Dostoevsky, Fyodor (translated by Constance Garnett). 2004 (1862). House of the Dead. Mineola, NY: Dover.

Eco, Umberto. 2002. 'Sullo stile del Manifesto.' In Umberto Eco, Sulla letteratura. Milano: Bompiani.

Fisher, Mark. 2009. Capitalist Realism: Is There No Alternative? Alresford, UK: Zer0 Books.

Graeber, David. 2018. Bullshit Jobs: The Rise of Pointless Work and What We Can Do about It. London: Penguin Books.

Harman, Chris. 2009. Zombie Capitalism: Global Crisis and the Relevance of Marx. London: Bookmarks Publications.

Ma, Ling. 2018. Severance. Melbourne: Text Publishing Company. 
Malone, Tyler. 2018. 'The Zombies of Karl Marx: Horror in Capitalism's Wake.' Literary Hub, 31 October. lithub.com/the-zombies-of-karl-marx-horror-in-capitalisms-wake.

McNally, David. 2012. Monsters of the Market: Zombies, Vampires and Global Capitalism. Chicago, IL: Haymarket Books.

Steven, Mark. 2018. 'Reading Marx on Halloween.' Jacobin, October. jacobinmag.com/2018/10/marxgothic-halloween-horror-capitalism-zombies-vampires-frankenstein. 


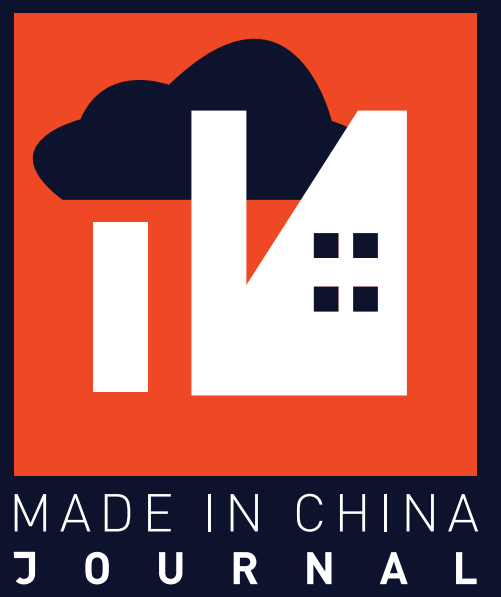

